


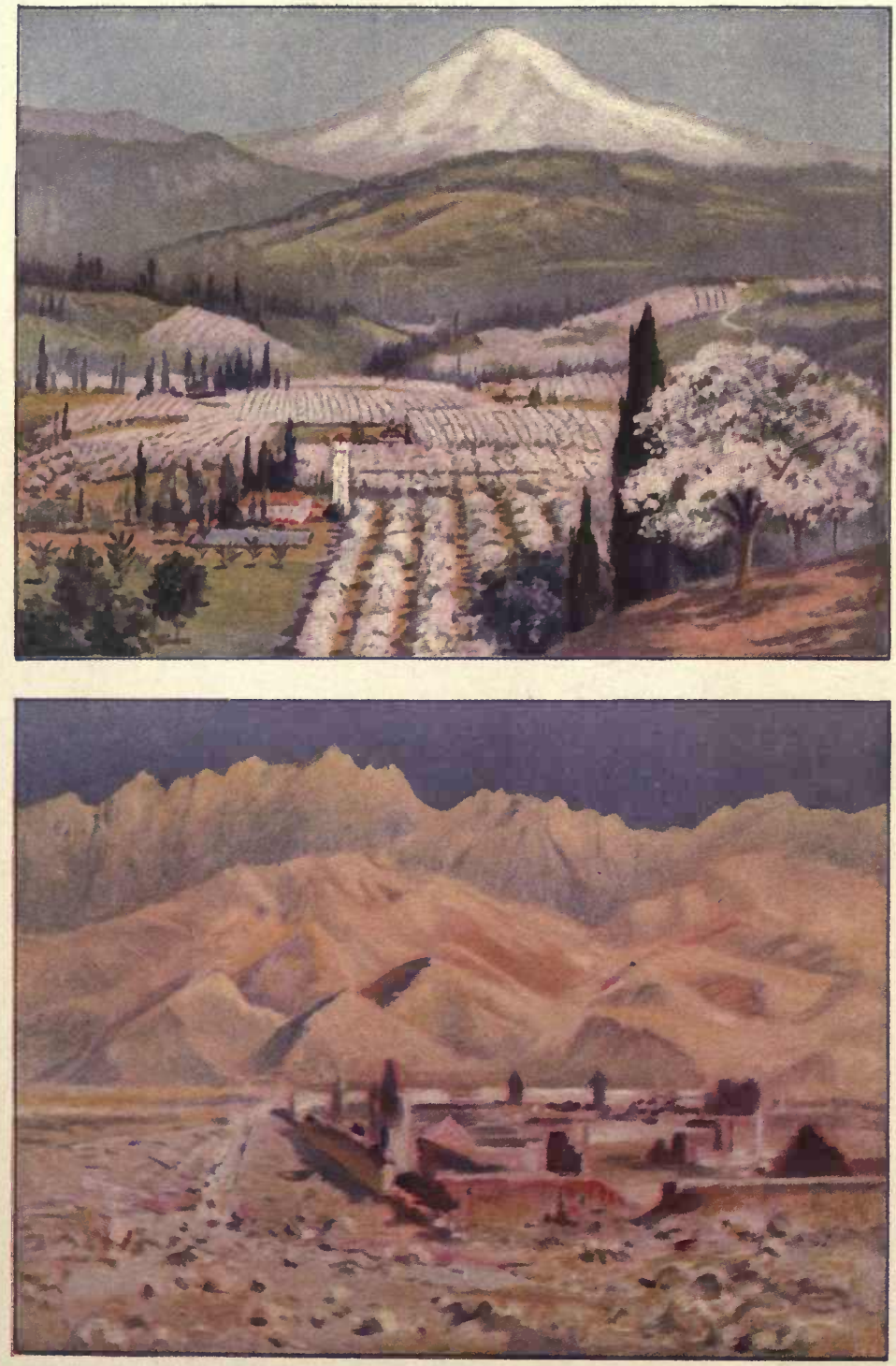

PLATE I. A MAN-MADE PARADISE OR A MAN-MADE DESERT. WHICH? 


\section{CIVIC BIOLOGY}

A TEXTBOOK OF PROBLEMS, LOCAL AND

NATIONAL, THAT CAN BE SOLVED

ONLY BY CIVIC COÖPERATION

\section{BY}

CLIFTON F. HODGE, PH.D.

PROFESSOR OF SOCIAL BIOLOGY IN THE UNIVERSITY OF OREGON AUTHOR OF "NATURE STUDY AXD LIFE"

\section{AND}

$$
\text { JEAN DAWSON, PH.D. }
$$

DEPARTMENT OF SANITATION, BOARD OF HEALTH, CLEVELAND FORMERLY OF MACDONALD COLLEGE, CANADA, AND CLEVELAND NORMAL SCHOOL; AUTHOR OF "THE BIOLOGY OF PHYSA" AND "BOYS AND GIRLS OF GARDEN CITY"

It will teach only such uses of authority as are necessary to secure coöperation of several or many people to one end; and the discipline it will advocate will be training in the development of coöperative good will. - CHARLES W. ELIOT.

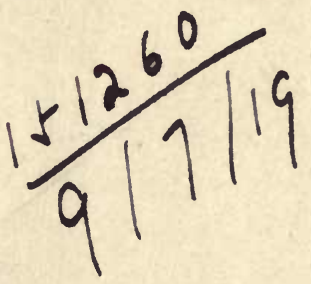

\section{GINN AND COMPANY}

BOSTON - NEW YORK - CHICAGO - LONDON

ATLANTA - DAllas - COLUMBUS - SAN FRANCISCO 
COPYRIGHT, 1918, BY CLIFTON F. HODGE AND JEAN DAWSON ENTERED AT STATIONERS' HALL

ALL RIGHTS RESERVED

318.10 


\section{PREFACE}

Discovery is pushing forward in every direction as never bufore in the history of the world, and still it would seem that enough is already known to make living well-nigh ideal wid the world almost a paradise, if only enough people knew. In how many of our civic units does every citizen know enough to conserve effectively the valuable bird life, the trees, the soil, and water on his own premises, to exterminate the rits and English sparrows, the flies, mosquitoes, and San José siale, the hookworms, diphtheria, and tuberculosis germs? If every individual citizen knows enough to do these things, in how many communities do all the people know enough t. coöperate,-- to work together with efforts so timed and planned that the good work of one, or of all but one, shall not be rendered vain by the failure of someone else to do his part?

The tides and currents, storms and floods, of living nature are too vast and powerful to be held within any dikes less secure than those built by the common, united effort of the whole community. The measure of our present need is seen in the wastage and loss that is streaming through our ineffectual defenses, - the probably not less than five hundred thousand raluable lives sacrificed annually to the currents of preventable disease, along with the several billions of dollars' worth (if foods and other property swept away by rats, insects, weeds, and fungi. How much higher must the cost of living soar before we begin to awake from the dream that we are a scientific and efficient people? As we are now organized 
(or, rather, disorganized), who knows whether his nextdoor neighbors know what to do in solving common eivic problems? From the way they do and live he may conclude that they do not know, but they may all be passing the same judgment upon him. So, instead of each one doing his civic part, and knowing that the rest are doing theirs, we are caught at every turn in the do-less net of "what's-the-useness." A would gladly protect his birds, but not to feed Mrs. B's cats. C could easily exterminate his own flies, but they continually swarm over from D's filthy premises. And so it goes for the thousand and one civic problems, - at every turn the deadly question, "What's the use?" How can we extricate ourselves from this net?

Coöperative good will is the essential idea in civic biology, as it is in the progress of civilization itself. This means that civic biology consists of all those problems whose solution requires coöperative effort. In the nature of the case we cannot control many of the forces of living nature by any amount of uncoördinated individual effort, any more than we can turn back the ocean tides by haphazard sweeping with brooms. The problem of civic biology, therefore, is to make it possible for everyone to know what these forces are, for good or for ill, and to understand how to do his part for his own good and for that of the community. Coöperative building of the defenses offers our only hope of success, and our education needs to be so organized that every citizen shall know enough to stop a breach the instant he sees it.

Acknowledgments in the text accompany pictures and other contributions, except in the following cases: The figures of ticks, in Plate IV, are rearranged from those published by the United States Department of Agriculture and the United States Public Health Service. The upper view in the frontispiece is taken from a photograph looking northward 
down the Hood River valley, Oregon, across the gorge of the Columbia, with Mt. Adams in the background. It is used by the courtesy of the United States Reclamation Service. The lower view is from one of Bailey Willis's photographs of Shingkung, China, and shows desert conditions, man-made within the short space of about the last two centuries. With complete deforestation of the mountains, the once fertile valley has been buried under the wash of floods, which, alternating with burning droughts, have made the country uninhabitable. We are indebted for use of the print to the Carnegie and Smithsonian institutions.

The idea of the book is expressed at a glance in the frontispiece, the question "Which?" being applicable to every lindscape and home in the world.

C. F. H.

J. D. 



\section{CONTENTS}

CHAPTER

I AGE

I. Plan of the Course as a Whole . . . . . . 1

II. Equipment, Apparates, and Library . . . . 10

III. The Insect Problem . . . . . . . . . . . 18

IV. BrRds. . . . . . . . . . . . . . . . 23

V. Methods of Bird Stum and Special Problems. 35

VI. Tree Study and Civic Forestry . . . . . . . 55

VII. Plant Problems: Preservation of Wild Flowers,

Control of Weeds, Medicinal and Poisonous Plants . . . . . . . . . . . . 67

VIII. Home Planting ani Laniscape Gardening . • 77

IX. Practical Biology of Agricultural Production and Civic Utrlization of Land . . . . . . 91

X. Insect Type Problems: Important Flies. . . 107

XI. Insect Type Problens: Mosquitoes. . . . . . 12:

XII. Insect Type Problens: Cabbage Butrerfly • 136

XIII. Insect Type Problems: Axts . . . . . . . 141

XIV. Special Problems of Insect Control . . . . . 148

XV. Arachnids. Problems of Spiders, Mites, And Ticks 163

XVI. American Mamal Problems . . . . . . . 169

XVII. The Rat Problem. . . . . . . . . . . . 173

XVIII. Fungi : Bacteria, Yeasts, Molds, Mildews, Rusts,

Swuts, AND Mushrooms . . . . . . . . . 186

XIX. Fungr Continued: Mushroons, Poisonous AnI

Edible . . . . . . . . . . . . . 200

XX. Fungous and Bacterial Diseases of Plants . 207

XXI. Bacteria . . . . . . . . . . . . . 218

XXII. Bacteria Contrnued : Laboratory Methods . . 224 vii 
XXIII. Control of Bacterial Diseases . . . . . 231

XXiV. Control of Animal Parasites . . . . . . 253

XXV. Civic Problems Relating to Mollusks. . . 271

XXVi. Crustacea . . . . . . . . . . . . . . . 285

XXVII. Problems of Fish and Fishing . . . . . . 295

XXVIII. Amphibia : Sirens, Proteans, Salamanders, Frogs,

Tree Frogs, and Toads... . . . . . . . 313

XXIX. Reptiles: Crocodiles, Alligators, Turtles, Terrapins, Tortoises, Lizards, Snakes . . . . 321

XXX. Practical Laws of Life . . . . . . . . 330

XXXI. Knowing How to Know How . . . . . . 346

XXXII. Progress in Discovery . . . . . . . . 355

$\operatorname{INDEX}$. . . . . . . . . . . . . . . . 363 

Working together will be one of its fundamental ideas, - of men with God, of men with prophets, leaders, and teachers, of men with one another, of men's intelligence with the forces of nature. It will teach only such uses of authority as are necessary to secure coöperation of several or many people to one end ; and the discipline it will advocate will be training in the development of coöperative good will. - Eцioт, " Religion of the Future," p. 22

Physical forces or the exhaustion of purely physical resources never have, and for at least five million years in the future, so the astronomers tell us, cannot extinguish human civilizations. Floods or volcanic eruptions may cause small and local effects; while biological forces are oceanic, subtile, allpervasive, continuously active, ever ready, whenever a break in the vital defenses of knowledge occurs, to surge in and obliterate individual, nation, civilization. Even the great movements of human races, conquests and wars, are not so all-annihilating in their effects as the ceaseless struggle of mankind against other living species. Disease, pestilence, plague, and famine have taken their millions to war its scores.

These forces are so powerful, so vast in their sweep, that for one individual to attempt to cope with them is like Mrs. Partington trying to sweep back the ocean with her broom. Our education must be so organized that each may know and do his part.

It is not labor, not capital, not land, that has created modern wealth or is creating it to-day. It is ideas that create wealth, and what is wanted is more ideas - more uncovering of natural reservoirs, and less labor and capital and land per unit.of production. . . .

Muscular effort can be stimulated by the lash - intelligent supervision, intellectual production, never ! One single idea may have greater value than all the labor of all the men, animals, and engines for a century. The age of muscular human effort and of the lash is passing away, and the old morality with it: the age of supervision, of coöperative stimulus, is in full advance; and with it comes a new morality, under which the Golden Rule can be extended from the relations between individuals to those between classes, nationalities, and races. - Emerson, "Twelve Principles of Efficiency," pp. $x$ and $x i$ 


\section{CIVIC BIOLOGY}

\section{CHAPTER I}

\section{PLAN OF THE COURSE AS A WHOLE}

Motto of the course: "That we may know enough to work together."

United effort is the central idea in civic organization, and its extension underlies advance in civilization. Civic biology cousists in that group of problems in the control of living nature to solve which requires that a community unite in working together intelligently. There is a large body of such problems which must be made a vital part in the education of every citizen, for in no other way can they ever be solved.

We are suffering enormous losses, - in destruction of natural resources, in unfruitful labor, in damage to property, in preventable disease, - due to lack of proper civic organization. One ignorant or careless member of a community may kiudle a forest fire, or clear a watershed that will cause a water famine over an extensive territory. He may permit insects or vermin to breed, or allow fungi or bacteria to grow, that will cause great damage to property, and disease and even loss of life among his neighbors.

It is a slight matter to extinguish a match or a camp fire ; it may require the strenuous efforts of thousands to cope with a burning forest. So with every member of a community coöperating intelligently, slight effort may achieve great results, utterly impossible unless all work together. 
As an illustration, take the case of the common rat. 'These animals are probably costing the country $\$ 500,000,000$ annually in spread of disease, in damage to buildings, merchandise, and produce, and in cost of traps, poisons, and labor; and since bubonic plague has gained a foothold in America, they positively must be exterminated. A single pair may breed

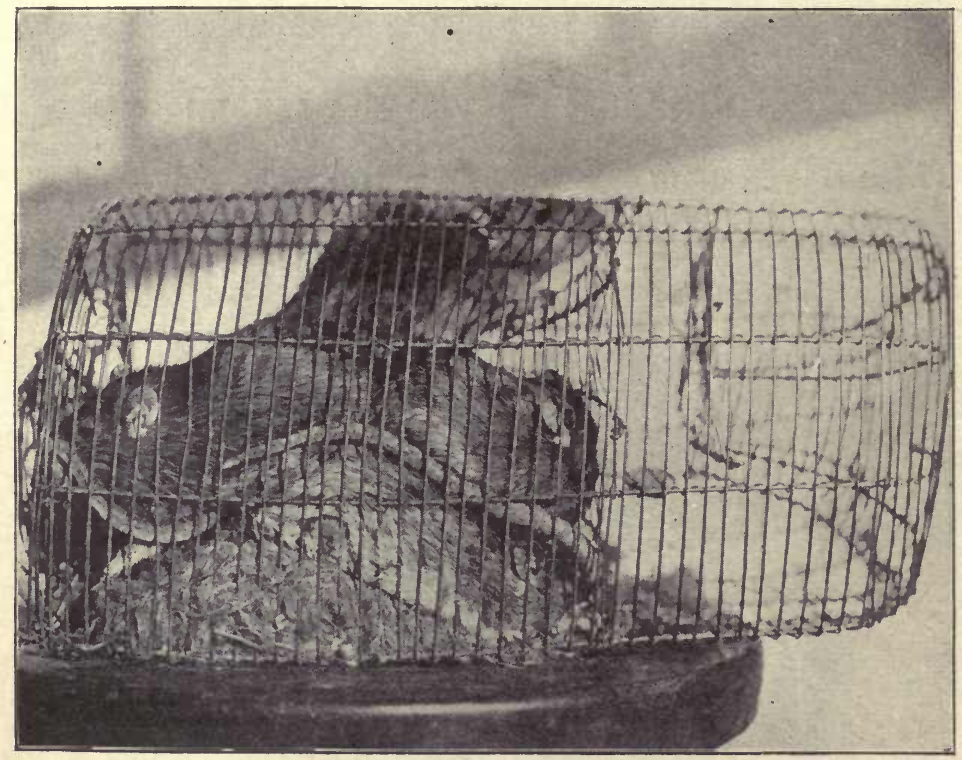

Fig. 1. Rats, where they all belong

1250 rats in a year. As we are now doing, Smith attempts to rid his premises of the pests in October, driving many of them over to Jones. Jones undertakes the work in November, driving them back to Smith, and in December both are practically where they were before. The same amount of effort, properly coördinated, might have proved effective. This principle applies with added force to larger groups, and it is quite possible that with even less expense and labor than is now almost 
wisted annually, the rat could be exterminated from the continent within a year or even within a single month.

Civic organization applies not only to the control of injurious forces, but equally to saving valuable species from extermination. Lacking such organization, a number of species of great value have already been exterminated from vast areas, and several more are in imminent danger. A few of these,

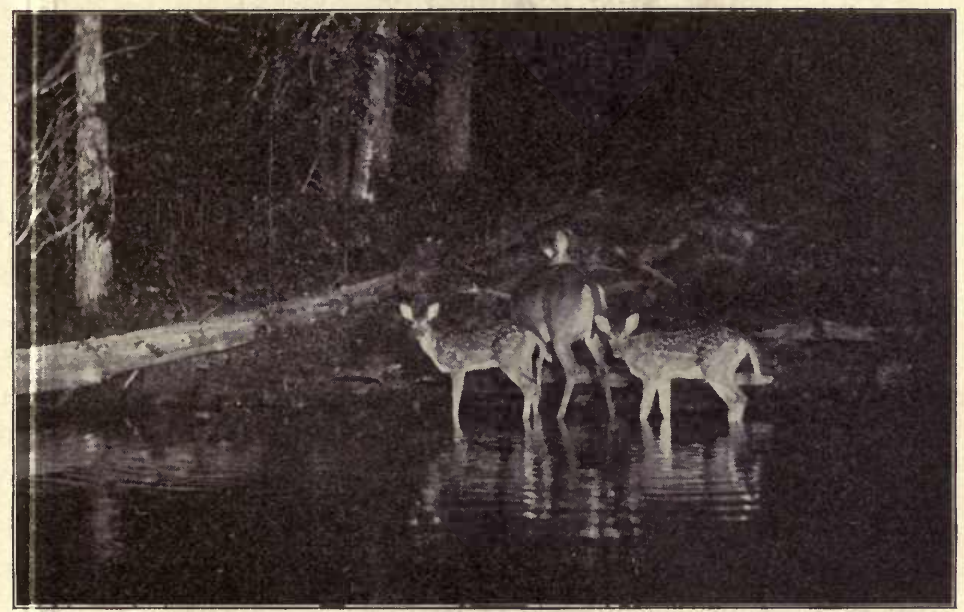

Fig. 2. Virginia deer

Photograph by George Shiras

chiefly among our game birds and game and fur-bearing arimals, will receive attention in the appropriate chapters.

At best, among the great number of such problems, we shall be able to study only a few typical ones that touch the life of the community most vitally. Three or four insect types are all we shall have time for, but thousands of others may be studied by similar methods. The purpose of the course is thus to cultivate habits of observation, insights into the workings of living nature, and, above all, civic ways of thinking and civic methods of studying and of attacking such problems; and 
the highest product of the course will be citizens who know enough to work together.

Select the problems that your community needs to have studied most. A single problem actually worked out to a definite civic advance will be worth more educationally than a hundred problems memorized from a book.

With the school year arranged as it is, it will be necessary to start many different lines of work in the early fall. A store of material must be collected for use during the winter, and as far as possible this should be done by the class, - to give practice in collecting, insight into problems, and at least glimpses of the various forms in their natural environment. ${ }^{1}$

In order to collect intelligently and plan and organize the work of the year, first run through the book rapidly and copy into a pocket notebook the names of all the birds, insects, fishes, trees, and so on, described in the text. Estimate importance of topics and leave required space for notes between the names; page and make an alphabetical index at the back of the notebook. This gives a place where every observation made during the year may be recorded and referred to instantly when wanted. Indent margins, date and space so that each note shall stand out clearly. Records at the end of the year may read about as follows: ${ }^{2}$

\section{White Pine (Pinus strobus)}

SePt. 3. Noted on a trip into the country that the squirrels were cutting quantities of the cones from the tops of the pine trees and were feeding on the ripe seeds. The cones were closed and green, but the seeds were brown and ripe inside. Gathered nearly a bushel and spread on papers in the attic.

${ }^{1}$ This outdoor work is súch a vital part of the course that careful record should be kept of all types collected, and this should be understood to form the basis for a definite percentage or part of the pupils' required standing.

${ }^{2} \mathrm{~A}$ field notebook with printed index and topics is being planned to accompany this course. 
JAN. 10. Found cones dry and wide open, with many of the seeds fallen out. Brought enough to laboratory to supply the class. ${ }^{1}$

Fer. 22. Planted in a flat, 10 by 15 inches, 3 inches deep, 200 seeds, with the wings intact. The flat was filled with leaf mold mixed with sand, and seeds were planted about $\frac{1}{4}$ inch deep.

March 15. Seeds beginning to germinate (Lab. Book, p. 77).

April 10. Made a seed bed according to directions in Forest Service Circular 67, and planted all the seed I had left. Transplanted seedlings not used in laboratory into this bed.

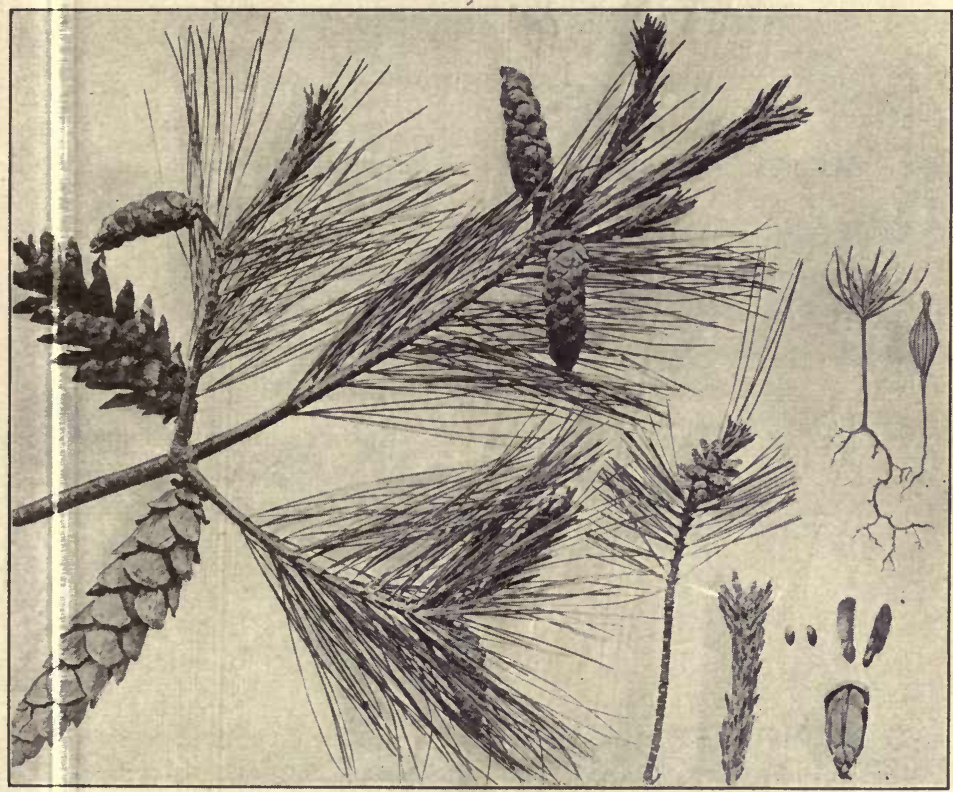

Fig. 3. Type collection, white pine

${ }^{1}$ It is supposed that this pupil undertook to supply the class with specimen $;$ of the white pine, other members of the class doing the same for other tree.s. References to the laboratory book mean that on pages 77 and 78 will be four d drawings of the specimens, - the leaf bundle, with possibly a sketch of a trie, the cone, the cone scale with the seeds in place, the seedlings in two or thiree stages of germination, and finally the flowers. He will also be able to till the class about methods of collecting, storing, and planting the seeds. 
May 7. Buds beginning to shoot. Seedlings coming up thick.

June 8. Collected blossoms, staminate and pistillate, together with cones one year and two years old on same branches (Lab. Book, p. 78).

Seedlings 3 inches high. Estimated that there are 5600 in my seed bed.

\section{The Humming Bird (Trochilus colubris)}

SEPT. 6. Seen daily about cannas, nasturtiums, etc.

SePt. 12. Saw last birds, I think. One alighted for a moment on bare twig and flew south.

Ост. 3. Found deserted nest while picking apples (Lab. Book, p. 14).

MAY 14. First arrival seen this spring, and first reported in class.

\section{Grape (Delaware)}

Sept. 9. Selected as specimen to study a Delaware planted by myself six years ago (Lab. Book, p. 42; sketch of vine, size of stock, area of trellis covered, drawing of cluster and leaf). Garnered grapes, 42 pounds in 12 minutes.

Nov. 3. Pruned vine 15 minutes. Buried a bushel of bones about roots (Lab. Book, p. 43 ; diagram of vine after pruning).

ApriL 27. Buds beginning to shoot.

MAy 15. Placed a cane 6 feet long in trench 3 inches deep, for layers.

June 19. Blossoms open, new shoots about 2 feet long.

\section{Codling Moth (Carpocapsa pomonella)}

SEPT. 21. Examined 100 apples and found 92 worm-eaten. Found 15 larvæ in the apples; the rest had completed their growth and gone. Where did they go?

SEPT. 22. In one hour's search, scraping apple bark, found 163 larvæ in their cocoons under the bark scales. They must have gone there when they left the apples.

Nov. 28. Observed a downy woodpecker at work on apple tree. From 8 to $8: 15$. saw him drill into 5 bark scales and remove 
the larvæ. Climbed up and secured the punctured scales for my collection. At this rate how many might a woodpecker eat in a year? Wish I could follow him and discover how many he actually destroys in a day. Put marrow bones and suet in the apple trees to attract woodpeckers to the orchard.

Dec. 6. Refer to Lab. Book, p. 41 (sketch of larva, etc.).

April 12. Hunted one hour again for larvæ; found only 8 , but have observed the woodpeckers working on the trees all winter, and counted 179 punctured bark scales from which the larvæ had been removed. Those found were still in the larval stage.

May 15. Apple trees in bloom. Hunted one-half hour; found 1 larva and 2 pupæ (Lab. Book, p. 42).

June 11. Apples about the size of marbles. 8 P.M., hung a lantern in a tree where apples were thickest. Caught a moth in act of laying an egg on an apple. As I raised my net to catch another, a bat flitted by and snapped it. Tried to catch bat but he was too quick for me.

'The main laboratory for this course is the out-of-doors, the yard, garden and orchard, streets and roadsides, pastures, fielcls, woods, streams, lakes, hills, and swamps. Thousands of interesting things are happening out there all the while, and it is there the student must go if he would really learn his lessons. With definite assignments of what to seek or to study and observe, most of this field work should be done either singly or in small groups of two or three. In addition to this there should be individual problem-working and lessonlearning for discussion and demonstration of the more general problems, such as the study of habitats; the struggle for life as seen in a dense woods; the distribution of a number of the types studied in the course; migration of birds; recognition of trees, birds, common plants. A number of special fielıl trips also should be arranged. The success or failure of these will depend upon the teacher's knowledge of the locality 
and of the times and seasons for the appropriate lesson. ${ }^{1}$ The course supposes at least seven field excursions: two in the fall, for general outlines; one in dead winter, for recognition of trees, study of animal tracks and doings, winter birds, hiding places of insects ; and four in the early and late spring. In these excursions plan to take in a model dairy, vineyard, orchard, nursery, tuberculosis sanitarium, fish hatchery, bird sanctuary, or other local institutions of interest.

Fall is the most favorable season of the school year in which to study insects and to begin the study of birds. The largest share of the time usually spent in "learning" lessons out of books or in the indoor laboratory will be devoted to collecting and studying specimens out of doors. Hunt particularly for the species required by the course. There are so many thousands of different insect species that you will soon find yourself bewildered and discouraged if you try to study them all. Any insect of special importance in your locality, however, may be substituted for those in the course, if desired. Collect, so far as possible, the complete story of the life and work of each species, - eggs, larvạ, pupæe and adults (male and female), injured fruit, eaten leaves, stings, galls, and the like.

While working over the ground for insects it will require but little additional time to collect the materials for several other lines of work to be done in the laboratory during the winter. Among the more important will be:

Leaves and fruits of forest trees.

Fruits and seeds of common plants.

Weeds and their seeds.

Common mushrooms and tree-destroying fungi.

As many as possible of the parasitic fungi described in the text, mildews, blights, rusts, and smuts.

1 It will often be necessary for the teacher to keep careful watch and go over the ground himself the day before a general field trip. 
Deserted birds' nests for study of nesting sites, and analysis of materials. Attach a label to each nest, stating locality and position, kind of tres, distance from ground, etc.

Fresh-water clams and snails, with duckweed, milfoil, stonewort, anil other aquatic plants common to the locality, for use in stocking aquaria during the winter.

Fronds of all the common ferns, fruiting and sterile. These should be pressed between sheets of paper and preserved dry.

The ants' nests must be stocked as early as possible, and may be maintained through the winter.

It is not advisable to try to keep frogs, salamanders, newts, turtles, snakes, or many fishes in the laboratory during the winter, since their normal period of hibernation will be interfered with and they are not lik.ly to do well. These may all be collected and studied to better adrantage in the spring.

In general, the order of chapters follows that indicated above: insects and birds with beginning plant lessons in the fall; fungi, bacteria, and animal parasites for indoor work during the winter; fishes and amphibia in early spring; and the emphasis on plants with the completion of bird and insect studies in the later spring months. A natural conclusion of the course is supplied by a brief statement of the principles anil laws of life with an outlook toward the biological organization of the nation. At best, with so many interests weaving a continuous pattern through the changing life of the year, the text will need to be used as a reference book rather than as a series of consecutive lessons.

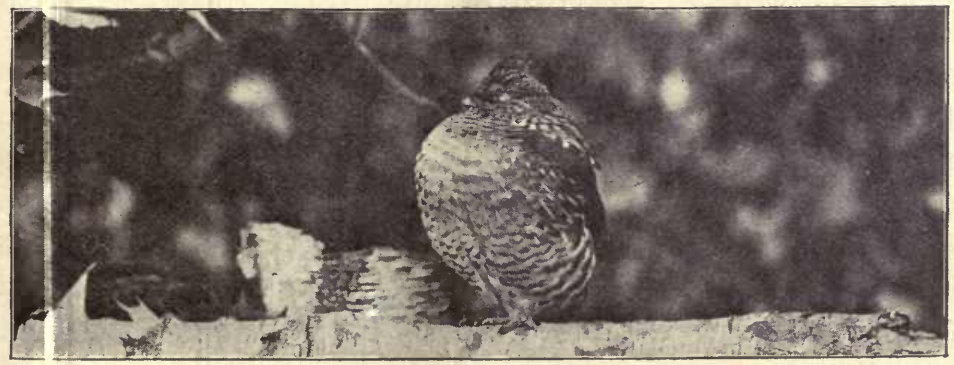




\section{CHAP'TER II}

\section{EQUIPMENT, APPARATUS, AND LIBRARY}

Laboratory outfit. Equipment for the more special problems will be described in appropriate chapters, but there are a few general needs which should be understood at the outset. First of all, the course demands more than usual individual storage room for students' material. Each student should have not less than 6 square feet of shelf, closet, or locker space. This will be supplied by a simple wall case 1 foot wide, 18 inches deep, and 3 feet tall, with three shelves about 9 inches apart. "The student must be given time to label and store his specimens neatly, since any appearance of "rubbish" about the laboratory is likely to prove fatal to the morale of the whole coursé.

The laboratory should be provided with at least two goodsized aquaria and two vivaria. A convenient size for all of these is 24 inches long, 12 inches wide, and 15 or 18 inches deep. They may all be made according to directions given below for aquaria and then be used either as aquaria or vivaria. Each student should have also a small aquarium, - about 12 inches deep, 10 inches long, and 6 inches wide, - which may be used nearly dry, for insect-rearing cases; moist, for salamanders, toads, frogs, and tree frogs ; or filled with water, for fishes and other aquatic animals and plants. By partially filling such aquaria with loam, sawdust, or sphagnum, covering the outside closely with black paper, tilting slightly, and planting different seeds close against the glass, they may serve for interesting demonstrations in germination and the development of root systems. 
Individual apparatus. In addition, the outfit of each studest should contain the following: one insect net, one small scrim net for collecting in water, one cyanide bottle, one pajer of assorted insect pins, one dozen insect-mounting cases (assorted sizes), and two notebooks (one pocket size for field notes and data of field collections, the other larger, unruled,

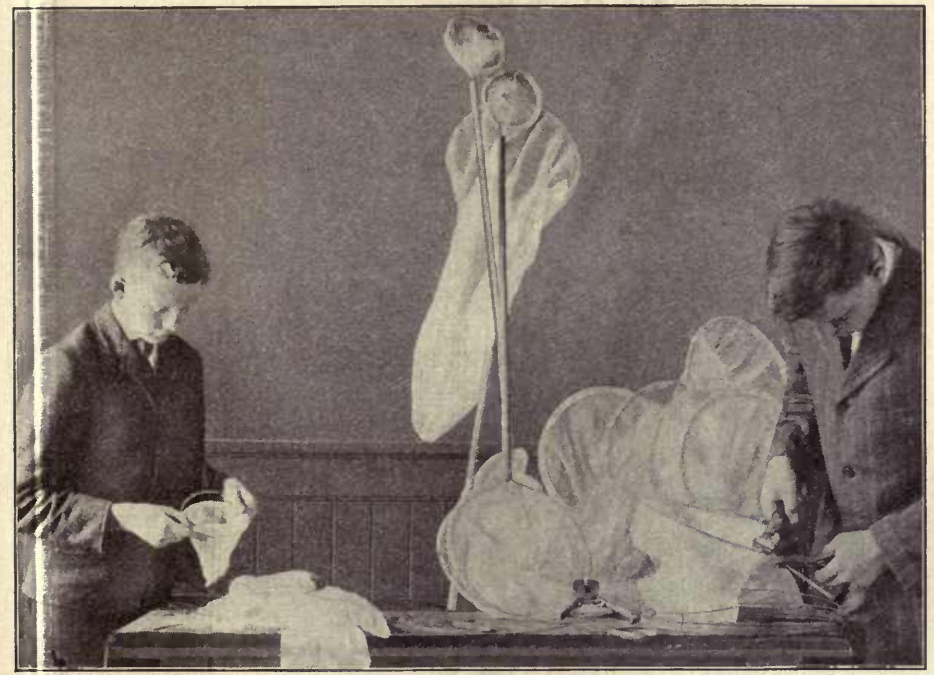

Fig. 4. Making insect nets

for laboratory notes and drawings). These should be paged and indexed for quick reference from one to the other.

I vital feature of the course is the making of simple apparatus by the students themselves. Since time in the fall is so precious for outdoor work, the necessary apparatus should be provided to begin with, but after the first year it should be made by the previous class; that is, each class should take a turn at making, apparatus during the winter in order that the laboratory $\mathrm{m}$ yy be well equipped for the work of the following autumn. Since it is to be hoped that the students will 
continue the study after the course is completed, it would be well if each could be given the chance to make at least the two collecting nets and a small aquarium for himself.

Materials for making the nets. Flat-drawn spring brass or tinned steel wire for the frames for the air and water nets respectively; the strongest cotton tape (mill tape, such as is used in wrapping electric wires,
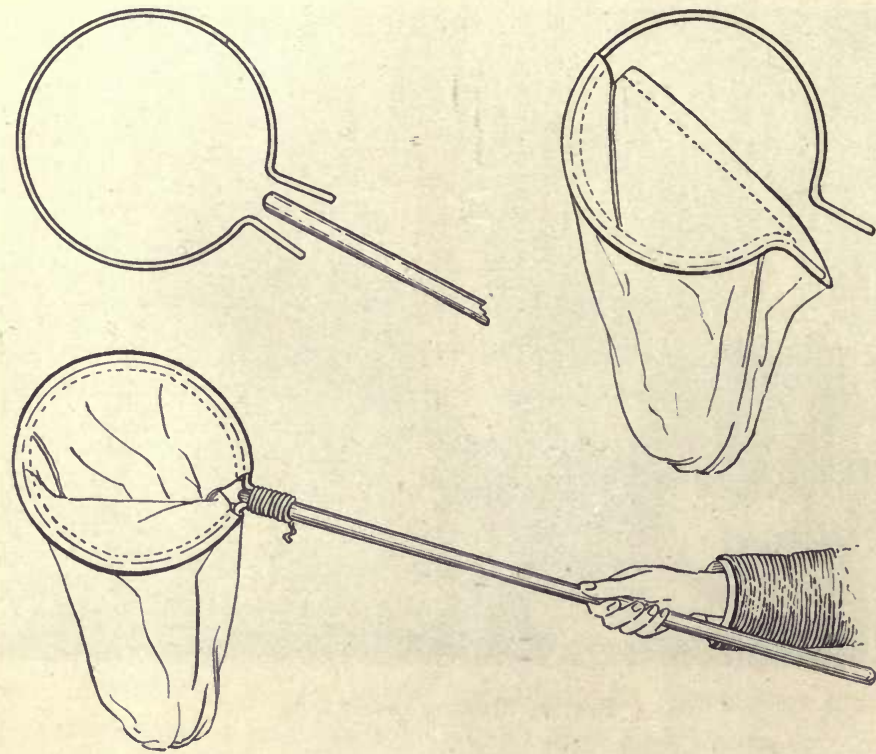

Fic. 5. Easy construction of insect net

1 , form of wire frame; 2 , slipping net on frame; 3 , net bound to handle with twine is good); then for the air nets, strong bobinet, light cheesecloth, or mosquito netting, according to preference. Mosquito netting, if the threads which cross run the long way of the net and care is observed to avoid water and briars, makes a fairly serviceable insect net. For the water nets use cotton scrim. There are several ways of making the nets, but for nets detachable from the handles the writer has found the method shown in Fig. 5 most serviceable.

Materials for aquaria. The aquaria may be made for little more than cost of glass, the materials being : 
Glass. Double-thick window glass for sides and ends, and ribbed skylight glass for bottom for sizes above $20 \times 10 \times 12$ inches. For smaller sizes, waste $10 \times 12$ in. negatives are good and cost little or nothing.

Angle or valley tin, sizes indicated below.

Aquarium cement.

Solder.

Green or black carriage paint and a little spar varnish.

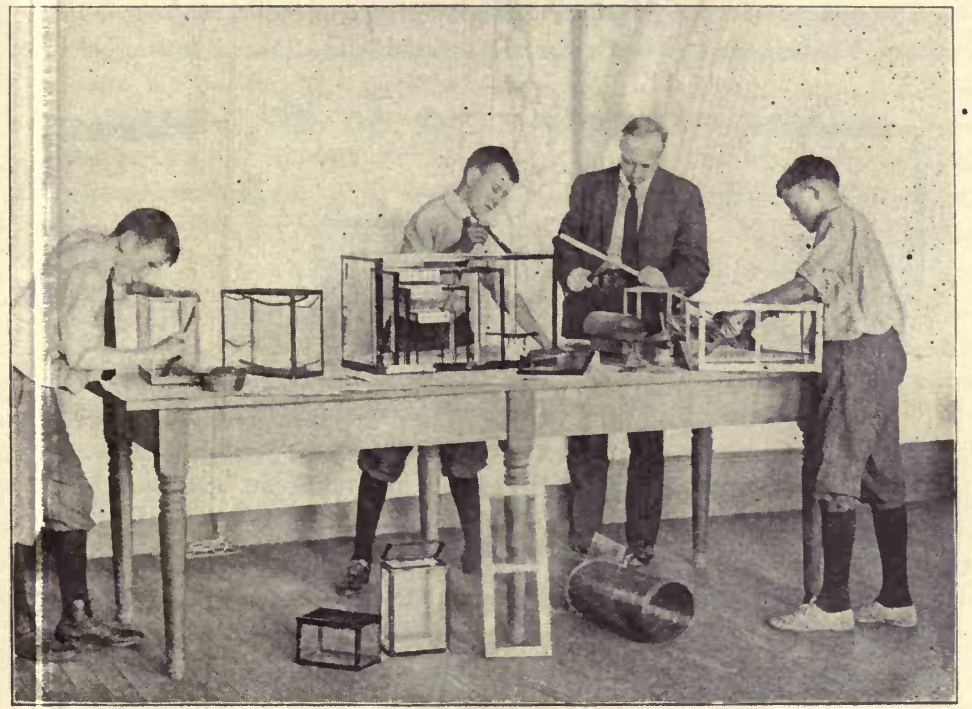

Fic. 6. Making aquaria

Frum left to right, laying the cement; glass set in one, with bent green twigs to hold it in place; painting frames, and frames of different sizes, $5 \times 7 \times 4$ to $24 \times 15 \times 10$; cutting the angle tin to measure; soldering the frame held in a square fastened to table

Tools. Every laboratory should be provided with a few simple tools, arrong which the following will be required in making aquaria:

Carpenter's square, - to hold the frame perfectly square at each angle while it is being soldered. A three-way square, made by nailing twi) 5-inch boards of convenient length at exact right angles and fastening them to a work table, greatly facilitates getting each angle right at the first trial. 
Tinsmith's snips and square-nosed pincers, for cutting and bending the angle tin.

A soldering outfit, - soldering iron and fluid or resin, and some safe and convenient means of heating the iron.

If the tools are not at hand, the frames may be made at the tinsmith's ; or often a handy janitor can make them in his shop, or a good-natured one may let the boys use his tools, if they are very careful to leave every tool in its place and the shop in better order than they find it.

Dimensions for the frames are given in the table below. "Threecross" tin is heavy enough for all smaller sizes, and "four-cross" for

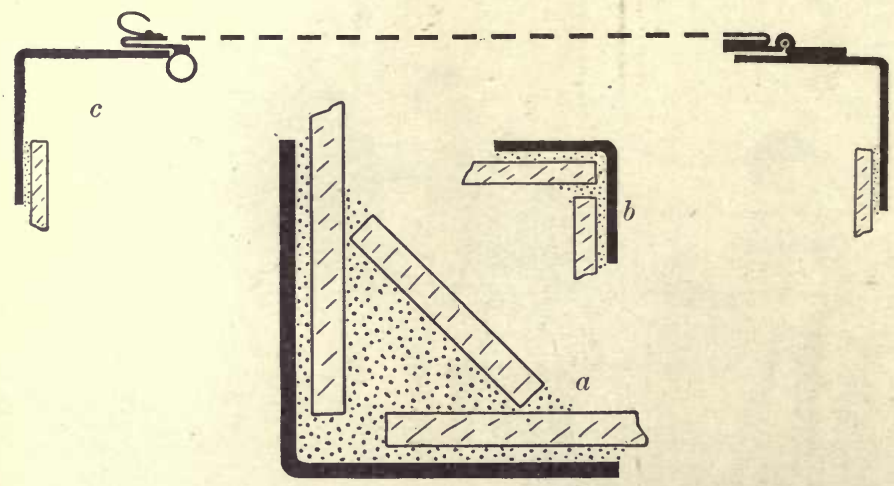

Fig. 7. Showing relations of frames, cement, and glass in aquaria, of different sizes

$a$, for the larger sizes; $b$, for smaller sizes; $c$, arrangement at top and cover.

Black lines, metal; flashed areas, glass; dotted surface, cement

aquaria between 15 and 24 inches in length. The more slender the frame the trimmer and better the aquarium appears. For aquaria-dimensions in inches:

$5 \times 7 \times 4$ to $8 \times 10 \times 5:$ use $\frac{3}{8}$-inch angle tin.

$10 \times 12 \times 6$ to $8 \times 10 \times 5:$ use $\frac{1}{2}$-inch angle tin.

$15 \times 12 \times 8$ to $18 \times 15 \times 9:$ use $\frac{8}{4}$-inch angle tin.

$20 \times 12 \times 9$ to $24 \times 18 \times 12$ : use 1 -inch angle tin (around base, and if the work is carefully done, $\frac{3}{4}$-inch, or even $\frac{1}{2}$-inch, is strong enough for the rest).

Fig. 7 gives the relation of cement to the angle tin and the glass for large and small sizes. In the larger sizes the strip of glass, with the 
mism of cement behind it, strengthens the angle and also protects the water from a large surface of cement, which might yield up enough of ts lead to injure delicate animals.

Lids may be made either of perforated tin, with the edges turned over to stiffen them, or of wire screen fastened to either wooden or tin frames. 'The lids will be needed when the aquaria are used as insect-breeding cages and for feeding tests with toads, frogs, or other insectivorous aniunals. The hinges of brass or tin should be soldered to the frames when they are made. These points are sufficiently illustrated in Fig. 7.

Aquarium cement. The formula used by the United States Fish Comunission is : by weight 6 parts whiting, 1 part red lead, 1 part litharge; unix thoroughly while dry, and as required for use make into a stiff jutty with pure linseed oil. The oil must be free from any trace of idulteration with fish oil, or the cement is likely to remain soft and sticky. Do not expect the cement to "set" hard. If it did this, the "xpansion and contraction, under changes of temperature of metal and. ylass with which it is associated, would be likely to crack either the glass or the cement. It should remain as a tough gum, solid enough to support the pressure of water and pliable enough to accommodate itself to changes of temperature.

Lay the right amount of cement in all the angles of the frame with " putty or case knife, and press the glass for bottom, sides, and ends into place in the order named; smooth all joints on the inside, removing sny extra cement; spring pliable green twigs against the sides and ends to hold them in place, and smooth up the outside joints. It is preferable to paint the frame, letting the paint dry well, before setting the glass. A coat of spar varnish along the angles on the inside will protect the cement from contact with the water and also insure against leaks. l.eaks seldom occur, but if they do, mark them, dry the aquarium thoroughly, press a little cement into the cracks, and give another coat of spar varnish to the inside corners. After drying for a week, the aquarium is ready to use.

Nore. It is easier to avoid daubs of cement than to clean them off the §lass. The same applies to hands, clothes, tables, floors, and everything else. $\Lambda$ class in aquarium-making can easily daub themselves and the Iaboratory s) as to disgust all concerned with the work; or, by the use of a few news$r$ apers, can avoid all this to the satisfaction of everybody. Since the cement contains lead, it is better not to let it come into contact with the skin more than is necessary. Stir, mix, and lay it with proper tools. 


\section{THE LABORATORY BOOKSHELF}

('The asterisk indicates books of special importance for this course)

Nothing so inspires to good work on a subject as knowledge of what is already known about it; hence this reference bookshelf is the vital basis of the whole course. 'The present list is intended to be merely suggestive, and should be freely moditied to suit local problems and diligently kept up to date. On every subject you study obtain the latest word from the extension department of your state imiversity, your agricultural experiment station, the United States Department of Agriculture, Bureau of Education, Burean of Fisheries, Smithsonian Institution, and local, state, and national health departments.

\section{Insects, etc.}

Donxe. Insects and Disease. Emerton. Common Spiders. Holland. Butterfly Book. Hollaxd, Moth Book.

Howa RD. The House Fly - Disease Carrier.

*Kellocid, Anerican Insects.
Mitchell. Mosquito Life.

* Saunders. Insects Injurious to Fruits.

Scunter. Everyday Buttertlies.

*Suıtr. Our Insect Friends and Enemies.

\section{Birds}

*BatLEx. Handbook of Birds of the Western Bird Guide (for west of Western United States.

*Chapmax. Handbook of Birds of Eastern North America.

*REev. Bird Guicles. Part I, Water and Gaine. Part II, Land and Song. the Rocky Mountains).

*'Traftox. Methods of Attracting Birds.

WEED and DeArBors. Birds in their Relation to Mall.

\section{Trees - Forestry}

*Apqials. Trees of the Northern United States.

*Grene. Principles of A puerican

SAmetert. Manual of the Trees of North America. Forestry.

\section{General Botany}

*Berges and Davis. Principles of Botany.

Britron and Brows. Illustrated Flora of Northern United States. *(iliar. New Manual of Botany.

\section{Fungi}

Atrinsox. Mushrooms.

*Cons. Bacteria, Yeasts, and Molds in the Home.

*Duggar. Fungous Diseases of Plants.

Gonimy. A Laboratory Course in Bacteriology.
*Osterhovt. Experiments with Plants.

*Stevens. Illustrated Guide to Flowering Plants.

*Jondax. General Bacteriology.

Mcilvaive and Macadam. One Thousand American Fungi.

Russell and Hastings. Experimental Dairy Bacteriology. 


\section{Agriculture}

*Burkett, Stevens, and Hill. *Hopkins. Soil Fertility and PerAgriculture for Beginners.

Cyclopedia of American Agriculture. Vol. I, Farms.

*Vol. II, Crops.

*Vol. III, Animals.

Vol. IV, Farms and the Commumanent Agriculture.

*King. Farmers of Forty Centuries.

*Plumb. Types and Breeds of Farm Animals.

Wilkinsos. Practical Agriculture. nity.

\section{Animals - General Zoölogy}

"Linville and Kellex. General Siraler. Domesticated Animals.

Zoölogy.

\section{Fishes}

*Jordax and Evermaxy. American

Food and Game Fishes.
* United States Fish Commission. Manual of Fish Culture.

\section{Miscellaneous}

*Allex. Civics and Health.

DARW1N. Earthworms.

*Darwin. Naturalist's Voyage around the World.

*DAvenport. Principles of Breeding.

Dickerson. Frog Book.

Ditmars. Reptile Book.

iribson. Sharp Eyes.
*Hodge. Nature Study and Life. ${ }^{1}$

*Hornaday. American Natural History.

Leввоск. Ants, Bees, and Wasps.

Newhalt. $\left\{\begin{array}{l}\text { Shrubs. } \\ \text { Trees. } \\ \text { Vines. }\end{array}\right.$

Wallace. Malay Archipelago.

WieEler. Ants.

\section{Journals}

Igricultural Department publica- *American Forestry. tions.

*Experiment Station Record.

*Monthly List of Publications.

*Weekly News Letter.

*Journal of Agricultural Research.
* American Journal of Public Health. *Bird Lore.

*Journal of Economic Entomology. *Journal of Heredity.

*School Science and Mathematics.

1" Civic Biology" presupposes a knowledge of the problems stated in this look. 


\section{CHAP'TER III}

\section{THE INSEC'T PROBLEM}

Work of insects in nature. Geologically the present is known as the age of man, but zoölogically it is the age of insects. There is but one species of man, - Homo sapiens, while over 300,000 species of insects have been described, and it is estimated that in all there are not fewer than $10,000,000$ species in the world. The number of individuals of any one species may cover the forests and fields or even darken the skies over large areas.

Compared with other animals insects are small, having. developed, instead of size, refinement of mechanism and organization and great reproductive power. This latter often surpasses belief, but since it shows us the importance of natural checks to the increase of insects, it must form one of the central features of our insect lessons. A pair of San José scales could produce progeny in a season to the number of $3,216,080,400$. A single female plant louse might give origin to $9,500,000,000,000$ in a season (Forbes). The house flies of a city, if all the young survived and could find food, would bury it before the people could escape (Jordan). We are led from these facts to see the importance of insectivorous animals; for example, it has been estimated that the birds of Nebraska consume daily 86,000 bushels of insects during the warm months (Brunner).

No insects are used for food by civilized man, and it is remarkable that in so great a number of species so few produce anything of value to man. Silk, honey and beeswax, shellac and cochineal, and cantharides virtually complete the 
list of important products. Many insects are of great value to man indirectly, because they destroy other insects. The greatest service, however, which they perform in nature consists in effecting cross-pollination of flowers, and many of our most valuable fruits and flowers would be infertile without their aid. Fortunately the honeybee is the most valuable insect for this work.

In contrast to the value of these few insects, however, is the great injury done by others in their attacks upon man and animals, causing annoyance, suffering, and often disease. The majority feed upon plants and thus compete with man, directly or indirectly, for the vegetable food supply of the world. Recent estimates of the Department of Agriculture divide this damage as follows:

Anvual Loss of Agricultural Products caused by Insects in United States

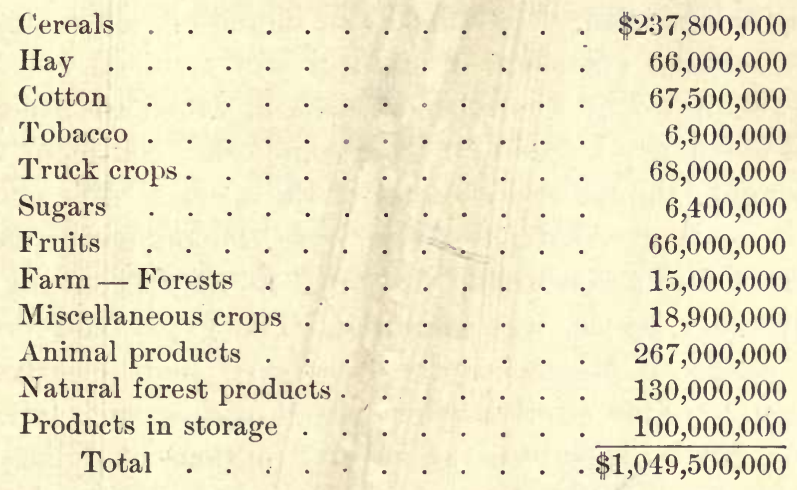

These estimates are conservative and relate to purely agri( ultural losses. They do not include the damage caused by (ommon household insects, - clothes moths, carpet beetles, roaches, ants, and several human parasites, which entail great labor and expense in fighting them. The annual cost of wire 
screen to keep flies and mosquitoes out of houses amounts to at least $\$ 12,500,000$ annually. Nor does the above estimate take account of the depreciation of property, loss of time, and cost of diseases like malaria or yellow fever, known to be carried by certain mosquitoes, infantile paralysis, carried by the stable fly, and typhoid, cholera infantum, dysentery, and many other filth infections which are transmitted by common house flies. With these additions it is safe to say that insects annually levy a tax of not less than $\$ 1,500,000,000$ on the people of this country, and this in addition to the annoyance and suffering which they cause to human and animal life.

Work for control of insects. Since insects possess such power of rapid increase, and since this increase is limited mainly by food supply, natural enemies, and artificial means of destruction, any relaxation of natural or artificial checks tends to permit insects to increase up to the limit of food supply. With these checks entirely removed, insects would take practically the entire agricultural product in an incredibly short time.

The relative efficiency of natural and artificial checks is well exemplified by a number of cases in which an insect has been accidentally introduced from some other continent without bringing the natural enemies of the species. The cottony cushion scale of Australia swept over the orange groves of California like a consuming fire until its natural enemy, the Vedalia lady beetle, was imported. The gypsy and browntailed moths in Massachusetts show even more clearly how ineffectual human effort is when pitted against such forces of nature. After expenditure of several millions of dollars and twenty years of futile effort we are brought to realize that our best hope of permanent success lies in the importation of natural insect enemies. The San José scale, accidentally introduced from China, is now rapidly exterminating fruit orchards and ornamental trees over almost the entire country. In 1901, Dr. Marlatt succeeded in importing a Chinese lady 
beetle (Chilochorus similis), which is efficient in keeping the scale in check in its native home. It has not as yet proved, lowever, an equal success in America.

Other cases in point are the Hessian fly, cabbage butterfly, codling moth, elm-leaf beetle, imported currant fly, and many nore; and these illustrate the almost irresistible power of an insect species when supplied with abundant food and relieved from its natural enemies. They also emphasize the need of watching all ports of entry with extreme care to prevent such expensive importations.

All work with insect enemies reveals the absolute necessity of the general dissemination of a knowledge of the problems involved. One ignorant or careless importation may cost the whole country irreparable loss. A neglected garden or orchard is often a menace to an entire neighborhood. For one individual to try to hold such natural forces in check is discouraging and well-nigh hopeless. In the successful handling of such problems all members of a community must unite. Each must know and do his duty and his part. If one person cannot or will not prevent his trees from breeding insect pests that damage his neighbors, he should promptly cut them down and burn them up. This law of nature applies with special force to the intelligent protection of birds and other insectivorous animals, in which all members of the community should unite. 

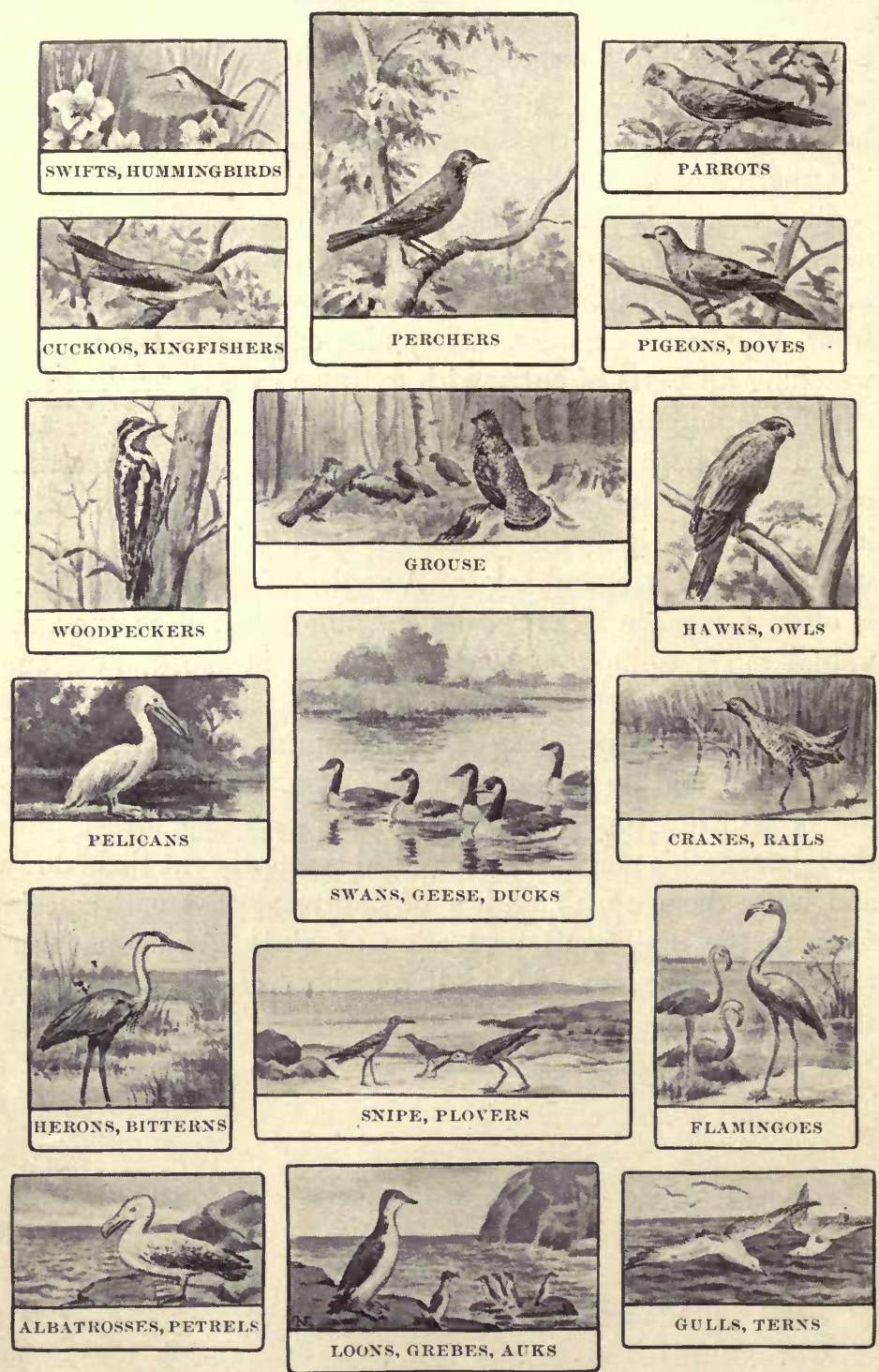

Fig. 8, Orders of American birds, with habitats 


\section{CHAPTER IV}

\section{BIRDS}

In the air swallows and swifts are coursing rapidly to and fro, ever in pus'suit of insects, which constitute their sole food. When they retire, the nighthawks and whip-poor-wills will take up the chase, catching moths and otber nocturnal insects which would escape day-flying birds. The flycatchers lie in wait, darting from ambush at passing prey, and with a suggestive click of the bill, returning to their post. The warblers, light, active creatures, flutter about the terminal foliage, and with almost the skill of a hummiıg bird, pick insects from leaf or blossom. The vireos patiently explore the undersides of leaves and odd nooks and corners to see that no skulker escipes. The woodpeckers, nuthatches, and creepers attend to the tree trunks and limbs, examining carefully each inch of bark for insects' eggs ant larvæ, or excavating for the ants and borers they hear at work within. On the ground the hunt is continued by the thrushes, sparrows, and other biris, who feed upon the innumerable forms of terrestrial insects. Few places in which insects exist are neglected; even some species which pass their earlier stages or entire lives in the water are preyed upon by aquatic bir ls. - Chapman, "Bird Life," p. 6

As planned for this course, bird study begins with the opening of school in September and continues throughout the year. No subject better repays attention. On the esthetic side it presents infinite possibilities for the discovery of beauty in grice of form and action, in harmony of color, and in variety of song. From the standpoint of science and pure natural history, no field is richer, - variety in size and form, instincts and intelligence, protective and recognitional coloring, geogruphical distribution, pathways of migration, and even the geslogical record showing the evolution of birds from reptiles.

Birds and insect destruction. In order that universal and ad quate protection may be extended to all valuable species, every member of the nation should know what the birds are 
doing for the common gool. From an earlier chapter we have learned of the enormous tax which insects impose. The chief economic service of birds consists in the destruction of insect pests, and our national bill of insect damage, $\$ 1,049,500,000$, may be roughly taken as a measure of our deficiency in bird life.

Reed estimates that with 5 birds to the acre and 100 insects daily per bird, the birds of Massachusetts require for food each day during five months of the year, 2,560,000,000 insects; or, allowing 120,000 insects per bushel, 21,000 bushels. The work of winter birds and migrants, he thinks, amounts to nearly half this number for the colder months, in destruction of hibernating insects and eggs, larvæ and pupæ. A chickadee has been known to eat from 500 to 4000 eggs in a single day. For Nebraska, Professor Lawrence Brumner's estimate is as follows :

'Taking as a basis for our estimations the figures given in my leaflet entitled A Plea for the Protection of Our Birds, we would have about $75,000,000$ birds, or approximately $35,000,000$ to $40,000,000$ pairs that nest here (Nebraska). Should each pair of this large number rear four young, there would be required a sufficient food supply for from 140,000,000 to $160,000,000$ young birds. If, as we suggested in that paper, a single bird requires on an average 25 insects per day, the enormous number of 4,000,000,000 insects, or 35,000 bushels of 120,000 insects, would be required each day to feed the young birds alone. But young birds need much more food than do old ones, and we should at least double this quantity for the young birds. Then to this must be added that required by the parent.birds themselves while taking care of the young, making a grand total of 86,000 bushels, or 107 carloads of 20 tons each, provided we allow 50 pounds as the weight of a bushel.

Feeding tests and the actual observation of birds from daylight to dark have given us our most valuable data with reference to the destruction of insects by birds.

A female wood pewee from 4.30 A.m. to 6.52 P.M. was seen to catch 568 insects. A brooding bird of the same species from 4.46 A.M. to 6 P.M. caught 208. The first was feeding her nest; the second merely catching for herself. 
A pair of house wrens were observed to feed their nest of five young - five days old - 230 insects, most of them large cabbage caterpillars; ti ne, 4.24 A.M. to 7.38 P.M.

A pair of orchard orioles, from 4.30 A.м. to 6.10 P.M., were observed to feed the nest, containing two nearly full-fledged young, 69 times, probably several insects at a feeding.

A pair of phobes, from 4.20 A.x. to 7.12 1...1., fed two young 266 times. A young phobe just out of the nest required as high as 200 gcod-sized grasshoppers per day. ${ }^{2}$

A young robin about three weeks old ate 70 large cutworms on one day, and two and a half ounces of earthworms the next. A young scarlet, tanager ate 150 cabbage caterpillars, besides other food, in a day. $\Lambda$ cuckoo on the tenth day at, 42 grasshoppers, 60 wolly caterpillars, and 39 cabbage cater\}illars. On th's twentieth day the same bind consumed 62 woolly cater] illars, 123 calibage caterpillars, and 43 grisshoppers,

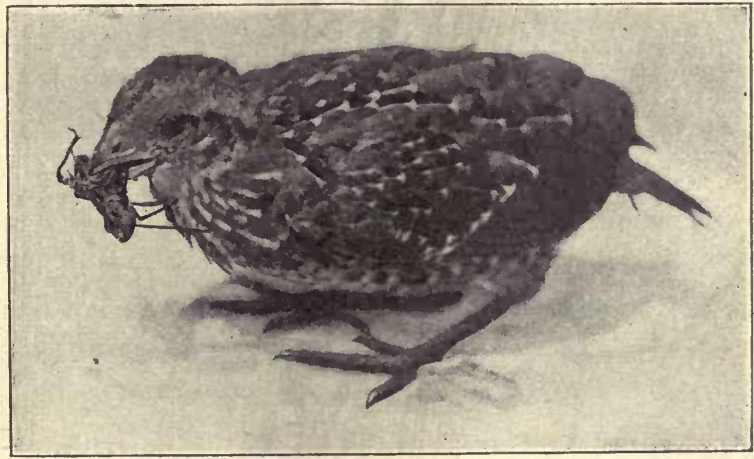

Fig. 9. Bobwhite chick three weeks old. Usual occupation Photograph by the author an ounting to three ounces of food. An adult cuckoo ate 225 cabbage caterpillars, or 150 large woolly caterpillars, anounting to about five ounces of food daily. (From feeding tests by Andrew J. Redmon.)

From such actual data as these we learn that the estimates given abuve are conservative. Much more accurate observation is required, however, before entirely reliable estimates can be made.

Outdoor laboratory work. This should extend throughout the year, and also to combine problems requiring continuous

${ }^{1}$ All the above data are taken from reports of students of the Indiana U1 iversity Summer School, Winona Lake, Indiana, for 1905 and 1906 (O. P. Dellinger in charge of class). 
observations upon birds, insects, trees, fungi, weeds, native flowers, and common plants, elaborate the following plan as early in the year as possible. Let two students combine upon the same tract of land, in order to secure greater completeness of the practical work, but each should make his own field charts in as careful detail as if he were working the tract alone.

Select some readily accessible piece of land of limited area. On a farm, the home lot with the dooryard, garden, orchard, and grove will be most suitable. The village lot of an acre or two is exactly adapted to this work. In an open city the home lot, if well planted, may prove the best selection we can make, but probably the residential block in which the home stands will provide necessary variety and scope. For the crowded city we must have recourse to public parks and gardens, and to accessible tracts in the. suburbs, for the study of which definite permission can be obtained. The tract should present, if possible, a variety of natural features, - hill, meadow, ravine, brook or edge of pond, and especially variety in plant forms, - lawn, garden, orchard, field, meadow, woods. A variety of shrubbery and low-growing trees makes a tract preferable to one with very tall trees, which are difficult and unsatisfactory to work. By properly dividing the neighborhood among the class, however, all the important features of the locality may be covered, and this will add interest and completeness to the work as a whole.

As a preliminary, draw an outline map to convenient scale, and with due regard to points of the compass. Within this, first sketch in standard contour lines and indicate location of water, marsh, swamp, rock outcrops, and all buildings and superficial subdivisions, - lawns, gardens, orchards, fields, pastures, woods.

We are now ready to plot the details. Count and locate all the trees, vines, and shrubs, and indicate clearly the areas covered by different plants or crops. Locate all birds' nests and 


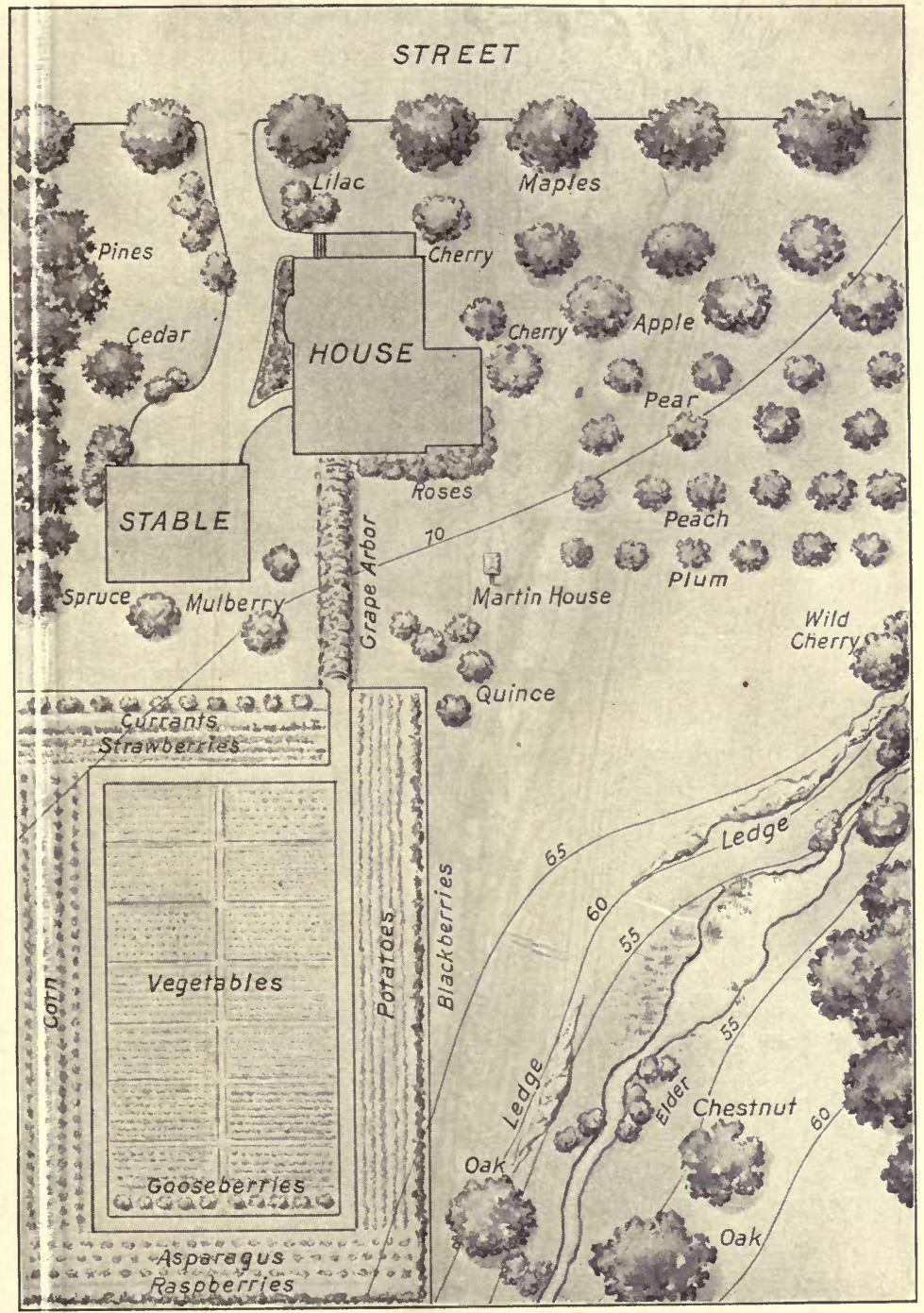

Fig. 10. An ideal bird-study tract 
determine the species as far as possible, indicating them by some device, like the initial letter of the name, on the plat. This work should be completed as soon as possible after the leaves fall in November. By inquiry it may be possible to locate nests that have been "collected" or destroyed by storms during the summer. This will give a "census" of the bird population of the tract.

The main question which this investigation is designed to answer is, Are there enough birds in the area to hold the insects in check? To aid in answering this question examine the district minutely for evidences of insect depredations, and make a list of important insect pests found upon it. Examine at least 100 of each variety of apple, pear, quince, possibly peach and plum, and tabulate the percentage of the different fruits injured by insects. Gather similar data, if possible, for the earlier fruits, - strawberries, gooseberries, currants, - and also for the various garden vegetables and other crops grown in the tract. Add to the bill of damage the cost of materials, apparatus, and labor expended in fighting insects. On the other side of the balance sheet record with equal care any injury caused by birds. Note what kind of birds caused the damage.

From all you know and can learn of bird life try to discover what special features attract the birds to nest on the tract, water, food, suitable nesting sites and materials. Suitable and accessible water for drinking and bathing will be found to be one of the main factors, and food supply and absence of enemies, other elements. Never lose an opportunity to see what a bird is doing, - what it is searching and finding for food. Clear observation on this point seldom fails to answer the question, Why is the bird here?

Study with equal care all the elements which can account for a scarcity of birds or the absence of particular species. What necessities of bird life are lacking? What natural 
tnemies of the different species are present? Much of this side of the problem will be worked out raturally in connection with nesting habits, the study of nest building, and the fate of the different nests in the spring.

Pay particular attention to the bird-food plants of the area with reference to abundance of food at different seasons. Note the condition in this respect for the different months. Is the area stripped of available food by the time robins and bluebirds have migrated in the fall? May this help to explain bird migrations?

Note in detail what pro$v$ isions have been made in your district to supply the necessaries of bird life, bird houses, drinking and bathing fountains, planting of food trees. What is done to protect the birds from enemies? What influence have these provisions exerted on the bird population as compared

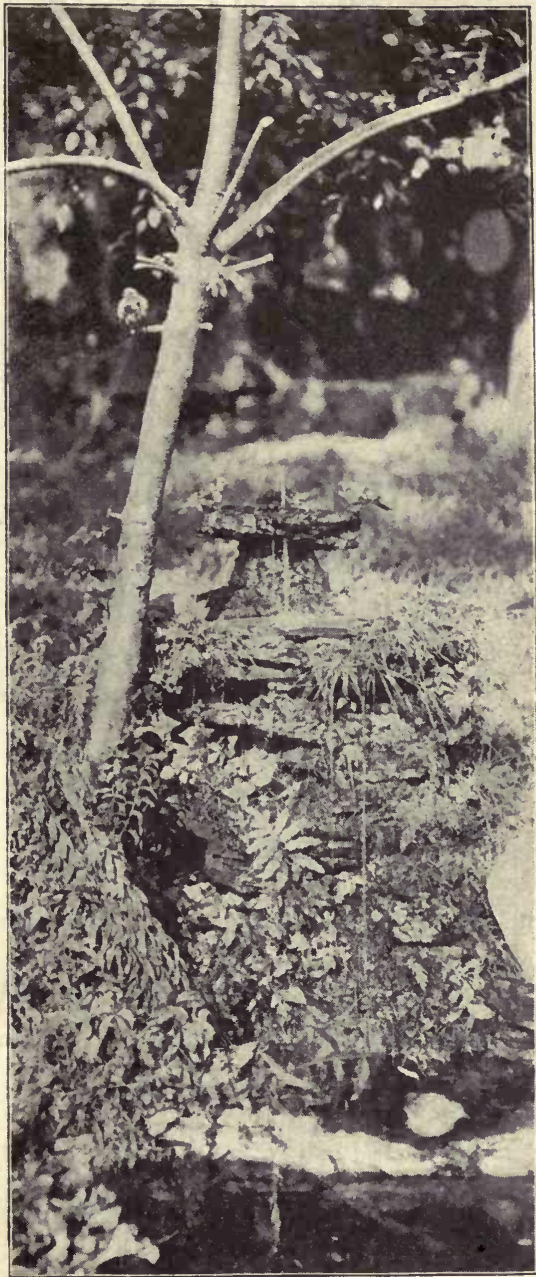

Fig. 11. Bird fountain. Natural rocks laid in cement with deep chinks filled with soil and planted with mosses, ferns, and wild flowers

Photograph by the author 
with neighboring districts in which no such provisions are made? What is the practical value of such work as shown by your account of insect injury? of losses caused by birds?

Other important lines of bird work relate to destruction of weed seeds and the control by owls, hawks, and shrikes of noxious mammals, - mice, moles, rats, gophers, etc. Keep these matters in mind throughout the year while doing the field work.

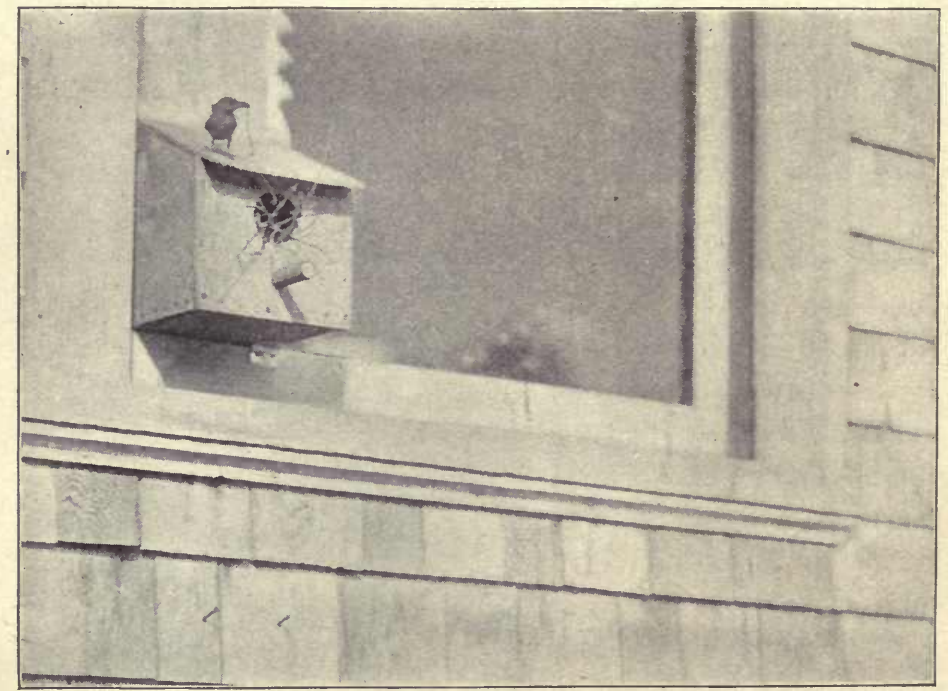

Fig. 12. Bird house for study of home life; windowpane is back wall of house Photograph by the author

The birds in your district will change during different seasons. During the fall migration the "summer residents" will leave for the south, and many species whose breeding range is farther north will migrate through the territory. These species may be designated as "transient visitants." They migrate by us to the northward in the spring and southward in the fall. After settled cold weather begins there will be left the " permanent residents," - about thirty-six species for the latitude 
of New York (Chapman), - and "winter visitants," seventeen species of birds that come from the north and spend part or all the winter.

Make provision for the winter birds. Suet and a piece of fat pork may be tied to a branch of a tree, with a tray also fastened to the trunk, in which seeds (millet, corn, sunflower, pumpkin, or squash) and cracked nuts (butternuts are especially good) may be kept, and on the ground close by a pile of chaff or loft sweepings. The purpose of this is to attract all the winter birds within range of easy observation. The tray may be attached to the living-room window sill, if on the south side of the house, an attractive branch may be fastened at the side of the window, and the heap of chaff may be put under it, close to the house. This latter must be kept free from snow through the winter.

The work of the year is intended to yield a complete picture of the life and work of the birds in your district. At stated intervals your observations should be carefully written up under various heads. We suggest the following:

September - My Bird Study Tract (giving chart and descriptions of natural features).

OCtober - To what Extent do Birds prevent Insect Depredations?

November - The Fall Migration of Birds.

December - Winter Provision for Birds, - Permanent Residents aud Winter Visitants.

February - The Work of our Winter Birds.

March - My Plans for Bird Work this Spring.

APrIL — Birds' Nests; Nest Building; Nesting Sites of Different Slecies; Materials.

MAY - Bird Songs and Notes, and what they mean.

MAY - Feeding Habits of Birds.

MaY - My Observations on Feeding of Young; Amount of Insect Food.

JUne - Summary and Results of my Bird Study for the Year. 
Other more general topics, like the following, are suitable as assignments for different members of the class to work out and report upon toward the close of the year:

The English Sparrow in the Locality _ may be subdivided into: Relations to Native Birds; Damage cansed by; Methods of Extermination.

The Life and Work of the Bluebird. (Substitute the name of any other common bird, if desired. It would be well if each member of the class could devote special attention to working up the life of some important species.)

By a free interchange of notes these reports may be made more complete, and in this way each is made the summary of the work of the whole class upon the topic. We may vary and enliven the reports by casting them in the form of debates about birl problems that are in dispute in the neighborhood. For example:

liesolved, that the robin merits protection. (Sulstitute other birds.)

Resolved, that the crow should be exterminated.

Resolved, that there should be a bounty on hawks and owls.

Resolved, that the bolowhite should be placed on the protected list for a period of ten years.

Resolved, that spring shooting of waterfowl ought to be prohibited by law in all states.

Resolved, that active measures be taken to establish a preserve for the breeding of grouse and waterfowl in this township.

Resolved, that it is better policy to preserve native species than to import grouse from other countries.

Resolved, that the killing of song and insectivorous birds for millinery purposes is legitimate.

Resolved, that a person who allows his cats to kill birds should be subject to the same fine as if he killed them himself.

Resolved, that a law be passed making owners of cats responsible for the birds they kill.

Resolved, that it is an unwarranted waste of bird life to make egry collections.

This list might be extended indefinitely.

Birds are divided popularly into " soft-billed," eating mainly worms, insects, and berries; and " hard-billed," feeding upon 


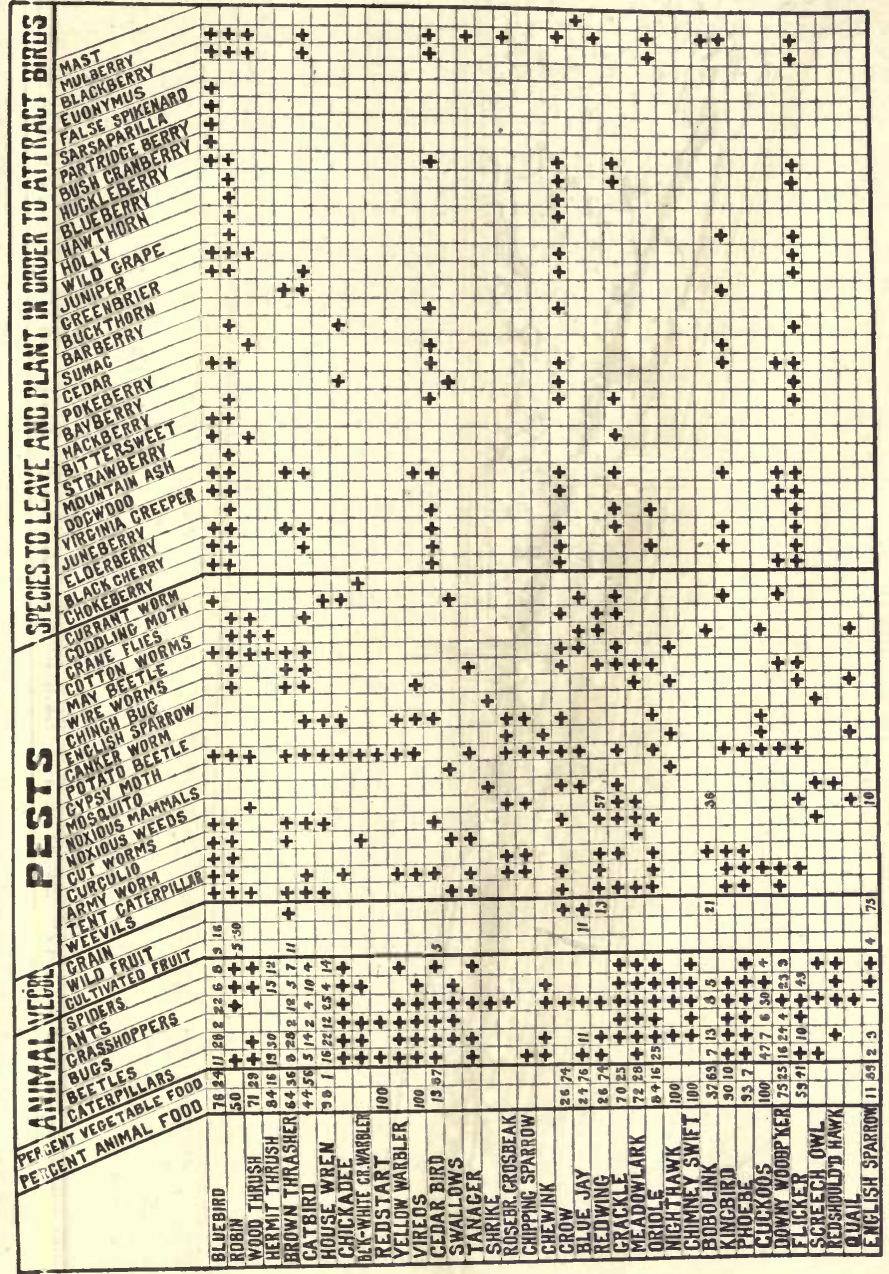

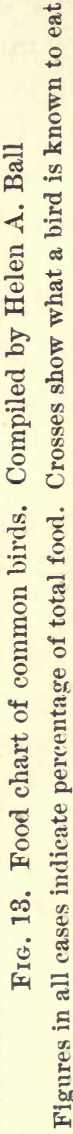


seeds. Both classes, however, feed the young mainly on insects. Our gardens, fields, and roadsides are weedy enough, but who can imagine what they would be, were not thousands of tons of weed seeds destroyed annually by the sparrows, bobwhites, doves, larks, blackbirds, and others. About fifty species of birds are efficient weed destroyers. Compare and draw a few typical hard and soft bills to fix this distinction. Beal has estimated that the tree sparrows alone in the state of Iowa destroy annually about 875 tons of weed seed. Are both weeds and seed-eating birds abundant in your bird tract?

Hawks, owls, and shrikes render service in destroying noxious mammals. Are the mice, rats, field-mice, or gophers numerous in your district, and what amount of damage do they cause by eating grain or girdling trees? Dr. C. Hart Merriam has estimated that a bounty act on hawks and owls, during its operation in Pennsylvania for a year and a half, cost the state not less than $\$ 4,000,000$.

The accompanying food chart shows about all we know of the foods of many of our commonest species. The blank squares in the chart indicate generally deficiencies in observation, and not that any particular bird does not eat any particular insect; hence they are in reality the most interesting part of the chart because they suggest further study. Observe the birds in your district, or, if you have a young or disabled bird, make definite feeding tests and record the results in your food chart. The chart will thus enable you to feed intelligently many birds that come to hand, and also to add to our knowledge of the subject. The probable diet of any bird not named on the chart may be judged from that of its near relatives. ${ }^{1}$

1 The authors would be grateful if those who make such feeding tests would send them any data secured. 


\section{CHAPTER V}

\section{METHODS OF BIRD STUDY AND SPECIAL PROBLEMS}

I have no doubt, therefore, that the wild pigeon is still with us, and that if protected we may yet see them in something like their numbers of thirty yє ars ago. - Johx Burroughs, 1906

In order to do the work outlined in the last chapter we must know the birds. It is supposed that practical acquaintance with the commoner species has been begun in the nature study of the grades. The present course is planned as an "advinced," and, so far as school life is concerned, a final year of bird study, which shall organize and complete previous knowlerlge, work out more thoroughly as practical problems the vilues and uses of different species, and help to answer the question, "How may a community make the most of its bird life?" If we are to have intelligent progress, every one must know these things, because the ignorance of one may vitiate the best efforts of a community.

After completing plans for individual bird-study tracts, discuss in the class what species merit a place in the year's course. Each member may present a list including his choices, and from these the official list for the year may be selected. The lists should be changed somewhat from year to year, as conditions change and emphasis is shifted from one to another group of problems.

In this connection, as well as in the general problem of organizing our knowledge of birds, scientific classification is of great assistance. Scientific books have described for the w orld 12,500 species of birds, and of this number 768 belong to North America. This large number of species means that 

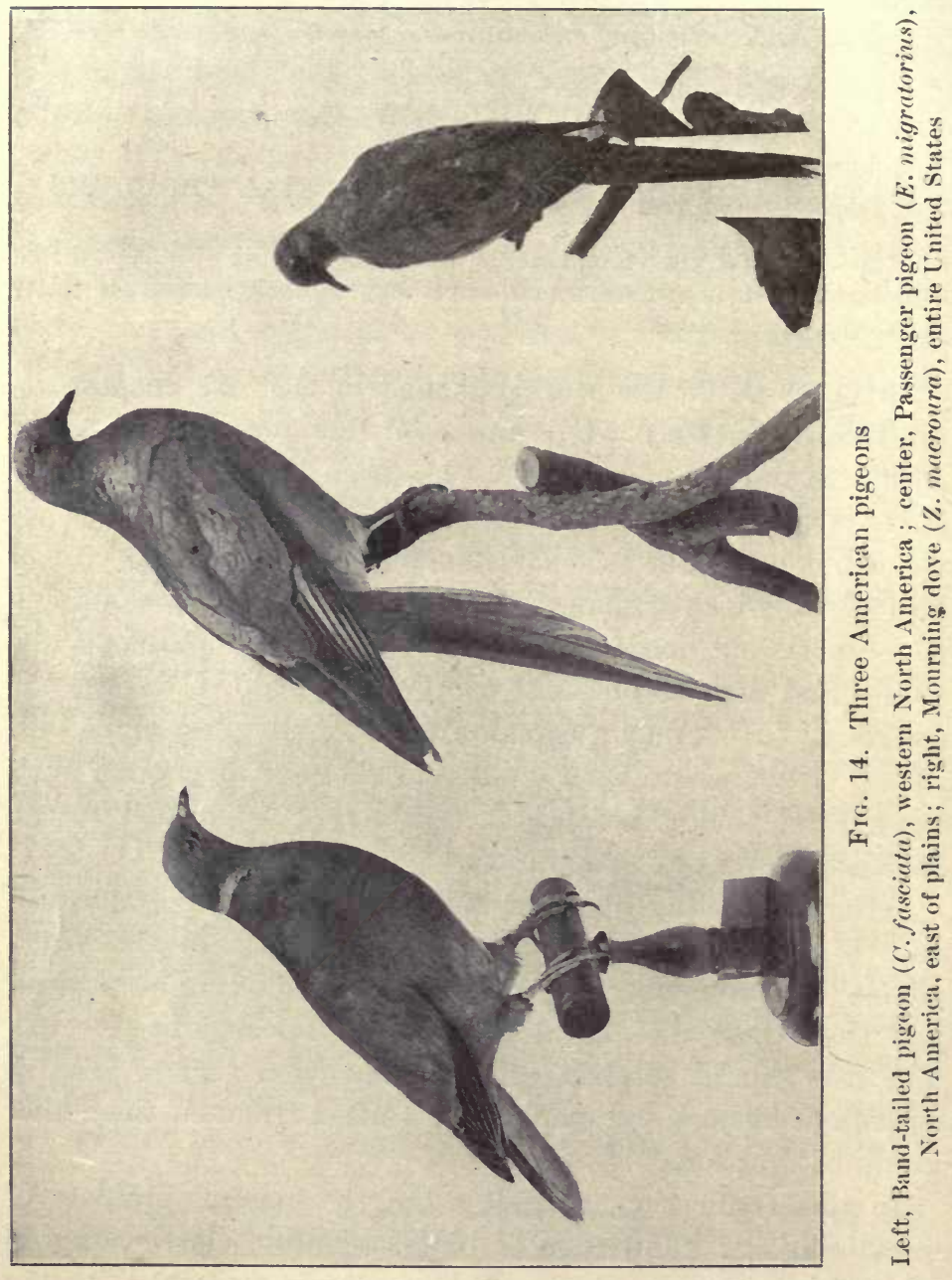
birds have become differentiated to fit all sorts of environments, - air, water, marsh, prairie, and forest. Those of similar activities, like machines built and adjusted to their work, have come to have similar structures, - of body, wing, foot, and bill. Discovery of these adjustments will add fresh interest at every twn and increase respect for scientific bird study. Fig. 8 is designed to fix in mind the fundamental relations of the different orders to environment. Common names often vary in

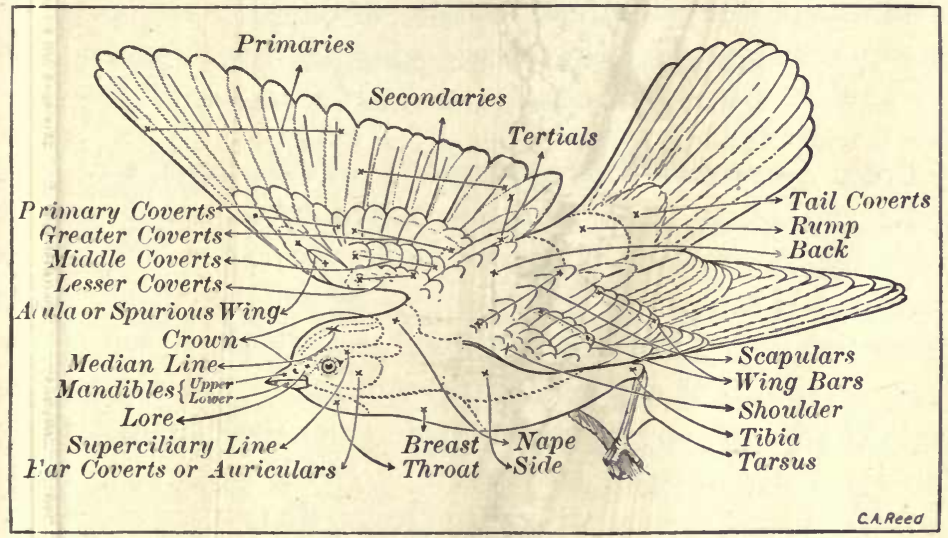

Fici. 15. Topography of a bird

C. A. Reed

different parts of the same country. Scientific names are the same for all languages the world over, and this is the time to learn them, if they are ever to be remembered.

Again, in order to describe birds quickly and accurately an $l$ as a help to seeing them properly - we must learn to name the external parts, the so-called "topography" of a bird. Tl e terms in Fig. 15 are, in the main, self-explanatory. The "primaries," "secondaries," and "tertials" are attached respec tiv ely to the hand, fore-arm, and upper-arm bones of the wing.

The following list, suited to central New England, is given $\mathrm{m}$ rely by way of suggestion, as if the writer were a member 
of the class. Several species not now found in the territory are included because they are related to problems which every intelligent member of the nation ought to be helping to solve.

Order Pygopodes ("rump-footed") — diving birds. The birds of this group enliven our waters, and the loons give us some weird music. While anglers may object to sharing the fish with them, the main question is whether we prefer to see them on our ponds and lakes or on the ladies' hats. The two common species within our territory are:

Pied-billed grebe-Podilýmbus pódiceps.

Loon; great northern diver-Gávia ímber.

Order Longipennes ("long-winged") - gulls, terns, etc. The gulls and terns have required active protection in recent years to prevent their extermination by the egglers and plume hunters. What would our seascapes be without them? The protection which has been accorded these birds is one of the most encouraging signs that values other than mercenary are beginning to be appreciated. Aside from their beauty, these birds are much-needed scavengers of our harbors and coasts, and the inland species are most efficient destroyers of insects. Two common types are:

\section{Herring gull — Lárus argentátus. \\ Common tern - Stérna hirúndo.}

Order Anseres (anser, "a goose") — ducks, geese, swans. The problem of our waterfowl is nearing its final stage. ${ }^{1}$ The vast breeding grounds in the Northwest are now open to sportsmen and settlers, and when the wild fowl have been exterminated from these, as they have been from their more southern ranges, the work of destruction will be complete and final. It is high time this is appreciated as a national problem, and effective measures taken toward its solution. The first step,

${ }^{1}$ See H. K. Job, Country Life in America, April, 1906. 
it seems clear, should be total prohibition of spring shooting from Florida, the Gulf, and Mexico to the Arctic Ocean.

Next, we should offer, for a period of years at least, complete protection and every inducement for all birds of this order to breed throughout the United States, wherever a pond, marsh, or lake can be guaranteed as a safe and permanent "preserve." All kinds of waterfowl quickly learn where they are safe, and if unmolested become tame and breed in great numbers even in small ponds. Is there a chance for a preserve in the neighborhood? The wood duck is already on the verge of extinction and should be absolutely protected in every stite. Nests discovered in the neighborhood should be guarded from disturbance. In New England, for a term of years, let the broods go unmolested even in open season on the chance that mire may return to breed the following spring. On the murderous and stupid principle, "If I don't shoot it, some one eke will," the last wood duck will fall to the ground and the rase of our most exquisite waterfowl be extinct. Exterminaticn of a valuable species is not only a national calamity, but a national crime, - a piece of monumental stupidity and folly as well. Let us change the above principle to read, "If I have the decency and sense to spare, some one else may." To the problem of increasing and protecting our waterfowl and reistablishing them throughout their native breeding ranges should be brought the best energies of the class. All members of the order should be considered in the light gained from a study of the following types:

Wrod duck - Aix spónsa.

Pintail - Dáfila acúta. Canada goose-Bránta canadénsis. Trumpeter swan-Ólor buccinátor.
Mallard duck - Ánas platyrhýnchos. Whistling swan-Ólor columbiánus.

Order Herodiones (herodios, "a heron") - herons, storks, etc. These birds of our marshes and swamps are mainly of æsthetic int erest and value, and althongh they eat a few fishes, frogs, and 
snakes, they are, on account of this value, accorded the protection of the law in Massachusetts. As examples we may take:

Night heron - Nycticorax névius - a generally common species.

Snowy egret-Egrétta candidissima - a Southern species, but one which ought to be known to every American North and South, in order to save it from extermination by the milliners.

Order Limicola (limus, "mud"; colere, "to dwell") - shore birds. Many of these birds of our marshes and muddy shores, wet brook beds, and upland pastures, merit protection on account of their valuable service as insect destroyers, and also because of the imminent danger of extermination in which several of the best species stand. 'The argument given for the wood duck applies with more than double force to the woodcock, because the former produces from eight to fourteen eggs to the woodeock's four. 'The same preserves would serve for the waterfowl and shore birds as well. Several of the plover are in great need of protection, but the five species that follow are possibly all we can_begin with, and will serve to illustrate the problems of the group:

Woodcock-Plilólıela mínor.

Spotted sandpiper - A ctítis maculária. Wilson snipe-Gallinágo delicáta. Eskimo curlew - Numénius lıneális. Golden plover-Charádrius domínicus.

Order Galline (gallus, "a cock") - grouse, pheasants. The problem in regard to all the birds of this order is again that of protecting those that remain, and of reëstablishing in their original ranges such species as have already been exterminated from certain regions. Were it not for stray and uncontrolled cats we could make town and city parks - in fact, the limits of all villages, towns, and even cities - preserves for grouse and waterfowl. We could in this way place them where the greatest number might enjoy seeing and hearing them; while a constant supply would overflow the preserve limits for our sportsmen. Special problems occur with each of the five following types suggested for study. 


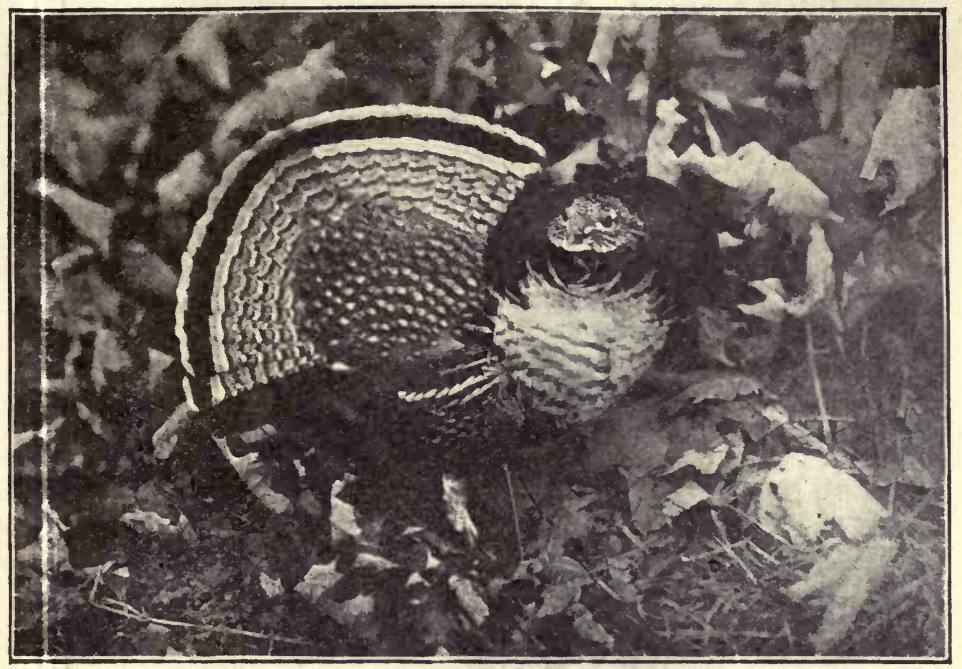

FıG. 16. Ruffed grouse cock strutting

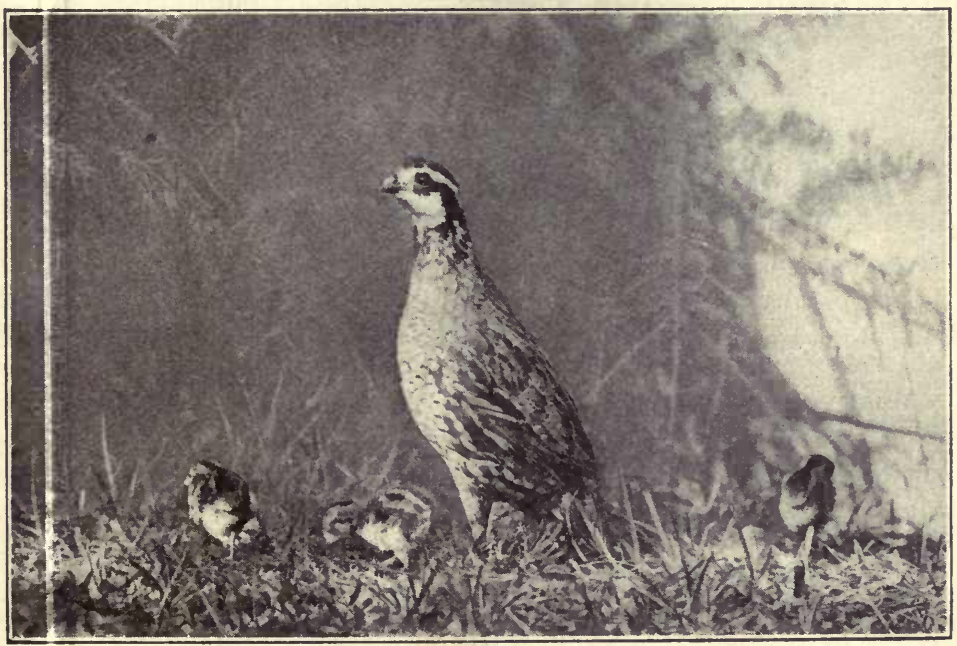

Fig. 17. Bobwhite cock caring for brood of fifteen chicks which he incubated and hatched

Photograph by the anthor 
Bobwhite - Colinus virginiánus. This species, if sufficiently abundant, could probably become our most important insect- and weed-seeddestroying ground bird for garden and field. The crop of one bird contained 101 potato beetles, another two tablespoonfuls of chinch bugs, and another 15,000 weed seeds. Winter protection and feeding is another problem which should receive attention.

Ruffed grouse - Bonása umbéllus. Wherever at all scarce, this finest

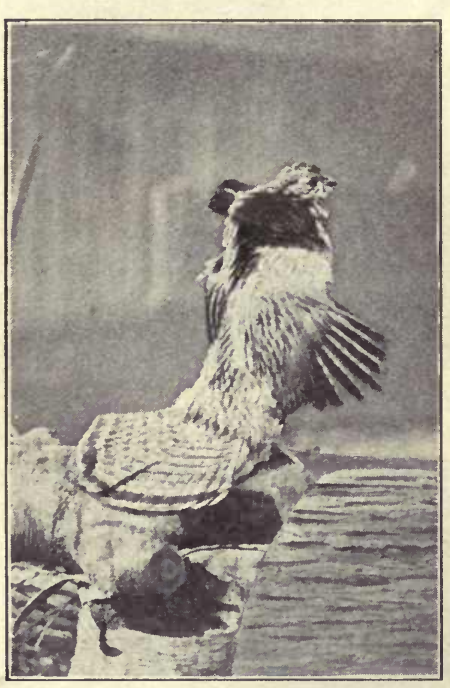

Fig. 18. Ruffed grouse cock drumming

Photograph by the author of our game birds should be provided . with safe covers which will insure -its increase in the locality.

Heath hen - Tympanúchus cupido. This species presents the problem of a numerous and valuable game bird, once generally distributed over New England and now reduced to a few pair confined to the oak barrens of Marthas Vineyard. It is a slightly variant woods form of the Western prairie chicken, which is rapidly being exterminated from the Mississippi Valley. Every effort should be made to save this remnant, and with it restock the mainland under conditions which shall insure the heath hen's regaining its original range.

Mongolian or ring-necked pheasant-Phasiánus torquátus. This is an introduced species, concerning the value of which there is much question at present.

Wild turkey - Meleágris gallopávo. As far as New England is concerned we must write the word "exterminated" after the name of this our largest game bird. By concerted action, and with a suitable game preserve, might the wild turkey not be reintroduced? Would it not be worth while?

Order Columba (columba, "a dove"). The pigeons and doves the world over are among our most valuable food and game birds. The dodo of Mauritius and the solitaire of Rodriguez were gigantic ground pigeons as large as swans, but with wings 
tow small for flight. The last record of the dodo was in 1681. Both of these remarkable species were unwittingly exterminated by the introduction into the islands of hogs, which destroyed their eggs and young.

There are in North America ten genera and seventeen species and varieties of pigeons and doves. Most of these are W estern and Southern. The two named below suggest most important problems for eastern North America. For the Rocky

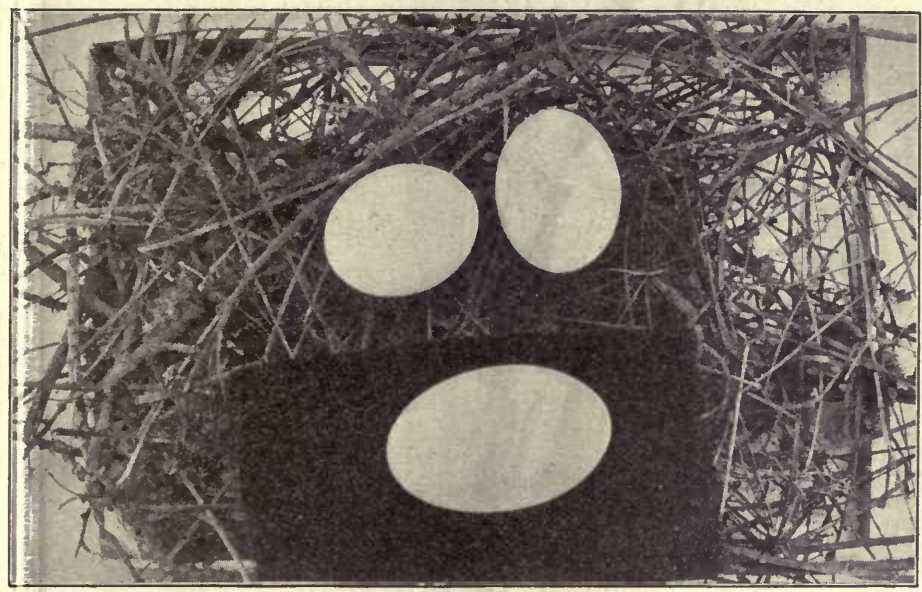

Fig. 19. Egg of passenger pigeon, on black velvet, in nest of mourning dove The pigeon laid only one egg, about $1 \frac{1}{2}$ inches long; the dove, two eggs about 1 inch long. This figure thus furnishes a decisive means of distinguishing the two sp cies. Photograph from specimens in the American Museum of Natural History

Mountain and Pacific States the types studied should be the band-tailed pigeon, Columba fasciáta, from British Columbia to Mexico; Viosca's pigeon, C.f. vioscoe, southern Lower California; and the red-billed pigeon, C. flavirostris.

Passenger pigeon-Ectopistes migratórius. This most valuable of Nirth American pigeons existed less than forty years ago in flocks wlich stretched from horizon to horizon. It is now a serious .question whether the last living specimen has not been seen. 
(For three years past rewards aggregating over $\$ 3000$ for discovery and report of undisturbed nesting pairs or colonies of passenger pigeons, anywhere in North America, have remained unclaimed, and no tangible evidence has been received of pigeons killed or even seen during this time. This is commonly accepted as proving the species extinct in the wild state. One old bird still survives in the Cincinnati Zoölogical fiarden. If nesting pigeons are ever found, they should be most carefully safeguarded, and all protective agencies, private, state, and national, be

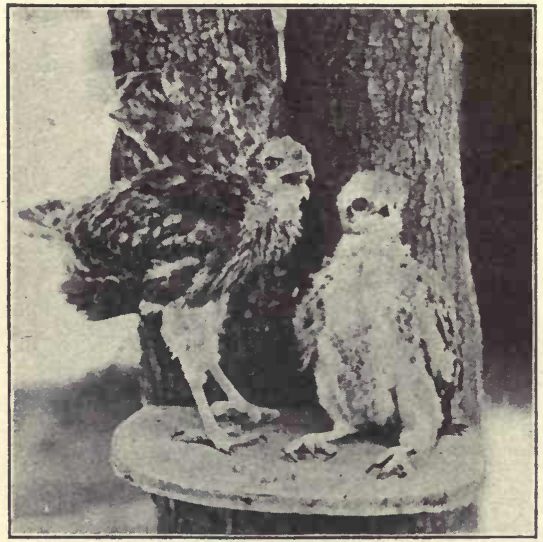

Fig. 20. Young red-shouldered hawks focused on their preservation and increase.)

Mourning dove - Zenaidéra macroúra carolinénsis. Every effort is now being made to save this species in New England. It is abundant in the South and Middle West.

\section{Order Raptores (raptor,} "a robber") - hawks, eagles, owls. The hawks and owls fümish perhaps the most complicated and difficult problem connected with our bird life. By many of the best authorities the majority are accounted among our most valuable birds, on account of the great numbers of noxious mammals - field mice, gophers, rats, etc. which they destroy. Most of the hawks, too, feed largely on insects when they are abundant, and take comparatively few birds, either tame or wild. In determining the value of birds in this class, however, it is always an open question whether the few insectivorous birds, - which may form only 1 or 2 per cent of the hawk's total food, - if allowed to live, might not have done much more valuable work than the sum total of the predacious species. We must leave questions of this kind to be worked out from practical experience and observation. 
When depredations on the poultry yard or disturbance among small birds is marked, it is all but certain that either a sharp-shinned or a Cooper's hawk is causing all the mischief. These two, of the commoner hawks, feed almost exclusively on other birds and bring practically all the popular ill-repute upon the rest of the family. In addition to these, the American goshawk, a Canadian species which enters the Northern States in winter, feeds largely on game and poultry; and the racer duck hawk, seldom seen far from the coast or larger witerways, feeds chiefly on waterfowl.

Some authorities are inclined to maintain that the smaller species, sparrow and pigeon hawks, may prove useful in towns and cities in destroying English sparrows. This is a good problem to assign, if some of these birds are known to nest in the neighborhood. In the only case known to the author a pair of sparrow hawks which nested on one of the buildings of the Worcester Polytechnic Institute had finally to be shot on account of serious inroads upon the valuable bird life of the campus. Common types are:

Marsh hawk - Círcus hudsónius.

Sharp-shinned hawk - Accípiter rélox.

Cooper's hawk - Accípiter coóperi.

American goshawk - Ástur atricapillus.

Red-tailed hawk — Búteo boreális.

Red-shouldered hawk - Búteo lineátus.

Bald eagle - Halicéetus leucocéphalus.

Duck hawk - Fálcỏ peregrínus ánatum.

Pigeon hawk - Fálco columbárius.

Sparrow hawk - Fálco sparvérius.

American osprey, or fish hawk - P'cution halićetus carolinénsis.

Screech owl - Otus ásio.

Great horned owl - Búlo virginiánus.

Order Coccyges (coccyx, "a cuckoo"). These are among our most valuable birds as destroyers of hairy caterpillars, and on 
this account they should be universally protected. The order contains the cuckoos and kingfishers. Types are:

Yellow-billed cuckoo-Coccýzus americánus.

Black-billed cuckoo - Coccýzus erythrophthálmus.

Belted kingfisher-Céryle álcyon. This is an interesting bird, and

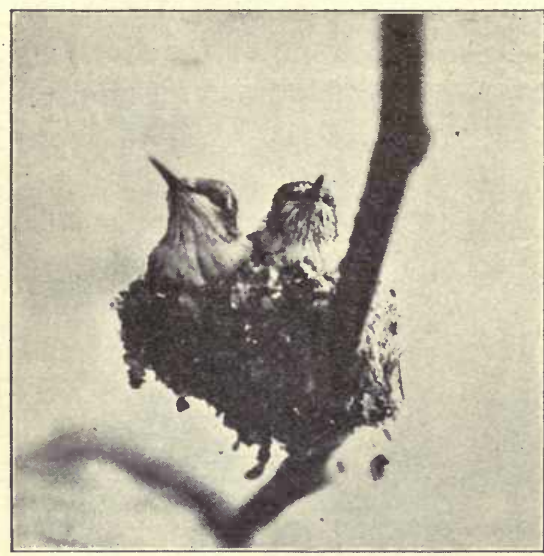

FIg. 21. Ruby-throat, nest and young

Photograph by E. E. Evans we need not generally begrudge it the minnows which it takes. About fish hatcheries and trout streams, however, it is in general disfavor.

Order Pici (picus, "a woodpecker"). The woodpeckers are in general of great value as destroyers of orchard and forest insects. The sapsucker is generally considered an injurious bird, and should be clearly distinguished from the valuable species which it resembles, and which may sometimes visit its sap holes. We should study the following common species:

Hairy woodpecker - Dryóbates villósus.

Downy woodpecker - Dryóbates pubéscens.

Sapsucker - Sphyrapícus várius.

Red-headed woodpecker - Melanérpè erythrocéphalus. .

Flicker - Coláptes aurátus.

Order Macrochires (makros, "long"; cheir, "hand"). The first three of the types given below are among our most valuable insectivorous birds, catching, as they do, both day- and nightflying insects. The humming bird feeds upon minute insects and spiders, and also largely upon the nectar of flowers and the sap of trees (from the holes of sapsuckers). It is most 
etisily tamed, and may be fed on honey and water, half and half, with plant lice and spiders. All should be familiar with the:

Whippoorwill - Antróstomus vocíferus.

Nighthawk - Chordeíles virginiánus.

Chimney swift - Chatuira pelágica.

Ruby-throated humming bird-Archílochus cólubris.

Order Passeres (passer, "a sparrow")-perching birds. In this largest order, which contains more than half the species to be studied, the family names will be of assistance in distinguishing the various groups.

\section{Family Tyrannida - flycatchers. Types:}

Kingbird - Tyránnus tyránnus.

Crested flycatcher - Myiárchus crinitus.

Phœebe-Sayórnis phébe.

Wood pewee-Myióchanes vírens.

Least flycatcher - Empilónax mínimus.

Almost the entire food of this group, as the name indicates, is insects, and stomach examinations have proved that the insects taken are mainly injurious. From the common habit of watching from a ec nspicuous perch and flitting out to eatch insects as they piss, the flycatchers are most interesting birds to study, especially in ascertaining exactly how many insects a bird may catch within a given time. A laboratory period devoted to st ch work will instill a higher appreciation of the value of bird life than will any other lesson in the course.

The only question as to the value of the group refers to the kingbird and its de-

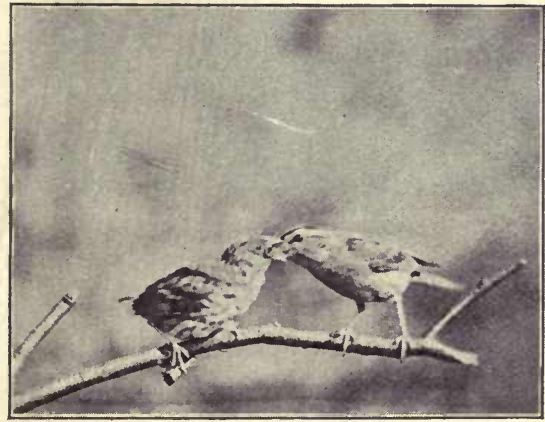

FIG. 22. Chipping sparrow feeding young cowbird st uction of the honeybees. While few bees have been found in its st mmach, and it was therefore acquitted of serious injury, hundreds of crushed bees have since been discovered under its favorite perches, when 
these are near the hives. This is a good problem to have thoroughly worked up in any neighborhood in which bees are kept.

Family Alaudide. (alauda, "a lark")-larks. Horned lark-Otócoris calpéstris. For open fields and prairies this is a valuable bird, as it



Fig. 23. Junco's nest in the aviary of Mr. Herbert Parker, Lancaster, Massachusetts eats great quantities of weed seeds and insects.

Family Corvida (corvus, "a crow")-crows, jays, American magpie. Blue jay - Cyanocíttu cristáta. 'This bird has an odious reputation for robbing other birds of their eggs and young. Study the bird for yourself, and before inflicting capital punishment decide whether the jay is good or bad for the locality.

American crow - Córus brachyrhynchos. The worst crime of the crow is also nest robbing. (I have known a pair to empty two robins' nests of seven young as a single, perhaps partial, breakfast.)

Family Icterida (icteros, "a yellow bird") - blackbirds, orioles, etc. Cowbird-Mólothrus áter. This bird is a parasite and compels other species, generally warblers, vireos, and sparrows, smaller than itself, to brood and rear its young at the expense of their own. Cowbirds' eggs should be removed from the nests of other birds whenever found.

Bobolink - Dolichónyx oryzivorus. In the North this bird is appreciated as one of our most fascinating meadow songsters, if it is not at the head of the list. In the South it is the destructive ricebird.

Bronzed grackle - Quíscalus quíscula ćneus. Red-winged blackbird - Ageldius phœníceus. Meadow lark - Sturnélla mágna. Baltimore oriole - Ícterus gálbula. 
Family Fringillida (fringilla, "a finch")-sparrows, finches. 'Types:

Purple finch - Carpódacus purpúreus.

American goldfinch - Astragalinus tristis.

English sparrow - Pásser domésticus.

White-throated sparrow - Zonotrichin nlliciollis.

Tree sparrow — Spizélla montícola.

Chipping sparrow - Spizélla passerína.

Junco_Júnco hyemális.

Song sparrow - Melospiza melódie.

Fox sparrow - Passerélla ilíaca.

'Towhee, chewink - Pípilo erythrophthálmus.

Rose-breasted grosbeak - Zamelólia ludoriciána.

Indigo bunting - Pusserína cyánea.

The problems in this group are the valuable service rendered by all the sparrows in weed-seed destruction; and, also, the damage caused br the English sparrow. A single observation of the killing of a tree swallow or a bluebird by sparrows, or their eating the eggs from a rolin's nest, is usually enough to convince a person of the advisalility of rilding the neighborhood of these pests. The year after all agree, the Einglish sparrow may be banished from the continent into which it was so foolishly introduced in 1851 . Until all agree, not much headway can be made against a species that has the power to increase from a single pair to $275,716,983,698$ in ten years.

Family Tanagrida - the tanagers. The scarlet tanager - Piránga er!yth ómelas. Why are not these beantiful birds more numerous in your lo:ality?

Family Hirundinida - swallows and martins. Few more efficient, and certainly no more agreeable, insect traps exist than the swallows. They should all be protected until they increase up to the limit of their insect fo d. The purple martin and tree swallow nest preferably in bird houses, and provision about barns should not be lacking for the cliff and barn su allows. Differences in nesting habits in species so closely related are of general interest. Types:

Purple martin - Prógne súllis.

Cliff, or eaves, swallow - Petrochelidon línifions.

Barn swallow - Hirúnlo erythrogástra.

Tree swällow - Iridoprócne bicolor.

Bank swallow - Ripária ripária. 
Family Ampelide (ampelus, "a vine") - waxwings. 'The cedar waxwing, Bombycilla cedrórum, known also as the cherry bird, is noted for

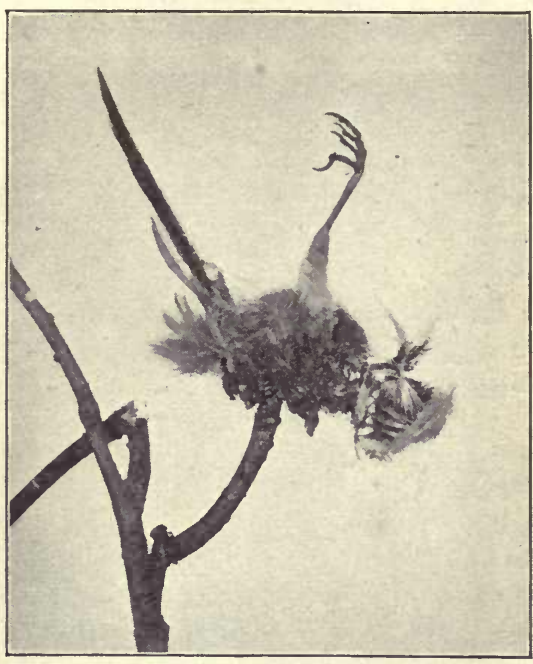

Fig. 24. Remains of chickadee killed by a shrike

Photograph by the author destruction of cankerworms in our orchards.

Family Laniida (lanius, " butcher") - shrikes. The loggerhead shrike, Lánius ludoviciánus, frequents hedgerows and borders of fields, where it feeds upon insects, field mice, and small birds. In cities it is said to be of some use in destroying English sparrows. Study the problem in your own locality. The number of our most valuable small birds — chickadees and wrens - which the shrike kills places it decidedly on the questionable list.

Family Vireonida (vireo, "a greenfinch") - the vireos or greenlets. These birds of the terminal foliage and pensile nests are among the best of our orchard and roadside insect police. We may certainly make the acquaintance of at least three of the seven common species.

Red-eyed vireo - Vireosýlva olivácea.

Warbling vireo-Vireosýlva gílva.

Yellow-throated vireo - Lanivireo flávifions.

Family Mniotiltida (mnion, "moss"; tiltos, "pulled out")-warblers. To make the first acquaintance with this interesting and difficult family we may begin with four of the common resident species.

Black-and-white warbler - Mniotílta vária.

Yellow warbler - Dendroíca astíva.

Ovenbird - Scúrus aurocapíllus.

American redstart - Setóphaga ruticílla.

Family Troglodytida (troglodyta, "cave dweller") - thrashers, wrens, etc. Mocking bird - Mímus polyglóttos. This offers the problem of a rare 
bird for our district, and one which is becoming rarer year by year. The $r$ ason is largely that specimens are desired for collections. Hence records commonly read: "Remarkable instance of a pair of mocking birds nesting in central Massachusetts. On June 8 both parents with nest and clutch of six eggs were collected and are now in..." etc. The mocking bird is often described as the most remarkable bird musician in the w orld, and we could certainly not do less than encourage it to breed as fir north as possible.

Catbird - Dumetélla carolinénsis.

Brown thrasher - Toxóstoma rúfum. Both of these birds are valuable tw control insects of garden and orchard, and, besides, are among our best nusicians.

House wren - Troglódytes aëdon. Every garden should be well stocked with this tireless insect destroyer.

Marsh wren, short-billed-Cistothórus stelláris. Compare with house wren for habitat, foods, nests.

Family Certhiida - creepers. Brown creeper-Cérthia familiáris americiina. One of our winter birds that should be generally known and protreted.

Family Parida - nuthatches and titmice. White-breasted nuthatch Sítta carolinénsis.

Chickadee - Penthéstes atricapillus. All are agreed that the chickadee is one of the most useful birds in freeing orchards of all sorts of insect pists, from cankerworms to aphides.

Family Sylviida - kinglets, gnat catchers, etc. The ruby-crowned kinglet - Regulus sátrapa.

Family Turdida - thrushes, bluebirds, etc. The thrushes are typical "soft-billed" birds, their food being largely insects, worms, spiders, etc. They also feed upon fruits in season, and this has complicated the problf $m$ of their economic value up to within recent years. A closer analysis of their foods has demonstrated that the birds prefer native wild fouits to cultivated; hence this problem may be solved humanely and sc ientifically by planting a succession of these. Esthetically the thrushes a e among our most highly valued songsters, and structurally they rank a) the highest family of birds.

Wood thrush - Hylocíchla mustelina.

Wilson's thrush - Hylocíchla fuscéscens.

Hermit thrush - Hylocíchla guttata pállasi.

American robin - Planésticus migratorius.

Bluebird - Siália síalis. 

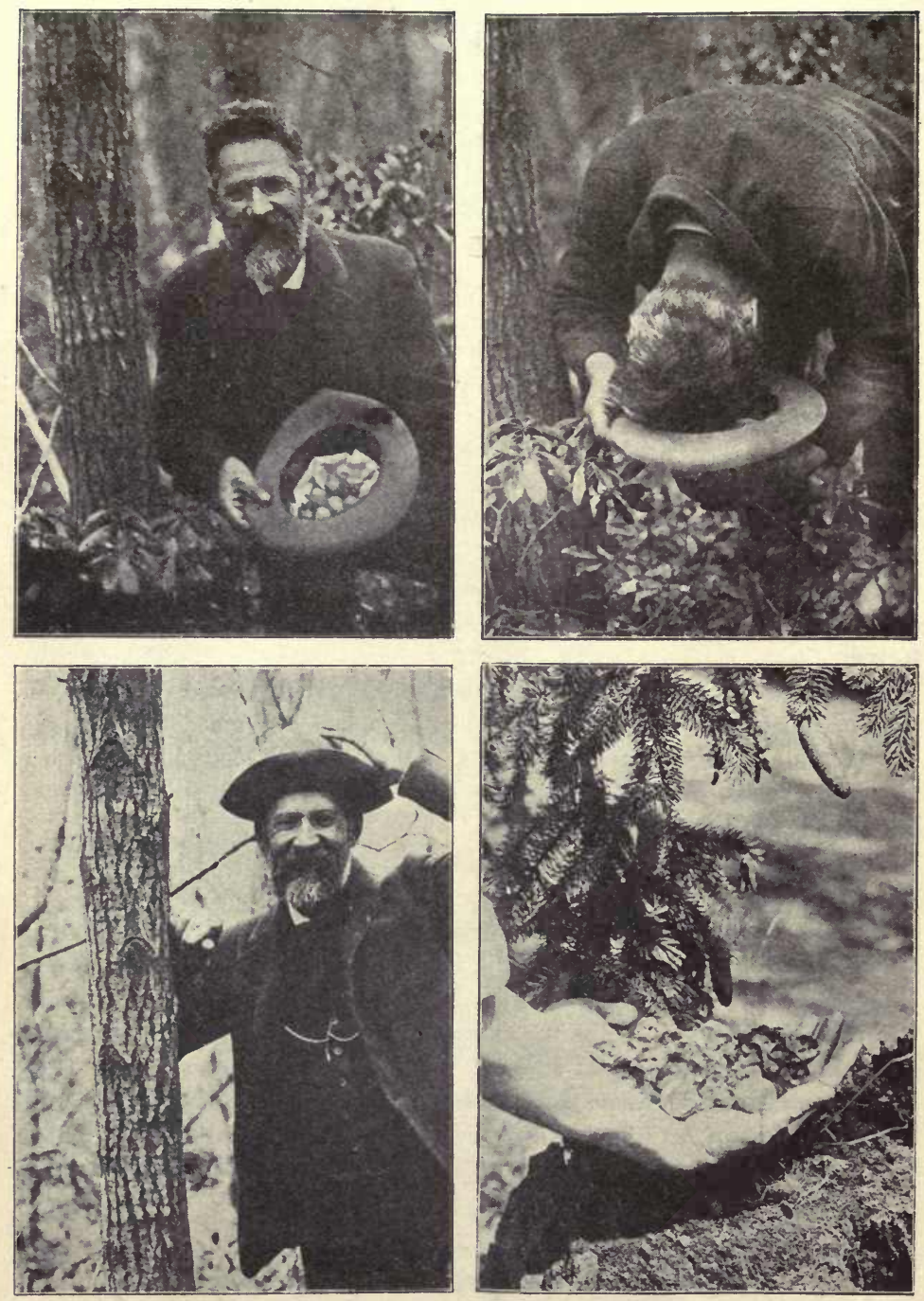

Fig. 25. Carrying incubated eggs (ruffed grouse) and the result Photograph by the author 
It should be repeated that the above list is suggested for central New England, and that it should be freely modified to fit the species and problems of other sections.

One of the most interesting civic problems in this field relates to conservation of American game birds. To accomplish this we need three things: (1) national control of migratory species; (2) universal property right in all game reared by individuals; (3) study of methods of breeding and rearing under control all kinds of American game birds.

The third factor will speedily follow from legal authorization of game breeding, (2), which is being accorded by recent state laws. Follow legislation in your own state and work for this at every opportunity. As long as the State clitims ownership in all game, people cannot afford to raise it, and often the lawless trespassing and annoyance of hunters on private land make the owners wish that the game were exterminated. As soon as we can secure the proper freedom from laws which work against conservation, breeding of game birds will become one of the most profitable of occupations.

Thousands of nests of wild ducks, geese, bobwhites, wild turkeys, ruffed grouse, and prairie chickens, are yearly broken up by various farming or logging operations. The eggs at any stige of incubation may be saved by earrying in the hat, as shown in Fig. 25. If all these eggs could be saved, they would speedily yield birds enough to restock portions of the country from which the species have been exterminated.

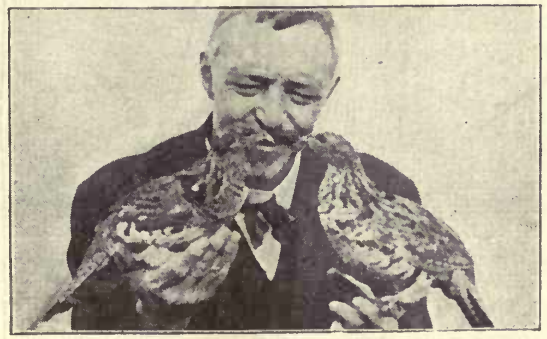




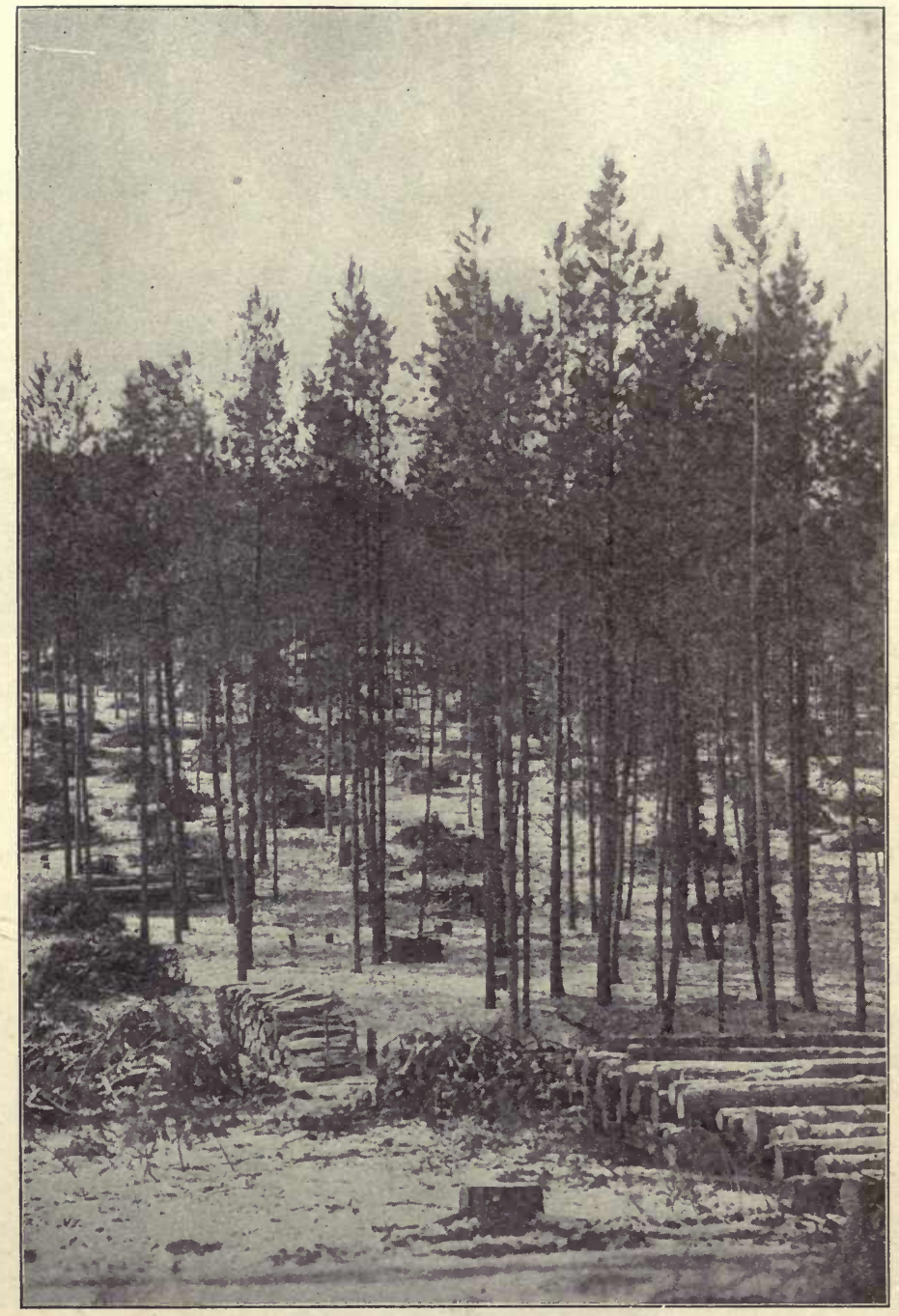

Fig. 26. Black Hills National Forest

United States Bureau of Forestry 


\section{CHAPTER VI}

\section{TREE STUDY AND CIVIC FORESTRY}

Why are there trees I never walk under but large and melodious thoughts de scend upon me?-WALT Whitman

How foolish does man appear to be in destroying the mountain forests, for thereby he deprives himself of wood and water at the same time.A Lexander von Humboldt

It is undoubtedly true that more pine timber has been destroyed by fire than the lumbermen have ever cut.-GREeN

The problem. The annual growth of all the forests of the United States is 7,000,000,000 eubic feet of wood, while our yuarly consumption amounts to more than $20,000,000,000$ cubic feet. In addition to this, since 1870 forest fires, for the most part preventable, have caused a yearly loss of fifty lives, $\$ 50,000,000$ worth of lumber, and a destruction, even greater, of all young growth and of soil fertility by the burning of the vegetable mold of the forest floor. Floods in the lower Mississippi alone during 1912, due to unwise and uncivic deforestation, in the main, caused great loss of life, extreme privation, and damage estimated at $\$ 82,187,670$. While this torrential run-off is flooding the lower river valleys, millions of woodland springs and even wells back in the foothills and mountains are going dry. From one to two thousand million tons of the firest and richest soil - enough to bury Rhode Island from or e to two feet deep - is being washed yearly from the farms, where it may be worth a dollar a ton, into our harbors, where it costs millions to dredge it out of the way.

Increasing population and consumption of wood, decreasing forests, inadequate control of forest fires, increased washing 
of soil, floods rising higher each year - these are the main. elements in the problem. Records of flood plane of the Mississippi at New Orleans are as follows:



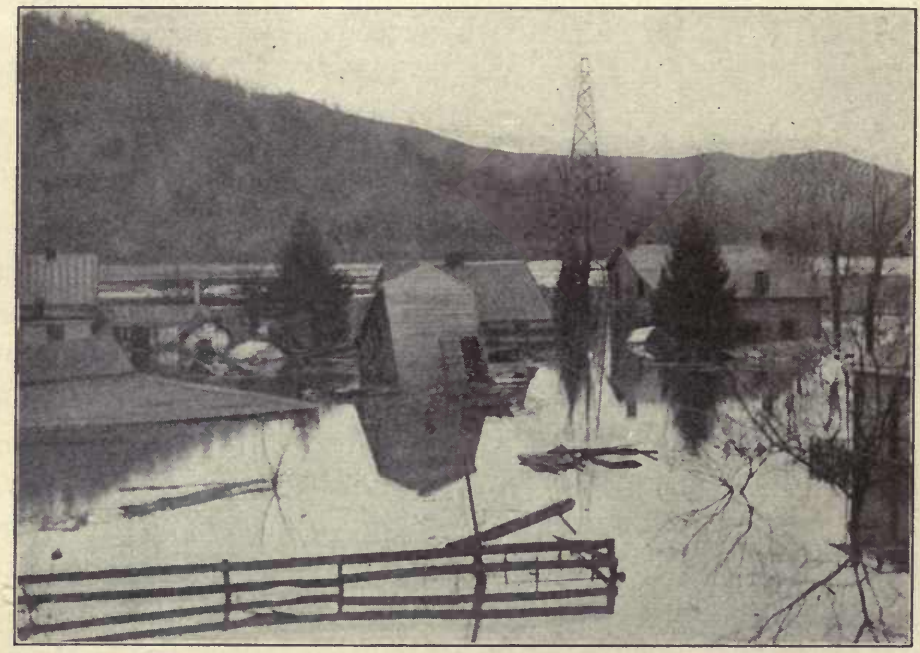

FiG. 27. Flood showing result of deforestation

If the flood of 1912 had not broken the levees and poured over 17,605 square miles above the city, the flood might have risen to thirty feet at New Orleans.

Vital civic coöperation must be developed in growing more wood, in holding the water and soil where they belong and can do the most good on every farm, and in prevention of forest fires.

These are not matters of private individual right and control; they are civic and touch the life of the whole people. 
Fivery particle of soil that a farmer in Pennsylvania, Minnesota, or Montana allows to wash from his farm eventually raises the mud bed of the Mississippi, helps to cause floods, taxes the nation to build higher levees. The clearing of a watershed at the headwaters of the Ohio or Missouri is the business of every one whose spring or well runs dry below it or whose

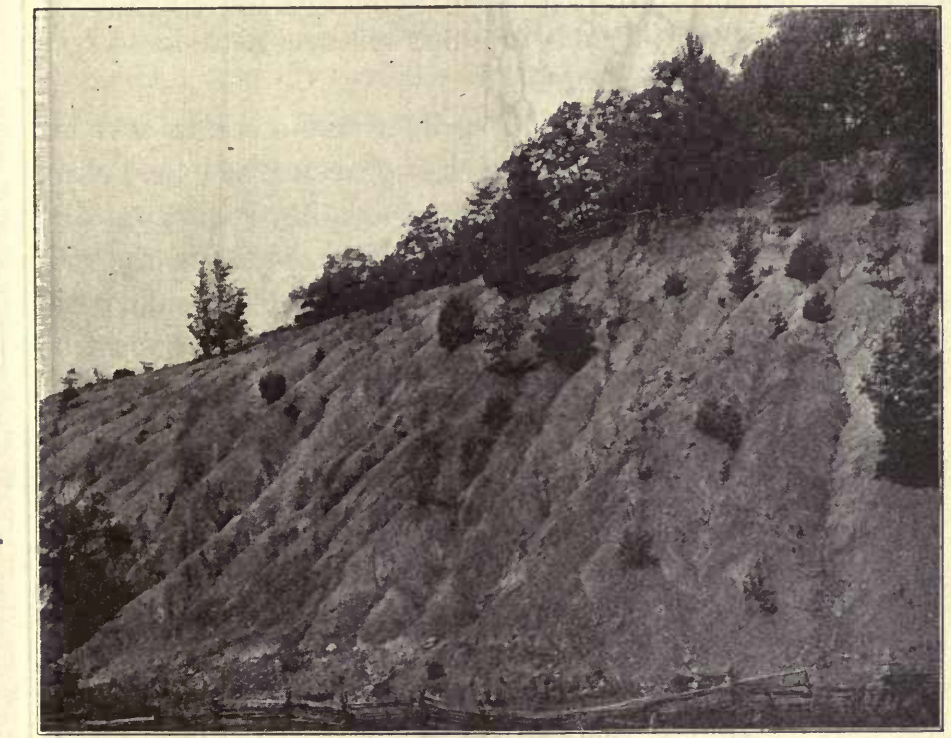

- Fig. 28. Deforested slope, North Carolina, showing erosion United States Bureau of Forestry

- home is flooded farther down the rivers, and also of every one who is taxed or who is called upon to contribute or to suffer in sympathy for the common loss.

Solution of problem. By the adequate planting of trees on every hill and mountain side and along every.gully and ravine, the rootlets of which will bind the soil and filter the water as it falls, we should have the water leaving every farm clear as erystal from perennial springs. Vast national projects are 
afoot for building dams and impounding the flood waters of our streams and rivers. Much of this will be necessary on account of past mistakes in clearing watersheds and also on account of the original configuration of certain regions; but first, and in connection with these plans, we should unite as a whole people in planting trees to conserve both soil and water on the farms. Otherwise, under present ignorance and mismanagement, how long will it be before our reservoirs are filled to the tops of their dams with mud?

Observe and study typical springs and streams, and learn the history of them for a number of years. Have they shrunk or gone dry? If so, is it because woods have been cut above their sources? They may be restored by replanting the watersheds. Has it been necessary to deepen wells during periods of drought? Has a man the moral right to clear off a woods that will cause his neighbor's spring or well to go dry?

Study in a practical way what the local streams are carrying, if muddy. Temporary streams will serve, if permanent ones are not available. After a freshet, are some streams clear and others muddy? How do their relations to woodlands explain the difference? Follow up a muddy stream and find where the soil is being eroded. Can you sketch a plan of planting with trees or permanent grass to prevent this? Make a list and map of all the places in the district that are washing badly, or survey typical farms with this feature in mind. Sketch a plan of planting which will improve conditions throughout the district. After this has been perfected and thoroughly discussed by the class and with parents most concerned, arrange for publication of the plan in local papers or make it the subject of consideration in a community meeting. All can then arrange for saving or procuring the necessary seeds or young trees and for doing the actual planting. If not too extensive, possibly all of this work can be done in outdoor laboratory periods by the class. At least the seeds might be 
gathered and many of the young trees be reared for a year or two in a nursery in connection with the school garden.

Suggestions for tree planting. The general plan should insure having the most valuable trees for each location as the permanent stand. It will thus be necessary to study conditions under which the different species will grow to best advantage. Some species bear shade or sun better than others when they are young. Analyze and study how and where young trees are thriving best. Especially note which species grow best on the driest hillsides and along the banks of brooks and streams. $\mathrm{I}_{\mathrm{t}}$ is often necessary, and profitable as well, to plant quickgrowing, sun-enduring species as "nurse trees" for a more valuable permanent stand.

The following table suggests possibilities in handling the different species of Eastern conifers and hard woods with reference to tolerance of shade or sun.

Shade Bearers INTERmediates

Light Demanders Conifers:

$\begin{array}{llll}\text { White cedar } & \text { Loblolly pine } & \text { Long-leaf pine } & \text { Sugar pine } \\ \text { Spruces } & \text { Virginia scrub pine } & \text { Short-leaf pine } & \text { Scrub pine } \\ \text { Balsam } & \text { White pine } & \text { Bald cypress } & \text { Cuban pine } \\ \text { Arbor vitae } & & \text { Tamarack } & \text { Yellow pine } \\ \text { Hemlocks } & \text { Jack pine } & \text { Pitch pine } \\ \text { Spruce pine } & \text { Red pine } & \text { Red cedar } \\ \text { Rock pine } & & & \end{array}$

Hard woods:

$\begin{array}{rlll}\text { Beech, Elm } & \text { Chestnut } & \text { Sourwood } & \text { Cottonwoods } \\ \text { Black gum } & \text { Black walnut } & \text { Locusts } & \text { Red gum } \\ \text { Maples, hard, } & \text { Butternut } & \text { Yellow poplar } & \text { Hickory } \\ \text { red, silver } & \text { Sycamore } & \text { Oaks } & \text { Black cherry } \\ \text { Basswood } & & \text { Birches } & \text { White elm } \\ \text { Ironwood } & & \text { Willows } & \text { Mulberry }\end{array}$

Note to Teacher. As early as possible in the year discuss with the class a list of trees desirable to study, and apportion, either by choice or lot, one or more species to each pupil, according to suggestions for the White Pine, p. 4. Each will then be responsible for seeds, 
Nut trees. 'The rocky hillsides of Italy and Spain, planted to chestnuts, are said to produce without labor as valuable crops as our own best wheat lands. We are importing annually over $\$ 14,000,000$ worth of nuts. How many, even then,

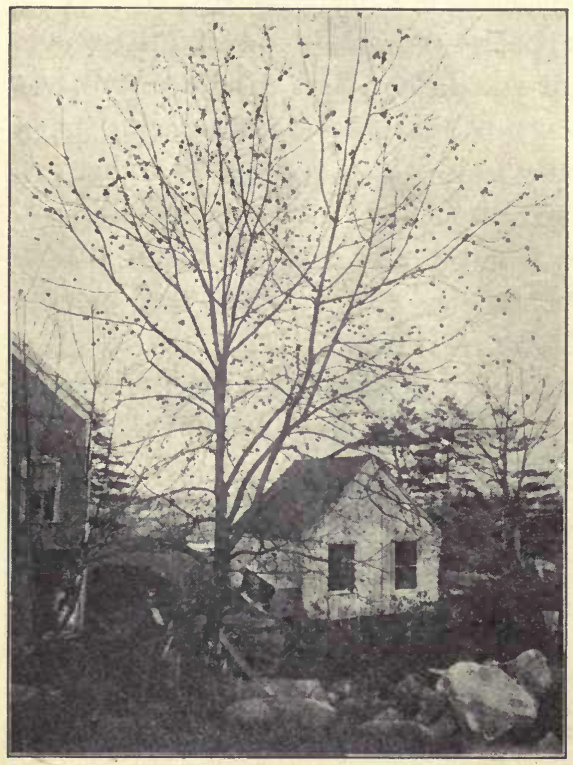

Fig. 29. Young black-walnut tree

The nuts hang on a few days after the leaves have fallen have all the nuts they want?

Make careful collections of all the different nuts in the district and prepare them for exhibition in class, keeping records of trees that produce the best. Preserve as many as possible of the best for planting, exchange with other schools, and arrange, if possible, to buy seeds or young trees, or obtain scions from the best varieties of pecan, hickory, walnut, and chestnut that can be had from any part of the country. Organize exhibits of nuts in connection with local horticultural fairs. By these means we may improve quality and increase yield of nuts to any desired amount. At the same time the wood of our native nut trees, - hickory, black walnut, chestnut, - for certain uses, is the best we can grow.

flowers, seedlings, and other specimens of his tree or trees, when needed by the class. Have each pupil study and be prepared to describe the method each tree has developed for scattering and planting its own seeds. 
State and national helps. The national Bureau of Forestry and your state forester print a number of practical bulletins and forestry leaflets, which may be obtained gratis or at cost. These will give directions for gathering, storing, and planting clifferent tree seeds, and advice as to best species to plant. Tree seeds and even young seedling trees may be obtained from state or (in Canada) from provincial departments of forestry.

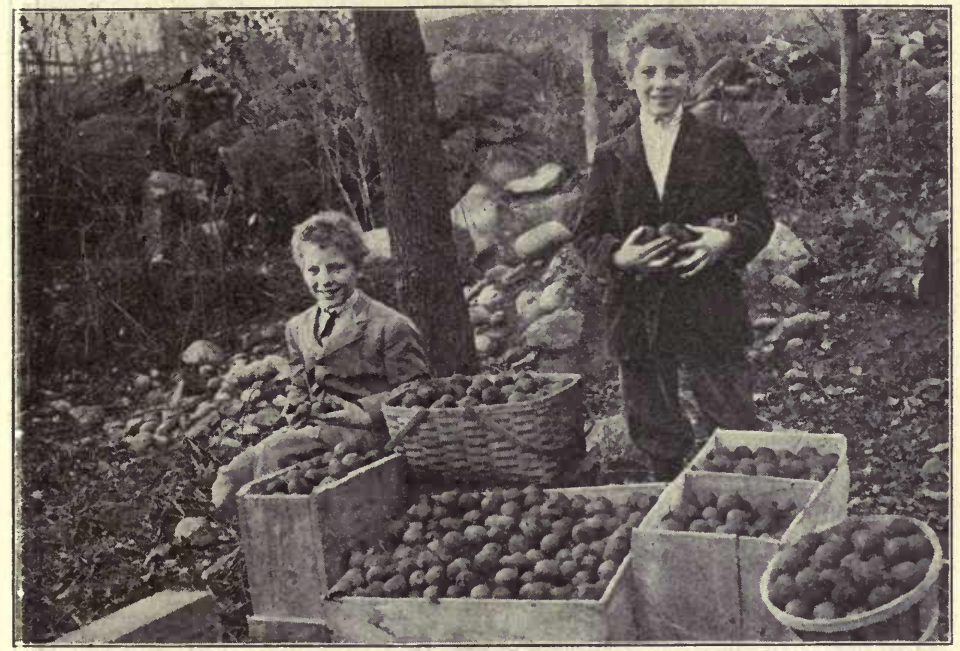

Fig. 30. Crop of tree shown in Fig. 29

We do not have to "wait" fifteen years for such a crop; we just plant the nut and go about our business

Since the planting of trees is an important public service, states are beginning to pass laws exempting land so planted from taxation. Massachusetts and New York exempt for thirty-five years all lands on which not fewer than twelve liundred trees are planted to the acre.

Forest fires. In a hot, dry wind a spark or carelessly dropped natch may start a fire which one standing over it cannot stamp cut; and it may run down the wind faster than wild horses 
can gallop. A smoldering camp fire may be blown into flame by the wind and give us another story like that of the Hinckley fire, which licked up several towns and 500 people in them, left 2000 people homeless, and destroyed $\$ 25,000,000$ worth

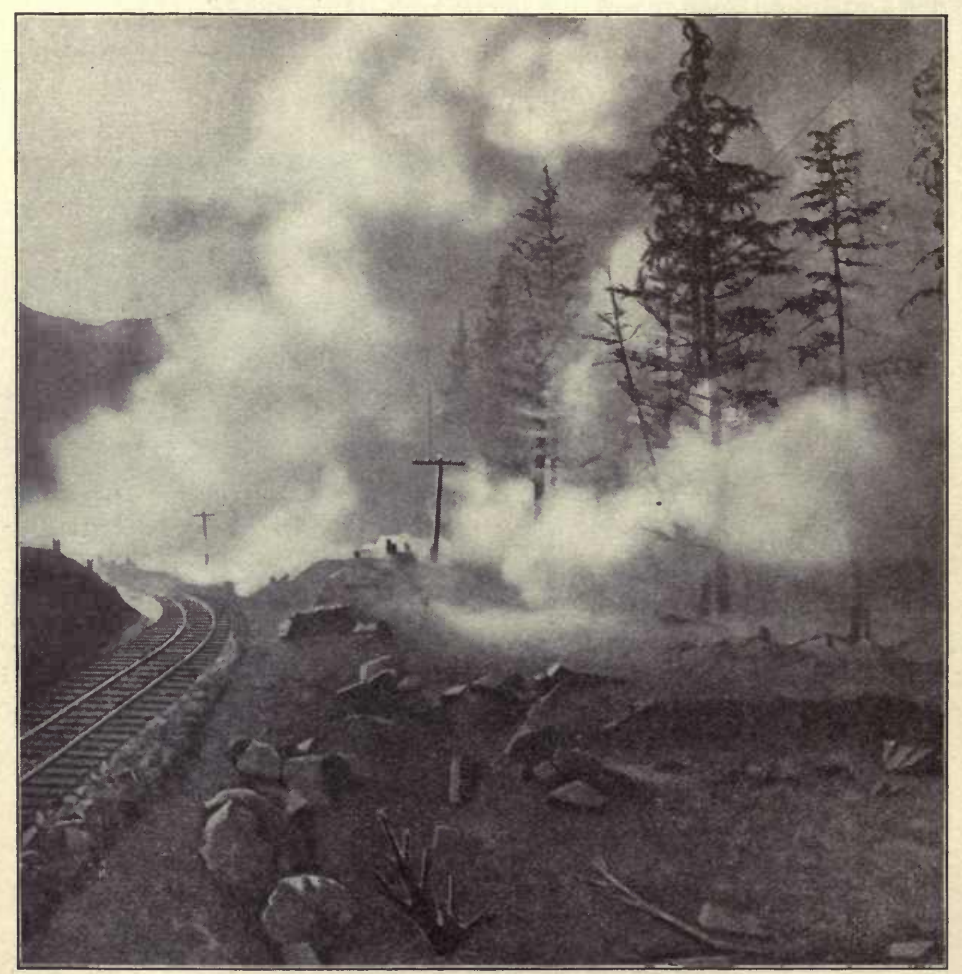

FIg. 31. Forest fire in Washington Photograph by J. L. Bridge

of buildings and timber. Let public and private forest-fire service organize lookouts and fire wardens and volunteers, at great expense; all these measures will not be effective until everybody is educated to be intelligent and careful about the little sparks that start the big fires. 
One evening last September when the men had quit work and were all in camp or on the way, a patrolman blew the fire signal at a "donkey" about sixty rods from camp and within three minutes fifty men were at work. In half an hour there were a hundred, and in fifteen minutes more, a hundred and fifty. Even with this prompt action it took all night and all the next day to extinguish the fire. Now what I should like to know is how to keep a fire from working you forty hours even when you see it start and can get your crev on the ground at once. It $\mathrm{w}$ as a dry slashing and a cigurette. How stop the cigirette? - Proceedings of Forest-Fire Conference, Seattle, 1912, p. 19

'This is the crucial, vital point in civic cooperation, to have every one, young or old, native or foreign-born, rich or poor, thoroughly careful about these little sparks that start the big fires.

For outdoor laboratory work organize the clais so as to utilize all local brush burnings

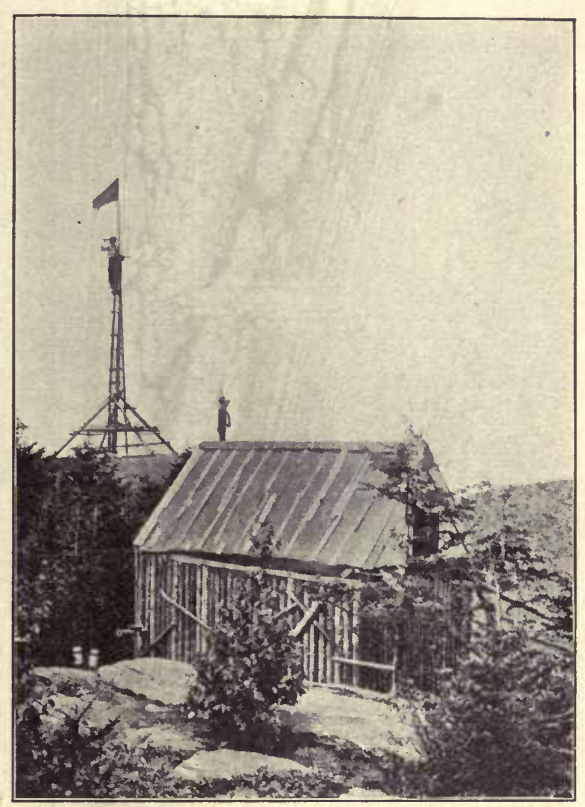

Fig. 32. Forest-fire lookout, Croydon Mountain, New Hampshire

Photograph by Charles I. Rice ancl actual forest fires. Make practical demonstrations of puttin $y$ out camp fires by the use of water and earth. Teaeh the factors that go to make up a safe, model camp fire - proximity to water or moist earth, use of stones and rocks to prevent spreading, and distance from dry stumps, logs, peat, or leaf mold. Finally organize a survey for danger spots and try to have these attended to before the danger season. 
Causes. Natural causes, lightning and friction, account for few forest fires, and as these occur during rainstorms, there is almost no damage from them. Study local forest fires and tabulate under the following causes:

Forest Fires in Massachusetts in 1908

\begin{tabular}{|c|c|c|}
\hline CaUse & NUMBER & REMARKS \\
\hline Railroad trains (Locomotives) & $490(38 \%)$ & $\begin{array}{l}\text { Usually cause about } 50 \% \text { of all } \\
\text { forest fires. Can be stopped by } \\
\text { proper use of spark arresters, } \\
\text { or by burning oil, by turning } \\
\text { hose into ashes before dump- } \\
\text { ing, and by clearing roadbed } \\
\text { of inflammable rubbish. }\end{array}$ \\
\hline Sawmills & $\%)$ & $\begin{array}{l}\text { Should have men organized, and } \\
\text { be provided with adequate fire- } \\
\text { fighting apparatus. }\end{array}$ \\
\hline Burning brush & $90(7 \%)$ & $\begin{array}{l}\text { Escape of these fires can be } \\
\text { avoided by burning when snow } \\
\text { is on the ground or during a } \\
\text { wet spell. }\end{array}$ \\
\hline Smokers & & $\begin{array}{l}\text { Those who must smoke in the } \\
\text { woods in a dry time should be } \\
\text { compelled by law to dive under } \\
\text { water to light up and stay down } \\
\text { as long as there is a spark in } \\
\text { their pipes or cigarettes. }\end{array}$ \\
\hline 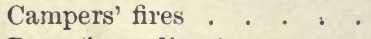 & & \\
\hline endiary) . . . & & \\
\hline Unknown. . . . . & c) & $\begin{array}{l}\text { Probably mostly set by smokers } \\
\text { and careless or incendiary boys. }\end{array}$ \\
\hline
\end{tabular}

In all, for Massachusetts 1378 forest fires were reported in 1908, which burned over 40,327 acres of woodland, nearly 2 per cent of the wooded area of the state. In the whole of Prussia 1400 acres have been burned in the past twenty-five years, or less than 0.02 of 1 per cent a year. At this rate the 
whole forest area in Massachusetts would be burned over in about fifty years, and in Prussia in 5000 years. Why this difference?

The actual loss by forest fires, although great, is not the worst feature of the situation. Forest fires discourage tree

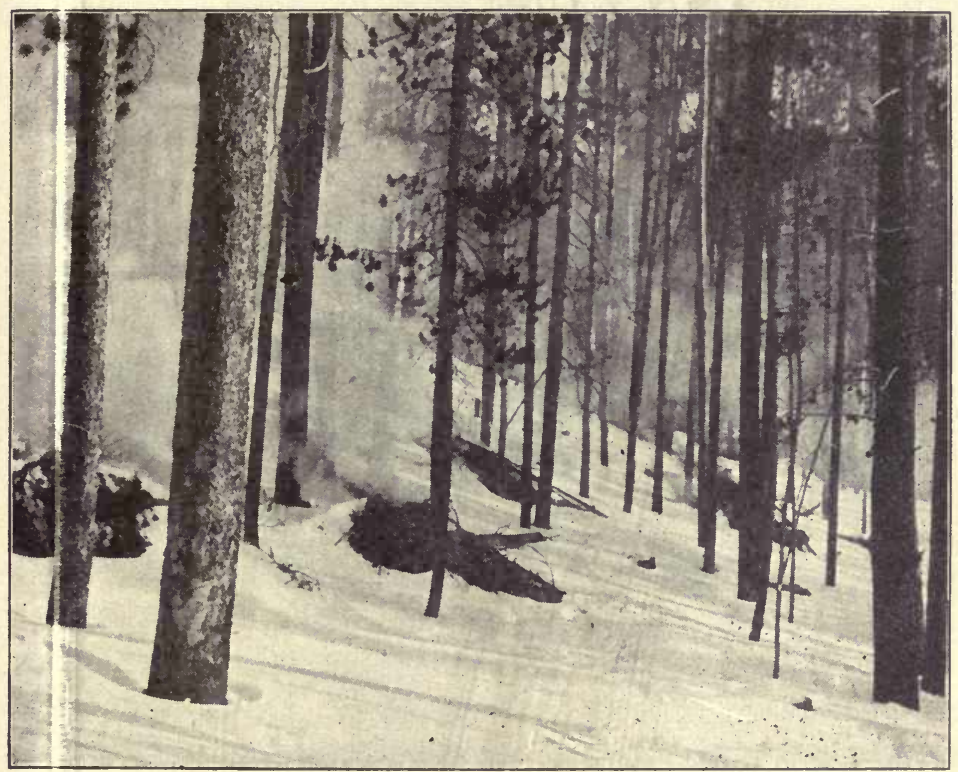

FIG. 33. Safe burning of brush

United States Bureau of Forestry

planting everywhere. Reduce or banish entirely danger of fires and tree planting will become a safe and profitable investment.

Note to Teacher. After working over the ground and with special reference to local problems ask the town fire warden to visit the class and explain the state laws and the apparatus, equipment, methods, and orgunization of the state and town for preventing forest fires and for quir $\mathrm{k}$ work with those that are started. 
To sum up the whole matter have each member of the class write a brief outline of a plan by which he thinks forest fires can be effectively prevented in the district, town, or county. The best of these plans may be printed in local papers or used as the basis for discussion in a timely neighborhood meeting. With every township safe and protected by a well-organized community, the entire country will be equally safe.

Forest-fire laws. Secure the latest forest-fire laws in your state or province and familiarize yourself with them. These laws represent the best thought of your community on the subject. What can you do to help in making them effective?

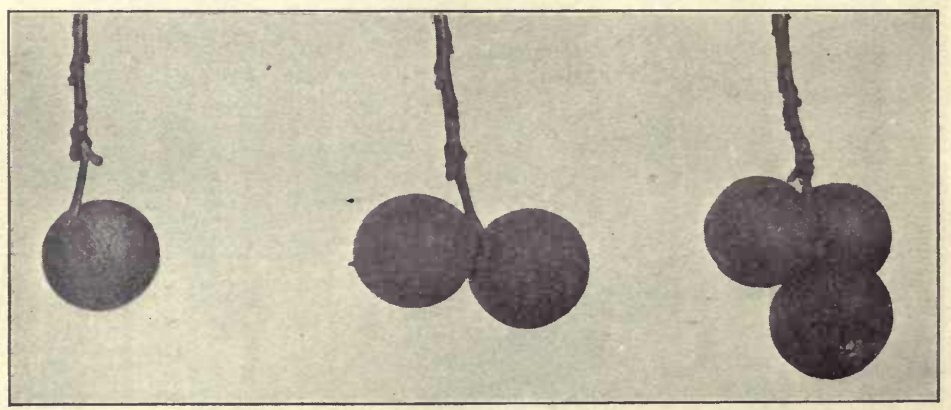




\section{CHAPTER VII}

PLANT PROBLEMS: PRESERVATION OF WILD FLOWERS, CONTROL OF WEEDS, MEDICINAL AND POISONOUS PIAANS

Groups of plants present civic problems of no less importance than those of birds and insects. For beautiful landscapes the people of a locality must learn to coöperate in preserving and planting native trees, shrubs, and vines. Additional study of these is taken up from this point of view in chapters on Forestry and Landscape Gardening.

Conservation of native plants. Many of our most beautiful native plants are in danger of extermination. To educate agiinst wanton destruction a society of national membership has been organized, ${ }^{1}$ and if all can be induced to join in reasonable conservation of these common interests, we may have much more attractive and interesting woods, parks, and country roadsides. Do you have trailing arbutus, fringed gentian, cardinal flower, maidenhair fern, pink lady's-slipper growing in abundance? By inquiry from parents, grandparents, or older members of the community, can you make out a list of native plants that have become rare and need protection in

1 Society for the Protection of Native Plants, Boston, Massachusetts. For leaflets, address the Boston Society of Natural History.

I'his society urges that we all use :

1. Moderation. Do not pick all that you find. Many flowers must be left to devilop seeds for future plants.

2. Care. Never pull up the plant, for the roots are of no use in a bunch of flow ers, and their destruction means the extinction of the plant. Cut when possible.

$\therefore$ Judgment. Many flowers, such as wild roses, asters, and goldenrod, may be 1 icked with impunity, but when flowers are few or rare do not pick them. Do not pick flowers which must die before you reach home, nor great quantities of those flowers whose grace and beauty are better seen in a few than in many massed together. 
the locality? Discuss together as a class plans for bringing them back to their native haunts.

Weeds. Fighting weeds is often the most laborious and expensive part of gardening and of raising certain staple crops. It was formerly said that weeds were the gardener's friends, because they made necessary the frequent stirring of the soil, which was considered beneficial to plant growth. Recent experiments in raising corn have shown equal production with absolutely none of this laborious stirring of the soil. In fact, earlier experiments on the root system of the corn plant had proved that the farmer actually, and very materially, reduced his corn crop by deep cultivation. Other crops await similar investigation. The results so far have been to rate the damage caused by these "robber plants" at much higher figures than formerly. If we could prepare the ground and plant our gardens and fields and never see a weed, the labor and cost of production from the soil might be reduced nearly, or quite, one half.

Damage caused by weeds. Weeds are defined as "plants which persist in growing where they are not wanted." No less than seven hundred such plants are listed for the entire United States. Make a list of weeds that are locally most noxious. Weeds reduce yield of erops by crowding, and by robbing the plants of water and food in the soil and of light in the air. They injure seeds and flour, cause objectionable flavors in milk, and poison stock. A recent estimate by the Division of Farm Management of the United States Department of Agriculture places the total annual damage of weeds at $\$ 500,000,000$. What part of this yearly tax is imposed on your own home, garden, or farm? What is the annual damage and cost of fighting weeds in your district, township, county, or state? ${ }^{1}$ Can you propose a plan of coöperative work by which this may be reduced?

${ }^{1}$ Secure your state bulletins on weeds to assist in working out the problems suggested. Write also for the Weed Laws of your state. 
Control of weeds. Select the largest specimens to be found in roadsides and vacant lots, barnyards, and gardens, of perhajs ten of the worst local weeds; dry carefully, thresh out and count or estimate the number of seeds in each. No one who takes part in such a lesson can ever be indifferent to allowing such weeds to ripen their thousands or even millions of seeds, ${ }^{1}$ when a stroke of scythe or hoe at the right time would stop them.

Failure to study weeds and get clear ideas of their powers of reproduction and of effective methods of exterminating them is responsible for the fact that more decisive headway has not been made in their control. Further topies in this cornection are the following:

Dispersal of weed seeds. Along with rats, English sparrows, the San José scale, and gypsy moth, many of our worst weeds are immigrants from the Old World. They come mixed with seeds and grains, in merchandise, and in all kinds of packing materials. Watching ports of entry has not succeeded in keeping out these unwelcome guests. Our only hope lies in knowledge sufficient to recognize and give the alarm and unite in eradicating vicious importations before they become widely estiblished.

The more widely a plant is able to scatter its seeds, the betcer the chance of growth. Naturally weeds lead the world of jlants in effective devices for dispersing their seeds. They are aided by different elements in the environment - winds, florving waters, and animals. Make a collection of weed seeds

${ }_{1}^{1}$ This suggestion carried out in the Cleveland Normal School yielded the foll, wing results :

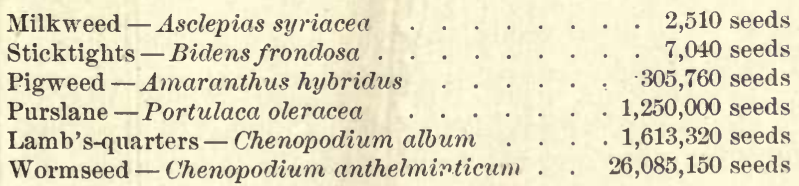


and study with reference to means of dispersal. These collections will also be useful in identifying impurities in garden and field seeds.

Vitality of weed seeds. The great length of time weed seeds remain alive in the soil furnishes another strong reason for not permitting them to ripen. Dr. Beal has found that seeds of pigweed, black mustard, shepherd's-purse, peppergrass, mayweed, evening primrose, smartweed, purslane, curled dock, foxtail, and chickweed are able to germinate after being buried for twenty-five years. How much longer they may survive remains to be determined.

Adaptability. Weeds, like other plants, attain their best growth under favorable conditions of soil, but they are able to produce seed under conditions of greatest hardship. A search of clay banks, ash heaps, gravel or cinder walks will reveal minute dwarf specimens of common weeds. Weeds also show extreme tenacity of life in many other ways. Uproot them, and if a rootlet remains in the soil, it will continue to grow and mature seed as it lies on the ground. If trampled down, branches that retain a shred of connection with the stem remain fresh and produce seed. Even when cut close to the ground, new branches quickly appear. An outdoor lesson devoted to this topic will prove valuable in many connections.

Classes of weeds. Success in fighting weeds must depend upon knowledge of each species. 'The methods used will depend in a general way upon whether the particular weed is:

An annual. Most garden weeds-chickweed, purslane, lamb's-quarters, pigweed, ragweed, pigeon·grass - complete their life cycle in a single season. To completely eradicate these from the soil it is only necessary to prevent any from maturing seed until seeds already in the ground have germinated. Barnyard manure or loam may reseed a clean garden plot, if not applied with great care. If manure is spread upon the top after plowing, all weed seeds in it are more likely to 
germinate the first year than if they are plowed under deeply. Some weeds of this class - chickweed, peppergrass, shepherd'spurse - germinate late in the summer or fall, live through the winter, and are known as "winter annuals" in latitudes where this occurs.

A biennial. These plants complete their life cycle in two years and hence rapidly disappear if prevented from maturing seed. Burdock, bull thistle, mullein, teasel, and wild carrot, all immigrants from the Old World, are familiar examples.

A perennial. Couch grass (a native American), Canada thistle, curled dock, plantain, wild onion, milkweed, bindweed, most of them importations from the Old World, are examples. Most of the hard problems relate to weeds of this clisss. The plants, besides producing seeds, live from year to year in the ground by means of perennial crowns, tubers, and burrowing rootstocks. Cultivation which would eradicate annuals or biennials may serve merely to subdivide and increase these pests of the soil.

The fact that certain weeds tend to thrive best with certain crops suggests rotation as a means of control. Land should have a radical change of treatment, if badly infested with wieds. Annual weeds of gardens and cultivated fields die out if the land is seeded to grass. This applies to grainfields which have become seeded to chess, cockle, or ragweed. Pasture lands "run out" to perennial weeds should be planted to annual crops. Thus a system of field rotation and general management may be adopted which shall give weeds the least possible chance to survive.

Chemical weed killers, herbicides. Salt or strong brine, arsenate of soda, coal oil, crude sulphuric acid, carbolic acid, and sulphates of copper or iron are the chemicals usually employed and suggest interesting experiments for the lawn or garden.

Medicinal plants. Many crude drugs and aromatic herbs used as condiments are now imported, although they grow in 
the United States. 'The table ${ }^{1}$ below gives the amounts brought in and the prices we pay for some of our most common weeds.

\begin{tabular}{|c|c|c|c|}
\hline WEEDS & PARTS USED & $\begin{array}{l}\text { ANOUNT 1M- } \\
\text { PORTED IN POCNDS }\end{array}$ & $\begin{array}{l}\text { PIRE PAII } \\
\text { IN CENTS } \\
\text { PER POUNI }\end{array}$ \\
\hline Docks - Rumex species . . . & Roots & 125,000 & $2-8$ \\
\hline Burdock - Arctium lappa L. . & $\begin{array}{l}\text { Roots } \\
\text { Seeds }\end{array}$ & 50,000 & $\begin{array}{l}3-8 \\
5-10\end{array}$ \\
\hline $\begin{array}{l}\text { Dandelion - Taraxacum tarax- } \\
\text { acum. . . . . . . . . }\end{array}$ & Roots & 115,522 & $4-6$ \\
\hline $\begin{array}{l}\text { Quack or couch grass }- \text { Agro- } \\
\text { pyron repens } \mathrm{L} \text {. . . . . . . }\end{array}$ & Rootstock & 250,000 & $3-7$ \\
\hline Mullein-Verbascum ihapsus L. & $\begin{array}{l}\text { Leaves } \\
\text { Flowers }\end{array}$ & 5,000 & $\begin{array}{l}2 \frac{1}{2}-5 \\
25-75\end{array}$ \\
\hline 'Tansy - Tanacetum vulgare $\mathrm{I}$. & $\begin{array}{l}\text { Leaves and } \\
\text { tops }\end{array}$ & 30,000 & $3-6$ \\
\hline $\begin{array}{l}\text { Horehound - Marrubium vul- } \\
\text { gare L. . . . . . . . . }\end{array}$ & $\begin{array}{l}\text { Leaves and } \\
\text { tops }\end{array}$ & 125,000 & $3-8$ \\
\hline $\begin{array}{l}\text { Jimson weed - Datura stramo- } \\
\text { nium L. . . . . . . . . . }\end{array}$ & $\begin{array}{l}\text { Leaves } \\
\text { Seeds }\end{array}$ & $\begin{array}{c}100,000-150,000 \\
10,000\end{array}$ & $\begin{array}{r}2 \frac{1}{2}-8 \\
3-7\end{array}$ \\
\hline $\begin{array}{l}\text { Poison hemlock - Conium mac- } \\
\text { ulatum L. }\end{array}$ & $\begin{array}{l}\text { Seeds } \\
\text { Leaves }\end{array}$ & $\begin{array}{c}20,000 \\
10,000-20,000\end{array}$ & 3 \\
\hline $\begin{array}{l}\text { Black and white mustard }-S i \text { - } \\
\text { napis species } . . .\end{array}$ & Seeds & $5,302,876$ & $3-6$ \\
\hline
\end{tabular}

While the demand for medicinal weeds is not great, marketing those that have useful properties would tend to check their spread, and might, in turn, pay at least for their removal.

Other native drug plants. Clearing of the forests and the work of the drug collector have resulted in almost exterminating many of our native drug plants. 'To save these the Bureau of Plant Industry has undertaken the work of domesticating them with the hope not only of supplying the home market but also of exporting them.

In the gardens at Washington some success in an experimental way has been attained in raising goldenseal, cascara

1 Compiled from Bulletin No. 188, United States Department of Agriculture, "Weeds used in Medicine." This gives prices and methods of preparing for market. 
sitgrada, Seneca snakeroot, and purple cornflower. Ginseng has already been domesticated, the total yield in states east of the Mississippi River being about one million dollars annually.

A considerable portion of crude drugs used in the United States is of foreign origin. 'To supply the home market and suve millions of dollars now spent on foreign drugs, the Pureau has interested itself in the experimental culture of these foreign plants in soil and climate similar to their own. F'lots of Asiatic poppy, camphor trees, cinchona, belladomna, foxglove, and red peppers have been planted in suitable parts of our country.

Poisonous plants. Certain plants are poisonous either when handled or eaten. For lack of statistics, no estimate can be given as to the amount of damage done by them.

Complaints have been so numerous against various plants which poison man and animals, that the Government has investigated them and has issued a number of bulletins on poisonous plants of the United States. ${ }^{1}$ (See Bulletin 86 , "Thirty Poisonous Plants.")

Of the thirty plants described, about one third are weeds; the others are fungi, herbs, shrubs, and trees. The most poisonous plants are mushrooms (Amanita muscaria and Amarita phalloides), the various species of water hemlock (Cicuta), and the loco weed (Astragalus). Damage to the live-stock business from loco weed is enormous. Colorado, in a vain attempt to exterminate it, spent $\$ 200,000$ in bounties between the years 1881 and 1895 .

1 Bulletins from United States Department of Agriculture:

28. Weeds and how to Kill them.

86. Thirty Poisonous Plants.

188. Weeds used in Medicine.

279. Methods of eradicating Johnson Grass.

Besides these, almost every state issues complete and fully illustrated bulI. tins on its own weeds. Canada issues weed bulletins on an elaborate scale. 
Much suffering is caused by poison ivy, the active poison being a nonvolatile oil found in all parts of the plant - even the dried wood. The oil is soluble in alcohol and may be removed from the skin by thoroughly bathing exposed parts in alcohol and then washing off with water. An alcoholic

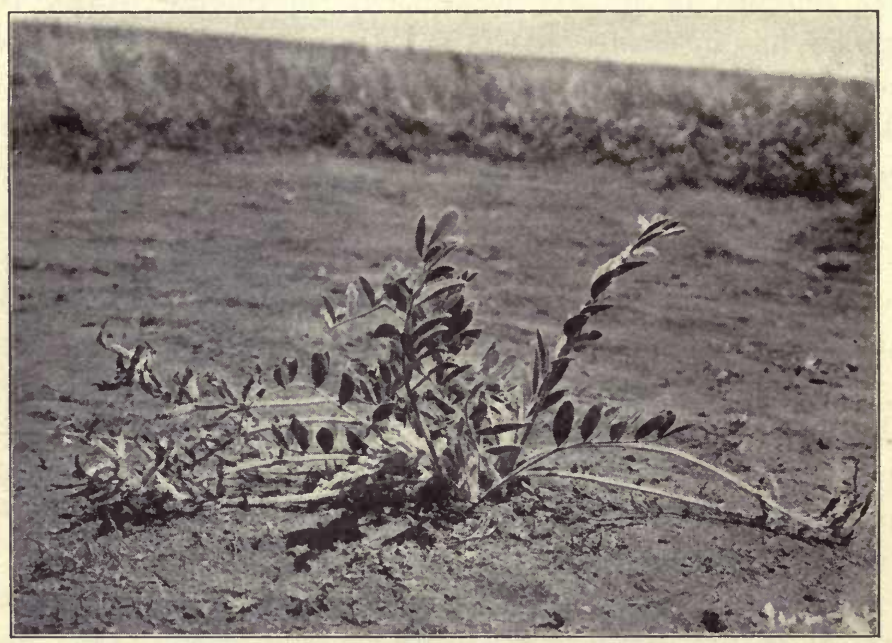

Fig. 34. Purple or woolly loco weed-Astragalus mollissimus

Photograph by C. Dwight Marsh, United States Department of Agriculture, Bulletin 112

solution of sugar of lead (lead acetate) destroys the oil. The same remedy applies to poison sumac and poison oak.

\section{Adjitional Studies}

1. Prepare a list of common weeds found along the roadside, railrcads, in grass, field, backyard, and garden.

2. Compare number of seeds borne by a weed with those of a wheat, oat, or barley plant.

3. What weeds do you know that are eaten as vegetables?

4. How is the fact that weeds are not valuable food for domestic animals to their advantage? 
5. Discuss the advisability of having foreign seeds and grains inslected before being allowed to enter this country.

6. Discuss the advantage of smothering weeds with quick-growing, tlickly seeded crops, like red clover and rye.

7. Test the germinating power of a weed by placing its seeds on damp b) otting paper between two plates.

8. Record instances observed of weeds damaging food plants. What did Darwin mean by the "struggle for existence" and "survival of the fi test"? (Ref.: Hodge, "Nature Study and Life," chap. vii.)

Copy the following list of poisonous plants into your notebook, and make the acquaintance of each one, if possible, during outdoor tramps. Increase the list by wider observation.

Poison ivy - Rhus radicans [poison oak, three-leaved ivy, mercury, b]ack mercury, markweed, pikry (Maine)].

Poison sumac - Rhus vernix [swamp sumac, dogwood (Massachusftts), poison elder (Alabama), poison ash (Vermont), thunderwood (Yeorgia, Virginia)].

Poison oak - Rhus diversiloba [poison ivy, yeara, California poison sumac].

Poison hemlock - Conium maculatum [hemlock, wild hemlock, spotted parsley, stinkweed, poison root, poison snakeweed, cashes, wode-whistle].

Water hemlock - Cicuta maculata [spotted parsley, snakeweed, beaver pison, musquash root, muskrat weed, cowbane, spotted cowbane, child'en's-bane, death-of-man].

Pokeweed - Phytolacca decandra.

Corn cockle - Agrostemma githago.

Black cherry - Prunus serotina [wild cherry, rum cherry].

Red buckeye and common horse-chestnut-Esculus pavia and hippocastanum.

Broad-leaf laurel - Kalmia latifolia [laurel (north of Maryland), ivy (south of Maryland), mountain laurel, sheep laurel, poison laurel, wood la urel, small laurel, high laurel, American laurel, poison ivy, ivy bush, ivy wood, big ivy, calico bush, spoonwood, kalmia, wicky].

Narrow-leaf laurel - Kalmia angustifolia [sheep laurel, lambkill, sheep prison, lamb laurel, small laurel, low laurel, dwarf laurel, wicky].

Jimson weed - Datura stramonium and D. tatula, the taller and pi rple-flowered species [Jamestown weed, common stramonium, thorn a] ple, apple of Peru, devil's apple, stinkwort, stinkweed, Jamestown lily, white man's plant (by the Indians)]. 
Caper spurge - Euphorbia lathyris [garden spurge, mole plant, gopher plant, wolf's-milk, springwort].

Snow-on-the-mountain - Euphorbia marginata.

Other poisonous plants are:

Death-cup mushrooms, of the genus A manita.

American false hellebore - Veratrum viride [white hellebore, swamp hellebore, Indian poke, pokeroot, Indian uncus, crow poison, devil's-bite, duck-retter, itchweed, bugbane, wolfsbane, bear corn].

Dwarf larkspur - Delphinium tricorne [staggerweed (Ohio) and purple larkspur - D. menziesii (also D. bicolor and D. trollifolium)].

Woolly loco weed - Astragalus mollissimus; and stemless loco weed Aragallus Lambertii and A. lagopos.

Rattlebox - Crotalaria sagittalis.

Oregon water hemlock - Cicuta vagans (also C. occidentalis).

Great laurel - Rhododendron maximum.

Staggerbush — Pieris mariana.

Branch ivy - Leucothoë catesbœi.

Black nightshade - Solanum nigrum.

Bittersweet - Solanum dulcamara.

Sneezeweed - Helenium autumnale.

Zygadenus venenosus.

Lupinus sericeus.

Asclepias speciosa.

Hyoscyamus niger. 


\section{CHAP'TER VIII}

\section{HOME PLAN'TING AND LANISCAPE GARDENING}

A good city can no more successfully be imposed from without, than a g sod character can be imposed upon an individual. A beautiful city and a beautiful public life must be the manifestation of the right spirit within. Therefore it is primarily incumbent upon every one interested in what has s) happily been called "the forward movement" to develop a character (.vholesome), a love for truth and righteousness, a Christian grace. As we grow in knowledge and grace, we will reflect it in our public life; and recipr.ucally, as our public life advances, it will be reflected in higher personal $s$ andards.

A Carnegie may build a library, a Marshall Field construct a great uı $\mathrm{ly}$ the people themselves. There is no magic to be availed of ; no Pauline conversion to be expected. Our municipal salvation must be wrought out ratiently, carefully, ofttimes in fear and trembling, and not by any one or two, but by the whole community.-C. R. WoonRuF

Just as the State grew out of the family, so the beautiful city can only be tre outcome of the beautiful home.-Alexandra BLemberi:

In general the physical features of a landscape supply the skeleton which life clothes with beauty of form and color, and, like skeletons, lifeless deserts or mountains are gloomy and forbidding. Without plants the animation imparted by animal life is also lacking, and the silence and loneliness of such scenes lecome oppressive. Hence the living factors which add attractiveness and charm to home and country are legitimate topics for study.

"Beautiful America" is the watchword of a national movenent represented in organized form by the American Civic $\triangle$ ssociation. This organization stands for more beautiful homes and country roads, more beautiful towns, cities, streets, and 


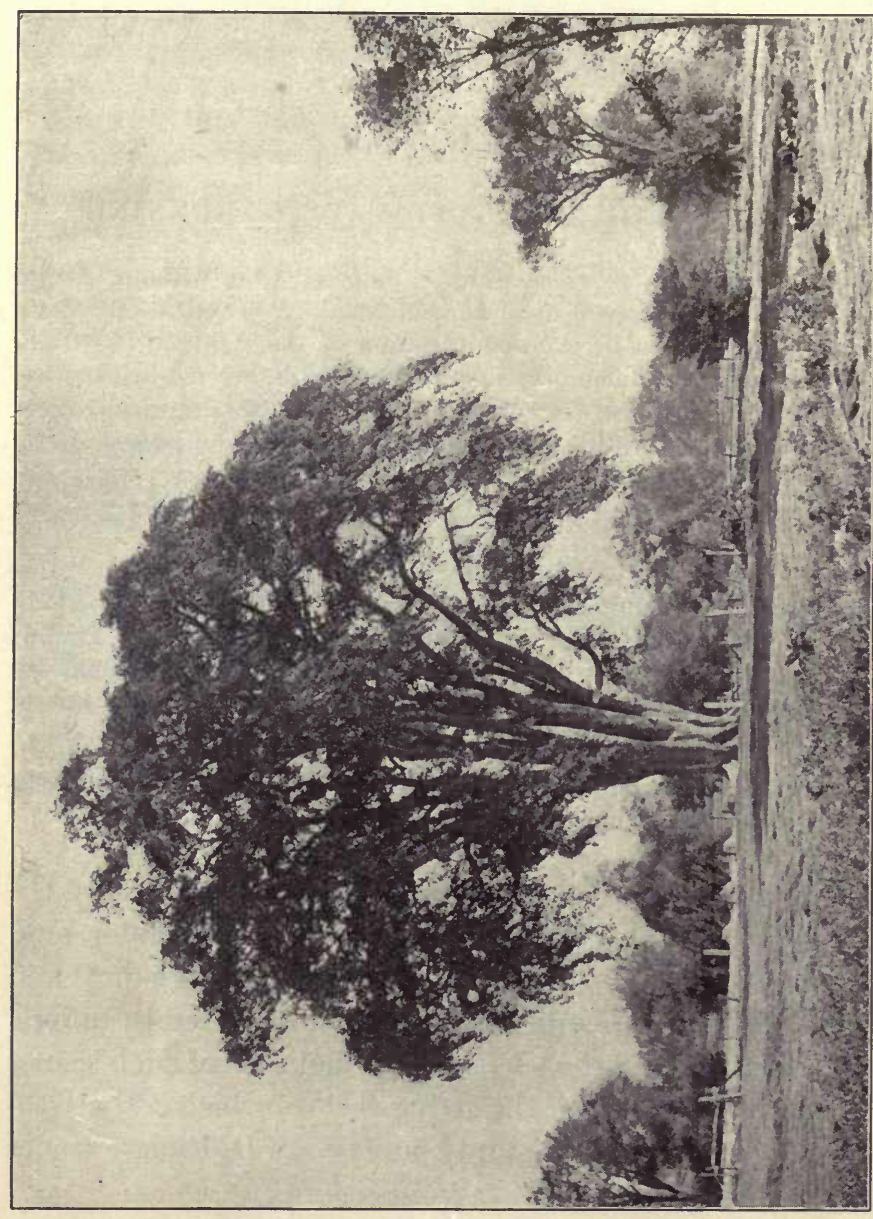

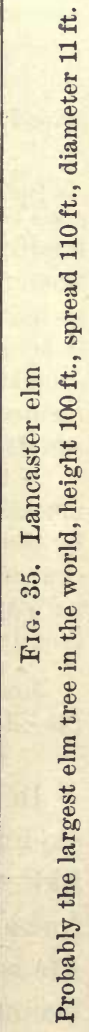


public parks and buildings, the abatement of smoke and billboard nuisances, conservation of the natural beauties of forest, mountain, waterfall, woodland, spring, glen, gorge, and canyon - for these real values to the whole people of a beautiful America.

The appearance of a country, especially of its homes, affords the best index of the character of a people. Some lomes express taste, refinement, good sense, and norals which warm the lieart of the passer-by with " friendly feeling for those who dwell within. Some express pride and repel with ostentatious display of wealth. Many are mere inuddles, accidents, cominercial affairs of the nurseryman. With the advent of the modern landscape gardener perhaps the greatest present danger is the monotony of set planting - a bit of shrubhery here, another there, " justso," which is frankly unore tiresome than nat-

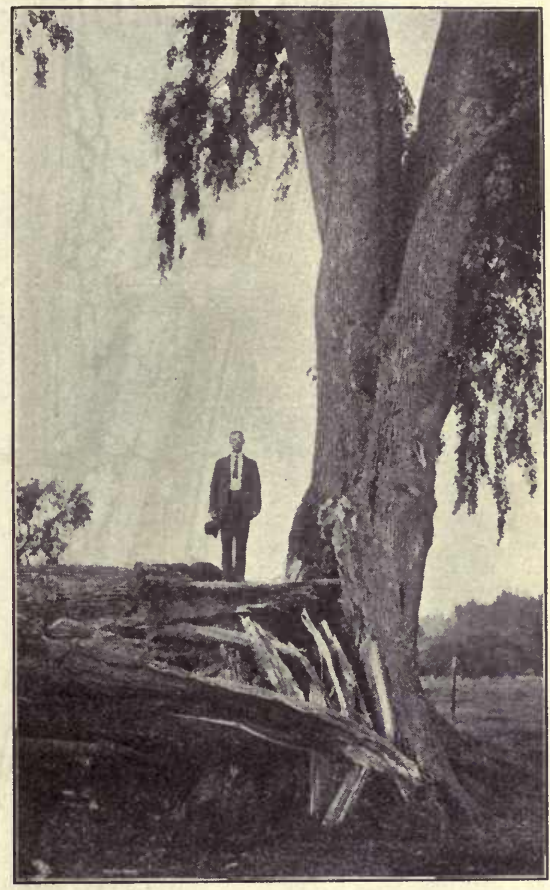

Fig. 36. Lancaster elm, after the storm ural accidents.

The practical biology of landscape gardening relates to (ffective planting of the home or street, park, town, or city. It consists in problems of forming pictures with actual trees, shrubs and vines, lawns and flowers; and the first requisite for success must be a clear knowledge of the living things with which we build. We must also bear in mind that we are 
forming not only one picture but a series of pictures to be viewed from different directions, and that planting is most effective which yields the most pleasing vistas. Then the

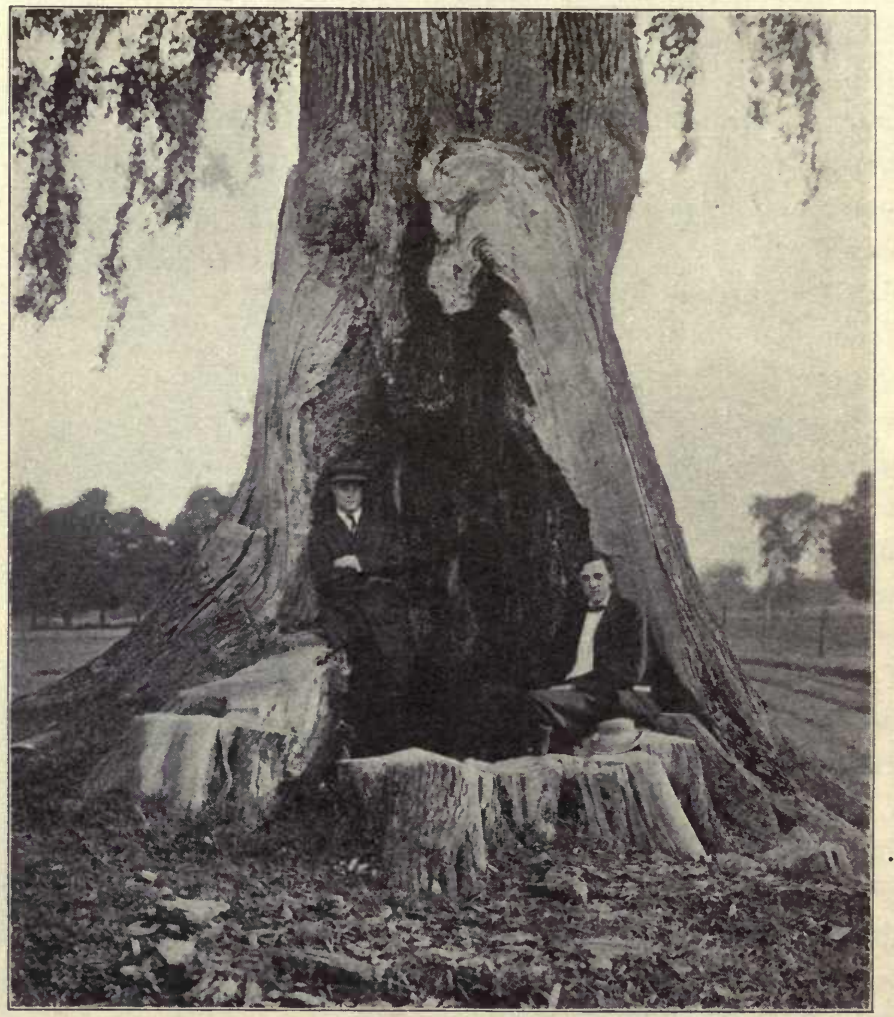

Fig. 37. Lancaster elm

Results of neglect and vandalism (the cavity had been burned out)

pictures will come and go, from the red maples, pussy willows, peach and apple blossoms of spring, through the procession of summer bloom, the fruits and foliage of autumn, to the crystal fairy lands of ice storms and snow scenes of winter. Then, too, 
our best effects will lack animation and charm without the action and music of birds; and to complete the whole, we must have fragrance - apple blossoms, lilacs and syringas of May, ruses and grapes of June, honeysuckle and moonflowers, cinnamon vine and mignonette of summer, and the spicy, health-giving aroma of pines, firs, and spruces all the year. And finally, our pictures will grow from year to year, so that when we plant trees we must imagine ahearl - ten, twenty, fifty, one hundred years.

Trees. Given the ground, the first thing to plan is the position and grouping of the trees. In order to do this intelligently we must know the biology of the different species the soil in which each grows best, and, especially for our future pictures, the height and spread and general form and color of each.

For outdoor laboratory work measure the height and spread tr) scale and sketch the general form of ten specimen trees of different kinds. These.data will be needed in determining the distances apart at which different trees are to be planted in the following plans of residence lots, parks, and streets. Arrange, by committee of the class or otherwise, to have all the trees of the district studied so that notes of the class may be combined into a table like that on page 82 , which shall give the planting data for all the native and horticultural trees available for the locality.

We need to develop clear ideas of these dimensions in order t) avoid the common mistakes of planting trees too near the house and too close together. In the one case the trees cause dampness and decay about the home, and in the other they grow into crowded jumbles rather than into beautiful pictures.

After learning the individual trees we may next study effective grouping as presented both in natural woodlands and in specimens of artificial planting in the neighborhood. Select some of the finest groups available and analyze into component 


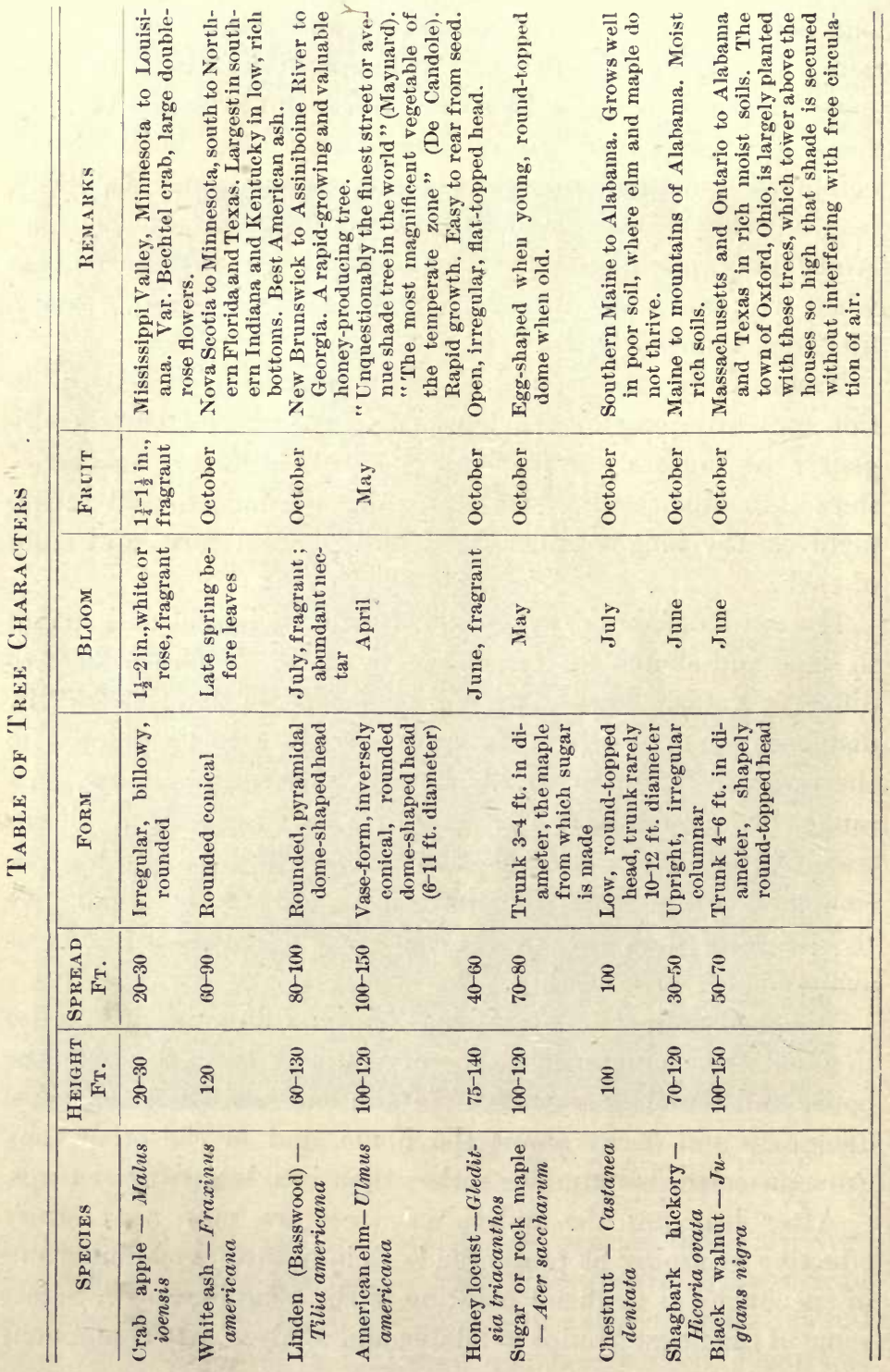


trees; measure distances apart and draw the ground plan to scale, and sketch or photograph the groups.

Rules for grouping trees are sometimes given. The following are modified from different authorities as suggestive and practical.

1. Specimen trees - those which stand alone - should be chosen for special beauty or character; oaks, chestnuts, black

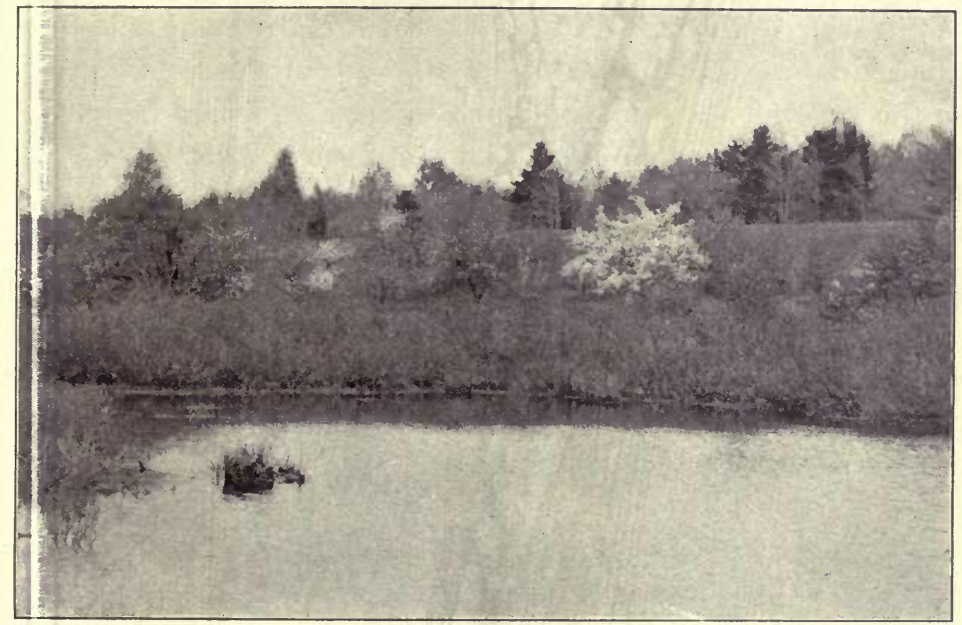

Fig. 38. A specimen of nature's planting

walnuts, old pines, and cedars for massive strength and dignity; hemlock, elm, larch, and spruce and the birches for graceful tracery of form and outline; Colorado blue spruce, purple beech, Schwedler, swamp and Japanese maples for rich coloring.

2. Groups should not be too compact, and on estates of linited extent are generally more effective if made up of trees of different characters. They should be unsymmetrical, irregular, "natural" in form. The taller trees should, of course, occupy the center, or form the background in boundary-line 
groups. 'There is opportunity here for fine contrasts in form, color, and character - oak and weeping willow or American elm, birches against white pine, etc.

3. Plant trees or groups to screen objectionable features of the landscape, and leave open spaces toward all pleasing views.

4. Plant deciduous trees on the south and west of the house for summer shade and winter sunshine, and evergreens along the northerly side to serve as stormbreaks in winter.

Shrubs. Given the bounds and main features in tastefully planted trees, the shrubbery lets the picture down naturally to the ground, and supplies much desired color and fragrance. Shrubs, too, more than anything else form the setting for the house, fit it to the earth, and make it a part of the landscape. The house being the center of the general scheme, we should place the choicest shrubs nearest to it.

For outdoor laboratory work study throughout the fall and spring, at least, good specimens of all the different ornamental shrubs to be found in your local parks or neighborhood. Observe them in all possible relations to trees, buildings, and other shrubs, so that you will be able to choose the shrubbery of a park or the home grounds with intelligent taste.

A local planting table like that suggested for the trees should be made, giving size, form, preferred exposure, and color and season of bloom. A selection of shrubs may be made which will furnish bloom for cutting and fine color effects in either flower or fruit for not only the growing season but the entire year. If it is desired to combine use and ornament, a tendency growing in favor, - nothing in the way of shrubbery can be more effective, either in bloom or fruit, than the dwarf fruit trees, especially peach, apricot, nectarine, cherry, pear, and apple. Lists and descriptions of desirable shrubs for the locality can be obtained from any good nursery catalogue.

"American trees and shrubs for American homes" is a rule with exceptions, but one that has much good sense in its favor. 


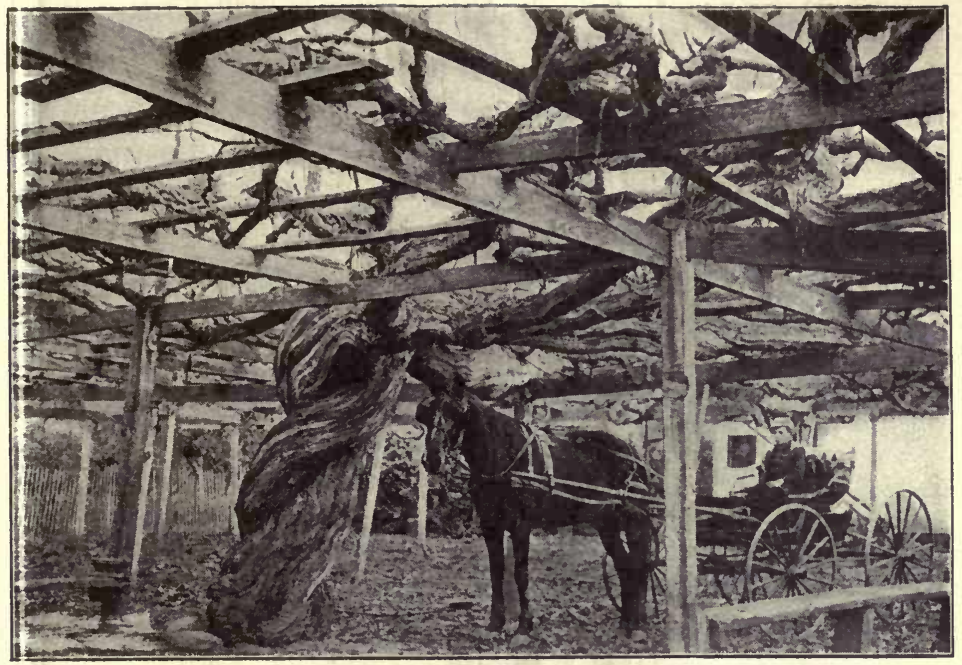

F.1. 39. Mission grape. Largest grapievine in the world Planted in 1842, in 1895 bore over ten tons of grapes, Carpinteria, California

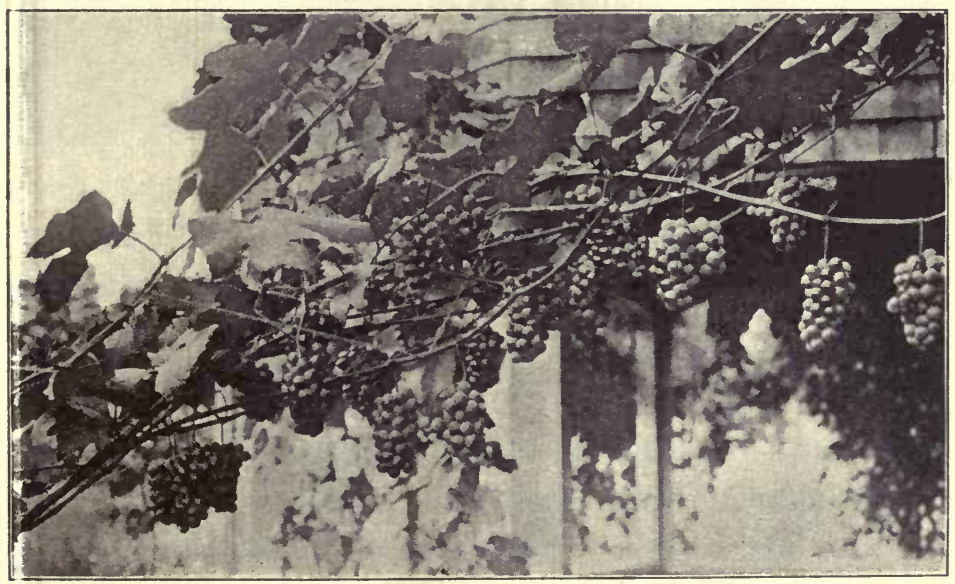

Fig, 40. Delaware grape

Living decoration for a dining porch 
What exotic is more beautiful than our mountain laurel or our rhodora, or more graceful than our sumacs and elderberry, or sweeter than our pepper bush and wild rose? It is no slight matter that a plant has become adjusted to its environment on a large continent through the many centuries of its struggle for existence.

Flowers. With shrubbery now as the background come naturally, in the finest landscape effects, the hardy perennials

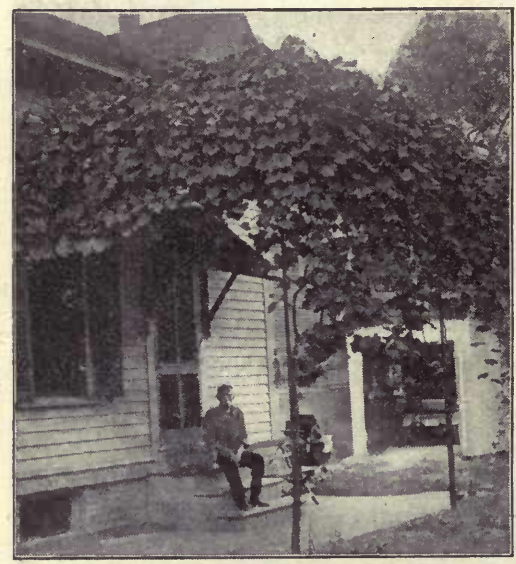

FIG. 41. The most beautiful back door in Worcester, Massachusetts

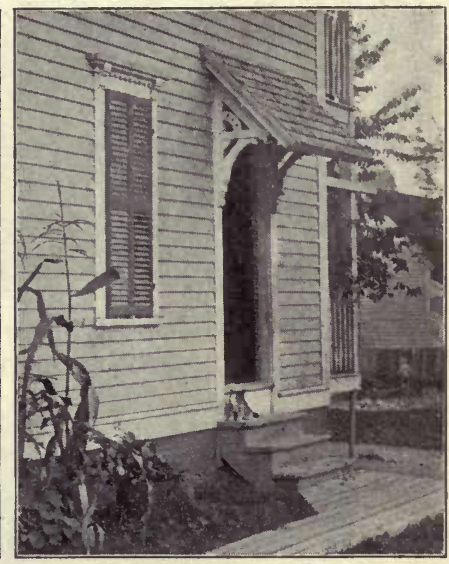

Fig. 42. An ugly back door

Compare with Fig. 41

- peonies, lilies, irises, hollyhocks and phloxes, goldenrods and asters, and a host of others; also the annual bedding plants, the cannas and dahlias, sunflowers, marigolds and zinnias, nasturtiums, sweet peas and flowering beans, and by all means, here and there, a few tuberoses and a bed of heliotrope and mignonette. These supply the finishing touches for both color and fragrance, and should be studied largely as a matter of individual preference and taste. Here is the test, however, for harmonious and pleasing effects in color, and, since we must live with our homes so much of the time, the 
whole effect should be restful and comfortable and as far removed from fussiness as possible.

Vines. Especially on the house and buildings, vines add a touch of comfort, as well as wildness and grace, without which few pieces of landscape gardening are complete. Vines of all plants are also the most plastic, convenient, and accommodating. With them we may have shade of any degree anywhere we wish, cover anything, from a snag, past, or rock to a factory wall, and we may have fragrance and flowers and even fruit thrown in for good measure.

As suggested for the trees and shrubs, make a special study of all the vines adapted for home and park planting in your locality, and include methorls of propagating and culture of each.

The world over, the grape combines in highest degree all the best qualities of both use and beauty. The way

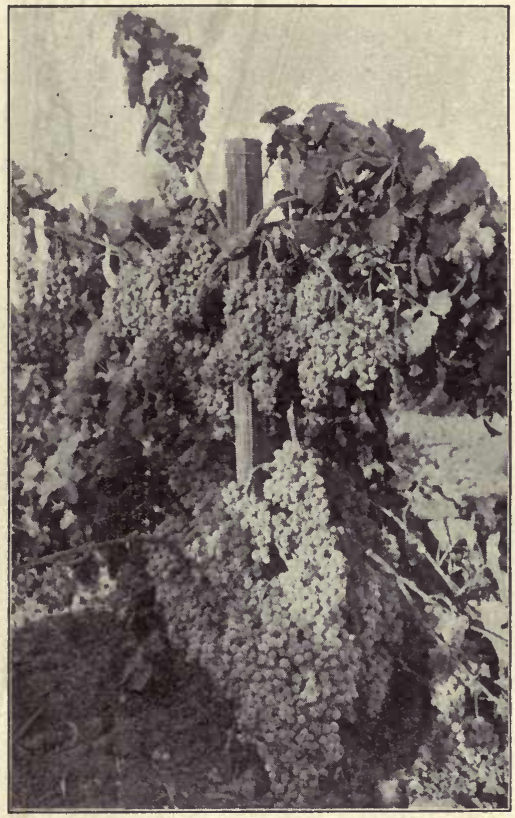

Fig. 43. California grapes

Photograph by George C. Husmann, United States Department of Agriculture our American wild grapes climb the tallest forest trees shows that with proper support they may be carried to any reasonalile height. A growth of sixty-three feet of vine from a single bud in a season proves how quickly any extent of wall can be shielded from the hot sun of summer by properly trained grapevines. For covering surface no other vine, 
excepting possibly the Actinidia, can compare with the grape, if well established. The fact that it climbs by tendrils makes it much easier to train, prune, and control than vines which twine around their supports. The grape thrives in poor soil, wet or dry, and can be depended upon to flower and fruit for centuries, renewing its youth often from the root. Varieties differ much in form and size of leaf and in vigor and rapidity of growtlı.

Make a special study, with sketch to scale, of at least one good specimen vine before it is pruned back in the fall. Note

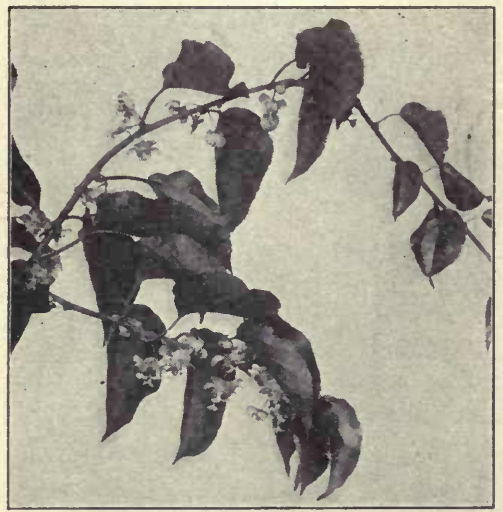

Fig. 44. Flowers of Actinidia

variety, age, size, and height of main stem and length of several of the most vigorous canes of the season's growth. Record, if possible, the amount of fruit produced. By each member of the class selecting a different variety, the grapes best suited to the locality may be compared and learned. Houses, even in crowded cities, might be transformed into bowers of shade and beauty by the adequate use of the grape alone.

Actinidia arguta is a close second of the grape. After becoming well established it is a most rampant grower, speedily reaching the tops of the tallest trees, and about buildings is likely to require severe pruning. The leaves are clean and glossy, with red petioles. Fragrant and attractive flowers appear in June, and the fruit ripens in September and October. This is a dull green drupe the size of a small plum, with a flavor and quality quite unlike anything American. The Actinidia comes to us from Japan and is hardy and well adapted to our climate. Along with other valuable importations from 
the same source it has the advantage. of not being attacked ly American insect pests. Rosa rugosa, the Japanese quince, and the Japanese snowball are other eases in point.

Following are some problems in landscape gardening:

1. Make a series of sketches, to scale, of your home grounds, - ground plan and at least one view, - naming and locating all trees, shrubs, vines, and bedding plots with their contents.

2. Draw a ground jlan and view of your lome grounds as you would wish to have them.

3. Can you suggest any improvements in the street tree planting (if your town, city, or neighborhood? Draw flans and specifications for special local problems of this kind the treatment of certain streets or roadsides.

4. Let each member if the class sketch a ground plan and view

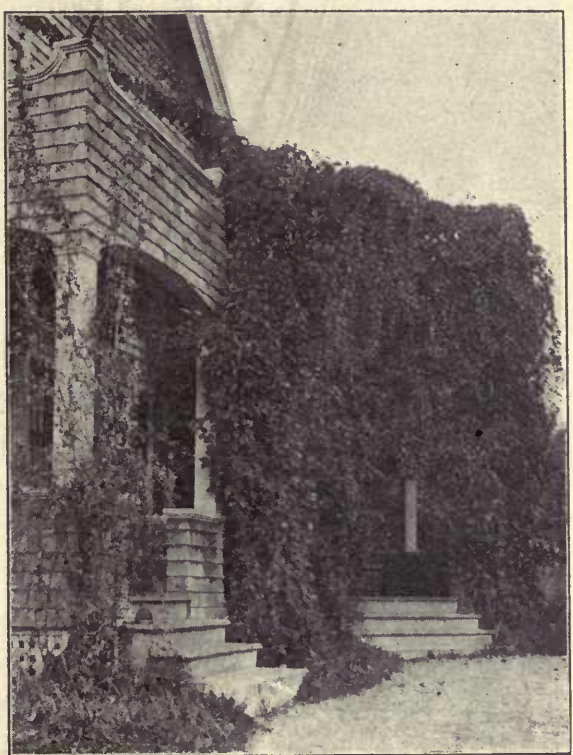

Fig. 45. Actinidia arguta

Two vines, three years from transplanting, afford dense shade for a porch of the school grounds, giving both specifications and cost.

5. Taking a local public square, park, common, or playground as a special problem for analysis and study, can you suggest improvements in its planting?

The simplest principles of landscape gardening are often :llucled to as the " $A, B, C$ " of the subject. They are based upon the pleasing arrangement of trees, vines, and shrubs and 
open glades as found in beautiful bits of natural woodland. $A$. Leave open glades for air and sunshine. They make even modest grounds seem roomy. $B$. Plant in masses, like the forms of clouds, leaving open vistas toward sunrise and sunset and all pleasing views, and covering unsightly features

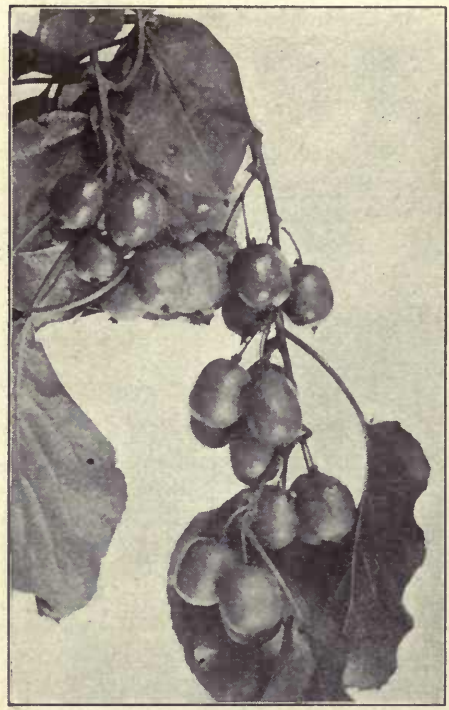

Fıg. 46. Actinidia arguta in fruit of the landscape. C. Avoid straight rows; Nature never plants that way.

Finally we may study home and city planting as an investment. If well done, probably no equal expenditure will result in larger returns. Figure out increased value of property along well-planted streets and in the vicinity of public parks. Let each member of the class study and analyze his own home with this point in view - figuring into the account first cost, yearly expenditures, and upkeep against enhanced values. A shade tree in the wrong place may be a positive injury to a home, while the same tree in the right place might enhance its value a hundred, or even a thousand, dollars. And in these, as in all similar cases, it is not the money values we are studying so much as the human health and comfort which they represent.

The planning and planting of a home or a country beautiful enough to inspire the love of a people is no unimportant matter. Compare Russia and Japan with this feature in view and in connection with the results of the recent war. 


\section{CHAPTER IX}

\section{PRACTICAL BIOLOGY OF AGRICULTURAL PRODUCTION AND CIVIC UTILIZATION OF LAND}

Public prosperity is like a tree : agriculture is its roots; industry and commerce are its branches and leaves. If the root suffers, the leaves fall, the branches break, and the tree dies. - Chinese saying, from Hopkins, "Soil Fertility and Permanent Agriculture"

In final analysis civilizations rest mainly upon agricultural efficiency. At least, this must be increasingly true as civilization advances. In this vital matter it is high time to cast aside all pride and conceit and wake up to a sense of our low agricultural efficiency as a people. In 1907 a total of 20,000 square miles of agricultural land in Japan supported $46,977,003$ people, or 2349 people to the square mile, with less than one dollar per capita excess of agricultural imports ('ver exports. Fertile regions of both China and Japan supyort as high as 3840 people per square mile. Compare these figures with those for Belgium, the most densely populated (ountry in Europe; here less than 300 people per square 1nile are supported. The best farming districts of the United Sitates support about 30 people per square mile.

Further, in little more than a brief century we have swept (ver a continent rich in the accumulated fertility of many thousands of years, and in ignorance have wasted and depleted (" mined" rather than "cultivated") the soil. As land in one region has been mined out, we have abandoned it and moved to virgin fields, but now, with practically no more new land available, we are forced to turn toward the more civilizing and socially ethical task of permanent American agriculture. 


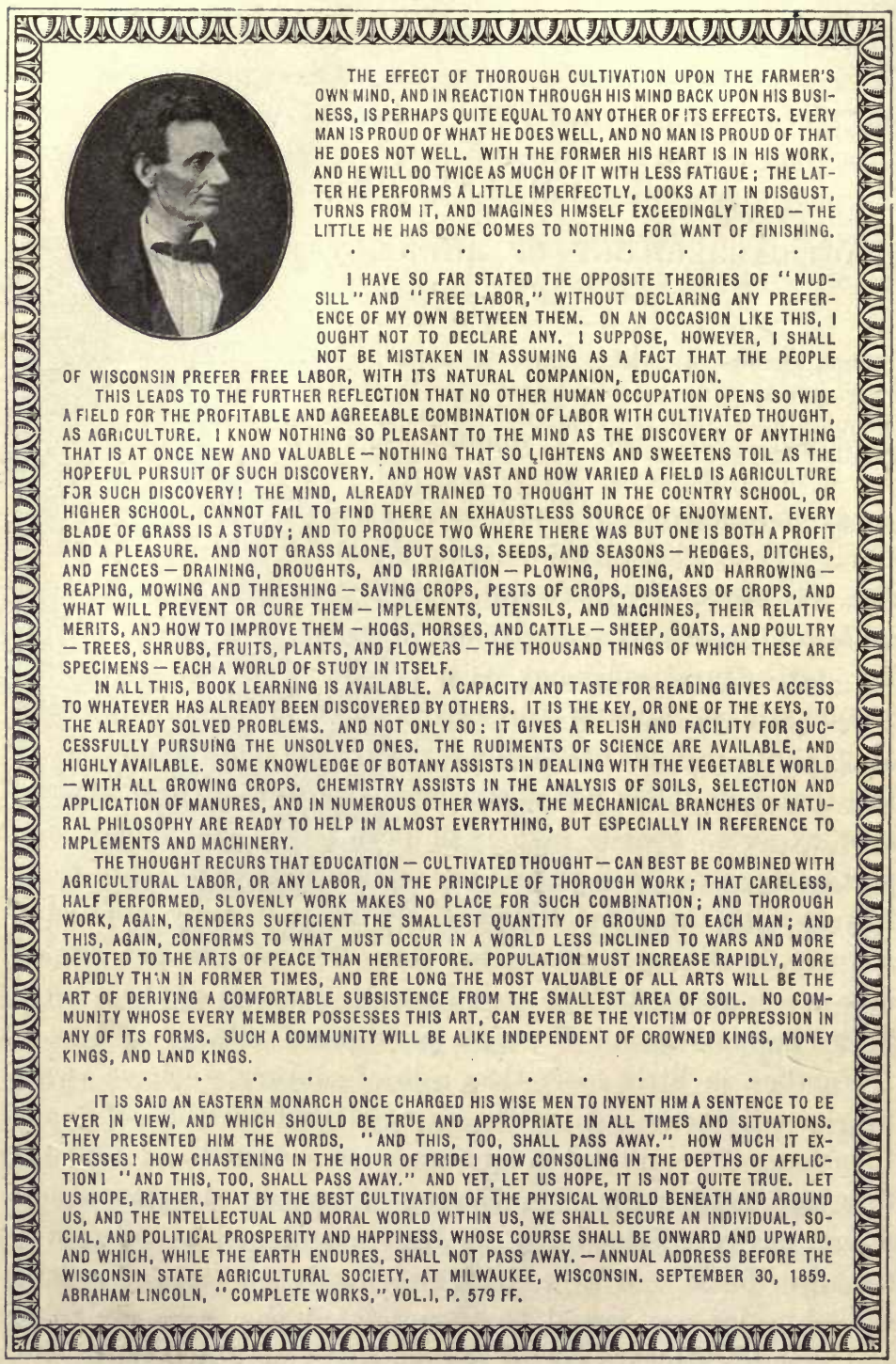


Agricultural efficiency. Wherever possible let each member of the class choose some local plant or animal industry and collect records, establish working standards, and figure out the local percentage of efficiency. This might well form the main thesis work of the year, and, in a community in which agriculture is important, by distributing theses to cover the different crops we may make this work contribute to civic advancement. $\Lambda$ recent estimate by Emerson yields the following results:

Standardas and Percentage of Efficiency' for Following Crops

\begin{tabular}{|c|c|c|c|c|}
\hline & $\begin{array}{c}\text { STANDARD YIELD } \\
\text { PER ACBE }\end{array}$ & $\begin{array}{c}\text { AVERAGE } \\
\text { YIELD }\end{array}$ & $\begin{array}{l}\text { PER CeNT OF } \\
\text { EFFICIFACY }\end{array}$ & $\begin{array}{l}\text { ANNUAL LOSS BY } \\
\text { LOW EFFICIENCY }\end{array}$ \\
\hline l'otatoes & $500 \mathrm{bu}$. & $96 \mathrm{bu}$. & 19 & $\$ 900,000,000$ \\
\hline Wheat & 50 bu. & 14 bu. & 28 & $1,000,000,000$ \\
\hline Cotton & 1 bale & 0.35 bale & 35 & $1,000,000,000$ \\
\hline Corn $^{1}$ & 100 bu. (record 239 bu.) & $28 \mathrm{bu}$. & 28 & $2,680,000,000$ \\
\hline ()ats 1 & 100 bu. (record $209 \frac{1}{2}$ bu.) & $32 \mathrm{bu}$. & 32 & $585,413,000$ \\
\hline
\end{tabular}

The standard of 500 bushels of potatoes per acre is admittedly low. By the mere addition of brains ("cultivated thought") to breeding and selection of variety, and scientific precision in fertilizers and culture methods, this standard unight be raised to 1000 bushels, possibly, without increasing per-acre cost of operation, except to pick up the additional 500 bushels. Probably Lord Rosebery holds the world's ıecord : 2053 bushels of potatoes - 1754 marketable and 299 lushels of culls per acre. With the standard at 2000 bushels our scale of efficiency falls to $4_{4}^{3}$ per cent.

Hills of potatoes vary remarkably in the same field, and heginnings have been made in "hill selection" of seed on this nccount. Tubers planted from strong hills have thus been found to yield as high as sixteen times as many pounds as

1 Data obtained elsewhere. 
tubers from weak hills of the same variety. Little, however, has been done by way of recording the yields of single hills. Grubb gives 16 tubers, weighing 8 pounds, as the ideal hill in field culture. Perry Nathan Pickett, aged twelve years, in

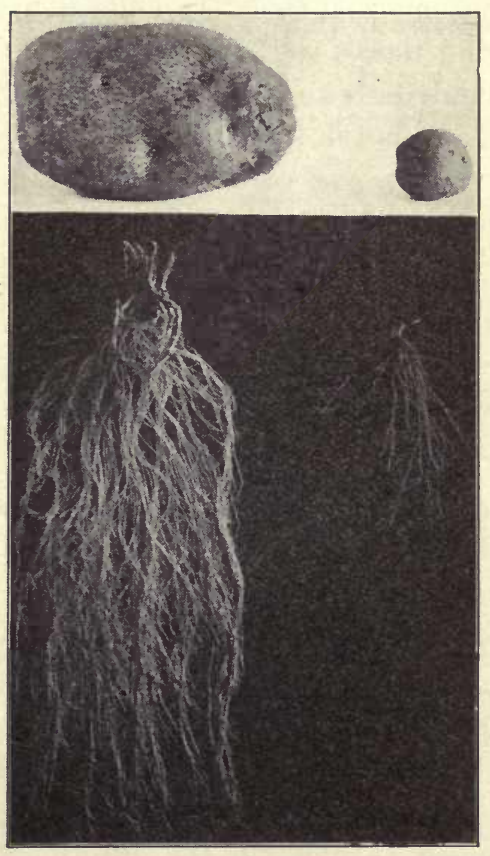

FIG.47. Growth race between potatoes

Potatoes weighed 186.7 and $9.8 \mathrm{~g}$. At end of fifty-eight days the roots had grown $8640 \mathrm{ft}$. and $155 \mathrm{ft}$. respectively. Photograph by Frances W. Tufts connection with his industrial project work in Salem, Oregon, in 1914, produced a record hill of Burbank potatoes, containing 13 large and 2 small tubers, weighing 16 pounds. A record hill from Lexington, Oregon, yielded 24 pounds, and Carl Gabrielson, aged eleven, Puyallup, Washington, has reported a volunteer hill in his school garden that dug 103 potatoes, ranging from 12 ounces to the size of a hen's egg and weighing 40 pounds 12 ounces. If we know how to raise one hill best, we may extend this knowledge to any number of hills. Hence, for an elementary standard unit the single plant will be a more usable one than the plot or acre. Any boy can find a place to raise one or ten hills of potatoes; he may try a different experiment on each hill, and thus learn more from a single hill than he might from an acre. The same is true of a single plant of wheat, corn, tomato, cabbage, lettuce, strawberry, blackberry, raspberry, grape, peach, apple, pear, rose, lily, or anything else. 
It is interesting that Lincoln should state the problem so clearly, more than fifty years ago. ${ }^{1}$

My first suggestion is an inquiry as to the effect of greater thoroughness in all departments of agriculture than now prevails in the Northwest-perhaps I might say in America. To speak entirely within bounds, it is known that fifty bushels of wheat, or one hundred bushels of Indian corn, can be produced from an acre. Less than a year ago I saw it stated that a man, by extraordinary care and labor, had produced of wheat what was equal to two hundred bushels from an acre. But take fifty of wheat, and one hundred of corn, to be the possibility, and compare it with the actual crops of the country. Many years ago I saw it stated, in a patent-office report, that eighteen bushels was the average crop throughout the United States; and this year an intelligent farmer of Illinois assured me that he did not believe that the land harvested in that State this season had yielded more than an average of eight bushels to the acre; much was cut and then abandoned as not worth threshing, and much was abandoned as not worth cutting. As to Indian corn, and indeed, most other crops, the case has not been much better. For the last four years I do not believe the ground planted with corn in Illinois has produced an average of twenty bushels to the acre.

Lincoln admits too much for the sake of argument, however, when he says:

Unquestionably it will take more labor to produce fifty bushels from an acre than it will to produce ten bushels from the same acre; but will it take more labor to produce fifty bushels from one acre than from five? Unquestionably thorough cultivation will require more labor to the acre; but will it require more to the bushel?

Recent experiments have proved that less labor, rather than more, may produce the larger crop. Goethe's proverb, Nichts ist schrecklicher als tätige Unwissenheit, "Nothing is more terrible than active ignorance," applies with unusual force to the delicate task of raising a plant best.

The most laborious and expensive factor in growing a field of corn has been "thorough cultivation." After this had been

1 Abraham Lincoln, Complete Works, Vol. I, p. 577. 
tearing off half the roots of the corn plants for centuries, and laboriously reducing the yields from 30 to 50 or more bushels per acre, some one hit upon the idea of studying applying " cultivated thought" to the roots of the single corn plant. It was discovered that many of them spread out near the surface, five, six, or even seven feet in every direction. Next came the thought, May not too deep cultivating injure these roots? The experiment has now been tried of shaving the weeds without stirring the soil at all, applying careful

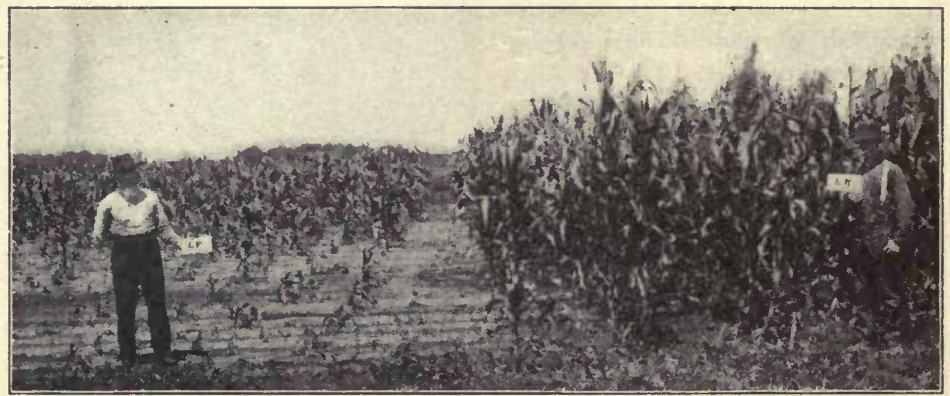

Fig. 48. Two plots of corn on peaty swamp land

Left, fertilized with phosphorus (not needed); crop, 0. Right, fertilized with potassium ; crop, 72 bushels per acre. Seed, cost of fertilizer, and labor on the two plots about equal. Photograph by Cyril G. Hopkins

shallow tillage to comparable rows in the same fields. Results have shown, on the average, equal yields from the uncultivated rows. Figure out, for your farm, township, county, state, or for the United States, how many dollars' worth of labor this one discovery may save annually.

Pure-bred selected strains. Again, we have leamed that by breeding and selection of productive strains the crop may be increased without additional labor. This fact gives the added value to pure-bred stock in animals and plants. Half the plants in an ordinary field of potatoes or coln may be "loafers"; half the trees in an ordinary orchard may be "resters"; half the 
liens or cows in the ordinary barnyard may be "boarders." A single specimen of plant or animal may produce a phenomenal yield, but the progeny may revert to loafers and boarders. l'ure-bred strains have been carefully selected for generations, until all bad heredity has been weeded out and the progeny (an be relied upon to be thoroughbreds, that is, to yield a ıniform, standard result. Collect records of various pure-bred strains in the neighborhood and compare yields, as below:

Differences in Yield Due to Varietr, Experiment Station, Rostern, Canada

\begin{tabular}{|c|c|c|c|c|}
\hline & $\begin{array}{c}\text { YIFLD } \\
\text { PEIR ACRE }\end{array}$ & $\begin{array}{c}\text { WEIGHT } \\
\text { PER BUSILEL }\end{array}$ & $\begin{array}{l}\text { TIME TO } \\
\text { MATURE }\end{array}$ & $\begin{array}{c}\text { UNMARKET- } \\
\text { ABLE }\end{array}$ \\
\hline 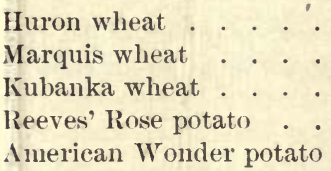 & $\begin{array}{l}73 \mathrm{bu} . \\
70 \mathrm{bu} . \\
37 \mathrm{bu} . \\
623 \mathrm{bu} . \\
371 \mathrm{bu} .\end{array}$ & $\begin{array}{l}59 \mathrm{lb} . \\
\text { (i1 1b. } \\
52 \mathrm{lb} .\end{array}$ & $\begin{array}{r}107 \text { days } \\
98 \text { days } \\
107 \text { days }\end{array}$ & $\begin{array}{l}46 \mathrm{bu} . \\
58 \mathrm{bu} .\end{array}$ \\
\hline
\end{tabular}

Disease-resisting strains. Variation applies to immunity from disease as well as to any other character, and hence the world is being searched for strains of animals and plants which lave developed resistance to prevailing diseases. Cattle from India are being introduced into the south, because they are immune to Texas fever. The ordinary Crimson Rambler rose is much infested with mildew, while Van Fleet's seedling is 1 ractically immune to it. Such immunity may extend even to freedom from insects, as shown by many foreign introductions, notably Rosa rugosa and the flowering quince and snowball from Japan. 'Thus in all sorts of epidemics it is of great importance to note any immune individuals, and these should be carefully preserved with a view to development of resistant strains. Collect the data on any local work along this line.

A good case in point occurred recently in the eabbage industry $0 \therefore$ southeastern Wisconsin. A fungus suddenly appeared which took 
practically the entire crop. The Agricultural Department at Madison was appealed to for help, and the experts, on visiting the infested territory, found here and there a cabbage plant that had not been attacked. Seed was saved from these specimens and a resistant strain secured. Another example is the resistance of mazzard stock to cherry gummosis.

Problem of soil fertility. Fifteen chemical elements commonly enter into or constitute the plant body. They are naturally the most abundant elements of air, water, and earth. Take, for example, the composition of corn:

\section{Per Cent}

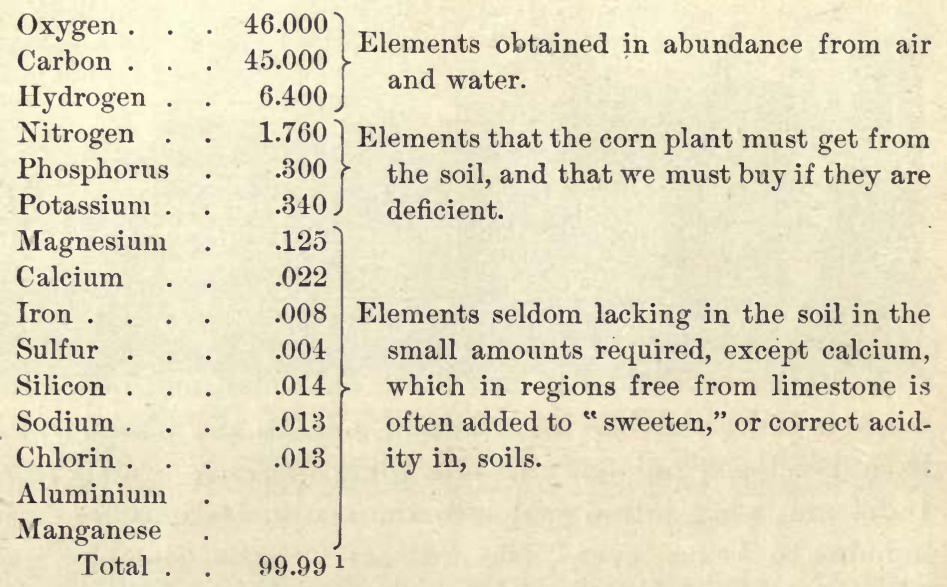

An acre of soil $6 \frac{2}{3}$ inches deep weighs $2,000,000$ pounds, and if we analyze this and determine how many pounds of the necessary elements it contains, and if we know how many pounds of these elements are removed in a given crop, we can figure roughly how long the soil will "last," that is, be able to produce the crop. Hopkins has done this in the table on the following page. ${ }^{2}$

${ }^{1}$ Cf. Hopkins, Soil Fertility and Permanent Agriculture, p. 13.

2 Ibid., p. 59. 


\section{Relative "Supply and Demand" of Seven Elements}

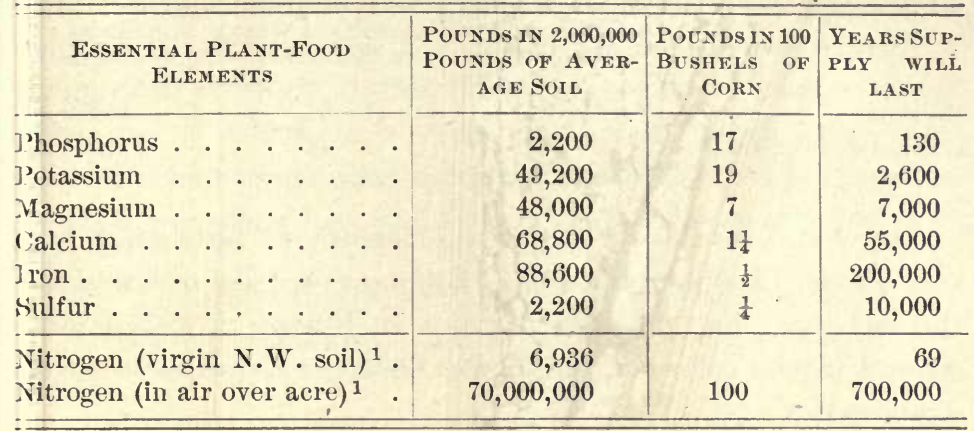

Of course the problem is not as simple as this table would indicate, hecause these elements are being returned to the soil in various ways - from the air and from the decay of plants and from animal wastes. The table does show what tends to happen in the ordinary process of depletion from continuous cropping, if care is not taken to thus return the needed elements to the soil.

The three absolutely essential elements which are likely to limit productivity of a soil are nitrogen, phosphorus, and potassium. Nitrogen, the most vital of all, does not exist in combination as a mineral in the soil, but must be added from the decay and waste matters of animals and plants or by bacterial action. Of the other two, phosphorus is likely to be the limiting element, but potassium compounds, as well as those (f calcium, are so easily soluble that they are likly to be completely leached away, as was the case in the peaty loam soil (Fig. 48). No matter what the abundance of the others, lack of any essential element limits plant growth; it is like a storehouse full of food, with the key lost. This is well shown in the Maryland Experiments with Lime. ${ }^{2}$

1 Added to table from p. 559.

${ }^{2}$ Cf. Hopkins, Soil Fertility and Permanent Agriculture, p. 167. 
Produce in Eleven Years, per Acre

\begin{tabular}{|c|c|c|c|}
\hline & $\begin{array}{l}\text { Bushels OF CORN } \\
\text { IN Four Crops }\end{array}$ & $\begin{array}{c}\text { BUSHELS OF WHEAT } \\
\text { IN THREE CROPS }\end{array}$ & $\begin{array}{l}\text { Toxs OF HAY IN } \\
\text { Four Crops }\end{array}$ \\
\hline $\begin{array}{l}\text { No lime } . \dot{0} \text {. } \\
\text { Ground shells }(2500 \mathrm{lb} .)\end{array}$ & $\begin{array}{r}98 \\
145\end{array}$ & $\begin{array}{l}32 \\
43\end{array}$ & $\begin{array}{l}2.60 \\
4.29\end{array}$ \\
\hline
\end{tabular}

Learn the results of local experiments in fertilizing land and collect all available records and data on local soil analyses and surveys. The possible value of such work is well demonstrated in the following from the Oswego Experiments with strawberries :

\section{Rich Bottom Lani, Season fairly Dry (1597)}

Plat I : $350 \mathrm{lb}$. dissolved rock per acre; yield, 13,597 qt. Plat II : $700 \mathrm{lb}$. dissolved rock per acre; yield, 20,066 qt. (An expense of $\$ 7.00$ marle a gain of $\$ 353.55$ over Plat I.)

Value of land. Some land may be dear as a gift. Agricultural nitrogen is worth $\$ 0.15$ a pound, potassium $\$ 0.06$, ground limestone $\$ 0.005$, and phosphorus $\$ 0.03$. At these prices let us compare the values of two samples of land.

\section{Pounds ix 2,000,000 Pounds of Soll}

\begin{tabular}{|c|c|c|c|c|}
\hline Plaxt Food & MANITOBA & VALUE & BAVARIAN BARRENS & VALUE \\
\hline Phosphorus . & 2,53 & $\$ 75.90$ & Trace & $\$ 0.00$ \\
\hline Potassium . . & 17,100 & $1,026.00$ & None & 0.00 \\
\hline Nitrogen . . . & 20,100 & $3,015.00$ & Trace & 0.00 \\
\hline Calcium & 27,000 & .00 & 1380 & 6.90 \\
\hline Total values. & . . . & $\$ 4.241 .90$ & . . . . & $\$ 6.90$ \\
\hline
\end{tabular}

Of course, beyond a certain limit additional amounts of any plant food may not be of immediate value, but the above figures indicate a fundamental reason for the rush of agricultural emigration to the northwest. Still, with all the experience of 
the past with exhausted and abandoned soils, the people on these rich lands are again talking of the "inexhaustible fertility" of the soil, and burning their straw and manure or laanling the latter onto the ice to befoul their streams. A comparison of virgin soil in the Canadian Northwest with soil andjoining it which had been cultivated twenty-two years showed a loss of nitrogen per acre from 6936 to 4736 pounds, or 2200 pounds, a loss of $\$ 330.00$ worth of nitrogen per acre.

\section{Fertility Contained in Different Faral Crops}

(Approximate maximum amounts removable per acre annually)

\begin{tabular}{|c|c|c|c|c|c|c|}
\hline \multirow{2}{*}{ Produce } & & \multirow{2}{*}{ YIELD } & \multicolumn{3}{|c|}{ Potixns } & \multirow{2}{*}{$\begin{array}{l}\text { TOTAL } \\
\text { VALUE }\end{array}$} \\
\hline & & & Nitrogiex & РнOSPHOR's & PotAASIOM & \\
\hline Corn, grain . & . . & $100 \mathrm{bu}$. & 100 & 17 & 19 & $\$ 16.65$ \\
\hline Stalks, cobs. & . . & $3 \mathrm{~T}$. & 50 & $6 \frac{1}{2}$ & 54 & 10.93 \\
\hline Corn crop . & . . & . . . & 150 & $23 \frac{1}{2}$ & 73 & 27.58 \\
\hline Wheat, grain & ... & $50 \mathrm{bu}$. & 71 & 12 & 13 & 11.79 \\
\hline straw . . & . . & $2 \frac{1}{2} T$ & 25 & 4 & 45 & 6.57 \\
\hline Wheat crop & . . & . . . & 96 & 16 & 58 & 18.36 \\
\hline Ilfalfa hay & . . & $8 \mathrm{~T}$. & $400^{1}$ & 36 & 192 & 72.60 \\
\hline Votton lint . & . . & $1,000 \mathrm{lb}$ & 3 & .4 & 4 & .70 \\
\hline Cotton seed & . . & $2,000 \mathrm{lb}$. & 63 & 11 & 19 & 10.92 \\
\hline Cotton stalks & . . & $4,000 \mathrm{lb}$ & 102 & 18 & 59 & 19.38 \\
\hline Cotton crop & . . & . . . & 168 & 29.4 & 82 & 31.00 \\
\hline l'otatoes . . & . . & $300 \mathrm{bu}$. & 63 & 13 & 90 & 15.23 \\
\hline Apples . . . & . . & 600 bu. & 47 & 5 & 57 & 10.62 \\
\hline leaves .. & . . & $4 \mathrm{~T}$. & 59 & 7 & 47 & 11.88 \\
\hline Wood growth & & $\frac{1}{50}$ of tree & 6 & 2 & 5 & 1.26 \\
\hline Apple crop & . . & . . . & 112 & 14 & 109 & 23.76 \\
\hline lat cattle.. & . . & $1,000 \mathrm{lb}$ & 25 & $\tau$ & 1 & 4.02 \\
\hline lat hogs . . & . . & $1,000 \mathrm{lb}$ & 18 & 3 & 1 & 2.85 \\
\hline Milk . . . & . & $10,000 \mathrm{lb}$. & 57 & 7 & 12 & 9.48 \\
\hline liutter... & . & $400 \mathrm{lb}$ & 0.8 & 0.2 & 0.1 & .14 \\
\hline
\end{tabular}

${ }_{1}^{1}$ Much of this nitrogen is taken from the air, and the roots go so deep that $\epsilon$ ven the phosphorus and potassium may be largely supplied from layers of soll below the reach of other crops. 
Losses in plant food due to cropping. Too many have not counted the cost of a crop to Mother Earth, and hence have taken it as a free gift, with no thought of making any return. The table above, modified from Hopkins, ${ }^{1}$ shows what a few typical crops actually take from the soil.

Complexity of the problem. It remains to add that the problem of soil fertility is much more complicated than the above brief statement would seem to indicate. Warren says: "The fertile surface soil may be carried away by erosion, by wind, or water. Probably more soil fertility is lost in this way than by cropping." 2 So the humus may be exhausted, and with it the soil may lose its power to hold moisture, so that it becomes hard and dry, and plant food in any amounts is of no avail. Or soil may be too wet and require drainage, and too free drainage may rapidly leach away nitrates, potash, and lime. Chemical changes are going on within the soil, and additions are being made to it from the air, which lead some authorities to claim that mineral plant foods are practically inexhaustible. Poisonous substances, it is claimed, are excreted by the roots of certain plants, so that proper rotation of crops is all that is needed to maintain fertility indefinitely. That is, the soil is "A bank account which requires for its maintenance only the rotation of the check book among the members of the family!" Hopkins sums up the whole matter as follows:

The possible enormous and irreparable damage of such teaching lies in the fact that even our remaining supply of good land will ultimately be depleted ... beyond the point of self-redemption, thus repeating the history of our abandoned Eastern lands, where the rotation of crops was the common rule of practice for more than a hundred years.

Problems in animal industry. Perhaps the most important dairy records are those of Professor Fraser of the University of Illinois. He tested 554 cows in 36 commercial dairy herds, each

1 Soil Fertility and Permanent Agriculture, p. 154.

2 Farm Management, p. 184. 
for a full year. The best 25 per cent produced 301 pounds of butter fat per year; the lowest 25 per cent only 133.5 pounds. He concludes from the experiment as follows: "If it costs $\$ 30$ a year to feed the poorer cows and $\$ 38$ a year to feed the better (ines, then at present prices a herd of 25 of the better will produce as much net profit as would 1000 of the poorer cows."

The Holstein, Banostine Belle de Kol, held the world's record for butter fat in $1912-1058$ pounds in one year.

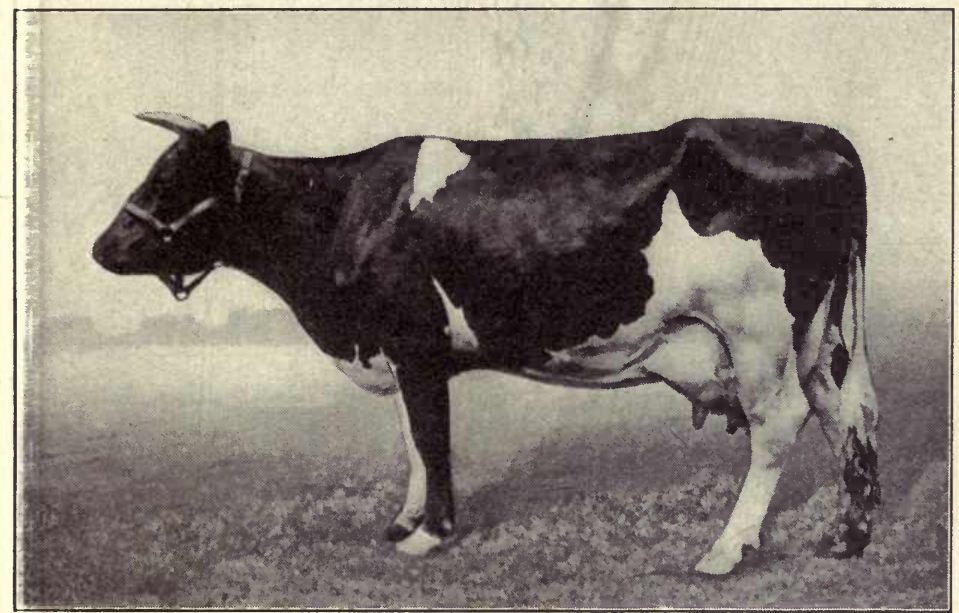

By courtesy of the Ohio Farmer

Frg. 49. Banostine Belle de Kol

According to above figures, five such cows would yield the ret product of 25 of the better dairy cows, and their calves night be worth even more for breeding purposes. The highest clairy record for 1913 is 1073 pounds of butter fat, scored by May Rilma, a Guernsey. And so progress in every branch of agriculture becomes a game which, if well played, may ever "lighten and sweeten toil.".

Poultry offers perhaps the most practicable field for ele1uentary experiments in the breeding and care of animals, and 
any branch of the industry, from pigeons and chickens to geese and turkeys and native game birds, is likely to yield a substantial profit from the start. One of the chief problems of present interest is that of breeding for egg production, the accepted unit being the number of eggs laid in a year. Some

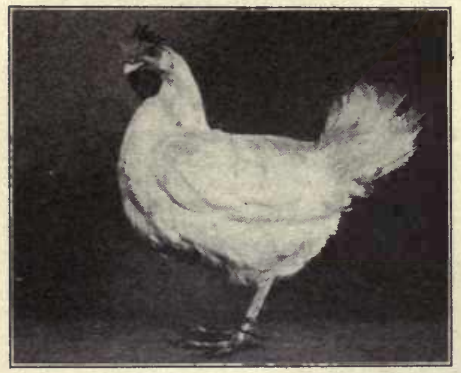

Fig. 50. Hen C. 521

Bred by Professor James Dryden, Corvallis, Oregon recent American records are shown in the table below.

Variations in growth of flesh or fat are similar to those in milk and egg production. This means that one animal may not digest or assimilate food as well as another, or one may use its energy in developing nervous activity (which is not edible) while the other is growing flesh and fat. Experiments have shown that one animal may thus require over 30 per cent more food to gain a pound of flesh than another. Here selection and thorough breeding are saving enormous losses and increasing productive efficiency.

American Egg Records

\begin{tabular}{|c|c|c|}
\hline YEAR & Number of Eglis & DEscrit'tox of Hex \\
\hline 1910 & 282 . & $\begin{array}{l}\text { Barred Plymouth Rock, Agricultural } \\
\text { College, Guelph, Ontario }\end{array}$ \\
\hline 1911 & 281 & $\begin{array}{l}\text { White Plymouth Rock, Lady Showyou, } \\
\text { Illinois }\end{array}$ \\
\hline $1912-1913$ & 308 & $\begin{array}{l}\text { Hen C. 521, cross between white Leg- } \\
\text { horn and barred Plymoutl Rock. } \\
\text { Reared at the Oregon Agricultural } \\
\text { College, Corvallis, Oregon }{ }^{1}\end{array}$ \\
\hline
\end{tabular}

1 This is held to be the world record up to date. In attempting to make a record of this kind it is necessary to have official control to guard against any possible mistakes or falsification, if the records are to stand. 


\section{BIOLOGY OF AGRICULTURAL PRODUCTION 105}

Special problems. Keep the record of a cow and figure profit or loss on basis of cost of feed and eare. Trap-nest a flock of hens and study variation in egg production, making results the basis for future breeding and improvement of flock.

Try different ehemicals or fertilizers in strips across the rows in the garden, to discover special needs of soil or crop.

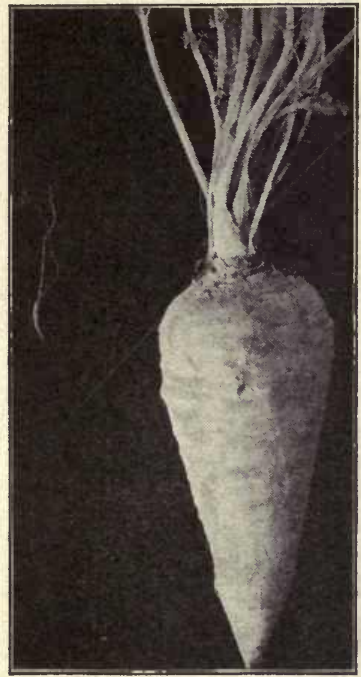

Fig. 51. Growth and opportunity

One of the 8 earrots, thinned to 4 to the foot, which weighed 11 pounds, and the smallest of 50 earrots, unthinned and standing 25 to the foot, which weighed 1.7 pounds

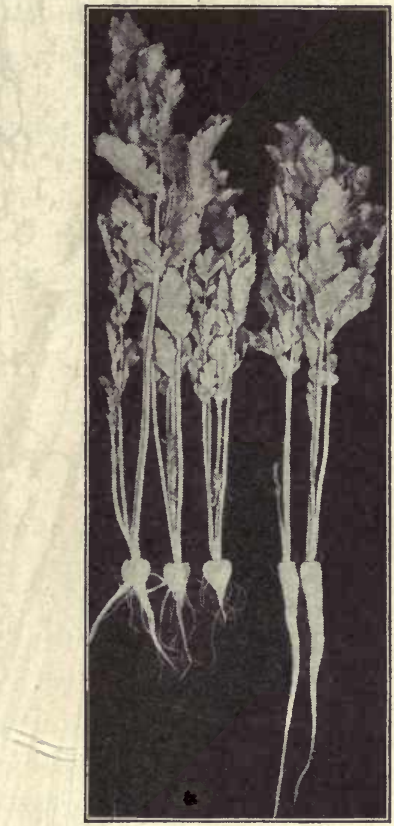

F1G. 52. Parsnips showing result of a hard spot in the row

Experiment with different consistency of soil : trench a strip two or three feet deep, dynamite a strip, or even leave a hard strip across the garden, in order to study differences in production due to tillage (Fig. 52), and thin plants to different distances (Fig. 51).

Test seeds of all kinds before planting in garden or field. By blowing off the light, small seeds and planting the 5 or 10 per cent of the heaviest and strongest seeds, crops of remarkable vigor and evenness are 
secured. Saving seed from strong, productive plants-potato, wheat,corn, cotton, timothy - has given rise to a large increase of production without other change or difference in method of cultivation.

In order to unite the work of the school with the interests of the community, offer to test all kinds of seeds, especially corn, if in a cornraising section. An increase of from 30 to 40 per cent in the corn crop of the district has resulted from such testing.

A most remarkable fact has developed with reference to seed potatoes. Immature tubers, about half or two thirds grown or ripened, may produce twice as many potatoes as dead or so-called overripe seed from the same field. Immature seed potatoes are specially raised and saved in Europe, and this one factor may account for the great difference in favor of European over American yields - more than 2000 bushels per acre as compared with less than 1000 as the best American record. This must be a matter of activity, or vigor, of buds, or of availability of the starch food supply. For information on raising seed potatoes, write your state experiment station.

Work for record production of thoroughly cultivated, pure-bred, pedigree single plants - the world-record hill of potatoes, the best plant of corn, wheat, cotton, oats, sunflower, tomato, cabbage, currant, raspberry, blackberry, grape, peach, plum, cherry, apple, etc. More may be learned from intensive practical study of a few plants, each of which is a special experiment, than from any number of less intelligently cultivated acres.

In all such problems, with both animals and plants, we need to learn all we can about the laws and forces of heredity, breeding, and breeds, and also all we can about favorable environment, feeding, care, and treatment. The former topics are treated further in the appropriate chapters. The latter should be made subjects of special study whenever it is possible to have the care of either an animal or a plant, and to secure an authentic record. Any one, by applying " cultivated thought," may render a world service by winning a new world record. 


\section{CHAPTER X}

\section{INSECT TYPE PROBLEMS : IMPORTANT FLIES}

If each egg of the common house fly should develop, and each of the larvæ should find the food and temperature it needed, with no loss and no destruction, the people of the city in which it happened would suffocate under the plague of flies. - Jordan and Kellogg, "Evolution and Animal Life," p. 59

And as for the typhoid fly, that a creature born in indescribable filth and absolutely swarming with disease germs should be practically invited to multiply unchecked, even in great centers of population, is surely nothing less than criminal. - L. O. Howard

What flies do. During the Spanish-American war typhoid fever wounded 20,738 United States soldiers and killed 1580 . The chief means of spreading this infection were the swarms of flies which infested the army encampments. To emphasize this menace to health, Dr. Howard has suggested that we change the name of the house fly to typhoid fly. This opened the way for thorough investigation of the insect, and its filthy habits were soon found to render it the possible distributor for many other filth-disease infections. Tuberculosis, cholera, enteritis (including epidemic dysentery and cholera infantum - the fly-time "summer complaint" of infants), spinal meningitis, bubonic plague, smallpox, leprosy, syphilis, gonorrhea, ophthalmia, and the eggs of tapeworms, hookworm, and a number of other parasitic worms - for all these and many more the fly has been discovered to be a ready actual or potential carrier. Since the fly is proved to be such an active agent of transmission between all manner of filth, on which it feeds and in which it breeds, and human foods, Dr. Stiles, of the Hookworm Commission, has proposed to call it the filth-disease fly. 

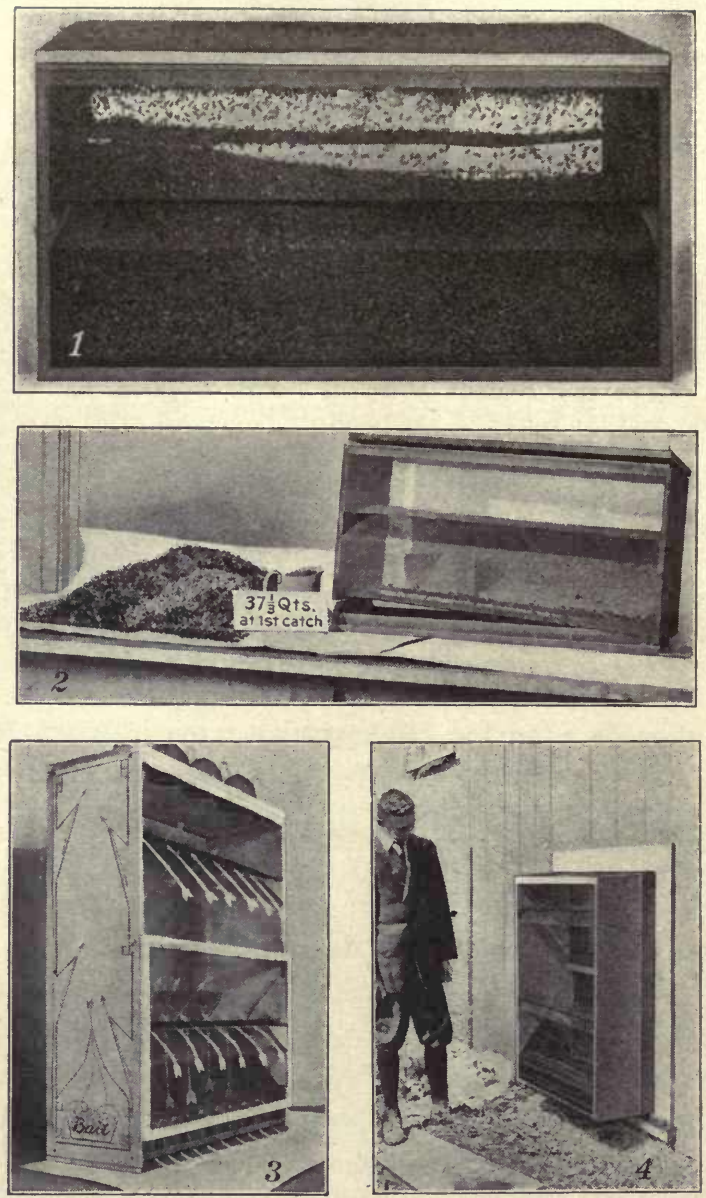

Fig. 53. Flytraps for barnyard or stable window

1, first model as found after being set one week; 2 , same, emptied by lifting off top frame ; trap lifted from bottom board to indicate construction; 3 and 4, larger window trap, showing construction and in position. The small traps in 3 are merely to take off samples of the catch for analysis. These traps are made to fit the window about which flies naturally congregate, gunny sacks are hung over the other windows to darken them and to flap in the wind, and, when properly placed and managed, one trap will catch practically all the house, stable, horn, black, bot, and blow flies and even the mosquitoes that try to get in or ont, or that either feed or breed about the stable 
First necessary step in health conservation. The most siguificant fact in the situation is that only by eliminating the fly can we form any notion of how much present sickness it is causing. On this account health officers everywhere are

The figure may be supposed to represent a model 12 inches wide, 12 inches tall, and 10 inches thick - a convenient size for ordinary use in a city yard. The specitieations will then be : two end boards $\frac{1}{2}$ inch or $\frac{1}{4}$ inch thick, $12 \times 10$ inches; four strips for the top frame, $1 \times \frac{1}{2}$ inch, two 12 inches and two 9 inches long; wire for top frame, $10 \times 12$ inches (raw edges folded over $\frac{1}{2}$ inch); two top shoulder strips $1 \times \frac{1}{2}$ inch, 11 inches long; four bottom strips $f$ inch thick and 12 inches long, two $\frac{1}{2}$ inch wide and two 1 inch wide; screen wire for sides and bottom in one piece, 12 inches wide and 41 inches long (allow 1 inch to fold over raw ends, $\frac{1}{2}$ inch each)

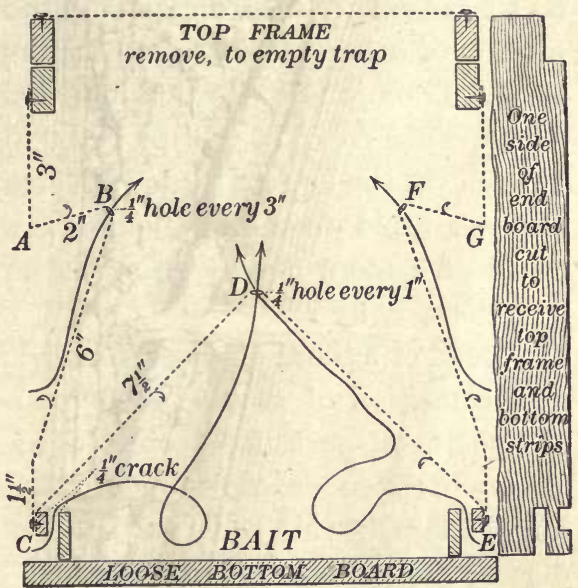

Fig. 54. Cross section and detail of stable-window or barnyard flytrap

These traps may be of any convenient size, to suit conditions, and may be made of box boards, strips, and screen wire. It is well to plan to use wire of standard widths. If used on the ground, the traps may be made without the trap-folds in the sides, which do most of the catching when the trap is set in a stalble window. Fold the wire squarely at the angles indicated in the figure, $A, B, C, D, E, F, G$, and at these points snip in $\frac{1}{2}$ inch. Fold the $\frac{1}{2}$-ineh flaps to a right angle, turning them in directions indicated by small hooks along the course of the wire (dotted line). This allows the bottom ridge and the trap-folds to drop smoothly inside the end boards, and the flaps are tacked to the end boards to help hold the wire in place and make the trap absolutely fly tight so far as any cracks along the corners are concerned. The holes in the wire are punched by pushing ten 40-penny wire spikes through the exact apex of the bottom ridge, about 1 inch apart. If good bait is used, the flies may become much crowded here. (This must be a sharp $90^{\circ}$ angle, not a rounded dome, or the flies will not find the holes.) Three holes are sufficient for the side folds. Punch all these holes after the wire is tacked in place. The trap is really as simple as a box. With proper tools a boy ought to eut out the end boards, rip ont the strips, nail up, fold, and tack the wire, all in about onc hour. The main feature of the trap is the $\frac{1}{4}$-inch crack opening upward to the bait

saying, in effect, "Clear the air of this universal distributor of filth, in order that we may be able to trace other ways of disease infection." Thus extermination of flies comes to be the necessary first step toward the effective prevention of disease. 
The evidence we have indicates that almost all dysentery and summer complaint (millions of cases and 56,000 deaths annually) are caused directly by the house fly. One third of the typhoid (about 300,000 cases and 30,000 deaths) is estimated to be caused by flies, and an unknown and unknowable proportion of tuberculosis, spinal meningitis, and other filth infections. Thus it is quite possible that flies carry the infections which cause from 70,000 to 100,000 deaths annually. About 2 people in the United States die yearly from bites of poisonous snakes; rabid dogs bite about 100 with fatal effect. Can you think of a more deadly animal than the common typhoid, or filth-disease, fly?

Spread of animal diseases. An additional factor is the probable causation of disease among domestic animals. As they are not even partially protected by screens, and flies swarm about their foods, epidemics of such diseases as fowl and hog cholera, bovine and fowl tuberculosis, and foot-and-mouth disease are almost certainly spread by flies. This matter has not been investigated as it should be, but we are likely to see a remarkable clearing up of animal diseases as soon as we exterminate flies from our farms.

Futility of fly screens. Finally, a minor consideration is the (estimated) $\$ 12,500,000$ we pay annually for screen windows and doors, which are not only expensive but disagreeable at best. These do not solve the problem, even if they did keep the pests out of our homes. We must prevent flies from contaminating foods on the farms and in the stores and markets of our cities. Thus the fight against the common enemy must be community-wide, and, since one careless or ignorant household can breed flies enough to infest all the houses within a quarter of a mile, positively every one must coöperate.

Need of universal coöperation. The general situation, especially the relations between country and city, is shown so clearly in the following case that we quote in full from the 
Bulletin of the Indiana State Board of Health, July, 1910. The note is entitled

\section{THIS HAPPENED IN INDIANA}

A few days ago a physician in Martin County called on the state bacteriological laboratory for Flexner's antimeningitis serum. Dr. Simonds went to the case and found a seven-months-old baby suffering from a very severe gastro-enteritis with the not infrequently accompanying meningism. The father of the child was a farmer living in a f jur-room house with few or no modern conveniences. On the wall of the largest room was a family-history chart done in brilliant colors, with three columns of lines for the record of marriages, births and deaths. The parents had been married ten years and six children had been born to them. In the death column were the names of four children, all under two years of age. Another name has since been added t) this list.

The cause of this sad story became evident on inspection. There was a shallow surface well in the back yard, a short distance from an open privy. A large pile of manure lay uncovered, almost against the side of the barn. If this farmer had attempted so unthinkable a thing as transforming his premises into a fly hatchery for commercial purposes, he could not possibly have achieved a more brilliant success.

The family and several of the neighbors were eating dinner on the back porch. Flies were swarming all over the table, but showed a special liking for a particular dish. They were so thick on this that it was absolutely impossible to tell definitely what it contained until one of the neighbors swung her arm over the table and cleared them away long enough for one, by looking quickly, to see that the dish contained cottivge cheese. The flies were so thick in the house that it was only with difficulty that they were fought away from the field of the spinal puncture and kept from lighting on the instruments.

On the death certificate the cause of the death of this child was doubtless given as "Gastro-enteritis." It would have been more in keeping with the facts to have said "Poisoned by Flies."

Different kinds of flies. About 43,000 different kinds of flies and related gnats and mosquitoes have been described, and Dr. Howard estimates that this group of insects contains no less than 350,000 species for the whole world. One large 
family, the tachina flies, many of which look much like common house flies, feed upon other insects and are among our most effective helpers in holding certain insects in check. Tachina flies are being imported from Europe to destroy gypsy and brown-tailed moths. Syrphus flies are another large family which feed upon other insects. Tachina and syrphus flies are found about rank vegetation in which other insects abound.

Of flies caught in and about houses the typhoid fly generally numbers over 90 per cent. It is distinguished by the "elbow" on the fourth vein as it curves up to the third vein near the tip of the wing (Fig. 55). The proboscis is an

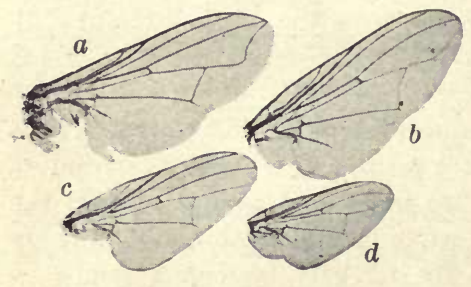

Fig. 55. Wings of $(a)$ house fly, (b) stable fly, (c) little house fly, (d) horn fly

Photograph by I. A. Field extensible trunk adapted for lapping up liquids, and cannot be used for either biting or piercing. The foot is provided with claws for climbing over rough surfaces, and also with two pads (pulvilli) covered with sticky, tubular hairs, which enable the fly to walk on ceilings and windowpanes. No more effective mechanisms for collecting duist could be designed than a fly's feet and proboscis, a combination of six feather dusters and thirteen damp sponges. The constant " cleaning" movements of flies are clearly designed to rub off and scatter the adhering germs everywhere they go.

The "little house fly" (Fannia canicularis), smaller than the common fly, is often seen in swarms hovering under chandeliers. In breeding and feeding habits it resembles the house fly.

Other flies found about houses are the following:

Bluebottles, greenbottles, and flesh flies, or blowflies, which so frequently lay their eggs on meat. These flies are scavengers, but we ean dispose of dead animals in much more 
simitary ways than by leaving them to the blowflies. Related to these, and of importance in the southern states, is the screwworm fly (Chrysomyia macellaria), which oviposits on wounds, the maggots feeding upon living flesh. These are the flies that sometimes lay their eggs in nostrils or ears of children or of people if asleep out of doors in the daytime, the maggots causing painful and even fatal wounds.

The stable fly (Stomorys calcitrons), which has somewhat the appearance of the house fly, except that it is provided with a strong, piercing beak, sucks the blood of animals. This fly is now convicted of inoculating the germs of infantile paralysis with its bite. It also causes great suffering to cattle. The smaller horn fly (Homatolice serrata), imported f:om Europe about 1886, is another bloodthirsty pest of cattle, biting both by night and day. It may be recognized by its habit of clustering in masses around the bases of the horns of cattle, and may be trapped by the method recommended for the stable fly.

The black flies, deer flies, sand flies,

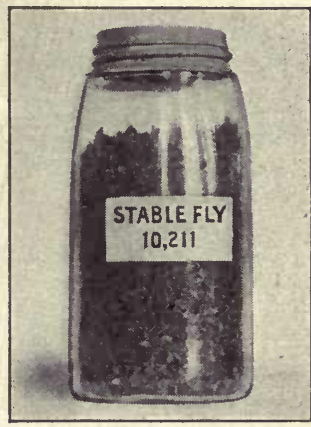

Fig. 56. Stable flies that a boy, with an insect net, caught on a cow in one day and the many botflies of horses, cattle, and sheep are all of civic importance to the districts where they abound. "The black flies of the genus Simulium are now under suspicion as possible carriers of pellagra. 'They breed in rumning water.

Life history of the typhoid fly. In order to discover best ways of attack, we must study natural enemies from every point of view. The ease with which mosquitoes have been exterminated has suggested similar methods for dealing with flies. But mosquitoes breed only in stagnant water, which is easily drained, filled, stocked with fishes, or oiled. Flies breed iı decaying filth, chiefly in horse manure, but can breed in any 
wet, fermenting matter, animal or vegetable. The maggots are hard to kill; they will live for an hour or more in pure kerosene oil and for over half an hour in alcohol. Tobacco kills many insects, but house flies have been bred from the snuff on a druggist's counter. This means that as long as there are flies about, they will find something in which to breed, and

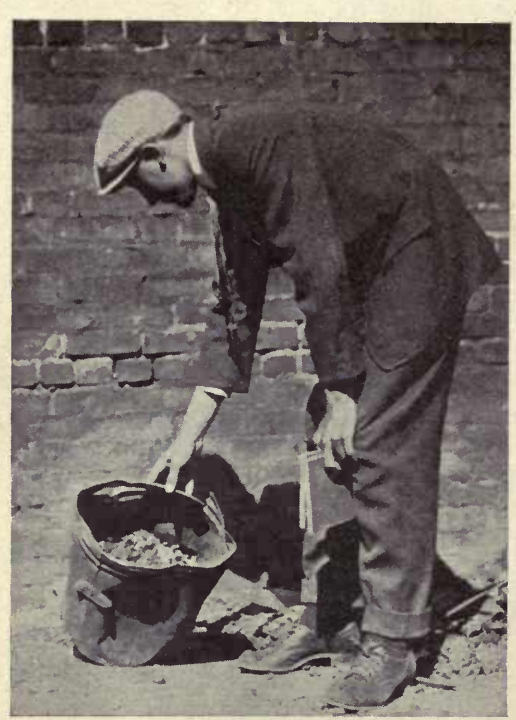

Fig. 57. Member of Junior Sanitary Police of Cleveland

Photograph by Dr. Jean Dawson that, with stables and barnyards, gutters, roadsides, and acres of pastures, with accidental accumulations, lawn clippings, compost and rotting weeds and fermenting garbage, prevention of breeding by doing away with breeding places and materials is beyond human possibility. It is easy in comparison to exterminate the breeders themselves.

Still, proper disposal of all this waste matter comes to be a problem of greatly increased importance when we attempt to prevent flies from breeding in it. If material becomes infested with eggs or maggots, the best treatment of it is probably to turn it out in the hot sunshine and dry it as completely as possible. If this cannot be done, the maggots may be killed by saturating the material with a solution of iron sulphate (copperas), two pounds to the gallon of water. Treatment of stables with chloride of lime has been recommended, but this is expensive and disagreeable, and the fumes (chlorin) are likely to injure the animals. Stiles has buried infested material six feet deep and found that the flies work their way out. For the farm home the cost of handling is doubled and fertilizer value reduced from 55 to 69 per cent by 


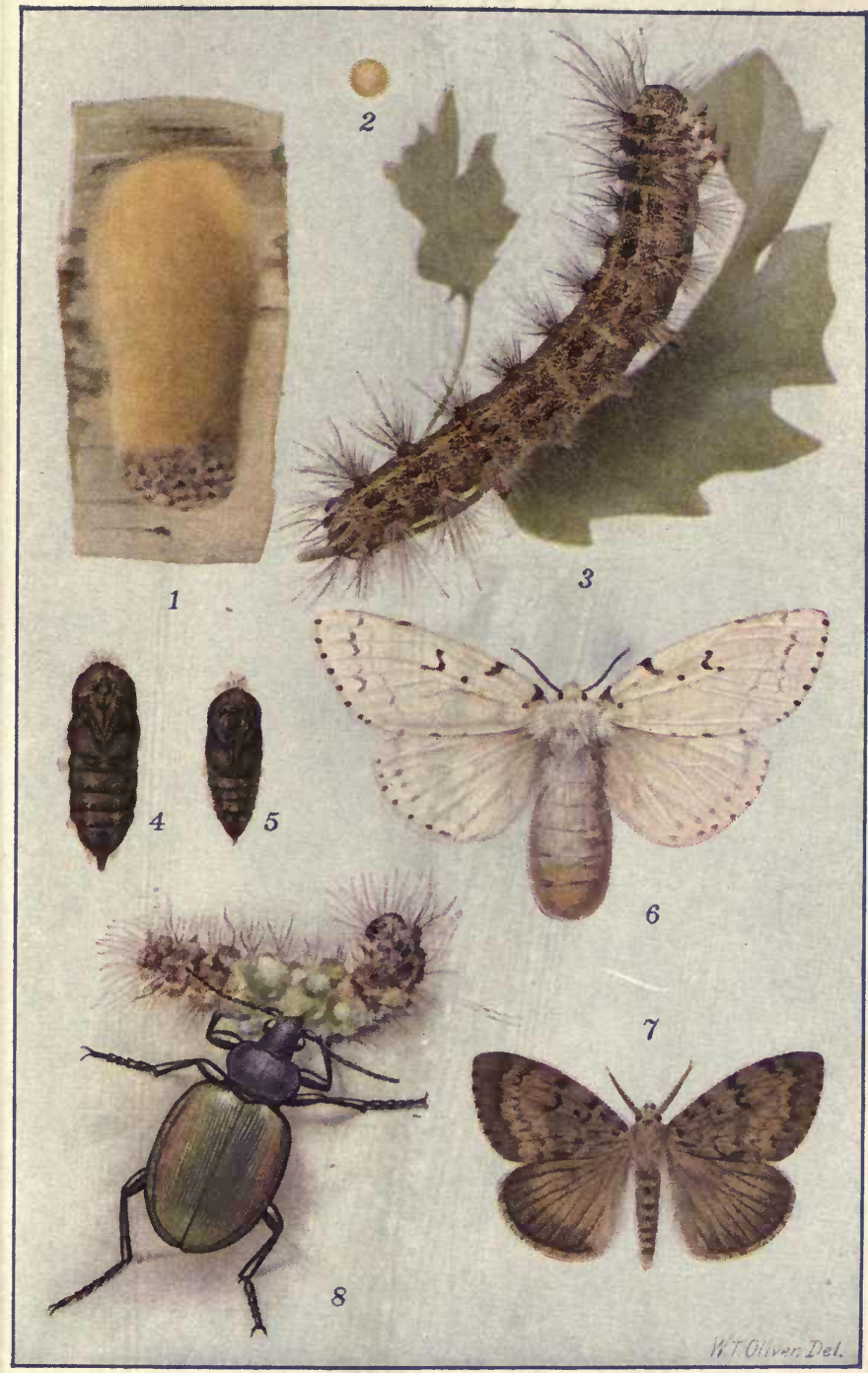

PLATE II. LIFE HISTORY OF 'THE GYPSY MOTH

, egg cluster : 2, single egg (enlarged about four diameters) ; 3, caterpillar ; 4 and 5 , female and male pupæ; 6 and 7 , female and male moths ; 8 , imforted lion beetle devouring a caterpillar. (All except 2 about natural size.) 

antiquated methods of storing, piling, and rotting. All stable waste should be hauled and spread on the land daily. It will generally become tco dry for flies to breed in.

The most expensive and disastrous fallacy in this whole problem is the "fly-tight" pit or receptacle for stable waste. This has been and still is recommended under the plausible excuse, "Make them fly-tight, so the flies cannot get in to lay their eggs." Eggs by the million are laid in the material before it is put into the pit; the tight construction makes it an artificislly perfected fly incubator, and when it is opened, as it must be daily, the flies swarm out. By this method we actually go to great labor and exp€nse to breed more flies.

In cities, instead of fly-tight st:able pits, we should have, by city ordinance, readily accessible elevated hoppers or concrete-floored bins, and the city should arrange to empty these clean to the concrete at least once a week from May to October. It would be much better, for purity of air and economy of fertilizer, to have this done daily. By proper organization of routes the city should be able to gather and dispcise of the material at greatly

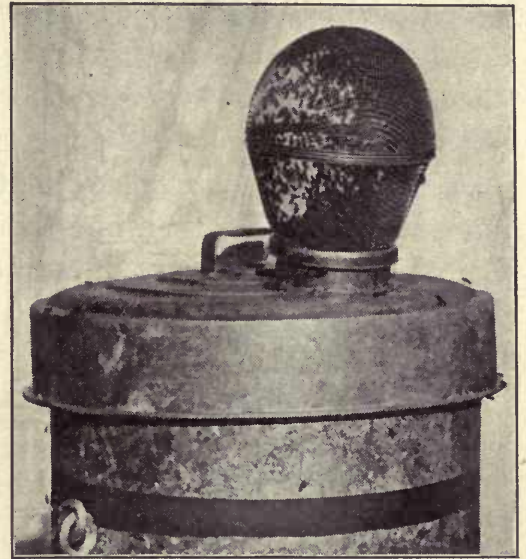

Frg. 58. First model of outdoor fly exterminator

This has been set fifty-eight minutes and has caught 2000 flies. It caught 2 quarts (about 16,000 ) the first day, and might as easily have caught 20 quarts if they had been there to catch - a vacuum cleaner of the air for flies. Designed by the author reduced expense over scattering and irregular private cleaning. It ought to be managed so as to pay st.ible keepers fertilizer value of material, less cost of handling, and still deliver it regularly to gardeners and farmers, as planned for, and for much less than it costs to collect the material privately. If this is nct feasible, then the proper officers can license farmers and truck gardeners to collect from specified stables, under contract to remove the material in the cleanly manner specified and at weekly intervals. $\mathrm{B}$ isides stables, the city should maintain strict supervision over all 
stockyards and slaughter-houses, public dumps, and all industries which handle materials likely to breed flies. It is utterly uncivilized and brutish that accumulations of filth, which allow flies to both feed and breed, should be permitted to vitiate the best efforts of thousands of good people, cover their foods and homes with filth, and cause not only annoyance but disease and even death. ${ }^{1}$

The eggs of flies hatch in about eight hours into maggots which feed actively and complete their growth in six or seven days. They then burrow into the ground under a manure pile. (hence the need of concrete floors) and transform into brown puparia, from which they emerge as adult flies in three days. After coming out as adults they fly about over an area not generally more than one thousand yards in diameter, and feed or drink from two hundred to three hundred times a day for from ten to fourteen days before maturing their first batch of éggs. This actually delivers the enemy into our hands. It means that, with flytraps on every garbage can or swill barrel, and with everything most attractive to flies very carefully kept in these receptacles, not a single fly will succeed

${ }^{1}$ In a large city the writer found, opening on an alley, and within a block of a great open public market, a pile of horse manure, entirely unprotected, at least thirty feet in diameter at the base and fourteen feet high. The outer layer of this whole pile was a solid, moving mass of housefly maggots. A moderate estimate for that pile would be ten barrels of fly maggots, which would make, when they reached their growth and emerged, from twenty to thírty barrels of flies. These flies were swarming black over the meat blocks and meats, fruits, fish, candies, cakes and pies of the whole market. The market people (some few had electric fans) were wearing themselves out shooing those flies from one to the other and back again. The filth of that manure pile was being carried into thousands of homes with the market supplies. The flies were feeding in the market and in hundreds of kitchens in every direction and going back to the manure to lay their eggs. It is unfair to place on the market people the burden of trying to protect their foods from flies under such conditions.

The horses in this large stable were kept on the second floor; the manure could have been cleaned into a hopper opening downward into a dump cart in the alley, and every morning before daylight, by effective civic organization of the work, it might have been out in the country and at work in the land, a paying proposition instead of an insufferable nuisance. 
in feeding for two weeks without getting caught. In this case no more eggs will be laid, and the pests will vanish.

Possible multiplication. Allowing ten days for eggs to become adults, and, for convenience, ten days of feeding between emergence and oviposition, figuring that a fly lays one hundred and fifty eggs at a batch and lives to lay six batches, compute the increase of a pair of flies beginning to lity May first. Half the progeny are supposed to be femáles. Test the following figures:

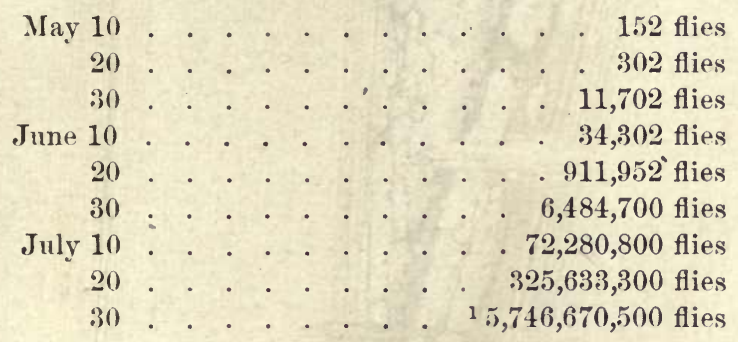

The common-sense question is, Why not let this pair of flies catch themselves in May? This rapid increase also means that anything short of extermination is hardly worth the effort. A fly is possessed of no more cunning than shot rolling down a board, and the last pair will run into a trap as easily as the first. Why not let them all catch themselves?

Hibernation. Very few house flies survive the winter in (anada and the northern states, and these hibernate as young adults in cracks about buildings. They come ont of winter quarters ravenously hungry and feed for about a week, at luast, before beginning to lay. If at this critical time every lousehold had some effective form of outdoor trap ready for them, every early spring breeder would be caught, and the

1 This last figure would equal about 143,675 bushels of flies from one pair iı three months. If we continue the breeding through August and Septemker, the figure is $1,096,181,249,310,720,000,000,000,000$ flies. 
whole battle would be won for the season. The first community that does this with absolute thoroughness, and whose every member is intelligent enough to realize the 143,000 bushels that one pair might propagate in three months, will first be free from the world-wide, time-old plague of the "house fly, disease carrier," and from the diseases it carries.

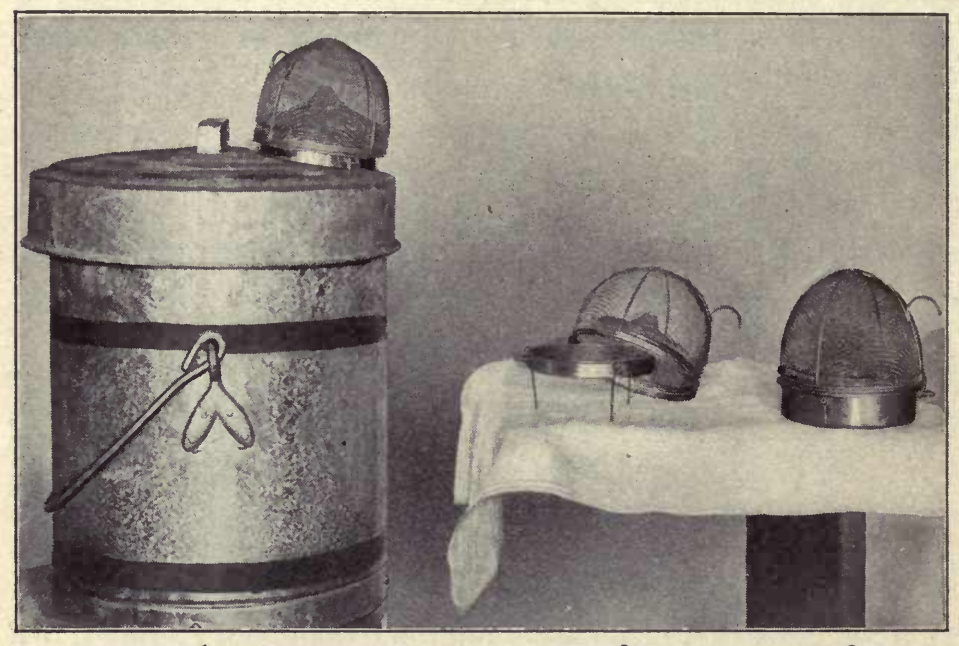

1

2

3

Fig. 59. Outdoor fly exterminator as adopted for manufacture

1, attached to garbage can (make hole in cover as large as inside of ring, to let in plenty of light); 2 , on ring with which attachment is effected; 3 , on its own good-sized bait pan. Designed by the author

Sketch a plan which shall prevent all flies - typhoid, stable, horn, and flesh flies - from either feeding or breeding about your own home. If the fight is carried out of doors into the camps of the enemy, this becomes one of the easiest problems to solve in the whole range of insect life, and its solution completely relieves us of the need of screen windows and doors, as far as flies are concerned; and, expense aside, screenless windows and doors in summer are a luxury. 
Study and experiment with all the most likely devices on the market for outdoor fly extermination, and invent better ones yourself, if you can. With the traps already available, outdoor fly extermination, as one man who tried it has said, "is so easy as to be almost humorous and so effective (the flies disappear so suddenly) as to be little short of the uncanny."

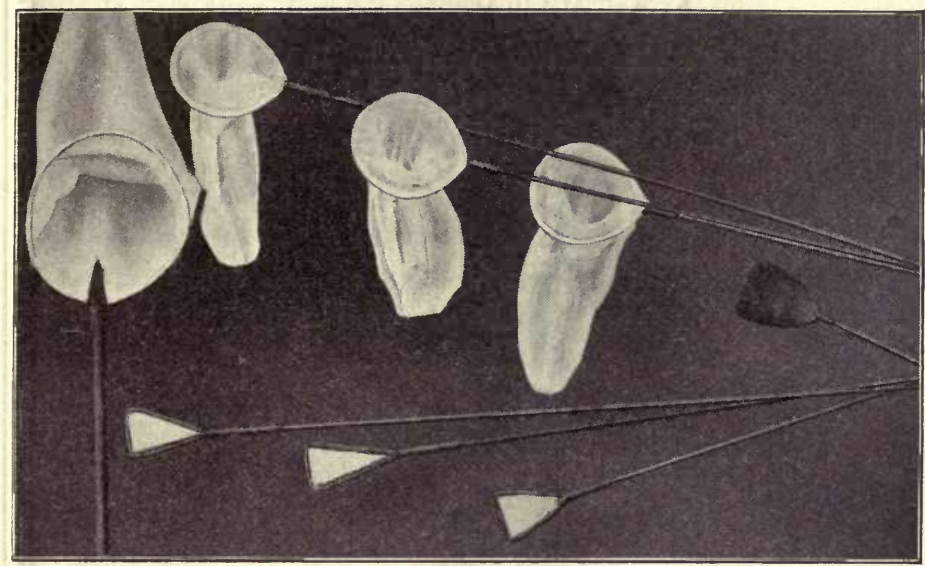

Fig. 60. "Getthelastone" fly nets

The handles are long enough to reach the ceiling without stretching and the floor without stooping, enabling one to catch any stragglers that may get by the traps and into the house. Make them of finer-mesh mosquito net according to directions (Fig. 5), cutting six nets to the yard. Long-handled swatters were tried, but they too often spotted the ceilings and did not prove as effective or easy to use as the nits. A larger insect net is most effective in exterminating stable and horn flies from a dairy. Designed by the author

Civic fly campaigns. As the fly problem becomes generally understood by a community, the campaign comes naturally to a dollar-and-cent basis. People will not trade in fly-infested. st ores, markets, or milk depots, or patronize hotels or restcurants that are not free from flies. For this reason store and restaurant keepers must see to it that no fly feeding or breeding is possible on their own premises, and they must 
insist that all their neighbors do likewise. 'Thus general civic coöperation tends to enforce itself along lines of financial necessity. Work out a plan of campaign good enough to insure enlisting every home. In order to give time for discussion and publication of plans for the active work the following spring, this should be done in connection with insect lessons in the early fall, when flies are abundant and troublesome. Killing the breeders in the fall is as good or better than killing them in the early spring, and on one farm where this was done scarcely any flies appeared the next spring, while farms half a mile away were swarming with them.

Nothing can take the place of bringing the actual specimens into the laboratory and of studying the flies and maggots as they swarm in and about the filth of outhouses and stables, gutters and spittoons. If every one could be shown, - could be made to see and study the flies as they live, - the community would be in the fight to a man, and this is all we need for complete success. One teacher who tried this writes :

Last week I had some maggots in horse manure. ${ }^{1}$ It was an unusual thing to do in school, but I wished to emphasize the idea of filth. I think it was successful, for the disgust was great when they saw that they changed into flies. People are so irresponsible that they have to be shocked to awaken their fighting power.

Things to avoid in civic fly campaigns. During any season when breeding is possible, avoid offering prizes or money enough to encourage raising flies. Also, never give more than ten days - the time of a generation - in prize contests during the breeding season. A fortune might be made raising flies at ten cents a quart.

Avoid delay. While spring is the ideal time to start a campaign, one begun in midsummer or even fall will result in much good and will help educate a community in plans and methods for effective work the following season.

1 This can be done in a safe and cleanly manner by means of large bottles. They must be stoppered securely, as maggots are strong and can burrow and squeeze through minute cracks. 
It has been customary in many early spring campaigns to offer children ten cents a hundred for all house flies brought in before, say, the first of May, or before breeding begins in the locality. On this basis bills of five or six hundred dollars may be expected in good-sized cities, and it would probably be better to offer one cent a hundred, and be sure to avoid paying for bluebottles, greenbottles, or other large flesh flies. These will always be killed along with the rest, but they begin active breeding much earlier in the spring and, if not ruled out, might easily swamp any treasury. The four flies whose wings are shown in Fig. 55 may be included in the list to be paid for.

Life history of the stable fly. During the sunmer of 1912 a serious outbreak of stable flies occurred in grain-raising sections of northern Texas, Oklahoma, Kansas, and Nebraska. Cows fell off in milk and even went dry, operations had to be suspended in the fields because the animals could not endure the torment of the swarms of flies, and many mules, horses, and cattle were killed outright. Investigation showed that the flies were breeding in the following substances, named in approxinate order of importance: in the wet, fermenting straw of oats, rice, barley, and wheat, and in horse and cow manure, especially where mixed with straw. 'Thus most of the trouble arose from decaying strawstacks in the fields and from uncleaned barnyards. The minimal time required for the different stages of development was found to be: egg, one day; larva, eleven days; mpa, six days; making eighteen days from egg to adult fly. Probably most of the stable flies pass the winter in the larval or the pupal stage and so are ready to emerge during warm spells in winter and with the first warm days of spring. Where stock can be stabled, these flies can be successfully caught in the stable window traps shown in Fig. 53.

Life history of the horn fly: The horn fly breeds exclusively in freshly dropled cow manure. 'The flies leave the cows and swarm to fresh droppings to lay their eggs, often covering the material as thickly as they can stand. This occurs especially in the early morning hours, and by following the herd a few mornings with a hand sprayer loaded with kerosene or any good oil mixture used to keep the flies off from animals practically all the horn flies can be killed. Covering the fresh droppings with lime also prevents the flies from breeding in them.

Health statistics. Watch local health statistics and reports, especially as to typhoid and cases and deaths from summer complaint, tuberculosis, and pneumonia, and any 
other prevalent filth infections. If the stable fly has been successfully dealt with, compare the monthly reports on cases of infantile paralysis with corresponding reports of previous years. ${ }^{1}$

Some people may object to fly campaigns on the ground that flies were created for a good purpose. Any such should refer to Exodus viii, 31:

And he [Moses] removed the swarms of flies from Pharaoh, from his servants, and from his people; there remained not one.

All we ask is that " there remain not one."

1 While the above is passing through the proof the discovery is announced that maggots of flies (species not determined) which develop in the bodies of chickens dying of limber neck infect animals to which they are fed with the germs of infantile paralysis, or poliomyelitis. All such fowls should be completely burned up. If buried, the flies easily work their way to the surface and may spread the infection. (Latest evidence points to contact infection by human carriers, and excludes any influence of flies or other insects in spreading this disease.) 


\section{CHAPTER XI}

\section{INSECT TYPE PROBLEMS: MOSQUITOES}

Mosquitoes and disease. The discovery that malaria and yellow fever are transmitted by certain mosquitoes shows how



FIg. 61. Anopheles mosquitoes and malaria in a city

1, Anopheles mosquitoes breeding; dots, houses where malaria occurs. There would be more dots in various parts if there were any houses

important a rôle an insect may play in the affairs of human ife. No obstacles have so seriously blocked the progress of civilization in the tropics as these two diseases. The Panama 

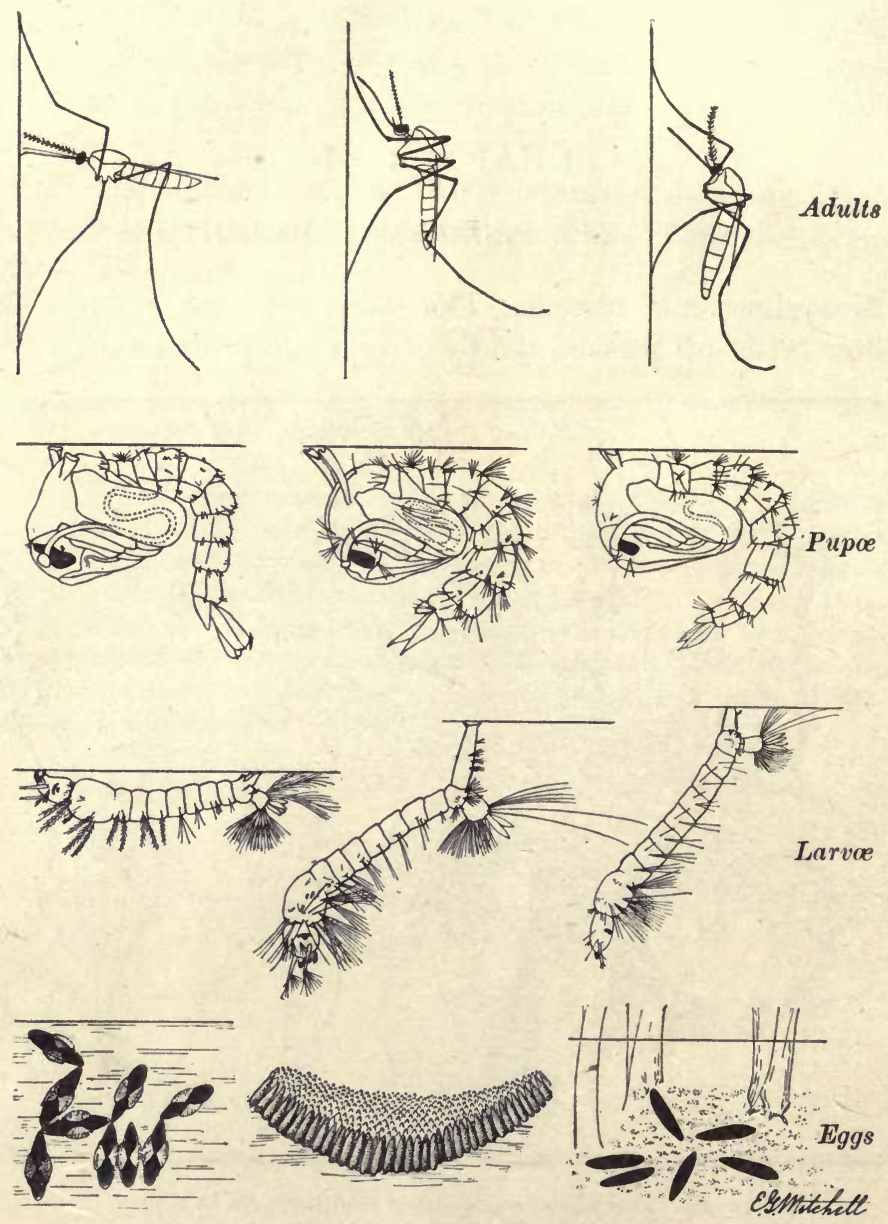

Fis. 62.

Left, Anopheles (malaria) ; center, Culex pipiens (common nuisance); right, Aedes calopus (yellow fever) 
Canal has been made possible mainly through the control of malarial and yellow-fever mosquitoes.

Of the ten genera of mosquitoes of North America, Anopheles, Aedes (à $\overline{\mathrm{e}}^{\prime} \mathrm{de \overline {z }}$ ), and Culex concern us chiefly. There are tirree species of Anopheles distributed throughout the (c)untry, and it is important to rumember that it is through these mosquitoes only that malarial fever is spread. This disease is not as fatal as some others, but is important because so widely distributed and lecause in malarial countries from 25 to 60 ler cent of the jeople are afflicted. In the United States, incording to the ('stimate of Dr.

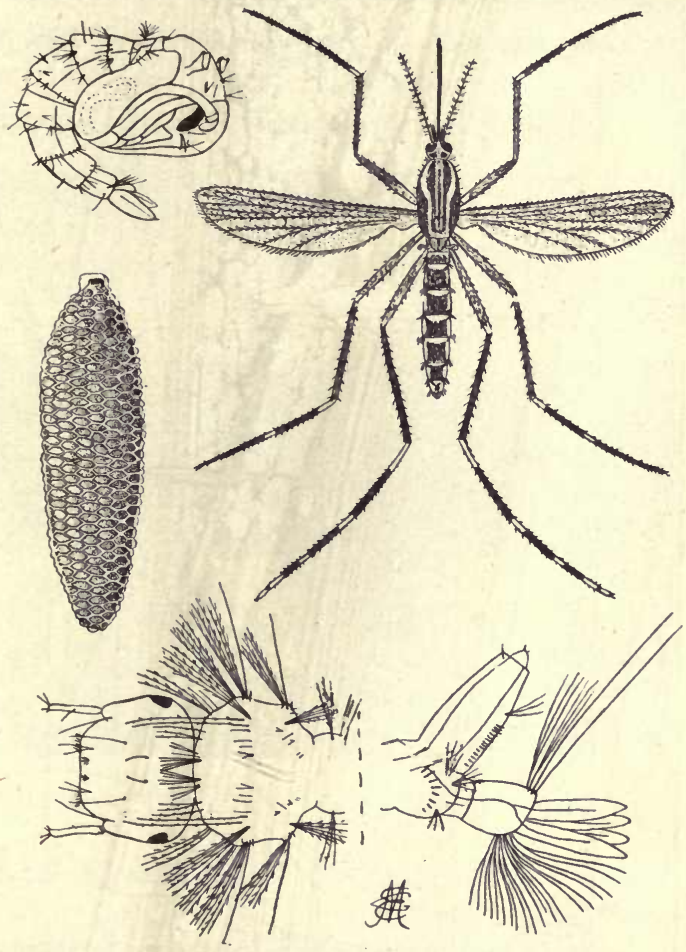
FIG. 63. Aedes calopus - Yellow-fever mosquito Egg, larva, pupa, and adult .

7. O. Howard, there occur $3,000,000$ cases, causing a loss of $\$ 100,000,000$, annually. In India, where the fever assumes a fatal form, 5,000,000 people have succumbed to it in one year. Anopheles is particularly active during the early part of the ıight. It may be distinguished from other mosquitoes at a 
glance by its mottled wings and by its posture. It resembles somewhat a thorn in the wall, standing as it does at an angle of almost ninety degrees to the surface, with proboscis in line with the body, whether the surface is vertical or horizontal.

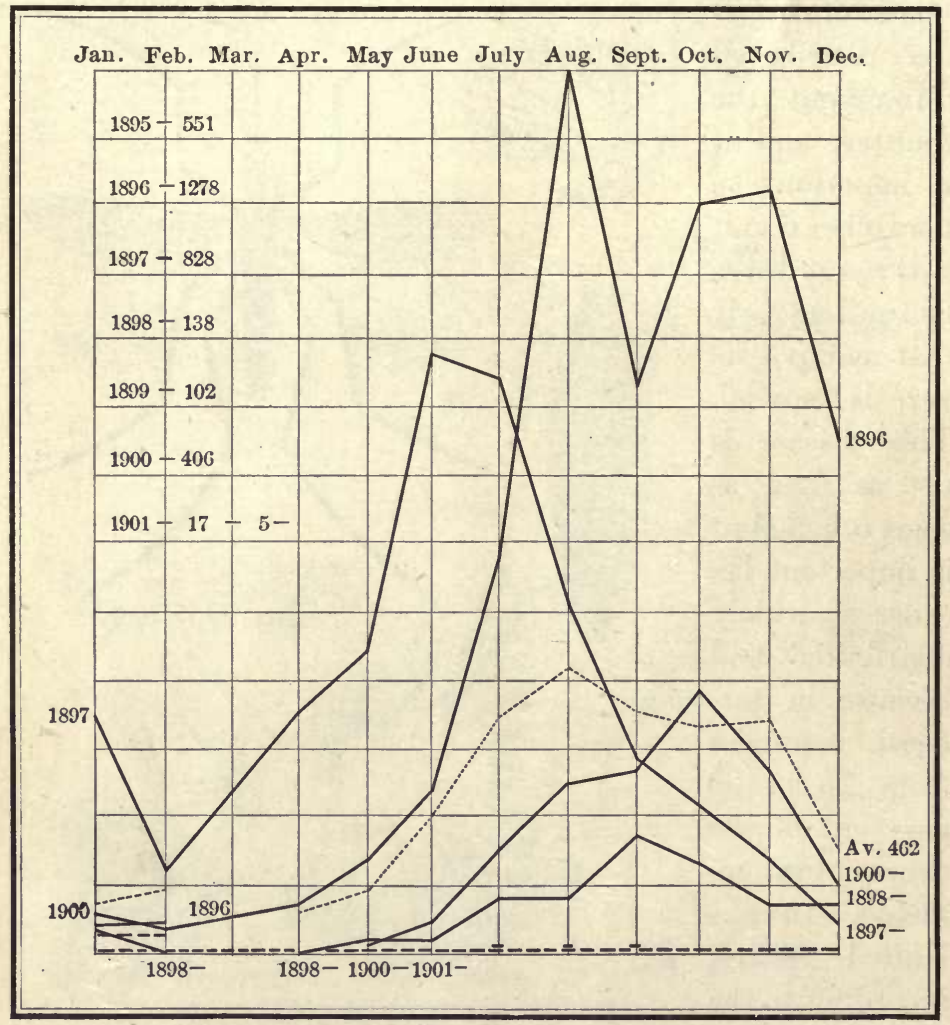

Fig. 64. Yellow fever in Havana

Aedes calopus. This is the mosquito responsible for the transmission of yellow fever, which in the memory of man has left its dead unburied in some parts of our country. Indeed, in the early part of the summer of 1905 a mosquito infected with 
yellow-fever blood came on a cargo from Central America to New Orleans. The fever spread rapidly and by the middle of Suptember 2462 people had been attacked by the disease and 329 had died. Aedes is the common rain-barrel mosquito of the South; it is frequently referred to as the "calico mosquito" because of conspicuous banding of its legs, thorax, and abdomen with black and white. This mosquito is unable to survive the winter of the Northern states (Fig. 63).

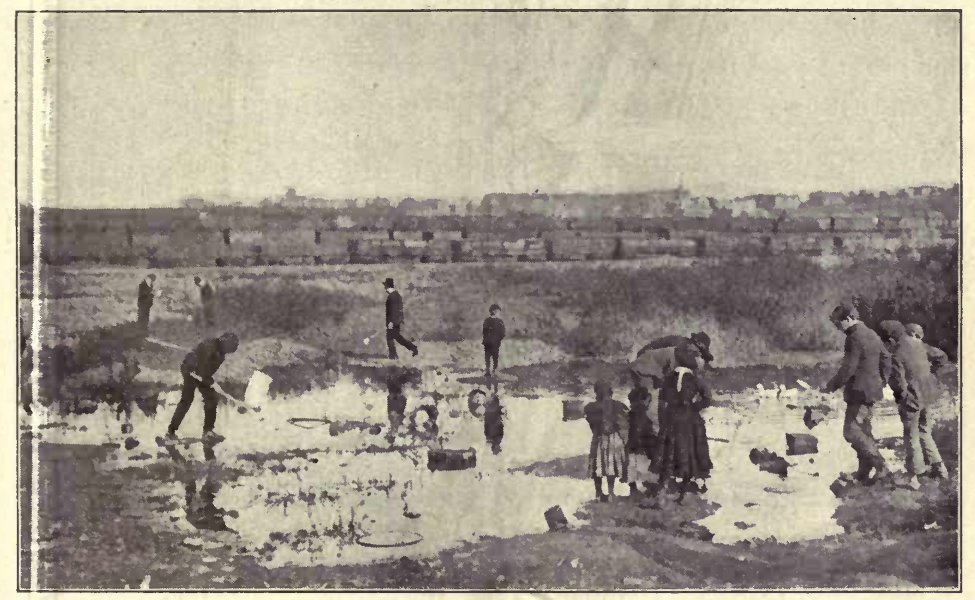

Fig. 65. Outdoor laboratory work in a malarial district of the city

Culex mosquitoes. To this genus belong our most common household forms. They are generally brown and may be distinguished from Anopheles by the fact that they rest with body parallel to the plane of support and head and proboscis bent, giving a humpbacked appearance. While these mosquitoes are not known to be injurious to health, the annoyance and distress they cause furnish ample reason for the general movement to exterminate them. Culex pipiens is the common household pest throughout the country. Howard says these nıosquitoes will not fly far from their breeding places unless 
they are carried by light and continued winds. With the exception of two species of Culex that breed in salt marshes and migrate for long distances, mosquitoes seldom go more than two hundred yards from where they are hatched. In a town or city away from these marshes the work of exterminating mosquitoes is simple and not expensive. Indeed, the class in civic biology can accomplish the task as an interesting and valuable turn at outdoor laboratory work. Before beginning the work, however, much more should be learned about the habits and life history of the mosquito.

Habits and life history. Mosquitoes are nocturnal ; during the bright part of the day they hide under leaves, in grass, in cellars, wells, cisterns, in barns, and in the dark corners of the house. Even the "day mosquito," Aedes, does not fly about or bite in the bright sumlight of midday. As winter approaches, the female mosquitoes seek dark, damp places in cellars, caves, hollow trees, and loose bark in which to hibernate. Can you find them?

Mosquitoes may be distinguished from gnats and other mosquito-like insects by the presence of a fringe of scale-like hairs on the margins of the wings.

Like many other insects, especially those that suck blood, they are strongly attracted or repelled by different people. It is a matter of common experience that some people are annoyed by this class of insects much more than others. Odors like a mixture of oil of tar, oil of pennyroyal, and olive oil are effectual repellents, as is also a mixture of cedar oil (one ounce), oil of citronella (two ounces), spirits of eamphor (two ounces), If an odor could be discovered that is highly attractive to mosquitoes, it might be effective in ridding a neighborhood of the pests if used in connection with a trap or some form of sticky fly paper.

Mosquitoes seem to possess other likes and dislikes. They are attracted to dark colors and are repelled by lighter shades; 
an l certain musical sounds seem to possess a charm. The song of the mosquito varies with the species and with the sex; it is believed these insects find their mates by the pitch of their song.

Mosquitoes are not without their natural enemies. Birds (especially nighthawks, swallows, and whippoorwills flying at dusk), also bats and dragon flies, feed upon adult mosquitoes. One observer reports having found six hundred mosquitoes

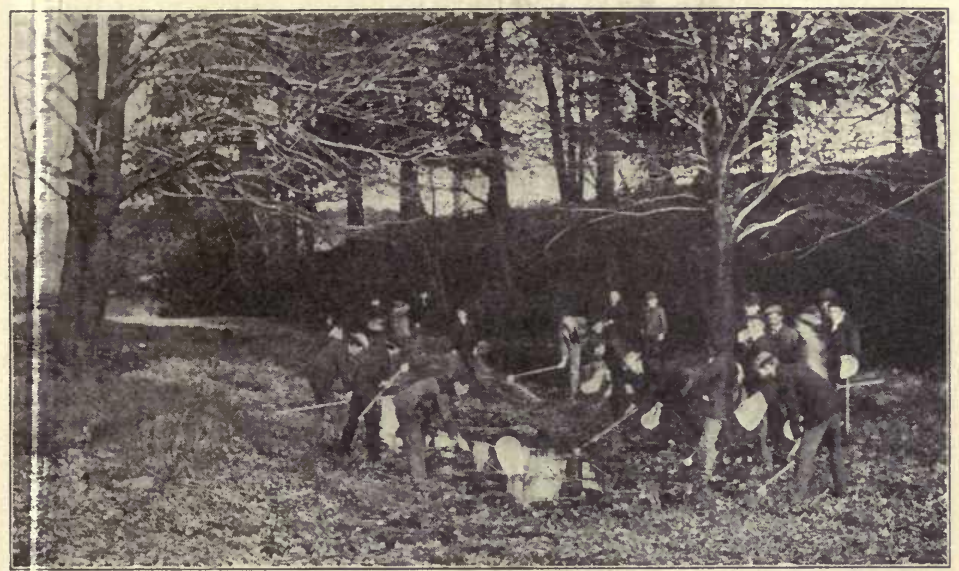

Fig. 66. Collecting mosquitoes

Equipment: insect nets and smaller scrim nets for use in water

in the crop of a nighthawk. A minute red mite may often bo: found clinging to mosquitoes, and it is said to greatly reduce their numbers in some localities.

Young mosquitoes are aquatic. Mosquitoes lay their eggs on the surface of water, usually about three days after they have taken a meal of blood. The eggs are laid in the early morning hours and hatch into larvæ about two o'clock the same day. Culex lays from two hundred to four hundred cigar-shaped eggs which float on end in boat-shaped masses. 'The larvæ, better known as wrigglers, swim actively about in the water, 
feeding upon minute forms of animal and vegetable life which are swept into their gullets by the constant motion of little brush-like mouth-parts. A long respiratory tube comes from the eighth segment of the body, through which the larva breathes by opening it to the air. After undergoing three different molts the larva reaches maturity and changes into a pupa in from ten to fourteen days. The pupa differs radically

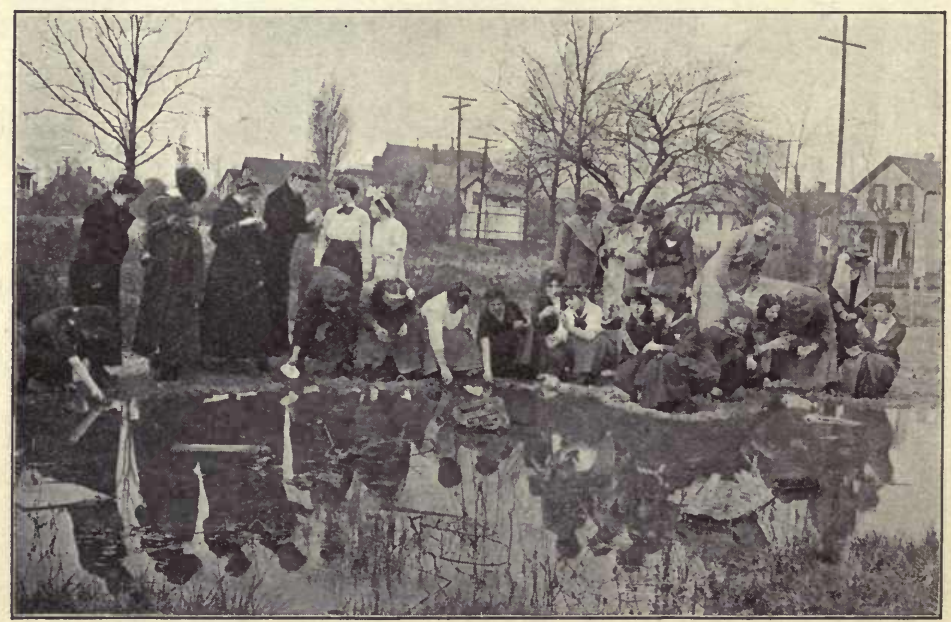

Fig. 67. Survey of mosquito breeding places by a normal-school class

Equipment : bottles, tumblers, and saucers

from the larva in appearance, and breathes from the ear-like organs on the thorax (Fig. 62). Except when disturbed the pupa remains at the surface of the water. After two days it splits down the back and the adult mosquito rises from the pupa skin.

Anopheles and Aedes lay their eggs scattered singly, those of Anopheles floating while the eggs of Aedes sink to the bottom (Fig. 62). The larva of Aedes resembles that of Culex, while that of Anopheles lies horizontally, just under the surface. 
Its respiratory tube is short, its body black and spotted with tufts of long bristles protruding from the sides (Fig. 62). The pupæ of the different species are not readily distinguished. Under favorable conditions the time required for the eggs to hatch and grow to adult mosquitoes is ten days; when the weather is cold it may be indefinitely extended. Three days after emergence the adult may lay eggs. Culex has produced from seven to ten generations in a season and Anopheles four. Allowing 150 eggs to a generation, the possible progeny of a pair of Anopheles in one season would be $31,000,000$. The natural enemies of immature mosquitoes are fishes, newts, salamanders, dragon-fly nymphs, the larvæ of water beetles, and even young turtles.

Location of breeding places. After members of the class have learned to distinguish the different mosquitoes and their larvæ at a glance, they should divide themselves into groups corresponding to convenient divisions of the district to be studied. Each group should be responsible for a full report upon the breeding places and the kind of mosquitoes found in its territory. Collect specimens and put the eggs, larvæ, and pupæ frum each territory into separate glasses

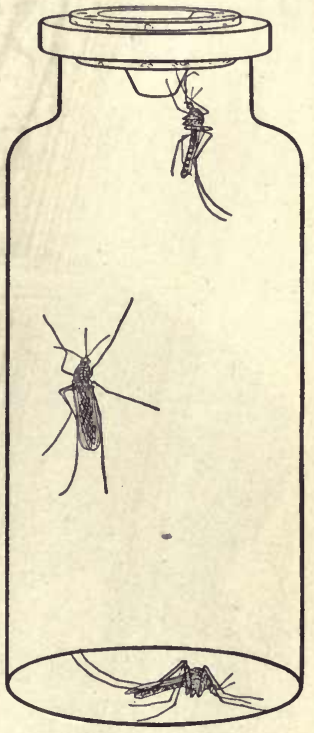

Fig. 68. Insect-catching bottle

For handling delicate insects this is better than a net. The essential feature is a paper cone opening inward through the thin cork or into vivaria with screen tops (Fig. 69). Keep a dish of witer and a bit of fruit (apple, grape, banana) in the vivaria fo: the adults and have green algæ in the water with the la:væ. Catch full-fed mosquitoes about animals or in bedrooms and keep in glasses arranged as shown in Fig. 70. 
Watch for eggs, and examine the water for larvae. How many eggs were laid and how long did they take to hatch?

Wherever you have found mosquitoes breeding, indicate it upon a map of the locality with letters, $A$ denoting the presence of Anopheles; $C$, Culex; and $Y$, Aedes. Fig. 61 shows the relation between malaria and the Anopheles mosquitoes as worked out in this way by a biology class.

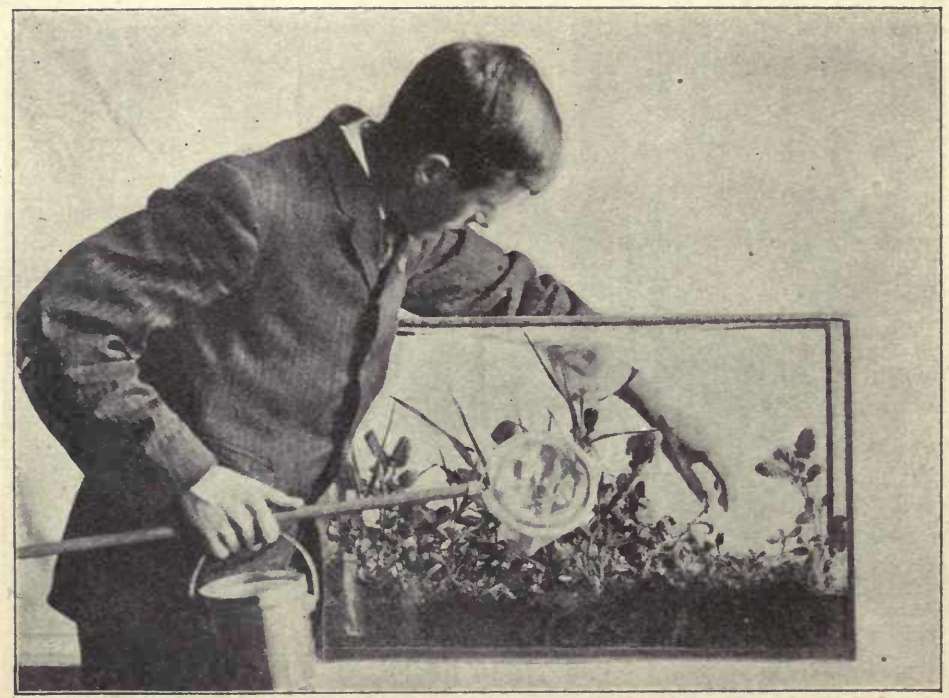

FIG. 69. Vivarium set up for studying mosquitoes

Cheesecloth top with sleeved opening and glass dish of water in moss at one end

Did you find that, in general, Anopheles breed by preference in spongy bogs and stagnant water, green with algae; Aecles in cisterns, tanks, buckets, tubs, rain barrels, flowerpots, saucers, flower vases, and water pitchers; Culex pipiens in ditches, stagnant pools, catch basins, or in any water near homes, indoors or out? But algae may quickly change any neglected water into a green bog hole for Anopheles to breed in. 
Methods of extermination. It is fortunate for us in our work of exterminating mosquitoes that they pass the first three stages of life in water, and that the adults must come to water to lay their eggs, that is, mosquitoes are strictly dependent upon suitable breeding waters. In all successful campaigns undesirable pools in which mosquitoes may breed have been drained or filled. Streams and ponds have had their shores cleaned of veeds, brush, and stumps, and have heen graded so that pools were not left in which mosquitoes could breed after freshets and storms. Then they have been stocked with fishes which feed upon the young of mosquitoes. All water which was too temporary to drain (r) too polluted for fishes has been covered with crude petroleum (one ounce to fifteen square feet of surface). This treatment has been repeated as often as wrigglers have appeared. A mosquito (an walk on the surface of water but it (annot stand on oil ; hence, as all mos(quitoes come to the near-by water to lay their eggs, they soon perish. Precautions lave been taken not to allow water to stand in tubs, barrels, or cisterns with(ut being covered insect-tight.

Through systematic application of

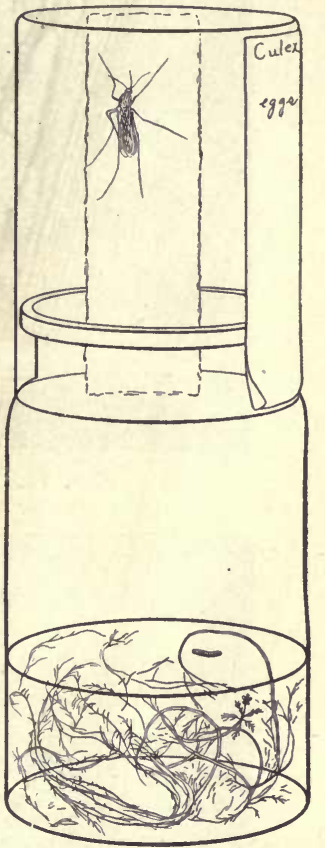

Frg. 70. Jam bottle and tumbler arranged so as to secure eggs of a single mosquito these methods, Panama, Cuba, New Orleans, and many cities in the north have effectually rid themselves of mosquitoes. The results of these campaigns prove that the extermination (if the mosquito from any locality is no longer a matter of coubt or experiment. Through drainage of salt marshes whole 


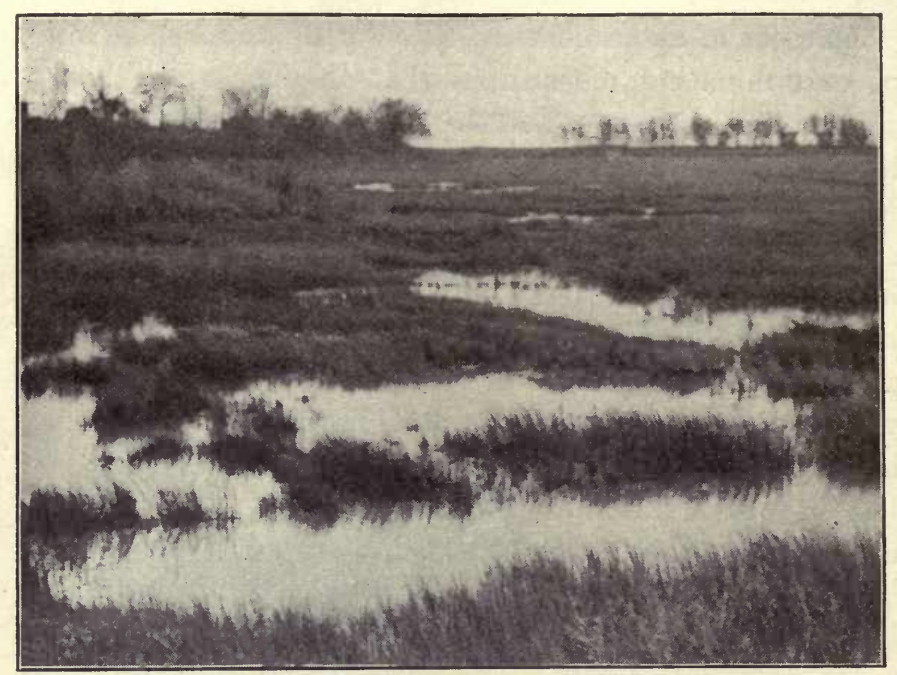

FIG. 71. Connecticut salt marsh before draining

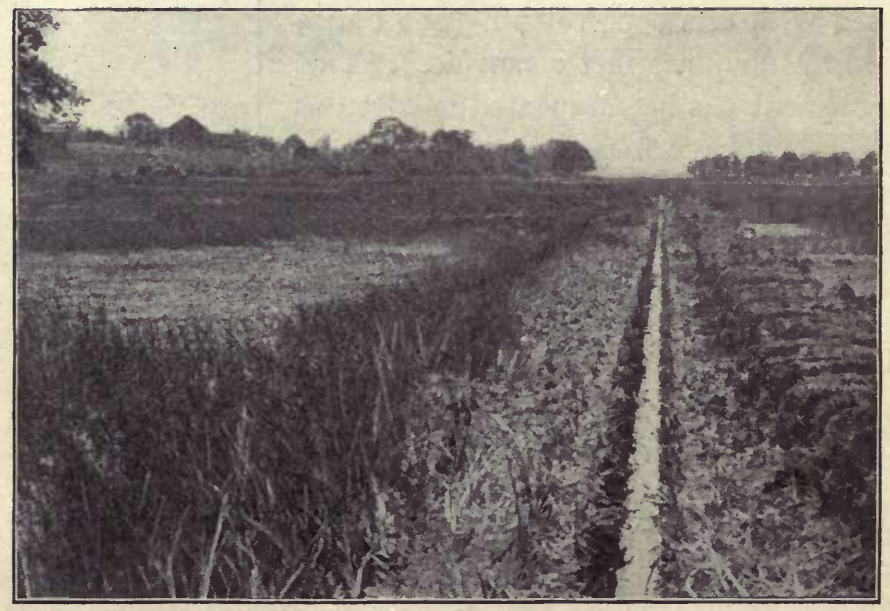

FIG. 72. Connecticut salt marsh after draining Photographs by W. E. Britton 
states are being freed from migrating mosquitoes (Figs. 71, 75). Incidentally, the yield of marsh hay is increased on these swamps, so that it more than pays for the cost of drainage.

Locating Anopheles and Aedes mosquitoes in a neighborhorod does not necessarily mean that malaria and yellow fever are present. These mosquitoes are not dangerous to health unless they have first bitten people sick with malaria or ycllow fever.

Planning a campaign. You may carry on a campaign against the mosquito in a single neighborhood or you may conduct it as a city-wide movement. In either case offer your services as a class to the board of health. If malaria is present, your map showing location of breeding places of Anopheles might be offered to the board and coöperation secured in wiping out the disease. Arrangements should be made to have a doctor examine, free of charge, any one who his even a slight suspicion that he has malaria. Quinine is a ctire for this disease, and every malarial patient should make use of this remedy (under the direction of a physician) and should be screened from mosquitoes to prevent them from becoming infected.

Allow the newspapers to publish the results of your work, together with the accounts of mosquitoes and the methods of exterminating them. It is of the utmost importance that er ery one enter the campaign with enthusiasm, as a few careless and ignorant people may continue to breed mosquitoes by-thousands in all sorts of rubbish that can hold a small aruount of water. 


\section{CHAP'TER XII}

INSECT TYPE PROBLEMS : CABBAGE BUTTERFLY

$$
\text { (PONTIA RAPAE) }
$$

Pontia rapa. This white butterfly commonly seen flitting over garden and roadside, has long been a serious pest. It gains its familiar name - cabbage butterfly - from ravages of the larva upon the Crucifer family, especially the cabbage. In the northernmost portion of North America it is two-brooded, in the latitude of New England three-brooded, and farther south many-brooded. A butterfly has been known to contain over 500 eggs, and the progeny of a pair of cabbage butterflies in a season in the latitude of Boston is estimated as 31,375,500.

The cabbage butterfly was accidentally introduced into America from Europe in 1860, and twenty-five years later it had spread over nearly the length and breadth of the land. This rapid invasion was due to the fact that its natural enemy, the ichneumon fly (Apanteles glomeratus), was not present to hold it in check. This insect, however, was introduced in 1883 and is increasing rapidly. The cabbage butterfly may be collected in its different stages and the specimens kept in breeding cages (Fig. 73) for study. Larvæ thrive well in the laboratory if they are supplied with fresh cabbage leaves.

Eggs and larvæ. The small yellow eggs are deposited singly on the undersurface of cabbage leaves. Keep in water in the laboratory leaves upon which eggs have been deposited, noting how long it takes the eggs to hatch. Measure the young larva and note the time it requires to double in length. Does its color match that of the leaf upon which it is feeding? What is the advantage of this? 
Place some larvæ in a cyanide bottle. Study and draw a specimen. Can you find the six single eyes (ocelli) on the side of the head? Note the small feelers (antennoc), and the strong teeth (mandibles). How many pairs of jointed legs has the thorax? How many unsegmented legs (prolegs) o. the abdomen? Note the number of segments on the a domen, and locate, if possible, all the spiracles.

Pupa. After a larva is full-grown it ceases to eat a)d becomes restless, leaving the cabbage and crawlin s.mptoms are seen, keep a larva under a glass for oiservation. Note that it sj)ins a mat of silk into which the claws of the lisst pair of prolegs are fistened, and a girdle of s lk over the middle of its back. After it is thus siscurely fastened it draws its head down. When it has remained in this positon for some time, the ssin splits over the head

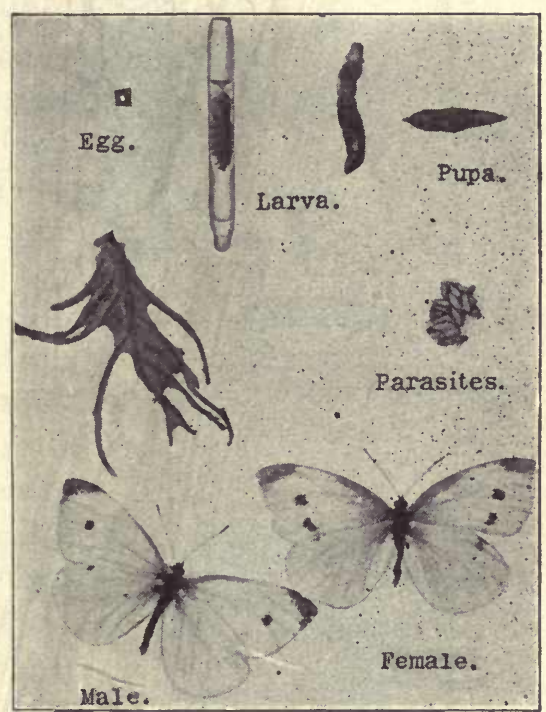

Fig. 73. Insect case to show biology of cabbage butterfly and thorax, and we find a chrysalis in place of the green larva. I)raw the pupa as it is fastened by its girdle. Search for $f$ upe and make a list of places where they are found. Save as many as possible in order to see the butterflies emerge.

Adult or imago. The rapid distribution of cabbage butterflies i; due to their flight across the country from garden to garden, and to the conveyance of the chrysalis on carriages and trains. J'ollow the butterfly for fifteen minutes and keep a record of 
all that it does. It sips.nectar from flowers, and does much to fertilize them. The female imago is distinguished by having two black spots upon its fore wing while the male has only one.

From your specimens in the laboratory study the butterfly, noting its parts. Draw from the side and from above. Make

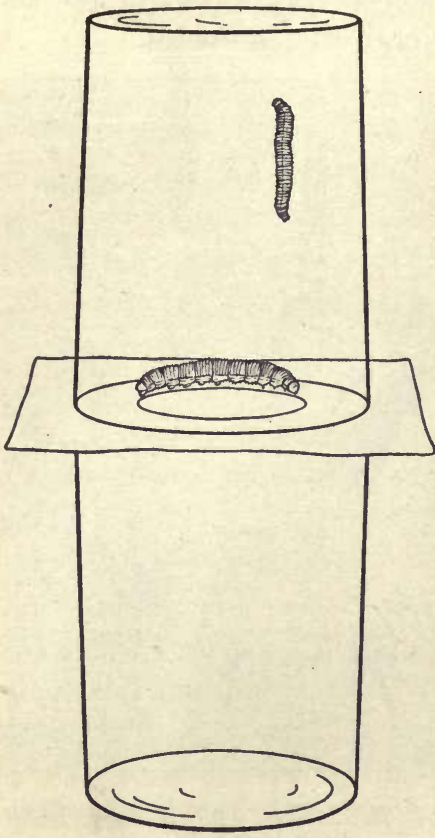

Fig. 74. Convenient arrangement for studying larvæ

Two tumblers with card between drawings of the head from the side, one with the proboscis curled up, and another with it extended. (Place a little thin sirup near the head and watch the butterfly unroll its proboscis and sip it.) Compare the structure of the body with that of the pupa. Mount, according to directions, the complete life history of the butterfly (Fig. 73).

Control of the pest. Artificial means of control are (1) Paris green, sprinkled over the leaves, killing the worms but not injuring the plant; (2) kerosene emulsion as a spray; (3) water, heated to $130^{\circ} \mathrm{F}$., may be used without injury to the plant; (4) systematic "netting" of adults. The most effective measure, however, has been the introduction of its natural enemy, Apanteles glomeratus.

This minute wasp-like insect deposits its eggs in the body of the cabbage caterpillar where they soon hatch and feed upon the tissues of the host. They grow until they are about to pupate, and then eat their way out and spin their silken cocoons on or near the body of their enfeebled host. The 
cabbage larva that is parasitized by the ichneumon fly usually lies before it transforms into a chrysalis. 'The adult ichneumon fly emerges from its cocoon in a week or ten days. It is not
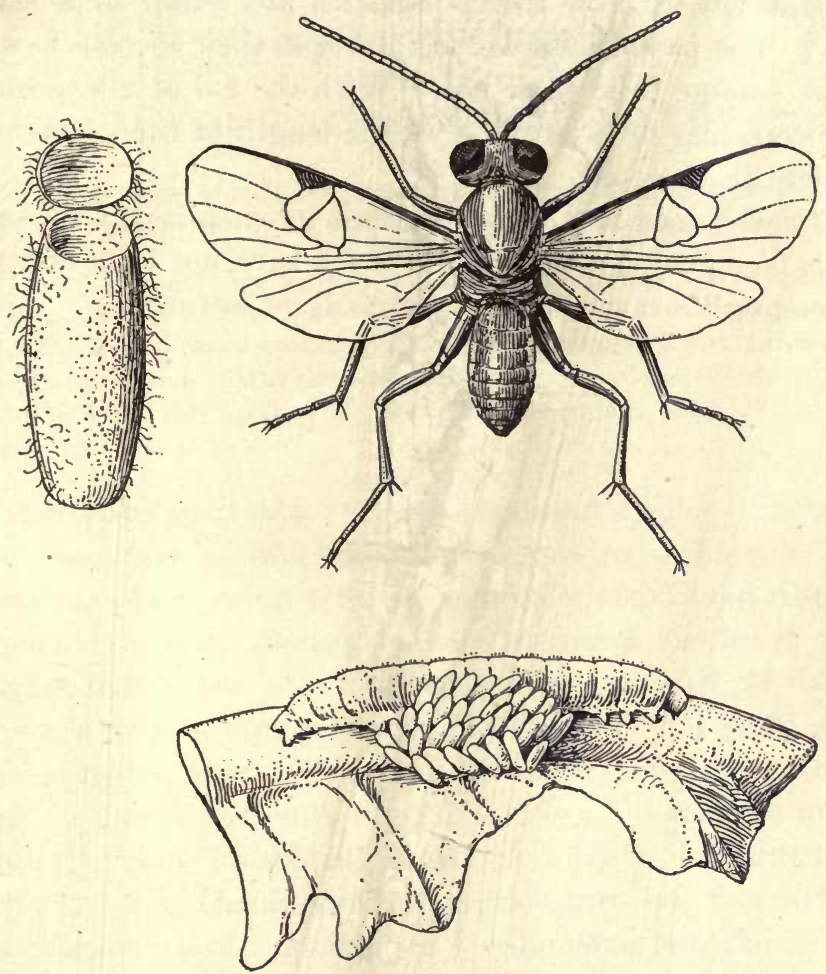

Fig. 75. Imported parasite of the cabbage butterfly Apanteles glomeratus

Open cocoon, adult insect, and mass of cocoons near parasitized larva. Highly magnified

known how long it lives or how many generations occur in a year. The fact that it is holding the butterfly in check in some localities would lead to the belief that it multiplies more rapidly than its host. 
The larvæ that are infested with the parasites are usually a paler green and are not so easily bent. Examine a number of larvæ, keeping in a closed vivarium those suspected of being parasitized. How many parasites are found in a single larva? The parasitic larvæ begin to spin their cocoons as soon as they emerge from their host. With the aid of a lens watch this interesting process and note the length of time it takes to complete the cocoons.

Apanteles does not escape without its enemies. Two small chalcis flies prey upon it, but thus far have not been effective in checking its ravages upon the cabbage worm. 


\section{CHAP'TER XIII}

\section{INSEC'T TYPE PROBLEMS: ANTS}

No otleer group of animals presents such a maze of fascinating problems to the biologist, psychologist, and sociologist. - WheELer, "Ants," p. 11

If I had to choose the form in which I would prefer to live again, I am not sure that I should not like to be an ant. You see that little insect lives under the conditions of perfect political organization. Every ant is obligerl to work, to lead a useful life; every one is industrious. There is perfect subordination to the good of all, discipline and order. They are happy, for they work. - Bismarck

Economic importance. Over a thousand species of ants have been described, of which about two hundred belong to North America. As a group they are generally considered distinctly beneficial insects, though among so many species it is not strange that a few are injurious. Forel counted 28 dead insects per minute brought in by the foragers of a large colony, and estimated that this colony collected 100,000 insects per day. In China live ants are an article of commerce and are regularly used to control injurious insects in gardens and orchards. The Department of Agriculture has recently tried the experiment of importing a Guatemalan ant, the kelep, in the hope of discovering an effective enemy of the cotton-boll weevil. Observations of ants attacking injurious insects should be carefully recorded and reported to the class.

Many species burrow deep into the earth, opening up the soil to air and moisture and preparing it for easy penetration of roots, and bring quantities of fine subsoil to the surface. In this way ants supplement the work of earthworms in the formation of vegetable mold. 
Three species, the red ant, little black ant, and pavement ant, are common household pests which can easily be looked up in state or national bulletins if they are locally important. ${ }^{1}$ Serious damage is sometimes inflicted by the corn-root louse (Aphis maidi-radicis). The eggs of this aphid are cared for over winter by the common brown ant (Lasius brunneus). They hatch early in the spring and the ants carry the young aphids to various grasses and weeds in the field, and later transfer them to the roots of the corn. Concerted work of farmers over an infested area by early spring plowing and repeated disk harrowing, so that no weeds are allowed to grow before the corn is planted, effectually controls both ants and aphids. This topic is well adapted to laboratory demonstration and experiment in infested districts and where education is needed to secure general coöperation.

The chief interest, however, attaching to a study of ants is their seeming intelligence and wonderfully perfect eivic organization of the colony.

The colony. Ant colonies are composed of queens, males, and workers. Queen ants are usually larger, are wingless when mature, and sometimes live fifteen years; the males are smaller, always winged, and never live more than one year. The workers may be distinguished readily from the queens and males by their small size and lack of wings. They do all the work of earing for the queen and her young, gathering food, building and defending the nest, caring for plant lice (aphids), and waging war.

Before mating, the queens have wings. In the summer and early fall clouds of young queens and males leave the different colonies, flying in thousands. The flight over, the queen is either adopted by an old colony or establishes a new one. When once established, she removes her wings and never leaves the colony. While there is usually but one queen in a colony, there may be as many as thirty.

${ }^{1}$ Hodge, Nature Study and Life, p. 86 ff. 


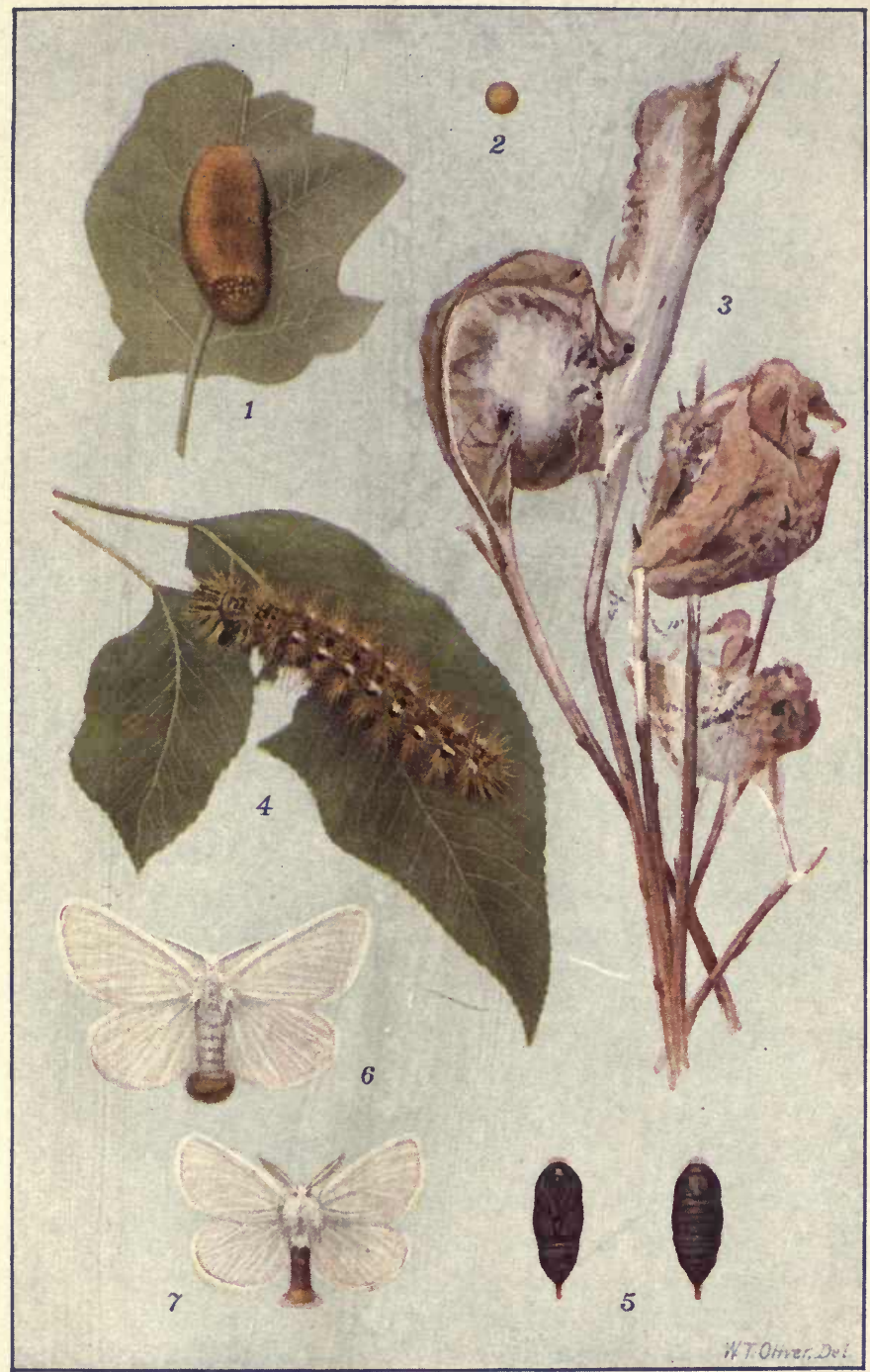

PLATE III. LIFE HISTORY OF THE BROWN-TAIL MOTH

1, egg cluster; 2, single egg (enlarged five diameters); 3 , winter nests (reduced about one half) ; 4, caterpillar ; 5, pupæ, male at right, ventral view ; female at left, dorsal view ; 6 and 7 , female and male motlıs 

Food. Ants feed upon both animal and vegetable matter. their foraging raids extend over a radius of forty yards from the nest. They often take food into the nest, and in cold climates they hibernate during the winter. Much of the food of the queen and larvæ is eaten by the workers and regurgitated from the crop when they return to the nest. Ants have a preference for sweet food, such as juices of fruits, sugar, honey, and honeydew. Aphids secrete honeydew, and on that account are cared for by the ants, taken into the ant nests over winter, and in the spring carried back to the plants upon which they feed. But the aphids are among the insects most injurious to vegetation, and their protection by ants may be of great economic importance to us. Watch the problem in your own locality.

Special senses. The organs of sight and hearing are very slightly developed in the ant, but the sense of smell is especially keen. This sense is situated in the antennæ. The ant travels from its nest and finds the way back by the odor of its own tracks. If a portion of the path the length of its own body is disturbed, the ant is lost and wanders about until it picks up the trail again, but a path left dry and undisturbed c: nn be followed by it five days later. Experiments show that its own nest is evidently detected at quite a distance by odor, but the odor of other ants is supposed to be recognized only by truching with the antennæ. Each species of ant has a distinct, cliaracteristic odor. Different colonies also of the same species differ slightly. In general, the odor of one species of ants is offensive to those of another species, and causes aversion and hostility. This is shown by well-defined warfare and slavery.

Slavery. While most ants will capture and carry away the young of another species whenever the opportunity is offered, there are three species in America (Formica sanguina, Polyergus rufescens, and Tomognathus americanus) that plunder the nest of their enemy and rear the young as slaves. 
The slaves undertake the work of the new nest much as they would that of their own. Can you find ant colonies with slaves?

Warfare. Many comparisons have been made betweelı ants and man because of the diversity of their activities. Ants are said to indulge in games and athletic sports and to carry on war. The following observations are recorded that they may incite some young Lubbock or McCook to find the cause and purpose of these wars.

On the morning of June 26, 1883, I observed numbers of large black ants wandering excitedly over a back piazza of my house in Boxford, Massachusetts. More careful observation showed a dozen of their dead bodies scattered around, while two living insects were struggling in a desperate conflict. In some places dissevered legs and antennæ were thickly strewn, while in retired nooks living ants were resting, either exhausted or skulking. I gathered over twenty corpses from the piazza and the ground. Some of these warriors, having mutually inflicted mortal wounds, had never relaxed their iron embrace, but lay dead in pairs.

The conflict was not yet ended, and I watched one of these Homeric encounters. An ant had his antagonist's feeler in his jaws. The combatant, thus held, twisted and turned to get his own mandibles upon feeler, leg, neck, or waist of his antagonist. He was, evidently, much unnerved by the other's hold, for these, antennæ seem as sensitive as the eyeball, and he was dragged about, resisting and struggling in every way, but all in vain. Finally, the antenna came off near the base and the two warriors parted.

Single combats like this probably went on through the day, and a few occurred the following night, for in the morning I found more dead bodies. One wounded soldier died in my custody, and many, doubtless, in cracks and nooks, but the level floor seemed to be the main battlefield. Altogether. I collected from the fight about seventy complete bodies or dissevered heads, which I preserved in a red pill box - the rather gaudy tumulus of this Waterloo:

In the same place on the morning of July 7, following, I found traces of another battle which was not yet finished. Again, July 19, there had been a battle during the night on the bare floor of a chamber at the opposite end of the house and upstairs. One morning in August, of the same year, I found traces of a similar battle in the cellarway of a neighboring house.-W.P. Alcotт, Bulletin, Essex Institute, 1897, p. 65 


\section{A Study of Ants in the Laboratory}

The nest (formicary). Most species of ants readily adapt themselves to an artificial nest. After the first few weeks they become accustomed to their surroundings, and may live for years working and rearing their young, much as they do in their natural environment.

Kellogg in his "American Insects" describes several of the more commonly used formicaries. The large-sized insectmounting cases serve admirably in this capacity. The case should be partitioned off into two or three rooms, by glueing strips of wood that reach nearly across. On the top of the walls of the case glue strips of 'Turkish toweling, so that air may pass to the rooms after the upper glass is in place. Choose two pieces of heavy glass of unequal size for the roof of the formicary, so that one piece will cover two rooms. Exclude the light from these rooms by placing blotting paper over the glass, and keep a wet sponge (finest texture) in each of the darkened rooms. All food should be kept in the light room, and should consist of small pieces of sponge cake, moistened with sirup or honey, apple, mashed nuts, dried fruit, and insects. Keep the sponges wet. In cool weather the food need not be changed oftener than once in two weeks.

How to obtain an ant colony. Dig up an ants' nest and take larvæ, pupæ, and workers. If you cannot find the queen, release the captives and try other nests until successful. Carry the queen by herself in an envelope, and the young and workers with some earth in a cloth or paper bag. Upon reaching the laboratory, empty the earth and ants upon a board afloat in water; pick out the ants and young from the earth and place them with the queen in the nest. ${ }^{1}$

${ }^{1}$ An easy way to manage this is to scrape a hollow in the center of the pile of earth, put the queen in this, and cover it with a chip. The ants will then collect all the eggs and larvæ into a pile, and they may be lifted into the nest with a spoon. 
The carpenter ant (Camponotus pennsylvanicus) is one of the most satisfactory species to study. The colony lives in wood, and hibernating queens may be obtained under the bark of stumps or logs in the fall or during a winter thaw.

In general the logs and stumps in which they are found are not badly decayed. Most frequently queens are hiding beneath bark that may without difficulty be removed with the

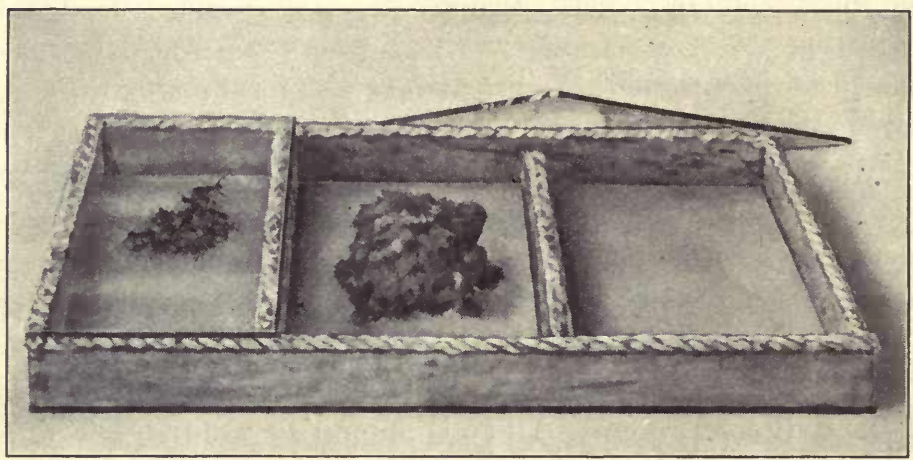

Fig. 76. Ants' nest

This is made of an insect-mounting strip, 5 by 7 inches, $\frac{1}{2}$ inch deep, glued, with the two partial partitions, to the bottom glass. The top glass is eut so that one piece covers one, and the other two, of the compartments. A braided cotton twine is glued along the top of the frame and partitions to insure ventilation. The sponge, in the middle compartment, is kept moist ; and the living chamber, to the left, is kept dark when not under observation. Designed and photographed by the author

fingers. The queen is curled up in a cleared space under the bark and may be alone or accompanied by several eggs, larvæ, pupæ, or workers.

Having secured a queen of Ćamponotus pennsylvanicus, place her, together with her young, in a nest and carefully observe the beginning of an ant colony. Observations should continue for the remainder of the year and careful notes made to reënforce those taken upon ants in the field.

Eggs. The queen may not lay for a month or more after 
she has been brought into the laboratory. Note the intervals during which eggs are laid. Describe the action of the queen and workers in regard to the eggs when the nest is disturbed. How soon do ants become accustomed to the careful interference of being observed? Fill the sponges with water, one day hot, another day cold. What effect upon the apparent care of the eggs has a difference in moisture, temperature, and light?

Larva. The time taken for the eggs to hatch depends upon the warmth and humidity of the atmosphere. The time of incubation is about twenty days. The larvæ are soft, footless grubs, the smaller end being the head. The presence of hooked hairs upon the bodies of the larva explains how they are carried in bundles. Note that the larvæ are helpless. They are not only fed by the queen and workers, but are carried about to places of proper temperature and humidity. With the aid of a lens observe how the workers and queen feed the larvæ. The queen has food stored in her body, which enables her to live and feed her first brood without herself taking food. This fact probably accounts for the small size of the first brood, which is composed of workers, as compared with subsequent broods. The queen is relieved of all work when the workers appear. They feed her and the larvæ and assume all work of the colony.

Note that the larvæ are of different ages, and that they spin cocoons as soon as they become full-grown. Are the larvæ and pupæ kept together? Ants have no regular places for their young; even in the natural nest they are carried to places which offer suitable conditions. The pupa stage like the larval lasts about twenty days when the temperature is about $80^{\circ}$. Observe that the cocoon turns yellowish before the young ant (callow) appears. How long before the callows assume the duties of adult workers? 


\section{CIIAPTER XIV}

\section{SPECIAL PROBLEMS OF INSEC'T CONTROL,}

'The life histories of insects lie at the foundation of the whole subject of economic entomology, and constitute, in fact, the principal part of the science, for until these are clearly and completely made out for any injurious species, we cannot possibly tell when, where, or how to strike it at its weakest point. - S. A. Forises

Control of insects by a community or nation must depend upon each citizen knowing the important species and actually doing his part. Insects are so small, tough, and hard to kill, and, above all, possess such powers of rapid dissemination and increase, that the problems of insect control are probably the most difficult in the whole field of living forces. However, in the life history of a species from the egg, through the actively feeding larval stage, in the quiescent pupal condition, or in the adult, egg-laying period, it is generally possible to discover some wrakest point at which it may be successfully attacked. To work out these life histories, discover these vulnerable points of attack, and devise best ways and means is the function of our scientific experts; but, in order that these discoveries accomplish their purpose, the people must learn and use the results.

Organization for both research and information is so perfect that if any one wishes to know about an insect he has only to inquire of his State Experiment Station or of the United States Department of Agriculture at Washington. If the answer to his question is known, it will be sent to him practically by return mail. If not, a special research may be ordered to solve the problem. 
As a nation we are paying about $\$ 25,000,000$ annually for the discovery and dissemination of just this sort of information. If we are not "getting our money's worth," it is our own fault. One truth with regard to an insect which causes disease or levies a tax of often hundreds of millions of dollars on some staple crop may be worth the entire annual cost of the scientific departments of the government, as soon as the knowledge is put to use.

With hundreds of experts working at these problems, knowledge is growing so fast that statements are likely to be superseded before the ink of a book is dry. In order to keep up to late, every biological laboratory should have available for all students two important publications, the Monthly List of Publications and the Experiment Station Record, both issued by the United States Department of Agriculture. These will keep the student informed of every advance in our knowledge of insects, as well as of a great many other matters of interest.

Make a list of the most important insects of the neighborhood, or those about which you wish to learn, and follow them through the indexes of the Experiment Station Record. Send to your State Experiment Station or to Washington for the bulletins you need, and, after studying them and collecting and observing your specimens in the field, mounting them so that they will tell as complete a story as possible, be ready to report your results to the class.

Working independently and without consultation, let each member of the class prepare a list of the insects which he thinks every member of the community ought to know in order to prevent annoyance, spread of disease, damage to household goods, stock or crops. This should be done after working through the laboratory types given in Chapters X-XIII, reading bulletins and books assigned, and studying the lists given below. After comparing and discussing individual lists, prepare a class list which shall include the most important local 
problems, and one which the class can reasonably cover during the year, and then write the names on slips and let each draw a certain number, or distribute by individual preference, as the class may elect. As these studies progress they should be reported and freely discussed. Thus the biology class may be the organizing center for a better understanding of local insect problems, and enlist coöperation of homes and of boys and girls in the lower grades for more effective effort and better local control.

The problem of insect classification. It is recognized that for an elementary and practical course the complete classification of insects is too difficult and would take too much time. The vast number of species, more than three hundred thousand, are commonly grouped into nineteen orders, and any student who is specially interested can find the subject fully treated in manuals. For all elementary purposes it will be sufficient to learn the names and characters of the seven more important orders. Every one ought to know what we mean by a "fly," a "bee," a "bug," a " moth or butterfly," a "locust," a " beetle," a "lacewing."

Since classification consists in gathering into groups forms with similar structures and parts, we need to learn something of the way an insect is constructed. To begin, take any large insect, a beetle or grasshopper, and work out all the apparent subdivisions of the body. Note the three main subdivisions head, thorax, and abdomen - and locate the breathing pores (spiracles) as indicated in Fig. 77. Insects, spiders, and myriapods, instead of having one pair of nostrils, a windpipe, and lungs to which the blood is brought to be oxygenated, circulate the air directly to the tissues by means of fine, elastic, branching tubes. These are known as tracheæ, and these animals are known, since this is a character of great significance, as tracheates. Contact insecticides - oil films on water for mosquitoes, oil-emulsion or soapy sprays - depend upon clogging these fine breathing pores and thus smothering the insect. 
Water will not do this, because the openings are protected against its entrance by oily secretions. Compare the effect of dipping an insect into water and into kerosene.

Next, beginning at the head, study all organs and movable parts (appendages): the eyes, feelers (antennæ, replacing Head Prothorax Mesothorax Metathorax Abdomen Compound Eye

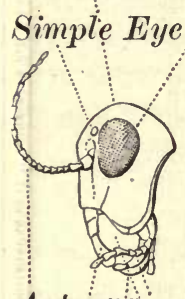

Antenna

Labrum

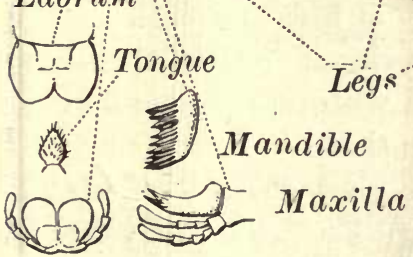

Fore Wing

Hind Wing

Labium

Mouth-Parts

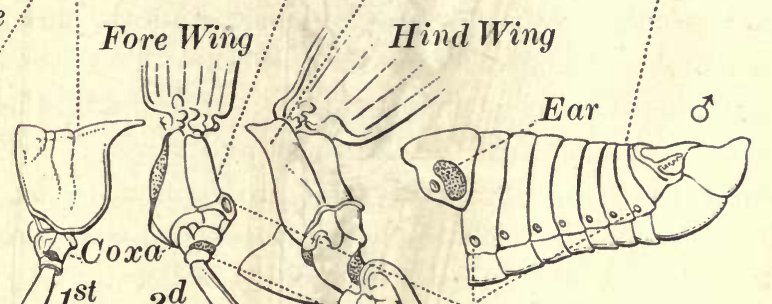

1 st

$2 \underline{d}-\frac{d}{d}-$ Spiracles

Trochanter

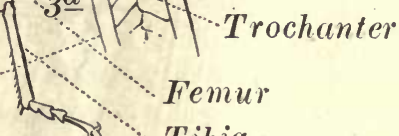

F.IG. 77. External anatomy of the grasshopper

( ars and nose as sense organs, at least partly), mouth parts ( very complicated, consisting typically of an upper and lower lip (labrum and labium) and two pairs of jaws (mandibles and maxillæ), which move sidewise instead of up and down). Watch a caterpillar or grasshopper eat a leaf and see if you (an discover why the jaws move sidewise. A study of mouth larts is again important with reference to methods of destroying insects. Those that bite and chew can be killed by spraying 
poisons upon their food plants or by mixing poisons with foods which attract them. Those whose mouth parts have been modified into an apparatus for piercing and sucking can be reached only by insecticides which kill by contact.

The thorax is divided by rather conspicuous sutures into three parts named prothorax, mesothorax, and metathorax. Each carries a pair of legs; that is, all insects have three pairs of legs. Wings may be present or absent. If two pairs, they are attached to the meso- and meta-thorax, and a single pair is usually attached to the meso-thorax. The insect wing is the most perfect flying mechanism in existence, and until man can match its structure for lightness and strength, he can hardly hope to solve completely the problem of flight.

Note that insect wings vary in texture from the hard, shelllike structures, as in the fore wings of beetles and the leathery or parchment-like wings of grasshoppers and many bugs, to the transparent membranous wings of bees and flies.

The abdomen is made up of a series of similar rings terminated by various organs concerned with reproduction, ovipositors, etc., sometimes modified into sharp stings.

The life history of an insect also gives characters for classification. With many insects the egg hatches into a worm-like maggot, grub, or caterpillar wholly unlike the parent, and later passes through a quiet stage (pupa or chrysalis) before becoming like the parent. In these cases the insect is said to show a complete metamorphosis (meta, "over"; morphe, "form" - "change of form"). Name insects that you know, of which this is true.

In other insects the egg hatches into something like the parent. To study this point, watch a nest of grasshopper or squash-bug eggs hatch. These insects are said to have an incomplete metamorphosis. In the case of a few insects the San José scale, aphides, and some of the flies - the eggs hatch within the body and the young are born alive. 


\section{Of the nineteen orders the seven most important are:}

I. Diptera (di-, "two"; pteron, "wing"). Two membranous wings, mouth parts for piercing and sucking or for lapping; metamorphosis complete, larva various in form and habit but always footless; maggots, wrigglers, etc. Examples : flies, mosquitoes, gnats; 40,000 known species; estimated number, 350,000 (Howard).

II. Coleoptera (koleos, "sheath"; pteron, "wing"). Four wings, the front pair horny cases which cover the membranous hind wings; mouth parts for biting; metamorphosis complete, the larva a grub, with usually six legs. Examples: beetles, potato beetle, June beetle, lady beetle; 100,000 known species (Galloway).

III. Hemiptera (hemi-, "half"; pteron, "wing"). Fore wings membranous, parchment-like or with horny bases and membranous tips; hind wings membranous; many wingless forms ; metamorphosis incomplete, the young resembling the adults, but wingless the true "bugs." Examples : plant lice, scale insects, cicadas, lice, water bugs; 20,000 known species; probably 80,000 in all (Howard).

IV. Orthoptera (orthos, "straight"; pteron, "wing"). Fore wings parchment-like, net-veined, hind wings almost always membranous; mouth parts for biting; metamorphosis incomplete, the young resembling the adult, but wingless. Examples: grasshoppers, crickets, cockroaches, walking sticks; estimated more than 10,000 species.

V. Lepidoptera (lepis, "scale"; pteron, "wing"). Wings and body scale-clad; mouth parts modified into a coiling, sucking tube, or absent; metamorphosis complete, larva a caterpillar. Examples : butterflies aud moths; 25,000 known species (Galloway).

VI. Hymenoptera (hymen, "membrane"; pteron, "wing"). Wingśs four, membranous, a few wingless forms; mouth parts for biting and lapping; metamorphosis complete, larva maggotlike. Examples : bees, ants, wasps, sawflies, ichneumons; about 30,000 known species; estimated number, 300,000 (Iloward).

VII. Neuroptera (neuron, "sinew" ; pteron, "wing"). Wings four, nembranous, usually net-veined; mouth parts for biting ; metamorphosis incomplete or complete; larva usually unlike adult, sometimes aquatic. Examples : dragon flies, lacewings, etc. ${ }^{1}$

1 This group is now subdivided into eight orders, among them the caddis flies (Trichoptera), dragon flies (Odonata), and white ants (Isoptera). 
Most insects in the following lists belong to the above orders. Each represents a problem of interest to the community and home, and the time will come when each citizen must realize that he has no moral right to breed pests which cause annoyance and damage to his neighbors. In reading the lists review what you have learned of each in previous years, especially rumning over the life history.

It is convenient also to classify insects according to their point of attack or their food plants ; as, insects of the household, garden, field, forest; insects of the apple, grape, peach, etc. Many books for practical horticulturists and the agricultural bulletins treat them this way.

\section{INSECTS OF THE HousehOLD}

FuIEs : House fly, typhoid fly, or filth fly - Musca domestica; small house fly-Homalomyia canicularia; stable fly - Stomoxys calcitrans; cluster fly - Pollenia rudis; bluebottle fly or blowfly - Calliphora erythrocephala; green-bottle fly - Lucilia ccesar; fruit fly - Drosophila ampelophilia; cheese or ham skipper-Piophila casei.

Mosquitoes : Common domestic species, in rain barrels and stagnant pools everywhere-Culex pipiens; malarial mosquitoes - Anopheles maculipennis, punctipennis, and crucians; and the yellow-fever mosquito, throughout the South and wherever it is found breeding-Aedes calopus.

Clothes Motus: Case-making clothes moth-Tinea pellionella; Southern clothes moth — Tineola bisselliella; tapestry moth — Trichophaga tapetzella; carpet beetle - Anthrenus scrophulario; black carpet beetle - Attagenus piceus.

House Crickets - Gryllus domesticus and G. assimilis.

RoAches : American cockroach - Periplaneta americana; oriental cockroach - Periplaneta orientalis; German roach, Croton bug - Ectobia germanica.

BEDBug : Common bedbug - Acanthia lectularia ; blood-sucking conenose - Conorhinus sanguisuga; kissing bug - Opsicœtus personatus

LICE: Head louse-Pediculus capitis; body louse-Pediculus vestimenti.

FleAs: Human flea-Pulex irritans; cat and dog flea - Ctenocephalus canis; rat fleas - Ceratophillus fasciatus and Pulex cheopis; chigoe, 
burrowing flea (chiefly tropical) - Sarcopsylla penetrans; hen flea (burrows into the eyelids of fowls), Southern states - Xestopsylla gallinacea.

This group was formerly classed with the diptera but is now usually given as an order by itself, the Siphonaptera (siphon, " a sucking tube"; a, "without"; pteron, "wing" "wingless bloodsuckers").

White Avts: Termites - Termes flavipes. These are not ants, but belong to another order, the Isoptera (isos, "equal"; pteron, "wing"). Destructive to wood of buildings and furniture and even to living trees.

House Axts: Red ant-Monomorium pharaonis; little black ant Monomorium minutum; pavement ant - Tetramorium caespitum.

Beetues : Larder beetle - Dermestes lardarius; drug-store beetle sitrodrepa panicea; meal worms - Tenebrio molitor and $T$. obscurus; Indian-meal moth - Plodia interpunctella.

The above are only a few of the more important household insect pests. Many others may be found by searching the house, and can be identified, if they present interesting local problems, by reference to the books mentioned at the end of this chapter. The fact that no headway is made in the fight with these enemies is due chiefly to lack of organized coöperation. One family exterminates them and is reinfested from a neighbor who does the work at some other time.

\section{Insects Injurious to Vegetation}

Orchard Pests : Codling moth - Carpocapsa pomonella; tent caterpillars (apple-tree) - Clisiocampa americana; fall webworm - Hyphantria cunea; cankerworms (spring - Paleacrita vernata; fall - Anisopteryx: pometaria); yellow woolly bear - Spilosoma virginica; curculio beetles, weevils (apple - Anthonomus quadrigibbus; plum - Conotrachelus nenuphar; quince-Conotrachelus cratcogi; grape-Craponius incequalis; borer beetles; round-headed apple-tree - Saperda candida; flat-headed apple-tree - Chrysobothris femorata (also attacks the plum); pear-blight beetle-Xyleborus pyri; pear-tree borer - Egeria pyri; cherry-tree borer - Dicerca divaricata; peach-tree borer-Sanninoidea exitiosa; apple-twig borer-Amphicerus bicaudatus); sphinx moths ("humming-bird" moth) (plum — Sphinx drupiferarum; green grapevine - Ampelophaga myron); 
scale insects (oyster-shell scale - Mytilaspis pomorum; scurfy scale Chionaspis furfurus; San José scale, Chinese pernicious scale - Aspidiotus perniciosus, the worst fruit-tree pest on the American continent; cottony cushion scale-Icerya purchasi); apple-tree enemies (yellownecked apple-tree caterpillar - Datana ministra; red-humped apple-tree caterpillar — Eilemasia concinna; apple sphinx, or hawk moth - Splinx gordius; apple maggot, "railroad worm "-Rhagoletis pomonella); enemies of small fruits (strawberry crown borer, weevil - Tyloderma fragraria; strawberry root borer - Anarsia lineatella; currant borer, American Psenocerus supernotatus; currant borer, importéd - Egeria tipuliformis; grapevine root beetle - Prion us laticollis; grape-berry moth - Polychrosis botrana; grape, gartered plume moth - Oxyptilus periscelidactylus; rose chafer-Macrorlactylus subspinosus); plant lice (aphids, grape - Plyylloxera vastatrix; woolly apple louse - Schizoneura lanigera; cherry louse - Myzus cerasi).

Vegetable, Grain, and Cotton Pests: Colorado potato beetleDoryphora 10-lineata; striped cucumber beetle-Diabrotica vittata; asparagus beetle - Crioceris asparagi; June beetle (May bug in the South) - Lachnosterna fusca and others; flea beetles - Halticini; blister or oil beetles - Meloille; cutworms - Noctuidce (larvæ of a number of owlet moths or noctuids); sphinx moths (tobacco, South - Phlegethontius sexta; tomato - Phlegethontius quinquemaculata); cabbage worm, imported Pontia rape ; cabbage looper - A utographer lrassice ; cabbage and radish maggot-Pegomyia brassicce; onion maggot-Phorbia ceparum; cotton worm - Aletia argillacea; bollworm (corn-ear and tomato worm of the North) - Heliothis armigera; army worm - Leucania unipuncta; Hessian fly - Merisus destructor; corn-root aphis - Aphis maidi-radicis; grain aphis or "green bug" - Toxoptera gramineum; chinch bug - Blissus leucopterus; squash bug - A nasa tristis; grasshoppers (Rocky Mountain locust) - Melanoplus spretus; red-legged locust-Melanoplus femurrubrum

Forest and Sinade-Tree Enkmes: Gypsy moth - Ocneria dispar (one of our most difficult problems); brown-tail moth - Euproctis chrysorrliea (a national problem); elm-leaf beetle - Galerucella luteola; whitemarked tussock moth - Notolophus leucostigma; cottony maple scale Pulvinaria innumerabilis.

Most of the Hymenoptera are highly beneficial insects, but among them are a few so injurious and troublesome that every member of a community ought to know them. These 
are leaf-eating sawflies, and many others of less importance are borers and gall insects.

Currant worm or slug - Nematus ventricosus; pear slug - Eriocampa cerasi; rose slug - Monostegia rosce.

Insects attacking Animals: Botfly (ox warble)-Hypoderma lineata; sheep botfly - Gstrus ovis; horse botfly - Gastrophilus equi; horn fly - Hcematobia serrata; screw-worm fly - Compsomyia macellaria.

Beneficial insects. As it is said to "take a thief to catch a thief," so it often takes an insect to catch an insect. From the usual study of injurious forms the impression is likely to be given that almost all insects are injurious. Yet even species which cause considerable damage may perform good service in cross-pollination of plants. The honeybee, our most useful species for this purpose, has the distinct advantage of wintering a large force of workers ready to cover the fruit bloom early in the spring, before our native, solitary bees have begun to breed in numbers.

The problem of the honeybee and fertilization of fruit trees about the home or in the neighborhood is one which may well repay study. The question is, Are there bees enough to do the work? 'The stone fruits are said to depend entirely on insect cross-pollination in setting fruit, and if the cherry, plum, and peach trees are not humming at some time during the bloom, there will be little or no fruit. Apples of some varieties and most pears are greatly improved in quality when cross-pollinated.

For at least one hour on a bright, warm day while the trees are in bloom, with watch in hand, time and count the number of blossoms visited by bees per minute. Do this for all the different kinds of fruit accessible. How many men would it take to do the work of one swarm of bees of fifty thousand workers?

Are there enough bees to pollinate the flowers and gather the nectar in the neighborhood?

Can you find any honeybees working on red clover? 
Test the practical value of insect cross-pollination by covering a twig of cherry, plum, or peach with wire gauze or mosquito netting during bloom. Compare the fruit of this twig with a similar one on the same tree which was not covered.

Is there any evidence that orchards near apiaries bear better than others?

What can you learn of the comparative merits of different races of bees in your locality?

National problems. In the above list three insects merit special emphasis as presenting civic problems of national importance. All are species of almost unthinkable destructive power imported from the Eurasian continent, and until recently, at least, without their natural enemies.

The San José scale was imported into the San José valley, California, in 1868, and has since spread over almost the entire United States. During this time it has probably killed more fruit trees than all other insect pests combined, and is now the most serious menace to the home fruit garden. Minute as is the insect, one pair may produce in a season $3,216,080,400$. This at once shows how little chance a tree can have and how futile any treatment is which leaves even a few pairs alive. After ten years of experimenting with the various spraying mixtures recommended, the writer is obliged to state as his opinion that nothing has yet been discovered which will exterminate the San José scale from a tree. Hence it is of the utmost importance for the class to follow all announcements of discoveries as to effective methods of dealing with this insect.

Make a thorough examination of your home premises and learn the history of the San José scale on the place. How much damage has it done from year to year? How much has been expended in fighting it? What and how many trees have been killed by it? In connection with the field and laboratory work search for natural enemies, fungus or insect. Make a list of food plants upon which the scale is 
found in your neighborhood. Compare results of different methods of combating it. From the data obtainable can you foretell the probable result? Will the home fruit trees be killed and the fruit industry confined to commercial orchardists who will care for their trees?

Gypsy moth. This pest is a European species. It was introduced into this country in 1869 by a Frenchman who was

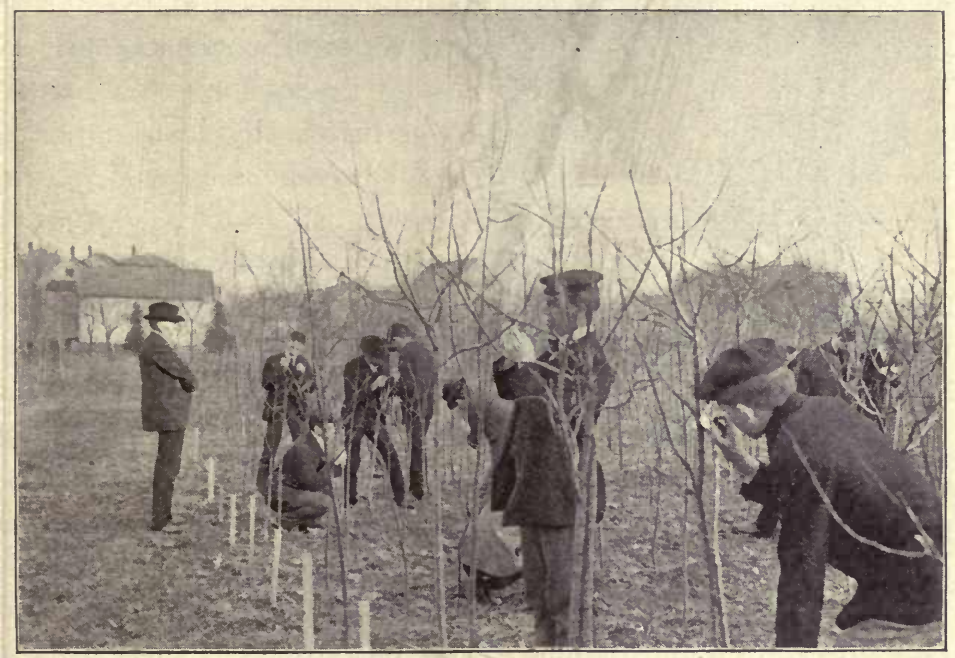

Fig. 78. Outdoor laboratory work

Class inspecting a local nursery for San José scale

attempting to improve our native silkworms. Through accident the insects escaped, but although the fact was reported, the grave danger was not realized until twenty years later. From a single nest in Medford, Massachusetts, the pest spread, slowly at first, and then like wild fire, over the towns and forests of New England. Millions of dollärs have been expended in its control, yet hundreds of acres of forest have been destroyed. A report of 1897 says, "At the present time there can be little doubt that the extermination of the insect is 
possible and that it will be only a question of a few years"; but now, nearly fifteen years later, it is still gaining ground.

Since a large portion of the year is passed in the egg stage, this is the natural time for extermination. The egg masses are conspicuous dark yellow splotehes, and in a badly infested region may be found anywhere, - on fence or stone wall, under porches, among dead leaves, - although the first and most common position is the trunk and branches of trees. The rapid fire which is sometimes sent through woods and underbrush to destroy other pests has no marked effect on these eggs. Attempts to remove the egg masses by scraping have proved equally ineffective, for eggs become scattered in the process and hatch as readily as ever.

Saturating the egg clusters with the following mixture: creosote oil 50 per cent, carbolic acid 20 per cent, spirits of turpentine 20 per cent, coal tar 10 per cent, is the method of extermination recommended by state authorities. It is applied with a small brush. This treatment must find every egg mass, and therefore must be begun the instant the presence of the insect is known. The insatiable appetite of caterpillars makes so omnivorous a creature as the gypsy moth even more dreaded, for when one feeding ground is exhausted, a fresh one over the fence or across the road is quickly attacked. Thus the pest moves on, leaving every twig stripped behind it.

Every effort must be made to keep the pest within its present limits. The female imago does not fly; therefore distribution is effected by the caterpillars which frequently spin down from the trees and fall upon passing conveyances, or by egg masses which are overlooked on lumber or are carried in various ways.

Brown-tail moth. The problem of the brown-tail moth is one of even greater importance to the country at large because of the greater rapidity of distribution. Both male and female are strong, swift flyers, and eggs may be deposited at 
great distances from the original colony. Windstorms also aid in furthering the flight, and steam cars and trolleys transport these pests. Besides the injury to orchard, shade tree, and forest, the brown-tail caterpillar inflicts serious pain upon many persons. This is caused by fine hairs which pierce the skin, the irritation becoming severe enough in some cases to cause illness. A free use of vaseline will give relief.

The brown tail cannot be controlled by an attack upon the eggs, since they are usually on the leaves and for a short time only. Spraying is employed to destroy the swarming caterpillars, but the most effective method is destruction of the winter nests. These are conspicuous on the tips of branches between August and April. They may then be cut with pole shears, and must be carefully collected and burned.

Parasites. The great aim in the attempt at control of any pest is to discover its nat-

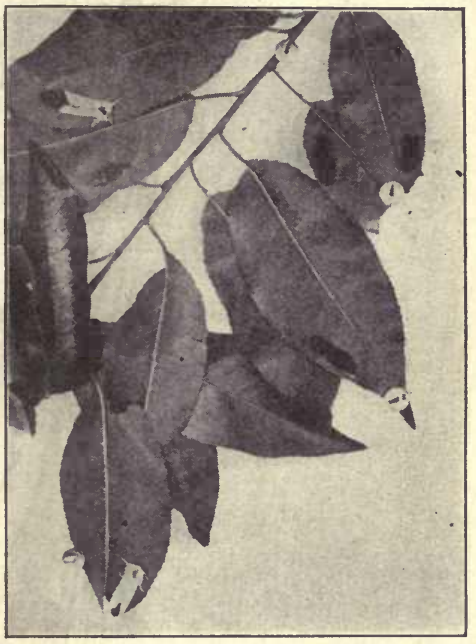

Fig. 79. Brown-Tail Moths

Four egg masses and two moths laying, July 10. Photograph by Katharine E. Dolbear ural enemy. In the case of insects like the gypsy and brown-tail moths, a series of parasites is necessary, for the parasitic insects restrict themselves to one stage only in the development of their host. The insect which attacks the egg takes no notice of the caterpillar, and the insect which attacks the caterpillar is never found upon pupæ. Several native parasitic insects are known to attack these pests, and many have been imported; but as yet the series is not complete and has failed of effective control. 


\section{Comparison of Gyesy and Brown-Tail Moths \\ GyPsy Moth \\ Brown-'Tall Moth}

Eggs. August to May. On the trunks and branches and everywhere, especially on undersides and inner surfaces of objects.

Masses. Light brown, long, broad, about the size of a silver quarter. $300-1400$ eggs.

Caterpillar. May to August. On underside of leaves. Night feeders. Cluster in shelter during the day.

Winter form. Egg.

Full-grown. Two and one-half to three inches long. Rows of conspicuous spots on the back blue near the head, red on posterior part of the body. Hairy tufts on the sides.

Pupa. Late July. Found in some places as egg masses. Dark brown female larger than the male.

Moth. Female, white with brown markings. Spread of wing, from two to three inches. Never goes far from pupa case. Male smaller, brown.
Eggs. July. Seldom on trunk or branch. Generally on underside of leaf.

Masses. Smaller than the gypsy, more elongated, brighter, reddish brown color. About 300 eggs.

Caterpillar. Hatched in August. On upper side of leaves in clusters. Day feeders.

Winter form. Caterpillar in nest. Nest four to six inches long, composed of leaves and silk, contains about 250 caterpillars. Emerge in April, attack bud, blossom, and foliage of fruit trees, and then move to others.

Full-grown. One and one-half to two inches long. Broken white stripe on each side of back, two red spots near posterior end. Hairy tufts on the sides.

Pupa. Late June. Five eighths of an inch long. Dark brown, with yellowish hairs.

Moth. Pure white. Female-slightly larger, with conspicuous bunch of brown hairs at tip of abdomen. Spread of wing, one and one-half inches. Night flyer, attracted by light. 


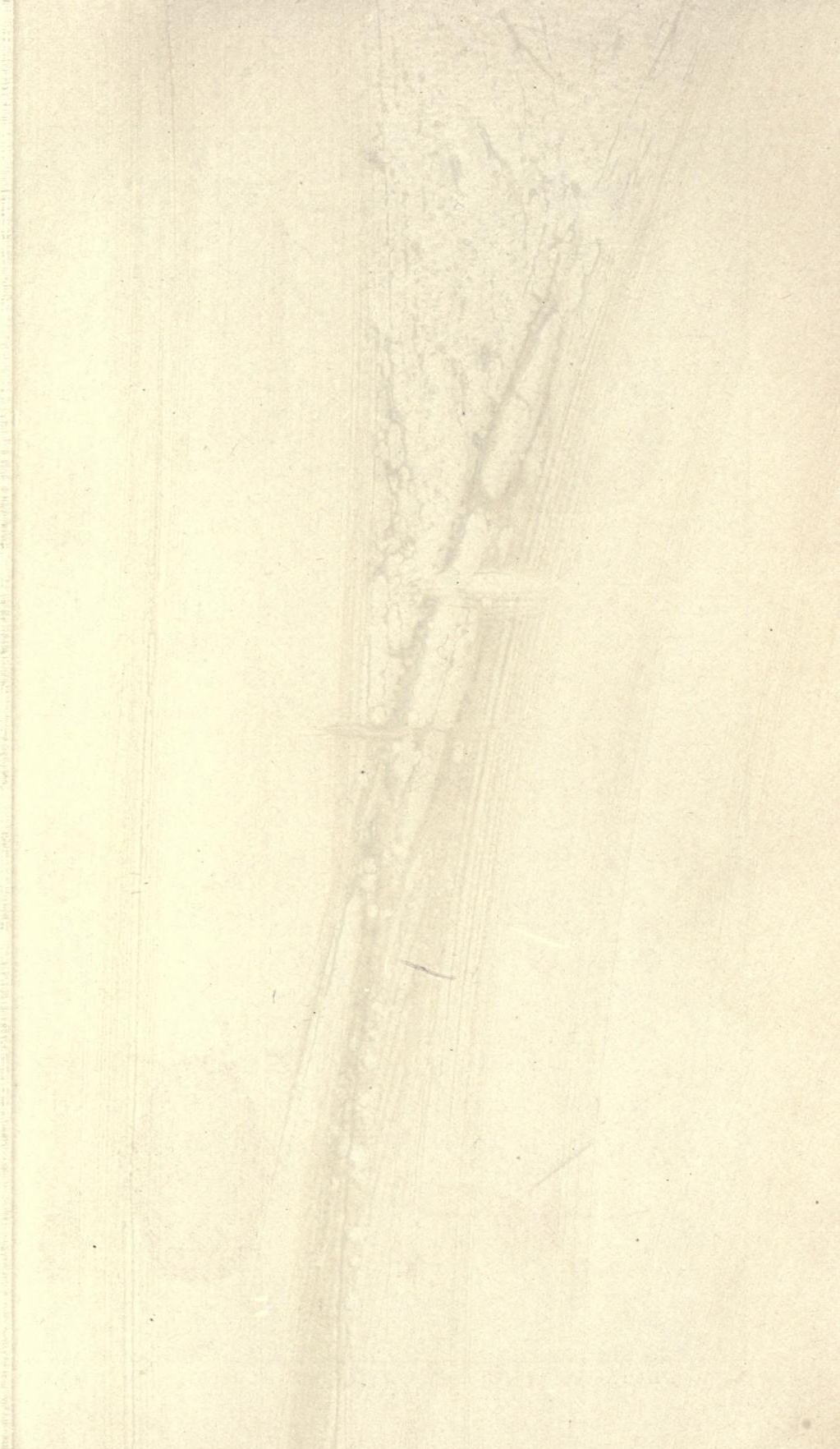




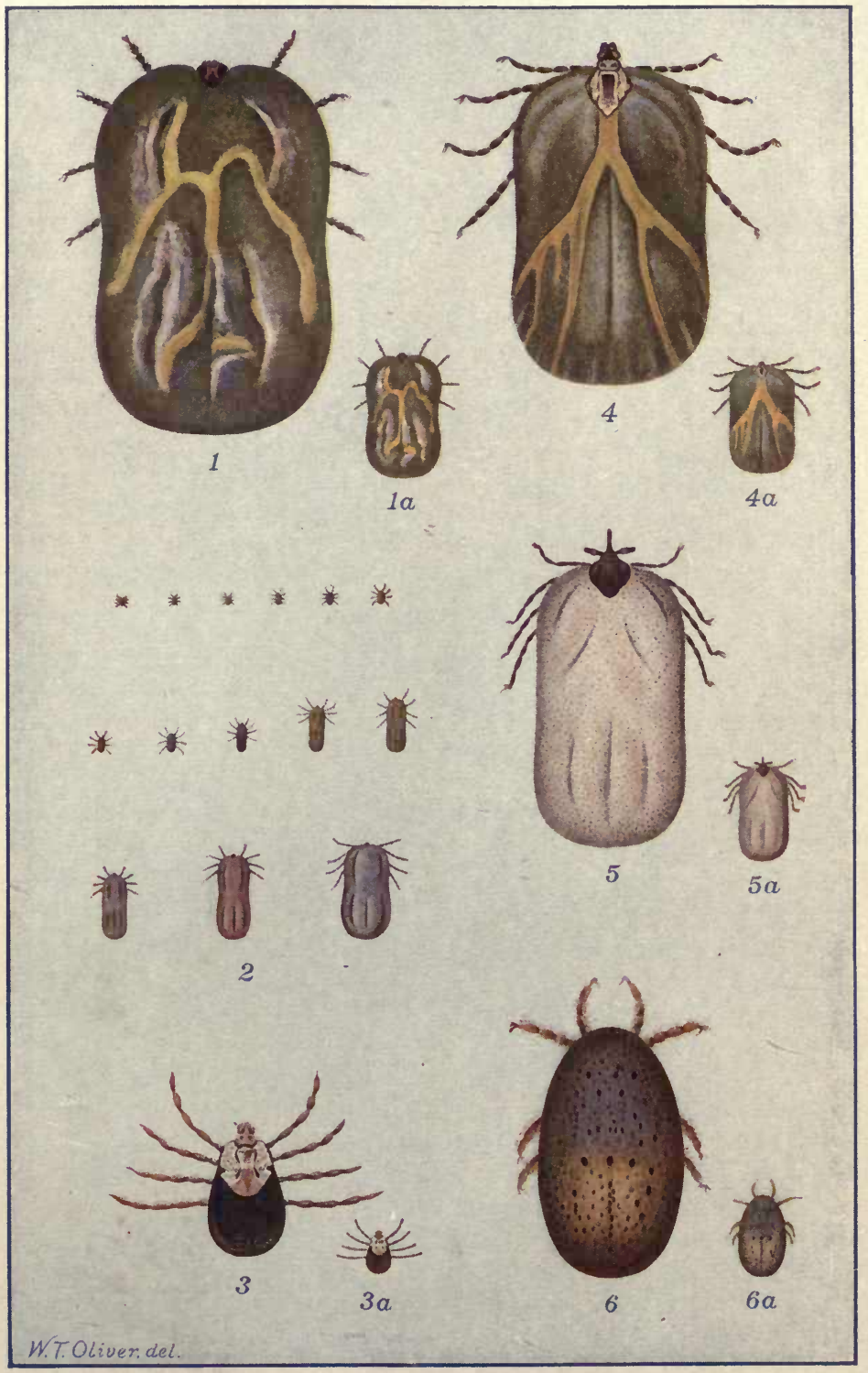

PLATE IV. AIULT FEMALES OF FIVE IMPOR'TAN'T TICKS * 


\section{CHAPTER XV}

\section{ARACHNIDS. PROBLEMS OF SPIDERS, MITES, AND TICKS}

Prices would be higher, the demand greater, and the odium attached to ticky cattle at the stockyards removed. Pure-bred Northern cattle could then lie brought into the South to improve the native breed, without danger of (eath from Texas fever; Southern cattle could enter the show rings of the North without restriction; and the total cost of tick extermination would te far less than the amount saved in the first year after it had been accomIlished.-John R. Mohler, 1914

Closely allied to insect problems are those of the arachnids. This group includes scorpions, spiders, mites, and some of the ticks. Interesting as they are, scorpions and spiders are far surpassed in economic importance by the insignificant mites and ticks. Among the latter are the cattle tick (carrying the germ of Texas fever), the sheep seab mite, mites which attack poultry, and the red spiders and harvest mites which infest vegetation.

Since arachnids are often mistaken for insects, compare any common insect and spider, noting their similarities and differences. Make a diagrammatic sketch of each.

Similarities. Both insects and arachnids are ringed or jointed animals. Both are tracheates, though a few of the arachnids, particularly spiders, have also pulmonary sacs.

Differences. These will be found in the relation of head and body, the number of legs, presence of antennæ, comparison of palpi.

* Five species are shown, enlarged and natural size. 1 and $1 \alpha$, adult female cattle (Texas-fever) tick; 2 , growth stages and variations in color (f this tick; 3 and $3 a$, Rocky Mountain spotted-fever tick, adult female; 4 and $4 a$, female dog, or wood, tick; 5 and $5 a$, female European dog tick; ( and $6 a$, female chicken tick. (Reproduced from plates issued by the Inited States Department of Agriculture and the United States Public I Iealth Service.) 
The larger arachnids, in spite of their bad reputation and terrifying appearance, are comparatively harmless. Even those of the poisonous varieties, tarantulas and scorpions, make no

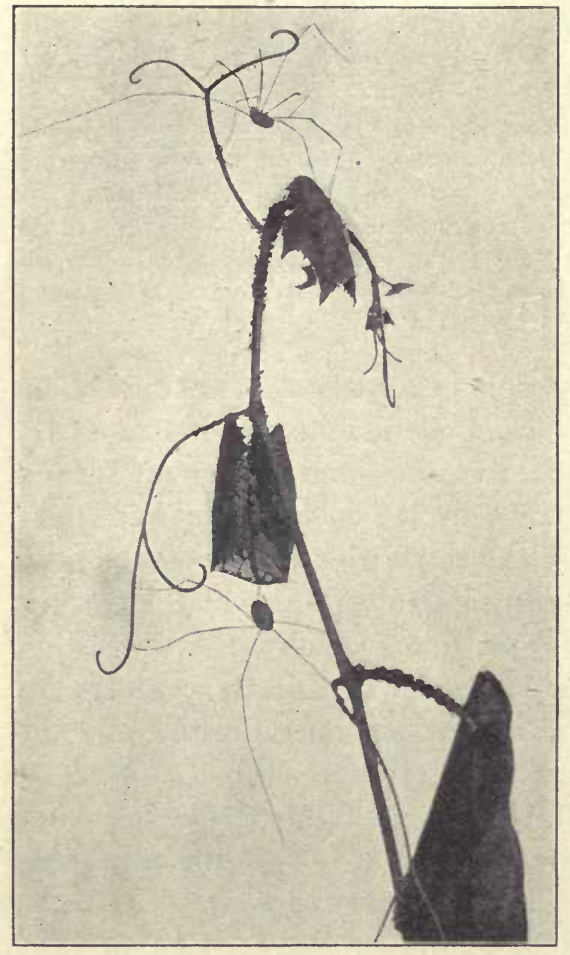

FIG. 80. Harvestmen clearing the plant lice from a grapevine

Photograph by the anthor attack upon man unless frightened or molested. 'Their economic importance is not con-. sidered great, though since they are insectivorous, they may be distinctly beneficial.

The smaller arachnids, mites and ticks, cause great destruction of vegetable and animal life. They are characterized by an unsegmented body, the abdomen as well as the head being joined to the thorax. While we must not overlook the service of some species as scavengers, we are concerned much more with them as parasites upon living animals and plants.

Red spider - Tetranychida, "four-clawed."

This greenhouse pest is found both indoors and out, and on various plants and trees. It is one of the commonest families, containing sixty species. 'The red spiders are most troublesome in times of drought and are found chiefly on the underside 
ff leaves. So minute are they that a single one is scarcely visible to the naked eye, and they are often not noticed until he plant is badly infested.

They pierce the surface of the leaf and suck its juices, and very soon the plant begins to appear yellow and sickly. When $t$ is practicable the garden hose will exterminate these pests. Under other conditions spraying with fish oils or soap solution is effective.

Clover mite - Bryobia pratensis. As the name indicates, these nites are found chiefly upon clover, but also on apple and jeach trees, cottonwoods and arbor vitæ, and even on boards, stones, and fences. During the fall and winter they appear also on plum, almond, poplar, and elm trees, and frequently eave vegetation entirely and become very troublesome in houses.

Of species found upon animals, there are some which cannot be considered a real menace to health, yet they are exremely irritating and troublesome. The most common of these ure harvest mites and wood ticks, the former being one of the smallest of mites, a mere pin point of red, and the latter me of the largest of ticks, reddish brown, a quarter of an nch in length and swelling, as it feeds, to the size of an olive.

Harvest mite - Trombidium holosericeum. When in the larval stage, these are the "chiggers" of the Middle States. During arly summer harvest mites will be found on grasslands and sandy slopes, or in the woods. They can be seen most easily in July, when the eggs are being laid, and that is the time also when they begin to attach themselves to any passing animal. The creatures of the woods, especially moles and hares, are sometimes literally infested with them, and dogs, cats, horses, and cows often show signs of intense itching from them. In some localities there are few people who have not felt their presence. Sulphur ointment or friction with a cloth dipped in benzine or strong alcohol will give speedy 
relief, if applied soon after exposure and before the mites have become embedded in the skin.

Itch mites - Sarcoptes scabiei (scabere, "to scratch"). These mites have long been a terror to man. They multiply at the rate of $15,000,000$ from a single pair during the season, are easily passed from one animal to another, and are extremely difficult to control. There are many varieties of itch mites,

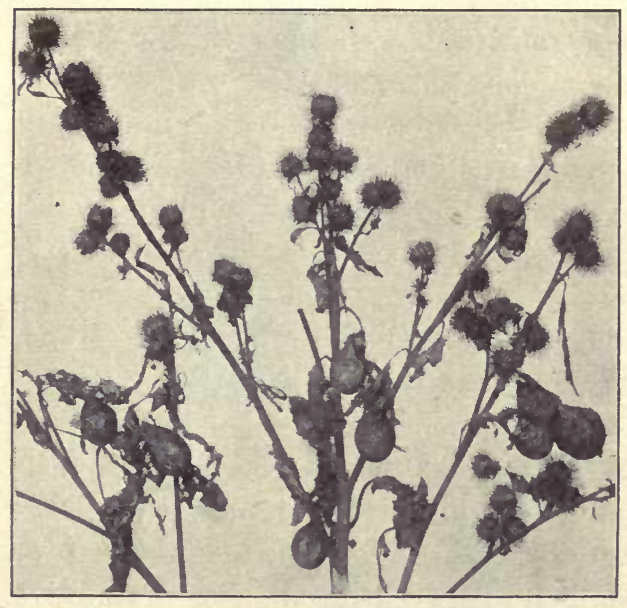

FIG. 81. Egg cocoons of spiders on burdock

Photograph by Dr. J. P. Porter differing in size according to the thickness of skin of the animal they attack. The pig, horse, wolf, goat, camel, sheep, dog - each has its own variety (decreasing in size in the order here given) and the human mite is the smallest of all. The punctures made in the skin by mites are soon covered with a crust, the eggs being found beneath it. The human mite is best held in check by warm baths with free use of soap followed by an application of sulphur ointment. The same treatment is equally good for dogs.

Sheep-scab mite. - Psoroptes communis (var. ovis). This parasite is distributed over the entire world and has proved so destructive that most countries have passed laws to prevent its importation or spread. With intelligent coöperation in the use of precautions and methods of treatment now understood, sheep scab could soon be eradicated. 
The poultry mite - Dermanyssus gallina. This is a viciouslooking creature when seen under a microscope. In color it varies from yellowish white to blood red when fully gorged.

Its presence is sometimes not suspected, for it is a night worker, and during the day it disappears into cracks, especially in the ceilings. If extremely numerous, adults may be found on the fowl, but generally not even the indications of their punctures are visible and only the condition of the poultry shows their existence. There is danger of this mite being earried to the stable, if near by, and the effect upon horses is sometimes serious. Absolute cleanliness in the henhouse is the price of freedom from this pest.

The Rocky Mountain spotted-fever tick. - Dermacentor venustus. The germs of spotted fever are carried from native wild animals to man by the bite of this tick. 'The life history of the tick consists of four stages - the egg, "seed " or larva, nymph, and adult - and occupies from one to three years. Failure to find a host during any of the three active stages results in death of the tick by starvation, and the discovery that earlier stages are largely dependent on the rodents of the region has resulted in a plan of coöperative effort to exterminate rodents and ticks together. Since most of the host species are destructive to agriculture, the work is doubly worth doing. "Coöperation by all landowners in a district is essential to success of any extensive campaign of rodent. destruction." 1 It has also been observed that sheep rid land of this tick, and this suggests that they might prove useful against chiggers and other ticks.

Cattle tick-Margaropus annulatus. The germ of Texas ever is now known to be carried by this tick. The loss to the South as a result of this disease has been estimated by the

1 Clarence Birdseye, "Some Common Mammals of Western Montana in Relation to Agriculture and Spotted Fever." Farmer's Bulletin No. 484. Washington, 1912. 
govermment to be $\$ 63,250,000$ amnually. Texas fever does not become established in the North, because the tick cannot survive the winter; nevertheless it frequently appears there. Northern cattle have been attacked by it as early as thirteen days and as late as ninety days after the tick-bearing cattle have passed through the locality. ${ }^{1}$ Eight species of ticks have been found on cattle in this country, but only Margaropus annulatus carries the germ of Texas fever. It may be distinguished readily from the other seven by its tiny reddish-brown head, contrasting with its dull yellow or even olive-brown body, and by its shape and size. 'The body is broadly oblong, sometimes reaching fifteen millimeters in length, and shows irregular markings of yellow. Notice differences between Margaropus annulatus and comparatively harmless ticks common on cattle (Plate IV).

Dog tick or wood tick - Dermacentor electus. Aristotle calls the wood tick, dog tormentor. Whoever has experienced one on himself knows well the firm grip which it takes, and appreciates the name. Force in removing the tick results either in pulling away the body and leaving the head still attached, or in carrying away a bit of flesh with the head. The better way is to touch the tick with a drop of kerosene or turpentine. It then loosens its hold and is easily removed.

These are only a few of the mites and ticks. Frequently one comparatively unknown is discovered to be the cause of some baffling disease or a possible check to some pest. Your observations now may assist in the future. Keep a record of each new parasite you find - insect or arachnid; note name of specimen, date, locality, host (plant or animal upon which it is found), and any facts likely to be useful.

1 This necessitated drawing the quarantine line of 1891 across the continent from southern California to southern Virginia. This line has been pushed southward since active tick eradication was begun in 1906, and coöperation of stockmen must eventually relieve the entire South. The problem is one for serious study in all schools within or near tick-infested territory. 


\section{CHAPTER XVI}

\section{AMERICAN MAMMAL PROBLEMS}

Each form of animal or plant should be looked upon as an experiment in making a machine which shall best fit its enviromment and most effectively do the work required of it. The fit live; the unfit are relegated to the biological scrap heap, that is, become extinct. Care of offspring and protection from the elements are prime factors in fitness to survive. Mammals excel in both of these functions and characters, and while the feather is as light and perhaps more beantiful, hair is tougher and stands harder wear, and milk earried by the mother is a safer provision for the young than food packed in the shell of an egg. Above all, the intelligence which fashions adaptable protection from the elements, elothes and houses, caps the climax of purely biological fitness.

Mammals. 'This group, to which man himself belongs, ranks highest in the scale of animal life. Its various forms dominate easily sea and land and yield only to birds dominion of the air. Every one knows a bird at sight, but, unlike this compact group, mammals differ extremely in structure from fishlike porpoises and. whales to birdlike bats. In general, hair is as characteristic of mammals as feathers of birds; and aside from a few freak forms, like the Australian duckbill (Ornithorynchus paradoxus, "bird-nosed paradox"), which lays eggs and incubates them like a bird, mammals agree in nourishing the young with milk.

Among the more important problems relating to American mammals are the following:

1. Extermination of predacious forms as the continent has been opened up to settlement - panthers, bears, lynxes and wild cats, wolverines, wolves, minks, skunks, and weasels.

2. Utilization of native wild animals - bison, elk, moose, deer, antelope, mountain sheep and goats, hares and rabbits. 

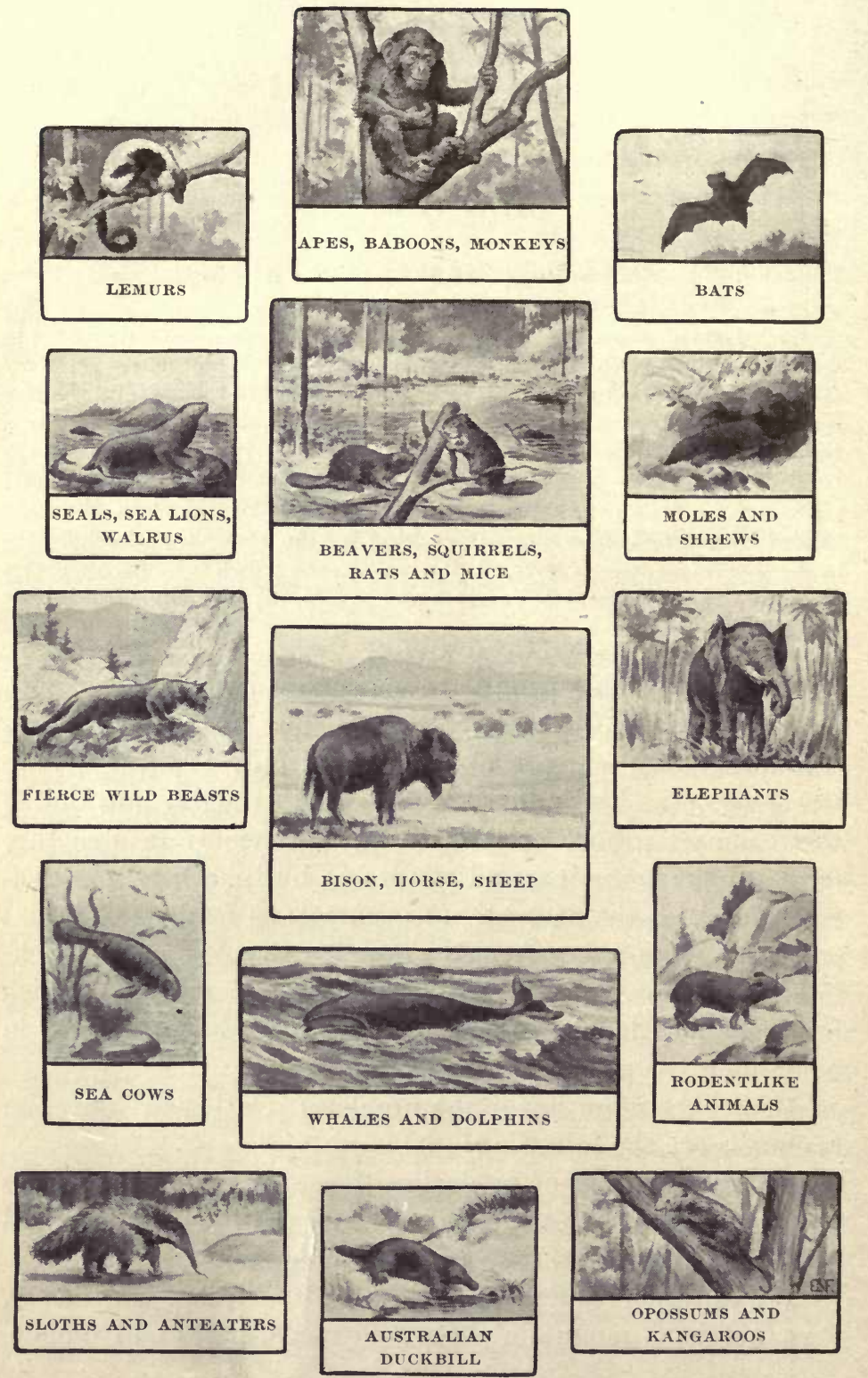

FrG. 82. Orders of mammals, with habitats 
These have been an important source of food during the early settlement of the country.

3. Trapping fur-bearing mammals - beaver, otter, marten, sable, badger, muskrat, moles, and others.

5. Efforts to prevent the total extinction of valuable species. This last feature of the American problem has been late in developing.

Our destruction of animal game resources is commonly spoken of as wanton, and in many instances this is undoubtedly true. Still the problems are not so simple as they often appear; for example, thousands of bison were shot for the mere sport of shooting, and the species is now practically extinct in the wild state. This seems a great waste, but it is impossible to use the same range for both bison and domestic cattle, and cattle are much more valuable. The bison herds swept the range cattle with them in their migrations and strewed settlers' fences over the plains. When full-grown they are not amenable to ordinary means of control and probably could not be profitably domesticated. Even tame buck deer and bull elk are dangerous animals. Rearing the bison in specially fenced preserves is quite a different matter, and has proved - at present fancy prices for robes and heads - a profitable industry. Both the United States and Canada have undertaken to thus safeguard the species from extinction, and the American Bison Society has been recently organized to make sure that the largest, and in many ways most picturesque, American mammal shall never entirely disappear from the earth.

Those in charge of zoölogical parks and private forest preserves, as well as of the extensive national forest reservations, are all making preservation of native animals a strong feature of their work. Many states are also beginning to legislate to prevent extermination of valuable animals. Several states derive considerable revenue from hunting licenses, and, in order to attract sportsmen, must maintain the supply 
of game. Wild deer are beginning to be seen in eastern Massachusetts, the state allowing but a single week for hunting them and paying all damage which they cause to crops. These damages are increasing, however, so fast that it is a serious question whether such an animal should be allowed to range at large in a state not possessing extensive tracts of waste land. State forest reservations, private hunting preserves, and special parks will probably solve the problem in such a manner that the species will be preserved and the people permitted to see and enjoy them in their native haunts, while promiscuous damage is prevented.

The preservation of the fur seal has come to be an international problem which is engaging in its solution the best experts of England, Russia, Japan, and the United States. There is thus a good chance of saving a great industry to the interested nations and a number of fine species of seals to the world.

As the animals have been trapped off, the price of furs lias steadily advanced, until the rearing of fur-bearing animals notably the silver fox - is becoming a paying industry. At present prices it ought to be possible to rear many of our furbearing animals at enormous profit. "The beaver," says Professor Shaler, "particularly the North American form, offers a most attractive opportunity for a great and far-reaching experiment in domestication. On this continent, at least, the creature exhibits a range of attractive qualities which is exceeded by none other in the whole range of the lower mammalian life." Here is a new field of biological interest, experiment, and human advance in control of animal life which ought to appeal to boys who live on farms affording opportunities for such work. Methods of caring for the animals in confinement or under control may be learned to advantage from zoölogical gardens; and anything in the way of local " deer farming" or "fur farming" should be studied and reported on by interested members of the class. 


\section{CHAPTER XVII}

\section{THE RAT PROBLEM}

The rat is the worst mammalian pest known to mall. Its depredations throughout the world result in losses amounting to hundreds of millions of dollars annually. But these losses, great as they are, are of less importance than the fact that rats carry from house to house and from seaport to seaport the germs of the dreaded plague.-David Lastz, "The Brown Rat in the United States," p. 9. Bulletin No.33, Biological Survey, United States Department of Agriculture

The smell of mice shall be in their nostrils and they shall die._-Old saying

To pay $\$ 1,000,000$ for the last pair of rats on the North American continent, after the Panama Canal is cut through, and every harbor is properly sea-walled, might be money well expended. The warfare which has been going on for thousands of years might then be terminated in at least one continent - and may not all good Americans unite in the hope that ours may be the first continent of which this is true?

The failure of all attempts to deal with this vile enemy may be traceable to lack of a vivid realization of what the "last pair" may do in the way of increase. The brown rat may breed five times in a season and have from 6 to 23 young at a litter. Allowing 8 young, the increase from a single pair in a season may amount to 880 ; and if we figure 10 in a litter, this number is increased to 1250 . In three years with only 6 young in a litter Lantz has computed the possible increase at $20,155,392$. From these data it is clear that any scientific method of dealing with this problem in any home or locality must catch the last pair, and also, under existing conditions, insure catching the first pair as soon as it comes. 
Damage annually caused by rats has been figured for several countries as follows:

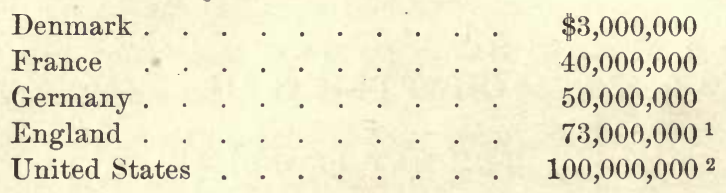

This estimate of $\$ 100,000,000$ worth of grain is based on the amount actually eaten by rats, and Lantz maintains that they destroy and pollute "fully as much as they consume." But a

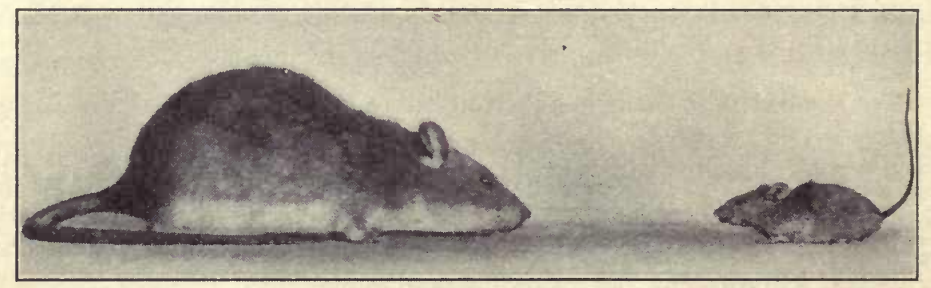

Fig. 83. Common brown rat and mouse

Photograph by the author

damage tax of $\$ 200,000,000$ levied annually on cereal crops is by no means the whole story. The poultry industry yields $\$ 600,000,000$ annually, and rats take an enormous toll of eggs and young chicks. "I have known them to take nearly all the chicks on a large poultry ranch, and in the same neighborhood and over a large territory, to destroy nearly 50 per cent of the season's hatching" (Lantz). The writer learned of an instance of a large rat killing and carrying away an entire brooder lot of over two hundred newly hatched chicks in a single night. Ducks, turkeys, pigeons, game, and song birds

1 Great Britain and Ireland, rural damage, and does not include losses in towns and cities and that inflicted upon shipping.

2 For destruction of grains only. 
suffer likewise from their attacks. Finally the rat is the primary boast of trichina which causes so much damage and oss in the raising of swine. One of the prime requisites in all such industries, if they are to be conducted with safety and success, is rat-proof construction.

The depredations of rats on fruits and vegetables, bulbs and seeds of all kinds, and all manner of merchandise, meats, and stored provisions are too well known to require more than passing mention. Buildings are damaged, water pipes gnawed

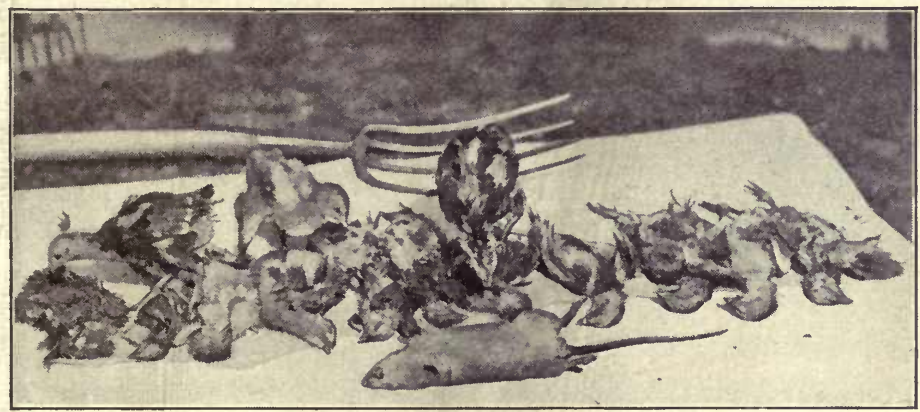

Fig. 84. A small night's work for a rat

Jleven chicks have been killed and dragged into the hole and three bitten so that they died. Photograph by the author

and buildings flooded, the insulation of electric wires destroyed, which, together with matches carried into their nests ind ignited, cause numerous fires. "It is conservative to place the entire yearly loss to the people of Washington from rats ind mice at $\$ 400,000 "$ (Lantz). For Baltimore, Lantz estiznates the yearly damage at $\$ 700,000$; and for cities in the United States of over 100,000 inhabitants these studies would indicate an annual loss of $\$ 20,000,000$.

Black death, the bubonic plague, beginning in China in 1334, swept westward over Europe, and in that single epidemic killed, it is estimated, 25,000,000 people in Europe 
alone. One half the people of Italy were killed by it. Whole villages and towns were left without a living inhabitant, and cattle ranged at will among the unharvested fields. In the recent epidemic it is estimated that the plague has killed in India, up to 1907 , no less than $5,250,000$. It has gained a foothold in this country, but San Francisco, in the most thrillingly interesting civic effort ever recorded in human history, and with the best assistance the national government could

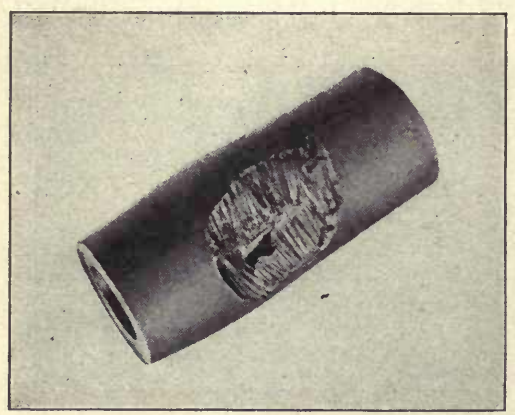

Fig. 85. Lead pipe gnawed by rats

This flooded a house and fortunately caused only $\$ 7$ damage give, stamped it out after taking a meager toll of seventy-seven lives.

"He died of the plague and all my family with him. I have no home or wife or relation to go to so I will take no leave this year." - Reply of a native soldier in India to a question about his brother.

Bubonic plague in man is entirely dependent on the disease in the rat.

The infection is conveyed from rat to rat and from rat to man solely by means of the rat flea. - Lantz, quoted from "Etiology and Epidemiology of Plague," p. 93. Calcutta, 1900

Thus a bacterium, an insect, a mammal, and man are bound together in a biological relation which has cost the world hundreds of millions of human lives and centuries of misery and horror. At last modern biology has discovered this relation, and the fact that an intelligent people can learn and realize its truth and act together for the common good has made the difference between the San Francisco epidemic and that of India - 77 lives to $5,250,000$. If the rat did no other damage, is not this sufficient reason to induce every citizen of a civilized community to exterminate rats from his premises? 
It has been said that "of all highways a rat loves a drain the best." Our whole scheme of sanitation depends apon the principle of washing all filth and disease germs into our sewers. Here then we have an animal which wallows and crawls and swims in this filth and nightly distributes it over exposed foods, merchandise, markets, and homes. In this way rats are often responsible for persistent local epidemies of any disease whose germs are washed into sewers, - typhoid, diphtheria, scarlet fever, and many others. These facts, together with common decency and intelligent cleanliness, are again suffiient reasons for extermination of such filthy pests.

On all three counts, therefore, - general destructiveness, arriers of Black death, distributers of disease and filth rats deserve absolute extermination. They were formerly considered valuable as scavengers, but modern methods of sanitation are thwarted by them, and these have rendered their further services in this line doubly undesirable.

The simple duty of every citizen is to exterminate the rats from his own premises. Modern methods - traps, poisons and poisonous gases, concrete and rat-proof construction render this entirely possible, and at a fraction of the cost which the presence of the pests yearly entails.

All methods of driving rats away, scattering them among the neighbors, accomplish no real good and are besides uncivic.

Trapping is at once the safest and, for boys, the most educative method of keeping a home free from rats. It is no more expensive and much more interesting to keep traps set all the time than to allow them to be lying idle. If we conld fire a pistol that could be heard across the continent, and from that day on have all the boys of the country keep all the idle rat and mouse traps set and baited in the most likely places about their homes all the time, the battle would be nine tenths won. Stores, mills, stables, factories, depots, and wharves could then deal with their own problems effectively 
and not have the constant stream of rat and mouse immigration from surrounding homes.

To work for days and finally outwit a wise old rat and catch him often gives one a game and a story almost as instructive in animal cunning as that of old Lobo Rex Currumpr. Being chiefly nocturnal, and living, as they do, in the total darkness of burrows and drains, rats sense danger mainly by smell, and the smell of man, his archenemy, will scare a rat away from a trap recently handled. But leave the trap, carefully covered with earth or bran or loft, sweepings, in a natural runway or at the mouth of a burrow a week, the man

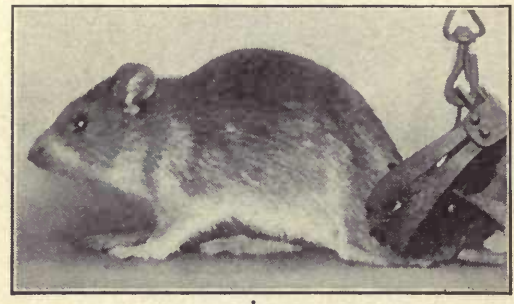

FIG. 86. A durable and effective trap scent disappears, the wisest old rat has a moment of absent-mindedness, and the last one "puts his foot in it."

A study of rat traps is interesting, but is apt to suggest that their manufacturers are chiefly concerned with making something which will not exterminate

their business by catching rats. All authorities to the contrary, notwithstanding, the writer, after ten years' active study of the problem, would discard all rat traps which depend upon being baited, except the cage or box traps to be described below. Give him an old-fashioned steel spring trap, and, by keeping it set year in and year out, he will guarantee, with the aid of other methods to be described, to catch the last and the first rat on any home premises. This does not apply to mouse traps which require baiting, and which, if kept baited and set all the while, insure catching the last and first mouse in any house or barn.

If the focal method described below cannot be adopted, a French cage trap may prove of some use about a home, if it is 
kept well baited all the time, and open. As soon as it is noted that the rats are feeding in it freely, close the trap end and make a catch.

Poisons are rather "unbiological" and require some care in handling. The Department of Agriculture has recommended barium carbonate as the cheapest and safest poison to use for rats and mice. It is tasteless, and in the small quantities used is not dangerous to domestic animals. Another advantage is that it is slow in acting and the vermin leave the premises to die. Mix oatmeal with one eighth of its bulk of the poison into a stiff dough with water, and place a teaspoonful in a

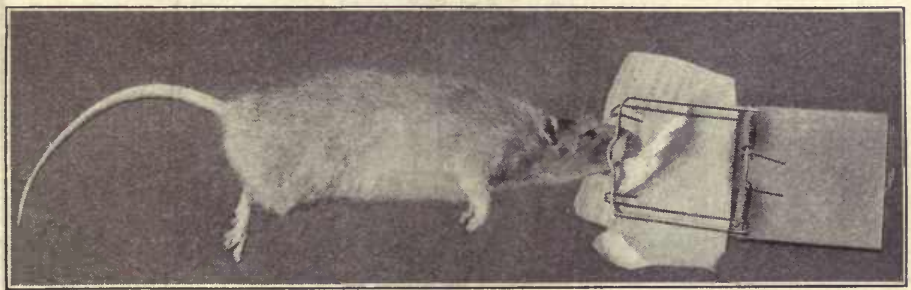

Fig. 87. A good design for a runway trap

'These traps were so poorly made that they were likely to fly to pieces when nnapped, and never caught a good-sized rat for the author until he had put in a row of tack points along the end of the bottom board

1) late about likely places. Or moisten a slice of bread and rub in a quantity of the barium powder on both sides, spreading butter over it; cut into inch cubes and place in the runways. () r mix two teaspoonfuls of the barium with an egg, thicken io a stiff paste with oatmeal, corn meal, or bread crumbs, and listribute as before. Pieces of raw Hubbard squash with the joison rubbed well into all the cut surfaces, and with cuts nade in the flesh and filled with it, make excellent baits. It is well to change the kind of bait and at first to feed freely with the same material unpoisoned, and even then, according to the writer's experience, you will not succed in fooling the 
last old wise ones. Above all, use clean scalded dishes and utensils and avoid all possible taint of man-smell on the bait.

Arsenic is one of the most common ingredients of rat poisons and has the advantage also of being tasteless and of causing intense thirst so that the auimals leave the premises in search of water. It may be used in combination with any of the baits described above. In mixing with corn or oatmeal take one twelfth by weight of the poison. In putting the above poisons in houses or barns be sure to have no water accessible inside the buildings; but leave doors and windows open, and, if a pan of water is sunk in the ground in the yard, rats and mice
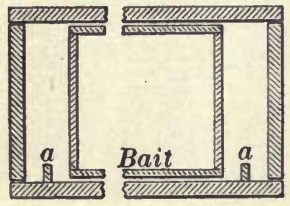

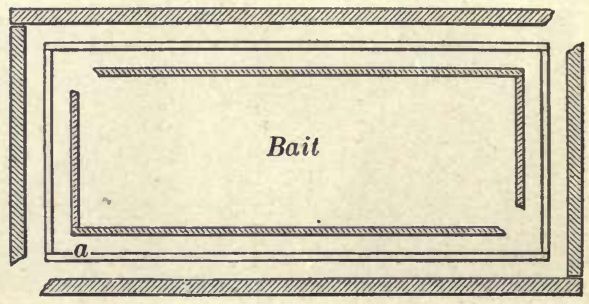

Fig. 88. The poison box

The inner box, where the bait is put, should be about 4-6 inches smaller in horizontal dimensions. The strip $a, \frac{1}{2} \times 1$ inch, is nailed all around the bottom of the larger box to prevent scattering of poisoned material. Bait with pieces too large to be carried out. Leave holes in lower corners small for rats to enlarge

in numbers may be seen dying and dead around it. 'They even lose all fear of man and crawl to the water to drink in broad daylight, and commonly remain at the water until they die.

To destroy rats on farms. Each evening when the cows are milked place a little fresh milk in a shallow pan where the rats can get it. Continue this for a week or more until the rats get bold and impatient to get at it. Then mix arsenic with the milk and await results. This plan is said to entirely clean a barn of rats. - Quoted by Lantz from E. H. Reihl, in Colman's Rural World, January 29, 1908

Strychnine acts so quickly that there is danger, when used about buildings, that the animals may die in the walls. In 
other places it may be used very effectively, and still, on account of its intensely bitter taste, it seldom catches the sly old ones. Strychnized grain used in poisoning sparrows is rqually effective for rats and mice $\left(\frac{1}{8}\right.$ oz. strychnia sulthate dissolved in $\frac{1}{2}$ pint of boiling water, thoroughly stirred into 2 quarts of cracked corn or wheat, dried and labeled and stored safely for use). The writer has been told of (learing a barnyard and large stable by first feeding the Jats with raw, unbroken eggs, then substituting eggs heavily charged with strychnine, the crystals of the poison being pushed through small holes in the shells. The ground near these eggs was described as "strewn with dead rats."

Phosphorus pastes commonly sold as rat and mouse poisons annot be recommended, as they are too likely to cause fires. The other ingredient, glucose, is likely to be leached or weathered away, leaving the phosphorus strong enough to ignite spontaneously, and lumps of the material may be carried by rats from perfectly safe places - in a cemented cellar - up into the nests anywhere in the building. Even fields of grain have been fired in this way.

Fumigation with poisonous gases is perhaps the most effective method of dealing with vermin that burrow. It is such sport to absolutely exterminate rats from fields, dumps, poultry vards, and cellars that the game is worth the expense.

Carbon bisulphide is the agent most commonly used. Moisten a tuft of cotton or a rag the size of an egg with about a tablespoonful of the bisulphide, push it down the hole, and tamp tightly with earth. If the hole is dug out, and remains inhabited, - which can be ascertained by filling the mouth with earth a few times, - repeat, using a double dose. Carbon bisulphide is poisonous to breathe and is not only highly inflammable but very explosive; therefore keep all lights away while using.

What we have called the "focal" method of dealing with civic pests consists in discovering something which attracts 
them above everything else. This is a method of attracting (focusing) all vermin to a particular place, and is diametrically opposite to all the common devices for "driving away" or scattering our pests among our neighbors. When we find something which will attract every fly, mosquito, flea, rat, English sparrow, stray eat to a certain spot and eatch and kill them there, the work of control or extermination will be easy. A dog is a natural focus for every flea about the premises. Lather him with soap daily or once a week for a few weeks and every flea will be exterminated.

The natural focus of any animal is its preferred food, and for rats and mice about the home this is the granary, feed room, pantry, or storage cellar. It is only necessary to make these absolutely rat and mouse proof, - easily accomplished now with cement, sheet metal, or wire net, - and then leave no food exposed outside these places, and, to all practical intents and purposes, we have our premises rat proof. We can then easily establish a focus which will catch or kill every rat or mouse which comes to us for food.

Take the example of a home which has a horse and cow and poultry. Each place will present its own problems, but the following scheme will apply to all sorts of conditions.

If possible, have all feed for poultry and stock kept in a rat- and mouse-proof feed room. The wall of this room is tight, preferably steel lath and cement, except a space six inches high by one foot long in one of the corners against the outer wall of the barn. This space is closed by both heavy wire net of one-quarter-inch mesh to exclude all rats and mice, and also with fine wire gauze to keep out all insects. Rats and mice seek their food by smell, and this opening will focus to that place all the animals as they come to the premises, if no other food is accessible anywhere else. Keep the bag of Spratt's dog biscuit and the poultry scrap meat and a bag of sunflower seeds near this hole, and if rats 
and mice are coming in rapidly, as they often do in the fall, keep and feed well for a while a female rat in a wire cage against this opening. Now bore a hole through the side of the barn close to this corner. It is well to make this hole one inch in diameter and allow the rats themselves to enlarge it so that it will be an actual "rat hole." Fasten securely a cage trap so that all rats and mice which enter the barn must do so through this trap. If all doors and windows are properly screened and kept closed and all holes are stopped up, this will insure catching the first rat or mouse that comes and thus prevent even the beginning of breeding foci about the premises. 1

Possibly enough expense is incurred annually in many towns and cities and enough effort expended to effectually exterminate rats and mice, but the work is not organized. A may exterminate the pests from his place in October, B from his in November, $\mathrm{C}$ from his in April, and all three of their premises be infested again for the season's breeding, the work of one driving the old cunning rats over to neighbors. We have effective methods enough to accomplish the complete extermination with a small part of the effort and expense wasted by our communities annually. What we lack is effective organization. Rats and mice tend to leave buildings n the spring and migrate back to them in the fall. Since our experience with rats and the plague in San Francisco, and in view of the fact that other cities or even towns may be called upon at any time to fight the plague, every home ought to do ts part, and every community ought to be able to exterminate its own rats. The disease to-day is widely distributed,

${ }^{1}$ An even more serviceable trap which will set itself and thus catch a ontinuous stream of animals may be made by any ingenious boy, possibly $\mathrm{n}$ connection with the manual-training work. If vermin are likely to gain iceess to the building by other openings, it is well to have an entrance to the trap inside the building as well. 
and no one can tell where some migrating rat will carry it next. Thus while other considerations of lamage and general public health make this work expedient, danger from plague renders it imperative. People who do not know have no right to opinions in such vital matters, and the time must come when the ignorant and negligent shall not continue to vitiate the best civic efforts of our towns and cities. ${ }^{1}$

Cannot the biology class in the high school or local academy, assisted by the boys of the upper grades, supply the intelligence and generalship, and bring about the coöperation

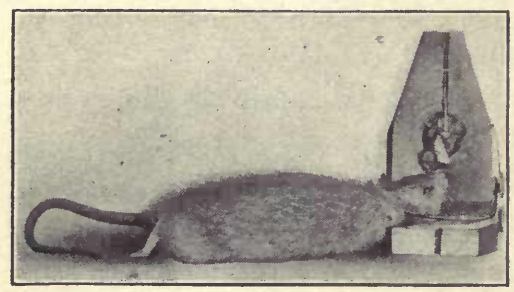

Fig. 89. The only rat this trap caught A poor design - wholly dependent on bait and organization of the civic effort to render the work of extermination effective even to the last pair in the town, or the first pair that migrates to it? Might not this work alone go far toward repaying to the community the cost of public education?

Mice should be dealt with as thoroughly as rats in all these campaigns, and they possess so little cunning that they can easily be exterminated from any premises. Aside from nuisance and damage caused by mice the theory has been advanced that germs of pneumonia become more virulent on passing through the mouse, and thus cause severe and often fatal infections.

1 The thing to do, brothers, is to get together; coöperate with the health officers; lend them your moral support as freely as you have your material aid; and, above all, do your part in suppressing the scoffer, the man who laughs in his ignorance, and who in that ignorance wants to trifle with a situation like this.

Remember, in these matters each one of us is in a measure his brother's keeper, and let us show this man that if he is not willing to do his part, we are not only willing to do ours, but we are going to see that he does his, whether he wants to or not. - San Francisco Report, 1909, p. 254 


\section{Practical Problems}

The practical laboratory work of this section shall consist in actually exterminating rats and mice from your home premises.

Make a complete survey and locate every rat hole in the ground and in the walls of buildings, and draw a careful diagram with all holes located. Stop all holes with earth and mark on your diagram in red ink all that are reopened. Locate on your diagram also rooms or buildings of rat-proof construction.

Make as complete a collection of rat and mouse traps as the neighborhood affords. It will be well to have each member of the class bring in all the traps he has used at the end of this campaign, and compare and discuss the merits and demerits of different traps.

Devise and construct a better rat trap than any used.

Write a brief statement of your own experience in clearing your home of these pests. 


\section{CHAPTER XVIII}

FUNGI : BACTERIA, YEASTS, MOLDS, MILDEWS, RUSTS, SMUTS, AND MUSHROOMS

Although the great mass of material phenomena elsewhere had been brought into apparent orderliness and system, here was a region in which the unscientific imagination rioted in mystery and extravagance. The penetration of this realm of obscurity by the discoveries of bacteriology gave the human race for the first time in its history a rational theory of disease, dispelled the myths of spontaneous generation, and set the process of decay and kindred phenomena in their true relation to the great cycle of living and nonliving matter.

The new conception of the microscopic underworld which bacteriology brought into biologic science must be reckoned as a conspicuous landmark, and, in so far as it has changed the attitude of man toward the universe, should be regarded as one of the most important triumphs of natural science.-Jordax, "General Bacteriology," p. 23

The rôle of fungi in the life of the world. Saccardo's "Sylloge Fungorum" has described to date 66,615 species of fungi. This means that somewhat more than one fourth of all the plants known to science belong in this group, and over 1000 new fungi are being described each year. Food supply is the vital problem of plants, animals, and man, and in order to appreciate the position of the fungi in nature we must study the continual flow of food material and try to understand how the world is fed.

Fungi lack chlorophyll; hence they are dependent for food upon other plants and upon animals. Some tend to be omnivorous, like the common molds of the household, and take almost any food that comes their way, while others are close feeders, living on some one animal or plant or even upon certain organs, tissues, or substances produced by their necessary 
host organisms. The great work of fungi in nature is thus to break down organic matter and return the elements to Mother Earth, that they may be caught up in the circle of food supply and live again. Without this beneficent work of the fungi all the animals and plants that have died since the beginnings of life in the world, if they had not been eaten or burned, would still cumber the earth; that is, the food of the world would be locked up in dead forms. Burning returns the nitrogen to the air, - a most wasteful process, - while the decay of the dead bodies and waste matters of animals and plants caused by fungi holds this most precious of all foodstuffs in chemical combination as nitrates, ready again to be built up into the grains, seeds, fruits, and other food products of green plants (see Chapter IX). Thus, in burning wheat straw the farmer may rob his land of twenty-five pounds of

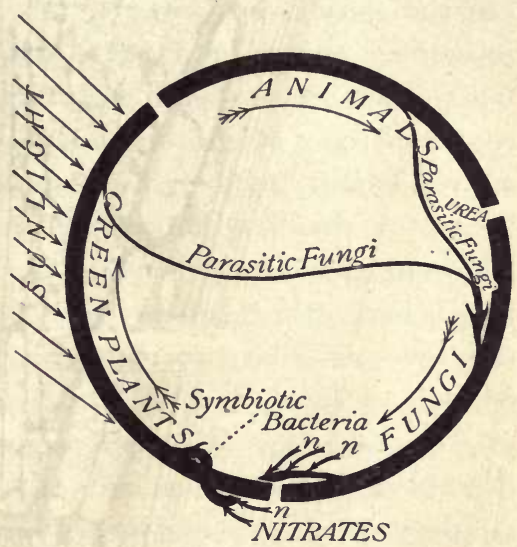

Fra. 90. Circulation of protein food materials in nature

Nitrogenous food (protein) is the one essential food of both animals and plants. The green plants build up this entire food supply from the chemical elements by the energy of sunlight working through leaf green, or chlorophyll; $n n$ represents free nitrogen from the air, drawn into combination by symbiotic bacteria in the root tubercles of clovers, beans, etc. The nonnitrogenous foods - starches, sugars, gums, fats, and oils - are built up along with the proteins and are finally oxidized to carbon dioxide and water, whether in the animal or plant body or by rotting or burning nitrogen in combination, worth $\$ 3.75$ per acre per year, and an acre of corn stover or cotton stalks may contain respectively $\$ 7.50$ and $\$ 15.30$ worth of nitrogen. Where it is customary to burn these materials is it any wonder that the wheat, cotton, and corn fields are worn out? 
Functional subdivisions, saprophytic, parasitic, and symbiotic fungi. Saprophytic fungi are those that live upon the dead bodies or waste matters of animals or plants. Parasitic fungi attack living animals and plants and injure or kill them. 'They are the causative agents in the larger part of contagious or infectious animal and plant diseases. Symbiotic fungi live with other organisms, to the advantage of both. Bacteria in root tubercles of the legumes are familiar examples. While convenient, these lines of classification are not hard-and-fast, because it may be difficult, or even impossible, to tell whether an organism, or any part of it, is really dead or alive. The rough bark and the heartwood of a living tree are as dead as they ever will be; so may be the hair or cuticle of a living animal, or the rind or pulp of a ripe fruit, or the food material of a seed or egg. Who can say whether the sap of a plant or the blood or milk of an animal is dead or alive? So there are all degrees of liveness or deadness, and a usually beneficent saprophyte may attack a half-dead plant or animal, which we would call alive, but the fungus may know better. Accordingly we have hemiparasitic and hemisaprophytic, or, so-called, facultative parasitic or saprophytic, fungi that attack the living or the dead according to degrees of vitality or variations of external conditions.

Botanical position of fungi. All fungi are devoid of chlorophyll, but not all plants that lack "leaf green" are fungi. Dodder and the Indian pipe are flowering plants that have adopted the parasitic habit, and with this degenerate life they have lost the mechanism and the power of making their own fool. So we find from a study of their ways of growth and methods of reproduction that fungi have developed from the alga. Flowering plants reproduce by seeds, which are embryo plants provided with food for the start in life. The ferns, mosses, alga, and fungi reproduce by spores, which, compared with seeds, are almost inconceivably small. Many seeds are 
provided with hairs or wings to carry them in winds, and many float in the water in order to be widely scattered; but the spores of the fungi are so light and small that they float invisible in either air or water, and so they far outstrip in distribution the best devices of the higher plants. As a result, while the flora of seed plants is very different in different countries, the molds and mushrooms, yeasts and bacteria, are more likely to be the same species the world over.

Compare seeds and spores as to size and numbers produced. For spores use the dust from a patch of mold and from a puffball, and try to see, feel, smell, and taste them. The finger tips may be black or green with millions of mold spores, but how much can we feel them? We can see the cloud of "smoke" from a puffball, but as the spores scatter, can we see them in the air (unless in a ray of sunlight in a darkened room), and have we ever tasted them in food? Some people enjoy the tastes of certain molds and bacteria in cheese, _ Camembert, Roquefort, Stilton, Limburger, - and they may be as wholesome as any other vegetable. How do the different kinds smell? How many spores may we be breathing in with every breath in a musty room? How does the number of seeds of a grain plant or weed compare with the spores produced by a puffball?

Size and power of growth. A baby grows to double its weight at birth in five months. A yeast plant or bacterium may double in size in twenty or thirty minutes. The fungus thus has from seven to ten thousand times the power of growth of the baby. Why this difference?

Food, again, is the basis of growth. 'To dissolve, digest, absorb, circulate to every part of a large body, assimilate (that is, build over the foreign matter into the particular protoplasm of the species) are slow and laborious processes. Solution of food substances, especially the proteins (white of egg, gluten, casein, lean meat), is difficult, and absorption through 
the cell membranes is slow. The amount absorbed is proportional to the absorbing surface exposed to the solution. With these points in mind we may understand why the active mechanisms in living things are so minute, for only in this way are they able to present the largest possible sur-. face for both the escape of waste matters and the absorption

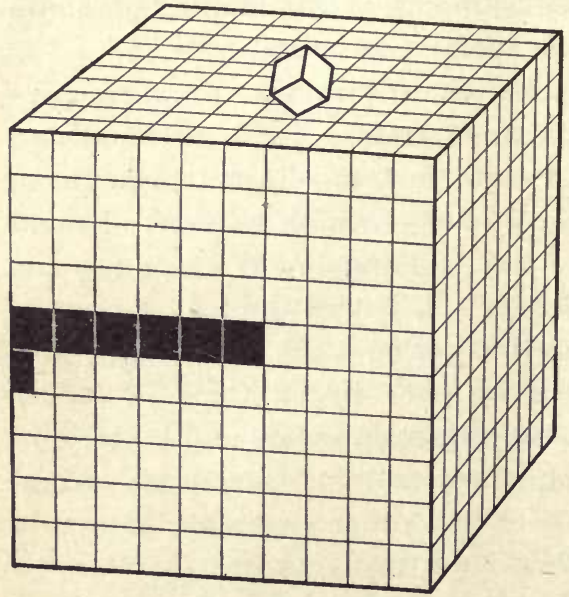

Frg. 91. Diagram to show relation of surface to bulk in large and small organisms

The law is: Bulk increases as the cube, while 'surface for absorption increases only as the square. Since bulk so rapidly outstrips surface, this relation tends to limit the size of organisms, and suggests one of the fundamental reasons why minute organisms possess such phenomenal powers of growth and reproduction

of food. The diagram on this page presents these relations in simple form. A one-inch cube is seen to have six square inches of absorbing surface, while in a ten-inch cube each cubic inch has only six tenths of one square inch of surface. The rate of absorption being the same, the smaller cube could absorb ten times as fast as a similar bulk of the larger cube. So we see why the smallest organisms may be the most efficient in ab sorbing food and have the greatest power of growth. It is estimated that a bacterium $\frac{1}{1000}$ of a millimeter in diameter, which can double in size in twenty minutes, given food and suitable conditions, might grow to a mass the size of the earth in about five days. A yeast plant, which is much larger but which can double in thirty minutes, might grow to a similar mass in about two weeks. How 
long would it take a pair of elephants to multiply to a mass of the same weight?

Size. As we have seen, mere size counts for little. Bacteria, the smallest plants known, are infinitely more powerful than sequoias or whales. Fungi range in size from the giant puffball (the fruiting body of which may grow to three or even our feet in diameter) to microscopic bacteria, and some of these are quite possibly too minute to be visible under our best microscopes. In the fruiting portion of a large mushroom we see but a small part of the whole fungus. This consists, as we shall see later, of a feltwork of microscopic threads (the
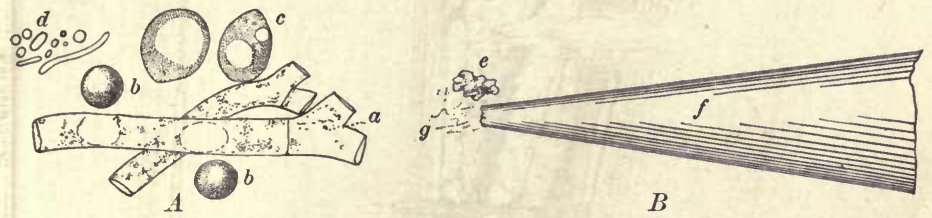

Frg. 92. Size of microscopic fungi

Comparative size of: $A, a$, molds; $b$ and $c$, yeasts ; $d$, bacteria equally magnified ; $B, e$, minute particle of dust; $f$, point of finest cambric needle; $g$, bacteria under less magnification. After Conn

teeding, or vegetative, portion), which permeate the soil, leaf mold, wood of a tree, or other substance in which the plant is yrowing, possibly for many feet in every direction.

Yeasts (Saccharomycetes, the sugar fungi- saccharon, "sufgar"; myces, "fungus"). Yeasts are the "sweet tooth" fungi, and their work in nature is to break down sugars by the process known as fermentation. The end products are alcohol, carbon lioxide, and various oils and flavors characteristic of different species of yeast. The process of fermentation is represented by the following simple chemical equation:

$$
\underset{\text { Sugar }}{\mathrm{C}_{6} \mathrm{H}_{12} \mathrm{O}_{6}}=\underset{\text { Alcohol }}{2 \mathrm{C}_{2} \mathrm{H}_{6} \mathrm{O}}+\underset{\text { Carbon Dioxide }}{2} \mathrm{CO}_{2}
$$

Size and color. Common yeast plants are spherical or ellipsoidal bodies about $\frac{1}{30 \overline{0}}$ of an inch in diameter; a cake of 
compressed yeast contains approximately 10,000,000,000 of them. In order, once for all, to gain a notion of the minuteness of microörganisms, perform the following simple experiment:

Sharpen the point of a teasing-needle to a fine knife blade; take a bit of moist compressed yeast, the size of a large pinhead, on a piece of clean, polished glass (a microscope slide) and cut the lump in halves. Throw away one half and repeat the operation and continue as long as you can see to divide the particle. At the last division carefully plant one half in a vial half full of filtered, boiled molasses and water (a tablespoonful of molasses in half a pint of potato water makes a good culture fluid), to watch it grow from day to day. Then, with the point of a clean needle, on a perfectly clean part of the glass, cover the other half
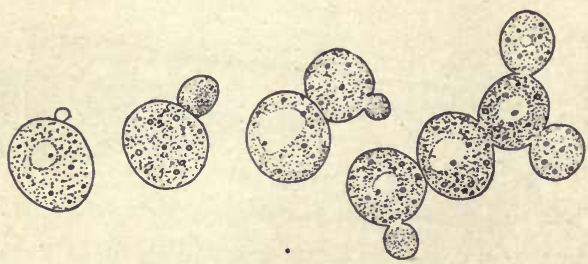

Fic. 93. Yeast plants, highly magnified, showing successive stages of growth by budding

\section{After Conn}

with a minute droplet of water. Cover with a perfectly clean cover glass and try to count the torulæ (yeast plants) in the speck that you can just see with the naked eye.

In color most of the common yeasts, when seen in mass, are whitish or slightly yellowish gray, the color of a fressh yeast cake, but a few species are pink, red, or black.

Distribution. Yeasts are everywhere; so the question is not, Where shall we go to find them, but, Where go to escape them? We eat them by billions, baked, in our daily bread; we drink them by millions, alive, in our cider, beer, or wine; we breathe them in, alive, with every breath, and drink them, alive or dead, according as the water is raw or boiled; with every drink of water we take; they are all over us all the time, in our hair, on our skins, in all our clothes, and we cannot possibly beat them out, brush them off, or even wash them away - the harmless, useful, patient, persistent, omnipresent little sugar-hunting yeast plants. We might suck 
most of them out of our carpets and homes with a vacuum cleaner, but this would not be worth our while if it were not for the fact that they are associated in the dust with less riputable bacteria.

There is just one point that we should learn in a way we c:in never forget. 'The skins of fruits, of course, are covered

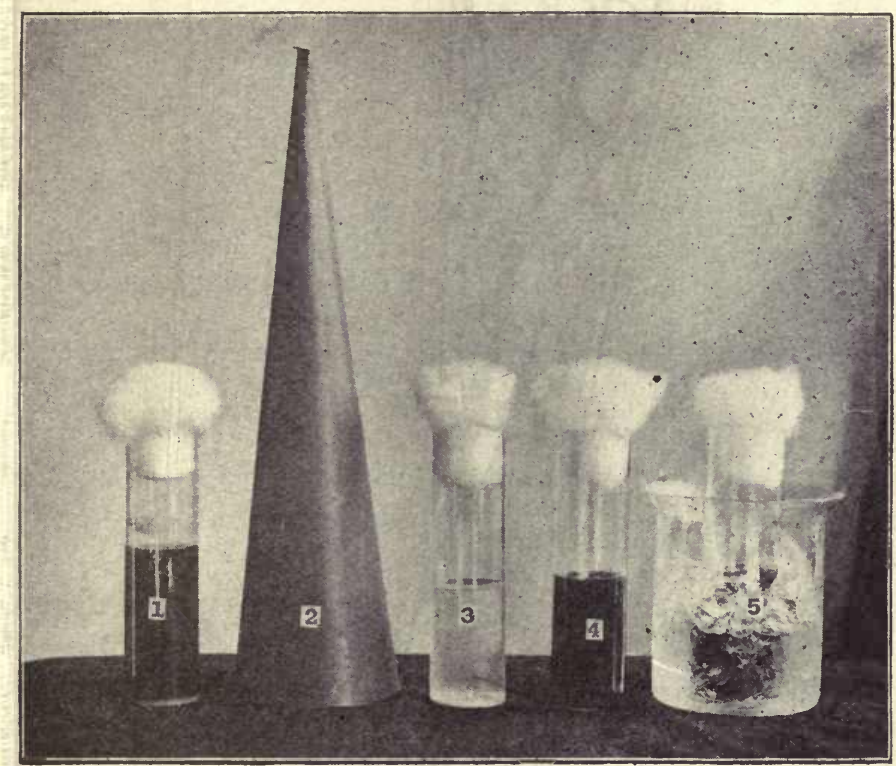

FIG. 94. Experiments in growing yeast

1 , yeast planted in molasses 1 part, water 5 parts, kept at room temperature; 2, same, kept in dark; 3, planted in filtered, boiled, or distilled water; 4 , same as 1 , not planted ; 5 , same as 1 , kept in cracked ice

with yeasts and with spores of molds. This fact is related to one of the large industries of the world - the picking, handling, and marketing of fruits.

Experiment 1 . Have the class collect a number of the fruits availa)le at the season. Scrape the surface lightly with a sharp, clean scalpel puint or knife-needle (or wash with a fine brush into a drop of water on 
a slide). Mount scrapings in a small droplet of water and examine under a microscope. Be particular to scrape especially in the little crack around the stem. Can you see from results why stems should not be pulled out in picking fruit?

Experiment 2. Pull out the stems and make slight punctures and scratches through the skins of a number of apples or pears, set them aside with an equal number of perfectly sound fruits, and examine from time to time for signs of decay.

Experiment 3. Plant scrapings from the skins of the various fruits in vials of dilute fruit juice (filtered cider, the juice from canned fruit, diluted with half water if too sweet), plug with cotton, and examine later for growth of yeasts and molds.

If microscopes are not at hand, Experiments 2 and 3 can be done perfectly well without them. What do these experiments mean with reference to honest hand picking and packing of fruits? If one decayed fruit wets or touches another, what is likely to happen? Contagion?

Uses. In making bread we use the carbonic acid which the yeast plants give off to form bubbles in the dough. These bubbles are hardened in baking, the alcohol is driven off, and the bread remains light. In making alcohol we use the sugar of fruits or the starch of potatoes, barley, corn, rye, which has been changed to sugars by digestive ferments; then either the wild yeasts that were on the fruits or the pure-culture yeasts that we add to the fruit juice mash or wort ferment the sugars, and the alcohol may be distilled off by heat.

If the yeast fermentation has been too slow, or if the material is allowed to stand after alcoholic fermentation is complete, other microörganisms, with which yeast is always associated, begin to turn the alcohol into acetic acid, and we have sour bread, sour beer, and vinegar. This process may be roughly represented by the equation

$$
\underset{\text { Alcohol Oxygen Acetic acid }}{\mathrm{C}_{2} \mathrm{H}_{6} \mathrm{O}}+\underset{\text { Water }}{\mathrm{O}_{2}}=\underset{\mathrm{C}_{2}}{\mathrm{H}_{4}} \mathrm{O}_{2} \mathrm{O}
$$

Then if vinegar is exposed to the air, another organism may change the acetic acid further into carbonic acid and water, and the decomposition of the starch or sugar is complete. 
Experiment. To a quart of warm potato water, not filtered, add a alf pint of molasses and a yeast cake, previously mixed to a smooth ream in a gill of fresh milk. Keep in a dark place at between $75^{\circ}$ and $90^{\circ} \mathrm{F}$., and observe from time to time. When bubbles are rising rapidly, "onduct the gas into a vial of imewater, as shown in Fig. 95, roting that the same change akes place that occurs when we "xpire into limewater:

$$
\begin{gathered}
\mathrm{CaO}+\mathrm{CO}_{2}=\mathrm{CaCO}_{3} \\
\text { Lime } \\
\begin{array}{c}
\text { Carbon } \\
\text { dioxide limestorie }
\end{array}
\end{gathered}
$$

Test the liquid by odor and especially by taste. As soon as fermentation is complete (that is, when the sweet taste has distppeared), pour out half a pint into a flat dish and set in a warm lace, protected from dust, to study the formation of vinegar. With the remainder attach the lask to a small still, heat carecully, and test the first gill for alcohol by taste, smell, and by burning.

In doing this experiment difcerent members of the class, or

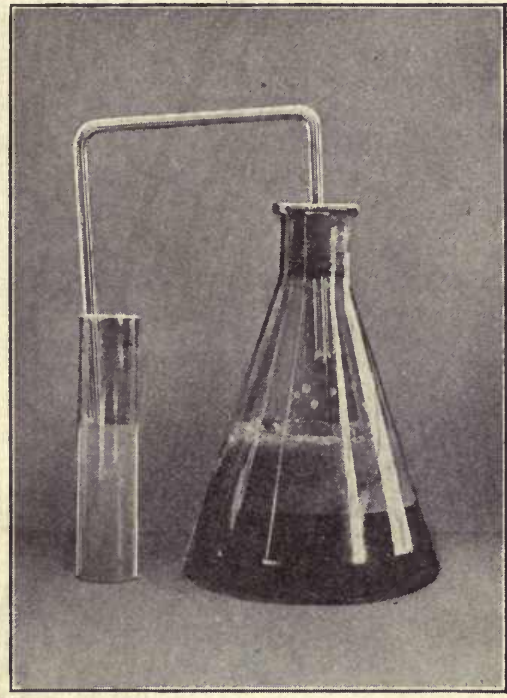

Fig. 95. Testing the gas from yeast fermentation with limewater lifferent class groups, may use different materials - fruit juices, potato, "orn or rye mashes, malt decoction - and thus add to the interest.

Pure cultures. Before reading the next experiment try hard to think how you would make a pure culture of a plant $\frac{1}{3000}$ of an inch or $\frac{1}{50} \frac{1}{0} 00$ of an inch in diameter. Let each nember of the class write out his method and then compare his result with those of the rest of the class. This is a test and measure of power to think, imagine, and reason. When Louis Pasteur first thought this out, he marked the greatest poch in control of disease that history records. Pasteur did this first with the yeast plant in 1856. Up to this time 
fermentation was supposed to be a purely chemical process, and accordingly brewers and vintners had employed chemists to try to relieve them from the great losses caused by diseases of wine and beer. We now know that these were caused by wild yeasts and other microörganisms, and the problem is a logically simple one of weeding them out of the cultures. The first requisite is to isolate and study the different organisms involved, in pure cultures, and this is equally true of any germ disease of plants, animals, or men.

Experiment 1. First necessary step: Get the yeast plants single; that is, make a uniform suspension in water. To do this make a dilute,

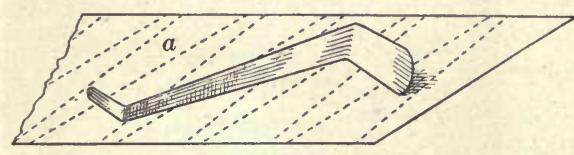

Fig. 96. A lifter, cut from tin, or, better, from thin sheet aluminium

It is sterilized by holding the end in a flame for an instant, giving it only time to cool before using. $a$, sheet of metal indicating how the lifters are cut. (One half natural size) well-rubbed-up suspension in a slender test tube or straight vial, and force down through this a tight, hard plug of sterilized absorbent cotton. The liquid above the cotton will be pretty sure to contain nothing but single yeast plants.

Experiment 2. Second step: Get the single plants far enough apart so that we can work with them; that is, dilute the suspension. Add a drop to, say, one quart of boiled, filtered water, and shake thoroughly. (If too many plants are still present, we may have to repeat the dilution.)

Experiment 3. Third step: Plant a drop or a few drops (according to the dilution) in some medium solid enough to keep them from flowing together and getting mixed up, and clear enough so that we can see them after each one has grown sufficiently to form a visible colony. Starch jelly made with sweetened water (or potato water filtered) makes a good medium for yeasts and molds. Stir the drop of suspension thoroughly into a tablespoonful of the jelly as soon as it is cool enough not to injure the yeast (when it feels neither cool nor warm to the hand), and pour in a thin layer into a Petri dish (or on a clean piece of glass which can be covered securely from the dust). Keep in a warm place away from the light, and in a day or two whitish specks begin to appear, if the work has been carefully done, scattered 
( venly through the mass. If a speck is spherical and clearly distinct from all others, we may pick it out with a sterilized lifter and be reasonably sure that we have yeast plants all descended from a single larent plant - that is, a pure culture.

Diseases caused by yeasts. Quite naturally one species of yeast causes blight of sorghum, and another, a disease of the crocus, and one or two others attack animals and man.

Molds and mildews. These are the most troublesome fungi (if the household. They take everything in the way of food (r clothing, carpets, linen, and even books, that they can get their spores on, if conditions, especially of moisture, favor their growth; and since they always can get their spores on everything that the air touches, it behooves the home-keeper to see to it that nothing of value is left where dampness, air stagnation, and darkness may permit growth of these little robber plants. Conn's statement is: "If the air of a room liecomes damp or ' close,' as we say, it is almost certain that nolds will begin to grow upon any organic substance." While is common household parlance molds and mildews are supfosed to be distinct, the microscope reveals them as identical, the only difference being that they grow less luxuriantly on leather, cloth, and paper than they do on richer and moister foods.

Botanical position and structure. The word "mold" is nerely a popular designation for a variety of different kinds (f plants. The term has no botanical standing, but is so $f$ rmly fixed in common usage that we cannot improve upon $i$ ic to designate the somewhat similar felt-like growth that is likely to cover everything damp. This growth is techrically known as the mycelium of a fungus, and when we examine it we find the key to understanding the growth and structure of all the higher fungi, molds, and mushrooms that is, those above the bacteria and yeasts, and some of these form similar mycelia. The single element is a microscopic 
thread, the hypha, which in some fungi is tubular and in others is septate, that is, composed of cells end-to-end. Hyphæ branch continually and seek the cracks and minutest pores, and so are able to burrow and digest their way into all sorts of apparently solid substances. The hyphæ are functionally of two kinds : first, the threads that burrow and feed in or on
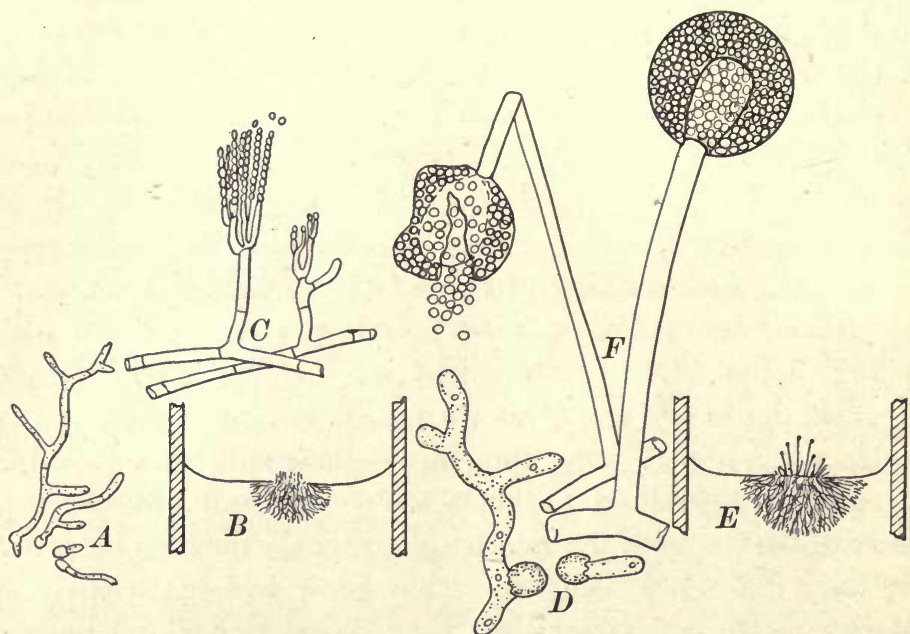

Frg. 97. Two common molds in different stages of growth

$A, B, C$, a common blue mold, Penicillium; $A$, spores germinating; $B$, as seen growing in vial of liquid; $C$, aërial (or fruiting) hyphæ more highly magnified;

$D, E, F$, similar stages in the growth of a black mold, Rhizopus

the food material - the vegetative hyphæ; and, second, the fruiting hyphæ, which grow out of the mass into the air (or water in case of the water molds) to form the various kinds of spore-bearing organs. These ideas are fundamental to control of fungi, and we should be sure that they are entirely clear in working out the following experiments. As we aim to destroy weeds before they go to seed, so we must adopt methods to prevent our fungus enemies from ripening their spores. 
Observations and experiments. 1. For at least one hour in preparation of this lesson have each member of the class hunt over his home jremises and collect specimens of everything he can find that appears to be moldy. Compare these, to try to see how many different molds we have. The mycelium of nearly all molds and mushrooms is white, lrut the spores and sporing organs may be any color - white, red, green, gray, brown, or black. Note particularly the kinds of places in which molds are found growing best, with especial reference to dampness, lack of light and direct sunshine, and lack of ventilation.

2. Select typical specimens and arrange in jelly tumblers (or even in straight-necked vials) for further study. Keep covered when not in use.

3. Make a series of mold gardens in small vials, trying to have as pure cultures as possible. Use all. sorts of materials - foods and even linen and cotton cloth. Plant spores from No. 2 by touching a patch of mold with the point of a needle and then touching it to a single joint in the material in the vial. Watch it grow from day to day, noting particularly how long it takes to begin to produce spores. To insure dampness the vials should be covered or corked tightly (heavy infoil pressed over the mouth of the vial makes a convenient cover), and should contain a little water. The material may be held out of the water on a bit of glass.

Stand some of the vials in bright sunlight, and keep the rest in the lark, noting differences in growth. Keep some on ice (cold storage) and compare. Keep some protected from dust in a dry air, not covered tightly, and note influence of dryness on growth of molds.

In order to see the growth clearly, make a series of mold gardens ${ }^{1}$ in a perfectly transparent liquid medium. Fruit juice, diluted with one half water, filtered, serves the purpose well. Plant spores from the lifferent molds on the surface, study from day to day, make careful drawings, and note especially the time required for spores to begin to form.

4. Sketch a plan by which you would keep a home as free as possible from molds.

${ }^{1}$ Hodge, "Nature Study and Life," p. $457 \mathrm{ff}$., describes and figures mold gardens. 


\section{CHAP'TER XIX}

\section{FUNGI CONTINUED : MUSHROOMS, POISONOUS AND EDIBLE}

To know several different kinds of edible mushrooms, which occur in greater or less quantity through the different seasons, would enable those interested in these plants to provide a palatable food at the expense only of the time required to collect them. To know several of the poisonous ones also is important, in orrler certainly to avoid them.-ATkissox, "Mushrooms," p.iv

General. Persistent search extending through a series of years in any favorable locality would reveal the presence of about 1000 species of these our largest and most conspicuous fungi. In one season one might expect to find from 200 to 400 species. Of the entire number, according to McIlvane, nine species (all amanitas) are deadly poisonous, about a dozen contain minor poisons, and are rated as suspicious or dangerous, 735 are edible, while the rest have either not been tested or, on account of woodiness, disagreeable taste, small size, or extreme rareness, are of interest only to the specialist.

Form and structure. Mushrooms, like other fungi, are active in causing decay, chiefly in waste matters of plants and animals, but a number attack the roots and wood of trees, and, naturally timber and wooden structures.

From our knowledge of the molds it is an easy step to the life history of a mushroom. Both organisms begin as spores; in both, these sprout and grow to form a mass of food-absorbing mycelium. In mushrooms this may extend many feet in the soil, in leaf mold, or in the wood of a tree. In both, some of the mycelial threads finally grow out of the food substance and complete the life cycle by producing the spores with which 
ve started. The conspicuous part of a mushroom is thus a small fraction of the entire plant - the spore-bearing organ, (1) sporophore.

Combine the collecting of mushrooms with the field work with birds, insects, and trees in the early fall. In fact, this is the most favorable part of the school year for all forms "xcept the morels, whose season is May or June. Preserve

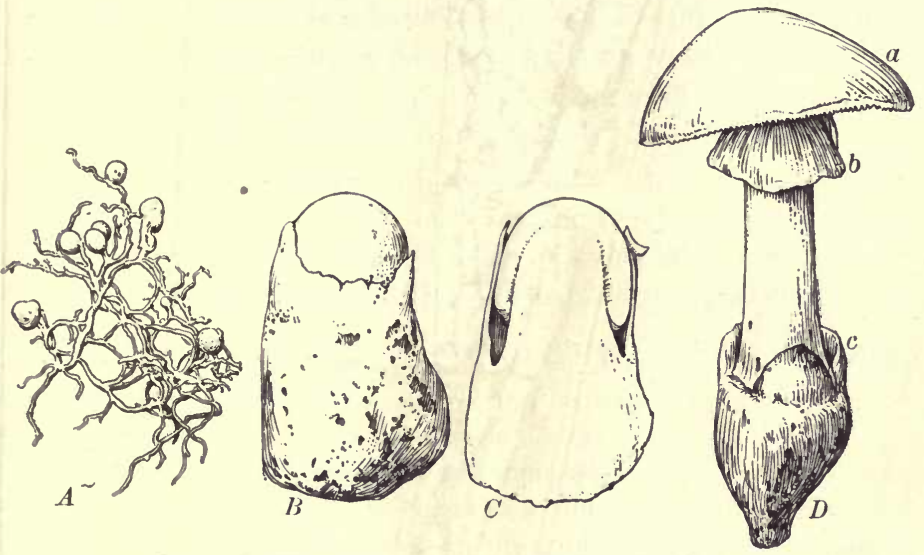

F16.98. Growth stages of a mushroom

A, mycelium with forming buttons, drawn from Agaricus campestris. The other figures are from Amanita phalloides (the deadly amanita) and show: $B$, a button bursting the volva (or sac) ; $C$, the same in longitudinal section; and $I$, a mushroom showing $a$, the pileus (or cap), $b$, the velum (or veil), which has torn from the margin of the cap and remains as a ring around the stem, and $c$, the remains of the volva, which forms a cup

the mushrooms collected for winter study by drying; even many of the softer ones may be preserved in this way if they are dried in a current of hot air.

Amanitas. Before collecting mushrooms, fix clearly in mind the characters of the deadly genus Amanita.

Other varieties of fungi may interfere with digestion, but to the Amanitæ all deaths from toadstool poisoning are traceable. Its subtile alkaloid is absorbed by the system, and in most cases lies unsuspected 
for from six to twelve hours, then its iron grip holds to the death. For centuries it has defied all remedies. - McIlvane, p. 5

The amanitas are the most conspicuous, beautiful, and, too often, the most abundant mushrooms to be found in the woods from frost to frost. Of the twenty-eight species nine are deadly, ten are doubtful, and nine are considered edible.

The three characters which infallibly mark an amanita are white spores, a ring, and a volva, or cup. In order to understand these terms and others that we need to know, study an amanita as a type. Fig. 98 shows all the constituent parts and all the characteristic stages of growth of Amanita phalloides.

The parts in order of growth and formation are

Mrcelium : extremely fine white threads, uniting here and there to form larger strands - the nutritive, or vegetative, part of the fungus.

Buttons:- white knots or balls in the mycelium, the beginnings of spore-forming bodies (mushrooms). One button cut lengthwise shows the parts, which will be more clearly differentiated later on. Note especially that the mushroom proper at this stage is completely enveloped in a sac. Not all mushrooms have this sac. SPOROPHORE, consisting of

1. Stem: the part which springs directly out of the mycelium and supports the pileus.

2. Pileus, or Cap: the umbrella-shaped part which carries, on its under surface, radiating, leaf-like structures - the gills.

3. Gills: the organs from the surfaces of which the spores are set free. The shape that the spore-forming surface assumes is a prime character in classification. It is produced into gills in the Agaricacere, into spines in the Hydnacece, into tubes in the Boleti, and into fine pores in the Polypori.

Spones: Place a cap from which the stem has been removed, gills down, on a piece of white or black paper, and cover tightly with a tumbler or bell jar. Leave for an hour or so, and examine the spore print and, if a microscope is available, the spores.

Volva, or SAC: the membranous sac which may envelop the entire sporophore in the button stage; also applied to the portion which, after rupture, remains as the cup at the base of the stem. 
WARTs : irregular flecks, or-patches, on the surface of the cap, formed if the volva ruptures about the equator and the upper portion is carried up and remains adherent to the growing pileus (not the case with Amanita phalloides).

VeLUM, or VEIL : a membrane which, in some forms, attaches the margin of the pileus to the stem. When, in growing, the cap tears away from the velum around its margin, the velum remains attached to the stem as the annulus, or ring.

The presence of the three characters, white spores, ring, and cup (which may be reduced to a scaly, bulbous base to the stem), mark the specimen as an amanita. In collecting, why should we be sure to have the base of the stem complete? Why should we never mix buttons with edible mushrooms?

Classification. Sort the mushrooms collected, using the outline given below. If you place the dried specimens in a jar packed with wet paper the day before beginning the work, many of them will absorb moisture and become approximately like fresh specimens:

1. All forms with gills underneath the pileus may or may not have stems - Agaricacece.

2. Hedgehog mushrooms : forms whose spore-forming surface is produced into spines which hang downward. They may be umbrella-shaped or irregularly tuberculate or branched - Hydnacece.

3. Mushrooms with a honeycomb structure of tubes in place of gills; soft and with the tubes readily separable from the cap - Boleti.

4. Fungi with fine pores underneath the pileus. Many species become corky or woody, the bracket fungi of the woods - Polypori.

5. Coral mushrooms: may be simple, erect clubs or large, branching masses, the branches being erect. The spores are produced over most of the exposed surface - Clavariacece.

6. The morels and cup fungi. Some of these have stem and eap, but produce the spores in pits or irregular depressions on the outer surface of the conical or cylindrical cap. Other forms are cup-shaped or saucershaped - Discomycetes.

7. Puffballs and earthstars : mushrooms in which the spores are produced within a closed cavity, which may open by an apical pore or by the irregular breaking of the wall (peridium) - Lycoperdacea. 
8. Stinkhorns, mushrooms which, once smelled, can never be mistaken for anything else or forgotten. The immature plants, known appropriately as witches'-eggs, resemble puffballs externally ; but as one matures, out shoots a long, hollow stem bearing pendent from the tip a small pileus, and this carries the spores in reticulations of its outer surface Phalloidew.

9. Trembling mushrooms : soft, gelatinous fungi (witches'-butter) in color varying from white to orange, red, or brown, generally found growing on wood or parasitic on other fungi - Tremellacere.

The first purpose of these lessons should be to learn to recognize the deadly genus Amanita. 'Then let each student acquaint himself with as many as possible of the abundant edible mushrooms. An excellent plan is to have the class unite in making a neat card catalogue of the most abundant and valuable mushrooms found growing in the locality - this catalogue to be left in the laboratory as part of its biological equipment during the year. A sample card might read about as follows:

ORDER : $A G A R I C A C E A$
Greves : Lactarius
Species : deliciosus
SPOR rs: White

Delicious Milky Mushroom

Edible, excellent (first taste a little acrid)

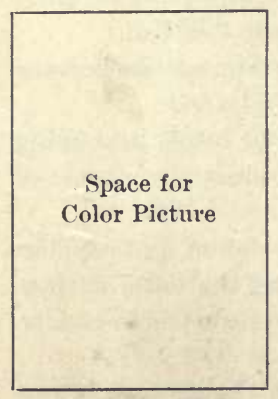

$3-10 \mathrm{~cm}$. high ; $5-13 \mathrm{~cm}$. broad; fumnel-shaped.

Color: orange, in concentric darker and lighter zones around cap; becomes lighter, often greenish, with age.

Gills: decurrent, saffron yellow. Milk at first reddish orange, quickly turning to dull greenish - characteristic of every part of plant when bruised.

Odor: aromatic.

Taste : delicious.

Habitat: damp coniferous woods.

Season: July to October.

Notes: Have found it abundant since our first field work-September 10 up to October 23. 


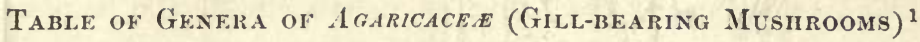

PILEUS DISTIXCT FIRON FLESHY STEN

\begin{tabular}{|c|c|c|c|c|c|}
\hline SP'ORES & $\begin{array}{l}L_{\text {EUCOSPORAE }} \\
\text { (White) }\end{array}$ & $\begin{array}{c}\text { RIIODOSPORE } \\
\text { (Pink) }\end{array}$ & $\begin{array}{c}O_{\text {CHROSPORAG }} \\
\text { (Yellow-brown) }\end{array}$ & $\begin{array}{l}\text { PORPII YROSPORE } \\
\text { (Purple-brown) }\end{array}$ & $\begin{array}{c}\text { MELANOSPORE } \\
\text { (Black) }\end{array}$ \\
\hline ling and volva & Amanita $^{2}$ & & & & \\
\hline Volva, no ring & Amanitopsis ${ }^{4}$ & Tolveria ${ }^{3}$ & Acetubularia & Chitonia & \\
\hline Ring, no volva & Lepiota 4 & &  & Agaricus ${ }^{4}$ & Coprinus 4 \\
\hline No ring & & Pluteus & Bolbitius & Pilosace & \\
\hline
\end{tabular}

PILEUS CONTINUOUS WITH FLESIIY STEM

\begin{tabular}{|c|c|c|c|c|c|}
\hline Ring & Amillaria 4 & & $\begin{array}{l}\text { Pholiota } \\
\text { Cortinarius }\end{array}$ & Stropharia: & Gomphidius \\
\hline \multirow[t]{2}{*}{ Sinuate gills } & Tricholoma & $\overline{\text { Entoloma }^{3}}$ & Hebeloma ${ }^{3}$ & \multirow[t]{2}{*}{ Hypholoma 4} & \multirow{2}{*}{$\begin{array}{l}\text { Panæolus } \\
\text { Anellaria }\end{array}$} \\
\hline & $\begin{array}{l}\text { Lactarius }{ }^{3} \\
\text { (milky) }^{\text {(milky }} \\
\text { Russula } \\
\text { (brittle) }\end{array}$ & & Inocybe & & \\
\hline $\begin{array}{l}\text { Gills of ten decur- } \\
\text { rent }\end{array}$ & $\begin{array}{l}\text { Hygrophoriss } \\
\text { Clitocy be } \\
\text { Cantharellus } \\
\text { Xerotus } \\
\text { Nyctalis } \\
\end{array}$ & Clitopilus4 & $\begin{array}{l}\text { Flammula } \\
\text { Paxillus }\end{array}$ & & \\
\hline $\begin{array}{l}\text { Growing on wood. } \\
\text { Stem nsually ec- } \\
\text { centric, lateral, or } \\
\text { wanting }\end{array}$ & $\begin{array}{l}\text { Lenzites } \\
\text { Lentinus } \\
\text { Pleurotus } \\
\text { (fleshy) } \\
\text { I'anus } \\
\text { (leatliery) } \\
\text { Trogia } \\
\text { (gills crisped) } \\
\text { Schizoplyyllum }\end{array}$ & Claudopus & Crepidotus & & \\
\hline
\end{tabular}

I'ILEUS DISTIXCT FROM CARTILAGINOCS STEM

\begin{tabular}{|c|c|c|c|c|c|}
\hline $\begin{array}{l}\text { Nargin of pileus } \\
\text { inrolled in young } \\
\text { plant }\end{array}$ & Collybia & Leptonia & Naucoria & Psilocybe" & \\
\hline & $\begin{array}{l}\text { Marasmius } \\
\text { Heliomyces }\end{array}$ & & & & \\
\hline $\begin{array}{l}\text { Margin of pileus } \\
\text { straight in young } \\
\text { plant }\end{array}$ & $\begin{array}{l}\text { Mycena } \\
\text { Hiatula }\end{array}$ & Nolenea & $\begin{array}{l}\text { Phuteolus } \\
\text { Galerx }\end{array}$ & P'sathyra & P'sathyrella \\
\hline $\begin{array}{l}\text { Gills decurrent, } \\
\text { pileus usually um- } \\
\text { bilicate }\end{array}$ & Omphalia & Eccilia & Tubaria & Deconica & Montagnites \\
\hline
\end{tabular}

1 Arranged by 'Theodate I. Smith, Ph.1).

2 Contains deadly poison species. No species of Amunita should be eaten without identification by an expert.

8 Contains suspicious species or those having minor poisons.

4 Contains edible species and none known to be poisonous except those given below :

Lepiota morgani has green spores; it is one of the finest edibles, but makes ill about one person in six.

Russula emetica causes nausea in some people, but is harmless for others.

Tricholoma sulphureus smells like illuminating gas and is reputed poisonous. Hygrophorus conicus is reputed poisomous.

Clitocybe illudens smells and tastes like soap and is reputed poisonous. 
The table on the preceding page will enable the beginner to place any agaric in its proper genus, and indicates the genera that contain edible species. The other families, especially the puffballs, morels, boleti, coral and hedgehog mushrooms, also contain many edible species. In fact, almost all of them that are agreeable to the taste are perfectly safe if taken in prime condition. All the soft-skinned puffballs, if perfectly white to the center, are free from suspicion, as are all the morels, all the hydnums, and all but one of the coral mushrooms - Clavaria dichotoma, a rare, pure-white form, in which all the branches fork regularly. Among the boleti the group luridi, characterized by red mouths of the tubes, contain species that are rated as poisonous.

Raising mushrooms is a growing industry. Can members of the class visit local mushroom cellars and report on methods employed? If none are grown locally, cannot a committee of the class try the experiment as an industrial project? Several of the state experiment stations and the United States agricultural department publish bulletins that will give the necessary information.

- As a people we are permitting a considerable food supply to go to waste. As we study the matter, can we estimate the amount and value of the mushrooms that grow annually on our home premises and in our gardens, lawns, woods, and meadows? What might these figures be for our township, county, and state? 


\section{CHAPTER XX}

\section{FUNGOUS AND BACTERIAL DISEASES OF PLANTS}

Estimates which have been placed upon the damage caused by prevalent plant diseases during a single season amount frequently to a very considerable per cent of the total value of the crops. In the United States alone the destruction wrought by fungous diseases is sometimes not far from half a billion dollars. - DugGar, "Fungous Diseases of Plants," pp. 7-8

Civic aspects. Line fences of farm or city lots offer no barriers to clouds of fungus spores in the air. So the spores

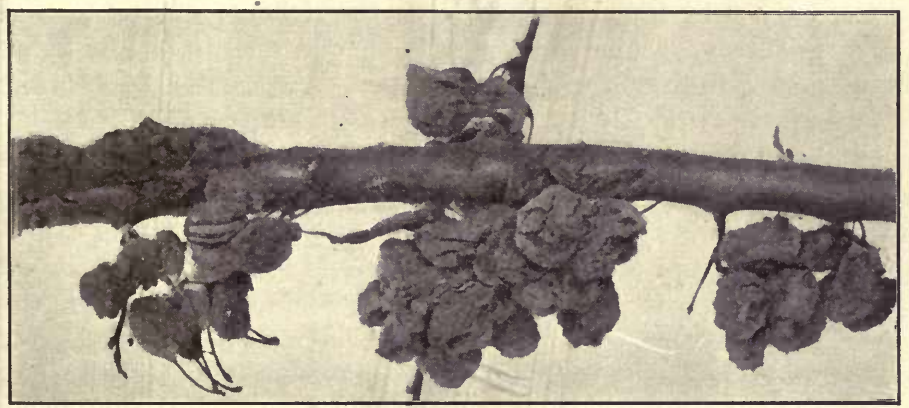

Fig. 99. Mummied plums destroyed by brown rot (Sclerotinia fructigena). At left, tumor on branch, caused by black knot (Plowrightia morbosa)

of rusts and smuts of grains may sweep over the fields from Texas to Manitoba, or they may live unseen on seeds and thus be distributed the world over. The spores or mycelium, as is the case with smut of corn and onion, scab and rot of potato, and clubroot of cabbage and turnip, may rcmain alive in the soil from year to year. Such fungi can be controlled only by strict rotation of crops. We thus bcgin to realize the size of our problem in its world-wide 
scope, and may be prepared to conclude that its final solution must depend on intelligent, world-wide coöperation.

Irish famine. It was the great famine in Ireland in 18451847 that opened the eyes of the whole world to what a fungous disease of a plant might mean to a people, and the awakening that followed marks the beginning of modern plant pathology. The case illustrates, too, the apparent suddenness of the attack, and also the total destruction of the crop the second year if rotation is not resorted to. Ireland had become densely populated, a large part of the people were almost wholly dependent on the potato for food, and the fungus that caused the famine was the late blight, or rot, of the potato - Phytophthora infestans.

The harvest of 1845 promised to be the richest gathered for many years. Suddenly, in one short month; in one week it might be said, the withering breath of a simoom seemed to sweep the land, blasting all in its path. I myself saw whole tracts of potato growth changed in one night from smiling luxuriance to a shriveled and blackened waste. A shout of alarm arose. But the buoyant nature of the Celtic peasant did not yet give way. The crop was so profuse that it was expecter the healthy portion would reach an average result. Winter revealed the alarming fact that the tubers had rotted in pit and storehouse. Nevertheless the farmers, like hapless men who double their stakes to recorer losses, made only more strenuous exertions to till a larger breadth in 1846. Although already feeling the pinch of sore distress, if not actual famine, they worked as if for dear life; they begged and borrowed on any terms the means whereby to crop the land once more. The pawn offices were choked with the humble finery that had shone at the village dance or the christening feast; the banks and moneylenders were besieged with appeals for credit. Meals were stinted, backs were bared. Anything, anything to tide over the interval to the harvest of "Forty-six." O God, it is a dreadful thought that all this effort was but more surely leading them to ruin! It was this harvest of Forty-six that sealed their doom. Not partially but completely, utterly, hopelessly, it perished. As in the previous year, all promised brightly up to the close of July. Then, suddenly, in a night, whole areas were blighted; and this time, alas! no portion 
(f) the crop escaped. A cry of agony and despair went up all over the land. The last desperate stake for life had been played and all vas lost. The doomed people realized but too well what was before them. Last year's premonitory sufferings had exhausted them and now? - they must die.

We raised a public subscription, and employed two men with horse and cart to go around each day and gather up the dead. One by one they were taken to a great pit at Ardnabrahair Abbey and dropped through the hinged bottom of a trap-coffin into a common grave lelow. In the remoter rural districts even this rude sepulcher was impossible. In the field and by the ditchside the victims lay as they fell, till some charitable hand was found to cover them with the "djacent soil. - Lorn E. Fitzmaurice and J. R. Thursfierd, in Jarned's "History for Ready Reference," Ireland, 1845-1847

Here we have our problem in the large and in concrete orm. An enemy has killed by starvation nearly a million jeople. What is this enemy? Who saw it come or go? How does it operate? Why did it do this? How can we prevent future calamities of this kind? 'The world had to :twait alleviation of fears and superstitions, discoveries in many fields, and growth of the science of botany before many of these questions could be answered. Nothing can surpass in human value and interest, however, the quality of mind that works out solutions for such problems. In the ight of the Irish famine, what may be the human value of such discoveries?

To get an insight into growth of knowledge in this field, call for at east three volunteers. Let number one read up the story of this amine further and report to the class. This is to develop a feeling or the need and motive for such study. Let number two look up and eport on the story of discoveries leading up to determining and raming the fungus and devising methods for its control. ${ }^{2}$ Number

1 Returns to date (September 15, 1915) give total losses, killed, wounded, ind missing in the British army, after more than a year of the great war, it less than 400,000 .

2 See work of Dr. Berkeley (1846), Louis Pasteur (1856), especially De Bary (1861 and later), and Millardet, discoverer of Bordeaux mixture (1883). 
three may collect specimens showing all stages of infestation of leaves and tubers for actual demonstration, make pictures of the fungus and diagrams showing how it attacks the potato plant, and finally give the best methods for its control.

Infection. The process of infection is as simple as that of planting seeds in a garden plot and raising the particular kind of flower or vegetable or of inoculating mold spores in any sort of food cultures. The spores of the parasite germinate in contact with their host plant, and the hyphæ enter through wounds or stomata or actually eat their way through the cells of the surface.

In order to develop perfectly clear ideas, perform all sorts of inoculation experiments with fungi that happen to be available. Let members of the class use different kinds and demonstrate methods and results. Use any of the following, or others of local importance.

Inoculate by touching point of pin to spores and pricking surface:

A potato tuber or leaf with spores of blight or scab;

Seedlings of corn, or other grains, with smuts or rusts ;

Lettuce plants with spores of "drop" (Sclerotinia libertiana) if locally important;

An apple with spores of bitter rot;

A plum, peach, or cherry with spores of brown rot (Sclerotinia fructigena), always at hand everywhere;

Bean seedlings with germs of bacterial blight (Pseudomonas phaseoli) or spores of pod spot or anthracnose (Colletotrichum lindemuthianum).

In these days of quack nostrums, illogical thinking, and even hysterical denial of cause and effect in matters of disease, these lessons with plants, which are not subject to fears and perverted mentality, may help to keep us sane.

Wound infection of trees. A search through the orchard or wood lot is all too likely to show trees with mushrooms of different kinds - polypori, hydnums, oyster and honey mushrooms - growing upon trunks or roots. Inspection seldom fails to reveal the wound in the bark through which the fungus entered the wood. It is probable that these 
parasites destroy more timber anmually than do forest fires. 'The visible portions, the sporophores, of these tree-destroying fungi are pushed out at certain seasons, or during certain weather conditions, and pour clouds of spores into the air to infect surrounding trees. These disease breeders should be the first to be made into firewood in annual cutting from the wood lot. The sporophores should also be destroyed as soon as they appear. By a little intelligent coöperation a-community could bring these pests under control, and however valuable the trees may be in themselves, the study will be worth while as an example of spread and prevention of disease.

Root rot of fruit trees is a matter that will call tor special attention in certain sections. Two conspicuous mushrooms, $\mathrm{Cli}$ tocybe parasitica and the common honey mush-

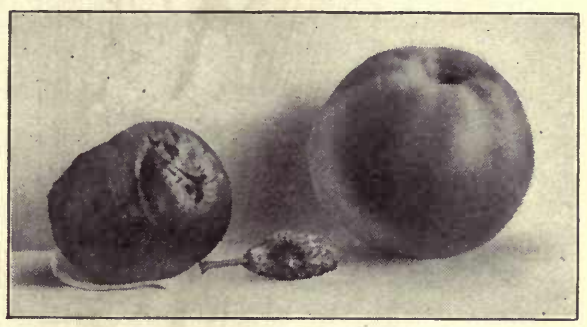

Fig. 100. Apple inoculated, at pin, with spores of brown rot from mummied plum. Control apple

As instructive as a case of smallpox room (Armillaria mellea), show strong parasitic tendencies when brought into contact with the roots or crowns of apple, peach, or cherry trees. In clearing land for orchards it is advisable to remove all stumps and roots that are likely to harbor these fungi.

Invite the local forester or tree surgeon to discuss these problems with the class. Learn from him the best treatment for tree wounds. (Wounds of any size made in pruning should be sealed with paint or gas tar.) As laboratory work let the class, in convenient groups, make some experiments in tree surgery where most needed about homes, school yard, or streets.

Civic types for study. Duggar describes, or mentions, in his book "Fungous Diseases of Plants," 238 fungi that attack the common plants and trees of forest, orchard, garden, and field. He also gives a most useful Host Index 
(the host is the organism that supports a parasite), in which he lists 174 plants, with the fungi that attack each. From this we see that everything we try to raise has its fungus enemies : 'alfalfa has anthracnose, leaf spot, root gall, European root disease, and root rot; the apple has 24, among them anthracnose, or bitter rot, fire blight, crown gall, rust,

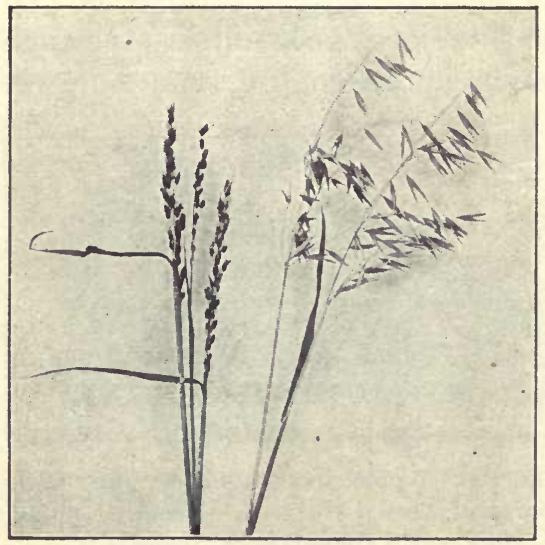

Fig. 101. Loose smut of oats (Ustilago avence) and normal heads and scab; beans have 7 ; corn, 6 ; cotton, 9 ; the grape, 9 ; potato, 6 ; tomato, 8 ; wheat, 7 ; violet, 6 ; pine, 6 ; oak, 7 ; and so on through the list.

The following bacterial diseases are common:

Pear and apple blight. Leaves turn brown as though burned with fire. The germ was supposed to be carried by bees to the blossoms, but it is probably inoculated by aphides. Limbs that show symptoms of the disease should be cut below traces of the blight and burned.

Wilt disease. This disease affects tomatoes, cucumbers, melons, cotton, and Irish potatoes, and causes the plants to wilt rapidly and die.

Black rot of cabbage. The germ attacks cabbage, turnips, rutabaga, and cauliflower. Leaves turn black and the plant dies. This disease is common in America and Europe.

Try, at least, to make a preliminary survey, and then choose for intensive study the local types that are most important, and especially those that require general knowledge and united effort of the community to control - the civic 
types. It may be possible for each pupil to make a table giving for each fruit, vegetable, and farm crop the loss caused by fungi - that is, to answer the question, What part of the half-billion-dollar tax does my home pay? A suggestion for such a table is given below.

Losses Caused by Fungi on a Grain Farm of 320 Acreg 1

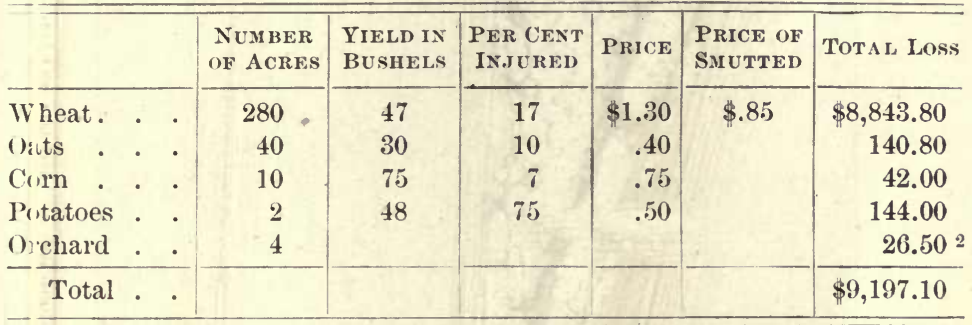

National and world problem. 'The general situation is aptly expressed by the complaint heard on every hand:

The world is not fit to live in any more, and it's getting worse and w orse every year. We never used to hear about all these new-fangled diseases all the time, and everything didn't use to rot and smut and b]ight when I was a girl back on the old farm.

This is literally true and for several good reasons. People did not then know what was eating them out of house and

1 Wheat is supposed to be affected with stinking smut, which Duggar says sc metimes takes "from one half to two thirds of a crop" of some sections. L ose smut, corn smut, and early blight are the fungi supposed to have at tacked the oats, corn, and potatoes respectively. Estimates are not exct ssive. The percentages for the wheat, oats, and corn are figured by countirg 100 stalks taken at random in ten different parts of the field. (Save sf veral of these bundles of wheat or oats for demonstration in the laboritory and at neighborhood meetings.) The potatoes are estimated from unual results in case of sprayed and unsprayed field plots. The cost of tr eating the wheat and oats with formalin would have been a trifling in surauce against the loss incurred.

${ }^{2}$ Cost of three sprayings and one pruning for blight, bitter rot, etc. 
home. They called it Providence and did not talk about it. Again, modern commerce and travel are rapidly mixing

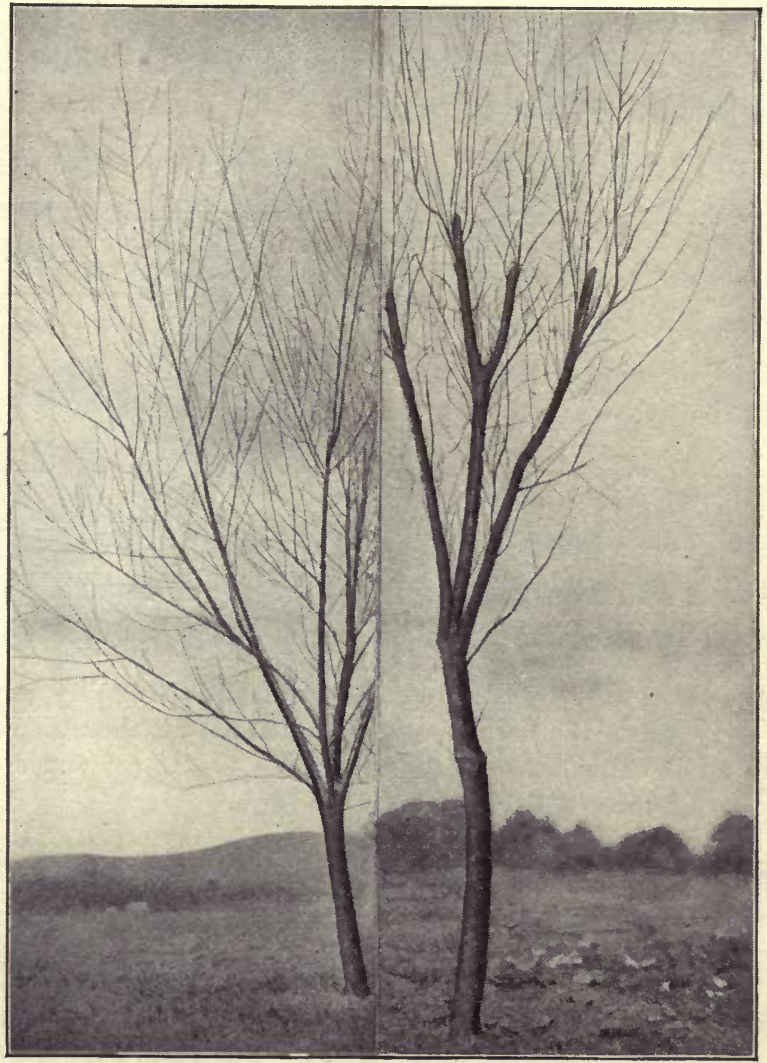

Fig. 102. Tree (on the right) infected with peach yellows

Peach yellows is a contagious disease, exterminative of the peach in northeastern United States, that has baffled all attempts to discover its cause. The tree shown on the right is in the last stages of the disease; the one on the left is healthy

the bacteria, fungi, and insects of all the world, and these are the forces that have often determined both the floras and the faunas of continents. More American Indians have been 
killed by European bacteria than by bullets. Measles struck the Fiji Islands like a deadly pestilence. So we inspect and quarantine against the importation of such germs as those of bubonic plague, Asiatic cholera, and foot-and-mouth disease, but they slip by in spite of all precautions. The eanker, or chestnut-bark disease, appeared about ten years ago, coming probably from Japan. Working as it does, between wood and bark, it cannot be reached by sprays, and there are not men enough available to prune and burn the diseased trees. It is said to have destroyed over $\$ 30,000,000$ worth of chestnut trees, and predictions appear to be well founded that it may not leave a single one alive in eastern North America. ${ }^{1}$ A third reason is that we are planting large areas to the same crop, with field against field. This is like piling up kindling for a fire, when a disease gets a start.

Control measures. Methods are improving continually, and the only safe course to pursue in this field is to correspond with our nearest experiment station and. secure their latest spray calendars, take the monthly list of publications, and keep abreast of discoveries. The underlying principles, however, should be generally understood.

1. Be sure to plant healthy, uninfected, free-from-disease seeds, tubers, bulbs, or nursery stock. This refers to germs of disease inside the seed, tuber, or stock, and applies, of course, to buds and scions.

Peach yellows, while the germ has not been discovered, is known to he transmitted from diseased trees in seeds, buds, or scions. Wilt disfase of sweet corn, or Stewart's disease, sometimes destructive to from s0 per cent to 100 per cent of the crop, is transmitted on, and proba bly in, the seed. Seed should not be saved, or distributed to uncontaminated land, from infected fields. The same is true of anthracnose (f beans and cotton; bean blight; bacterial blight, or wilt, of potato;

${ }_{1}^{1}$ The species might be saved to the continent if nuts from sections as ret uninfected could be sent to suitable places on the Pacific coast and jlanted and reared beyond probable reach of infection. The United States .3ureau of Forestry would probably be glad to supply safe seeds to biology classes that would agree to follow out directions for planting and culture. 
late blight, or rot, and dry rot, or stem blight, of potato; and crown gall of grapes, berry bushes, and fruit trees. So, too, pear and apple blight have often been scattered broadcast from nurseries because disinfection of pruning tools was neglected. In general, disease shows up clearly in the nursery or field, while it would require bacteriological and microscopic methods to find the germs within the seeds or stocks. Go out and hunt over local nurseries or seed farms. Ask experts from them to come in and demonstrate and discuss their methods. All who

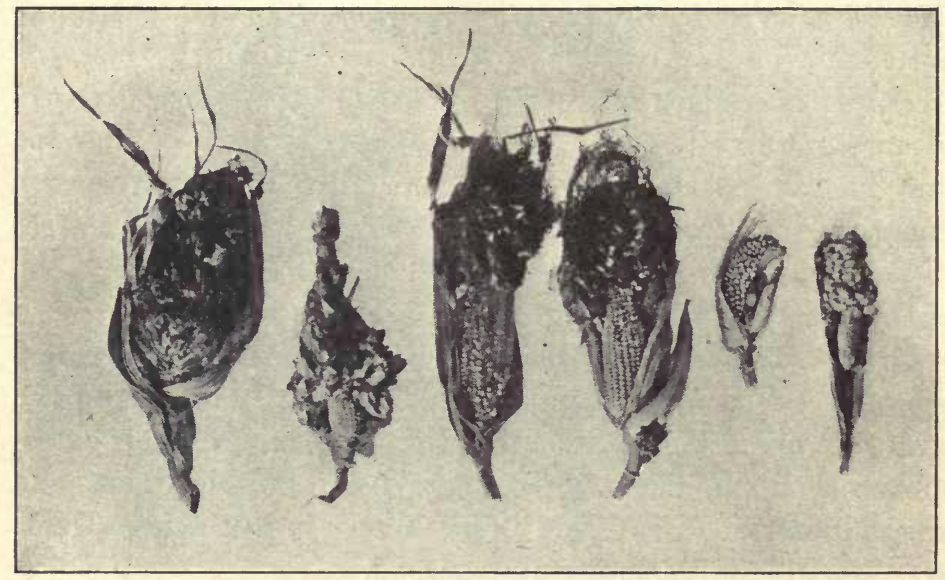

Fig. 103. Corn smut (Ustilago zece)

propose to distribute these important supplies to the public ought to know their business by this time. The best firms employ trained experts to see to it that stock is free from disease, and then they may send it to branch farms, far away from any possible contamination, to have it propagated for the market.

2. If spores are alive on the seeds or tubers, ready to attack the embryo plant when it germinates, kill them before planting.

Scab of potatoes and smuts of grains are examples. Soak seed potatoes for two hours in formalin solution ( 1 ounce to 2 gallons of water) or in mercuric chloride (corrosive sublimate) solution ( 1 ounce to 8 gallons of water). External spores of the smuts on wheat, oats, and barley are killed by soaking for from ten to twenty minutes in formalin solution (1 pint to 30 gallons of water) or by warming up the seed in water at $110^{\circ}-120^{\circ}$ and then holding it for ten minutes in water at $132^{\circ}-133^{\circ} \mathrm{F}$. 
3. If living spores are continually sifting down from the air, we nmst keep the surface of leaf or fruit covered with something that will kill them as they germinate. If we wait till they get in, the crop will be ruined. Various Bordeaux solutions and lime-sulfur washes are effective for this purpose, and, naturally, while leaves are unfolding rapidly or fruit is growing, we must spray every few days.

4. If the spores are alive in the soil, there is nothing to do but rotate. Plant something they cannot grow upon - something that vill starve them out; there is no other way of killing them out of the ground.

5. Seek continually for resistant varieties and strains. With everykody on the lookout for these valuable variations, we may hope for nore rapid progress in the control of fungous diseases of plants.

6. Observe general soil and plant hygiene. With the soil mellow and rell drained we may minimize danger from root rots and damping-off fungi ; with plants well spaced to let in sunlight and allow free circulition of air, or pruned with this in view, and with fruits thinned so as not to touch, we may greatly reduce danger from air-borne spores.

Every community organization, rural or suburban, ought to have a committee on fungous diseases of plants and their practical control. The local class in biology might well be the laboratory right arm of such a committee. By working sut coöperative plans, thoroughly agreed upon, which might spread from neighborhood to neighborhood as they were developed and perfected, many of our worst fungus enemies might be completely stamped out. No real estimate of the loss caused by them has ever been even attempted. We do not know enough about them. Duggar's guess of $\$ 500,000,000$ year is very low, and, while it might approximate the losses to the large markets and channels of trade, we must certainly add to this all the damage to the home garden and orchard, with the labor and expense of fighting. fungi in them. The class in civic biology which gives us even a first attempt at a detailed account of the expenses and losses chargeable to fungous diseases of plants in any community will mark a distinct forward move in this field. 


\section{CHAP'TER XXI}

\section{BAC'TERIA}

Size. Bacteria, the smallest plants known, range in size from ultramicroscopic to 6 microns thick by 80 microns long. Even the largest single bacterium known is far too small to be seen with the unaided eye, and for the smaller species, like the germ of grippe, Bacillus influenzoe, which is .3 $\mu$ thick by $.75 \mu$ long, we might have $2,867,417,289$ spread in a single layer over one square inch of finger tip, and the smear might be even 100 germs deep, that is, contain $286,741,728,900$ bacteria, and still be invisible to the eye and too thin to feel.

Form. Bacteria appear under the microscope as spherical (the micrococci), as slender rods (the bacilli), and as forms bent like commas or twisted into spirals (the spirilla). Humorously they are said to resemble "balls, cues, and eorkscrews."

Distribution. Bacteria are everywhere in nature except in the air at high altitudes, over perpetual snows and over midocean, in the deeper layers of sand or clay soils (they may be carried to almost any depth and almost any distance by streams in crevices of rocks), and, most important of all, in the blood or sap and internal tissues of healthy animals and plants.

Bacteria of the air. Bacteria are blown about as free dust with every current of air. The table on the next page, made in France from data collected monthly for ten years, shows the variation in number of bacteria in the air of city and country at different seasons of the year. 


\begin{tabular}{|c|c|c|c|c|c|c|c|c|c|c|c|}
\hline & & & & & & & & & & COUNTRY BACtERIA & City BaCteria \\
\hline Winter. & . & - & . & $\bullet$ & . & . & . & - & • & 170 & 4,305 \\
\hline Spring . & . & . & . & . & . & . & . & . & . & 295 & 8,080 \\
\hline Summer & . & • & . & . & . & . & . & . & . & 345 & 9,845 \\
\hline Autumn & . & . & . & . & . & . & - & . & • & 195 & 5,665 \\
\hline A verage & . & . & . & $\therefore$ & . & . & . & . & . & 250 & 6,975 \\
\hline
\end{tabular}

Bacteria of water. Streams ordinarily contain about 500 bacteria per cubic centimeter, collected from the air and soil over the area drained. The river Seine, as it enters Paris, has about 300 bacteria per cubic centimeter, but after it receives the sewage from this city it contains 200,000 bacteria per cubic centimeter. The supposed self-purification of streams is found to be mainly due to dilution. Experts are impounding running water in reservoirs previous to supplying cities, since kacteria disappear from still water. Microscopic organisms (plankton) upon which young fishes feed are found in greater abundance in quiet water, and it is thought that they in turn feed upon bacteria.

Water in wells varies greatly in number of bacteria. Artesian wells are practically free from them; ordinary wells may contain from 1000 to 8000 bacteria per cubic centimeter. Ice varies in number of bacteria according to water from which it is taken. Clear ice from the Hudson River contained 398 bacteria per cubic centimeter, while its snow ice contained 9187. Why?

Bacteria of the soil. The number of bacteria of the soil varies with the amount of moisture and organic débris. Superficial layers contain from 10,000 to $5,000,000$ bacteria per rram; if polluted with organic débris, they may contain as ligh as $100,000,000$ per gram. The number of bacteria diminishes rapidly as we pass down into the earth; at a depth of from ten to fifteen feet few if any ean be found. This is the reason that in many cities water is passed through sand filters before it is used for drinking purposes. 
Reproduction in bacteria. Bacteria multiply by division, which is even more simple than the budding of yeast. The cell, when mature, divides transversely into equal halves. Under favorable conditions a bacterium may divide every twenty minutes to half an hour. Can you calculate the progeny of a single bacillus for twenty-four hours?

Bacteria do not grow and reproduce without food, and their astonishing power of multiplication helps us to understand the altered condition of milk and meat if kept in a warm place for even a few hours.

Some species develop spores within the cell and these are much more difficult to kill than the bacteria themselves.

Conditions favorable for the multiplication of bacteria. Like other plants, bacteria demand food, moisture, oxygen, and warmth for growth. Remove any one of these conditions and they will either cease to multiply or die.

Moisture. Bacteria grow only in liquids or moist substances. Dry foods and those containing less than 20 or 30 per cent of water they cannot attack. Drying weakens and kills many bacteria. Spores, however, are much more resistant to continued drying than the vegetative or growing cell.

Why should houses not be allowed to become damp? Why is meat salted and dried? Why is canned fruit sealed? What influence has sugar in preserving fruit? Why are such foods as molasses, condensed milk, flour, seeds, and grain bacteria-proof?

Temperature. Temperature affects growth of bacteria. As in higher plants, there is a temperature known as the optimum at which each species thrives best. A tubercle bacillus grows within a range of 5 degrees, while a few other species can grow anywhere within a range of 50 degrees.

Bacteria do not multiply during the time they are exposed to low temperature, but their vitality is not affected; the tubercle bacillus has been exposed to a temperature of liquid air 
$\left(-190^{\circ}\right.$ C. $)$ for periods varying from six hours to forty-two days without killing it. The retardation of bacterial growth in low temperature is of importance from the public-health standpoint, since it makes possible the shipping and temporary rreserving of perishable foods in cold storage.

Heat in sufficient amount kills all bacteria whether in the spore or vegetative state. Steam heat is more effective than lry; a few minutes of steam heat at $120^{\circ} \mathrm{C}$. will kill spores that would take $180^{\circ} \mathrm{C}$. of dry heat to destroy.

Light. Contrary to the effect produced upon green plants, light has an unfavorable action upon bacteria. Bright sunlight serves to kill the vegetative cell and weakens the spores; liffuse light retards growth; in the absence of all light they grow best. This destructive action is intensified by moisture and fresh air.

Oxygen. Pasteur was the first to demonstrate that some bacteria live without free oxygen. He divided all bacteria into three classes: aërobic, those species that can grow only in the presence of air ; anaërobic, those that can grow only in the absence of air; and facultative, those that can grow either with or without air. Bacteria that grow in the inner tissues of the body of a plant or animal are examples of anaërobic species; they do not grow without oxygen, but get a supply by breaking down organic substances that contain it. The majority of bacteria are aërobic, as evidenced by the many cases of decay which begin on the surface and work toward the center.

Work of bacteria. Like other fungi, bacteria are parasitic (attacking living plants and animals), saprophytic (feeding upon dead or waste animal or plant matters), and symbiotic (living in plants to the mutual benefit of bacterium and plant). Because some species can attack living tissue and produce disease, all bacteria have come to suggest disease to the popular mind. This reputation is as unjust to the 
saprophytic bacteria as it would be to condemn all higher plants because a few of them are poisonous. In general, saprophytic bacteria do no more harm than dust if breathed, or than vegetables if eaten.

Nitrifying bacteria. Certain bacteria of the soil are symbiotic upon the roots of leguminous plants, such as clover, alfalfa,

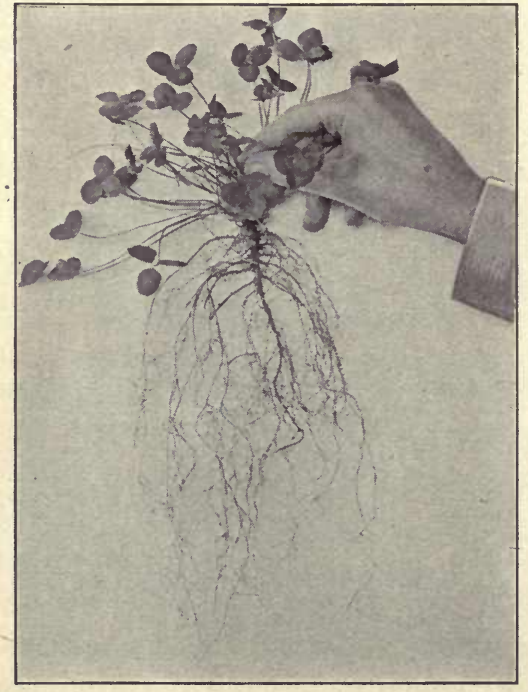

Fig. 104. Clover plant with many bacterial nodules on roots beans, and peas, and cause tubercles to form. These bacteria gain entrance through the root hairs of the plant and cause smooth young roots to assume a nodular appearance (Fig. 104).

Experiment shows that if a legume, notably clover, is grown upon soil of known composition, a part of which has been sterilized (baked), the erop upon the unsterilized soil will be notably larger and the soil will have nitrogen added to it. These bacteria are important, since they can fix the free nitrogen of the air and give it to the soil in the form of nitrates. The benefit to the soil resulting from clover cropping was discovered and practiced by farmers long before the cause was known.

Much experimental work is being done with these nitrifying bacteria, and pure cultures are being sold to inoculate soil that does not contain them. To prevent extravagant and misleading claims of dealers, the United States government has issued the following statements: "No beneficial results can be 
expected for a particular crop if the bacteria for the crop are already in the soil. But little, if any, benefit can be expected from the use of these bacteria if the ground is decidedly in need of other fertilizers, such as phosphates, potash, and lime. But little, if any, benefit can be expected from inoculation if the soil is already rich in nitrogen."

Carefully wash the roots of different elover plants. Are the nodules of nitrifying bacteria present? Are they found upon alfalfa and peas in your region? Are pure cultures of these bacteria sold in your state? Read the state and government bulletins upon these bacteria. 


\section{CHAPTER XXII}

\section{BACTERIA CONTINUED: LABORATORY METHODS}

Apparatus and material. To grow bacteria in the laboratory the following apparatus and material are necessary: a steam sterilizer, hot-air sterilizer, two platinum needles ${ }^{1}$; test tubes, Petri dishes, absorbent cotton, litmus paper, sheet gelatin, agar-agar, extract of beef, potatoes, caustic soda solution, and hydrochloric acid.

Gelatin medium. Dissolve in 1000 cubic centimeter's of distilled water 10 grams of peptone, 5 grams of common salt, $2 \frac{1}{2}$ grams of beef extract, and 100 grams of sheet gelatin, and place in the steam sterilizer until dissolved. ${ }^{2}$

Let the mixture cool to $55^{\circ} \mathrm{C}$. (you can hold it in your hand) and add a teaspoonful of albumen dissolved in cold water, or the whites of two eggs. Boil until the liquid looks clear. $^{3}$ Line a funnel with wet absorbent cotton or with filter paper designed for gelatin or agar-agar filtration. Pour the gelatin mixture into the funnel and catch in a sterilized flask. Place in a steam sterilizer. If the funnel is kept thoroughly warm, the gelatin will pass through the filter in about an hour. Test the gelatin with litmus paper. It will be found to be acid. Add a weak solution of caustic soda to it, drop by drop, until blue litmus paper does not change

1 Cut platinum wire (No. 27) into two-inch lengths. Fuse one end of each into a glass rod, and bend the free end of one of the needles thus made into a small loop, to be used in measuring drops in liquid cultures.

${ }^{2}$ A portable sheet-iron oven and an ordinary steam cooker may be used if necessary.

3 A fact that must be borne in mind in preparing gelatin is that its gelatinizing power is injured by prolonged heating during the process of preparation or sterilization, and is lost immediately when heated to $140^{\circ} \mathrm{C}$. 
color. Pour about one and one-half inches of gelatin into each est tube and plug with cotton. Sterilize the tubes twenty minutes for three consecutive days, so as to kill all spores.

Agar-agar medium. Mix the same as the gelatin medium, 1sing 15 grams of agar-agar in place of the 100 grams of grelatin. The preparation of agar-agar medium, however, is nore troublesome than the gelatin. Agar-agar does not dissolve easily and is difficult to filter. To obtain a quick result it is best to perform the filtration in parts. If the funnel, lined with absorbent cotton, is well heated, about one half of the tgar-agar mixture will have passed through the filter in fifteen minutes. Remove the funnel and reboil the remaining agaragar and pass through a fresh filter. Repeat the process until the mixture is filtered. ${ }^{1}$

Potato medium. Pare the potatoes and cut with a cork borer of suitable size for the test tube. Divide the cylinders into two-inch lengths and then cut diagonally across. Place the "potato slants" thus prepared in water for several hours, to extract the product which turns them black when exposed to air.

Put into test tubes, slant side uppermost, plug, and sterilize in a steam sterilizer for twenty-five minutes at $100 \mathrm{C}$. for three successive days. A small piece of glass rod placed in the bottom of the test tube holds the potato above the condensed steam.

Rules and methods of manipulation. (1) Learn as early in the course as possible that all dishes should be washed and sterilized in the hot-air sterilizer before using. All microorganisms are killed when they are heated as follows: three hours at $150^{\circ} \mathrm{C}$., or until paper is brown; one half hour at $160^{\circ} \mathrm{C}$.; one fourth hour at $170^{\circ} \mathrm{C}$.; one minute at $190^{\circ} \mathrm{C}$. (2) Before sterilizing, wrap the Petri dishes in paper and

${ }^{1}$ If time is limited, obtain the prepared gelatin or agar-agar from a local hospital laboratory or board of health, or order from a regular dealèr in such supplies. 
plug the test tubes. To make plugs, tear a strip of cotton about two inches wide and as long as needed, fold lengthwise, and roll into a plug. Insert this not more than half an inch into the test tube. Cotton plugs are quite generally used in bacteriological work, since they allow a free circulation of air and prevent the entrance of germs. If material

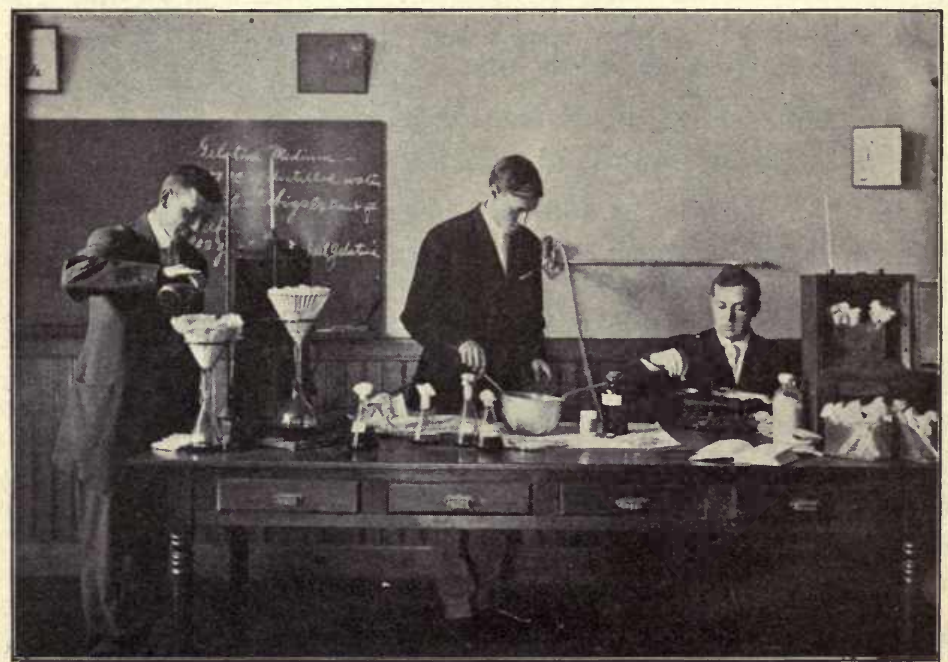

FIG. 105. Preparing culture media Photograph by the author

is properly sterilized and plugged with cotton, it will keep indefinitely. (3) Do not open the hot-air sterilizer until the temperature is down to $40^{\circ}$ or $45^{\circ} \mathrm{C}$. It is preferable to leave the dishes undisturbed in the sterilizer until used.

Before planting (inoculating) your culture media with bacteria observe the following:

Unless otherwise directed, always inoculate media with platinum loop or needle. (1) Heat the wire in the flame just before and immediately after using. (2) Avoid having 
currents of air in the room. (3) Upon opening a culture inedium for inoculation, pass the mouth of the tube through the flame (flaming); if it has stood for some time, flame the cotton before opening the tube. (4) Never allow the tube and of a plug to come in contact with anything while removed from the tube. (5) If a plate culture is to be made, melt the gelatin in a test tube (placed in warm water) and pour into a sterjle Petri dish. If Petri dishes are not ivailable, test tubes may be substituted, provided the gelatin in them is allowed to cool while they are lying in a nearly horizontal position. (6) Inoculation should not take place before the gelatin hardens, unless germs from a liquid are to be grown. In this case the gelatin is inoculated in the test tube and then poured into the Petri lish. (7) Unless otherwise directed, all cultures that have been inoculated should be kept in the dark, or in diffused light and at room temperature. (8) If possible, duplicate each experiment, using both potato and gelatin media. Note appearance of growth in

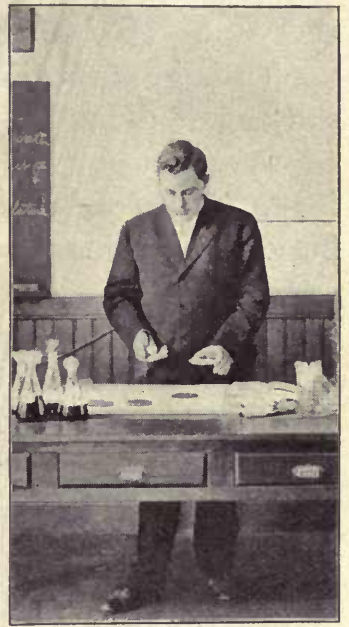

Fig. 106. Exposing Petri dishes

Photograph by the author each case. Label and keep careful records of each experiment. (9) After your experiments are finished, do not allow the media to dry; place all dishes in water and boil for fifteen or twenty minutes before cleaning them.

Experiments for bacteria of the air. ${ }^{1}$ (1) Expose a Petri dish of gelatin for five minutes in the laboratory before the class enters. (2) Expose another for the same length of time

${ }^{1}$ Each member, or group of members, of the class should perform one or more of these experiments. 
in the same room just after the class has left. (3) Expose a Petri dish of gelatin in a room for five minutes immediately after wiping up the dust. with a dry cloth or after using a feather duster. Compare this plate with one that was exposed for the same length of time in a room immediately after it had been dusted with a damp cloth. (4) Expose a plate in a living room for five minutes and compare with the air in the yard. (5) Compare the number of bacteria in the air upon the ground with that of the first and fourth stories of the same building. Is it true that a child breathes less pure air than a man? Is it more desirable to sleep upstairs, as far as air is concerned? (6) Expose a plate of gelatin in a busy street before and after it has been sprinkled, or before and after a rain. (7) Compare the number of bacteria in a well-cleaned street with the number in one that is not cleaned. What do you think of the system that cities are using for flushing their streets? (8) Compare as to number of bacteria the air before and after a snowstorm or rainstorm. Inoculate plates with rain or fresh snow. Keep these experiments in a drawer in the laboratory. In a day or so count the colonies of bacteria and record results. (9) Sweeten and cook fruit, such as apples, in a test tube. Plug with cotton. Does canned fruit keep if air is present and bacteria are excluded? (10) Discuss the desirability of having children's playgrounds upon the roofs in large cities.

Experiments for bacteria of water. (1) Make a culture of water from a stream (dip your platinum loop three times) and compare with the same amount of water from the reservoirs and lakes of the locality. (2) Compare the water above and below the point where the sewage is emptied. (3) Compare the different drinking waters of the locality. (4) Make cultures of water that is rich in organic débris and compare with the same water that has been boiled for fifteen minutes. (5) Filter some of the water used in the above experiment 
through several inches (twelve or fifteen) of clean sand. Is it sand filter effective? (6) Make cultures of milk. How loes fresh milk compare in the number of its bacteria with that which has stood for some time? (7) What is meant by l'asteurizing milk? If possible, visit a milk station where milk for babies is sold. What measures render it safe?

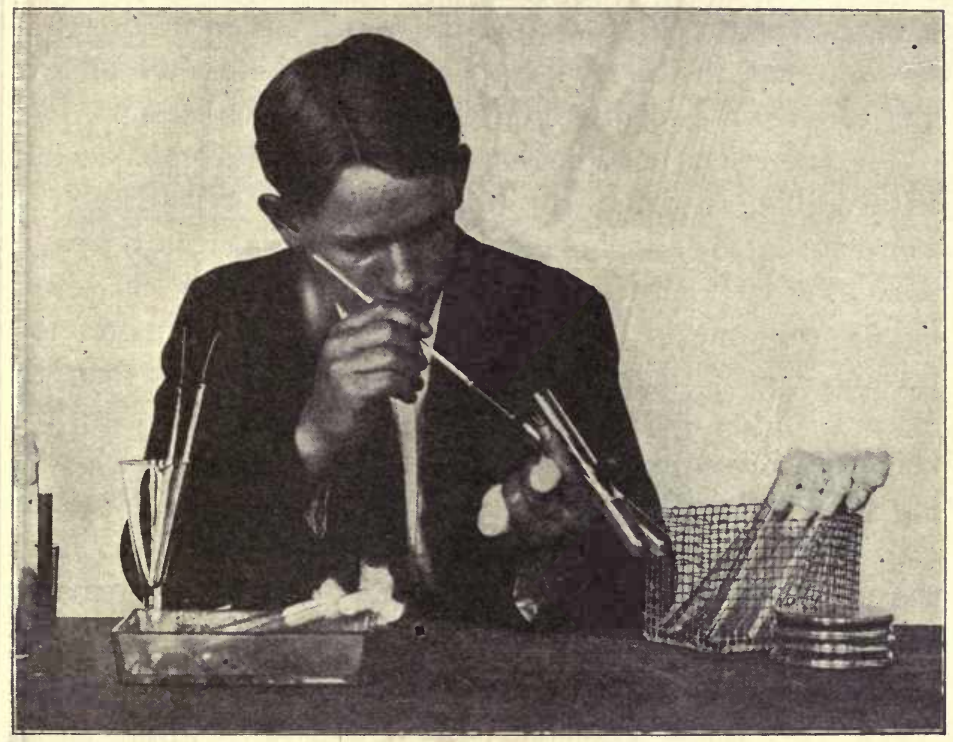

Fig. 107. Inoculating gelatin tubes with platinum loop

Note the way in which cotton plugs are held between the fingers

Additional experiments. (1) Scrape the surface of a silver oin with a sterile knife and make a plate culture. Compare with cultures made from copper coins and paper money. No paper money is used in the Hawaiian Islands because of the danger of transmitting disease. (2) Make plate cultures from the surface of a pencil that a child has used for some time; from the edge of a common drinking cup, door handle, straps 
in a street car. (3) Make a culture from a dishcloth that is washed and boiled once a day, and from one that is not. (4) Compare the number of bacteria in rancid and fresh butter. (5) Allow a fly to walk across a plate of sterile gelatin ; record results. (6) Make a stab culture by running a straight platinum wire, with germs upon it, down through several inches of sterile gelatin in a tube. Upon removing the wire the gelatin closes around the germs left in its track, and serves to cut off the air supply except at the surface. Do you find three classes of bacteria growing in the culture?

The excretions of bacteria render the most favorable medium unfavorable. In general, bacteria do not grow as well upon acid as upon slightly alkaline media. (7) Make a culture from the dust of a dark corner of a room; from a surface in diffused light; from one in bright sunlight. Can you think of more favorable conditions for the growth of bacteria than that offered by the mouth? How can you keep your teeth from being destroyed by them? (8) Inoculate a plate with cleaning of a finger nail, dandruff, single human hair, eat hair. (9) Breathe into a gelatin tube without touching the lips to the glass; make a plate culture. Can the breath carry bacteria? (10) Make a plate culture of some of the substance that has gathered upon the back of the teeth. (11) A bacillus has a characteristic growth upon a culture medium. From the appearance of the colonies do your experiments show that you have grown different species of bacteria? Can you see that by selecting a species of bacteria and inoculating a fresh culture with it, and then from it again selecting and inoculating a fresh medium, you would soon obtain a medium with a "pure culture" of that species of bacteria? (12) Can you now explain the need of such rules and precautions as are given in the early part of this chapter? 


\section{CHAPTER XXIII}

\section{CONTROL OF BACTERIAL DISEASES}

Aristotle (384-322 в.c.) instructed Alexander the Great to have his solliers boil their water in order to prevent epidemics of disease in camps. Possibly to this bit of practical biology Alexander owes his conquest of the world.

Advertendum etiam, siqua erunt loca palustria, et propter easdem causas, et quod (arescunt) crescunt animalia quaedam minuta, quae non possunt oculi consequi, et per aera intus in corpore per os ac nares perveniunt atque efficiunt difficilis morbos. ${ }^{1}-$ VARRo (B.c. 116-27), "De Re Rustica," Lib. I, 11-12 (Keil, 145)

Already in his studies on silkworms, Pasteur's first experience in the domain of disease, the dawn of a new era in the contest of man with contagion opens up before him. He says : "Il est au pouvoir de l'homme de faire disparaitre de la surface du globe les maladies parasitaires, si, comme c'est ma conviction, la doctrine de la génération spontanée est une chimère." 2-Frankland, "Life of Pasteur," p. 123

Bacteria and disease. The majority of bacteria are harmless or beneficial. A few are venomous, as are a few species of snakes, fishes, trees, or mushrooms. The venomous bacteria strike plants, animals, and man just as really as do lead bullets, and wound and kill in essentially similar ways. The notion is current that bullets hit the fittest, while bacteria seek out the unfit, but there is not much ground for this

-1 "One should be on guard, if there should be any swampy places, both for the same reasons and because there grow certain minute animals; which the eyes cannot perceive, and which, permeating the air, enter the body through mouth and nostrils and cause serious diseases." - Professor S. F. Duss, University of Oregon, Translator

2 "It is within the power of man to cause to disappear from the surface of the globe the parasitic diseases, if, as is my conviction, the doctrine of spontaneous generation is a chimera." 


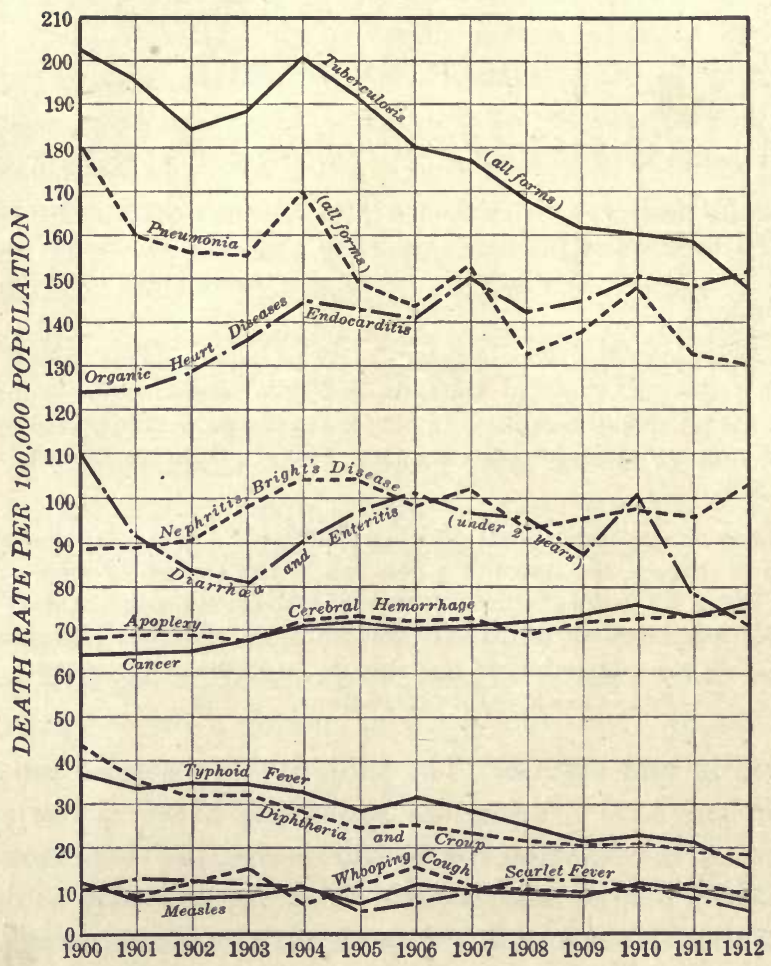

Fic. 108. Death rate per 100,000 population in the registration area of the United States

From the Census, Mortality Statisties, 1912 
jdea. ${ }^{1}$ Ignorance aside, there is no more reason for allowing surselves to be bitten by bacteria than by rattlesnakes. About two people die from snake venom annually in the United States; 20,000 die yearly in India from snake bite, jecause cobras are accorded superstitious protection. We eligiously preserve our bacteria, with the filth in which they hrive and the flies that distribute them; the Hindus, their relatively harmless snakes.

- A few of the more familiar germs, with the disease and death they are causing, are presented in the table on page 234 . When we all know how to kill and avoid these bacteria, as well as we know how to deal with rattlesnakes, we may be as free from them as we are from the snakes. All must know and each must do his part, for one ignorant person can scatter bacteria by the million from Maine to California.

The table is by no means complete. In the next chapter we shall study a similar list of diseases caused by parasites of animal origin. There is another list, known to be infections, - smallpox, yellow fever, scarlet ferer, measles, spotted fever, and foot-and-mouth disease, - the specific causes of which have baffled all attempts to discover. Still another class of ailments, noninfectious, chronic and organic,of the heart and arteries, brain and kidneys, - of heavy and increasing fatality, may have to do with organs weakened by parasitic attack. Finally, we have no statistics of the number of the wounded, the weakened or crippled, and the number of minor ailments, very numerous and of constant occurrence, that impose their burdens of sheer misery - the millions of cases of rheumatism, tonsillitis, boils, felons, carious teeth and toothache, indigestions, diarrheas and dysenteries, and "colds," most wretched of all, probably not less than 200,000,000 of them a year. When we add to all this the bacterial diseases of animals (hog and fowl choleras, bovine, avian, and other tuberculoses and pneumonias, white diarrhea of chicks and foul brood of bees,

1 "Neither regularity of life nor bodily strength was any preservation against it. The strong and the weak were equally struck down; and death spared not those of whom care was taken, any more than the poor, destitute of all help." (The fleas of that time bit all alike.)-Gasquet, "The Black Death," p. 12 


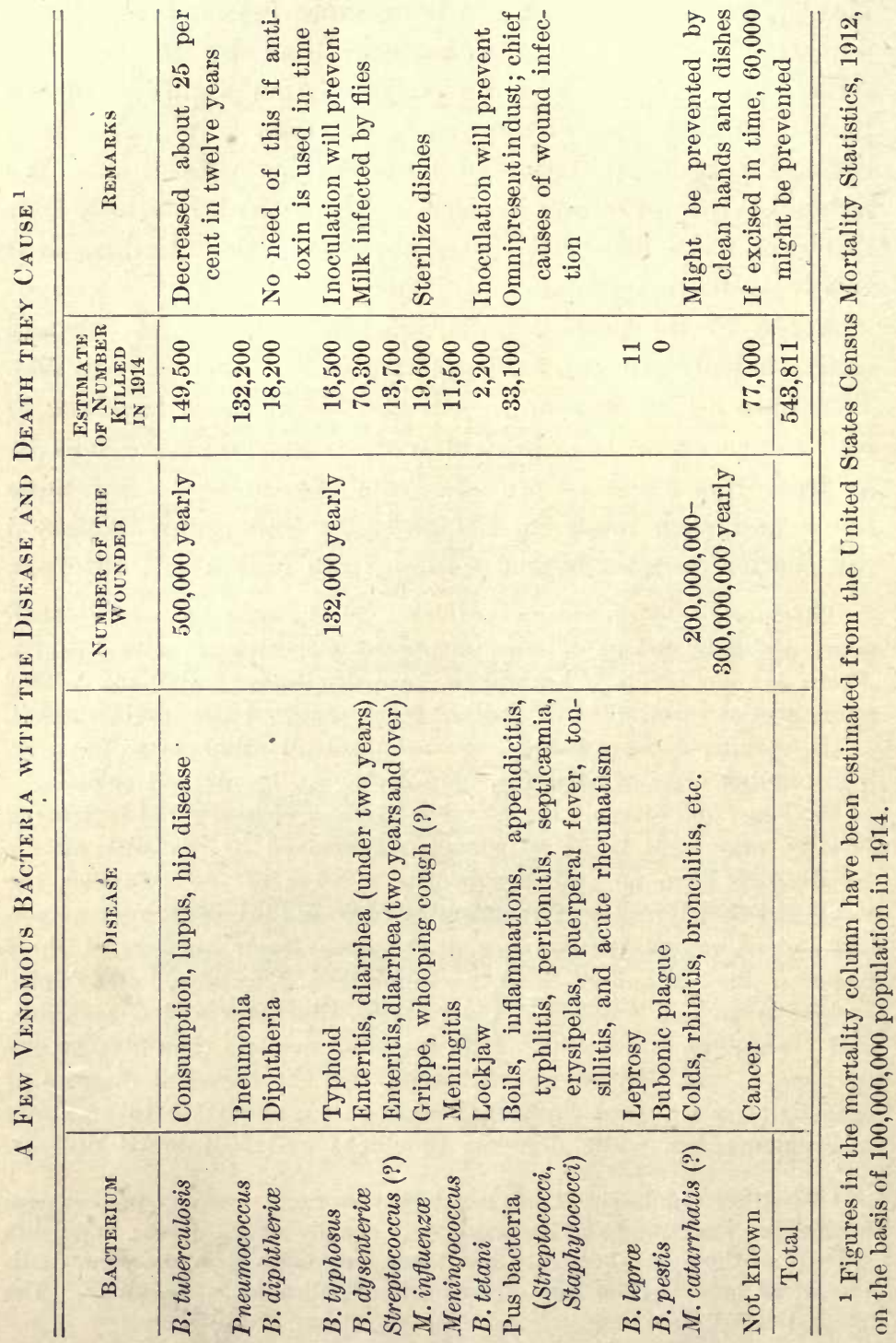


anthrax and glanders, and many others) and the long list of bacterial liseases of plants, already briefly considered, we begin to realize that the very, edge of the struggle for existence lies between mankind and the bacteria.

The three questions. The following questions apply to the parasitic diseases - bacterial, protozoan, vermian, and all the rest. When Pasteur was "wasting his time" disproving spontaneous generation, one of his friends wrote: "He makes me uneasy, he does not recognize the limits of science, he only loves insoluble problems." Now that we know that "la génération spontanée est une chimère," the problem of the control of disease becomes the comparatively easy one of preventing the spread of the living germs from the sick to the well. In every case of contagion or infection the germs escape alive from the body of the sick, are carried to the well, and gain entrance. Therefore the three fundamental questions are :

1. How do the germs of each disease escape from the body of the patient?

2. How is each kind of germ carried?

3. How does each kind of germ gain access to the body?

Paths of escape. Parasitic germs of the lungs, nostrils, throat, or mouth (of diphtheria, tonsillitis, pneumonia, tuberculosis, rhinitis, bronchitis, and influenza, as well as stomach and intestinal diseases that involve vomiting - typhoid fever, enteritis, and cholera) escape with any discharges from mouth or nose. Careless coughing and sneezing may scatter the germs over anything or anybody within a distance of about six feet. Spitting in any public place is an abomination, and laws against it should be rigidly enforced in the interests of public education as well as health.

Bacteria from the digestive and renal-reproductive organs pass out with the dejecta-dysentery, choleras, typhoid. Typhoid bacilli have also been found in the perspiration. 
Germs circulating in the blood are usually drawn off by blood-sucking insects, ticks, or mites; malaria and yellow fever, by mosquitoes; typhus fever, by body lice (and perhaps by fleas and bedbugs); plague, by fleas (possibly also leprosy); typhoid, by bedbugs; Texas fever and spotted fever, by ticks; infantile paralysis (?) and anthrax, by the

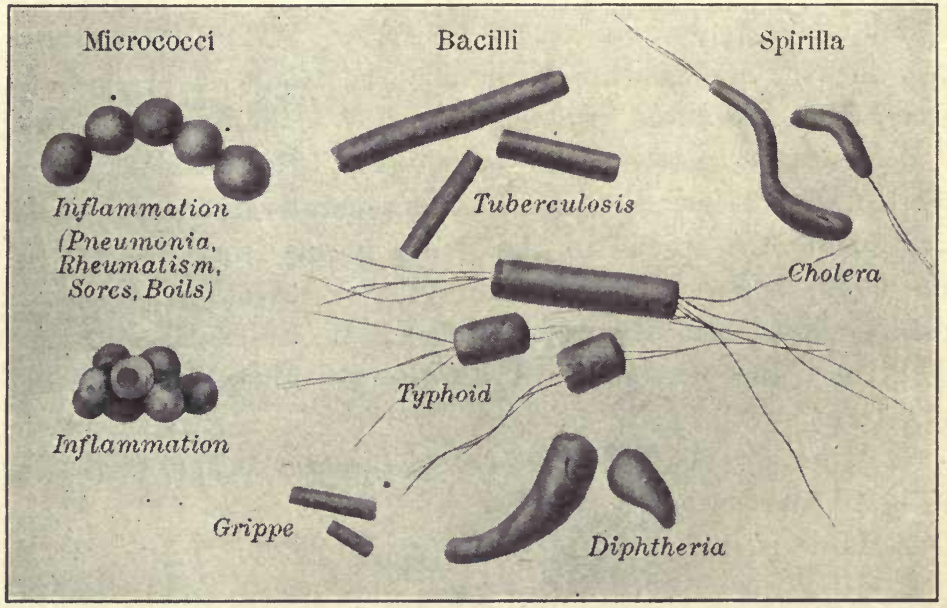

Fig. 109. Pathogenic bacteria modeled to scale in plasticene (micra $=$ centimeters), magnification of models being 10,000 diameters

A suggestion for a laboratory collection. Mount in insect eases under glass. Photograph by the author

stable fly; and sleeping sickness, by one of the tsetse flies. Diseases marked by lesions of the skin - measles, scarlet fever, smallpox, and probably dandruff and eczema - may escape with the scales of cuticle or the contents of blisters or sores.

How living disease bacteria are carried. The greatest barrier to the learning of truth is apt to be a firm belief of an error. No set of ideas has cost the world more misery, suffering, and loss than false notions, prejudices, and superstitions regurding the transmission of diseases. First they were carried 
ky angry gods, demons, and witches; next, by the air as riasms and effluvia; then, by fomites in dust of clothing or rnerchandise; and, finally, we have come down to the sure fvidence of science that contact infection, chiefly by the liands, accounts for almost all the spread of common diseases, ind insects, by contact or inoculation, for most of the rest.

Air not an important carrier. Just now the air is rapidly losing all its terrors, smallpox being the only disease which unay possibly, though not probably, be carried from house to house by this agency. (This does not mean that insects that ly may not transmit many infections by contact.) Chapin juts the case carefully and sensibly as follows:

Only a few authorities now assert that disease is carried by the itmosphere outside of dwellings, and this assertion is made only in regard to smallpox.... Infection by air, if it does take place, as is ommonly believed, is so difficult to avoid or guard against, and so universal in its action, that it discourages effort to avoid other sources of danger. If the sick-room is filled with floating contagium, of what use is it to make much of an effort to guard against contact infection? If it should prove, as I firmly believe, that contact infection is the chief way in which the contagious diseases spread, an exaggerated idea of the importance of air-borne infection is most mischievous. It is impossible, as I know from experience, to teach people to avoid contact infection while they are firmly convinced that the air is the chief vehicle of infection.... Without denying the possibility of such infection, it may be fairly affirmed that there is no evidence that it is an appreciable factor in the maintenance of most of our common contagious diseases. We are warranted, then, in discarding it as a working hypothesis and devoting our chief attention to the prevention of contact infection. It will be a great relief to most persons to be freed from the specter of infected air - a specter which has pursued the race from the time of Hippocrates; and we may rest assured that if people can as a consequence be better taught to practice strict personal cleanliness, they will be led to do that which will, more than anything else, prevent aërial infection also, if that should in the end be proved to be of more importance than now appears. - ChapiN, "Sources and Modes of Infection," p. $263 \mathrm{ff}$. 
Even the air of the sick-room has no dangers if modern methods for bacteriological cleanliness are strictly observedthat is, if all waste matters or discharges go straight from the patient into the fire or sterilizer, and if the rubber gloves with which all handling of the patient is done are disinfected immediately after using. Except by the cough spray a bacterium cannot leave a moist surface, and by the above precautions no living germs can become dry and so enter the dust of the room.

Fomites. "Persons and not things transmit diseases." This slogan is coming more and more to dominate the whole field. Ships, in numbers, have been sunk, cargoes and all, to insure against purely imaginary fomites. No sharp line can be drawn between infection by contact and infection by fomites. Contact infection implies the more immediate transfer of germs, as in shaking hands, exchanging pipes, swapping gum, using the same drinking cup or towel, interchanging dishes at successive meals, touching foods, candies, fruits, etc. with unwashed hands; while the theory of fomites implies infection by germs carried alive and virulent in clothing, merchandise, baggage, and mail matter for long distances and during considerable periods of weeks or even years. As we shall see in the next paragraph, when we begin to pay attention to them, there are so many ways by which bacteria are carried fresh and green from mouth to mouth, by direct or indirect contacts (and not only from mouth to mouth but from dejecta to mouth), that it is sheer dishonesty to crowd our own responsibilities for really inexcusable contacts over onto the theory of fomites. If common notions of fomites were true, we should have to arm our postal mail clerks with fumigator masks and rubber gloves or bury the whole force every night. As a matter of fact, bank tellers, handling "dirty money" all the time, mail clerks, handling letters sealed and stamped in everybody's 
saliva, second-hand clothing dealers, and even rag sorters, all live in average freedom from infections. Doty's testimony on this point is as follows:

The author has carefully investigated the influence of money as a mins of infection. The results show that those who are constantly hendling money, such as bank officials, do not contract infectious dis- eases any oftener than others. The Treasury Department at Washington furnishes exceedingly valuable information on this subject. Here la'ge quantities of filthy and offensive paper money are being constantly hi ndled and rehandled prior to destruction, and not the slightest evi$d \in$ nce has been presented at that place to show that infectious diseases are transmitted by this material. Than this, no more important or conclusive evidence on this subject can be presented. - Doтr, "Prevention of Infectious Diseases," p. 10

Even epidemics in schools - of measles, diphtheria, and scarlet fever - have been found by the medical examiners of New York City to be caused by mild or incipient cases and by unsuspected "carriers" - that is, by contacts of persons and not of things.

Terminal disinfection (fumigation or disinfection at termination of a disease or of quarantine) was abandoned in Providence in 1905, "except in those very few instances in which the family was willing to wait for tro successive negative throat and nose cultures from each of its memburs," the idea being that it was a waste of public money to disinfect rooms while members of the family were carrying living diphtheria girms, and there has been no marked increase of recurrent cases. "The New York City Health Department has given up fumigation after cases of infectious disease, as a costly procedure, the inutility of which has b.en well established." 1 A more conservative opinion is expressed by an eminent authority as follows: "Though the results obtained in some cities since abandonment of terminal disinfection after certain diseases siem to show that heretofore much useless disinfection has been done, it is not felt that the evidence thus far adduced fully justifies its discuntinuance." 2 The idea underlying this position is that if terminal disinfection saves even a few infections, it should not be entirely abandoned. The above is sufficient to show that this important matter is still an open problem; for the best light upon which we should consult

1 American Journal of Public Health, Vol. I (1915), p. 166.

${ }^{2}$ H. S. Hasseltine, United States Public Health Reports (July, 1915), p. 2060. 
our local health authorities (when possible) and the best current health literature. All are agreed that in case of gross uncleanliness or of new, rare, and exceptional infections, the means of transmission of which may not be known, terminal disinfection is advisable. It may take years, or even centuries, of hard work, but nothing can ever take the place of exact knowledge of the definite means by which each parasitic germ is harbored or transmitted. Knowing this, we now exterminate the guilty mosquito instead of sinking the ship to prevent spread of yellow fever, and we pay attention to the rats and fleas in case of plague instead of burning the village, inhabitants and all.

Contact infection. It was a lesson, never to be forgotten, when his family physician once confessed to the writer that he had caused the death of a young mother by failing to scrub the little-finger edges of his hands carefully enough. Upon such honesty as this we can depend for progress of both science and practice. Could we be as honest with our own hands for one day, we might each learn a lesson of lifelong value to our own ideas of rational cleanliness. Suppose we mark with red ink every spot on fingers or hands moistened by saliva or mucous secretions from the nose, and with black ink all areas soiled by contacts with things which it would be utterly disgusting or dangerous to put into the mouth - the fly we crush, the cat we touch (that has licked her own saliva over her fur), the dead mouse we have taken from a trap, the pus from a pimple or sore, and so down the list. If we did this for half a day even, could we ever again go to the table without obeying the scriptural injunction to wash the hands before breaking bread? And we would not be content with ceremonial touching of water, but would wish to scrub them with soap until all the ink spots were off. If such definite instruction were universal, we might not have examples like the following:

Spread of gonococcus infections, persistent and impossible to prevent or trace, in the New York City Babies' Hospital, uncontrolled for several years by laborious disinfection of buildings and equipment (after 
finally discovering that the same night nurse tended the infected cases an 1 new infections in a distant ward) ceased completely when the nurses began disinfecting their hands after attending each case. HoLt, New York Medical Journal, Vol. LXXXI (1905), p. 521

Men detailed as hospital orderlies were, after they had performed thr duty of emptying bedpans, seen to go directly to their meals wi hout washing their hands, and even to distribute food to their comrades. ${ }^{1}$ - Chapis, p. 129

Thus, at one of the finest hospitals in this country, with separate wards for scarlet fever and diphtheria, a considerable number of cases have arisen in the general wards. The germs were supposed to be airbo'ne, as it was said there was no other possible avenue of infection. When I saw the head nurse lick her finger to facilitate turning the bedsice charts of diphtheria patients, I suspected that the principles of modical asepsis had not been entirely mastered. - Chapis, p. 16.)

The superintendent of another hospital invited another visitor and myself to eat ice cream from the same spoon with himself, which spoon wis then replaced in the freezer which was to supply the wards. I was must of all impressed with the fact that at the International Congress on Tuberculosis in 1908 a large number of the readers of papers moistened their fingers with their tongues when turning the pages, and in each of th sections only one drinking glass was provided for all the speakers; and this continued for a day or two without protest. - CuAprs, p. 16.)

The following observations were made by the author in 191 .

1. Stopped to buy candy in order to observe "home manufacture"; saw elderly man molding nut drops lick off his fingers and go on moldill s. Threw candy away.

2. Asked for pound of preserved ginger at a fine confectionery store; wititress clawed it out of tray with hands. Paid for it and threw it aray.

3. Called for glass of milk at railway-station lunch counter; swarthy foreigner removed cap from quart jar, put his dirty hand over bottle, turned it bottom up and shook it violently, scraped palm of hand on mouth of jar, and poured out the glass. He was told to drink it himself.

${ }^{1}$ From a description of an army typhoid epidemic. 
4. Observed ${ }^{1}$ flies swarming on crates of raspberries and blackberries, absolutely open and unprotected (caught about sixty flies with one sweep of the hand over such a crate).

Carriers and contact with food. Typhoid Mary was discovered by Soper in 1906. She was apparently healthy, but wherever she served as cook typhoid fever was sure to follow, and she was found to be alive with virulent typhoid bacteria. She had already caused several small and at least one large epidemic. From 1907 to 1910 Mary was detained in the isolation hospital of the New York Board of Health and then was released upon her promise to change her occupation. Early in 1915 an epidemic of 25 cases broke out in one of the New York hospitals, and there in the kitchen, under an assumed name, was found Typhoid Mary.

About 4 per cent of those who recover from the disease remain as typhoid carriers, either continuously or intermittently, and some may not even know that they have ever had typhoid at all. For some unaccountable reason there are about five women carriers to one man. A typhoid epidemic occurred at Hanford, California, March, 1914, the study of which by the health officers proved most instructive. A church dinner, of which 150 partook, resulted in 93 cases and 3 deaths. The infection was traced to a woman who had cut the bread and prepared a dishpan of Spanish spaghetti. She had nursed her daughter through typhoid thirty-five years before, but did not know that she herself had ever had the disease. In order to test the matter a dish of spaghetti, not so large, was similarly prepared, and, although baked much more thoroughly than that served at the dinner (until the top was brown, the points on the surface were charred, and the edges were boiling furiously) living typhoid bacilli were found within half an inch of the

1 In a public market, Washington, D.C., July 3, 1915. 
surface and at the center of the mass they were swarming, and the temperature there was only $28^{\circ} \mathrm{C}$. This proved that "ordinary baking merely incubates the interior of these misses of food." 1

At a Gettysburg soldiers' reunion one of the men "not feeling very well" was assigned mess duty. As a consequence (probably of his handling the bread) fifty-five of the company developed typhoid.

Naturally extreme danger attaches to contact infection of foods in wh ich bacteria may multiply - lobster, shellfish, cooked meats, and esperially milk. Formerly epidemics following the eating of these things were explained on the theory of "ptomaine poisoning" - that is, that po sons (ptomaines) were formed by bacterial growth in the substance, wl ich were not destroyed by heat. Jordan says of this: "Many of the epidemics of 'meat poisoning' etc. are now known to be due to infection with a specific microörganism rather than to the action of a formed po son." ${ }^{2}$ Milk is a most favorable culture medium for bacterial growth, an 1 naturally many epidemics are traced to it. Chapin gives the following figures: 315 outbreaks of typhoid, 125 of scarlet fever, 51 of diphthr ria, and 7 of tonsillitis (epidemic sore throat). Immediate report to the board of health of the milk route on which a case of illness occurs mikes it possible to nip many an epidemic in the bud, a visit to the dairy generally revealing the souree of the infection.

Recent outbreaks of typhoid on two milk routes in Hartford, Connecticut, -12 eases in September, 1914, and 34 cases in November,were traced to the same carrier, an occasional milker, who had moved frim one dairy to the other.

All the typhoid, 21 cases, in a Minnesota town for five years was traced to one earrier in a dairy. ${ }^{8}$

An epidemic of diphtheria in Lincoln, Nebraska, of 110 cases and 2 leaths (97 received antitoxin promptly, and none of these died) was traced to a diphtheretic "sore throat" of a milker. The money cost to th community of this "trifling sore throat" is estimated at $\$ 10,000$, in ad dition to the suffering, labor of nursing, and the 2 deaths. ${ }^{4}$

${ }^{1}$ Sawyer, Journal of the American Medical Association, 1914, p. 1537.

2 Jordan, General Bacteriology, p. 101.

${ }^{3}$ H.W. Hill, American Journal of Public Health, Vol. IV (1914), p. 667.

4 Wait, "Report of Milk-borne Epidemic of Diphtheria," American Journal of Public Health, Vol. IV (1914), p. 418. 
Clean milk. For many, possibly for all, communities no better healthconservation work could be undertaken than solving, each member of the class for his own home and the whole class for the home community, the problem of safe and clean milk. Milk is safe when all disease germs are kept out of it, and it is clean when free from filth of all sorts, usually indicated by numbers of other bacteria. As secreted by healthy cows, milk is pure, and by observing hospital-operating-room precautions it can be kept so. ${ }^{1}$ Von Behring's statement that milk should not be used for infant feeding if it contains more than 1000 bacteria per cubic centimeter is rarely lived up to. Boston's standard of purity (which Spargo thinks is worse than no standard at all) allows 500,000 bacteria per cubic centimeter, and "certified milk" may run as high as 10,000 bacteria per cubic centimeter. Secure copies of specifications for local certified dairies. ${ }^{2}$ If possible, have a committee of the class, or each member, work up the technique of making the bacterial count and examine local milk supplies. ${ }^{8}$

We have been too long scoring dairies according to buildings and equipment, and nothing could be more convincing for the truth of Dr. North's contention that dirty milk is 90 per cent due to dirty or ignorant dairymen than his demonstration in ten Kelton dairies. Ten trained Oxford dairymen were shipped over to Kelton in time to do the evening milking in ten of the dirtiest Kelton dairies, with the result shown on the next page: bacteria in the milk reduced from millions to less than 10,000 per cubic centimeter, in all but No.6, a most instructive exception. ${ }^{4}$

Four things necessary to production of clean milk:

1. Milking with dry hands into covered pails.

2. Proper washing and sterilization of milking pails and milk cans.

3. Cooling milk by placing cans in tanks of cold water or ice water.

4. Regular laboratory testing of milk for bacteria, and payment based on the laboratory tests.

Pasteurized milk. Dangerous milk can be made safe by heating to $60^{\circ}$ for twenty minutes, and this does not seriously injure its nutritional value. This treatment kills all non-spore-forming disease germs of

${ }^{1}$ Rosenau, The Milk Question, p. 73. (Tells how Mr. S. L. Stewart, Newburgh, New York, produces milk free from bacteria.)

${ }^{2}$ Rosenau, Requirements for "Certified Milk," pp. 151-160.

${ }^{8}$ Russell and Hastings, Experimental Dairy Bacteriology, p. 122.

" North, "The Dairyman versus the Dairy," American Journal of Public Health, Vol. V, pp. 51?-525. 


\section{Bacterial Tests of Mrlk produced in Kelton Dairifs (Bacteria per Cubic Centimeter)}

\begin{tabular}{c|c}
\hline \hline BY KeltoN DAIRMEN & BY OXFord DAIRYMEX \\
\cline { 2 - 2 } April $5:$ & April $6:$ \\
$1,830,000$ & 3,300 \\
$1,520,000$ & 3,100 \\
$4,830,000$ & 4,600 \\
$4,000,000$ & 7,000 \\
$1,450,000$ & 4,100 \\
$3,600,000$ & $61,000^{3}$ \\
$60,000^{1}$ & 800 \\
$9,000^{2}$ & 2,500 \\
70,000 & 1,600 \\
500,000 & 5,600 \\
\hline
\end{tabular}

tukerculosis, typhoid, dysentery, diphtheria, tonsillitis, cholera, and the virus of scarlet fever. This does not make the milk any cleaner, nor does it kill the more resistant bacteria, but if it is dangerous, it renders it vafe.

Flies, vermin, house pets as transmitters of contact infections. After the human hand come other active germ carriers, and among these the house fly probably stands first not only in transmitting germs of filth and disease to foods but in combining air-carriage with contact. This problem has been treated in a previous chapter. Roaches and rats and mice should be universally recognized as too filthy to eat with, and should be completely exterminated, along with the flies, from every household. Cats, on account of their often intimate contact with children, have been responsible for innumerable infections, especially of diphtheria. Since this germ attacks cats virulently, they assume the double role of irresponsible patients and mechanical carriers in the family.

1 This dairy, on April 3, had a count of $8,000,000$.

2 This count was made March 30.

${ }^{3}$ Due to Kelton dairymen raising dust by sweeping at milking time. 
Every case of "cold" or "sore throat" in a cat should be considered diphtheretic or tubercular until proved otherwise. Serious epidemics of diphtheria have been traced to cats, and these have had to be killed or rigidly excluded from homes before spread of the disease could be stopped. Cases of scarlet fever are sometimes traced to cats as passive carriers. ${ }^{1}$ While dogs may act as mechanical carriers of bacteria, and are responsible for harboring several animal parasites, which we shall have to consider later, they are almost immune from bacterial attack.

\section{Recent civic advances due to acceptance of contact infection.} Public drinking-cups and common towels have vanished as if by magic. Sanitary regulation of dishwashing and bed linen in hotels and restaurants, sanitary protection of drinkingstraws and cleansing of glasses in soda fountains, wrapping and boxing of bread, other foods, and candies to prevent contact in handling, liquid and individual soaps, and many other items of modern improvement are active steps in the direction of rational prevention of contact infections. As with the dairies, when we all realize that intelligence in personnel is of more importance than equipment, we shall see to it that only the healthy and cleanly and those who know are allowed to work in dairies or take care of foods in markets or eating houses. No man who does not know better than to put his bare hand over a milk bottle, or woman who does not know better than to take candy from a tray with her bare fingers, has any right to serve the public. Our millions of preventable infections and our more than 500,000 deaths annually are the measure of our need in this direction.

Resistance, susceptibility, and immunity. Possibly every American chestnut tree on the continent is susceptible -

1 Caroline A. Osborne, M.D., "The Cat a Neglected Factor in Sanitary Science," Pedagogical Seminary, 1907 ; also "The Cat and the Transmission of Disease," Medical Recorder, Chicago, 1912. 
unable to offer resistance - to the fungus of bark disease. In thit case, unless some specimens can be taken beyond reach of the spores, every chestnut tree in America will be killed. If immune trees can be found, it may be possible to propagate from them a strain of immune trees and so save the species to the continent. It is possible, though not probable, that something may be discovered which, injected into the sap of the tree or fed into the tree from the soil, will enable it to resist the fungus, that is, give the tree an artificial or acquired immunity. It is conceivable that we might inject some of the sap from an immune tree into a susceptible tree - vaccinate, or inoculate - and so immunize it and save its life.

Every animal or plant offers some resistance to being eaten alive by a parasite. This resistance may be natural or acquired ; it may be mechanical (skin, bark, cuticle, too resistant for parasites to break through) or, as is more common, it may be chemical (some poisonous, toxic substance is produced that weakens or kills parasites). As a nation stung by foreign attack begins to make ammunition, so cells of the host may be stimulated by the toxins of a parasite to produce defensive substances - antitoxins or antibodies. In this case the acquired resistance, or immunity, is said to be active. If the defensive substance, antitoxin, is injected from some other person or animal, as if a foreign nation sent in its army and ammunition, the immunity conferred is said to be passive, and this is not likely to last so long as active immunity. Recovery from certain diseases (whooping cough, measles, mumps, scarlet fever, smallpox) generally leaves the body armed with acquired immunity against a second attack by the same germs - that is, leaves an experienced army that can prevent another invasion. This, in a true sense, is the case, the white blood corpuscles (phagocytes) often gaining the power to eat the germs, probably alive, instead of being eaten by them. The process is not always as simple as this. 
The white corpuscles may not be able to ingest some bacteria unless there are certain substances in the blood to help them. These are called opsonins (Gr. ó $\psi \omega \nu \epsilon \epsilon \omega$, I prepare food for), and their amount in the blood as compared with a normal standard is known as the opsonic index. The injection of killed bacteria of the exact kind that are causing the trouble (made with cultures taken from the patient - autogenous bacterins) often results in a sharp rise in the opsonic index and with this a quick defeat of the invading germs.

Great prejudice has existed against the use of these vaccines, antitoxins, bacterins, and serums, and one accident attributed to them, perhaps falsely, is often made to outweigh in popular prejudice the literally thousands of deaths caused by the natural course of infections. Beginning with vaccination, discovered by Jenner, in 1796, we now have safe and effective vaccines, antitoxins, bacterins, and serums for rabies, diphtheria, tetanus (lockjaw), pneumonia, boils, pimples, and inflammatory fevers, cholera, bubonic plague, bacterial dysentery, cerebrospinal meningitis, and typhoid fever, and, among animal diseases, anthrax, distemper of dogs, hog and fowl choleras, blackleg, and tetanus, with many more that are on the way toward perfection. It is claimed by some high in authority that the present great war will result in lengthening the average of human life by as much as fifteen years, by breaking down apathy and ancient prejudice and demonstrating the value of modern bacteriological science. Typhoid has been banished from our army by preventive inoculation. Let some pupil volunteer to look up the story of this and report to the class.

Asepsis, antisepsis, germicides, and paths of entrance to the body. Blood wells from a wound, carrying out the germs that may have entered, rendering it germ-free, or aseptic, and then it clots to seal it over. This is nature's primitive aseptic surgery. The saliva is somewhat antiseptic, and the acid 
genstric juice of the stomach is strongly germicidal, these being nature's provisions for turning the food over to the absorptive organs germ-free. Breaks in the skin and mucous membranes and the mouth are the great channels of entrance for germs, and the fact that there are so many preventable infections proves that under modern conditions of life nature's provisions need constant reënforcement. In normal breathing through the nostrils the gerins are caught before they reach the lungs, so that even pulmonary tuberculosis is coming more and more to be considered a mouth infection, reaching the lungs either by way of inflamed tonsils or by way of stomach, intestine, thoracic duct, and circulation.

When the rôle of bacteria in causing disease was first discovered, chemical poisons were sought which might kill the girms without quite killing the patient. Carbolic acid (phenol), mercuric chloride (corrosive sublimate), and formalin were the germicides first used most extensively, and the govesmment standard of efficiency, "the phenol coefficient," is the germ-killing power of phenol. Later came the delicate, specific, exact antitoxins and resistance serums that kill the particular germ and have no poisonous action on the cells of the body. Other nonpoisonous germicides, especially the hypochlorites, from general use in purification of drinking water and sewage, are being adapted to dairy, home, and personal use. Here oxygen is the active germicide, and the end products of the reaction are harmless calcium chloride in case of hypochlorite of lime, and, with sodium hypochlorite, sodium chloride, or common salt. ${ }^{1}$.

1 "Three grains of a practically harmless substance will kill the myriads o germs in a barrel of water. To do the same work with the poisonous corrosive sublimate would require at least one ounce, or of the equally poison0 is carbolic acid five pounds (p. 23).... Hypochlorous acid is one of the $\mathrm{n}$ ost powerful oxidizing agents known to chemists. The 'acid mixture' u ill, within a minute, kill spores which resist 5 per cent solution of carbolic a id for weeks" (p. 54). - Hooker, Chloride of Lime in Sanitation, 1913 
Keeping abreast of discovery. Bacteriology is a young science, and hundreds of students are pushing discovery forward so rapidly that we must "step lively" to keep up. Have committees of the class invite members of the state and local boards of health and public-spirited physicians to - come in and discuss their problems. Try to gain clear ideas of just those problems in dealing with which the community most needs to develop "coöperative good will," and make a test of what a biology class can do to help. No matter where it is, or how large or how small it may be, any community that can, by intelligent, united effort, demonstrate accomplished control of such infections as tuberculosis, grippe, common colds, pneumonia, diphtheria, typhoid, and summer choleras of infants, may "go to the head"; and the class of young men and women who help to attain this result will have a story to tell that the sick and tired old world has waited thousands of years to hear.

Problem summary. What do we mean by "clean hands"? Are our fingers generally clean enough to put into our own mouths or into the mouths of other people, that is, to handle our own food with and that of others?. Tests: Touch finger tips, unwashed and washed, to agar plates, incubate, and compare growths. To determine how many germs we may collect on the hands in a half-day's work, wash the hands without soap (cleaning the nails thoroughly) in two liters of sterile water. Inoculate a plate with 1 cubic centimeter, incubate, count colonies, and estimate total number. - Read "Dirty Hands and Typhoid Fever," American Journal of Public Health, Vol. IV (1914), p. 141.

Study conditions in local stores, bakeries, and candy shops. Are foods and confections that go directly into the mouth handled with the bare hands? Can you devise practical ways and means of doing away with all such handling?

Look up thoroughly hygiene of mouth, throat, and nose, and adopt a definite plan that shall insure perfectly sound teeth, uninfected tonsils or nares, and absence of adenoids. Arrange a campaign to see that ordinances against spitting in public places are obeyed. Report infractions to board of health. 
Let each member of the class work out one of the following problems in detail and present results to class: How would you plan to take sole care of a case of typhoid (to insure against catching it yourself or permitting it to spread to others)? of tuberculosis? of grippe? of pneumonia? of diphtheria? of dysentery? of erysipelas? of leprosy? of scarlet fever? of measles? of pellagra? of smallpox? (Refer to best available manuals for trained nurses.)

What precautions would you take if you were a typhoid carrier? if you were a diphtheria carrier? if you were infected with tuberculusis? if you had the grippe? if you had tonsillitis? if you had a cold? Is the Schick reaction used in your district to test immunity to diphtheria? Look up use of Widal reaction in detection of typhoid carriers.

Make out a complete list of diseases of man and other animals for which we have reliable antitoxins, vaccines, or bacterins. Discuss their lse in your district and get reports from those who have tested them. Jile this list in the laboratory and note changes and growth from year to year.

It is estimated that in 1914 diseases of farm animals caused damage to the amount of $\$ 212,000,000$. Can the class work out plans of coöptration by which any of these diseases may be brought under control ?

Compare the merits, for various purposes, of different disinfectants, intiseptics, and germicides on the market. Study especially the home ind dairy use of the hypochlorites. Get the reports on all these things from the United States Public Health Service, Washington, D.C.

Collect and discuss national, state, and local quarantine and health laws and ordinances.

Visit as many of the local dairies as possible. Obtain the official score cards from your dairy inspector and study the scoring he has given. Are the dairymen included in the scoring?

In the light of all you have learned about bacteria, discuss the problem of washing dishes properly. Should we banish the "common dishtowel" along with the "common roller towel." Make plate tests for numbers of bacteria in " dishcloths," in "dish-towels," in " dishwater," and on the dishes after different methods of washing and drying. How lo these tests compare with those made on dishes after actually boiling ior five minutes in the rinsing water? after treating with hypochlorite in rinsing water, without wiping?

It is being claimed that spread of infections in families, especially of colds, grippe, and tonsillitis, might be greatly reduced by sterilization of dishes. Can the class find a test for this in their own homes? 
¿ ¿

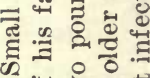

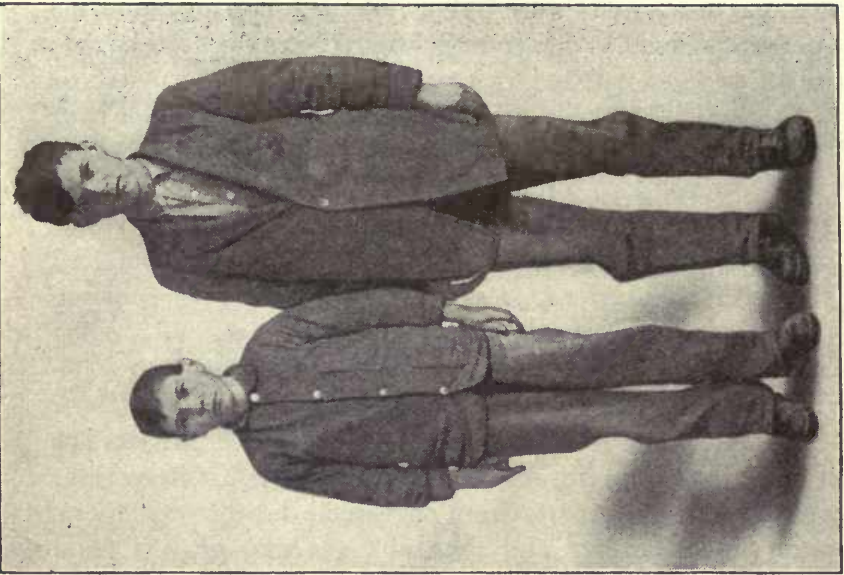

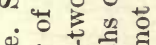

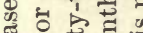

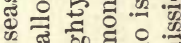

20.



के क्षे

式可曲?

중

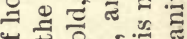

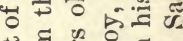

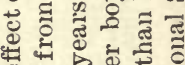

-

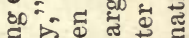

도월

胥 ช

:

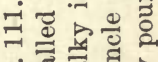

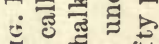

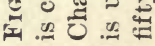
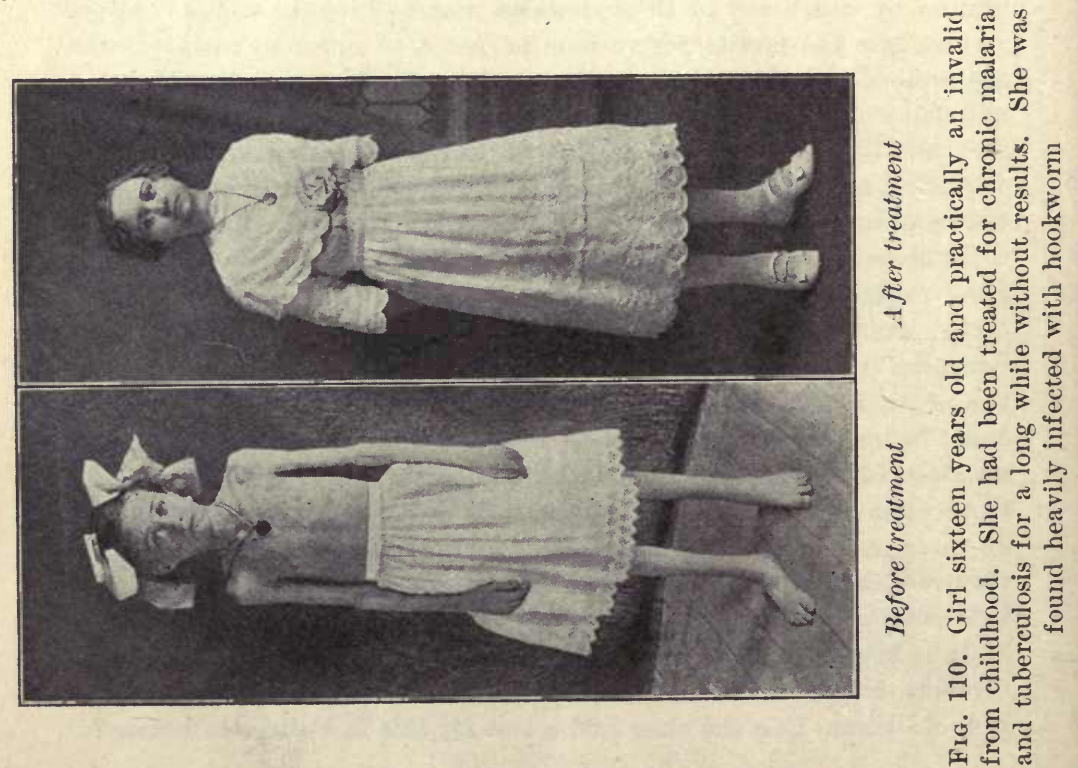


\section{CHAPTER XXIV}

\section{CONTROL OF ANIMAL PARASITES}

1. To what is hookworm disease due? Describe the worm. 2. What are the symptoms? 3. How is the disease spread? 4. Give the life history of the hookworm from the time the egg is laid until the worm is back in the intestine. 5. Can the disease be cured? Which is better, cure or prevention? 6. How can it be prevented? 7. Suppose you had charge of a hookworm patient, describe your treatment and precautions. 8. What can s chool children do to eradicate the disease in Essex County? - From a 'fuiz given in a Virginia high school

With this as a part of public-school work for boys and girls, one miglit he tempted to call the disease a blessing; for what else could have brought the old "education" on such a long journey toward common sense? Of course it will not stop with this particular subject. It will deal more and nore with the kinds of subjects that have to do with healthful living here and now. How whimsical Fate is, that we should be mightily helped to the ight kind of schools in the United States by an intestinal parasite that poisoned the Pharaohs!- Walter H. PAGE, "The Hookworm and Civilizaion," The World's Work, Vol. XXIV (1912), pp. $515 \mathrm{ff}$.

But that the mosquito bite not only annoys but may kill, by infecting the punctured tissues with the germs of malaria or yellow fever or filariasis, three of the most wide-spread and fatal diseases of man, - this alarming fact is a matter which has come to be really recognized only recently, and the general recognition of which has given to the practical study of insects an importance which years of warning and protesting by economic entomologists have been wholly unable to do. . . . In addition I may simply jay, when in malarial regions avoid the bite of a mosquito as you would that of a rattlesnake. One may be quite as serious in its results as the otler. - Kellowa, "American Insects," pp. 303, 630

Importance. The world over, it is quite within the range of possibility that animal parasites are sapping half the lifeblood and strength of the human race, and many other plant and animal species are similarly afflicted. This one parasite, the hookworm, belts the world between $36^{\circ}$ north 
latitude and $30^{\circ}$ south, influencing, more or less, the lives of $940,000,000$ people - more than half the population of the globe. "In Porto Rico the disease has reduced the average efficiency of the labor on the coffee plantations to 50 per cent of normal efficiency, and in some cases to 35 per cent." 1

Theory of control. Precisely the same argument applies to animal parasites as was developed in the preceding chapter with reference to parasitic bacteria. All must know the facts in order that each may be able to do his part for the safety of the whole community.

\section{A case in point is the following:}

The caretaker of an expensive pheasant farm was recently observed laboriously twisting the gapeworms out of the windpipes of his young pheasants and scattering them on the ground of his breeding pens. They were killing hundreds of his birds, but he did not know the life history of the parasite. It would have saved him time, labor, and worry, and cost him nothing, had he simply wiped them on a bit of newspaper and burned them.

It may be easy to prevent outbreaks of trichinosis, hookworms, tapeworms, malaria, yellow fever, and all the rest, as soon as each one knows exactly what to do to prevent multiplication and spread of the organisms.

Stiles's argument in regard to scattering hookworms applies to all infections. ${ }^{2}$ We have the parasites concentrated in the wastes of the patient, and we can kill them by the good old Hebrew "cleansing by fire," or with chemical disinfectants

1 Thus there is a distinct loss of 10 to 20 per cent in the wages and a corresponding loss in crop returns. In some places (this refers to our own South) I should estimate the loss at even a higher percentage, say an average of 25 per cent, while in several families which I have examined I should say that uncinariasis is reducing the laboring capacity, hence the productiveness, of the family to as low as 30 to 40 per cent, thus entailing a loss of 60 to 70 per cent. - C. Wardell Stiles, "Prevalence and Geographical Distribution of Hookworm Disease," Hygienic Laboratory Bulletin No. 10 (Washington, 1903), p. 96

${ }^{2}$ Stiles, loc. cit., pp. $93 \mathrm{ff}$. 
(chloride of lime), before they become scattered in sewage or water or in the soil, or are carried, no one can know where, by flies, earthworms, or other living agencies. This is an effective method and can be definitely worked into the habits and sanitary régime of every home, and will eventually free us from all dangerous infections; whereas the most intelligent and conscientious of us cannot possibly keep our hands clean enough, boil or filter all our drinking water, or consistently and always observe all the precautions necessary to prevent infection if the organisms are scattered everywhere in soil, water, and food.

Practical problems. The field is so vast and difficult, and knowledge is growing so fast, that the only course for the student to follow is to make connection with the best sources of information,- local boards of health and the scientific departments of each state and of Washington,- so as to keep abreast of important discoveries. In this way all will be able to help themselves and one another. Apply the quiz at the heginning of this chapter to all the parasitic diseases - of flants, animals, or man - of local importance. Braun ${ }^{1}$ has clescribed nearly 400 animal parasites of man - 31 protozoa, 40 flatworms, 43 threadworms, 39 ticks, and over 250 insects. The mere figures indicate how little we know about what is literally "eating" us most of the time. Our present knowltdge marks little more than a beginning, and in addition to liuman parasites other hundreds prey upon plants, and probably thousands upon other animals, domesticated and wild. We shall be able to suggest but a few types, and all the rest snay be studied along lines similar to those indicated.

Parasitic protozoa, Although discovery of protozoan parasites in the blood of animals began with the studies of Chaussat (1850) and Lankester (1871), and several others in the interim, it was the work of Laveran (1880) on the

1 Braun, The Animal Parasites of Man. 1908. 
parasite of malaria that aroused the scientific world to the possible importance of this subject. This was about the time Koch demonstrated the tubercle bacillus as the cause of consumption; but while bacteriology has made enormous progress, owing to definiteness of form and ease of culture of most bacteria, the growth of protozoölogy has been comparatively slow because it has been so difficult to distinguish animal cells in and among animal cells, and so hard, or impossible, to discover methods of cultivating the protozoan parasites in artificial media. Probably most infectious diseases the parasites of which are still unknown-smallpox, yellow fever, measles, scarlet fever, spotted fever, typhus fever, infantile paralysis, foot-and-mouth disease - are caused by protozoa.

Amœba of dysentery - Entameba histolytica. This parasite is said to have killed more northern soldiers during the late war than bullets. It is most active in the tropics, but is not rare in temperate zones. It is carried in drinking water and on vegetables that are eaten raw.

Rabies, or hydrophobia. The evidence, while not entirely conclusive, points to a protozoan present in the saliva of rabid animals as the cause of this disease. All mainmals are susceptible to the virus, which attacks the nervous system, following up the nerves from a bite or scratch of a rabid animal until it finally reaches the brain. The animals transmitting the infection, in order of decreasing severity, are the wolf, cat, dog, skunk, and other domestic animals. In case of a suspicious bite the brain or head of the animal should be immediately sent to a physician or to the nearest laboratory, where the organisms, known as negri bodies, can be quickly demonstrated, if present. As it requires from fourteen to sixty days for rabies to develop in man, there is time for the patient to reach a Pasteur institute for treatment, if the examination indicates that the germs are present. Spread of the disease is prevented by muzzling and confining dogs when there is danger of an epidemic, and it should be more generally understood that control of cats may be equally important.

Parasites of malarial fevers - Plasmodium vivax, $P$. malaria, $P$. immaculatum or falciparum. The malarial sporozoa are a group of parasites that have thrown a girdle around the earth wider than that of the hookworms, 
- from $40^{\circ}$ north latitude to $40^{\circ}$ south, - rendering many of the most fertile valleys uninhabitable. Manson declares that malarial parasites caitse more death, and more predisposition to death from other causes, thin all other human parasites taken together. Howard estimated (in 1909) that they caused $3,000,000$ cases of malaria and nearly 12,000 deaths annually in the United States, and actually imposed a yearly tax upon this country of not less than $\$ 100,000,000$.

The malarial parasite is carried to man by the bite of an anopheline musquito. 'The minute vermicules, or sporozoites, enter the red corpuscles and grow until the substance of the corpuscles is absorbed, when they divide asexually into, generally, from 16 to 24 spores, merozoites. These burst ont of the corpuscles, and this, probably on account of their poísonous waste products set free in the blood, causes the "chill." While thus unprotected in the blood plasma the parasites of our common, temperate-zone malarias ( $P$. vivax and $P$. malarix) may be killed by heavy doses of quinine. The parasites of the malignant malarias of the tropics are not affected by this drug. Our common malaria is caused by $P$. vivax, which passes through its life cycle in the blood every fortyeight hours - the usual time between chills. This is also known as tertian malaria. Quartan malaria, the other temperate-zone type of the disease, caused by $P$. malarice, which requires seventy-two hours to complete its life cycle, is characterized by chills every third day. S.me authorities distinguish two types of malignant tropical malaria, the quotidian, in which the parasite completes its asexual life cycle in twenty-four hours, and the tropical tertian, in which the cycle is forty-eight hours. All these parasites multiply sexually within the anopheline mosquitoes.

Reasoning from the above data, we see that there are three ways by which malaria may be banished from a locality: 1. Exterminate the mosquitoes (see Chapter XI). 2. Prevent the mosquitoes from biting healthy people. 3. Prevent mosquitoes from becoming infected by biting malarial patients. As soon as every responsible member of any community becomes able to grasp these simple facts, that community may free itself completely from the most vicious blood parasites that afflict mankind.

The Piroplasmas; Texas fever, or bovine malaria. While the cattle tick acts as carrier, the parasite of Texas fever is Piroplasma (Latin firus, "a pear") bigeminum, which attacks the red blood cells of cattle. Jick extermination is banishing this costly parasite from our Southern states (see Chapter XV). Horses, sheep, dogs, and other animals 
have malaria-like diseases caused by different species of the genus Piroplasma - P. equi, P. ovis, P. canis, etc.; and birds, frogs, turtles, and many other animals serve as hosts for blood parasites of other kinds.

Yellow fever. No one has been able to demonstrate the parasite of yellow fever, although many investigators have hunted for it diligently. It is so small that it passes through the pores of a Berkefeld filter and is therefore supposed to be too small to see with a microscope. This may be true, or the organism may be soft and elastic enough to squeeze through the pores of a filter, and so transparent and unstainable that no one could recognize it in the field of the microscope. It is generally agreed that the organism is a protozoan, because it is proved to have a life cycle in a certain species of mosquito (Aedes calopus, formerly named Stegomyia fasciata) and is transmitted solely by its bite. It has been transmitted experimentally by injecting into nonimmunes a few drops of blood (or the serum of such blood after passing through a Berkefeld filter) drawn from yellow-fever patients during the first three days of the attack. After filling with yellow-fever blood the mosquito is not infective for at least twelve days, indicating a definite life cycle, and then the mosquito remains infective as long as she lives - fifty-seven days in one case. (For discussion of this topic in relation to mosquito extermination see Chapter XI. ${ }^{1}$ ) Few stories of discovery are more instructive or fuller of inspiration and hope for the future than this work upon the cause and prevention of yellow fever. Will some member of the class volunteer to look it up and report?

Smallpox. This is clearly a parasitic disease, the germ of which has eluded discovery, as have the organisms that cause measles and scarlet fever-epidemic disorders of the same class. We have, however, gained control of it by vaccination. About 1770 Edward Jenner happened to hear a woman say: "I can't take smallpox, because I have had cowpox." The idea was common at the time in several countries. Jenner studied the problem of immunity among the dairymaids for twenty-six years. On May 14, 1796, he made his first experimental vaccination, upon James Phipps, son of one of his friends. On July 1 he vaccinated James again with virus from a case of smallpox, at the same time vaccinating a

1 Sternberg, "The Transmission of Yellow Fever by Mosquitoes," Popular Science Monthly, Vol. LIX (1901), p. 225 ; Kelly, Walter Reed and Yellow Fever, New York, 1907 ; McCaw, Walter Reed Report, Smithsonian Institution, 1905, p. 549. 
nonimmune man with the same virus. The man took smallpox as usual; James did not. Crude methods at first, making inevitable mixed inoculitions with other germs, raised violent objection to vaccination, but at that time the disease itself was so much more serious than any such complications, that the practice spread rapidly over the world. Modern bacteriological methods have made the virus safe, so that countries like Germany, in which vaccination under two years, with revaccination between ten and twelve, is compulsory, have reduced smallpox to the vanishing point. In England, however, the old opposition has persisted, and this has resulted in many serious local epidemics. The same is true of our own country and Canada. A new difficulty has also arisen. The disease has been so nearly exterminated that even the most conscientious people are saying: "Why vaccinate our children against a disease to which they will never be exposed?" This argument is sufficiently answered by the many local epidemics of recent years. Study carefully the history of at least one such epidemic. ${ }^{1}$

No less than eighteen other cities and towns in New York State, and several more in other states, were infected with smallpox from Niagara l'alls in 1914, and Canada was obliged to quarantine against the city. Is it right for one person, or one city, to endanger the safety of others in this way? Look up the prevalence and mortality of smallpox, and Itethods of "inoculating" from mild cases, before 1800, and compare with present conditions. Study also the story of the introduction of smallpox into America by the Spaniards. It is said to have killed $\because, 500,000$ natives in Mexico.

The trypanosomes (trypanon, "auger"; soma, "body"). This genus ('ontains about sixty known species, which live as free-swimming parasites in the blood plasma of many vertebrates, from fishes to man. Their \}rimary hosts are probably bloodsucking flies, which, at any rate, act as (arriers. Surra, a disease of cattle, horses, and camels in India and the Philippines, is caused by $T$. evansii; and nagana, or tsetse-fly disease, which long made impossible the introduction of European cattle, horses, and sheep into East Africa, is caused by a similar blood parasite, l. brucei. Nearer home a serious disease of horses, dourine, long known in Europe, and more recently reported from western Canada, is caused hy T. equiperdum. This forms a notable exception among diseases of this class in being spread exclusively by breeding, and has no known connection with biting insects.

1 Dr. L. R. Williams, "Smallpox Epidemic at Niagara Falls," American Tournal of Public Health, Vol. V (1915), p. 423. 
Trypanosoma gambiense, which has long been the scourge of the west coast of Africa and is now spreading rapidly up the Congo, is the parasite of sleeping sickness in man. It is found in the blood of a number of native animals and is carried to man by the bite of one of the tsetse flies, Glossina palpalis.

The flatworms, flukes, and tapeworms - Platyhelminthes (platys, "flat"; helminthes, "worms"). The flatworms comprise a group of diverse forms which vary in size from

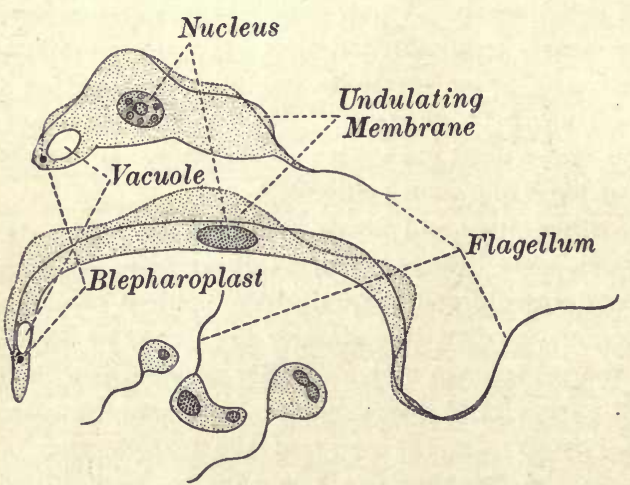

Fig. 112. Trypanosoma gambiense, from a case of sleeping sickness, different forms

After Manson almost microscopic flukes to tapeworms 60 feet in length. Two large classes, the trematodes (to which the flukes belong) and the cestodes (to which the tapeworms belong) contain only forms that are parasitic on or in other animals. Two hosts are commonly required for one of these parasites to complete its life cycle, which depends on the practice, common among animals, of eating one another raw. So, in parts of the world where fish, pork, beef, and other meats are commonly eaten raw, man comes in for his full share of these parasites. People with raw-flesh-eating habits, coming to us from the ends of the earth, bring their internal pets with them ${ }^{1}$ and proceed to take up a collection of American forms. The eggs are minute, and flies swallow them and

${ }^{1}$ A tapeworm has been known to live in man for thirty-five years. BRAUN 
pass them uninjured or may carry them to human foods as dust on their feet-eggs of eighteen worm parasites have been found on or in flies. It is estimated that a tapeworm produces 12,000,000 eggs a year, and the flukes may be equally prolific. Such powers of reproduction demand a number of different hosts, or host and parasite would die trigether. One authority states the problem thus:

If a liver fluke were to deposit its million or so of eggs in the bile ducts of the sheep, and these were to develop in situ, the host could not withstand the increased drain upon its vital resources, and host and parasites would perish together. Hence it is clear that the infection of a second host by trematodes is highly necessary.

So, while many of the bacterial parasites "don't know any better" than to kill their hosts outright,

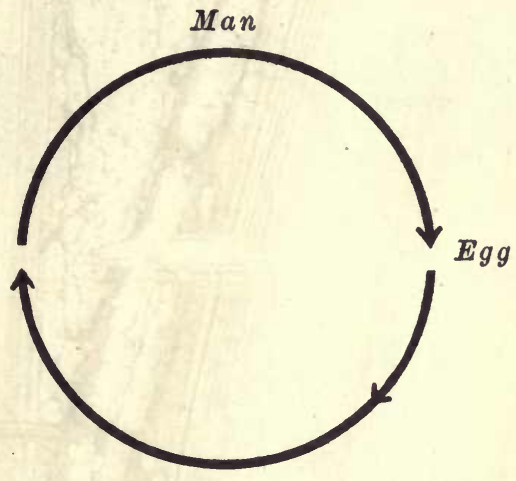

Bovine (cysticercus)

FiG. 113. Life cycle of human tapeworm; infection from raw beef these animal parasites, as a rule, sap and drain slowly and are the cause of prolonged misery rather than of death. Reasonable cleanliness in rearing of farm animals, proper inspection of meats, and, above all, proper cooking of meats on the part of everyone will finally relieve us from these disagreeable pests. The life history of one or two types should be generally known, and any of the following that nay be of local interest should be worked out to practical conclusions in nature and in the books.

Liverfluke - Fasciola hepatica. The adult is most commonly found in the liver of the sheep, but may occur in the horse, deer, camel, antelope, goat, pig, rabbit, kangaroo, beaver, squirrel, and, rarely, in man. 
The eggs pass out through the bile ducts and hatch into minute, freeswimming embryos (the miracillia), which bore into fresh-water snails. Within the snail the parasite derelops into a sporocyst, which produces still another form of the worm, known as the redia. The redie, in turn, produce asexually other redia or still another form (the cercaria). The

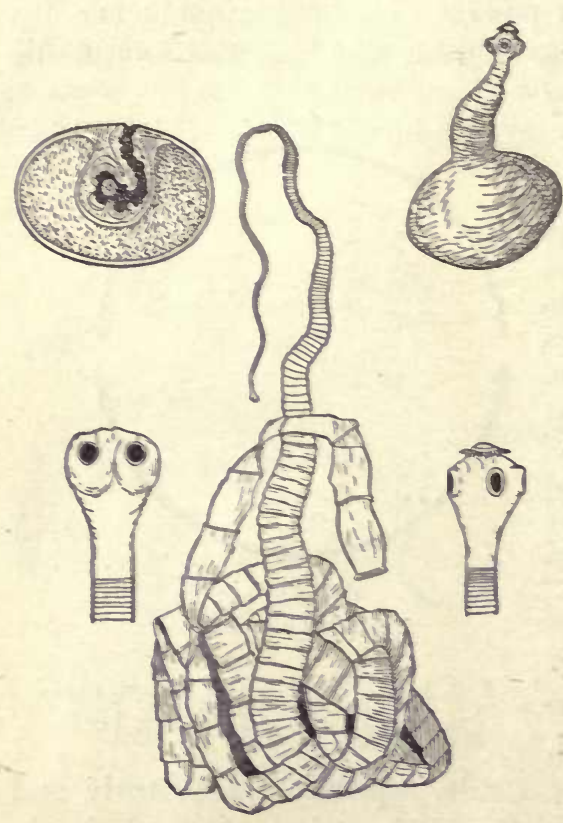

Fic. 114. Tapeworms cercariae are tadpole-shaped, and, passing out of the snail, swim about in the water until the tail drops off and they encrst upon the leares of plants. Here they are eaten by animals and make their way up the bile ducts, and so the life cycle is repeated. The adults in the liver are hermaphroditic. A large species (Distomum magnum), probably imported from Italy, may beconre a serious obstacle, especially to sheep-grazing, in portions of the West. The main remedy is aroidance of low pastures during wet seasons.

Tapeworms - cestodes (cestos, "a girdle"). An idea of the general form of a common tapeworm, adult and bladder stages (eysticercus), is giren in Fig. 114. In the adult the head is a small knob provided with four snckers and a circlet of hooklets. This head has no mouth or sense organs, but serves merely to anchor the worn to the wall of the intestine. The neck is the short, nnsegmented portion close to the head, and behind this the characteristic segments begin to form. These grow by absorption of the digested food through the skin; hence there is no need of digestive organs, the entire contents developing practically into reprodnctive cells, eggs, and sperm; and finally the joints (proglottides) break off and pass out, containing each its many thousands of minute fertilized eggs. In 1861 Lenckart 
fei the ripe proglottides from man to ealres, and was thus able to discoper how man acquires this tapeworm from eating measly beef. The tiuy egr hatches in the stomach of the con, burrows through the wall of the intestine, and in from three to six months has growu to a bludder, or eyst (the cysticercus), the size of a small bean, and is then foand in the muscles. After the cysticereus passes through the human st masch, the head everts (pops out like turning a glove-finger), bringing the hooks and suckers to the ortside; these anchor in the intestine and begin a new life cycle. While the beef tapew orm (Ternia saginata) may ce use some irritation, and undrubtedly steals some digested frod, it seldom does serious in jury. This is due to the simple fact that its eggs cannit hatch and pass into eystiarrei in the muscles or other o yauns of man. The cysticer$c$ is stage is confined closely to cottle, and the adult stage as c osely to man. The eggs of sere al of the other species do, howe rer, develop cysticerci in man, w hich renders them much more

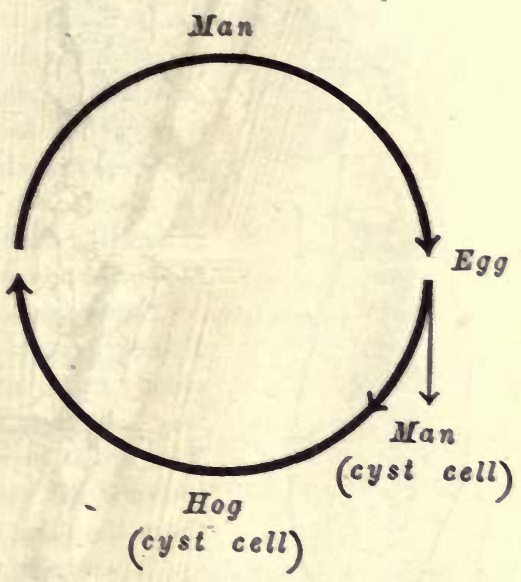

Fic. 115. Life cycle of pig tapeworm ; infection from uneooked pork dangerous and sometimes fatal.

The pig tapeworm - Tania solium. This parasite is distributed the v orld over, wherever the pig is raised and eaten raw or rare. It is found a iso in the wild boar, sheep, deer, dog, eat, bear, and monkey. The eggs and newly hatched.embryos (oncospheres) are microscopic, the latter only 0.02 millimeter in diameter - so small that they are easily carried t , foods on dirty hands, eaten with polluted regetables, or even swalI nwed by flies and earried to foods anywhere. These eggs, if swallowed, $r$ tay find their way to any part of the body - muscles, eyes, brain, and eren heart, and there become crsticerci. These, too, are large (6-20 milli1 leters long by 5-10 millimeters thick), so that even one may prove fatal. 1 a expelling this tapeworm great care must be used to aroid causing nau$s \approx$, for a single ripe proglottis, forced back into the stomach and releasi ag its myriad embryos, would leave little chance for a patient's recovery. 
Tapeworms of the dog - Tania echinococcus. Unfortunately our faith$\mathrm{ful}$ friend has been found to harbor twelve different species of tapeworms. The most dangerous of all is $T$. echinococcus, which has a different life history and mode of growth from those just described (see Figs. 116, 117). The adult worm is minute (from 2.5 to 6 millimeters long) and occurs only in the dog, wolf, and jackal, often in enormous numbers. The. cysticercus stage is found in twenty-seven different mammals, including

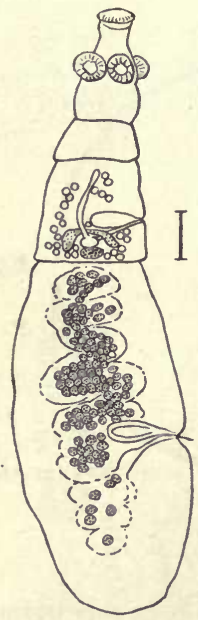

FIG. 116. Dog tapeworm ( $T$. echinococcus), twenty-five times natural size

After Braun man. Instead of forming a cyst with a single scolex, or head, this worm forms a cyst that may grow for several years, to the size of a goose egg or even a " child's head," and its wall forms numbers of vesicles which may develop hundreds of scolices. Dogs infested with this tapeworm should be mercifully killed and cremated, and dogs, generally, should not be permitted to lick the face or hands or to eat out of dishes used by man.

Tapeworms of fishes - Dibothriocephalus latus. Fishes harbor a number of tapeworms, which, chiefly in oriental countries, naturally find their way into men, who consider raw fish a delicacy. The broad tapeworm, D. latus, is found in the muscles of various fresh-water fishes, among them the pike, salmon, and perch.

Tapeworms vary in size from almost microscopic to ribbons half an inch broad and many feet in length, but this signifies little. The rate of growth for $T$. saginata and D. latus has been determined as 7 centimeters and 8 centimeters per day respectively. At this rate, in thirty-five years a broad tapeworm might grow to be 3406.6 feet in length.

\section{Roundworms (nematodes) and threadworms (nemathelminthes)} (nema, "thread"; helminthes, "worms"). These worms attack plants, all sorts of animals, and man, and are the real terrors among vermian parasites. One species, Heterodera radicicola, has been found infesting the roots of four hundred and fifty different plants, the list including all garden-truck crops, many field crops, and a great variety of fruit trees, ornamental trees, shrubs, and flowers. They infest greenhouses 
everywhere, often destroying entire crops and making it necessary to sterilize the soil with live steam or to remove all the earth frequently and disinfect the benches. In the south they are often most serious pests of outdoor garden

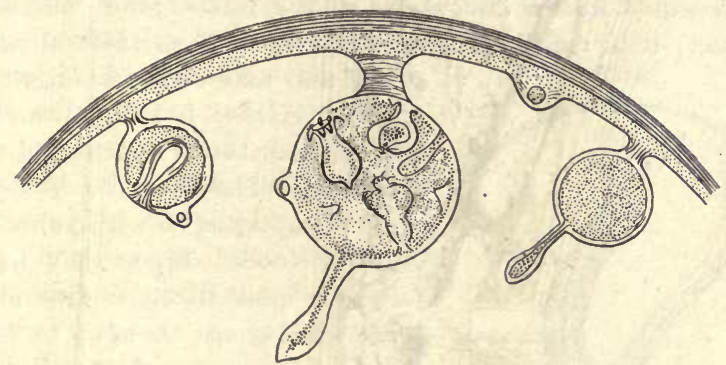

Fig. 117. Portion of cyst wall (T. echinococcus)

After Braun

and field crops. This whole side of plant injury, however, we must leave for interested pupils to work up, with the aid of their experiment stations. ${ }^{1}$

General characters. Familiar nematodes are vinegar eels, hair snakes, and the large, round worms so common in dogs, horses, and man. As seen from these examples, they vary from microscopic size to 1 or 2 feet in length. Many are free-living in water (marine and fresh) or in damp ground, but great numbers are parasitic. The life cycle of parasitic

${ }^{1}$ Nematodes bore into the roots and cause worm-swellings, galls, and knots. The plants most seriously attacked (Schofield) are beets, carrots, celery, cucumber, eggplant, lettuce, muskmelon, watermelon, clover, cowpeas, rape, soy beans, catalpa, cherry, elm, and peach. They are most often distributed in nursery stock and seed potatoes, which should be most carefully examined for them before planting, especially strawberry and tomato plants. - See Bessey, "Root-Knot and its Control," Bulletin No. 21\%, Bureau of Plant Industry, United States Department of Agriculture, 1911; Schofield, Bureau of Plant Industry, United States Department of Agriculture, Circular 91; and Cobb, Yearbook, United States Department of Agriculture, 1914, pp. 457-490 (19 illustrations). 
forms may be direct (that is, worm, egg, worm in the same host). or it may require two or even three hosts for its completion. The sexes are usually distinct. Typical nematode parasites are

Roundworm - Ascaris lumbricoides. This is the most common parasite of man; it is reddish-yellow, resembles the earthworm in general

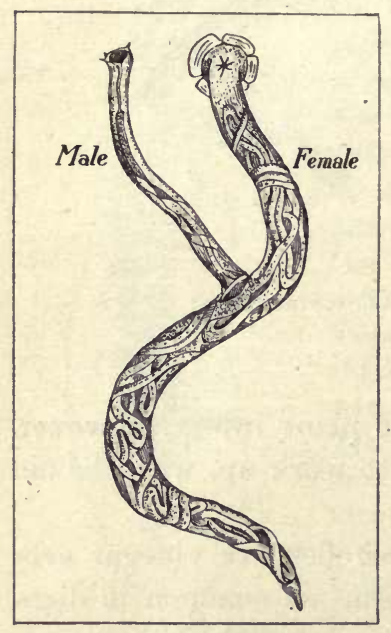

FIG. 118. Gapeworms, female with small male attached shape, and may attain a length of from 12 to 15 inches. It lives in the small intestine, and, being unattached, is easily dislodged. The life cycle is direct, the eggs being taken in with polluted water or dirty foods. Since they have been found to pass through flies uninjured, these insects are thought to be one of the active means of distributing the eggs to human foods.

Pinworm - Oxyuris vermicularis. This is a minute nematode, from 4 to 12 millimeters long, that affects children the world over. Its life cycle is direct.

Gapeworm - Syngamus trachealis. The habitat of this parasite is the trachea or bronchi of birds. The male is smaller than and permanently attached to the female, and the eggs are not laid, but are set free by the disintegration of the mother in the soil. Here they hatch in about a week, in warm weather, the embryos are picked up by the birds, and the direct life cycle is repeated.

Trichina worm - Trichinella spiralis. The presence of this parasite in man causes the well-known disease trichinosis; and our constantly recurring epidemics prove that, with all the publicity given to the matter, we have not reached a solution of the problem. Has proper attention been directed to extermination of rats from premises where swine are raised?

The course of infection is indicated in Fig. 119. The adult worm, the size of a very fine hair 2-4 millimeters long, lives in the wall of the small intestine, where the female gives birth to from 1000 to $1500^{1}$

1 The Cambridge Natural History (Vol. II, p. 146) estimates 12,000. 
living young about 0.1 millimeter long. These burrow their way, or sure carried by the blood, into the muscles, where they feed actively and grow rapidly. They go to all parts of the body, but gather in greatest numbers in the respiratory muscles, intercostals, and diaphragm. The females live and produce young in the intestine for from five to seven weeks, and the first young begin to reach the muscles in nine days after infection; hence the disease is proJonged, and, from the nature of the :ttack, is extremely painful. After thus feeding in the muscles for an indetermined time the full-grown larva encysts (Fig. 120) and may live for years (thirty-one in man, accordjng to Braun) or until the flesh is taten raw by some other animal, when the life cycle is repeated. The rat is continually eating its fellows, and since this is the most common host of the parasite, infection of these pests is continuous. The pig eats the lead rats, or the cysts in filthy sties get into its food, and so it becomes a common host. Cats, naturally, are often badly infested. Cooking all pork thoroughly is the safeguard of man, but we should always remember the dish of spaghetti and the typhoid epidemic (p. 242), and realize that the center of a roast, a pork chop, or a cake of fried sausage may
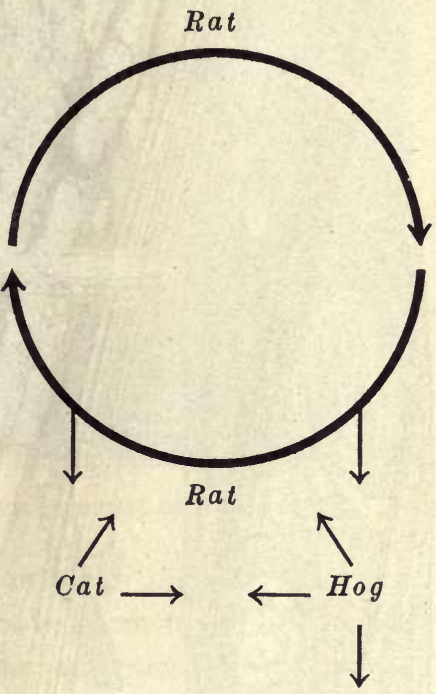

Man

Fig. 119. Life cycle and hostrelations of trichina worm be scarcely warmed through when the outside is browned to a crisp.

Here is a fine problem in civic biology. In connection with rat extermination, why not examine the diaphragms of all rats and mice killed, and tabulate and plot on a map the results obtained? Then examine diaphragm and intercostal muscles of all hogs slaughtered in the district, and tabulate and map the results. Placing this map over the other, note whether there is more trichina in the hogs where rats are numerous and badly infested. File all these maps and tabulations in the school library, so that when the rats and mice are exterminated, the next year's class can examine the pork and thus record progress. 
The first school able to report complete freedom from this parasite should write up the story for the benefit of other communities. This one job might be worth the total cost of the public schools in some communities.

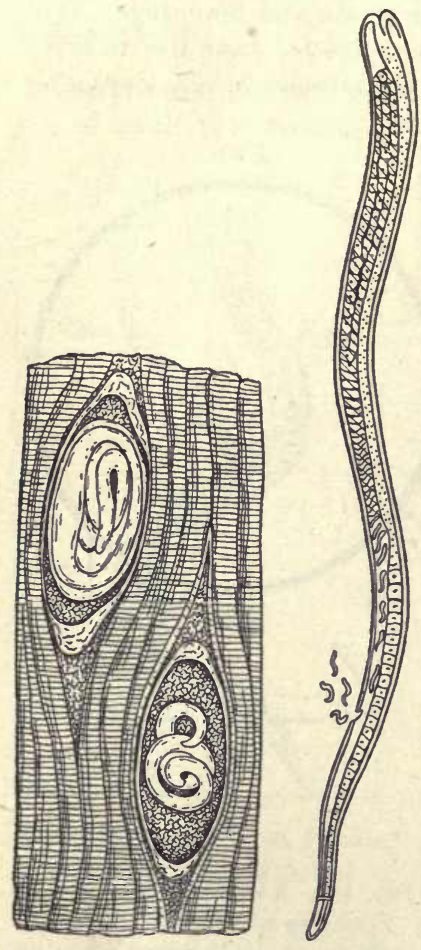

Fig. 120. Trichina worm embryo cysts in human muscle and adult female from intestinal wall

After Leuckart

Hookworm disease, uncinariasis Uncinaria americana. It only remains to add a word as to life history and mode of infection. The adult worms live in the small intestine, where they gnaw holes in the lining membranes and suck blood. Besides this the patient is likely to bleed badly from the wounds. How long the adults may live in the intestine, if the case is not treated and no new infection occurs, is stated by Stiles to be certainly six and a half years and probably from ten to twelve years. With this rich food supply, eggs are produced in great numbers. These hatch in about twenty-four hours and feed and grow in the soil for about five days. The microscopic embryos may then be swallowed with polluted foods or water (carried to foods especially by flies), or, on coming in contact with the skin, most commonly of bare feet, they bore in, causing "ground itch," and make their way to their final destination in the intestine. Stiles says that the embryos live in the soil "probably eight to twelve months."

This is a sectional problem, and every school (especially every high school) in the South should have in its school library the latest information obtainable from the Rockefeller Sanitary Commission for the Eradication of Hookworm Disease, ${ }^{1}$ and also the bulletins of the United States Bureau of Public Education, notably Bulletin No.20, "The Rural School and Hookworm Disease," Washington, D.C., 1914. Knowledge is growing so fast that the latest and best should be secured from year to year.

1 Address, Washington, D.C. 
While the study of these parasites of disease may seem lisagreeable at first, where cain we find keener inspiration than in the thought of their control by human coöperation

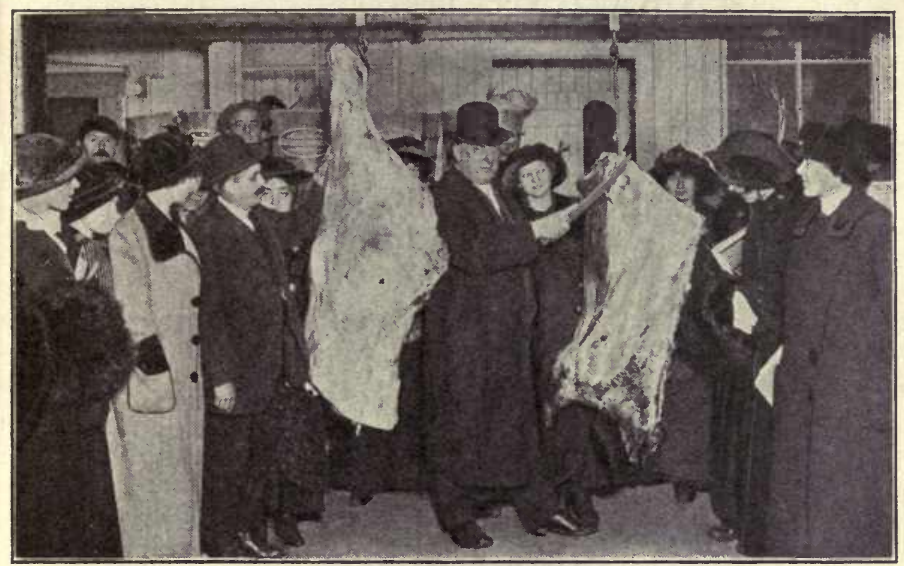

Fig. 121. Class with state inspector; meats in cold storage

and intelligence? By this road only ean mankind free itself from these time-old and world-wide tormentors and sappers of human life. So may even the parasites of the Pharaohs help to teach us lessons in coöperative good will. 


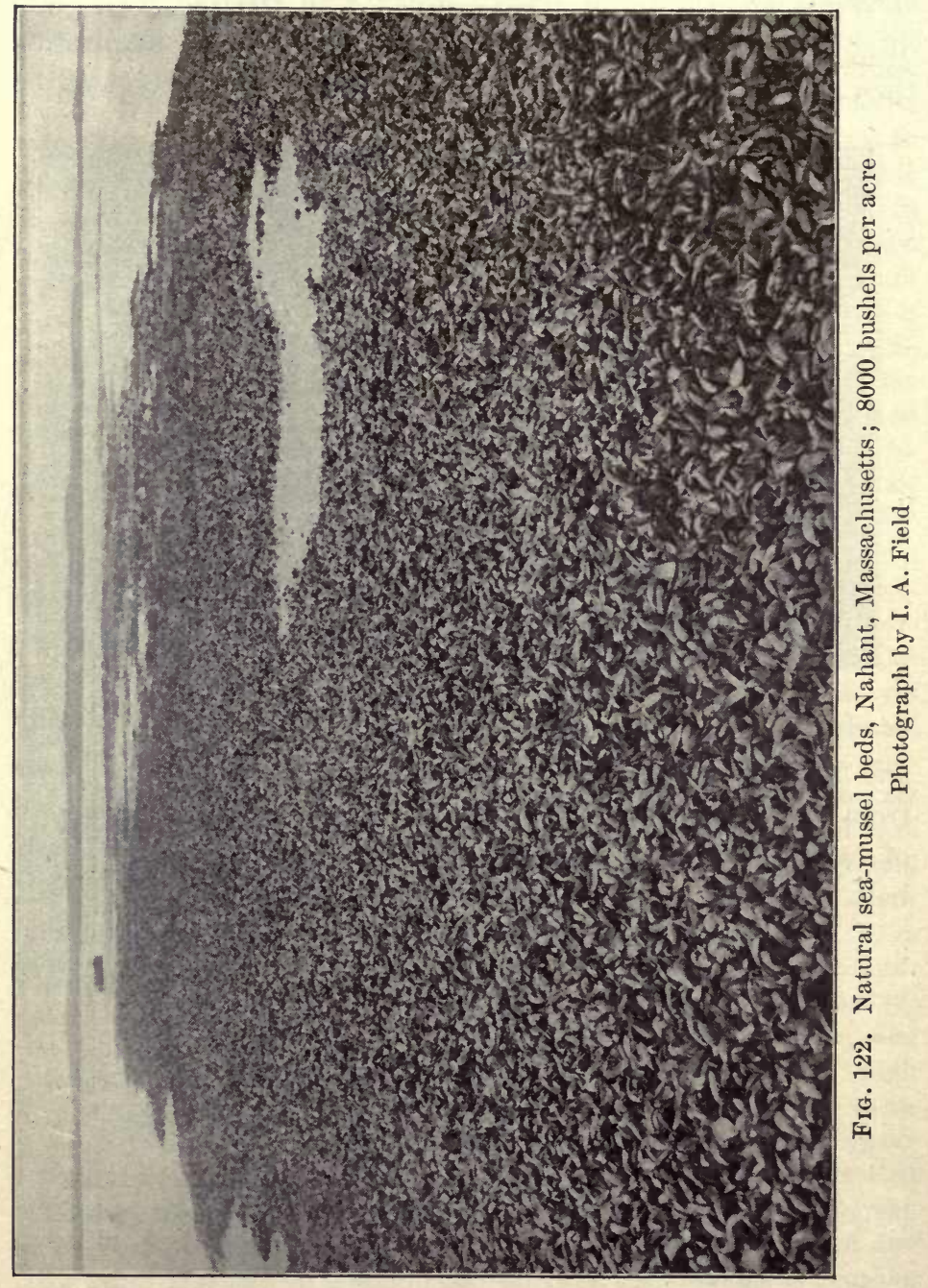




\section{CHAPTER XXV}

\section{CIVIC PROBLEMS RELATING TO MOLLUSKS}

It is doubtful whether there is any farming land in the United States which yields as great a profit to the acre as the bottoms which are used for oyster-planting in Rhode Island.- W. K. Brooks, "The Oyster," p. 135

The sea mussel (Mytilus edulis) is one of the most important food resources of the ocean, and as yet France, Belgium, and Holland are the only nations that appreciate its real food value. No shellfish grows so rapidly and abundantly. Natural beds often contain as many as 8000 bushels to the acre, and planted beds yield at the end of three years from 4000 to 6000 bushels per acre. At present prices this means from $\$ 1600$ to $\$ 2400$ per acre every three years.

The high nutritive value and low cost of sea mussels make them the most economical shellfish on the market. The same money will buy four times as much food in mussels as if spent for long clans, and ten and twenty times as much as if invested in oysters and lobsters respectively. They are also most palatable and easily digested. As these facts come to be better understood it is hoped that the American people will no longer neglect this vast source of food supply, but convert it into the wealth of the nation.IRVING A. FieLD

Possibilities of marine food supply. "Four feet square of the ocean is capable of producing food enough to support a human being." 1 This statement, made in a public lecture by an eminent authority, may seem incredible, but it may also serve to indicate that we have scarcely begun to realize the wealth of life in the waters. Of the 518,900 species of animals known, 61,000 are mollusks, almost all aquatic. In regard to how many of these do we know anything? Oriental peoples utilize a considerable number of them, and Europeans, since remote antiquity, have feasted upon delicious mollusks, common but unknown to us.

${ }^{1}$ Statement by Major McGee in an address at the University of Wisconsin, 1892. 
Sea mussels. These most abundant mollusks of our coasts might supply the soup and fish courses for every dinner in North America without strain upon their reproductive possibilities. How many have ever heard of them? How many have tasted them in prime condition, or even at all? Some may have heard from irresponsible sources that sea mussels are poisonous. So are oysters or clams that are taken from sewage-polluted waters or that are dead and half decayed; and

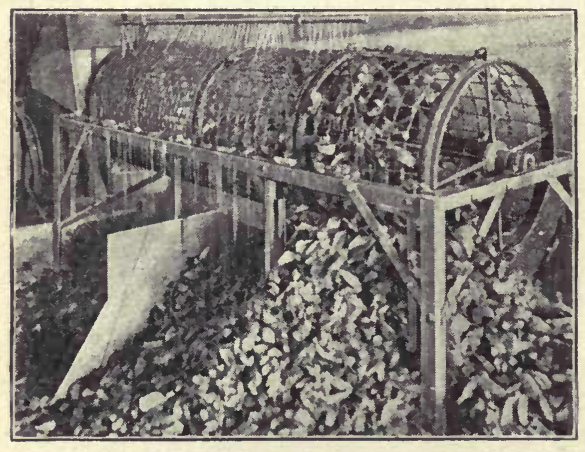

Fig. 123. Cleaning sea mussels commercially Photograph by I. A. Field stale lobsters, crabs, chicken, veal, and even milk may be poisonous. "Mussels taken from pure water which has free circulation have never been known to produce injurious effects. A New York dealer who has been selling mussels for years has never known of a case of poisoning from them. Nevertheless, too much emphasis cannot be laid on the fact that care must be exercised in choosing proper localities for the cultivation and collection of mussels for market. They must be sold to the consumer in a perfectly fresh condition or serious results will be likely to follow." 1

It would be an interesting problem for any community unit to figure out its aquatic resources and possibilities, analyze the different elements, and estimate the percentage of present utilization. For the United States as a whole this is roughly attempted in the following table.

${ }^{1}$ Irving A. Field, "Food Value of Sea Mussels," Bulletin No. 742 of the United States Bureau of Fisheries, 1911, p. 125. 
Amount and Value of Molluscan Products in the United States ${ }^{1}$

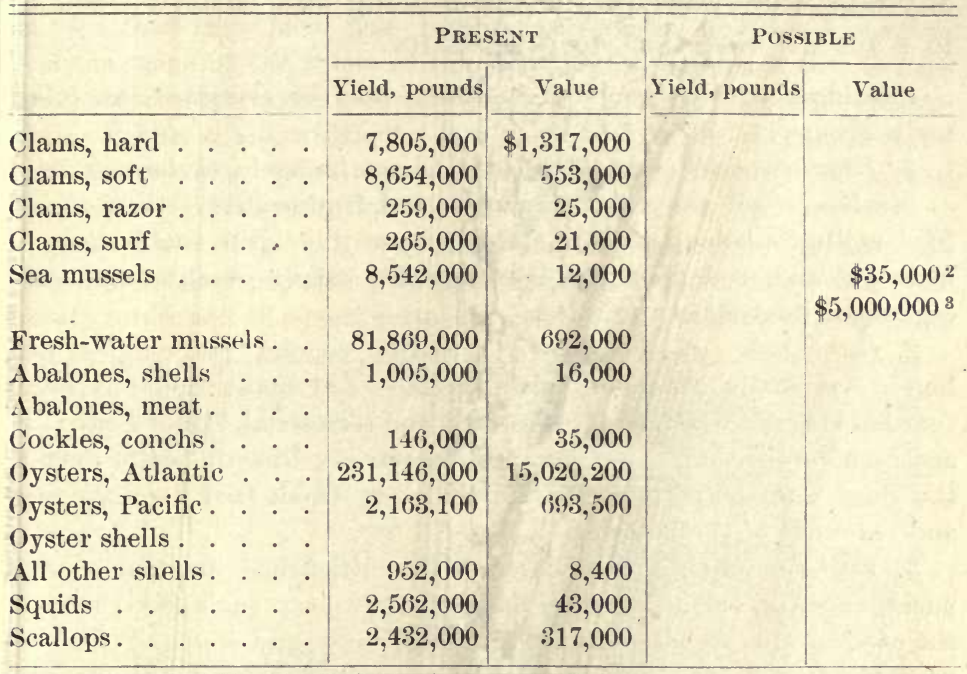

'The most instructive factor in such problems is likely to be the causes that work to depress actual below possible resources. Here we shall find ignorance of values, lack of knowledge as to life history of forms and hence of practical means for development, and, above all, in any development of aquatic resources, the old, uncivic spirit of piracy, handed down from the times of natural oyster beds, which still holds that anything whatsoever under water belongs to the one who can get it. "Oh yes, this is a fine location for oysters, and I did go to considerable expense and planter a lot, but

${ }^{1}$ Statistics furnished by the United States Burean of Fisheries for 1908. At present the Bureau cannot supply any estimates of possible yields. Fill out the table and keep it up to date as figures become available. Make a similar table of actual and possible yields for local waters.

2 Dr. Field's estimate of value of sea mussels produced in 1915.

${ }^{3}$ Dr. Field's estimate of possible value of sea mussels produced in any one year. 
I never got an oyster. As soon as they grew to amount to anything the oyster pirates came along and cleaned them up in a night. So I had to give it up." 1

Classification. Our common mollusks may be classified into three main groups :

1. Lamellibranchs (lamella-gilled): Clams, mussels, oysters, scallops, - bivalves, - all are aquatic (marine and fresh-water). All the great food mollusks belong in this class, because their gills enable them to filter out and feed upon the inexhaustible supply of algæ and other organisms floating in the water.

2. Gastropods (stomach-footed): Snails, conchs, periwinkles, abalones, - typically coiled univalve shells, - and many shell-less forms (garden slugs) are marine, fresh-water, and terrestrial. Most gastropods are carnivorous, but a number are vegetarian, like the edible snails, the slugs, and the periwinkles and abalones, which feed upon the algæ and seaweeds of the bottom.

3. Cephalopods (head-footed): Squids, cuttlefishes, devilfishes, octopuses, nautilus, are all marine, the molluscan over- (or under-) lords of the ocean. The cephalopods are all carnivorous, and many of them are used for food by oriental peoples. Our common squids, used now for fish bait, are good food mollusks.

Typical problems and life histories. While schools along the seacoasts have the advantage, the mollusks of our rivers, lakes, and ponds, and even of our woods and gardens, offer problems of no mean interest.

Oysters. Ostrea virginica is the native oyster of the Atlantic coast from Cape Cod to the Gulf of Mexico. It has the reputation of being the finest edible oyster in the world. A small, starveling variety, the "coon oyster," forms extensive natural beds throughout the salt-marsh sedges and mangrove swamps of the Southern states. A small but delicious species, $O$. lurida, is native to the American Pacific, and young $O$. virginica, since 1870 , have been shipped across the continent to grow and fatten in the favored coves of the Pacific coast. Almost the entire Pacific coast line, however, from Puget Sound to Mexíco, is a waste of desert sand, unindented and open to the ocean front, with line after line of huge beach combers out as far as the eye can reach - terrific instead of "pacific," and not at all suited to the oyster. The United States Bureau of Fisheries has made repeated experiments in colonizing Atlantic oysters in favored places along the Pacific, but,

1 Experience of a shore owner on the Chesapeake. 
while they evidently find food and conditions generally favorable to rowth, there has been difficulty in getting them to spawn. It is claimed that they have now become acclimated and are spawning treely in some of the inlets of the Washington coast. If this is true, such oysters ought to be used exclusively for seeding all available coves of the Pacific coast, which are few at best. To use them otherwise, until this is done, would be monumental folly. Pacific-coast schools should give special attention to this problem.

Ostrea edulis is the native oyster of the European Atlantic, and, like O. lurida, is hermaphroditic, while $O$. virginica is bisexual. For a community interested in oyster culture a good topic would be a comparison

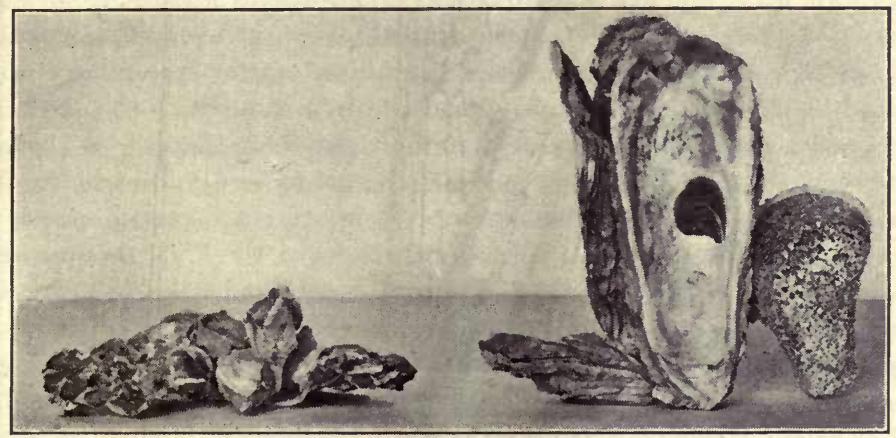

F1G. 124. Ostrea virginica

Left, old shell covered with young oysters; middle, shells of four large specimens about 6 inches long; right, shell of an old oyster riddled by boring sponges

of local with European methods. Possibly France has attained nearest to 100 per cent efficiency in the use of her available oyster beds. The French attend not only to the rearing of the oysters but to the propagation of certain kinds of algæ which impart desired colors and flavors to the finished product.

The civic problem which must be solved by the rising generation is that of developing the oyster industry to as near 100 per cent efficiency as possible. Much as we have already done in this direction, probably not more than 2 per cent of the possible production of American waters has been attained. How we can develop to 100 per cent efficiency in each community is the problem for each community to solve.

Sea mussels - Mytilus edulis (and other species). The range of Mytilus is circumpolar, fringing the northern coasts from Japan around to the 
Mediterranean and from North Carolina around through the Arctic Ocean to San Francisco. In depth it ranges from halfway between tide marks to probably 100 fathoms. Under most favorable conditions, in American waters, the mussels may grow to an average length of from 2 to 3 inches in a year. In England, by the bed system of cultivation, they require two and generally three years to attain a length of 2 inches; but in France this size is secured, by the buchot method, in a year and a half. A female mussel has been observed to lay 12,000,000 eggs in fifteen minutes, almost the entire substance of the animal, except the heart and gills, being transformed into eggs or sperm, which are thus quickly shed once a year. The spawning season varies with latitude and with the temperature of local waters, extending from February to September; and since the mussels are in prime condition when full of reproductive products, the beginning of the spawning season should be determined for each typical bed in a locality, to the end that the yearly crop may be harvested at the right time, that is, just before spawning occurs. Thus mussels may be made to fill the gap in the markets from May to August, when oysters are out of season; and, in fact, according to the extended investigations of Dr. Field, sea mussels may be found in fair or prime condition every month in the year. Of course, as long as no one knows how good they are, this vast food supply will continue to go to waste. As a matter of practical biology, then, why not arrange for a course of mussels in class banquets or other entertainments, and agree to call for them frequently in local restaurants and hotels. When once mussels hare been tried, the demand for them, and consequently the supply, will grow until the whole country is benefiter.

Soft, or long-necked, clams - Mya arenaria. 'This is popular for clambakes along the New England shore and far inland. Mya ranges from South Carolina to the Arctic Ocean, but, unlike Mytilus, has not as yet reached the Pacific by that route. It was, however, introduced into San Francisco Bay in 1870 , and spread rapidly. It appeared in Willapa Bay, Washington, in 1880, was transplanted to Puget Sound a little later, and has become abundant at many points in the Sound. Pacific-coast schools may well lay emphasis on this problem; for in this burrowing clam we may possibly have the form best able to transform the endless barren sand wastes of the Pacific into productive sea gardens. Mya can be much more easily, cheaply, and quickly raised than oysters, coming to market size in a year, under favorable conditions; and the young, in passing from the free-swimming, larval stage to the adult stage, often 
rather in solid masses in tide pools, a single find of this sort often suficing to plant acres of barren beach at almost no cost. Antiquated and atterly destructive beach laws and customs, remains of piracy, are keeping barren and totally unproductive thousands of acres of New England beaches and flats that might, under enlightened civic management, be vielding per acre from $\$ 300$ to $\$ 500$ worth, or more, of these delectable mollusks. These places are not adapted to the culture of either sea mussels or oysters.

Hard, or little-neck, clam (quahog) - Venus mercenaria. As relations now stand, Venus ranks second in commercial importance among the Atlantic-coast mollusks. It is par excellence the chowder clam of the country, and when young it is also relished on the half shell. In range Venus is a southern form, thus supplementing Mya. The two overlap from ('ape Cod to South Carolina, and from the Chesapeake southward and through the Gulf of Mexico Venus lives in enormous beds; unknown and consequently unutilized. This clam has short siphons (whence the name "little-neck"), and buries itself only about the depth of its shell. It supplements the oyster in marine aquiculture, growing best on soft, muddy bottoms from between tide lines ont to water ten fathoms or more in depth. ${ }^{1}$

Scallops - Pecten irradians and $P$. magellanicus. Epicures have assured us that "the scallop is the daintiest of all foods the waters produce." The smaller pecten, $P$. irradians, occurs in the shallow, eel-grass waters south of Cape Cod, down the southern Atlantic, and in the Gulf of Mexico. While piratical methods are exterminating it from its northern range, farther south there are quantities, totally unknown and unutilized, which might support profitable fisheries.

The northern, or "giant," scallop ( $P$. magellanicus) lives in water from 40 to 60 fathoms deep, over rocky bottoms difficult to dredge, which

1 Kellogg figures the crop from an acre, one year after planting with small seed little-necks, at 600 bushels, worth at least $\$ 3$ per bushel, that is, $\$ 1800$, the net profit being probably about $\$ 1000$. "Present prices for this baby clam are high, the clammer sometimes receiving four dollars a bushel for his catch, while one who orders them on the half shell at a Boston or New York restaurant pays for them at the rate of fifty dollars a bushel." Kelloga, Shellfish Industries, p. 229

${ }^{2}$. Demurrer filed in favor of Mytilus, taken in prime condition and fried or roasted brown in cracker crumbs. To make a practical test and settle this controversy, have both scallops and mussels prepared alike and served at a biology-class banquet. Decide by ballot at end of banquet, and print result, with discussions that may arise, in local papers. 
makes it scarce in the markets except along the Maine coast. This scallop reaches a diameter of 7 inches, and the sexes are distinct, while the southern pecten is hermaphroditic and seldom grows over half this diameter. The life history of $P$. irradians has been studied carefully and has a direct bearing on its practical utilization. These pectens are spawned in midsummer, grow rapidly, and spawn when a year old. They continue to grow, but rarely survive to spawn a second time, most of them dying in the early spring of their second year. It is thus clear

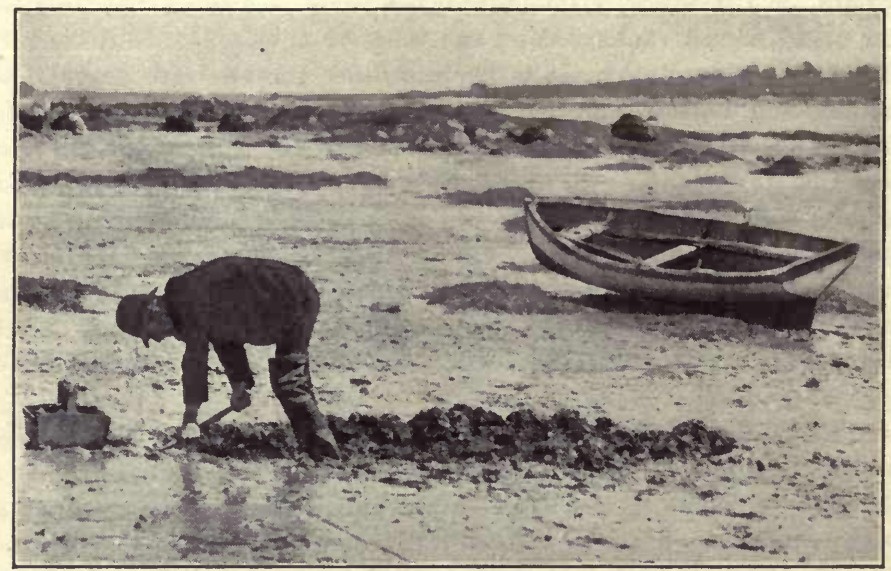

Fig. 125. Digging soft clams

United States Bureau of Fisheries

gain to utilize all of these pectens over one year old. This will not cause any decrease in the species if all those under a year old are left on the breeding grounds.

The fine Pacific clams, the geoduck, or giant clam (Glycimeris generosa), that grows to weigh 6 pounds, the gaper clam (Schizothcrus nuttalli), now becoming rare in the western markets, the western littleneck (Tapes staminea), and the butter clam (Saxidomus nuttalli), along with the western species of Mytilus and the closely similar, and equally edible, Modiolus, are all fine subjects for study in western-coast schools. The Pacific has also two valuable scallops.

Life history. In general outline, the life histories of all the marine bivalves described above are similar. Eggs are produced by the millions, and hatch within a few hours into free-swimming embryos entirely 
unlike the parent. 'This free-swimming period enables the species to ke distributed widely by tides and currents, and it also offers opportunity for the culturist to increase his stock almost beyond belief by maki ing conditions more favorable for the young. - The embryo oyster, for example, swims for from one to six days. By the end of this time the shell begins to form and it must sink to the bottom. If it happens to lind on a clean, hard surface, it may survive; if it falls in an ooze of slime or silt, it is quickly smothered. So the oyster culturists scatter clean

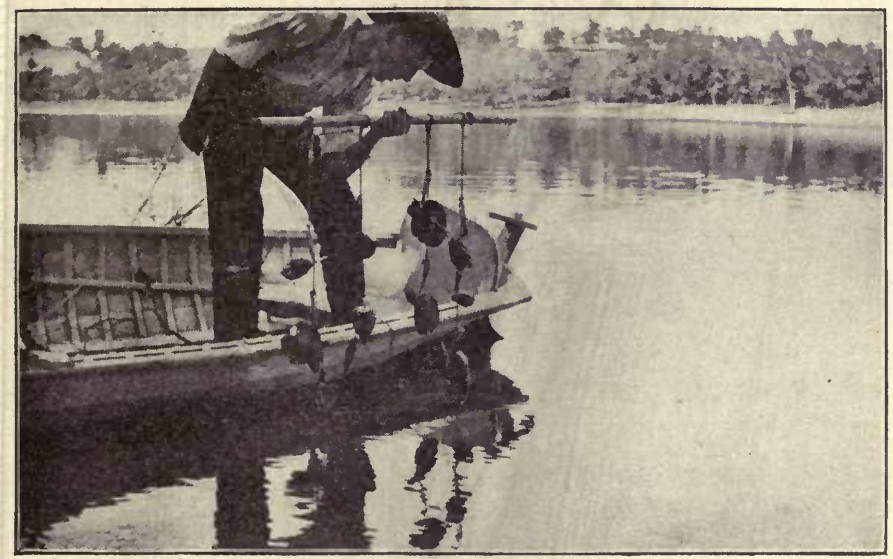

Fig. 126. Pearl fishing in the Mississippi River

Photograph by the author

shells — "cultch" - over the bottom about the beginning of the spawning season. If too many of the young oysters succeed in attaching to these, they must be dredged up and the clusters broken apart and replanted evenly over the bottom, so that all may find food and have room to grow. The left valve of the oyster, which is spoon-shaped, always makes contact with the support and is quickly cemented to it by a secretion like that which forms the shell. The other marine bivalves anchor by means of a peculiar mechanism, the byssus (byssos, "fine textile fiber"), which is secreted by a gland in the foot as a viscous fluid that hardens on contact with the water. The byssus is retained in Mytilus, but is lost in the clams and scallops soon after they assume adult form.

Fresh-water mussels (" clams ") - Unionida. The fresh waters of eastern North America-contain about 600 species of lamellibranchs. Tough, and muddy of taste, they were considered as food only for 
muskrats until discovery of their pearls and still more valuable shells turned prosaic farming districts into "pearl fisheries" and developed a flourishing industry. As with everything else, from forests to clams, when it is discovered to possess commercial value, the American public has hastened to kill the goose that laid the golden eggs; so the waters, many of them, are already depleted and the shell industry is in danger.

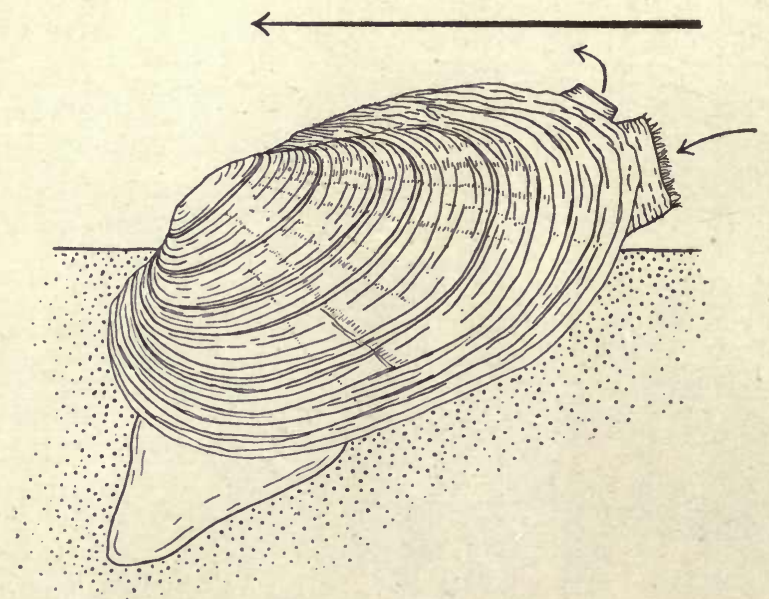

Fig. 127. Mussel in sand, moving in direction of large arrow, foot protruding from anterior, and inhalent and exhalent, siphons from posterior, end of shell

As a consequence the United States Bureau of Fisheries has made extensive surveys to discover the distribution of useful species, and has established a biological station at Fairport, Iowa, to study practical methods of propagating mussels in the great Mississippi basin. All this is likely to prove a futile expenditure of time and money, unless communities cau learn to control their piratical impulses and members, and unite upon rational plans for conservation of these industrial resources.

It is estimated that a "niggerhead " requires from fifteen to eighteen years to grow to a diameter of four and one-half inches, and pearls of value are never found in mussels less than five years old. Other species of nearly equal value may be grown in a shorter time - possibly in from four to six years. Growth lines on the shell are commonly taken to indicate age, or at least the years required for a mussel to reach adult size. 
It is quite possible that these humble creatures are doing a work of ralue many times greater than that represented by their shells and pearls, in the constant purification of our lakes and streams. Experiment has shown that a good-sized mussel filters about four gallons of water through its gills per hour, and siuce it breathes and feeds continuously, this means nearly 100 gallons daily year in and year out.

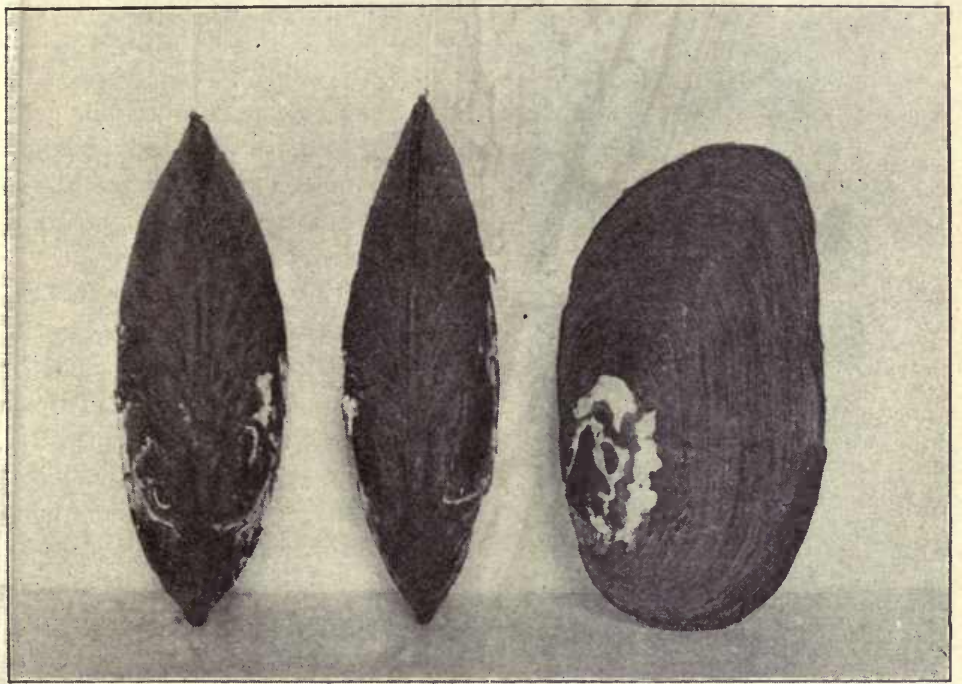

Fig. 128. Fresh-water mussels, female, male, and side view, showing growth lines

Set up two perfectly clean glass aquaria exactly alike, put a mussel in one of them, and note the difference in clearness of the water. What may this mean in keeping reservoirs and park waters clear aud wholesome?

Glochidia (glochis, "arrow point"). Life history. The eggs develop in the gills of the parent mussel into minute bivalves so unlike the adult that they were long considered parasites. 'These are the glochidic and when ripe they are extruded into the water. Here further development. depends upon their attachment to gills, fins, or other parts of fishes. A long byssus thread is present and probably helps in catching the fish, and some species have the valves tipped with sharp-barbed hooks, which catch into the skin of the fish when they are snapped together. The 
species that do not have hooks are taken in with the breathing currents of fishes and clamp on to the gill filaments. The tissues of the fish grow over the glochidia, and within the sac thus formed they grow and change into the adult form. Finally, at the end of from two to ten weeks, according to their species and the temperature of the water,

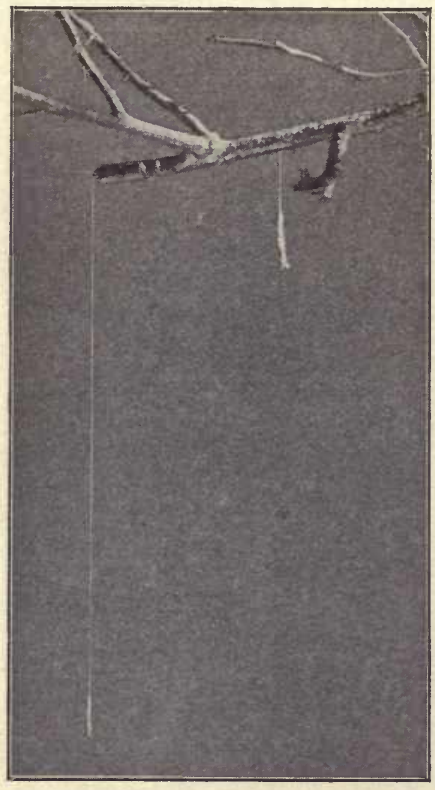

FIG. 129. Garden slugs spinning mucous threads

Photograph by the author they kick themselves out of these cysts and begin their free life on the bottom. So far as we know, this is the only way a young fresh-water mussel can be carried over this critical stage from glochidium to adult, and this means that extermination of fishes must result in extermination of mussels as well.

Problems. Ascertain from the nearest markets which species of mussels produce the most valuable shells, and make a collection of these for the school museum.

Examine specimens of valuable species and make a table showing the months when the gills contain glochidia. Discuss the advisability of a closed season including these months. Estimate the number of glochidia per adult mussel.

Examine all fishes caught for glochidia in gills or fins and skin. How many may a fish carry?

Try, possibly with the help of the state fish commission or the United States Burean of Fisheries, to make a plan for the best possible utilization of streams, ponds, and lakes in the locality, for both mussel and fish culture.

Gastropods. Comparatively slight civic values attach to this group. The abalones are of interest in California, and the periwinkle (Littorina), brought to the Atlantic coast from Europe, where it is used for food, has become abundant from New England southward. It is also of value in cleaning oyster beds of seaweeds. A number of other marine forms, the oyster drill (Urosalpinx), Fulgur, and Natica, feed upon oysters and clams. 
The edible snail (Helix pomatia) is imported from Europe and is raised in specially fenced gardens and fattened for market. 'This may

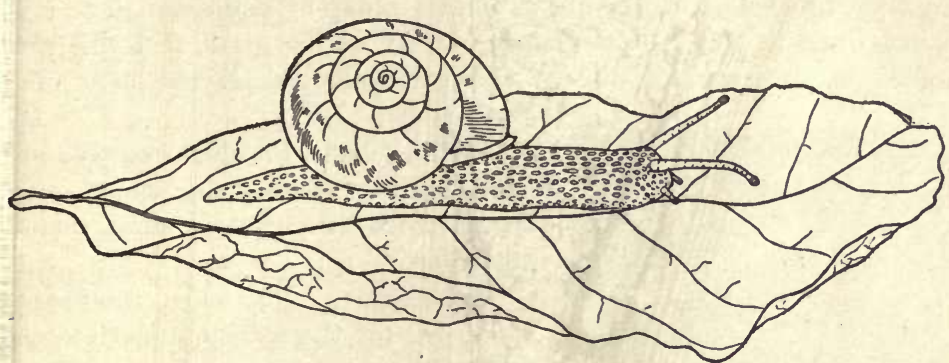

Fig. 130. A common land snail

be studied as an interesting novelty in most American communities. For all we know, may not our big, fat garden slugs be food delicacies?

Compare garden slugs with marine or fresh-water snails, which they may be seen to resemble, except in respect to the rudimentary shell. These slugs are often as destructive in gardens as any insect, and, being nocturnal, are little known. Collect the eggs (translucent, yellowish, about the size of buckshot, in masses of thirty or more, found in damp places under boards) and keep them in a glass jar or aquarium to watch their development. If the life history of these pests were better known, we might control them more effectively about our gardens and greenhouses.

In connection with other field work, make a collection of common marine, fresh-water, and terrestrial gastropods. Keep them in suitable aquaria or vivaria, to study habits and foods. Note that some snails are "left-handed" and most are "right-handed." (If held with opening up and spire pointing away from you, the

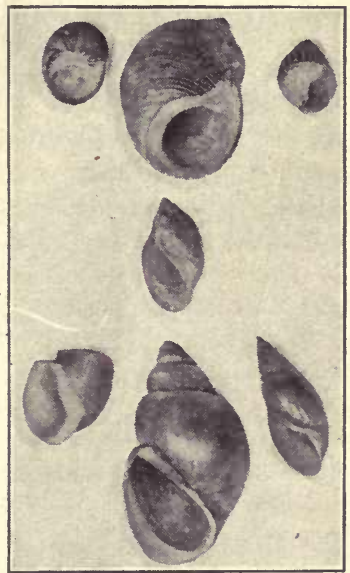

Fig. 131. Common snails, sinistral and dextral dextral shells have the opening to the right, the sinistral, to the left.) The commonest and most.interesting are the pond snails, belonging to the genus Physa, which can be readily distinguished by their sinistral 
shells. If kept in a balanced aquarium, Physa will serve to demonstrate most of the interesting reactions - locomotion, spinning mucous threads, feeding, breathing, egg-laying - of this group of mollusks. The eggs will be laid in transparent masses of jelly on the glass, and will thus afford opportunity to observe the embryological development of a

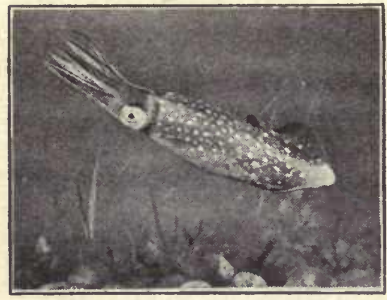

FIG. 132. Atlantic squid gastropod.

Tyrian purple, the dye, was obtained from marine gastropods, which have been known as purpuras since remote antiquity.

Cephalopods. No more interesting specimens for the marine aquarium can be had than the young of our common squids, with their flashing changes of color, their hiding, ink-cloud maneuvers (equaled only by the most astute politicians), and their lightning-like efficiency in catching fish nearly as large as themselves. It is almost impossible to believe that these keen, active, intelligent creatures are really mollusks.

The cephalopods furnish bait for our cod fisheries, sepia for artists, and cuttle bone for canaries, and are used extensively for food along the Mediterranean and among oriental peoples. Some of the deep-sea forms reach enormous size; we hear thrilling stories of their encounters with whales, and they probably furnish whatever basis there may be for sailors' yarns of sea serpents. 


\section{CHAPTER XXVI}

\section{CRUSTACEA}

The fishes in a school of mackerel are as numerous as the birds in a flight of wild pigeons. Goode, in his "History of Aquatic Animals," tells of one school of mackerel which was estimated to contain a million barrels, and of another which was a windrow of fish half a mile wide and at least twenty niles long; but while the pigeons are plant eaters, the mackerel are rapacious hunters, pursuing and devouring the herrings, as well as pteropods and pelagic crustacea.

Herring swarm like locusts, and a bank of herring is almost a solid wall. In 1879 three hundred thousand river herring were landed in a single haul of the seine in Albemarle Sound ; but the herring are also carnivorous, each one consuming myriads of copepods every day. In spite of this destruction and the ravages of armies of medusæ and siphonophores and pteropods, the fertility of the copepods is so great that they are abundant in all parts of the ocean, and they are met with in numbers which exceed our powers of comprehension.

On one occasion the Challenger steamed for two days through a dense cloud formed of a single species, and they are found in all latitudes from the Arctic regions to the equator, in masses which discolor the water for miles. We know, too, that they are not restricted to the surface, and that banks of copepods are sometimes a mile thick. When we reflect that thousands would find ample room and food in a pint of water, we can form some faint conception of their universal abundance.

Modern microscopic research has shown that these simple plants [the algæ in the water], and the globigerinæ and radiolarians which feed upon them, are so abundant and prolific that they meet all the demands made upon them and supply the food of all the animals of the ocean.

This is the fundamental conception of marine biology. The basis of all the life in the modern ocean is to be sought in the microörganisms of the surface. - W. K. Brooks, "Salpa," pp. 146-147

All the ingenious men, and all the scientific men, and all the fanciful men, in the world, with all the old German bogy painters into the bargain, could never invent ... anything so curious, and so ridiculous, as a lobster. - Kingsley, "Water Babies" 


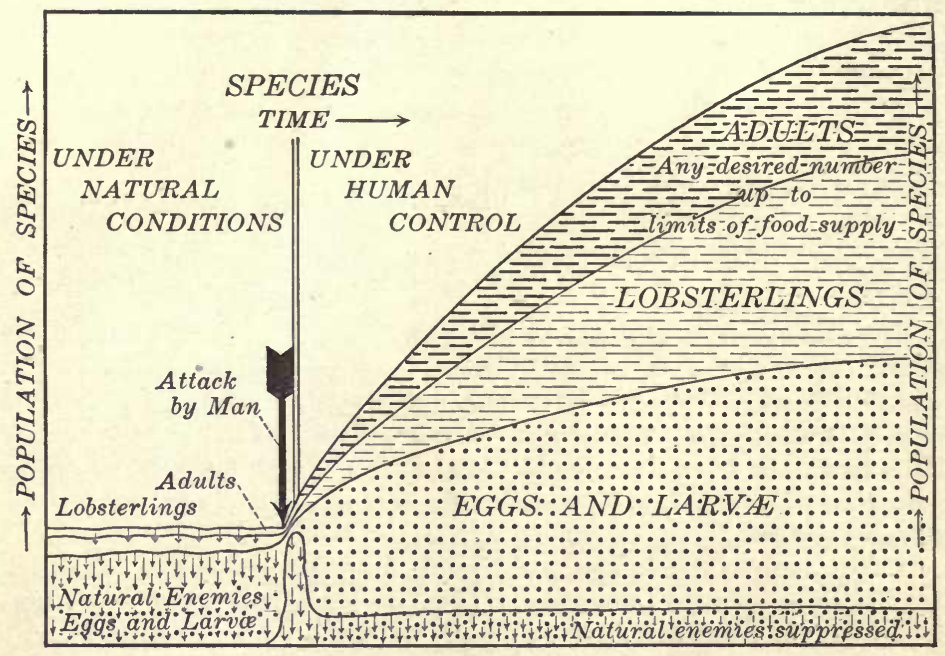

Fig. 133. Diagram expressing Brooks's law of the extermination of a species by man as applied to the lobster problem

The species is shown flowing along from an indefinite past under natural conditions, with minor fluctuations, but maintaining a practically constant population, having adjusted itself to its natural enemies by developing great fecundity, as seen in the wide stream of eggs and larvæ, most of which are taken in the larval stage by natural enemies. At the large arrow eivilized man attacks the slender stream of adult lobsters which nature has selected to keep up the supply of eggs. This strikes the species as a "catastrophe." Man's attack is unlike that of all other enemies. Instincts of self-preservation, thickness of shell, and large size, which made the adult lobsters almost immune from attacks by other enemies, all are of no avail. Althongh man takes but a small number of adults, the balance is disturbed, fewer eggs are produced, natural enemies crowd and tend to take a larger proportion, and the species swiftly approaches extermination. Even if man ceases his attack when the numbers have become reduced so as to render their further pursuit unprofitable, natural enemies may kill off the stragglers, and before we realize what has happened, the race is extinct. If we did shut off all the streams of young and adults at the point of the large arrow, we should have a picture of the extermination of the lobster. Under human control, if even a few adult breeders are left, man can increase the number to any desired amount; he can lift the eggs and young above the reach of natural enemies, or crowd them down, or both, and so increase the species to the limits of room or of food supply. This is what we hope is now being done, and we shall watch the future curves of increase in the expectation that the price of lobsters may begin to decline toward reasonable limits. This diagram is applicable to any species exterminated or in danger of extermination by man-passenger pigeon, dodo, great auk, and many other species now lost to the world 
General. Crustacean problems parallel those of the mollusca. Lobsters, crabs, shrimps, and crawfish are valuable for food. Some of the most highly prized species require to be protected by law, and we are beginning to work out methods for their artificial propagation. Some of the terrestrial crawfish are locally injurious to vegetation. There is this difference: crabs and lobsters move about more freely than clams and oysters, and hence are not so well suited to stable aquiculture. On this account the United States Bureau of Fisheries, and the fish commissions of the states concerned, must assume responsibility for keeping up the supply by propagation, since this cannot be done with profit by private individuals.

Economic value. The table below presents the chief economic Crustacea, and its most suggestive feature is likely to be the wide difference between actual and possible utilization of these resources.

Crustacean Products of the United States in 1908

\begin{tabular}{|c|c|c|c|c|c|c|c|c|c|c|c|c|}
\hline & & & & & & & & & & & actual Value & Possible Value \\
\hline Lobsters . . & . & . & . & & - & . & . & - & & - & $\$ 1,931,000$ & \\
\hline Blue crabs . & . & . & . & - & - & . & . & . & & - & 912,000 & \\
\hline Shrimps, praw & ns & & . & . & . & . & . & . & . & . & 494,000 & \\
\hline Pacific crabs & . & $\cdot$ & . & . & ${ }^{\circ}$ & . & . & . & 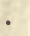 & & 127,000 & . \\
\hline Crawfish. & . & . & . & & 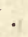 & 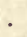 & 1 & 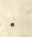 & 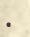 & & 32,000 & \\
\hline
\end{tabular}

Classification. The Crustacea are divided into two main groups, the Entomostraca (mostly microscopic or small, including the ostracods, copepods, and barnacles) and the Malacostraca (the lobsters, crawfish, shrimps, prawns, and crabs).

Entomostraca. Although inconspicuous and little known, these minute Crustacea are of the greatest biological significance. If we had them all gathered into a ball, and all the rest of the animal matter of the world rolled into another 
ball, it is quite possible that the Entomostraca would be the heavier of the two. ${ }^{1}$ They form the main food of the young of fishes and many other aquatic animals, and also of the adult fishes that are provided with gill rakers - the herrings, smelts, shad, and others. They are thus the connecting link between the vast store of floating, microscopical plants and animals (the primitive food supply) and all higher life in the water. Daphnia and Cyclops are examples that may be found in almost any fresh-water aquarium or in streams, ponds, and pools everywhere. The fairy shrimp (Branchipus) is also found in the icy pools of early spring.

The Lobster (Homarus americanus). Of the invertebrates used for food the lobster ranks next in importance to the oyster, and of all marine animals, for the past thirty years, it has been in the greatest danger from overfishing. The reason for this is seen in the following table, the supply having been drained to the utmost on account of soaring prices.

New Linglani) Lonstrik Fishery

\begin{tabular}{|c|c|c|c|c|c|c|c|c|c|c|c|c|}
\hline & ' & & & YeAr & & & & & & Pounds & VALUE & PRICE PER POUND \\
\hline 1880 & . & . & - & . & & & . & & & $19,836,233$ & $\$ 473,341$ & $\$ 0.024$ \\
\hline 1890 & . & . & . & . . & & . & . & ${ }^{\circ}$ & & $30,449,603$ & 833,746 & 0.027 \\
\hline 1900 & . & . & . & . . & & . & . & . & & $15,567,081$ & $1,362,962$ & 0.088 \\
\hline 1908 & . & - & . & . . & - & . & . & . & • & $14,734,000$ & $1,855,000$ & 0.125 \\
\hline 1913 & . & . & . & . . & & . & . & . & 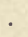 & $11,504,257$ & $2,254,486$ & 0.196 \\
\hline
\end{tabular}

1 The writer has thought, as he steamed through a veritable slush of copepods that colored the ocean for hundreds if not thousands of miles, that here must be the greatest of all untapped and unthought-of sources of supply of animal matter. If the ship's engines could be geared to some efficient filtering machine, a cargo could be secured as fast as hoisting and storing machinery could handle it. The material might prove as good, or better, than lobster for salads (but the microscopic spines and bristles would be likely to interfere with human edibility). It might prove of value for poultry and swine, for oil production, and, at any rate, for fertilizer. Perhaps it would solve the problem of food in fish hatcheries, especially for marine species, and make possible the rearing of young lobsters in any quantity. 
Range. The American lobster ranges along the Atlantic seaboard from Labrador to North Carolina. Possibly no venzure in the field of marine aquiculture would prove of greater 3conomic value than the introduction of this species into the Pacific; but although egg-bearing lobsters have been shipped across the continent by thousands and in carload lots, up to his time all attempts of the United States Bureau of Fishries to colonize the Pacific have failed. While hiding among the crevices of rocks would seem to suit the habit of the lobster best, it apparently thrives as well on sandy and even muddy bottoms, and it ranges from the tide pools to water 100 fathoms, or even more, in depth. ${ }^{1}$

Size, growth, and life history. Female lobsters spawn once in two vears; the eggs as laid are cemented to the swimmerets underneath the abdomen, and here they are carried during the long incubation period from July or August of one year till May or July of the next. The hatchlings - delicate, transparent creatures about one third of an inch in length - swim feebly, or rather "tread water," and so tend to rise toward the surface. They feed voraciously upon copepods and diatoms that they find floating in the water, and they eat one another whenever they can - a vicious habit which is one of the chief difficulties in rearing them artificially. They swim thus for two or three weeks, growing and molting three times in the interval, all this time at the mercy of every tide, wave, and current and of every open mouth they may encounter. This is the critical period in the lobster's life, and probably not one in ten thousand, under natural conditions, survives its accidents and dangers.

At the third molt.the young assumes adult form, and the tiny lohsterling tends to seek the bottom and may even begin to burrow for greater protection. It is now a little over half an inch in length, still a helpless morsel for every sharp-eyed minnow. When it is about twentyfive days old, the fourth molt brings the lobsterling to the fifth stage,

${ }^{1}$ Barnes, Methods of Protecting and Propagating the Lobster, E. I. Freeman Co., Providence, Rhode Island, 1911. Refer to this for further data on the habits and natural history of the lobster. Also, if undertaking special work on this problem, write to Experiment Station, Wickford, Rhode Island, for up-to-date information. 
when the bottom habit is more strongly fixed. It is comparatively easy to hatch lobster eggs, but if the fry are liberated as soon as hatched, nothing is gained over natural hatching. For about thirty years experiments have been in progress in this country to discover methods of rearing lobster fry through the critical free-swimming stages to the fourth, or bottom, stage. For years results were negligible, but at last,

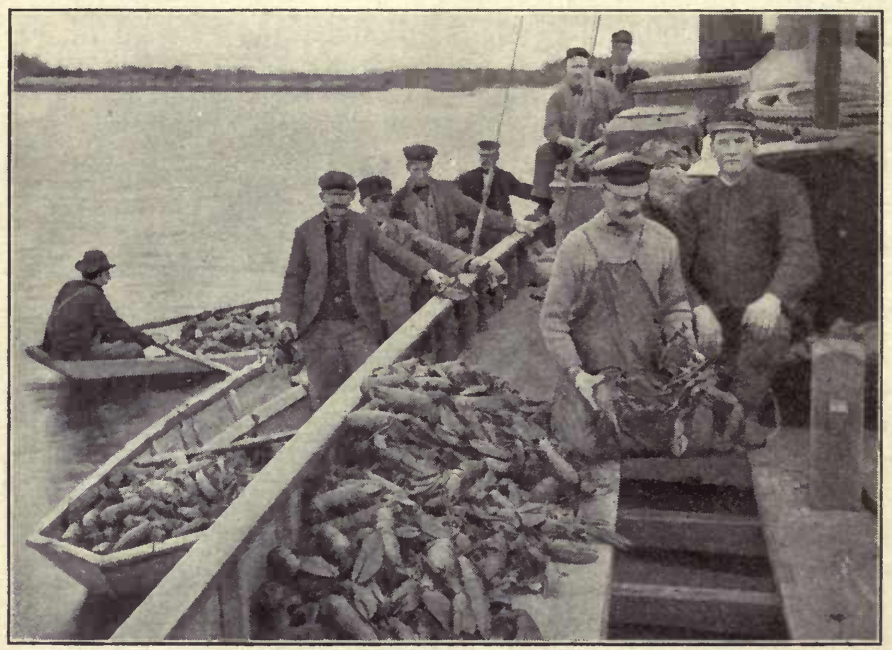

Fig. 134. Berried lobsters, taken from pound at Boothbay Harbor (Maine), in course of transfer to wells of the steamer which is to convey them to the hatchery for stripping

United States Bureau of Fisheries

in 1910 , by holding them in floating cars the Wickford station was able to score a record of 8946 fourth-stage lobsterlings from a counted lot of 10,000 newly hatched fry. The best European result at that date was 6.6 per cent, beginning with 1500 in the second stage.

By the end of its first year the young lobster has reached the length of $2 \frac{1}{8}$ inches, and not until its sixth year does it attain the respectable market length of 10 inches. In the usual effort to save the lobster industry and the species, laws have been passed by the states most concerned; but these have not been effectual, on account of lack of knowledge, and those of different states still conflict seriously. Study 
the lobster law in your own state and in neighboring states and discuss pactical improvements. ${ }^{1}$

Probably no one has ever seen a lobster known to be dead of old aire. While specimens over 15 inches long and weighing more than 2 or 3 pounds are now rare in the markets, specimens 2 feet in length and weighing 10 pounds were not rare some years ago. The largest labster on record was caught off the New Jersey coast in 1897. From end of chelæ to tip of tail it measured 42 inches, and it weighed $3 \mathrm{t}$ pounds. Growth has been followed up to the thirty-third year, at which time the lobster is almost 2 feet long. If a lobster lives forty y ars and produces twenty batches of eggs, averaging 100,000 each, an alult pair would produce $2,000,000$ eggs. This would mean, with the s]ecies holding its own in the struggle for existence, that under natural cunditions only one egg in a million grows to become adult. If man kills the one that nature has preserved out of the million to keep up the s)ecies, eggs and young will fail and the lobster will become extinct. Cur laws are based on the totally inadequate assumption of the fishermien that if a lobster is spared until it grows to be 10 inches long and linys only one batch of eggs - about 10,000 - the population of the species will be maintained. Both theory and experience prove the fillacy of this idea.

Brooks's law. We must work out a biologically correct solution of this problem or lose our lobsters. Dr. W. K. Brooks ${ }^{2}$ has given a discussion of the problem as applied to marine fishes. This might well be

1 Rhode Island has led the way by making a closed season, from Novemker 15 to April 15. All the states except New York fine from $\$ 5$ to $\$ 100$ for killing an egg lobster, but the eggs are easily brushed off. Short-lobster laws differ. In Maine a lobster must measure $4 \frac{3}{4}$ inches, body length (equal to $10 \frac{1}{2}$ inches long); in New Hampshire, $10 \frac{1}{2}$ inches ; in Massachusetts, 9 inches; i 1 Rhode Island, $4 \frac{1}{8}$ inches, body measure; and in New York, 9 inches. According to the biologically correct view of Dr. Field, of the Massachusetts Fisheries and Game Commission, all these short-lobster laws protect the wrong end of the animal's life. A lobster 10 inches long produces 10,000 $\epsilon$ ggs ; one 12 inches long, 20,000 ; a 16-inch lobster, 100,000. The old lobster is thus ten times as valuable to the species for egg production, and, 1 eing coarser and tougher, may not be as valuable for food as the legallimit lobster. According to Field, lobster pots should be made with openi ings too small for the large lobsters to enter, $3 \frac{1}{4}$ or $3 \frac{1}{2}$ inches in diameter, and with slats open enough to permit all lobsters under a certain size to escape.

${ }^{2}$ Brooks, "The Artificial Propagation of Sea Fishes," Popular Science IFonthly, Vol. XXXV (1889), pp. 359-367. 
called "Brooks's Law of Extermination of Species by Man." Stated in his own words, this law is "To marine food fishes man is a catastrophe, not a natural enemy." This means "Man takes the adults which natural

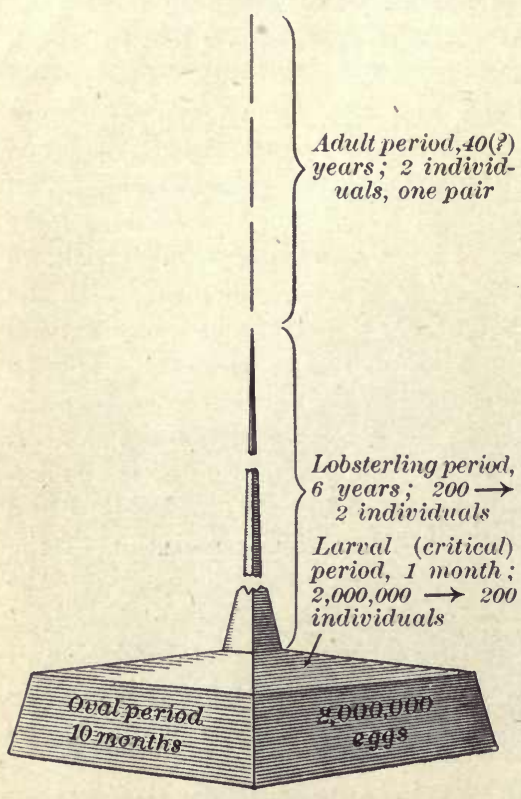

FIG. 135. Diagram representing the individuals at different stages in a generation of lobsters

This is another form of expression of Brooks's law. The typical form is a pyramid, with a broad base of eggs and young maintained by a small apex of adults. Each species of animal or plant has a form of its own depending on number of eggs and duration of the different stages. The large number of eggs, the long life of the adults, and the extreme reduction of numbers in the short critical, larval stage reduces the typical pyramid in the case of the lobster to a monument with a broad base of eggs which shrinks suddenly during the larval stage to a slender spire representing the adults enemies have spared to continue the species." Figs. 133 and 135 show this law diagrammatically as it applies to the lobster. It is applicable to every species that man attacks, from oysters and lobsters to whales and pine trees. When man disturbs the nice balance of nature he must assume control ("have dominion") or lose the species.

Blue crab - Callinectes sapidus. This common crab of the Atlantic-coast markets ranges from Massachusetts Bay to Mexico, and, while it is taken by millions every year, shows as yet no alarming signs of decrease. Two facts in the natural history of the species may largely account for this: the eggs are minute, a female laying on the average more than $3,000,000$ at a batch; and, while molting, each female is protected by a hard-shelled male.

\section{Pacific crab - Cancer magister.} This robust crab, 7-9 inches broad by 4-5 inches long, ranges from Alaska to Lower California. In the markets of the Pacific it supplies the place of both the lobster and the blue crab of the Atlantic. State laws are beginning to 
lrotect these crabs by making closed seasons and by specifying size limits, but the natural history of this species has not been adequately s.tudied.

Crawfish - Astacus (Pacific); Cambarus (Atlantic). Many species of these two genera inhabit North American fresh waters and lowlands, several of them growing to 6 inches in length. They are extensively used for food in Europe and are growing in favor in some parts of this country. The flesh is delicate and sweet, like that of lobsters and crabs, and there is no good reason why they should not be much more widely

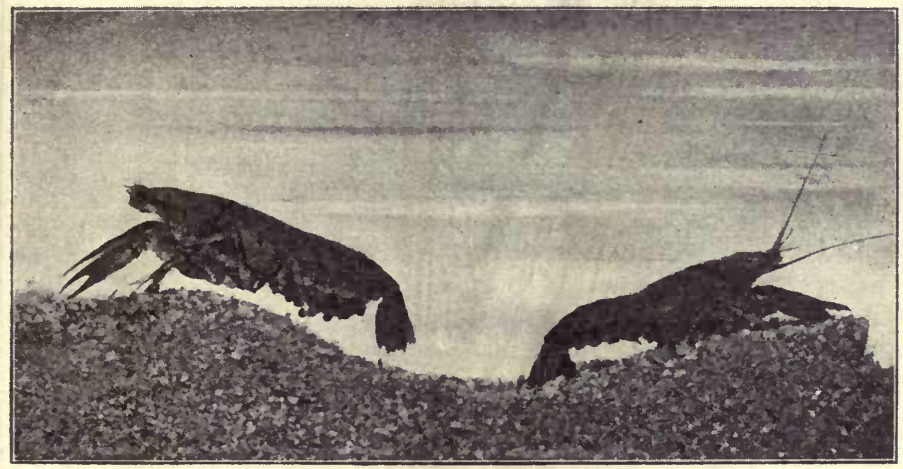

Fic. 136. Female and male crawfish, the female with eggs

appreciated and utilized. In the waters they often form the chief food of our game fishes, especially of the black bass.

Crawfish are found in the fresh waters of the temperate zones of all the continents except Africa, and it is evident that they have developed from a number of different marine forms. The largest crawfish in the world is Astacopsis franklinii, found in the small streams along the north and west coasts of Tasmania. These often weigh as much as 9 pounds; and if they could be safely introduced, they might give us an industry for our fresh waters that would rival lobster culture.

The land crawfishes, known as "chimney builders," dig holes in soft ground, generally down to water. These are about an inch in diameter and are surrounded by a chimney of excavated earth. This burrowing habit makes them serious pests in embankments and levees. They are also, in part, vegetable feeders and are often destructive to young plants of field or garden. A few drops of carbon bisulphide in a burrow will 
kill the occupants. The Biological Survey has designed a special dropping can to deliver the proper amount, so that extermination of crawfish from land is now quickly accomplished with slight labor or expense. Crawfish are also excellent food for poultry.

The female crawfish, distinguished from the male by her broader abdomen, carries the eggs attached to her swimmerets, as do the lobsters and crabs (Fig. 136), the young passing through the nauplius, or free-swimming, stage within the shell. Even after hatching, as tiny crawfish they remain attached to the mother until after the third molt, when they scatter to take care of themselves.

One or two pairs, kept in an aquarium or vivarium during the hatching period (March to June), will afford most valuable opportunities for observing the instincts and habits of a crustacean. Perhaps some member of the class will volunteer to do this. If so, he must study carefully to make conditions as normal as possible, and must feed well, or they may kill and eat each other, and the females may even devour their own eggs. 


\section{CHAPTER XXVII}

\section{PROBLEMS OF FISH AND FISHINGG}

You might have the rivers as pure as the crystals of the rock, beautiful in falls, in lakes, and in living pools - so full of fish that you might take them out with your hands. - Ruskin

Now what happens if, after each one of the natural enemies has claimed its victims, a new enemy not provided for by Nature suddenly attacks the few adult survivors which Nature has provided to perpetuate the species? What happens when the last drop falls into the brimming bucket? What liappens when the proverbial last straw is put on the load? It may be quite true that, for each codfish which man catches, the natural enemies destroy a znillion. That has no bearing on the subject. Nature has provided for the destruction of the million. Before their birth they were destined to premature leath. The one was reserved by Nature for another purpose.-W. K. Brooks

After all that has been said about anglers and angling, two thirds of the line fishing of the world is done by boys. The boy may fish with a fly, but he does not spontaneously take to this method. Fly fishing is an art, a fine :urt beyond a doubt, but it is an art and, like all art, it is artificial. Fishing with an angleworm is natural. It fits into the need of the occasion. It fits in with the spirit of the boy.... The angleworm is perfectly at home on the hook. It is not quite comfortable anywhere else. It crawls about on the idewalks after a rain, bleached and emaciated. It is never quite at ease even in the ground, but on the hook it rests peacefully, with the apparent feeling that its natural mission is performed.- Holder and Jordan, "Fish stories," p. 237

Civic problems. Are the waters of your neighborhood stocked with the best fishes (for food and sport) that are suited to them? Are they supplied with such numbers as the lakes, streams, and ponds can reasonably support? Are the waters clean and clear, unpolluted by the wash of soil not properly held on the farms, where it belongs, by chemical wastes from factories, or by sawdust from lumber mills, so that they remain well adapted to the valuable fishes native to 
them? Do all the people have all the good fish and goods fishing they need to keep them good-natured?

There are millions of springs and brooks and flowing wells, many of which might be turned to good account in forming home fish ponds. These might be made to serve as storage reservoirs for irrigation or stock watering, and might be so developed over the country as to help in solving problems

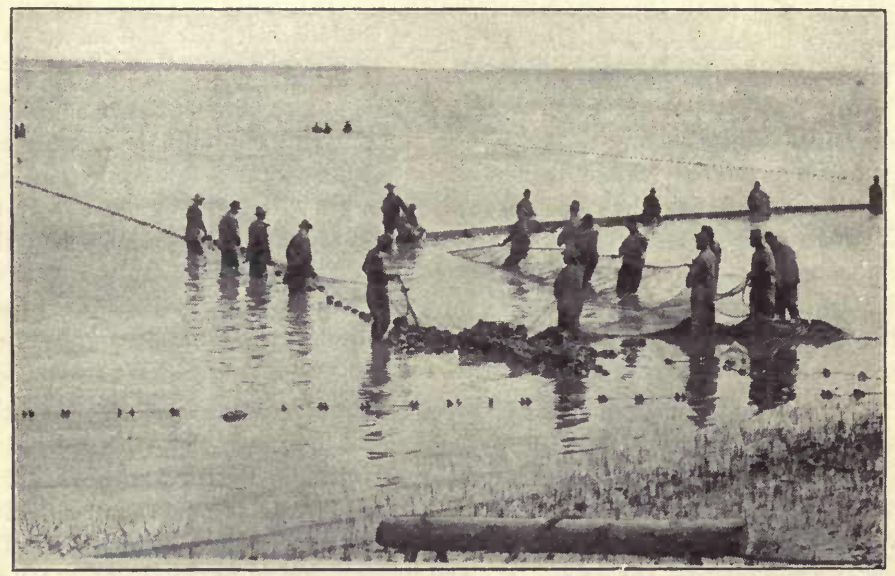

Fig. 137. Fxterminating shad from a Virginia river

Largest seine in the world, 9600 feet long. The seine was hauled by steam power and the labor of $80 \mathrm{men}$, and was drawn twice daily, at ebb tide, throughout the season. As many as 3600 shad were taken at one haul, and 126,000 in one season: 250,000 alewives were caught at one time. The season's yield of shad fell to 300 , and the fishing was consequently discontinued in 1905 , after having been carried on for a century. This seine was a source of eggs for the Bureau's shad hatehery on this river, Stony Point, Virginia. United States Bureau of Fisheries

of increasing floods in the river valleys. Waste hollows and ravines might be turned into the most productive areas of our farms, acre for acre, when properly stocked with fish. Has this been adequately worked out for the district? ${ }^{1}$

'Johnson and Stapleton, "Fish Ponds on Farms," Document No. 826, Bureau of Fisheries, Washington, 1915. 
If for any district in the United States or Canada the above questions can be answered in the affirmative, there remains still one thing for the class in civic biology to do. Write up the story to tell how the community did it. It will prove the most interesting and instructive "fish story" ever written.

Survey of district. The first step toward a solution of the above problems is a survey of local waters. An interested group, or committee, of the class may subdivide the district among its nembers, each of whom will go over his part and make a map, to scale, of lakes, streams, and ponds, along with available pond sites, springs, and flowing wells. Indicate stream flow by arrows and depths by contour lines, and adopt some uniform method of showing areas of vegetation and kinds of bottom - rocky, gravelly, sandy, or muddy. While working over the ground in this way, observe and

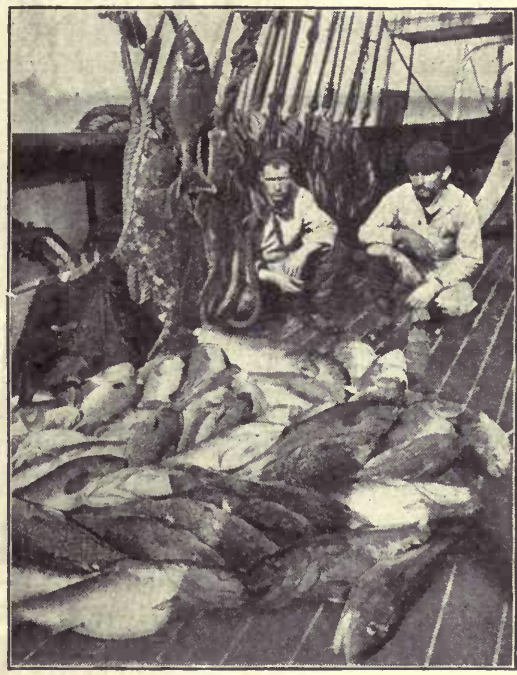

Fig. 138. Trial fishing on the Albatross Experimental catch of cod and halibut taken in twenty minutes by the Albatross while exploring a new bank off the coast of Alaska. United States Bureau of Fisheries record condition of water. Is it clear or muddy? Do sources of pollution exist? How might these be remedied? (Consult state laws in this connection.) Record all fishes seen, and gather records, from neighbors and local fishermen and markets, of the numbers and values of the different fishes taken during the past season. This should result in a complete list of the fishes of market value, with their relative 
importance, and from these data we should be able to construct a table showing the crop of each kind of fish for the entire district. We may then figure per acre production and percentage of effective utilization of each water unit. ${ }^{1}$

In making the survey, seek to arouse the interest of the community. Ask your fish experts - the fish warden, the one who has charge of the nearest hatchery, or some of the best local anglers - to visit the class and present their views for stocking the district. Study the publications of your state fisheries commission and of the United States Bureau of

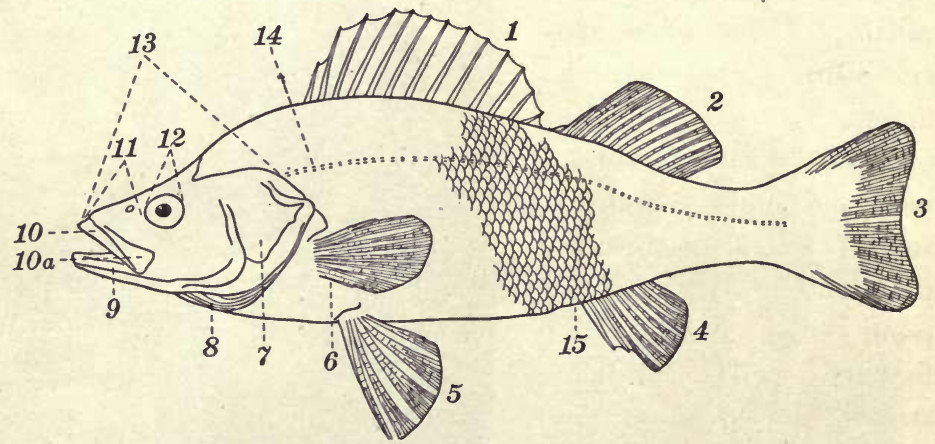

Fig. 139. Topography of a fish (Yellow perch)

1 , spinous portion of dorsal fin; 2 , soft portion of dorsal fin; 3 , caudal fin; 4 , anal fin; 5 , ventral fin; 6 , pectoral fin; 7 , opercle; 8 , branchiostegal rays; 9 , mandible, or lower jaw ; 10 , premaxillary ; $10 a$, maxillary ; 11 , snout ; 12 , eye ; 13 , head ; 14, lateral line; 15, series of scales, counting from front of anal fin upward and forward to lateral line

Fisheries. Ferret out all such bulletins in private collections and induce their owners to loan or donate them to the school or public library; and write to Washington or to your state department for any others that may be needed.

1 "It is difficult to estimate the capacity of ponds for the various stages in the growth of fish. It depends for the most part upon the amount of appropriate food available. A 2-acre pond producing 10,000 one-year-old black bass from 4 to 6 inches long would be a remarkably successful enterprise, and 20,000 one and one-half to two inch yearling crappie or sunfish to an acre of water wonld be likewise notable. These numbers have been realized and in some instances exceeded, but the average results are doubtless much smaller."-Johrson and Stapleton, loc. cit., p. 25. 
Finally, draft a plan for stocking and maintaining the waters of the district at their maximum production, and have this printed in the local papers.

Fishes Day. ${ }^{1}$ We have Bird Day and Arbor Day and Apple Day. Why not have Fishes Day? We ought to know our fishes better. We ought to know their habits and habitats, their foods, and especially their nesting and spawning seasons; and if we did, it would come to be considered as much an outrage to take a fish from her nest as to kill a mother bird on hers. When we all know these things and come, as a whole people, to have a right feeling for them, we may then combine intelligently to have our waters teeming with all the best fishes they are capable of supporting.

\section{Aquarium manage-} ment. This may be

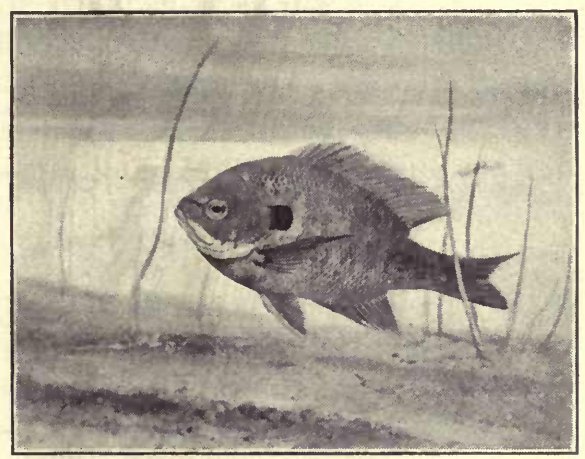

Fig. 140. Bluegill sunfish — best fish for pond culture

Photograph by Reighard used as a key to the solution of our problems. A "balanced aquarium " is one in which just the right proportions of animal and plant life are maintained, with the right amount of light, so that the water remains clear and sweet. This means that there are plants enough, under the light admitted to the aquarium, properly to oxygenate the water for the animals, and animals enough to supply the carbonic acid and nitrogenous wastes

${ }^{1}$ Anglers often wonder why the fishes do not interest the public as do the birds, as they are also attractive and their habits interesting, indeed, fascinating. The reason, possibly, is, that birds are always in sight, while it takes searching to find the fishes.-Holder and Jordan, "Fish Stories," p. 226 
which the plants require for healthy growth. The common mistake of beginners is to overcrowd the aquarium with both animals and plants; more waste matters are produced than are continuously used, and bacteria develop and foul the water.

- Too much light is the other common danger; this results in the excessive growth of algæ, which green the water and overgrow the glass. A pond receives light only from above, while the aquarium may be lighted from the sides as well. Hence aquaria do better in north or east windows, and even here must be provided with cardboard shades to shut out almost all direct sunlight from the sides. South and west windows may be used if three sides are shaded and the top partially shielded from direct sunlight if algæ become troublesome. Great care must be exercised not to overfeed, because uneaten food will decay and quickly foul the water. In an aquarium properly planted with good oxygenators temperature of the water not allowed to go over $15^{\circ}-18^{\circ}$ $\left(60^{\circ}-65^{\circ} \mathrm{F}\right.$.) - two fishes 3 inches long per gallon is the rule. Large specimens cannot be made comfortable in small aquaria; consequently small ones must suffice for schoolroom demonstration and study. Predacious fishes (pickerel, basses, and sunfish, eels, and all except the smallest catfishes) should ordinarily be kept, each kind and usually each size, in a separate aquarium; and it will be necessary to watch them and to remove any vicious specimen or to partition it off with a pane of glass. In equipping a laboratory or in planning an exhibition it is better to have a considerable number of small and medium-sized aquaria - easy to set up and each with its own distinct and clearly labeled exhibit - than to have a few cumbersome aquaria with impossible or difficult combinations mixed up in them.

The temptation is to make aquaria too big. Taking the dimensions given on page 14, we have the following data for approximate capacity 
in gallons and weight of water. Any size can be figured, 231 cubic inches (weighing 8.34 pounds) being a gallon.

\begin{tabular}{|c|c|c|c|c|c|c|}
\hline \multicolumn{4}{|c|}{ SIZE } & Gallons & Pounds & $\begin{array}{c}\text { NUMBER REQUIRED FOR A ClASS } \\
\text { OF FORTY }\end{array}$ \\
\hline \multicolumn{7}{|c|}{ Width Height Thickness } \\
\hline 5 & $x$ & 7 & 47 & .667 & 5.5 & ( 40 (1 apiece), used for insects, \\
\hline 8 & $x$ & 10 & $5\}$ & 1.7 & 12.8 & $\{$ fungi, and feeding tests with \\
\hline 10 & $x$ & 12 & $6\}$ & & 25. & sinall animals. \\
\hline 20 & $x$ & 12 & $x$ & 9.4 & 78.4 & 4-12, used for demonstrations \\
\hline 24 & $x$ & 18 & 12 & 22.4 & 186.8 & 2 , used for demonstrations \\
\hline
\end{tabular}

Demonstration aquaria are usually built into the walls so as to be lighted from above and viewed through the glass from inside the room. This arrangement can be imitated by setting the aquaria on suitable supports just outside the windows, on the window sills, darkening the outer glass (or making the ends and outer sides of slate).

When we begin to realize the value of aquatic biology, we shall build our aquaria into the basement walls, and then, by proper placing and grading of the building, we can have abundance of room for either stillwater or running-water aquaria, under conditions as normal as those of natural ponds and streams, with which to study all manner of problems. If the aquaria were figured into the original plans, they might cost nothing and the basement walls might be even less expensive than the usual solid construction of stone or brick.

Our commissioner of fisheries says ${ }^{1}$ : "This is a wide field; I do not know of any more promising field in the government service than in the culture of fish. The possibilities of making new discoveries, especially in the line of intensive breeding and selective breeding, are almost inexhaustible. I would expect that a tremendous boom to the fish industry of the entire country would be given by a fisheries school such as this if established here."

The still-water aquarium is the only kind recommended for ordinary school use; running water is not at all necessary for most fishes,

1 H. M. Smith, California Fish and Game, Vol. I (July, 1915), p. 189. (From remarks before the Pacific Fisheries Society, Seattle, on the plan of establishing a school of fisheries in connection with the University of Washington - on a par with schools of forestry and agriculture, mining and commerce.) 
and danger of a stoppage of escape pipe, and consequent flooding of building, is too great a risk. The absolute rale should be that one person shall take the sole responsibility for an aquarium, and no one else be permitted to put anything in or take anything out of it. As long as the aquarium is properly balanced and managed, the water need never be changed. Water is always water, and as it evaporates, clean pond or brook water

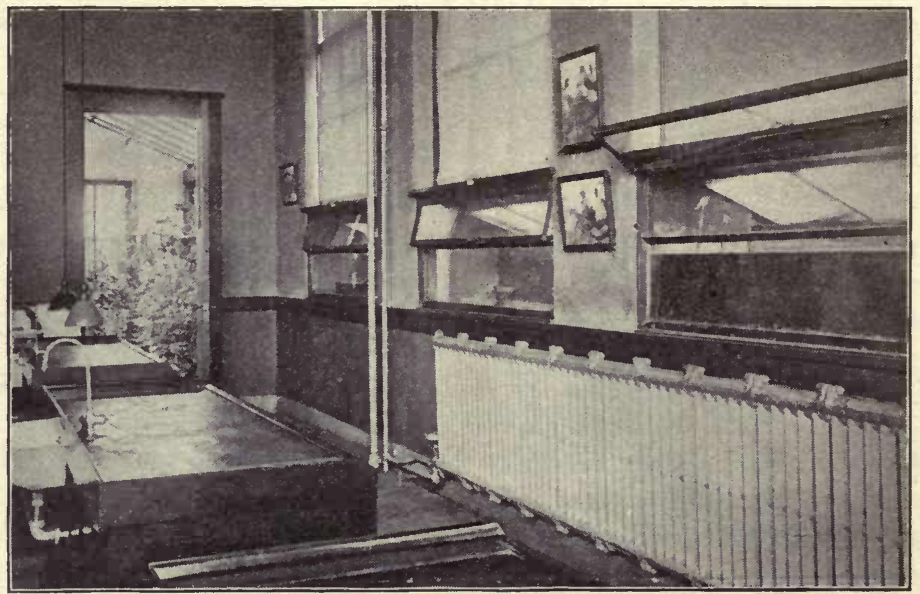

Fig. 141. Biological Laboratory, Cleveland Normal Training School

View of the west end, showing three of the four large aquaria built into the wall under the windows, and a small greenhouse opening out of the laboratory ${ }^{1}$

must be added to keep the level about constant. If adding any considerable quantity, allow the water to stand in the room a day, or until it is of the same temperature as that in the aquarium; for even small changes of temperature, if sudden, may be injurious, or even fatal, to some fishes. The hand should never be put into the aquarium; it carries too many troublesome bacteria. Use the proper tools - dipping-tubes and siphons, dip-nets and scrapers. A spirit of good-natured rivalry should be

1 The architect overruled the location of these aquaria in the north wall and changed their specifications. They should be two feet, instead of about one foot, deep, bringing the bottom two feet from the floor and giving double the depth of water. The glass roof, if present at all, should be raised to the middle bar of the window, and the flap, which can be lowered to shut the space above the aquaria from the room, should be two feet wide. 
encouraged, to see who can have the most beautiful aquarium and the n lost instructive one, and hold it longest without change of water. A denerit mark is deserved, and may be given, for every time a pupil permits the water in his aquarium to become foul enough to require changing.

In this way, by gaining experience through the year, the students r.ay keep the aquaria running in fine balance, each with some specimen (f native fish, and so afford a most instructive exhibition. This may be lield in connection with appropriate lectures by specialists and a general discussion of the plans which have been worked out. for the adequate stocking of local vaters. Whether we call it Fishes' Day or make it a feature of more general exerrises will depend on community interests ind preferences.

A few important features of such an "xhibition may be

1. Species of value and relative importance of each.

2. Habits and proper habitats of each species (so far as these can be shown by arrangement of aquaria).

3. Table of spawning seasons; preserved specimens of eggs and fry; photorraphs and other pictures of fish nests; liagrams of local waters, with distribution of nesting places of different species.

4. Eggs actually being hatched (Fig. 142) and fry being fed and reared for distribution.

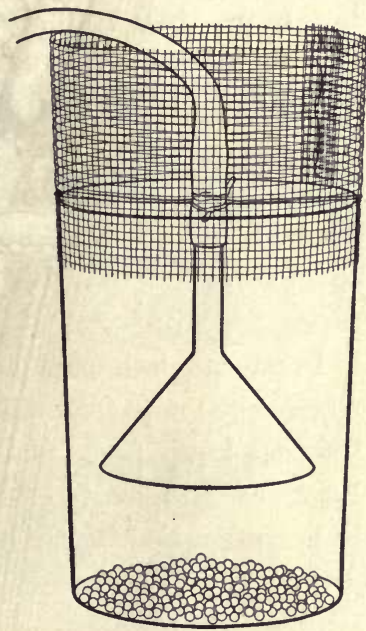

Fig. 142. Tumbler hatchery

Water running through funnel keeps eggs aërated. Author's design

5. Foods of different species, with natural food supplies.

6. Extermination of mosquitoes by fishes, with data from feeding tests in the school aquaria and from park or pond waters properly stocked.

7. Data of growth of different fishes, fed in different ways.

8. Diagrams and records of production of home fish ponds. (Why not have fish projects and fish clubs as well as corn clubs and pig clubs?)

9. Enemies of different-fishes, and means of their control.

10. Fish course, composed entirely of local varieties in season, prepared by domestic-science classes for the exhibit luncheon. 
11. One or two of the most wonderful curiosities of fish natural history : a nest of sticklebacks, "nothing short of marvelous" (Hornaday), or a paradise fish with his nest of bubbles; or exchange with coast schools and devote one of the large aquaria to artificial sea water and marine forms.

Classification and species. About as many different kinds of fishes as of birds are known to science (13,000, Galloway), but more than four times as many fishes as birds are found in the inland and marine waters of North America (3263 species). ${ }^{1}$ Any list (published by your state fish commission or by the United States Bureau of Fisheries) giving the distribution of fish and fish eggs for the preceding year will contain about fifty of the more valuable food and game species, and from this we may choose the most instructive types for study. ${ }^{2}$

Ponds as balanced aquaria: foods and overstocking. The work with aquaria may be made to help in understanding how to keep park waters and reservoirs in good condition. Lack of proper balance results in fouling the water, and is accompanied with offensive odors and appearance. The fishes die, beginning with the more overcrowded or more sensitive kinds, and ending with the catfishes, which can live in fairly wholesome mud. Probably in most such cases the prime reason why the fishes die is because they lack proper

1 Jordan and Evermann, Descriptive Catalogue of North American Fishes, 3313 pages, 392 plates. "The work has been carefully devised to be of no use whatever to anyone save an ichtllyologist" (Hornaday).

2 The list recommended for pond culture is as follows: black basses (small-mouthed and large-mouthed), crappie, calico, rock, and warmouth basses, the bluegill sunfish, and the catfish, or bullhead (either Ameiurus nebulosus or A.n. marmoratus, a variety known in the South as the marble cat). Strong local prejudice and lack of outward beauty are against the humble catfish, but for edibility Dr. Jordan has placed it above all the basses, perches, and pikes, and just below the trout, salmon, and whitefish. The bluegill is the only sunfish recommended for use by the Bureau of Fisheries, " and it is believed to be the finest pond fish available for private culture."-Johssox and Stapletox, loc. cit., p. 18. 
food; that is, if they were thriving and growing, they would resist attacks of saprolegnia or other disease germs. A variety of plants and animals is essential in a balanced pond if it is to supply food continuously to all its inhabitants. As with similar problems on land, the most necessary thing is an abundance of plants, to supply food for snails, mussels, insects, worms, crustacea, and vegetable-feeding fishes; then raussels should be present in sufficient numbers to strain out any excess of floating algæ and fungi; and, finally, there must be enough carnivorous forms to prevent excessive multiplication of the vegetarians. Of ( ourse this natural balance of lakes and ponds is a more complex matter than that of our aquaria, since these are never required to produce all the foods of the fishes.

Even good-sized lakes unay lose balance, and cer-

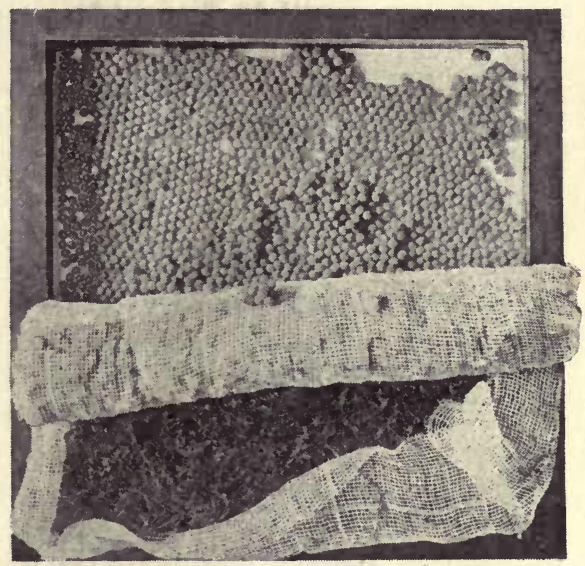

Frg. 143. Tray of wild-trout eggs, with mosquito net and moss in which they were packed

United States Burean of Fisheries tain species may suffer. The white bass in Lake Mendota, Wisconsin, in the summer of 1889 , died in such numbers that windrows of them were vashed upon the shores, necessitating the removal of over 200 wagonloads trom the mile or so of beach in Madison. They had become overcrowded und weakened by starvation. Lake Louise, in Penusylvania, was stocked vith black bass, and the rules of the fishing club that controlled it required that all the fish caught be returned to the lake. In a few years the lake nad nothing but black bass in it, and these were so starved that the tish were almost all heads and mouths, with shrunken bodies. The case was investigated by the United States Bureau of Fisheries, which idvised fishing out the surplus black bass and transferring them to the 
Susquehanna River, where there was abundance of food, and introducing food fishes (perch, minnows, and crawfish) and aquatic insects. The starved black bass very soon grew to proper form when well fed.

Food being practically the limiting factor, self-sustaining ponds are said to be capable of producing from 5000 to 6000 pounds of fish per acre. ${ }^{1}$ This yields a cash value, at 10 cents per pound, of from $\$ 500$ to $\$ 600$, "and this with no expenditure for food." No figures are available for limits of possible production in well-planted and aërated ponds if the fish are given adequate variety and quantity of food. Estimates might prove more amusing than instructive. For example, in a self-feeding pond of one acre, 3 feet deep, we have 130,680 cubic feet of water. At 5000 pounds per acre, we should have 1 pound of fish produced in about 26 cubic feet of water. Suppose, by proper care and feeding, we could produce 1 pound per cubic foot ( 7.48 gallons)? Can anyone so feed and care for a bluegill or a catfish, in a five-gallon aquarium, that it will gain 1 pound in a year?

Successful combinations in aquaria may suggest similar treatment of ponds. That is, can anyone manage and feed a bluegill and a catfish in the same five-gallon aquarium so that each will gain a pound in a year? Thus we see that by learning the habits and preferred habitats of different fishes we may have all parts of our pond occupied and so increase production. The pout will choose the stagnant holes with muddy bottoms; the perch, the deeper channel, where there is some current; the crappies, rock bass, and sunfish, the shelter of stumps and brush and weed patches. The water will be purified if the bottom is well stocked with the best available mussels, and crawfish (if there is no danger from their burrowing) may do the scavenging and turn waste matters into food for the fishes. Frogs and toads, if allowed to breed, may further help in the balance of life; and, finally, a few pairs of mallards, teal, or wood ducks might fit in, both for ornament and for profit. ${ }^{2}$

1 N. R. Buller, "What an Acre of Water Will Do," Bulletin No. 10, Pennsylvania Department of Fisheries, 1914, p. 7.

${ }^{2}$ In a project of this kind, like working for a record production of corn, potatoes, or poultry, we open a new field of interesting possibilities. Who can produce the largest and best-balanced and most varied crops from an acre of water? Water cress, water lilies (of many rare and beautiful kinds), cowslips, gentians, and cardinal flowers, the fishes, frogs, crawfish, possibly fingerlings for distribution, perhaps a ton or so of highest-grade mussel shells, and a fine flock of wild ducks for distribution and propagation will results from such a home-pond project bear out the statement that "an acre of water may be made to produce as much as five acres of land"? 
A record at the end of a-successful year might read somewhat a: follows :

\section{Record Production from a Pond of One ACre, from One to 'Ten Feet Deep}

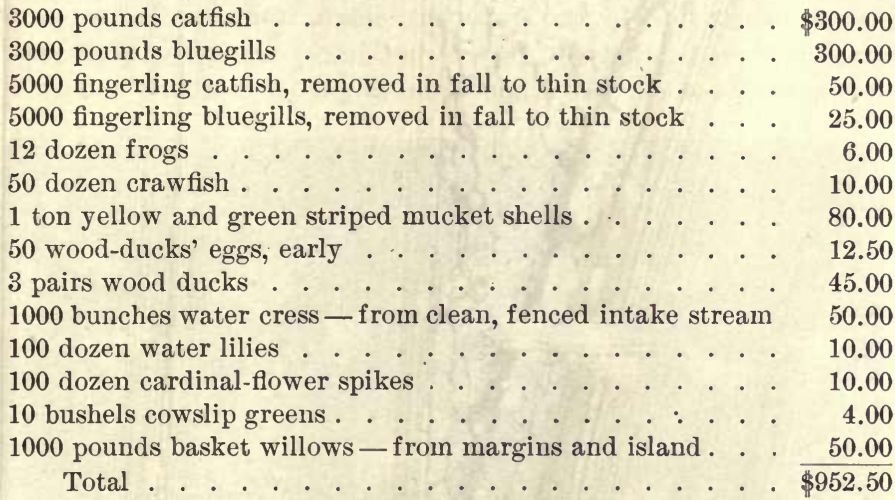

Seeds, tubers, bulbs, and plants of aquatic duck foods, any of which, if present in excess, might be made to increase the account, are quoted in a price list as follows :

Duck potáto, or wapata (Sagittaria latifolia): bulbs, 15 cents each ; $\$ 5$ per 100 .

Wild celery (Vallisneria spiralis) (must be wet): 35 cents per pound.

Water cress (Nasturtium officinale): plants, 10 cents each; $\$ 4$ per 100 ; $\$ 20$ per 1000 ; seed, 50 cents per ounce; $\$ 5$ per pound.

American lotus lily (Nelumbo lutea): tubers, $\$ 1$ each; $\$ 10$ per dozen; seeds, \$1 per 100 .

Wild rice (Zizania aquatica) (must be wet): seed, 35 cents per pound.

Potamogetons (mixed): $\$ 1$ per quart; $\$ 20$ per bushel.

Wild sago (Potamogeton pectinatus): $\$ 1$ per quart; $\$ 25$ per bushel.

Musk grass (Chara) (mixed or single species): $\$ 7.50$ per crate.

Duckmeat (Lemna): $\$ 1$ per quart; $\$ 10$ per dozen quarts.

Anacharis, or Elodea (Philotria canadensis): \$6 per crate.

Coontail, or hornwort (Myriophyllum) (various species): $\$ 7.50$ per crate.

To this list we might add :

Cardinal flowers (Lobelia cardinalis), seeds and plants.

Water lilies (Castalia or Nelumbo) (various species), seeds and rootstocks. 
Professor Forbes of the University of Illinois has made a special study of the foods of fishes. He has found that with most fishes foods change with age, the life of a fish being, in fact, divided into two and often three distinct periods. In the first, which we may call the "fry" period, from hatching to one or two inches in length, all species feed on small crustacea. In the fingerling stage, from one or two to four inches, they feed largely on insects but begin to devour their smaller fellow fishes as well. When adult, the larger species feed chiefly upon

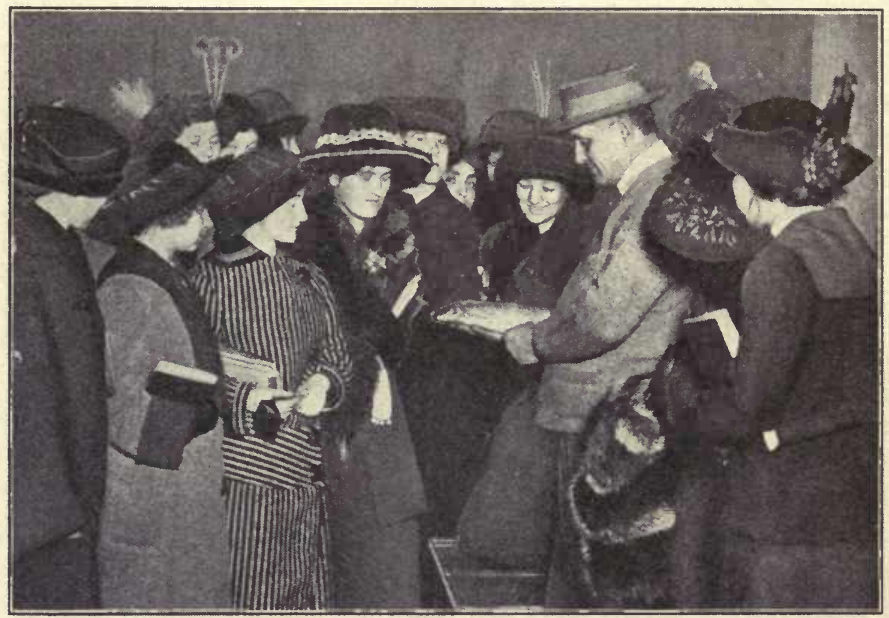

Frg. 144. Visiting Municipal Fish Market, Cleveland, Ohio

Class learn to distinguish fresh fish by the red gills and the unsunken eyes

smaller fishes, while the smaller species continue to feed mostly on insects. Adult fishes possessing fine gill rakers continue to strain out the minute crustacea; those with heavy, blunt teeth feed largely on mollusks; and worms play but a small part in the food of fresh-water fishes.

Spawning habits and seasons. Brooks's law, as stated in its application to the lobster, with the diagrams illustrating it, applies with equal force to food and game fishes. With the powerful machinery at his disposal, man strikes all species as a catastrophe and not as their natural enemy; and he must make good his attack by intelligent dominion or lose 


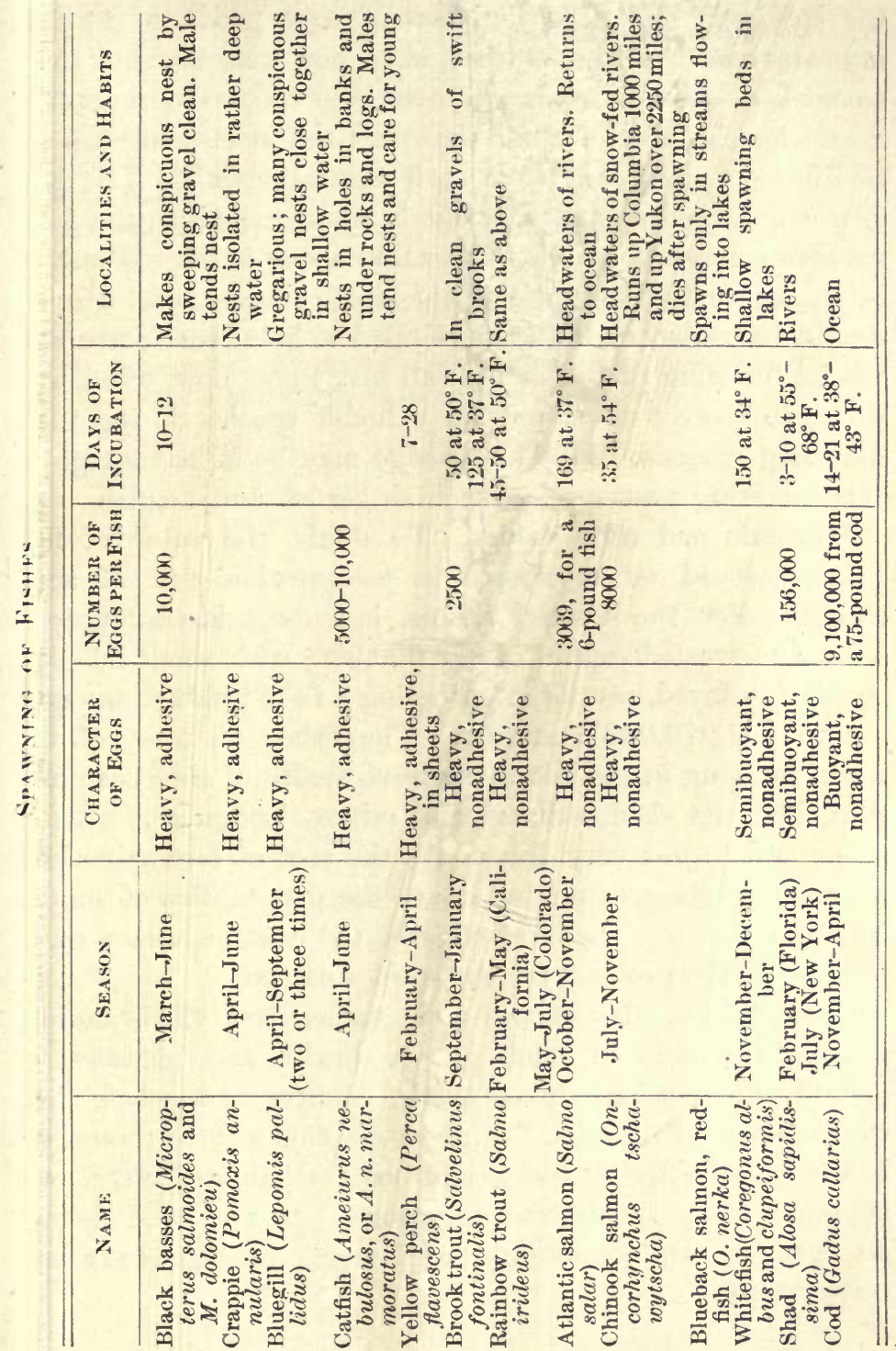


the species. The large numbers of eggs produced by fish indicate how quickly we may have our waters abundantly stocked, as soon as we learn enough to coöperate in leaving a sufficient number of adult spawners and in insuring protection of eggs and young from their natural enemies. The data in this field must be worked out in connection with the local surveys suggested above. The table above is offered merely by way of further suggestion. The biology class in each district should have its own table, developed to give local dates and precise breeding places, so that all may know how, when, and where to protect effectively all valuable species during their spawning seasons. This knowledge may be of advantage in exterminating pest species, such as garfish and dogfish.

Economic and civic values. To doubt the value of fish culture would be as absurd as to question that of agriculture. For the United States, including insular possessions, an invested capital of $\$ 79,000,000$, with about 165,000 people employed, results in gathering a food product amounting to $\$ 91,073,000$ annually. The fishes do most of the work, foraging in the boundless food-wealth of the ocean and then, like the shad, salmon, and others, bringing it up our rivers and to our very doors. As the cost of food advances, we are beginning to ask what are the possibilities of supply from our waters. The brief table on the next page may serve to indicate the problem for the species named.

Sport fishing also carries civic values and yields annual returns, not only in catch but in health and pleasure, of possibly no less importance to the country as a whole than the commercial fisheries. It gives employment to thousands in the manufacture of tackle and boats, stimulates travel, and supports many special outing resorts. Is not good fishing an asset to any community, well worth careful study and conservation? 


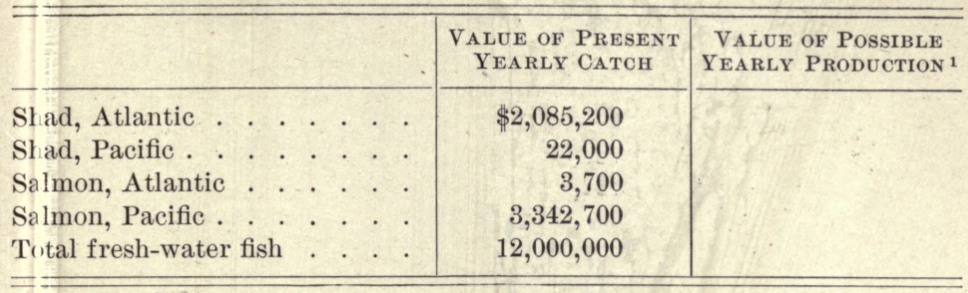

1 This table was submitted to the United States Bureau of Fisheries, but no estimates were available. Dr. George W. Field estimates that under proper management the marine and fresh waters of Massachusetts might be made to yield $\$ 50,000,000$ worth of products annually. 




FIG. 145. Toad catching ants

Photograph hy Newton Miller

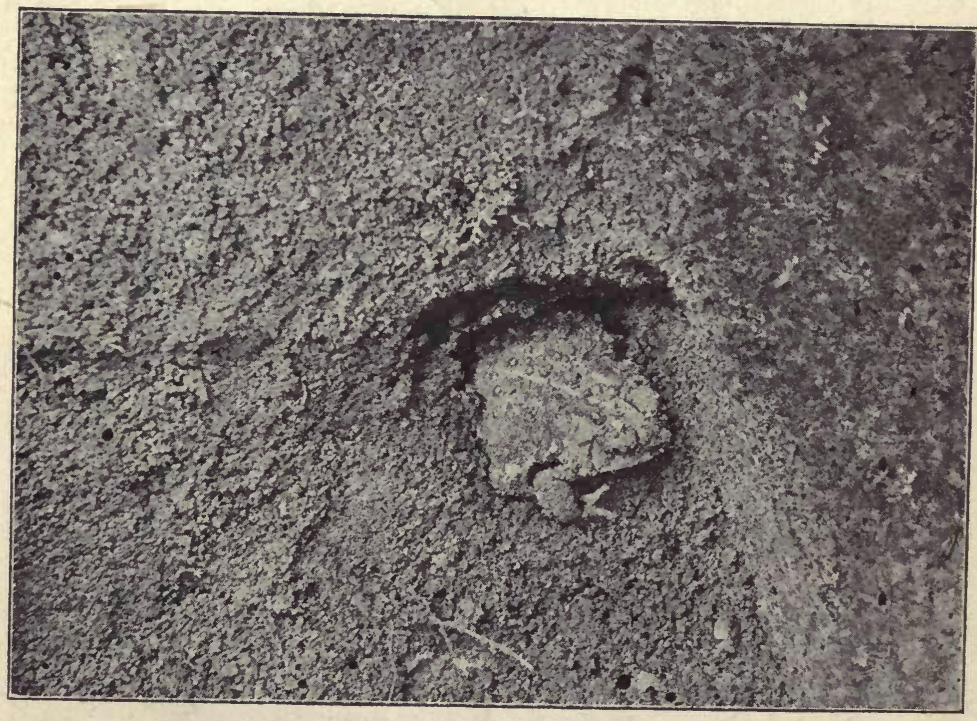

Fig. 146. Toad exposed in its hibernation cavity

Note protective coloration and granulation of skin in relation to earth. Photograph by Newton Miller 


\section{CHAPTER XXVIII}

\section{AMPHIBIA : SIRENS, PROTEANS, SALAMANDERS, FROGS, TREE FROGS, AND TOADS}

For an insectivorous animal which conforms to every requirement of the situation - ease of control and rapid increase, noninjurious in any numbers, an active feeder in abundance and a patient faster in scarcity - the toad stands probably first on the list among American insectivorous animals. Miller, "Biology of the American Toad," American Naturalist, Vol. XLIII (1909), p. 643

The amphibia are a relatively small group of about 1400 species, of diverse kinds (from wormlike crecilians, through the two-legged and four-legged sirens and salamanders, to frogs and toads) - aquatic, semiaquatic, and terrestrial - forming, as the name implies, a transition series from the fishes to the higher land animals. All amphibia are carnivorous, many of our common forms ranking with birds as efficient destroyers of insects ; and as a group they cover the whole field, for salamanders, bullfrogs, and other aquatic species hunt the waters of our ponds and streams and their immediate shores, wood frogs and toads and many of the salamanders follow insects of the ground both by day and by night, and tree frogs are especially adapted to feeding upon insects of forest and orchard. ${ }^{1}$

Amphibia belong exclusively to fresh waters and the land. They are comparatively small, the largest modem amphibian being the giant salamander of Japan, which is said to reach a

1 Hornaday's statement, "With very few exceptions, the amphibians are quite useless to man" (Natural History, p. 360), is evidently made without due regard to their powers of insect destruction or even to their uses as fish bait. 
length of 6 or 7 feet. Gigantic species formerly disported in

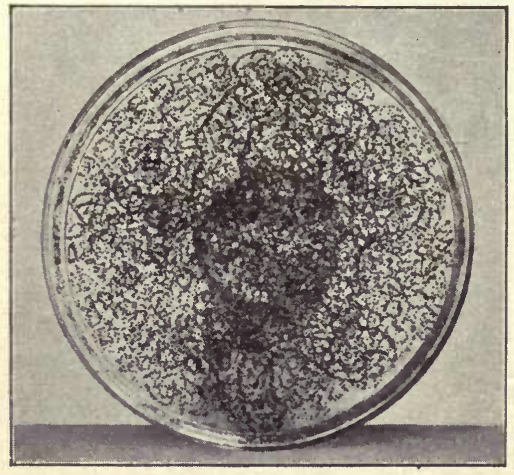

Fig. 147. Laying of a toad-15,835 eggs

Photograph by Newton Miller the vast swamps that have given us our coal formations. With few exceptions, amphibia deposit their eggs in water, and they all pass through a truly larval stage, the "tadpoles" being fishlike-aquatic, legless, and breathing by gills. In addition to insect destruction by the adults, the tadpoles perform an important service by eating all manner of slimes and scums and decaying animal and vegetable matter, thus helping to purify surface waters. Aquaria with and without tadpoles may be made to demonstrate this point in a striking manner, and the results may well be applied to the problem of cleansing local park and reservoir waters.

\section{Natural history of local} species: In connection with other outdoor work, collect all the different species of toads, frogs, tree frogs, newts and salamanders, mud puppies, and sirens common to the locality. Special interest attaches to spawning habits and seasons, since knowledge of

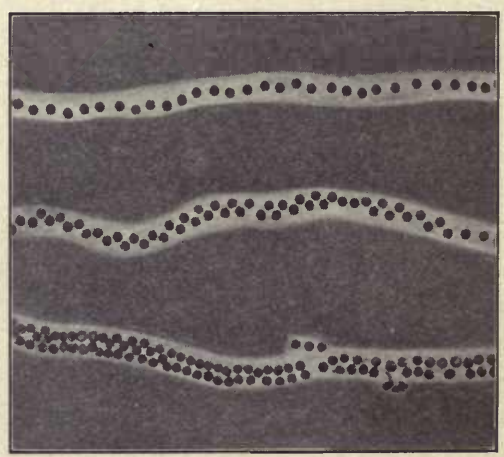

FIG. 148. Different portions of single laying of toads' eggs

The top specimen shows the usual arrangement; the other two show the crowding and irregular spacing of the eggs in the gelatinous tube near the end of the laying. Photograph by Newton Miller 
these data will enable a community to give effective protection to valuable species. Frogs and toads proclaim this season, each species with its own peculiar note, from the earliest shrill whistles of the spring peepers, and the croaks, clucks, trills, and warbles of the frogs, toads, and tree frogs, to the bass-viol br-wums and jug-o-rums of the bullfrogs in late June and early July. The eggs are most interesting forms with which to follow embryological development, and their numbers indicate possibilities of increasing valuable species, when we learn to provide favorable conditions. The toads' eggs are found in strings; the green frogs' and bullfrogs', in loose, floating films; the wood frogs', leopard frogs', and pickerel frogs', in globular masses of jelly; and the peepers', single or in small clusters. Observa-

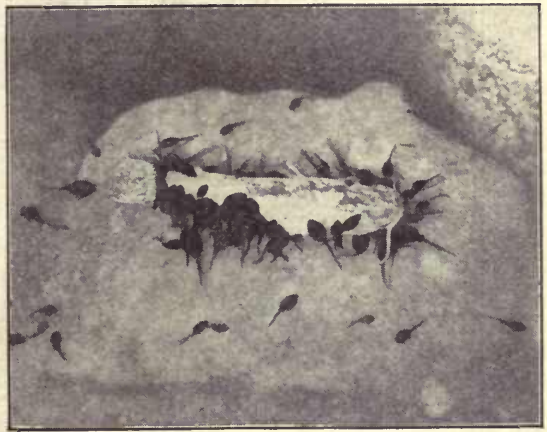

Frg. 149. Toad tadpoles as scavengers, eating dead pout at margin of pond

Photograph by Newton Miller tions by the class may yield a table for local species somewhat like the one shown on the following page.

The feeding test. Amphibia afford most convenient animals with which to study foods and feeding habits. Imitate natural habitats in the arrangement of terraria and aquaria moist earth, moss, or sod for toads, wood frogs, and land salamanders, with a forked branch and a small pool for tree frogs, and a larger pool, with a bank of moss at one end, for aquatic frogs and salamanders. Then, for the tests, introduce all sorts of insects, spiders, millepeds, crustaceans, slugs, and worms, counting the numbers and kinds eaten. No single laboratory exercise shows so convincingly the value of the 


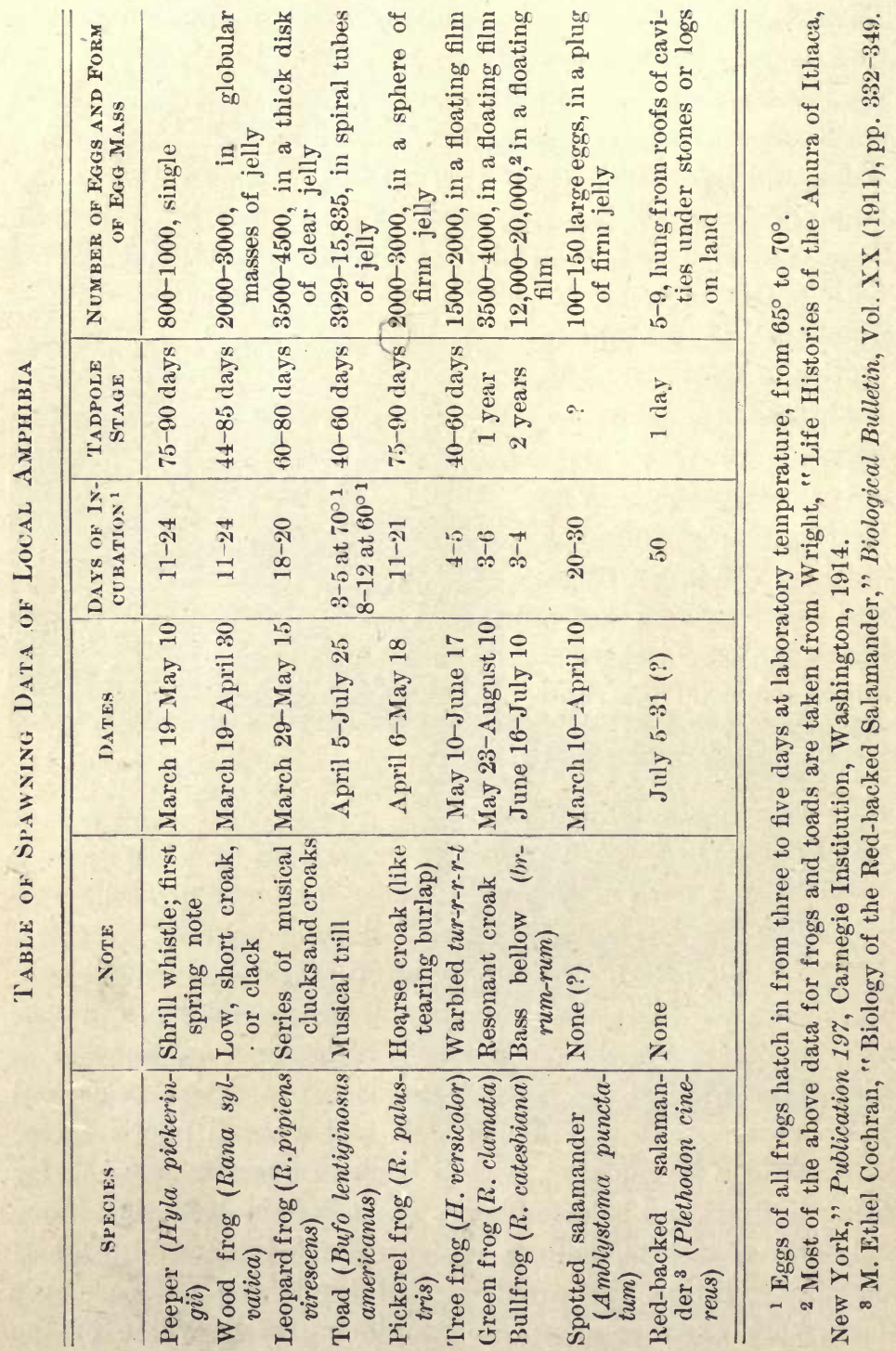


work of a species. Different members of the class may take different species, and the data obtained should be applied to solving the insect problems of the locality.

Almost all insects come to the ground at some time, and we have, especially in the toads, a possible force of insect police that ought to be better known and utilized.

Commercial values. Toads are regularly sold in the markets of Europe, being used by gardeners to control insect pests. ${ }^{1}$ Is there any local market for them? Could such a market be developed as a result of studies and demonstrations to prove their value? The following numbers of insects have been eaten by a toad at a meal or were found in a toad's stomach : 90-100 rose beetles (Fllen M. Foskett); 55 army worms, 77 myriapods, 65 gypsy-moth caterpillars (A. H. Kirkland, in three stomachs); 24 gypsy-moth caterpillars (fourth molt), taken in ten minutes (Wilcox); 86 house flies, snapped up in less than ten mimutes (Hodge). From examination of 149 stomachs, Kirkland ${ }^{2}$ estimates that a toad will eat, in the three months of May, June, and July (why he does not include August and September is not stated; these months would add materially to the account), 3312 ants, 2208 cutworms, 1840 myriapods, 2208 sow bugs, 368 weevils, and 368 carabid beetles. Subtracting the cutworms that might have been killed by the carabids, we have 1988 cutworms to the toad's credit. He estimates the killing of these as worth one cent a piece to a gardener, and thus, for cutworms alone, the possible value of the toad's work is $\$ 19.88$ for the season. Miller ${ }^{8}$ is more conservative and estimates a toad's work for a season at, possibly, about $\$ 5$ "for greenhouses, gardens, and truck farms" and not so much in ordinary farming districts.

Frogs, especially bullfrogs, are much more inclined to feed upon animals other than insects - fish, birds, crawfish, and, above all else, upon other frogs. This is the great obstacle to frog culture - except on paper. No matter how many we succeed in bringing through the tadpole stage, we have few big frogs in the end. The difficulty in feeding frogs artificially is that they take only active, moving, hence living, food. It would

1 Kirkland states (Farmers' Bulletin No. 196, p. 14) that English gardeners pay $\$ 25$ per hundred.

2 Kirkland, Hatch Experiment Station, Bulletin 46 (1897), p. 27.

${ }^{3}$ Miller, "The American Toad," American Naturalist, Vol. XLIII (1909), p. 668 . 
seem entirely possible to solve the problem of supplying such foods in quantity and variety that would largely prevent even the bullfrogs from eating each other. We might have lighted insect traps to deliver their catches of moths and beetles all night long into the water beneath them;

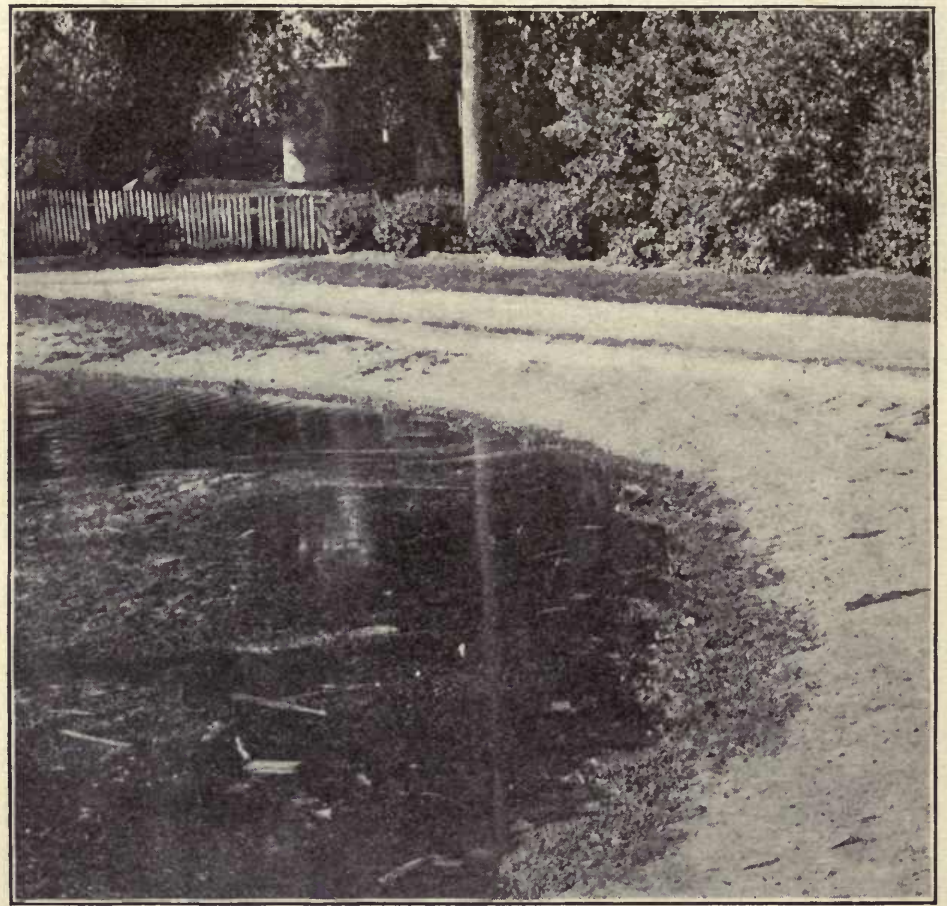

Fig. 150. Toad tadpoles (broad, dark margin of pond); young toads emerged and moving landward (irregular gray edge of shore)

Photograph by Newton Miller

sweeps designed to catch grasshoppers alive; blowfly maggot hatcheries, made to drop the maggots into the water as they ripen; or, if all these should not suffice, crawfish and the smaller species of frogs could be added. Meehan ${ }^{1}$ states that " 30,000 tadpoles have been safely carried

1 Meehan, "Possibilities of Frog Culture," Country Life in America (1908), p. 315. 
to frogdom in a pond 30 feet by 15, having a depth of 2 feet of water." As eggs of leopard frogs, pickerel frogs, and wood frogs can usually be

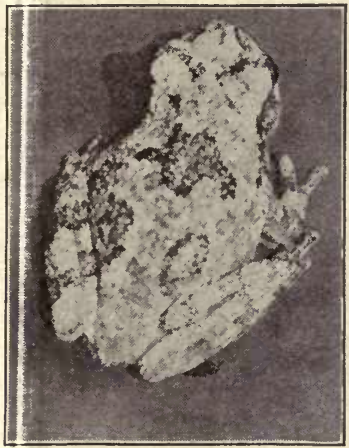

Fig. 151. Common tree frog

Photograph by Millett T. Thompson gathered in any desired quantity, this would indicate almost unlimited possibilities of live-food production.

In addition to their uses, actual and potential, as insect traps, frogs have commercial values which threaten their extermination in many localities. In some places small ones bring from $\$ 1$ to $\$ 2.50$ per 100 for fish bait. The frog is the animal most commonly used for laboratory study the world over; frogs used for this purpose bring from 50 cents to $\$ 3$ per dozen. Moreover, while they were rarely used for food a few years ago, frogs' legs have now become a well-known delicacy. "The meat is white, delicate, and very wholesome and palatable." Hence catching frogs for market often yields good profit, and it affords a mildly humorous form of outdoor sport. As these values come to be recognized, valuable species can be protected by closed seasons (from the opening of spring until after they spawn), local waters can be kept stocked to their full capacity, and an abundant crop can be secured each year.

Some special problems. 1. In a pond stocked with liullfrogs, how can we feed so as to prevent cannibaljsm and thus secure the greatest number of large specimens from a given ¿rea?

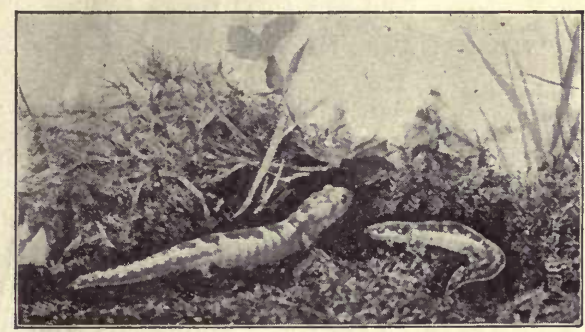

Fig. 152. Pair of spotted salamanders

Photograph by Millett T. Thompson

2. How can the largest number of toads be reared from a pool a foot rquare and a foot deep? (We have one record of 3938 from April to lugust; the main foods were algæ, dog biscuit, and fresh fish.)

3. Are toads being exterminated from agricultural districts by draining their breeding pools, by farm animals, and by the operation of farm 
machinery? Could this be prevented? If so, how? Might it be worth while, as a measure for insect control, to try the experiment of stocking a farm with them, and comparing the damage done by insects on such a farm with that on a similar farm where there are no toads?

Elementary classification and distribution. The names at the head of this chapter present the main groups of amphibia in ascending order.



Fig. 153. Coast newt depositing eggs in an aquarium

Photograph by Loye Holmes Miller They are placed there to serve as handles by which any form that is of local interest or importance may be looked up in the dictionaries, natural histories, or zoölogies.

Jordan's "Manual of Vertebrates" describes eighty-one species of salamanders for the United States. So little is known about their habits, foods, spawning seasons, and general natural history, that they offer an alinost virgin field for young American naturalists - a field that needs working the more on account of senseless prejudices concerning the venomous character of these harmless and valuable animals. The mud puppy (Necturus maculosus) of the upper Mississippi and Great Lakes basins destroys the spawn and young of fishes, but this is the only one of the tailed amphibia that is considered harmful.

Recent books describe fifty-thrèe species of the tailless amphibia as native to the United States - the frogs, tree frogs, and toads. Of the fourteen species of toads the greater number occur in 'Texas and southwestern United States, indicating this region as the probable center from which the group has spread over the continent. 


\section{CHAPTER XXIX}

\section{REPTILES : CROCODILES, ALLIGATORS, TURTLES, TERRAPINS, TORTOISES, LIZARDS, SNAKES}

However, the Reptilia take up a very central position in the evolution of the main classes of the Vertebrata. On the one hand, there is not the slightest doubt that they are evolved from some branch of the Stegocephali, whilst on the other hand the reptiles, probably through some branch of the Theromorpha, have given rise to the mammals; some other reptilian branch, at present unknown, has blossomed out into the birds.-Haxs Givow, "Cambridge Natural History," Vol. VIII, pp. 277-278

In the absence of birds, what, then, holds the devastating hosts of irsects in check, for insects abound in all warm countries where vegetation is luxuriant? This, in my opinion, is the lizard brigade, - those spry and cheerful little fellows in brown "homespun," of which $L a$ certa muralis is the commonest kind, which are seen streaking it over walls and along the ground, in town and country everywhere. - F. H. HERRick, "Italian Bird Life as it impresses an American To-day," Bird Lore, Vol. VIII, p. 196

Why may not a good snake merit the same protection as a good bird? The reason is that we have not taken the pains to know the good from the bad, and our prejudice and fear, the children of ignorance, have dominated the field. As venomous snakes have been almost exterminated from iuhabited parts of the country, we are coming to be able to appreciate the beauty and acknowledge the good there may he even in a snake. In general a reptile is a good citizen if it does good work in the world, if it feeds upon injurious insects or upon rats and mice or other harmful animals, and if it is not venomous. In addition to this larger aspect, a rumber of reptiles supply valuable products - alligator and 


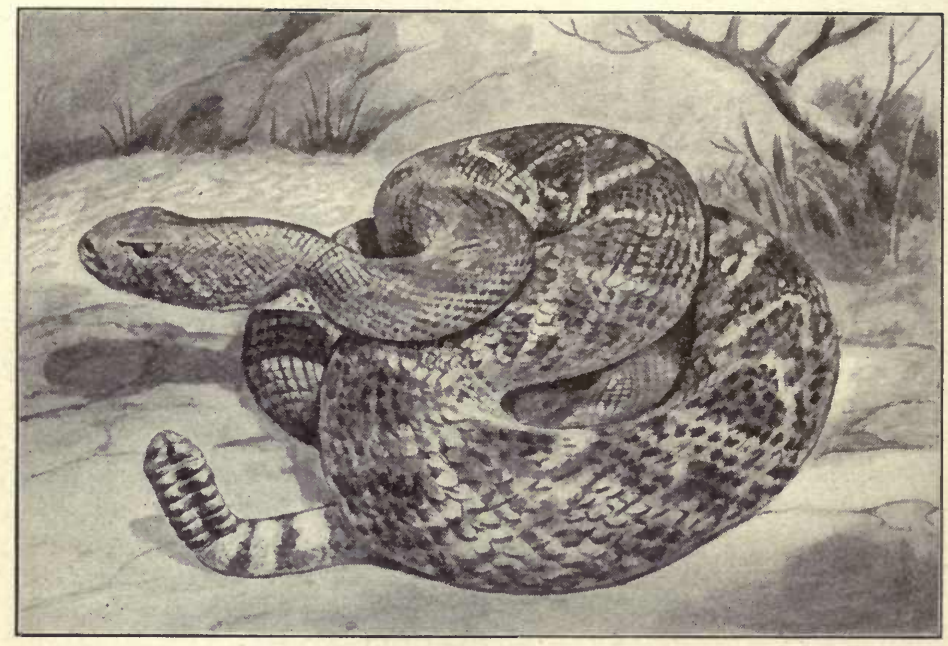

Fig. 154. Rattlesnake coiled to strike

After Ditmars

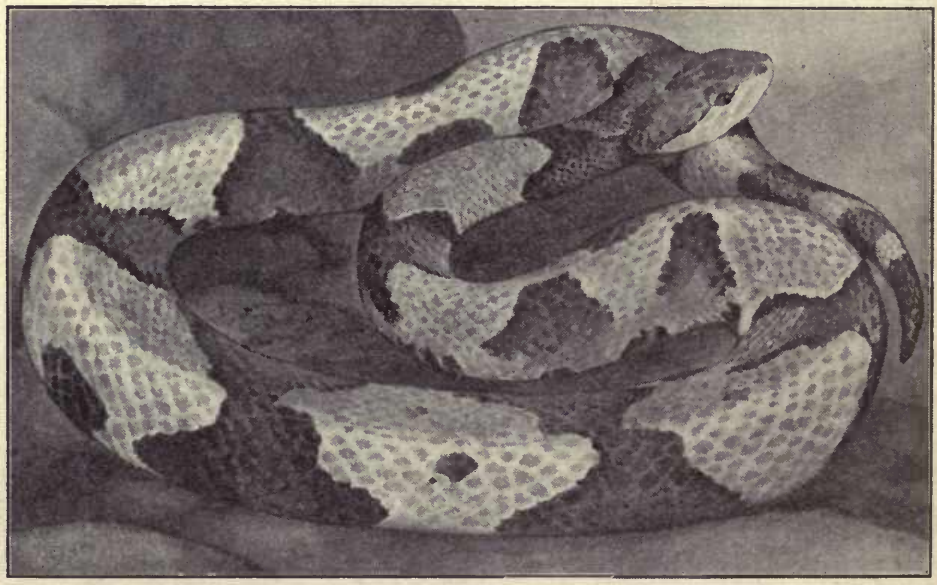

Fig. 155. Copperhead

After Ditmars 
snake-skin leathers, the tortoise shell of commerce, and the flish of some of the marine turtles and fresh-water terrapins. Here is a wide, almost new, field, and anyone who will make careful studies of habits'and life histories, especially of feeding tests with snakes, lizards, or turtles, and even tests of edibility in case of likely forms, has a good chance of advancing the cause of valuable knowledge and common sense.

Crocodilia. The warm regions of the world contain nineteen species of big, burly, bony-armored reptiles, with long tails, powerful jaws, and tempers as ugly as their own rough backs. - HorNADAY.

To see a live Alantosaurus immanis 115 feet long — said to be the ")iggest and bulkiest of all animals" (Gadow) - would make us realiz that our largest 20-foot crocodiles are mere pigmy survivals of the hinge reptiles that ruled the world during the Upper Jurassic. According to Hornaday only three of the nineteen species are dangerous maneaters - the Malayan salt-water crocodile and two African forms. The two that are natives of America, Crocodilus acutus and Alligator mississimpiensis, are not man-hunters. Still, to keep such hulks in food - consisting of fishes, waterfowl and poultry, pigs, and other animals such as they can catch - is expensive and must eventually limit their range to zcölogical gardens and alligator farms.

Turtles - Chelonia. Senseless waste and even cruelty have too often cliaracterized man's treatment of these defenseless and valuable creatures. Their nests have been plundered for the eggs, whose value is slight compared with that of the turtles which they might have produced; the mother turtles, when they draw out of the sea to lay, have been turned on their backs in numbers that could not be utilized, and most of them left to struggle under the hot sun until they died; the hawksbill, in some countries, is hung over a slow fire and roasted until thie precious shell plates loosen from the bone, when they are stripped oif and the turtle is put back into the water under the probably false irlea that it may live to produce another crop of shell. These are some 0 the abuses that ought to be stopped in the name of humanity. While i1 may be a far cry to ask savages of cannibal islands to treat sea turtles with humanity, we might, at least, see that turtles of our own coasts are theated in humane and common-sense fashion. They range the tropical and subtropical oceans the world around, but Gadow says that they probably return to the same beaches to lay. Hence, if we protect the turtles 
of our own southern coasts, and especially their eggs, we may hope to increase the American supply. May not classes in biology work up local statements of this problem and help to develop public sentiment?

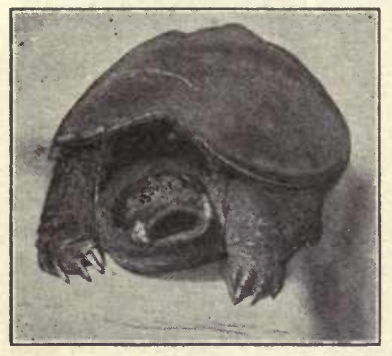

Fig. 156. Common snapping turtle

Of the four species the green turtle (Eretmochelys mydas) is most highly prized for food. While formerly specimens weighing 600 pounds were captured, now specimens weighing more than 50 pounds are rarely seen. The loggerhead (Thalassochelys caretta) is coarser and does not command so high a price. but may not be distinguished from prime beef even by a butcher (Hornaday). The hawksbill (E. inbricata) supplies the tortoise shell of commerce, but is not used for food. The harp turtle, or leatherback (Sphargis coriacea), the largest of all, is said to be unfit for food.

Terrapins and tortoises. The diamond-backed terrapin (Malacoclemmys palustris) is so renowned a delicacy with the epicures that extinction of the species has seemed imminent. It formerly ranged from Massachusetts to Mexico (the Chesapeake being a center of special abundance), inhabiting the salt marshes and feeding upon crustacea, small mollusks, and marsh vegetation. Prices have risen from $\$ 3$ a dozen for large ones to $\$ 70$ for small ones, and this has so stimulated the hunt for them that a well-grown specimen has become a curiosity in the wild habitat. Experiments of the United States Bureau of Fisheries, the results of which are given in a recent bulletin, have proved that

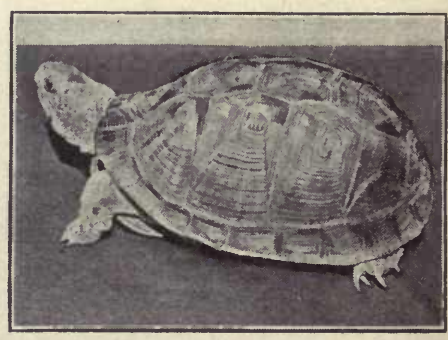

Fig. 157. Common box tortoise this terrapin may be profitably reared in inclosed tide pools. Waste tide flats are thus beginning to be used for terrapin farms.

The common snapping terrapin, or "turtle" (Chelydra serpentina), and the alligator terrapin (Macrochelys temmincki) of the Gulf states, while valuable for food, are "demons of the deep" (Thompson Seton) for destroying waterfowl and fishes. United effort should be made to exterminate them from waters where rearing of waterfowl is an industry, 
and from the natural breeding grounds of wild ducks and geese. The most effective means of doing this would be to find their nesting banks and destroy the eggs or catch the turtles at night, when they leave this water to lay. A female may produce from 2 to 4 dozen eggs. The sot t-shelled terrapin (Aspidonectes ferox) is said to be the best of all the fr'sh-water forms, even the shell, properly cooked, being considered a delicacy. They are, however, vicious destroyers of fishes and waterfowl.

Any of the smaller mud, or pond, terrapins, painted or spotted, and th': land tortoises, offer interesting problems in the study of foods and possible edibility. The common box tortoise (Cistudo carolina) makes an interesting pet, and its appetite for slugs renders it a valuable assistant to gardeners. The gopher tortoise (Testudo polyphemus) of the South may attain a weight of 15 pounds. It is considered edible.

The annual catch of food turtles, terrapins, and tortoises aniounts to about $1,400,000$ pounds, valued at $\$ 114,500$. What it might be if these resources were properly handled has never been estimated.

\section{Lizards-Lacertilia. The} lizards are an effective in-

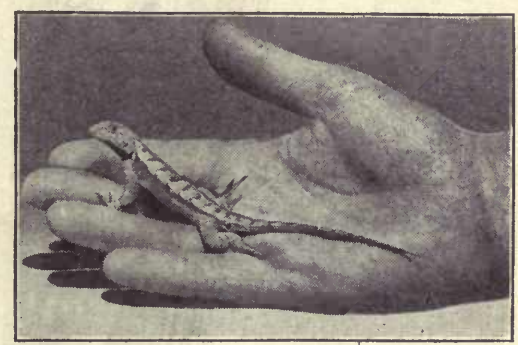

Fig. 158. Common lizard sect police for hot, dry habitats not covered by amphibia. They are difficult to keep in a laboratory, but if we have a sunny window, in which we can imitate desert conditions, we may make valuable feeding tests with a number of the commoner forms - the blue-tailed lizard, or skink (Eumeces fasciatus), the fence swift (Sceloporus undulatus), and one of the horned toads, or the chameleon (Anolis carolinensis). This may help us to realize the importance of the group in nature. Lizards are clearly distinguished from all salamanders of somewhat similar form by being covered with scales. None of our 97 species of small, agile lizards are in any way harmful or dangerous. The Gila monster (Heloderma suspectum) of the arid Southwest is the one venomous lizard native to the United States. 
Snakes - Ophidia. About 140 species of snakes are native to the United States, of which 17 are venomous. They are all strictly carnivorous, and the nonpoisonous species are beneficial or injurious, according to their foods. It is clear that snakes which specialize on insects or on rats and mice should merit general protection. Our little brown and green

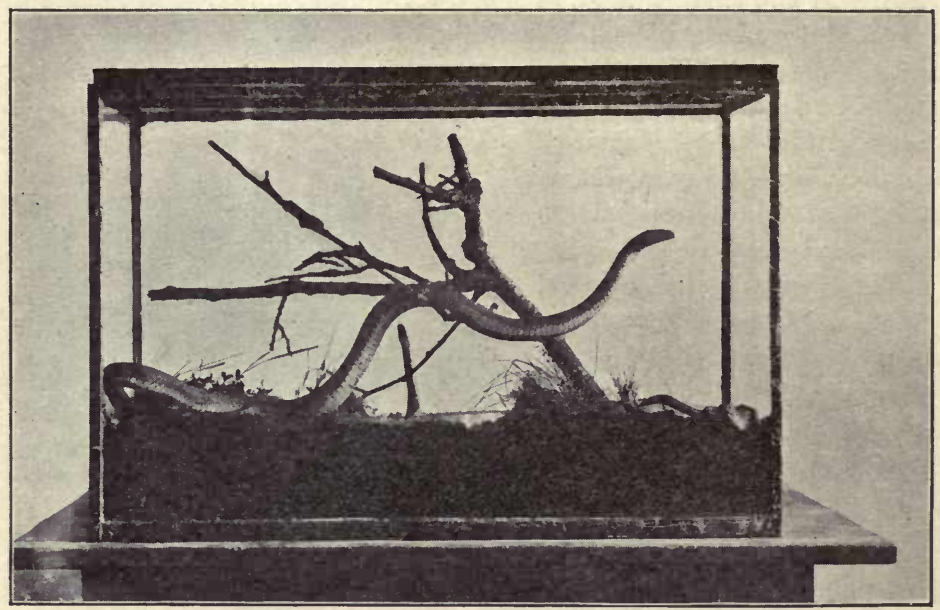

FIG. 159. Aquarium $\left(24^{\prime \prime} \times 18^{\prime \prime} \times 12^{\prime \prime}\right)$ made by student and stocked for study of native snakes

Photograph by the author

snakes feed on insects, and the corn snake (Coluber guttatus), often called the rat snake, and the gopher snake (Spilotes corais couperii) are often protected about the farmsteads of the South for their services in holding rodents in check. The snakes that feed upon birds and birds' eggs (the black snakes or the blue or green racers), those that feed on frogs and toads (the garter snakes and the blowing adder, or spreading adder), and those that feed on fishes (the water snakes) must be studied with care and treated according to local conditions and interests. 
Poisonous snakes. Fortunately none of our venomous snakes tend to infest houses, as does the hooded cobra of India. In consequence, snake bites are extremely rare with us, and probably not more than two deaths occur annually from this cause (Hornaday). Of the 17 venomous species 13 are rattlesnakes, belonging to the genera Crotalus and

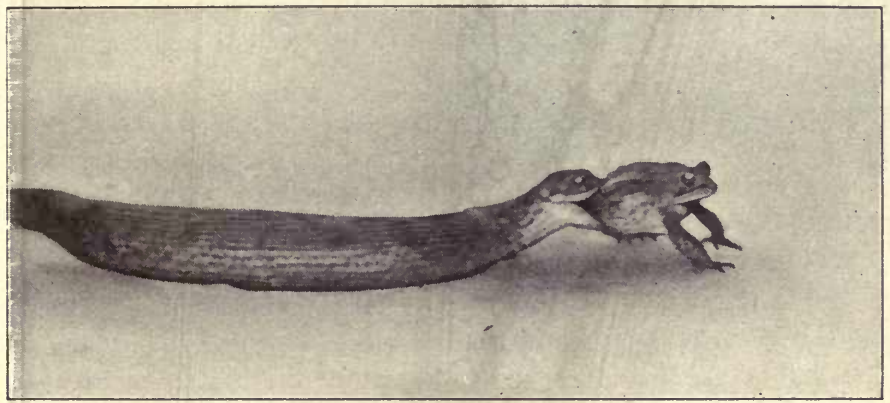

Fig. 160. Blowing viper, trying to make room for one more

Photograph by the author

Sistrurus (the massasaugas), so well known, so clearly distinguished by the rattles, and so nearly extinct from all settled regions, that they require no description. It is probably safe to say that a rattlesnake strikes only in self-defense and that it never gives chase. When coiled it cannot strike mure than one third of its length, and much less if the neck is drawn into an S-shaped loop, and its rasping buzz gives a wirning that is readily understood by both animals and man.

Closely related to the rattlesnakes are the two moccasins - the upland moccasin, or copperhead (Ancistrodon contortrix), and the ugly witer moccasin (A. piscivorus), often called the cottonmouth. The copperhead is found among rocks and in woods from Massachusetts to Florida, ranging westward to Texas and northward to Indiana. The water moccasin inhabits the swamps and grassy shores of the bayous of the Gulf states, feeding largely on fish and frogs, and on other snakes. 
The two coral snakes complete the list of venomous species for the United States. These suakes do not in the least resemble the rattlers and moccasins. Their heads are slender, not broad and spear-shaped;

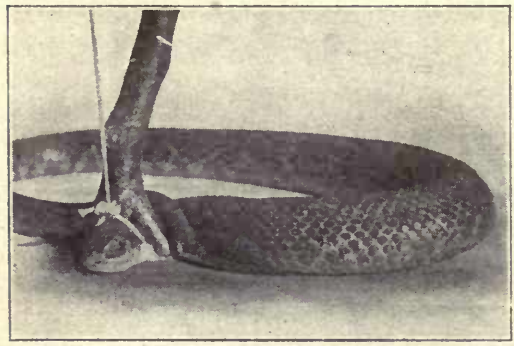

Fig. 161. Use of forked stick and noose in catching a snake the pupil of the eye is round and there is no pit between the eye and the nostril. They look so harmless that, as Hornaday says, "it is difficult to see how anyone can be bitten by this serpent without having it done by special appointment." This is all the more reason for having it definitely known that these snakes are venomous. They belong to the same family (Elapida) as the deadly king cobra of India. They are instantly recognized by the brilliant yellow, red, and black rings that encircle the body from the head to the tip of the tail. The two species are the harlequin snake (Elaps fulvius), which ranges from South

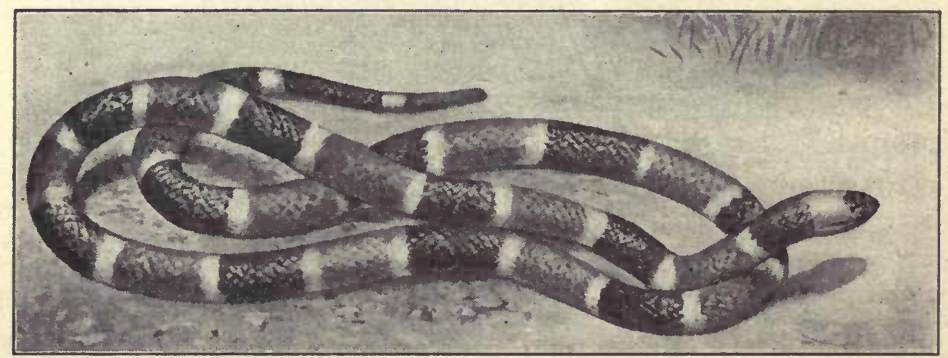

Fig. 162. Coral, or harlequin, snake, with yellow band around head and also between the red and black bands of the body

\section{After Ditmars}

Carolina throughout the Gulf states to Texas, and northward up the Mississippi to southern Indiana, - a persistent ground dweller, most often seen when turned out of the furrow by the plow, - and the Sonoran coral snake (E. euryxanthus), confined to Arizona, New Mexico, and northern Mexico. 
Snake venoms and the treatment of snake bites. Dr. Calmette, of the Pasteur Institute, succeeded in proving that snake venoms act upon the body and are reacted against by the tissues like any other toxins. From this it has followed that antitoxic sera may be developed for different snake poisons, - the antivenins, - which are able to neutralize tie poisons and thus confer certain degrees of passive immunity. When this subject has been thoroughly worked out, we may have specific and s ire remedies for all snake poisons, and this will do away with the old, ineffectual remedies - whisky, sucking the wound (very dangerous unless the mouth is perfectly sound), or instant ligature above the bite and quick excision of the poisoned tissues. ${ }^{1}$

1 Nogouchi, "Snake Venoms," Publication 111, Carnegie Institution, Washington, 1909. 


\section{CHAPTER XXX}

\section{PRACTICAL LAWS OF LIFE}

\section{Geometrical Increase and Struggle for Life. Vari-}

ation. Shlection and Survival of the Fittest. Heredity. Genetics. Eugenics

It is good thus to try in imagination to give to any one species an adyantage over another. Probably in no single instance should we know what to do. This ought to convince us of our ignorance on the mutual relations of all organic beings; a conviction as necessary as it is difficult to acquire. All that we can do is to keep steadily in mind that each organic being is striving to increase in a geometrical ratio; that each at some period of life, during some season of the year, during each generation or at intervals, has to struggle for life and to suffer great destruction. When we reflect on this struggle, we may console ourselves with the full belief, that the war of nature is not incessant, that no fear is felt, that death is generally prompt, and that the vigorous, the healthy, and the happy survive and multiply. - Charles Darwix, "Origin of Species," p. 96

An exact determination of the laws of heredity will probably work more change in man's outlook on the world and in his power over nature than any other advance in natural knowledge that can be clearly foreseen.Batesox, "Mendel's Principles of Heredity," 1902, p. 1

To unravel the golden threads of inheritance which have bound us all together in the past, as well as to learn low to weave upon the loom of the future not only those old patterns in plants and animals and men which have already proven worth while, but also to create new organic designs of an excellence hitherto impossible or undreamed of, is the inspiring task before the geneticist to-day. - WA WTER, "Genetics," p. 5

It is as impossible now to take the ideas of descent and of natural selection out of the world as to take a star out of the sky. - Cramer, "Method of Darwin," p. 61

Mankind is slowly discovering the laws of life. Ignorance cannot, in the nature of the case, bring exemption from the consequences of breaking laws; hence failure even to try to 
livarn the laws under which we live may amount to criminal carelessness. We discover and learn laws in order that we nsay be able to obey them, that is, bring our lives into harmony with them. Charles Darwin, by lifelong application and sacrifice, marked the greatest advance in discovery of the laws of life that the world has known. These are not far-away abstractions of thought, and nothing can be of more intense practical value than a knowledge of them. Work cone or life lived in accordance with them is always effective and successful, while that done or lived in opposition to them is always futile.

While it may be sufficient that a few specialists learn how to control the chemical and physical forces of nature in accordance with the laws of physies and chemistry, the forces of living nature are so numerous, affect the lives of all alike so intimately, and are so powerful that common welfare requires of every member of a civi-

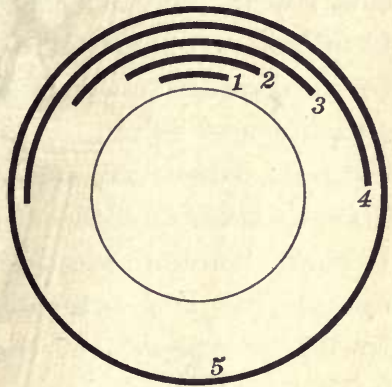

Fig. 163. Diagram showing five generations doubling by geometrical progression lized community that he know enough about them to do his part.

Law of geometrical increase. All living things tend to inrease in geometrical ratio. This is the problem of the farmer who promised to pay the blacksmith one kernel of wheat for the first nail in his horse's hoofs, two for the second, four for the third, and so on. The sixty-fourth nail alone would cost him $6,141,451,656,032$ bushels of wheat - more than the entire wheat crop of the world for 2000 years. The farmer did not know the law of geometrical increase when he promised to pay the wheat. Millions of "farmers" who do not know this law are promising to pay, in control of insects or fungi 
and in many other ways. Fig. 163 expresses this relation to the eye, showing how quickly the world may be covered or any limit be reached, whether of space or food supply, by the geometrical increase of a living species.

Each species has its own formula or equation of increase, its terms depending on the number of eggs, seeds, or offspring and the length of life of a generation. Every species that we need to control or exterminate, or which we wish to save or increase, finds expression for its power of good or evil in this law of increase. The mythical labors of Sisyphus typify humanity struggling with these problems. He was condemned to be eternally rolling a heavy stone up a mountain, the stone slipping and rolling down again when he had almost reached the top. Flies, rats, mosquitoes, or some other plague, become unendurable, and the community tries to rid itself of them. It rolls the stone almost to the top of the mountain. A little more effort, and extermination would be complete, the stone would be rolled over the summit and disappear; but those who do not know this law say, "Never mind these few, they can't do much harm." In a short time the work is all to do over again. So effective control or conservation cannot be developed until we have clear ideas of these equations of increase.

Work out formulas of increase for all sorts of types, good or bad, and develop clearly their significance in solving local problems.

The native American oyster-shell scale produces one generation (about 50 eggs) a year. Its equation of yearly increase is 2 (a pair) $=50$.

The Chinese (or San José) scale brings forth about 500 living young in a period of 45 days, having four or five generations a season. Its equation of increase for a year is $2=3,216,080,400$. What bearing has this upon thorough spraying of trees? The native insect rarely injures a tree perceptibly. The imported scale threatens to exterminate many species of trees from the continent.

The bobwhite has been known to produce 100 eggs in a season. Suppose each pair rears 10 young a year; how long would it take, if 
everyone coöperated, beginning with present numbers, or with ten pairs, to increase them to limits of insect and weed-seed food supply?

Figuring the number of buds produced by a grape, peach, apple, strawberry, or other fruit, the number of eyes by a potato, the number (if seeds by a grain or vegetable plant, how long would it take to supply tvery farm or garden with a favorable variation? This introduces us to the second practical law of life.

Law of variation. No two living things are exactly alike. Can we find two forest leaves, blades of grass, or human aces exactly alike? Living organisms are too complicated for it to happen, even by chance, that any two should be tlike. So this universal law of living nature has given us all our different kinds of plants and animals.

Domesticated plants and animals early attracted Darwin's attention as showing variations most clearly. ${ }^{1}$ Horses, cattle, sheep, dogs, pigeons, and all manner of cultivated plants have varied in the brief centuries of human control, and are still varying, in most wonderful fashion. We have horses, from Clydesdales and Norman Percherons to Shetland ponies, all produced by human breeding and selection. Ages before man appeared on the earth little Eohippus, not much larger than a fox, with five toes, four of them hoofed, trotted over the bogs of the times; and we can now trace in successive strata of rocks how the modern horse developed from this earliest form. The story of other animals and even of man himself we have not as yet been able to trace so clearly.

The great practical values attaching to variations in relation to agricultural productions are touched upon in Chapter IX. Since these depend so largely upon the possibilities of increasing and propagating favorable variations, we must consider this subject further in connection with the greatest of all biological laws.

1 Darwin, Variations of Animals and Plants under Domestication. 
Law of heredity. Organisms tend to produce offspring like themselves. Variation is as destructive as it is constructive. It may give us the Spitzenburg apple, and the seeds of a Spitzenburg may revert toward the original wild apple. Heredity is the force that enables us to conserve the gains supplied by variation. Organic reproduction is of two kinds - asexual, or vegetative, and bisexual. The asexual process is seen in growth and simple division, as found among the bacteria, or growth with budding, as in the yeasts and in plants generally and in many of the lower animals. In all this reproduction we virtually have continuity of the organism, and this can go on indefinitely with little or no variation. So buds, grafts, cuttings (of stems or roots), layers, runners, bulbs, bulblets, tubers, and, in short, all purely vegetative parts of plants capable of reproduction carry the variety true to name. This means that every bud on a Spitzenburg apple tree, rooted in the ground or grafted into any kind of apple root or branch, will produce a true Spitzenburg tree, while not a seed from all the Spitzenburg trees in the world might be able to do this. There is some talk, but little evidence, that varieties tend to run out, or grow old, under bud propagation. Still bud variation does occur. A branch of an orange tree may bear lemons, or a bud of a peach tree produce nectarines or apricots. Buds may also be weakened by association with disease organisms (as in diseased potatoes) or, possibly, by lack of proper nutrition, and so give rise to weakened stock. So we are beginning to hear of pedigree selection of seed potatoes from healthy, vigorous, productive hills, and of buds and scions from healthy and fruitful trees. If these points are attended to, there seems to be no reason why any variety may not by bud propagation be held true to type indefinitely.

All higher plants have adopted bisexual reproduction as one method of multiplication (all seeds), and all animals 
higher than the worms and some insects have come to depend upon it entirely. In sexual reproduction each individual is built up by the mingling of the germinal elements of two parents, and not only that, but of four grandparents, eight great grandparents, and so on. This mingling, by prepotence of some characters and recession of others, eauses active variation, and this seems to be the chief purpose of bisexual reproduction. By statistical analysis Galton proved that an individual receives on the average 50 per cent of his characters from his parents, 25 per cent from his grandparents, and the rest from more remote ancestors. Given all the forces of increase, variation, and heredity, another law comesinto play, the discovery of which was Darwin's

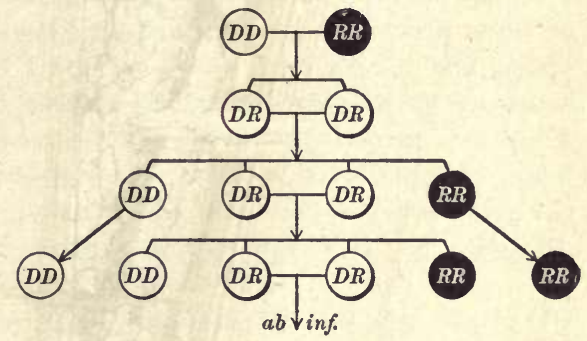

FiG. 164. Diagram illustrating Mendel's law of dihybrids, white being dominant and black recessive great contribution.

The law of natural selection. Nature selects the fittest to survive. From the beginning, man has imitated nature in selecting the plants and animals that suit his need or fancy, and this is commonly distinguished as artificial selection. Combination of these two processes has resulted in the species and varieties, strains and breeds, that we now see in the world. Progress has been made in the past chiefly by picking up chance variations as they have occurred in nature and accidentally among domesticated plants and animals. Only within recent years have we begun to learn how to select the parents in order to cause desired variations. By eight years of most accurate and painstaking experiments in crossing and rearing varieties of garden peas, the Austrian monk, 
Gregor Johann Mendel, discovered a law of heredity, claimed to be equal, for biology, to the law of gravitation in physics or to that of atomic equivalents in chemistry.

Mendel's law. Characters are represented in germ cells by units which tend to segregate or combine in definite proportions, the result of mating together first crosses falling in the ratios $1 D D+2 D R+1 R R$ for characters $D$ and $R$.

Illustration. A tall and a short pea are crossed. The seeds resulting from the cross produce only tall plants. When the seeds (self-fertilized) of these plants are grown, they are found to produce 75 per cent tall plants and 25 per cent short, or 3 tall to 1 short. Here tallness is dominant (character D) and shortness recessive (character R). A dominant character dominates the outward form of the plant or animal body, while a recessive character has its units persisting unchanged in the germ cells. When male and female germs again combine, they do so according to the law of chance (like dice, or any other free units) and so fall out $1 D D+2 D R+1 R R$. Since we cannot distinguish the DD plants from the DR plants, except by planting the seeds and analy\%ing the progeny, we have $3 \mathrm{D}$ to $1 \mathrm{R}$. All the $\mathrm{R} R$ plants are found to be as pure and to breed as true as if they had never been crossed, and so are all the DD plants when we propagate them. The DR plants will continue forever to produce $1 \mathrm{DD}+2 \mathrm{DR}+1 \mathrm{RR}$. A hybrid can never be fixed so as to breed true.

The above is the law for monohybrids - forms in which a single character or pair of characters is involved, and instead of assuming the presence of a unit (determiner) for a character (for example, shortness), the tendency is to assume merely the absence of the germinal determiner for tallness. In cases of two characters being involved in each parent, that is, in dihybrids (characters Dd and Rr), there is $1 \mathrm{DA}-\mathrm{Dd}$ and $1 \mathrm{Rr}-\mathrm{Rr}$, that is, 1 pure dominant and 1 pure recessive in 16. In ease of trihybrids only 1 offspring in 64 is pure dominant or pure recessive. If ten characters are involved, the offspring of the secund generation would fall into 1,048,576 different kinds, of which ouly 1 would be pure for each set of characters.

When we consider that this law of inheritance applies to fixation of all kinds of characters, from tallness of peas to tallness of men, from rust resistance in wheat, egg production in poultry, or milk production of cows to feeble-mindedness or normal intelligence in men, we begin 
to realize what Mendel has done for the world. As Walter sums up the case: "Thus in a few generations of properly directed crosses there ran be obtained combinations of characters united in one strain that ormerly were never obtained at all or were only hit upon by merest "hance at long intervals. Herein lies the scientific control of heredity which the trinity of Mendelian principles, namely, independent unit haracters, segregation, and dominance, has placed in human hands." 1

Historical. Mendel presented the results of his era-making experiments sefore the Natural History Society in Brünn early in 1865, and they were published in the Proceedings in 1866. Neither the reading nor the publication saused a ripple of interest. No one unlerstood its significance. Had Darwin learned of Mendel's law in 1865, the history of human science, philosophy, and even religion might have been pushed forward fifty years. Mendel died January 6, 1884, bitterly disappointed that no one could be found to share his rision, and his discovery slumbered for sixteen years longer.

In 1900, three men, working independently, rediscovered Mendel's law almost at the same time. These were De Vries

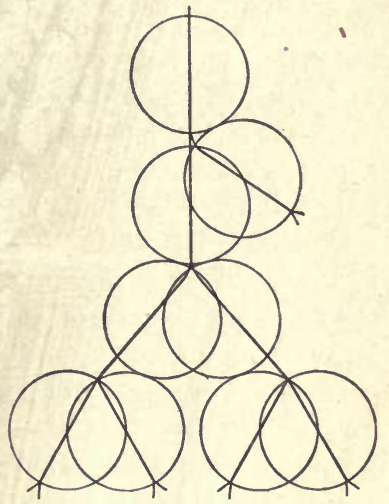

Frg. 165. Diagram illustrating relation of germ plasm (straight lines) to somatoplasm (circles)

in bisexual reproduction in Holland, Correns in Germany, and

'Tschermak in Austria. The time was ripe for its appreciation, and it immediately transformed the subject and, from a matter of abstract disquisitions, made heredity the most intensely practical concern of the experimental breeding plot and pen, of the hunt for variations in nature, and of even sociological analyses and surveys. "The practical breeder of animals or plants, basing his methods on a determination of the Mendelian units and their properties, will in many of his operations be able to proceed with confidence and rapidity. Lastly, those who as evolutionists or sociologists are striving for wider views of the past or of the future of living things may by the use of Mendelian analysis attain to a new and as yet limitless horizon." ${ }^{2}$

1 Walter, Genetics, p. 144.

2 Bateson, Mendel's Principles of Heredity, 1909, p. 17. 
Evolution, mutation, and Mendel's law. In his scheme of evolution Darwin emphasized the influence of slight variations continued through long periods of time. He realized at the outset that in heredity, in the power to pass on variations, lay the heart of his problem, but he went far astray in his own theory of heredity, pangenesis, ${ }^{1}$ and so failed to attain the goal he might have won. No one realized this more keenly than Darwin himself.

De Vries found that from the same seed capsule of Lamarck's evening primrose he could rear as many as nine distinct kinds of plants, so different that, had they occurred consistently in nature, they might have been named as separate species. On the basis of these and similar experiments he advanced his recent theory of mutation. This theory supposed that evolution goes forward by leaps and sudden changes. It now turns out that this evening primrose, Einothera lamarckiana, is a Mendelian cross, a hybrid; and this suggests that all mutations may be merely cases of segregation and recombination of unit characters in the germs of plants and animals, that is, outworkings of Mendel's law.

Weismann made a solid contribution when he distinguished sharply between germ plasm and body plasm, or somatoplasm. He called attention to the fact that the germs are all formed in the embryo long . before the body; the egg-germs, and many more than a hen can ever hope to lay, are all set aside at almost the very beginning of incubation.

1 Pangenesis (pan, "all," or " the whole," and genesis, "origin" - that is, "from the whole body") is the theory that the germ cells are built up by the streaming together, from all the organs of the body, of minute particles (gemmules, or pangens) - an infolding or involution of the body into the germ. Then when a germ unfolds or develops, each pangen reproduces the part of the body from which it came. This theory implies an active influence of the body upon the germ plasm, and if parts of the body or brain should be specially developed by exercise or training, or if parts or organs should be removed or lost by disease or accident, we should expect to find such additions or subtractions reproduced when the germs from such bodies developed. This we never find. There is no evidence that any acquired character is ever inherited. Lambs' tails have been bobbed for thousands of years, and lambs are born with tails as long as they ever were. Galton disproved pangenesis experimentally by exchanging the blood of animals. Since the blood is the only means by which the pangens could possibly circulate from the body to the reproductive cells, if we exchange blood between white and black animals, we ought to get some of the pangens mixed. Galton's experiments disproved the theory absolutely, as does every case of budding and grafting. 
Germ plasm forms germ plasm and builds up the body, but the body cannot form or reproduce a single pangen or minutest particle of germ plasm.

Organized study of genetics. What is your own community doing to improve its plants and animals? Many investigators and students in our universities and colleges, our

\section{Tlooked about to see what I could find}

among our wildings. The next thing to do was to find the best and earlisgl grape for geed and this I found in an accidental seedling at the foot of the hill. The crop was abundant ripe in August and of very good quality for a wild grape. I sowed the seed in the autunm of 1843. Among them the Concord was the only one worth Saving.

Fig. 166. Quotation from Mr. Ephraim Bull on the wooden tablet marking the original Concord grapevine at Concord, Massachusetts

Agricultural Department and experiment stations, practical seedsmen, farmers, and independent plant and animal breeders, are studying and experimenting and pushing discovery in this field. Invite local experts to visit the class and discuss their problems. Often by community coöperation better stock can be introduced than any one member could afford, and its rapid increase insures enormous profits to such undertakings. Railroad companies and the International Harvester Company have agricultural experts who are helping along these lines.

Hunt out stories of the discovery and introduction of new fruits, vegetables, grains, breeds of animals, and in the spirit 
of these try to find valuable variations in the neighborhood. Our native nut trees have been neglected in this matter, and the Department of Agriculture is calling for a special search of the entire continent for valuable varieties. With the whole country organized for the search and with breeding in control of experts, we may hope for better progress in every line of plant and animal improvement than ever was known before.

Injury of germ plasm. Germinal substance is, of course, obliged to draw its nourishment from the body; hence we may expect to find vigorous germs in strong, healthy bodies. Animals that become too fat are likely to have enfeebled germs or to be totally sterile, and conditions that show no appreciable injury to the body may prove fatal to the germ plasm. This is seen in Stockard's experiments with alcohol tabulated below:

Experiments with Guinea Pigs to test Influexce of Alcohol ox Germ Cells

\begin{tabular}{|c|c|c|c|c|}
\hline & $\begin{array}{l}\text { NUM- } \\
\text { BER OF } \\
\text { MAT- } \\
\text { INGS }\end{array}$ & $\begin{array}{l}\text { ABOR- } \\
\text { TIVE }\end{array}$ & $\begin{array}{l}\text { DIED } \\
\text { AT } \\
\text { BIRTH }\end{array}$ & LIVEI \\
\hline Alooholic & & & & \\
\hline Alcoholie males and normal females & 24 & 19 & 7 & 5 (all runts) \\
\hline Normal males and alcoholie females & 4 & 2 & 2 & 2 \\
\hline Alcoholic males and alcoholic females & 14 & 13 & 1 & 0. \\
\hline Control & & & & \\
\hline Normal males and normal females & 9 & 0 & 0 & 17 (all vigorous) \\
\hline
\end{tabular}

The germ cell from each parent builds half the embryo, and the twenty-four matings in which the sperm alone is alcoholized are a proof that an alcoholized sperm cell of a guinea pig cannot do its share toward building up a normal offspring. ${ }^{1}$

${ }^{1}$ Stockard allowed the guinea pigs to breathe fumes of alcohol for one hour a day, six days in the week. The animals showed no outward injury, in fact they gained somewhat in weight. 
The following table shows similar results obtained by Hodge from carefully balanced experiments with selected iogs. The males were brothers and the females sisters from two unrelated litters of pedigree cocker spaniels. Demme's c.bservations upon men are added for comparison.

Influenee of Alcohol on Progent

Dogs (Hodge)

\begin{tabular}{|c|c|c|}
\hline & Alcoholic PaIr & Normal Pair \\
\hline Number of whelps. & $(7-7-6-3) 23$ & $(5-3-8-8-5-6-3-7) 45$ \\
\hline Jeformed . & $(2-3-3-0) \quad 8$ & $(1-0-0-2-0-0-0-1) \quad 4$ \\
\hline l3orn dead & $(2-2-2-3) \quad 9$ & $(0-0-0-0-0-0-0-0) \quad 0$ \\
\hline Viable . & $(4-0-0-0) \quad 4(17.4 \%)$ & $(4-3-8-6-5-6-3-6) 41(90.2 \%)$ \\
\hline
\end{tabular}

Men (Demme)

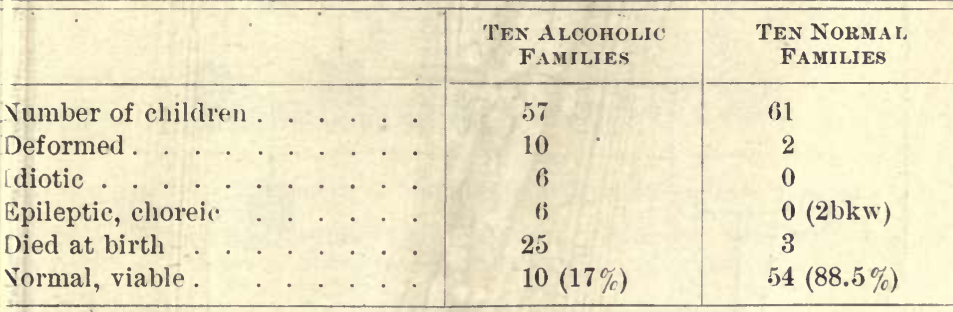

Moderate, nonintoxicating doses of chemically pure alcohol were fed to the dogs with their meals, and Demme's normal families were not total abstainers. In further study of the human problem Bezzola found that out of 8190 idiots in Switzerland the majority occurred in the wine districts, and that the larger per cent of these were born nine months after the great national drinking feasts. Schweighofer discovered a similar relation between stillbirths and the drinking festivals of Austria.

To keep the germ plasm of the nation on the up-grade, free from any injury, taint, or tendency to degeneration, is the most worthy subject for lifelong study by every man 


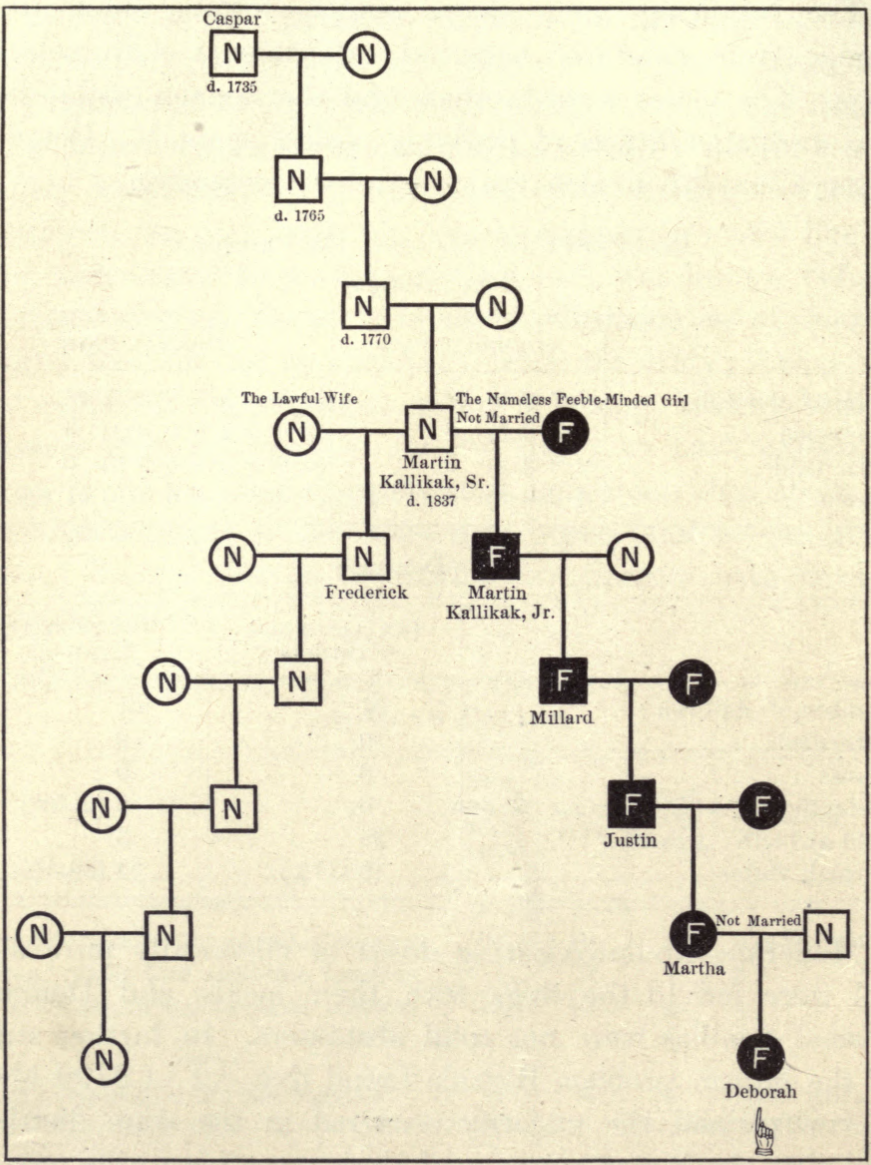

Fig. 167. Diagram outlining history of Kallikak family

Squares stand for males, circles for females; $N$ for normal people, $F$ for feebleminded. Five generations on the side of the feeble-minded girl contain 480 individuals - 143 feeble-minded, 33 immoral, 24 drunkards, and 3 epileptics. On the normal side are 496 descendants, none of whom are feeble-minded. After Goddard 
and woman. We are now just beginning to learn facts in this field which may save our present civilization from the decays that have overtaken those of the past. Whatever a min may claim for personal liberty, no one can claim any right to even risk mental or physical impairment of his own offspring or to impose the care of defectives upon the community. Alcohol is being barred from athletics, from the army and navy, from public service, and from all business, public and private, where strength, endurance, and dependability are required, and the evidence given above

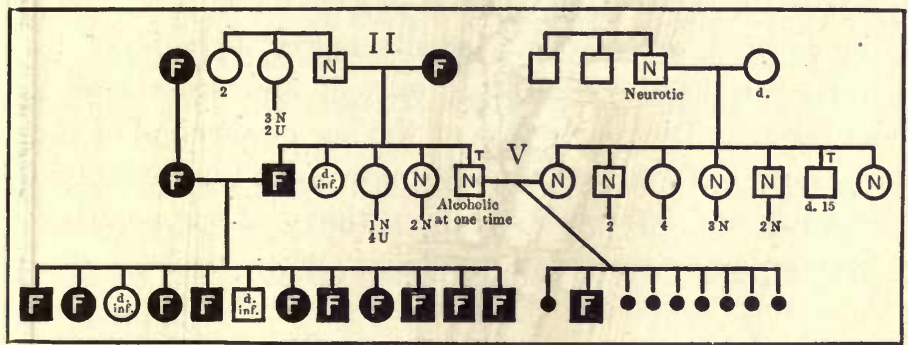

FIa. 168. Recessive character of feeble-mindedness and effects of alcoholism Sn:all black circles indicate stillbirths; d, died; d. inf., died in infancy : $T$, tuberenlar; U, unknown. For other symbols see Fig. 167. After Goddard

would seem not only to give society the right but to impose ujon it the duty of banishing alcohol from any possible contact with the supreme business of evolving the race.

"You can't be strong and well unless you live right." These words of Jess Willard are life-wide in their application. We are just beginning to learn from the new viewpoint of eugenics. Drugs like morphine and opium, cocaine alıd heroin, must be studied with special reference to their influence upon the germ plasm. The same is true of nicotine, and it may be that we shall have to set the age at which indulgence in tobacco may safely be begun at fifty-five yuars instead of at the usual sixteen or twenty-one. Any 
excess in the use of coffee or tea must be viewed with suspicion, and many of our best hygienists look with apprehension at the possible consequences to the race of our sudden, enormously increased gorging of sugar. We can only suggest these as possible lines of study.

Eugenics and Mendel's law; bad blood and good. "People say one must be able to read and write in order to get along in the world. Now there is Miss —. She cannot read or write, yet she gets along all right." 1

This judgment of a feeble-minded woman by an imbecile man helps to explain the rapid increase of such defectives. Avoider by the normal, defectives generally marry defectives. Since they are permitted to multiply at will and are shielded by modern charity from operation of the law of survival of the fit, this process has gone on until we now have nearly $3,000,000$ dependents and defectives - one in thirty of.our population. ${ }^{2}$ By far the larger part (quite possibly, when we have studied to the real genetic root of the matter, we shall find that almost all) of the heary burdens imposed upon society by the idiotic, imbecile, and insane, the paupers, alcoholics, and criminals, is caused by inherited mental and moral defect.

The exhaustive studies of Goddard seem to leave no room for doubt that feeble-mindedness is a recessive, Mendelian, unit character. Hence, according to Mendel's law, the children of feeble-minded parents must forever all be feebleminded. Goddard finds this to be true. Normal-mindedness is a dominant unit character. Hence, if one parent is pure normal (duplex) and the other feeble-minded (nulliplex), the children will appear normal but will all have feeble-mindedness recessive (that is, be simplex). When such people become parents, the children will be $1 D D+2 D R+1 R R$, that is three normal to outward appearance and one feeble-minded.

1 Goddard, Feeble-mindedness : its Causes and Consequences, p. 85.

2 Kellicott, Social Direction of Human Evolution, p. 34. 
Since these people are a burden to themselves and to society, no right-minded person could risk the responsibility for bringing them into the world; and as the facts come to be generally known, all such streams of bad blood will be prevented from increasing their kind and also from spreading out to contaminate streams of normal blood.

Color of eyes and hair, night blindness, color blindness, albinism, germinal deaf-mutism, and many other human characters have been found to follow Mendel's law, but discovery is only beginning to break into this field, and we nerely suggest it for future individual study. Most important studies have been made on typical streams of bad heredity. Let different members of the class volunteer to look up the following and report: "The Jukes Family," by I)ugdale ; "The Zero Family," by Jörger ; "The Hill Folk," ky Danielson and Davenport; "The Nam Family," by Listabrook and Davenport; and "The Kallikak Family," hy Goddard. 


\section{CHAPTER XXXI}

\section{KNOWING HOW TO KNOW HOW}

\section{National Organization for Biological Instruction AND RESEARCH}

I do not know what I may appear to the world; but to myself I seem to have been only like a boy playing on the seashore, and diverting myself in now and then finding a smoother pebble or a prettier shell than ordinary, whilst the great ocean of truth lay all undiscovered before me.-Sir IsAac Newton

It's easy enough to do it if you only know how. It's easy enough to do everything, if you - if you only know how. - Sma LL Bor (overheard on the street)

Conclusion of the whole matter. 'The best "knowing how". there is in the world is none too good for the humblest child of the nation to try to live and to work by. If there were one wish that the writers of this book could have granted for the asking, it would not be that everybody should know everything, but that every child of the nation should know how to learn only the best truth there is to help him with each day's life and work. The doing may be easy and cheap; the knowing how is very precious and may have cost years or centuries of trying, thinking, and experimenting. Still the knowing how may be easy, too, if we really know how to know how. Is it not being continually baffled by false, wrong, bad knowing how that makes all learning hard and work futile? It is easy to keep well and strong if we know how, but the knowing how must be right. It would be easy to exterminate tubercle bacilli if everybody knew how, but we cannot do this as long as even a few think they know 
how to do it with Dr. Muck's compound of punk, alias cheap whisky. It would be easy to breed and raise 100bushel wheat, 200-bushel corn, 1000-bushel potatoes, 1000 pound-butter-fat cows, 300 -egg hens, and so on down the list, if we only knew how. We are gaining ground yearly; the (loing is step by step a test of the knowing.

Fake sources of truth like poisoned wells. Sometime we nay be organized as a people, so that only the truth can be printed. Our pure food and drug laws are beginnings in this clirection, but the millennium is still a long way off, and so far attempts at assumption of human infallibility have been failures. All we can do is to appeal for information to our lest authorities. These pretend to no secrets for a price; they always present the evidence, the proofs, the experiments, on which their conclusions are based; and it ought to le possible to add, they never say they know a thing when they do not; that is, they never lie. No one can long remain in authority if often mistaken on this most important of all points, and a real authority is never afraid to say, "I do not lnow." Successful farmers in different lines, our county agricultural expert, local nurseryman and florist, local forester or tree warden, local bird man or woman (unfortunately we seldom have any local insect students), local health officers and reputable physicians, state and national experimentstation experts and health officers, and the extension faculties of our state universities - these are our best authorities. 'They belong to us; we pay some of them their salaries to give us the best knowing how there is; and they are gladder to do it than we are to wake up enough to ask them for help. By the divine right of being alive the best knowing how there is in the world belongs to any child of humanity who is hungry for it and who knows enough to ask for it and to learn it. Our country is organized, through its edurational forces, public press, and public libraries, to meet this 
right, as any child of the nation can test as often as he pleases. The great lack is that we are not educated to know and to utilize the resources for knowing how that belong to us. Another great difficulty is that the world is flooded with fake, false, selfish-motived misinformation, and we need to learn to shun all bad and second-rate sources of truth as we would poisoned wells. In proportion as one uses the best sources of information, he will develop the power to discriminate and to detect the bad. Civic biology should, first of all, save us from fake solutions of our health problems.

No, Mrs. Bonebrake, I am not going to try your religious fad in order to heal my sore feet; no, Mrs. Hardscrabble, I will not use your number rigmarole to improve my prospects; and no, Mrs. Likenbower, I will not wear your amulet to get rid of my rheumatism.

Why? Well, because I ain honest. I may not be very holy or soulemancipated, but I pride myself on being an honest man.

And I'm going to be as honest with myself as I am with my neighbor.

The fundamental ethics is the ethics of the intellect.

And that means that I will believe only upon examining the facts. My judgment shall remain absolutely automatic, and shall bend only by weight of evidence.

I shall not say I believe a thing just to see if it will not help me.

I shall refuse to proclaim a faith in order to help anybody else.

Ladies, you touch the quick of my virtue. I will not be disloyal to my réason - no, not even to get to heavell.

History is full of pious and learned men who put expediency before honesty. They did not believe what they professed - they did not even understand it; but they said they did, because they thought it would aid others, would not offend the weak, and would save their own souls.

But I will take my chances with intellectual integrity alongside of all the earnest souls who deceived themselves and everybody else because, so doing, they verily thought they were doing the will of heaven.

I know, Mrs. Bonebrake, you claim that your peculiar faith, resting upon a plain denial of facts, has healed many; so, Mrs. Hardscrabble, your cabala; and so, Mrs. Likenbower, your amulet. Why not try it? It has benefited others; why not me? 
Simply because every one of your cures can be traced as justly to the strange, mysterious, recuperative powers of nature as to your particular $n$ strum or form of self-hypnotism.

Thousands of invalids have got well after being given up by physicians, and got well without crossing their fingers and reading your b sok. In fact, most people, some time in their life, have miraculously mcovered when it seemed they should have died.

Hence, if you bottle Chicago river water and get enough people to " just try" it, you can collect innumerable testimonials. But doubtless if you published these you would not include in your report the equally inmumerable cases where the victim did not get well.

No, ladies; I appreciate your kindly interest in my bodily health and my. soul's salvation, but I'm going to stay honest and see what happens.

When I am met by a proposition that is based on facts, and not on t te ignoring of them, that is reasonable and convincing, and that is s ubstantiated by the known laws of evidence and squares with common s.nse, I will embrace it. Otherwise, no; and thank you all the same.

Nothing doing on the esoteric, the fuzz-wuzzy, the ecstatic, the self1 ypnotic, the what-if-it-is-true-after-all-you-can't-tell.

My intelligence may be pretty poor, but it's all I have. I'm going t. stand by it and refuse to prostitute it, no matter what the bribe.

The web of destiny is.complex, I know, and none of us knows the secret springs of life and events; but I have a notion that if a man sticks to the truth as he sees it, and declines the lure of truth as he does I ot see it, even if the latter promises health, wealth, and a happy hereafter, he will be likely to come out about where his Creator intended. ${ }^{1}$

Using a library. The best investment any community can nake is to buy, catalogue, and keep up to date a library relating to its interests and industries; and, in any modern rense of the word, that one is most efficiently educated who lest knows how to use such a library. If our local and school libraries are properly managed and catalogued, it ought to be easy to find quickly all that is known on every subject liscussed in this book. If every member of the class is collecting bulletins up to date and doing his share to help,

${ }^{1}$ By Dr. Frank Crane, in the Associated Newspapers. 
the laboratory bookshelf ought to be made to answer 95 per cent of the questions that arise. Individual pupils should also be gathering libraries relating to their own problems, interests, and projects. A really practical working method in using a library is of lifelong value to everyone. How many have acquired this at the end of their school or even college courses? This is the one thing necessary to reasonably intelligent modern living, and if many have failed to acquire it in the course of their schooling, is it not because they have not had any real problems to solve that required such use of libraries? Lincoln stated the case in a word when he said: "A capacity and taste for reading gives access to whatever has already been discovered by others. It is the key, or one of the keys, to the already solved problems. And not only so: it gives a relish and facility for successfully pursuing the unsolved ones" (p. 92).

Catalogues, publication lists, and indexes. A library may be too poor to buy many books, but still be 100 per cent efficient if it keeps these indispensable helps in order and up to date. People can then find everything that has been written on any subject or by any author, and the local library can usually borrow from the state library or from that of their nearest university; or people might often buy books and donate them to their local library when they have finished with them.

Every laboratory bookshelf must have for constant reference the Monthly List of Publications (which is sent free to all who apply for it) and the Experiment Station Record. ${ }^{1}$ The first lists every bulletin of the central Department at Washington, as it appears, and the Experiment Station Record gives a well-annotated monthly bibliography of everything relating to the practical biology of agricultural advancement for the entire country and, in fact, for the world. Another

1 For both these publications address United States Department of Agriculture, Washington, D.C. Subscription price of the Record is $\$ 1$ a year. 
publication of the Department is the Weekly News Letter, which contains brief, timely articles and notes. Some member of the class might subscribe for this and keep it in orderly file on the bookshelf.

The question with which we started is, How can we get the best information most quickly? A concrete case will answer this question for thousands of similar problems.

A botany class in a city was beginning the study of fungi, and in addition to the elementary book work each member was assigned an interesting fungus to work up and report upon. One of the boys, instead of the fungus assigned him, asked permission to take the black knot. The teacher was wise and honest enough to tell him that she knew nothing about it, but would be glad if he would learn all he could and give them all the benefit. He went to the library with a pack of postal cards and, going through the recent numbers of the Experiment Station Record, took down on the cards references to all likely articles on the black knot, addressed them, and within a week he had everything that everybody knew about the black knot.

The boy then went to work out doors, hunted through the woods, and collected the fungus on native wild plums and cherries, and he made a survey of the city in order to form an intelligent estimate of the damage cansed to cultivated fruits. He mounted a typical series of specimens in a glass case, all neatly labeled. He studied the fungus with the microscope and made careful drawings of all the important stages in its growth and reproduction. He drew colored wall charts from his pictures, supplemented by those in the books, and finally presented his results on the life history, distribution, and treatment of the black knot in a carefully prepared lecture which occupied an entire period of the class. One of his classmates happened to be a reporter on a local daily, and she presented the subject to the public in a well-written article of about two columns, and there followed such a cleaning up of black knot-as that city had not seen in at least fourteen years.

"What do you think about that work you did in school on the black knot?" the boy was asked some years later. He replied, "It exactly fitted my bent, and on that account I think I got more real good out of it than from any other one thing in my high-school course." Better than all, this wholesome little try at real study quite probably helped him to decide what he wanted to do for the rest of his life. 
Special organizations and journals. The science of our country and the world is not the dead, cut-and-dried facts, "classified and arranged" in books. Real science has been defined as the "everlasting struggle of the human mind after the truth" (Lessing). Or, as Huxley put it, "Science is trained and organized common sense." In essence, science is the living, growing, forward-moving stream of discoveries - the best . knowing how that all the strugglers after truth are daily finding out. As long as there is progress it must always be that the best that someone is able to discover to-day will be excelled by the discoveries of to-morrow, and all that we know is but a handful of pebbles on the shore of the ocean of truth still to be discovered. Thus, in order to make sure that progress in discovery shall never cease, men have organized universities and research foundations and the scientific departments and bureaus of the state and national governments.

In addition to the above are the many special associations of people drawn together -by mutual interest in various problems. These associations contain our best authorities on all sorts of subjects, and many of them publish special journals in which nembers first announce their discoveries. It may be years before these discoveries find their way into the books of our libraries. Hence, if we are to find the best knowing how up to date, we should learn what these organizations are and keep track of the articles in their journals from month to month. We should first make a list of all local organizations pertinent to civic biology. Some of these may be branches of larger societies, national or international. As we learn about their purpose and work we should consider joining any that may seem desirable, and so begin to take our places in the organization of the community for progress. A few of the national organizations are indicated below: 1 .

${ }^{1}$ See Handbook of Learned Societies and Institutions of America, Carnegie Institution, Washington, D.C., 1908. The World Almanac gives 
American Association for the Advancement of Sciexcf, Dr. L. O. Howard, permanent secretary, Washington, D.C., was founded in 1847 and has 11,000 members. The biological sections are F, Zoölogy; G, Botany; K, Physiology and Experimental Medicine; and M, Agriculture. Sister organizations are the British and French associations for the advancement of science. The official organ is Science, published weekly, and sent gratis to all members in the United States as part return for the annual dues of \$3. .The Scientific Monthly (continuation of the Popular Science Monthly) may be substituted if preferred.

American Society of Naturalists was first organized in 1840 (reorganized in 1883) and is the parent from which many of the more special scientific societies have split off. It has 400 members.

Central Association of Science and Mathematics Teachers (and many similar societies of science teachers). The official organ for all is School Science and Mathematics.

American Nature Study Society, founded in 1908; official organ, Nature-Studly Review, Ithaca, N.Y.

American Public Health Association. The official organ, A merican Journal of Public Health, should be in every biological library.

National Association for the Study and Prevention of Tuberculosis, founded in 1904, has about 2500 members and publishes accounts of annual meetings.

Society of American Bacteriologists, founded in 1899, limited to 75 nembers.

American Association of Pathologists and Bacteriologists, founded in 1900 .

American Cancer Rfsfarcir Socifty, headquarters, 1430 Wells Street, Chicago, Ill.

American Society of Zoölogists, founded in 1902, 137 members.

Botanical Socrety of America, founded in 1893, has 496 members and publishes the American Journal of Botany.

American Forestry Association, founded in 1882, has 15,000 members and publishes American Forestry, Washington, D.C.

American Fisheries Society, organized in 1870, has 700 members.

National Association of Audubon Societies, founded in 1905, now has about 4000 members, with branch societies in nearly every

a list of learned societies, with dates of founding, number of members, addresses of some of the officers, and names of journals published, with their places of publication. Local libraries may supply more extended lists. 
state. The official organ is Bird Lore, edited by Frank M. Chapman and published at Harrisburg, Pa.

American Ornithologists' Union, founded in 1883, has 1126 members, publishes the $A u k$, the official journal of American ornithology, and also prints and keeps up to date the A. O. U. Check-List, giving the authoritative names, popular and scientific, of all birds of the United States.

American Association of Economic Entomologists, founded in 1889, has about 500 members; official organ, Journal of Economic Entomology, Concord, N.H. A complete set of this journal ought to be accessible in every city and town library.

American Extonological Society, founded in 1859, has 140 members and is deroted to purely systematic entomology.

American Phytopathological Society.

American Pomological Society, founded in 1849 , has about 500 members and publishes biennial reports and special catalogues of fruits.

American Society of Landscape Architects.

American Genetic Association (continuation of the American Breeders Association), founded in 1903, has about 1200 members and publishes the Journal of Heredity, a monthly publication devoted to plant breeding, animal breeding, and eugenics. Washington, D.C.

We have given dates of founding and number of members in orler to emphasize the fact that organization for knowing how to do things is only just beginning, and that as yet very few are actively concerned with these vital problems. 


\section{CHAPTER XXXII}

\section{PROGRESS IN DISCOVERY}

Anything which sheds light on the nature of life and of man himself, his organic constitution and equipment, the laws and possibilities of his mind and body, his place and fate in and relation to the rest of the universe, will appear immeasurably more important than the fate of individual men or nations,- because those things have a fundamental significance for the whole human race everywhere and for all time, and likewise have the deepest sort of personal significance for everyone who is reflective enough to be conscious of the questions presented by his own being.

The great battles of man have not been fought on Grecian plains or Spanish mains or over European hill and dale, but within the skulls of the great investigators, up and down the brain valleys and ridges of the great thinkers and the immortal poets. It is the great captains of thought and feeling that have led forth the bright-shining forces of the human mind and soul in the only wars that have results of permanent and universal importance,- wars in which thoughts, ideas, facts, conceptions are deployed and maneuvered in phalanxes and battalions to the greater issues of our human fate.

Measured against such Himalayas of the human mind and soul as Darwin and Marx and Newton, Napoleon and Bismarck and Alexander are not even among the foothills of human significance. The publication of "The Origin of Species" was a more vital event in human history than the battle of Waterloo. - Courtne r Lemon, Pearson's Magazine, February, 1917, p. $183 \mathrm{ff}$.

I am impressed with the fact that the greatest thing a human soul ever does in this world is to see something and tell what it saw in a plain way. Hundreds of people can talk for one who can think, but thousands can think for one who can see. To see clearly is poetry, philosophy and religion all in one.-Emerson

Beginning at home. What biological discoveries have you made? Write down a list of them and tell in each case how you happened to make the discovery. Have you told anyone about them or published your discoveries so that 
others may be helped or benefited by them? How do you know that someone else has not discovered the same thing before you? Has your father or mother, or some other member of your family, discovered anything of value to the community? Do you know of anyone in your town or city who has discovered anything? If so, can you find the story in print or can you go to the person and get the story at first hand?

Do we know of anyone in the United States or Canadia, South America, Europe, Asia, Australia, or Africa, who has made notable biological discoveries? Who is he, and what is the story of his work? 1

Kinds of discoveries. Discoveries may be big or little; they may be easy, made at a glance, or even stumbled on by accident, though in this ease one must be intelligent enough to know what he has found, and be able to think what his discovery may mean to the world ("Accidents never happen among the Hottentots," it is said); or they may require years of application, complicated apparatus, and costly laboratories.

A little girl of eight, by working from daylight till dark, discovers that a bobwhite will eat 1286 rose slugs in a day, and that when fed abundantly on insects, she will lay eggs. These are valuable little discoveries and have doubtless influenced efforts to protect the bolwhite. A young woman devotes three years to studying the foods of the bobwhite, and publishes what is probably the most complete statement of the food of any bird. This will exert still more influence for bird protection and must hasten the day when we shall have enough bobwhites to reduce weed seeds and insect pests, and it may suggest to others similar studies of other birds. ${ }^{2}$

1 As early as practicable, when the course is well begun and interest aroused, bring up these questions and make them the main subject of a lesson period; or appoint a date and ask the class to prepare brief written statements in answer to the questions, and have them read and discussed. Invite some local discoverer to visit the class and tell of his aims, methods, and discoveries.

2 Margaret Morse Nice, "Food of the Bobwhite," Journal of Economic Entomology, June, 1910, p. $295 \mathrm{ff}$. 
In 1816 Mrs. Isabella Gibbs discovered the Isabella grape, and this liscovery is said to have turned attention to the culture of American grapes. Four years later Adlum discovered the Catawba. "A woman liscovered it growing wild," and we have a vigorous new blackberry, the Blowers, added to the American list. Judge Logan discovers a hance seedling, and the Loganberry is saved to the world. Mr. Bull works a few years, and the Concord grape, and with it a new industry, is added to American horticulture. Mendel works eight years in his garden, and discovers his law of heredity. Jenner and Darwin each work twenty years, and the ideas of vaccination and the origin of ipecies are placed at the service of mankind for all time.

Importance. "One single idea may have more value than all the labor of all the men, animals, and engines for a century." Here are "mines," free to all alike, that dwarf our Kimberleys, Nomes, and Klondikes to the small change of the passing hour, whose output is as much above gold and diamonds as mind is higher than matter. What kind of progress shall we make when all the people of the nation appreciate this point of view and begin to "know enough to work together" in pushing forward needed discoveries?

We are approaching this degree of civic organization, as is evidenced by the growth of research departments in our universities, by our experiment stations, and by the state and national scientific departments and the endowed private research foundations. All these are reaching down to search out talent, and ought to be inspiring every boy and girl to the most careful seeing and thinking of which they are capable. It is often said that Pasteur repaid to France the entire cost of her system of public education, from primary schools to university and from the beginning down to his time, by his one discovery of the cause and prevention of silkworm disease. So, as such values are being appreciated, the country and world are being searched for ability to discover. As its discoveries are the most priceless possessions of the race, and since advance in every field waits upon the discoverer 
to lead the way, the scientific organization of the nation and of the world says, virtually, to every young man and woman: "Show your mettle, demonstrate your ability to discover something worth while, and equipment and material support will be supplied, and every avenue of opportunity will be opened to you. Show power to think and to discover, and scholarships and fellowships are ready to place university apparatus and laboratories at your disposal."

Historical. How have discoveries been made in the past? How have we learned to make two blades of grass grow where one grew before? How may we make ten blades grow where one grows now? What does it matter that we know the value of fresh air, of pure water, of good food; that we know that the blood circulates; that we have brains and nerves and muscles which require exercise and care; and that we know about bacteria and parasites and the diseases they cause? Do not these things, and all the rest for which the science of biology stands, mean the difference between a world of jungles and barren deserts, scourged by famines and pestilences, and a world of farms and gardens, full of happy, healthy people?

Men have lived in the world for at least five hundred thousand years, and astronomers tell us that the earth will be habitable for about five million years to come. Is it not remarkable how little we know, how little all the millions and billions of men and women who have lived have been able to discover, - the handful of pebbles on the shore of the ocean of truth still to be discovered? How incredibly slow progress in discovery must have been at first. How much do animals really " see" (in the sense in which Emerson uses the word) of the flowers and trees, birds, insects, and fungi in the fields they roam? And how little the best of us really see of all the things that happen in our fields, roadsides, and gardens. Without doubt thousands of choice varieties of flowers, 
grains, fruits, and nuts have lived and died out because 110 one saw the difference clearly enough to be able to think what they might mean to the world; and thousands nore will go the same road until we learn to see and think civically.

Our present-day discoverers. A number of names referred to in the text under various topics may be used for refer(nce. Our best authorities, as indicated in the preceding (hapter, are often discoverers in their respective fields. 'They have probably won their positions by some creditable research work. Instead of trying to give a list of these it is better to gather the names as they appear as authors of our best books on birds, insects, forestry, agriculture, bacteria, health problems, and so on, or as they come to us from month to month in the biological journals or scientific bulletins. We should be thankful to our discoverers for what they write, realizing that their work requires patient appli(ation and great sacrifice of time; and while we follow their investigations in the libraries and journals, we should be very careful about encroaching upon their precious time by personal letters. Perhaps the most discouraging feature of our present situation is the overwhelming of our discoverer with inquiries by people who are too indolent to go to their libraries and read what he has written. For any special field we may have one or one hundred discoverers for our one hundred million people. Figure out about how snuch time it would take to answer a million letters.

Biological discoverers. From the following brief list, or from any history of science or of medicine, let each member of the class choose some one discoverer, with whom he will become intimately acquainted during the remainder of the year. Let him go to the biographies and histories and strive to catch the spirit that prompted the man to make his dis"overies. Then, toward the close of the year, let each one 
prepare a five-minute story to tell to the class. By timing these stories so that they follow in orderly sequence we may have the history of our science presented in an effective way. The aim is to kindle and foster the spirit of these men, so that increase in knowledge and progress in discovery may be assured from generation to generation. A number of names have been included for sake of completeness. The more important and those especially interesting on account of their contributions to civic biology are printed in black-faced type. ${ }^{1}$

B.c.

540 Xenophanes: first to recognize fossils as proving that the earth was formed under the sea and rose out of it

500 Heraclitus: often called the first evolutionist; he first advanced the principle, $\pi a ́ v$ $\tau a \dot{\rho} \epsilon \hat{\imath}$ (all things flow)

450 Empedocles : first to suggest natural selection and survival of the fittest

-400 Hippocrates: called "the Father of Medicine"

-350 Aristotle: founder of zoölogy

320 Theophrastus : first botanist

$\left.\begin{array}{ll}320 & \text { Erasistratus } \\ 300 & \text { Herophilus }\end{array}\right\}$ first anatomists

A.D.

- 79 Pliny : wrote first popular natural history

160 Galen: founded medical physiology

1542 Vesalius : foundẹr of modern anatomy

1548 Falloppio : anatomist
1551 Gesner: gathered first botanical garden (of fruits and flowers) and first zoölogical museum

1560 Eustachio : anatomist

1583 Cresalpinus: classified plants by flowers

1590 Janssen, J. and Z.: discovered compound microscope

1603 Fabricius: discovered valves in the veins

1603 Harvey: discovered circulation of the blood

1622 Ascello: discovered the lacteals

1649 Rudbeck: discovered the lymphatics

1650 Swammerdam: first great student of insects in relation to plants and medicine

1661 Malpighi: discovered the capillaries in the lungs; founded modern embryology by a study of the incubation of the chick (1672)

1667 Leeuwenhoek : first to see bacteria

I Historical books to which the class should have access for this work are Locy, Biology and its Makers, New York, 1908; Baas, Outlines of the History of Medicine (translated by Handerson), New York, 1889; Mial, History of Biology, New York and London, 1911. 
1668 Redi: disproved spontaneous generation of insects by the discovery of eggs and larvæ ; wrote "Esperienze intorno alla Generazione degl' Insetti"

1670 Mayow : studied animal respiration

l671 Hooke: worked out microscopical structure of plants

1680 Borelli: proved that all the movements of animals are caused by muscles pulling on bone levers; wrote "De Motu Animalium ",

1682 Grew : studied structure of plants

1693 Ray : classified plants

1727 Hales: investigated respiration of plants

- 1743 Haller: father of modern physiology

-1744 Réaunur : studied insects

- 1749 Buffon: wrote a natural history

-1753 Linnæus : classified plants

1761 Kölreuter : studied hybridization of plants

1761 Bonnet: evolutionist; grouped animals in an ascending series

1772 Rutherford: discovered $\mathrm{mi}$ trogen

1774 Priestley: discovered oxygen and studied the breathing of plants

1775 Spallanzani : disproved spontaneous generation of bacteria and molds and demonstrated presence of living germs in the air

1789 Galvani : discovered animal electricity

1790 Goethe : worked out a scheme for the metamorphosis of the parts of plants

1794 Darwin, Erasmus: grandfather of Charles Darwin; wrote "Zoonomia," a long poem outlining evolution of life

1796 Jenner: discovered vaccination

1796 Sprengel : studied fertilization of plants

1800 Cuvier: studied comparative anatomy; wrote "Le Règne animal," 1817

1801 Lamarck: invented a schemefor the evolution of animals (by conscious effort and inheritance of acquired characters ; not proved)

1801 Treviranus: introduced the name "biology" as distinguished flom " botany," "zoölogy," " physiology,"? " anatomy," etc.

1804 Humboldt: studied distribution of plants

1807 Rumford, Count : demonstrated absorption of carbonic acid by plants

1811 Bell, Charles: discovered motor and sensory nerve roots ; founder of modern neurology

1818 G. St. Hilaire : pointed out unity of plan in animals

1823 Baer: discovered the law of embryological development (higher forms repeat the evolutionary series as the embryos clevelop)

1830 Brown : described cell nucleus

1835 Dujardin : studied protoplasm

1838 Schleiden: discovered the cell as unit of structure in plants

1838 Schwann: discovered the cell as unit of structure in animals 
1839 Agassiz : wrote on fresh-water fishes

1841 Helmholtz : discovered rate of nerve impulse

1853 Mohl: studied protoplasm (living substance)

1857 Pasteur: studied fermentation

1858 Darwin: reported his work upon the origin of species by natural selection

1858 Wallace : reported his work upon the origin of species by natural selection

1858 Virchow : worked out cellular pathology ; founder of modern pathology

1863 Huxley: wrote "Evidence as to Man's Place in Nature"

1863 Lyell: wrote "The Antiquity of Man"

1865 Sachs: studied structural botany

1865 Mendel: discovered the law of heredity

1867 Lister: worked out aseptic surgery

1875 Galton: studied inheritance
1875 Hertwig, O.: studied fertilization

1880 Koch : proved the relation of bacteria to disease

1880 Laveran: discovered malarial parasite (in the mosquito)

1886 Leuckart: settled the modern classification of animals ; specialized on parasites

1893 Weismann: studied germ-plasm 1898 Reed discovered relation 1888 Finlay between yellow fever 1898 Lazear and the mosquito

1898 Howard: discovered relation between typhoid fever and the house fly

1900 De Vries 1900 Correns 1900 Tschermak $\left\{\begin{array}{l}\text { all, working inde- } \\ \text { pendently, redis- } \\ \text { covered Mendel's } \\ \text { law of heredity }\end{array}\right.$

1903 Stiles : discovered hookworm in the United States

1914 Goddard : proved feeble-mindedness a unit character

1915 Stockard: discovered influence of alcohol on offspring 


\section{INDEX}

Abalones, 273, 274

Acetic acid, 194

Actinidia arguta, 88, 90

Adder, 326

Aedes calopus, 124-128, 130, 132, 134, 154, 258; breeding places, 132 ; pictures of egg, larva, pupa, and adult, 124, 125; relation of, to yellow fever, 126,127

Aërobic bacteria, 221

Agaricacea, 201-205; orders of, 204, 205

Agriculture, 91-106; breeding selected strains, 96-98; efficiency of, 93-96; fungous and bacterial diseases, 207-217; practical biology of, 91-106; problems of animal industry, 102-104; relation of weeds to, 68 ; soil fertility, 98100 ; value of land, 100-102

Alcohol, 165, 191; influence of, on germ plasm, 340, 341, 343 ; manufacture of, 194, 195

Alfalfa, 101, 212, 223

Algæ, 188

Alkaloid, 201

Alligator, 321, 323

Alligator terrapin, 324

Almond, 165

Amanita, 73, 76, 200-205; description and picture, 201, 202

American birds, orders of, $38^{-40 \text {, }}$ 42-51; pictures of, 22

American Bison Society, 171

American cockroach, 154

American crow, 48
American elm, 84

American false hellebore, 76

American goldfinch, 49

American goshawk, 45

American insects, 253

American laurel, 75

American lobster. See Lobster

American lotus lily, 307

American magpie, 48

American mammals, 169-172

American osprey, 45

American redstart, 50

American robin, 51

Amphibia, 313-320, 325

Anaërobic bacteria, 221

Animal diseases, 110

Animal industry, 102-104

Animal parasites, 253-269

Anopheles, 127, 130, 131, 134, 154,

257 ; breeding places of, 132 ; picture of eggs, larva, pupa, and adult of, 125 ; relation of, to malarial fever, 123, 124

Antelope, 169, 261

Anthracnose, 210, 212, 215

Anthrax, 235, 236, 248

Antimeningitis serum, 111

Antisepsis, 248

Antitoxins, 243, 247-249

Antivenins, 329

Ants, 141-147; carpenter ant, 146,

147; economic importance, 141;

food, 143 ; rearing of, in laboratory, 145-147 ; red ants, 155 ; special senses, 143; warfare, 144 ; white ants, 153,155 
Apanteles, enemies of, 140

Aphids, 51, 142, 152, 156

Apoplexy, 232

Apparatus, 11

Appendicitis, 234

Apple, 94, 165

Apple Day, 299

Apple of Peru, 75

Apple tree, blight of, $212,213,216$; enemies of, 155,156

Aquaria, 10, 315; cement for, 15 ; making of, 12-15; management of, 299-303

Aquatic duck foods, 307

Arachnids, problems of spiders, mites, and ticks, 163-168

Arbor Day, 299

Arbor vitæ, 59, 165

Army worm, 156, 317

Arsenate of soda, 71

Arsenic, poison for rats, 180

Artesian wells, 219

Asepsis, 248

Asiatic poppy, 73

Asparagus beetle, 156

Asters, 86

Atlantic salmon, 309

Atlantic squid, 284

Australian duck-bill, 169

Bacteria, 176, 214; blight or wilt from, 215; control of bacterial diseases, 231-251; culture of, 224-230; distribution and forms of, 218; fungous and bacterial diseases of plants, 207-217; general discussion and treatment of, 186-191, 218-251 ; kinds of, 218, $220,221,234,236,242$; laboratory methods and experiments, 224-230; parasitic, 187; pictures of, 236 ; reproduction of, 220,221 ; saprophytic, 221 ; size of, 218 ; symbiotic, 187, 221; venomous

forms of, 234; work of, 221

Bacterins, 248

Badger, 171

Bald cypress, 59

Bald eagle, 45

Balsam, 59

Baltimore oriole, 48

Banana, food for mosquitoes, 131

Bank swallows, 49

Banostine Belle de Kor, 103

Barium carbonate, 179

Bark disease, 247

Barn swallows, 49

Barnacles, 287

Basket willow, 307

Basses, 309

Basswood, 59, 82

Bats, 129, 169

Bean blight, 215

Bear corn, 76

Bears, 155, 169

Beaver, 171, 172, 261

Bedbug, 154, 236

Beech, 59

Bees, 152, 153, 158; honeybee, 157

Beetles, 20, 21, 153-156, 317, 318

Belladonna, 73

Belted kingfisher, 46

Benzine, 165

Bindweed, 71

Biological library, 16, 17 ; using of, 349-351

Biology, instruction and research in, 346

Birch, 59, 83, 84

Bird Day, 299

Bird fountain, 29

Birds, 22-53, 313, 317 ; adaptation of, to environment, 37 ; attracting, $28,31,33$; conservation of, 53 ; destruction of insects, $23,24,25$; divisions of, 32 ; economic value 
of, 24 ; food of, $24,25,30,34,42$; food chart, 33 ; methods of bird study and special problems, 3553 ; migration, $29,30,31$; number needed, 28 ; orders of, 22, 37-53 ; outdoor laboratory work, 25-31; plan of course, 23; topics for study, 31,32 ; topography of, 37 ; winter feeding of, 31 ; work suggested, 31 Bison, 169, 171

Bitter rot, 210, 212, 213

Bittersweet, 76

Bivalves, 274

Black basses, 309

Black carpet beetle, 154

Black cherry, 59, 75

Black death, 175, 177, 233

Black flies, 113

Black gum, 59

Black knot, 207

Black mustard, 70

Black nightshade, 76

Black rot of cabbage, 212

Black snakes, 326

Black walnut, $59,60,82,83$; pictures of, 61,66

Black-and-white warbler, 50

Blackberry, 94

Black-billed cuckoo, 46

Blackbirds, 34, 48

Blackleg, 248

Blight, on bean, 215 ; fire blight, 212 ; on pear and apple, 212, 213; on potato, 210,215

Blister, or oil, beetle, 156

Blood, good and bad, 344

Blood-sucking conenose, 154

Blowfly, 154, 318

Blowing adder, 326

Blowing viper, 327

Blue crabs, 287, 292

Blue jay, 48

Blueback salmon, 309
Bluebird, 49, 51

Bluebottle, 112, 154

Bluegill, 299, 306, 307, 309

Blue-tailed lizard, 325

Bobolink, 48

Bobwhite, 34, 41, 42, 53, 332

Body louse, 154

Boils, 233, 234, 236, 248

Bollworm, 156

Bordeaux mixture, 209, 217

Borer beetle, 155

Botflies, 113, 157

Bovine malaria, 257

Bovine tuberculosis, 110, 223

Box tortoise, 324, 325

Bright's disease, 232

Broad-leaf laurel, 75

Bronchitis, 234, 235

Bronzed grackle, 48

Brook trout, 309

Brooks's law, 291, 292, 308; applied to food and game fishes, 308 ; applied to the lobster problem, 286, 291, 292 Brown creeper, 51

Brown rot, 207, 210, 211

Brown thrasher, 51

Browu-tail moth, 20, 156, 160-162

Bubonic plague, 2, 107, 175-177, 215, 234,248

Bugbane, 76

Bull thistle, 71

Bullfrogs, 313, 315, 316, 317, 319

Burdock, 71, 72

Burrowing rootstocks, 71

Butter clam, 278

Butterflies, 153; cabbage, 21, 136-140

Butternut, 59

Cabbage, 94, 98; black rot of, 212

Cabbage butterfly, 21, 136-140 ; control, 138-140; dispersal, 137 ; fecundity, 136; life history, 136-137 ; natural enemies, 136 
Cabbage caterpillar, 25

Cabbage looper, 156

Cabbage and radish maggot, 156

Cabbage worm, 156

Caddis flies, 153

Calcium, 98, 99, 100

Calcium chloride, 249

Calico bush, 75

Calico mosquito, 127

California poison sumac, 75

Camel, 261; itch mite of, 166

Campaign, anti-fly, 119, 120; antimosquito, 134, 135

Camphor tree, 73

Canada goose, 39

Canada thistle, 71

Cancer, 232, 234

Canker, 215

Cankerworm, 50, 51, 155

Cannas, 86

Caper spurge, 76

Carabid beetle, 317

Carbolic acid, 71, 249

Carbon, 98

Carbon bisulphide, used in destroying rats, 181

Carbonic acid, 187, 191, 194, 195

Cardinal flower, 67, 154, 306, 307

Carpenter ant, directions for study of, 146,147

Carpet beetle, 154

Carrot, 105

Casein, 189

Case-making moth, 154

Cases, insect-rearing, 10

Cashes, 75

Cat, $165,182,256,263,267$; relation of, to diphtheria, 245,246

Catbird, 51

Caterpillar, 45

Catfish, 306, 307, 309

Cattle, 171

Cattle tick, 167
Cedar, 83

Cedar wax wing, 50

Cephalopods, 274, 284

Cerebral hemorrhage, 232

Cerebrospinal meningitis, 248. See also Meningitis

Cestodes, 260, 262

Chameleon, 325

Chara, 307

Cheese, Camembert, 189; Limburger, 189; Roquefort, 189 ; Stilton, 189

Cheese or ham skippers, 154

Cherry bird, 50

Cherry louse, 156

Chestnut, 59, 60, 82, 83

Chestnut-bark disease, 215

Chewink, 49

Chickadee, 50, 51

Chickens sick with limber neck, 122

Chicks killed by rats, 174

Chickweed, 70, 71

Chiggers, 165

Children's bane, 75

Chimney swift, 47

Chinchbug, 42, 156

Chinese pernicious scale, 156

Chinook salmon, 309

Chipping sparrow, 47, 49

Chlorine, 98, 114

Cholera, 107, 235, 236, 245, 248 ; fowl, 110, 233; hog, 110, 248

Cholera infantum, 20, 107

Cicadas, 153

Cinchona, 73

Citronella, 128

Civic biology, definition of, 1 ; plan of course, 3-9

Civic fly campaign, 119, 120

Civic forestry, 55-66

Clam, 274 ; butter, 278 ; gaper, 278 ; giant, 278; hard, 273 ; life history of, 278, 279 ; little-neck, 277; razor, 273 ; soft, 273 ; surf, 273 
Cliff swallows, 49

Clothes moths, 154

Clover mite, 165

Cluster fly, 154

Clydesdales, 333

Coal oil, 71

Coast newt, 320

Cobra, 327

Cocaine, 343

Cockles, conchs of, 273

Cockroaches, 153, 154. See also Roaches

\section{Cod, 309}

Codling moth, 21, 155 ; type for study, 6

\section{Coffee, 344}

Cold, 233, 234, 246, 250, 251

Cold storage, 269

Coleoptera, 153

Collecting nets, 12

Colorado blue spruce, 83

Colorado potato beetle, 156

Common stramonium, 75

Conchs, 273, 274

Concord grapevine, 339

Condiments, 71

Conifers, 59

Consumption, 234

Contact infection, 246

Coontail, or hornwort, 307

Cooper's hawk, 45

Copepods, 287, 288, 289

Copperas, 114

Copperhead, 322, 327

Coral snake, 328

Corn, 93, 94, 95

Corn cockle, 75

Corn snake, 326

Corn-ear and tomato worm, 156

Corn-root aphis, 156

Corrosive sublimate, 249

Cotton, 93 ; pests of, 156

Cotton worm, 156

Cottonmouth, 327
Cottonwood, 59, 165

Cottony cushion scale, 20, 156

Cottony maple scale, 156

Couch grass, 71, 72

Cow, 102, 103, 165, 263

Cowbane, 75

Cowbird, 47, 48

Cowpox, 258

Cowslip, 306, 307

Crab, 287, 292-294

Crab apple, 82

Crappies, 306, 309

Crawfish, 287, 293, 294, 306, 307, 317,318

Crested flycatcher, 47

Crickets, 153

Crimson Rambler rose, 97

Crocodiles, 321, 323

Crocus, 197

Crops, standards and percentage of efficiency of, 93, 96

Cross-pollination, 157, 158

Croton bug, 154

Croup, 232

Crown gall, 212, 216

Crows, 48

Crude drugs, 71, 73

Grude sulphuric acid, 71

Crustacea, 285-294, 315, 324 ; products of, 287

Cuban pine, 59

Cuckoo, food of, 25,46

Culex mosquito, 124, 125, 127, 128, $129,130,131,132$; breeding places, 132 ; extermination of, 128 ; flight, 128 ; picture of eggs, larva, pupa, and adult, 129, 130

Curculio beetles, 155

Curled dock, 70, 71

Currant borer, 156

Currant worm or slug, 157

Cuttlefishes, 274

Cutworms, 25, 156, 317 
Dahlia, 86

Dandelion, 72

Dandruff, 236

Darwin, Charles, 330, 331, 333, 338

Datura stramonium, 72,75

Death-cup mushroom, 76

Death-of-man, 75

Deer, 169, 171, 172, 261, 263

Deer farming, 172

Deer flies, 113

Delaware grape, 85

Devilfishes, 274

Devil's apple, 75

Devil's-bite, 76

Diamond-backed terrapin, 324

Diarrhea, 232, 233, 234

Diphtheria, 177, 232, 234, 235, 236, $239,243,245,246,248,250,251$

Diptera, 153, 155

Discoverers, biological, 359-362 ; present-day, 359

Discovery, history of, 358,359 ; importance of, 357-358; kinds of, 356,357 ; progress in, $355-362$

Distemper, 248

Dock, 72

Dodder, 188

Dodo, 42,43

Dog, 165, 182, 257, 263 ; influenced by alcohol, 341 ; itch mite of, 166 ; as a transmitter of rabies, 256

Dog tick, 168

Dogwood, 75

Dourine, 259

Doves, $34,42,43$

Downy woodpecker, 6,46

Dragon flies, 129, 153; nymphs of, as enemies to young mosquitoes, 131

Drop, a disease of lettuce, 210

Drug plants, 72

Drug-store beetles, 155

Dry rot, or stem blight, 216
Duck, 38 ; attacked by rats, 174

Duck hawk, 45

Duck potato, or wapata, 307

Duckmeat (Lemna), 307

Duck-retter, 76

Dwarf larkspur, 76

Dysentery, 20, 107, 110, 233, 235, 245,256

Eagle, 44

Earthworm, 25

Eczema, 236

Effluvia, 237

Egg record, 104

Egret, 40

Elderberry, 86

Elk, 169, 171

Elm, 59, 82-84, 165

Elm-leaf beetle, 21, 156

Elodea, 307

Endocarditis, 232

English sparrow, 45, 49, 50, 182

Enteritis, 107, 232, 234, 235. See also Gastro-enteritis

Entomostraca, 287

Eohippus, 333

Erysipelas, 234, 251

Eugenics, 344

European root disease, 212

Evening primrose, 70

Evolution, 338

Excursions, plans for, $7,8,9$

Facultative bacteria, 221

Fall webworm, 155

Farm crops, relative fertility of, 101

Feeble-mindedness, causes and consequences of, 344

Felons, 233

Fence swift, 325

Fermentation, 191, 194, 195, 196

Ferns, 188

Field mice, 34,44 
Field observations and records, 4, 5 Filariasis, 253

Filth-disease fly, 107

Filth-disease infections, 107, 110

Fire blight, 212

Fish hatchery made from tumbler, 303

Fish hawk, 45

Fish ponds on farms, 296

Fishes, 39, 306, 317; classification and species, 304; economic and civic value, 310 ; enemies of mosquitoes, 131 ; habits and spawning seasons, 308 ; problems of fish and fishing, 295-311

Fishes Day, 299

Flat-headed apple-tree borer, 155

Flatworms, 255,260

Flea, 182, 236, 240 ; burrowing (chigoe), 155 ; cat, 154 ; dog, 154 ; hen, 155 ; rat, 154

Flea beetle, 156

Flesh flies, 112

Flicker, 46

Flies, 107-122, 152, 153, 182, 242, 245, 261, 268, 332 ; blood-sucking, 259 ; blowfly, 154, 318 ; bluebottles, 112, 154 ; botflies, 113,157 ; campaigns. against, $110,111,117,118,120$, 122 ; cluster fly, 154 ; fecundity of, 117 ; fruit fly, 154 ; greenbottle, 112,154 ; hibernation of, 117 ; hornfly, 113, 121, 157 ; kinds, 111, $112,113,118,154,318$; life history of, 116 ; nets for catching, 119 ; relation of, to disposal of waste, 114,115 ; screens for, futility of, 110 ; stable, 108, 109 ; traps for outcloors, 115,118 ; tsetse, 236 ; work of, 107, 110

Flood plane, 56

Floods, cause of and damage from, 55,56
Flowering beau, 86

Flowering quince, 97

Flowers in relation to landscaping, 86

Flukes, 260

Flycatchers, 47

Fomites, 237, 238

Food, law of absorption, 189, 190

Foot-and-mouth disease, 110, 233, 256

Forest fires, causes of, 61,64 ; damage from, 55, 62, 64; laws regulating, 66 ; relation of, to tree-planting, 65

Forest preserves, 171

Forestry, annual growth of trees, 55 ; consumption of wood, 55 ; effects of adequate planting, 57,58 ; natural enemies of trees, 156 ; study of local problems of, 58; study of trees and civic viewpoint, 54-66

Formalin, as germicide, 249 ; use of, to prevent potato blight, 216

Formicary, 145

Foul brood, 233

Fowl cholera, 110, 233

Fowl tuberculosis, 110

Fox sparrow, 49

Foxglove, 78

Foxtail, 70

Fresh-water mussel, 273, 279, 281

Fringed gentian, 67

Frog, 39, 306, 313, 314, 315, 317, 318,320 ; possibilities of culture, . 318

Fruit fly, 154

Fungi, 73, 97, 186-191; bacteria, general treatment of, 218-251; fungous and bacterial diseases of plants, 207-217; molds and mildews, 197-199; mushrooms, poisonous and edible, 200-206 ; yeasts, 191-197 
Fungous diseases, 207-213; damage from, 207 ; organizing for the control of, 217

Fur farming, 172

Fur-bearing animals, 3

Gall insects, 157

Game, 3; killed by rats, 174

Game birds, 3; conservation of, 53.

Gaper clam, 278

Gapeworm, 254, 266

Garden slug, 282, 283

Garden spurge, 76

Garter snake, 326

Gartered plume moth, 156

Gastro-enteritis, 111. See also Enteritis

Gastropods, 274, 282, 283, 284

Geese, 38, 53, 325

Genetics, 330,337 ; organized study of, 339

Gentians, 67, 306

Geoduck, 278. See also Giant clam

Geometrical increase, illustrated by diagram, 331; law of, 331-332

Germ plasm, 338 ; injury to, 340,343

German roach, 154

Germícides, 248

Giant clam (geoduck), 278

Gila monster, 325

Ginseng, 73

Glanders, 235

Gnat catcher, 51

Gnats, 111, 153

Goat, 169,261 ; itch mite of, 166

Golden plover, 40

Goldenrod, 86

Goldfinch, 49

Gonococcus infection, 240

Gonorrhea, 107

Gopher, 30, 34, 44

Gopher plant, 76

Gopher snake, 326
Gopher tortoise, 325

Goshawk, 45

Grackle, 48

Grain, pests of, 156

Grain aphis, or green bug, 156

Grape, 6, 85, 87, 88, 94

Grape-berry moth, 156

Grapevine root beetle, 156

Grasshoppers, 25, 152, 153, 156, 318; diagram of, 151

Great horned owl, 45

Great laurel, 76

Green frog, 315, 316

Green turtle, 324

Greenbottle fly, 112, 154

Grippe, 234, 236, 250, 251

Ground itch, 268

Grouse, 40

Grubb, 94

Guatemalan ant, 141

Guernsey, 103

Guinea pigs, experiments showing influence of alcohol upon, 340

Gull, 38

Gypsy moth, 20, 69, 148, 156, 159, $160,162,317$

Hair snakes, 265

Hairy woodpecker, 46

Hard, or little-neck, clam, 277

Hardy perennials, 86

Hares, 165, 169

Harlequin snake, 328

Harvest mites, 163, 165

Harvestmen, 164

Hawks, 30, 34, 44, 45

Hawksbill, 324

Heath hen, 42

Heliotrope, 86

Hellèbore, 76

Hemiptera, 153

Hemlock, 59, 75, 83

Hen, 104 
Hen flea, 155

Herbicides, 71

Herbs, 71, 73

Heredity, laws of, $330,334,338$

Hermit thrush, 51

Heroin, 343

Heron, 39, 40

Herring gull, 38

Hessian fly, 21, 156

Hickory, 59, 60, 82

High laurel, 75

"Hill Folk, The," 345

Hip disease, 234

Hog and fowl cholera, 110, 233

Hollyhocks, 86

Holstein, 103

Honey locust, 82

Honeybee, 157; relation of, to tree fertility, 157

Hookworm, 107, 255, 254, 256, 268

Hookworm disease, 254, 268 ; pictures of victims of, 252

Horehound, 72

Horn fly, 113, 157; life history, 121

Horned lark, 48

Horned toad, 325

Horse, 165, 257, 261; itch mites of, 166

Horse botfly, 157

Horse-chestnut, 75

House ant, 155

House cricket, 154

House fly, 20, 317; breeding places, 113,114 ; fecundity, 18 ; relation of, to filth, 116, 118. See also Flies

House pets, 245

House wren, 51 ; food of, 25

Household insects, 154, 155

Hydrogen, 98

Hydrophobia, 256

Hymenoptera, 153, 156

Hypochlorites, 249, 251

Hypochlorous acid, 249
Human flea, 154

Human mite, 166

Human tapeworm, 260

Humming bird, 6, 46

Humming-bird moth, 155

Ichneumon fly, 136

Imported currant fly, 21

Indian corn, 95

Indian pipe, 188

Indian poke, 76

Indian-meal moth, 155

Indigo bunting, 49

Infantile paralysis, $20,122,236,256$

Infection, 110, 122, 246

Inflammation, 234, 236

Inflammatory fever, 248

Influenza, 235

Insect-catching bottle, 131

Insecticides, 152

Insectivorous birds, 44

Insects, 44, 51, 97, 176, 250, 253, 313, 315 ; attacking animals, 157 ; beneficial, 157 ; cases for mounting, 11 ; classification of, $150,151,152$; damage and loss from, 19, 20, 24; fecundity of, 18; household, 154, 155 ; injurious to vegetation, 155 , 156,157 ; literature on, 149 ; nets for catching, 11, 12; orders of, 153; parts of, 152 ; size of, 18 ; work of, 18 ; work of controlling, 20

Ireland, famine in, 208

Iris, 86

Iron, 71, 98, 99

Ironwood, 59

Itch mites, 166

Itchweed, 76

Ivy, 75,76

Ivy wood, 75

Jack pine, 59

Jamestown lily, 75 
Jamestown weed, 75

Japanese maple, 83

Japanese quince, 89

Japanese snowball, 89

Jays, 48

Jimson weed, 72, 75

Jukes family, 345

Junco, 49

June beetles, 153, 156

Kallikak family, diagram outlining history of, 342

Kalmia, 75

Kangaroo, 261

Kerosene, remedy for dog tick, 168

King cobra, 328

Kingbird, 47

Kingfisher, 46

Kinglets, 51

Kissing bug, 154

Laboratory, outfit of, 10

Laboratory work, outdoor, 25

Lacewings, 153

Lady beetle, 153; Chinese, 20-21

Lady's-slipper, 67

Lamb's-quarters, 69,70

Lamellibranchs, 279

Lancaster elm, 78, 79, 80

Land, relative value of, 100, 101

Land salamander, 315

Land snail, 283

Landscape gardening, $7 \mathbf{7}-90$

Larch, 83

Larder beetles, 155

Lark, 34, 48

Larkspur, 76

Late blight, or rot, 216

Laurel, 75

Lawn, 71

Lead acetate, antidote for poison of ivy, oak, and sumac, $\mathbf{7 4}$

Leaf spot, 212
Leaf-eating sawflies, 157

Least flycatcher, 47

Leghorn, white, 104

Legumes, 188, 222

Lemna, 307

Leopard frog, 315, 316, 319

Leprosy, 107, 234, 251

Lettuce, 94

Library, using of, 349

Lice, 153, 154

Life, practical laws of, $330-345$

Lilies, 86

Lily, 94

Limber neck, chickens sick with, 122

Lime, 99, 100, 102, 223

Lincoln, 92, 95

Linden, 82

Little black ant, 155

Little house fly, 112

Liver fluke, 261

Lizard, 321, 323, 325

Loblolly pine, 59

Lobster, 286-294 ; propagation, 289

Lockjaw, 234, 248

Loco weed, 73,74

Locust, 59, 82

Loggerhead turtle, 324

Long-leaf pine, 59

Loons, 38

Louse, 154, 156

Lupus, 234

Lycoperdaceo, 203

Lynxes, 169

Magnesium, 98, 99

Magpie, 48

Maidenhair fern, 67

Malaria, 20, 123, 124, 125, 134, 236, 252,254 ; bovine, 257 ; prevention of, 133,257

Malarial mosquito, 154

Malarial parasites, 256, 257

Mallard duck, 39, 306 
Mammals, 34, 167, 176 ; American Mammal Problems, 169-172 ; orders of, with pictures of habitats, 170

Man, 176

Manganese, 98

Manure, barnyard, 70 ; disposal of, 115 ; relation of, to flies, 114,115 Maples, 59, 83

Marigold, 86

Markweed, 75

Marsh hawk, 45

Marsh wren, 51

Martin, 49, 171

Massasaugas, 327

Mayweed, 70

Meadow lark, 48

Meal worm, 155

Measles, 36, 215, 232, 2333, 236, 239, 247,256

Medicinal plants, 71

Mendel's law, 330, 337, 344, 345; diagram illustrating, 335, 338 ; history of, 336

Meningitis, 107, 234. See also Cerebrospinal meningitis

Meningococcus, 234

Mercuric acid, cure for potato scab, 216

Mercuric chloride, 249

Mercury, 75

Miasms, 237

Mice, 30, 34, 44, 174, 182, 183, 184, $185,245,267$

Vildew. See Molds

Milk, pasteurizing of, 244

Milkweed, 69, 71

Vinks, 169

Vission grape, 85

Vites, 163-168, 236; clover mite, ' 65 ; harvest mite, 163,165 ; itch - nite, 166 ; poultry mite, 167 ; red aite, 129 ; sheep-scab mite, 166
Moccasins, 327,328

Mocking bird, 50, 51

Molds and mildews, 97, 186, 189, 191, $193,194,210$; botanical position and structure of, 197, 198; observation of and experiments with, 199

Mole plant, 76

Moles, 30, 165, 171

Mollusca, classification of, 274

Mollusks, 271-284

Mongolian, or ring-necked, pheasant, 42

Monkey, 263

Moose, 169

Morphine, 343

Mosquito, 20, 111, 113, 119, 123-135, $153,154,164,182,236,240,253$, 257,332 ; breeding places of, 131 , 132 ; kinds of, 125 ; life history of, 124,128 ; methods of extermination of, 133 ; natural enemies of, 129,131 ; planning of campaign against, 134,135

Mosses, 188

Moth, 153, 318 ; case-making, 154 ; clothes, 154 ; codling, 6,155 . See also Brown-tail moth, Grape-berry moth, Gypsy moth, White-marked tussock moth

Mountain laurel, 75, 86

Mountain sheep, 169

Mourning dove, 43, 44

Mucket shells, 307

Mud, or pond, terrapins, 325

Mud puppies, 314, 320

Mulberry, „9

Mullein, 71,72

Mumps, 247

Mushrooms, 73, 186, 189, 197, 210 ; cause of root rot, 211 ; classification of, 203-206; poisonous and edible, 200-206

Musk grass (Chara), 307 
Muskrat, 171

Muskrat weed, 75

Musquash root, 75

Mussels, 273, 274, 279-281, 306

Mustard, 70, 72

Mutation, 338

Myriapods, 317

Myriophyllum, 307

Mytilus, 276, 277, 278, 279

Nagana, or tsetse-fly disease, 259

Nam family, 345

Nasturtium, 86

Native plants, conservation of, 67

Natural selection, law of, 335

Nautilus, 274

Nematodes, 264, 265, 266

Nephritis, 232

Nets, collecting, 11 ; fly, 119 ; materials for making, 12

Neuroptera, 153

Newts, 131, 314, 320

Nicotine, 343

Niggerhead, 280

Nighthawk, 47

Nightshade, 76

Nitrates, 102

Nitrifying bacteria, 222

Nitrogen, 47, 98-101, 187

Norman Percherons, 333

Notebook, instructions for keeping, in field and laboratory, 11

Noxious mammals, 30,44 ; destruction of, 44

Nuthatches, 51

Nuts, importance of, and suggestions for growing, 60

Oak, 59, 83, 84

Oats, 93

Octopus, 274

Oil, coal, 71 ; olive, 128 ; of $\operatorname{tar,~} 128$

Onion maggot, 156
Ophthalmia, 107

Opium, 343

Opsonic index, 248

Orchard orioles, food of, 25

Orchard pests, 155

Oregon water hemlock, 76

Oriental cockroach, 154

Orioles, 48

Orthoptera, 153

Osprey, 45

Otter, 171

Ovenbird, 50

Owls, 30, 34, 44

Oxygen, 98, 194

Oyster, 271, 274, 279; Atlantic, 273 ;

Pacific, 273; producing sickness, 272

Óyster drill, 282

Oyster-shell scale, 156, 332

Pacific clam, 278

Pacific crab, 292

Painted tortoise, 325

Pangenesis, 338

Panther, 169

Parasites, use of, to control insects, 161

Parasitic bacteria, 221

Parasitic protozoa, 255

Parasitic worms, 107

Parsnips, 105

Passenger pigeon, 36, 43, 44 ; egg of, 43 ; picture of, 36

Pasteur, 195, 209

Pavement ant, 155

Peach, 94, 165

Peach yellows, 214, 215

Peach-tree borer, 155

Pear, 94

Pear and apple blight, 212, 213, 216

Pear slug, 157

Pear-blight beetle, 155

Pearl fishing, 279, 280 
Pear-tree borer, 155

Pec in, 60

Peeper, 316

Pel agra, 113, 251

Per nyroyal, 128

Pec nies, 86

Peiper bush, 86

Pejpergrass, 70,71

Perch, 306

Pe ennial crowns, 71

Pe itonitis, 234

Periwinkle, 274

Pheasants, 40

Pl enol, coefficient of, 249

Pl loxes, 86

Plœbe, 47 ; food of, 25

Pliosphates, 223

Pliosphorus, 96, 98, 99, 100, 101 ; used for poisoning rats, 181

P' ekerel frog, 315, 316, 319

P ed-billed grebe, 38

Pig, 261 ; as host for trichina worm, 267 ; itch mites of, 166 ; tapeworm of, 263

Figeon, 35, 36, 42; killed by rats, 174 ; kinds of : band-tailed pigeon, 43 ; passenger pigeon, 43 ; redbilled pigeon, 43 ; Viosca's pigeon, 43

l'igeon grass, 70

J'igeon hawk, 45

? igweed, 69,70

'Pimples, 248

['ine, $59,83,84$; white pine, study of, $4,5,6$

Pintail, 39

Pinworm, 266

Piroplasmas, 257, 258

Pitch pine, 59

Plague, 236

Plankton, 219

Plant food, essential elements of, 99 ; losses in, due to cropping, 102
Plant lice, 153, 156, 164 ; fecundity of, 18

Plant problems, 67-76; conservation of native plants, 67

Plantain, 71

Plover, 40

Plum, 165

Plymouth Rock, 104

Pneumococcus, 234

Pneumonia, 121, 184, 232-236, 248, 250,251

Poison ash, 75

Poison elder, 75

Poison hemlock, 72, 75

Poison ivy, 74, 75

Poison laurel, 75

Poison oak, 74, 75

Poison root, 75

Poison snakeweed, 75

Poison sumac, 74, 75

Poisonous plants, damage from, 73; list of, 75,76

Poisonous snakes, 110, 327-329

Pokeroot, 76

Pokeweed, 75

Poliomyelitis, 122

Ponds, as balanced aquaria, 304 ; possible production from, 307

Peplar, 165

Porpoises, 169

Potash, 102, 223

Potassium, 96, 98, 99, 100, 101

Potato, 93, 97; blight or scab of, 210,215

Potato beetles, 42,153

Poultry, 103, 104

Poultry mite, 167

Pout, 306

Prairie chicken, 53

Prawns, 287

Proteans, 313

Protein, 187, 189

Protozoa, 255, 256 
Puerperal fever, 234

Puffballs, 189, 191, 203, 206

Pulmonary tuberculosis, 249

Purple beech, 83

Purple cornflower, 73

Purple finch, 49

Purple martin, 49

Purslane, 69, 70

Quack grass, 72

Rabbit, 169, 261

Rabid dogs, 110

Rabies, 248, 256

Ragweed, 70

Railroad worm, 156

Rainbow trout, 309

Raspberry, 94

Rat snake, 326

Rats, 30, 34, 44, 245, 267, 332 ; damage from, 2, 174, 175, 176; extermination of, $3,177-184$; fecundity of, 2, 173 ; poisoning of, $179,180,181$; problem of, 173-185 ; trapping of, 177,178 , $179,182,184,185$

Rattlebox, 76

Rattlesnake, 253, 322, 327, 328

Red ant, 155

Red buckeye, 75

Red cedar, 59

Red gum, 59

Red mite, 129

Red pepper, 73

Red pine, 59

Red spider, 163, 164

Red-backed salamander, 316

Red-eyed vireo, 50

Red-headed woodpecker, 46

Red-humperl apple-tree caterpillar, 156

Red-legged locust, 156

Red-shouldered hawk, 44, 45
Redstart, 50

Red-tailed hawk, 45

Red-winged blackbird, 48

Reptiles, 321-329 ; products of, 321, 323

Rheumatism, 233, 234, 236

Rhinitis, 234, 235

Rhizopus, 198

Rhododendron, 76

Roaches, 245. See also Cockroaches

Robin, 51

Rock bass, 306

Rock pine, 59

Rocky Mountain spotted-fever tick, 167

Rodents, 326

Root gall, 212

Root knot, 265

Root rot, 211, 212

Root tubercles, 188

Rosa rugosa, 89, 97

Rose, 86, 94, 97

Rose chafer, 156

Rose slug, 157

Rose-breasted grosbeak, 49

Round-headed apple-tree borer, 155

Roundworms, 264, 265, 266

Ruby-crowned kinglet, 51

Ruby-throated humming bird, 47

Ruffed grouse, 41, 42, 52, 53

Rum cherry, 75

Rust, 186, 207, 210, 212

Sable, 171

Saccharomycetes, 191

Salamanders, 313, 316, 319, 320, 325 ;

enemies of mosquitoes, 131

Salmon, 309, 310, 311

San José scale, 20, 69, 152, 156, 158,

332 ; fecundity of, 18

Sand flies, 113

Saprolegnia, 305

Saprophytic bacteria, 221 
Sapsucker, 46

Sawflies, 153

Sayornis phœbe, 47

Scab, on apple, 212 ; on potato, 210

Scale insects, 153, 156

Scallops, 273, 274, 277

Scarletfever, 177, 232, 233, 236, 239, $243,245,246,247,251,256$

Scarlet tanager, 25, 49

Schick reaction, 251

Scientific organizations, journals of, $352,353,354$

Scorpion, 163, 164

Screech owl, 45

Screens, cost of, 20

Screw-worm fly, 113, 157

Scrub pine, 59

Scurvy scale, 156

Sea mussels, $271,272,273,275$; picture of beds of, 270

Seed, 188

Selection and survival of the fittest, 330

Seneca snakeroot, 73

Septicæmia, 234

Serum, 248; antitoxic sera for snake poisons (antivenins), 329; Flexner's antimeningitis, 111 ; resistance of, 249

Shad, 296, 309, 310, 311

Shagbark hickory, 82

Sharp-shinned hawk, 45

Sheep, 257, 263; itch mite of, 166 ; liver fluke in, 261

Sheep botfly, 157

Sheep laurel, 75

Sheep-scab mite, 163, 166

Shepherd's-purse, 70,71

Shetland ponies, 333

Shore bird, 40

Short-leaf pine, 59

Shrikes, $30,34,50$

Shrubs, 84,86
Silicon, 98

Silver fox, 172

Sirens, 313, 314

Sistrurus, 327

Skink, 325

Skunk, 169, 256

Sleeping sickness, 236

Slug, currant, 157; pear, 157 ; rose, 157

Slugs, 282, 283, 315 ; eaten by box tortoise, 325

Small laurel, 75

Smallpox, 107, 211, 233, 236, 237, $247,251,256$; control of, by vaccination, 258,259

Smartweed, 70

Smuts, 186, 207, 210 ; on corn, 213, 216 ; on oats, 212

Snails, 274, 283

Snake venom, treatment of, 329

Snakes, 40, 321, 323 ; number of species of, 326 ; poisonous, 110, 327-328

Snakeweed, 75

Snapping terrapin, 324

Sneezeweed, 76

Snowball, 97

Snow-on-the-mountain, 76

Society for the Protection of Native Plants, 67

Sodium, 98

Sodium chloride, 249

Sodium hypochlorite, 249

Soft, or long-necked, clam, 276, 278

Soft-shelled terrapin, 325

Soil, effects of washing on, 57 ; elements in, 99 ; fertility of, 91, 98; loss of fertility of, 55,102

Song birds killed by rats, 174

Song sparrow, 49

Sonoran coral snake, 328

Sorghum, 197

Sourwood, 59 
Southern clothes moth, 154

Sow bug, 317

Sparrow, 34, 45, 47, 49, 50, 182

Sparrow hawk, 45

Sphinx moth, 155, 156

Spiders, 46, 51, 163-168, 315

Spinal meningitis, 107, 110

Spirilla, 218

Spirits of camphor, 128

Spitzenburg apple, 334

Spoonwood, 75

Spotted cowbane, 75

Spotted fever, 233, 236, 256

Spotted parsley, 75

Spotted salamander, 316

Spotted sandpiper, 40

Spotted terrapin, 325

Spruce pine, 59

Spruces, 58,83

Squash bug, 152, 156

Squids, 273, 274

Squirrel, 261

Stable fly, 20, 113, 121, 122, 154, 236 ;

life history of, 121

Stable-window fly trap, 108, 109

Staggerbush, 76

Staggerweed, 76

Staphylococci, 234

Stegomyia fasciata, 258

Stewart's disease, 215

Sticktights, 69

Stinkhorns, 204

Stinking smut, 213

Stinkweed, 75

Stinkwort, 75

Stork, 39

Strains, pure-bred selected, 96,97

Strawberry, 94 ; enemies of, 156

Streptococcus, 234

Striped cucumber beetle, 156

Strychnia sulphate, 181

Strychnine used for poisoning rats, 180,181
Sugar, danger from gorging with, 344

Sugar, or rock, maple, 82

Sugar pine, 59

Sulphate of copper, 71

Sulphur, 98, 99

Sulphur ointment, 165

Sumac, $74,75,86$

Simmer cholera. See Summer complaint

Summer complaint, 107, 110, 121

Sunfish, 306

Sunflower, 86

Surra, 259

Swallows, 49, 129

Swamp hellebore, 76

Swamp sumac, 75

Swan, 38, 42

Swatter, 119

Sweet peas, 86

Swine, 174

Sycamore, 59

Symbiotic bacteria, 221

Syphilis, 107

Syrphus flies, 112

Tachina flies, 112

Tadpoles, 314-318

Tamarack, 59

Tanagers, 49

Tansy, 72

Tapestry moths, 154

Tapeworm, 107, 254, 260, 262-264 ; of dogs, 264 ; of fishes, 264 ; of man, 261

Tarantulas, 164

Tea, 344

Teal, 306

Teasel, 71

Tent caterpillar, 155

Termites, 155

Terns, 38

Terrapins, 321, 323, 324, 325 
Tetanus, 248

Texas fever, 97, 163, 167, 168, 236, 257

Thorn apple, 75

Thrashers, 50

Threadworms, 255, 264

Three-leaved ivy, 75

Thrushes, 51

Thunderwood, 75

Ticks, $163,164,165,236,255$; cattle tick, 167, 168, 257 ; dog, or wood, tick, 168; Rocky Mountain, or spotted-fever, tick, 167 ; species of, 168

Titmice, 51

Toads, 306, 312-320 ; commercial value of, 317 ; eggs and tadpoles, 314-316, 318; food and feeding tests, $312,315,317$

Tobacco as an insecticide, 114, 343

Tomato, 94

'Tonsillitis, 233, 234, 235, 243, 245, 251

Tools, 13, 14

Toothache, 233

Tortoises, 321, 324, 325

Towhee, 49

Trailing arbutus, 67

Tree frogs, 313, 314, 316, 319, 320

Tree sparrows, 34, 49

Tree swallows, 49

Trees, characters of, 82 ; hard woods, 59 ; light demanders, 59 ; planting of, 61 ; relation of, to landscaping, $81,83,84$; shade bearers, 59 ; study of, 59,60

Trematodes, 260

Trichina, 175, 266, 267, 268

Trichinosis, 264, 266

Trout, 309

Trumpeter swan, 39

Truth, fake sources of, 347

Trypanosomes, 259, 260

Tsetse flies, 236, 259, 260
Tuberculosis, 107, 110, 121, 232, 234, $235,236,245,250,251,252,256$; avian, 233 ; bovine, 110,233 ; pulmonary, 249

Tuberoses, 86

Tubers, 71,307

'Turkeys killed by rats, 174

Turpentine a remedy for dog tick, 168

Turtles, 131, 321, 323, 325

Typhlitis, 234

Typhoid, 20, 110, 118, 121, 177, 232, $234,235,236,242,243,245,248$, 251 ; epidemic of, 241 ; relation of dirty hands to, 250

Typhoid fly, 107, 112; life history of, 113. See also House fly

Typhoid Mary, 242

Typhus fever, 236, 256

Uncinariasis, 268

Vaccination, 258

Vaccines, 248

Van Fleet rose, 97

Variation, 330, 338 ; law of, 333

Vedalia beetle, 20

Vegetables, pests of, 156

Venomous snakes, 324

Vermin, 245

Vinegar eels, 265

Vines, 87 ; relation of, to landscape gardening, $87,88,89$

Viosca's pigeon, 43

Viper, 327

Vireos, 48, 50

Virginia scrub pine, 59

Vivaria, 10, 131

Walking sticks, 153

Walnut. See Black walnut

Wapata, 307

Warblers, 48, 50 
Warbling vireo, 50

Wasps, 153

Water beetles, larvæ of, 131

Water bugs, 153

Water cress, 306, 307

Water hemlock, 73,75

Water lilies, 306,307

Water snakes, 326

Waterfowl, 38, 39, 40, 45, 324

Waxwings, 50

Weasels, 169

Weeds, $67-76$; adaptability of, 70 ; classes of, 70, 71; damage from, 68 ; destruction and control of, 34 , 69,71 ; medicinal, 71,72

Weeping willow, 84

Weevils, 155, 156, 317

Western little-neck clam, 278

Western prairie chicken, 42

Whale, 169

Wheat, 93, 94, 95, 97

Whippoorwill, 47, 129

Whistling swan, 39

White ants, 153, 155

White ash, 82

White cedar, 59

White diarrhea of chicks, 233

White elm, 59

White hellebore, 76

White man's plant, 75

White pine, 59, 84; type for study, $4,5,6$

White-breasted nuthatch, 51

Whitefish, 309

White-marked tussock moth, 156

White-throated sparrow, 49

Whooping cough, 232, 234, 247

Wicky, 75

Widal reaction, 251

Wild boar, 263

Wild carrot, 71

Wild cat, 169

Wild celery, 307
Wild cherry, 75

Wild duck, 53, 325

Wild onion, 71

Wild rice, 307

Wild rose, 86

Wild sago, 307

Wild trout, 305

Wild turkey, 42, 53

Willow, 59, 307

Wilson snipe, 40

Wilson's thrush, 51

Wilt disease, 212 ; bacterial blight, 215 ; stem blight, 216

Window flytrap, 108, 109

Wode-whistle, 75

Wolf, 169,256 ; itch mite of, 166

Wolfsbane, 76

Wolf's-milk, 76

Wolverine, 169

Wood duck, 39, 40, 306, 307

Wood frog, 315, 316, 319

Wood laurel, 75

Wood pewee, food of, 24,47

Wood thrush, 51

Wood ticks, 165, 168

Woodcock, 40

Woodpecker, 7, 46

Woolly apple louse, 156

Woolly loco weerl, 76

Worms, 51, 315

Wormseed, 69

Wrens, 50

Yeara, 75

Yeast, 186, 189-197; a cause of disease, 197; description of, 191, 192 ; distribution of, 192 ; pure culture of, 195 ; uses of, 194

Yellow fever, 20, 123, 124, 126, 134, $233,236,240,253,254,256,258$

Yellow perch, 309 ; topography of, 298

Yellow pine, 59 
Yellow poplar, 59

Yellow warbler, 50

Yellow woolly bear, 155

Yellow-billed cuckoo, 46

Yellow-fever mosquito, 124, 125
Yellow-throated vireo, 50

Zero family, 345

Zinnias, 86

Zoölogical parks, 171 








